TURISMENS PARADOKSER 



\author{
Arvid Viken
}

\title{
TURISMENS PARADOKSER
}

\author{
Turisme som utvikling og innvikling
}

\author{
i samarbeid med Rune Benonisen, Kristian Ekeland, Anniken Førde, Ragnar Nilsen, \\ Torill Nyseth, Carina Olufsen, Ola Sletvold og Gaute Svensson
}

Orkana Akademisk 
Arvid Viken, Rune Benonisen, Kristian Ekeland, Anniken Førde, Ragnar Nilsen,

Torill Nyseth, Carina Olufsen, Ola Sletvold, Gaute Svensson (C) 2020

Denne boken utgies med åpen tilgang (Open Access), og er regulert av åndsverkloven og betingelsene i Creative Commons-lisensen CC-BY 4.0.

Creative Commons-lisens CC-BY 4.0 tillater andre å kopiere og distribuere verket i ethvert medium eller format, og materialet kan benyttes til ethvert formål. Det må refereres korrekt til verk og forfatter, og referanse til Creative Commons-lisensen og hvilke endringer som eventuelt er gjennomført må inkluderes. Referanser til originalverket skal ikke presenteres på en slik måte at det gies inntrykk av at forfatter eller utgiver støtter gjenbruker eller gjenbrukers anvendelse av verket. Enhver anvendelse av materialet i dette verket kan ikke begrense andres rett til gjenbruk av materialet.

For en fullstendig beskrivelse av Creative Commons-lisensen se følgende nettside: https://creativecommons.org/licenses/by/4.o/legalcode.no

PDF: ISBN 978-82-8104-417-3

EPUB: ISBN 978-82-8104-418-0

HTML: ISBN 978-82-8104-419-7

XML: ISBN 978-82-8104-420-3

DOI: https://doi.org/10.33673/OOA20202

Turismens paradokser. Turisme som utvikling og innvikling

Arvid Viken i samarbeid med Rune Benonisen, Kristian Ekeland, Anniken Førde, Ragnar Nilsen,

Torill Nyseth, Carina Olufsen, Ola Sletvold og Gaute Svensson

Omslagsillustrasjoner: Ole Magnus Rapp

Baksideillustrasjon: Arvid Viken

Design: DesignBaltic

Satt i $12 / 14.4$ Adobe Garamond

Originalutgave: Orkana Akademisk

Orkana forlag as, 8340 Stamsund 2020

ISBN 978-82-8104-36I-9

www.orkana.no

post@orkana.no 


\section{Innhold}

\section{DEL I}

1. Turismens vesen og uvesen . .11

Arvid Viken

2. Reisende i Norge gjennom tidene . .27 Ola Sletvold og Arvid Viken

\section{DEL II: REISELIV - DYNAMIKK OG DRAGKAMPER}

3. Store skip og små steder - emosjon, interesse og dynamikker i destinasjonsutvikling ... 63 Christian Ekeland og Arvid Viken

4. Campingdrift i grenselandet mellom økonomiske og sosiale systemer .89 Arvid Viken

5. Hvalsafari Andenes - reiselivsetablering i møte mellom idealisme, vitenskap og forretningsdrift. 105 Anniken Førde og Arvid Viken

6. Nordkapp - annektert av turismen 131 Arvid Viken

7. Fra lokalt til eksternt eierskap - eksempel på finansialisering i norsk turisme 153 Arvid Viken, Ragnar Nilsen og Carina Olufsen

\section{DEL III: REISELIVET I SAMFUNNSUTVIKLINGSPROSESSER}

8. Hurtigruten som destinasjonskatalysator .177 Arvid Viken

9. Kontinuitet og brudd: fiskeværet Årviksand og bostedet Badderen 199 Arvid Viken

10. Langforden - utvikling uten institusjonell tilhørighet .231 Arvid Viken

11. Båldiplomati, gjensidig avhengighet, dialog og refleksivitet .247 Torill Nyseth og Arvid Viken 


\section{DEL IV: NATURBASERT TURISME - FORVALTNINGSUTFORDRINGER}

12. Det ustyrlige friluftslivet? 269

Arvid Viken, Rune Benonissen og Gaute Svensson

13. Turisme, kunnskapshegemonier og sjølregulering på Svalbard 303 Arvid Viken

\section{DEL V: EPILOG}

14. Utfordringer i dagens norske turisme. .333 


\section{Forord}

I denne boka beskrives paradokser forbundet med turismen. Vi vil ha turisme, men vi liker ikke alltid å være omgitt av turister. Turismen er på mange måter en bærekraftig næring, men bare med et volum som ikke er for stort. Det er bra at folk tjener penger på turistene, og at investorer banker på døra, men vi vil helst at overskuddet skal forbli der turismeproduksjonen finner sted. Det er denne typen problemstillinger som boka tar opp. Den tar ikke opp koronakrisen i 2020 - paradoksalt nok er viruset spredt av reisende i en globalisert verden - bokas analyser er gjort under førkoronatidas normalitet. Boka er basert på forskning, nordnorske case-studier, som har vært foretatt mellom 2009 og 2019, ved det som en gang var Høgskolen i Finnmark, og ved Universitet i Tromsø - Norges arktiske universitet. Med et så stort tidsspenn, kan noe av virkeligheten som omtales ha endret seg, men lærdommen fra casene vil trolig stå seg. Og sjøl om casene er nordnorske, har ikke kunnskapen en slik begrensning. Kapitlene springer ut av prosjektene "A chair in Arctic tourism research", finansiert av Utenriksdepartementet, "Vinterprosjektet», finansiert av Norges Forskningsråd, og «Forskningsnode Nordtroms», finansiert av Troms Fylkeskommune. Kapitlene er skrevet sammen med kolleger og stipendiater ved UiT Norges arktiske universitet, samt samarbeidspartnere i Nord-Troms. Takk til alle for godt samarbeid. Perspektivet i boka er turismen slik den arter seg på små steder, og hva den har å bety for steds- og distriktsutvikling. Som tittelen gjenspeiler, er feltet ganske innviklet med mange aktører, relasjoner og strukturer. I forskningen som ligger til grunn for boka har vi først og fremst snakket med mennesker på mindre steder og i mindre kommuner. For å få gjennomført vår forskning er vi avhengige av velvillige informanter. Alle takkes herved for å støtte opp om vår forskning. I boka er det også en del bilder. En særlig takk til Ole Magnus Rapp, som har tatt mange av disse. Og sist, men ikke minst til Elisabeth Johansen og Orkana forlag, både for tålmodighet, grundighet og arbeidsinnsats.

Tromsø, februar 2020 Arvid Viken 

DEL I 



\section{TURISMENS VESEN OG UVESEN}

Arvid Viken

\section{Innledning}

Turisme er en realitet de fleste steder i verden. Overalt er det reisende, og overalt er det noen som tjener penger på de reisende. I denne boka skal vi se på hvordan steder i Norge har blitt innlemmet i denne næringa, hvordan reiselivet inngår i lokal samfunnsutvikling, og hva slags utfordringer dette representerer. I boka skal det vises til hvordan utvikling av nye turistmål har blitt til, og hvordan dette kan bidra til levedyktige lokalsamfunn. Men vi skal også se på hvordan turismen kan være et problem, og at den må forvaltes for å redusere skadevirkningene. En kjent rekkefølge i et utviklingsforløp er som følger: først arbeides det for å få til turisme, så kommer turistene uten at man helt hadde forventet det, eller er forberedt på det, og etter en stund erkjenner man at stedet har skiftet karakter og har fått nye utfordringer, og kanskje noen negative ringvirkninger (jf. Butler 1980). En side ved en slik utvikling er at det ofte ikke er de som skaper og tjener på turismen som sitter igjen med problemene, eller kan løse dem. Det er fritt fram til å etablere virksomhet som tildrar seg turister, og slik samfunnet er ordnet i dag, har bedriftene som regel ikke et ansvar eller en plikt til å håndtere de utfordringene deres gjester i sum utgjør for samfunnet. Med en hovedaktivitet som er å se på, være i eller utøve aktiviteter i vår natur og kultur, påvirker turismen både miljøet og samfunnet. Det er fritt fram til å bevege seg, til å se og beundre, og til å oppholde seg i andres lokalsamfunn. 
Turistene er altså storforbrukere av fellesgoder og offentlig tilrettelegging, som de bare delvis er med og betaler for. Dette er et hovedmantra i boka: Turisme er en næring som man ønsker og tilrettelegger for, som har store friheter, som skaper, utvikler og omskaper lokalsamfunn, men som er vanskelig å styre og kontrollere.

Turisme er en type aktivitet menneskene bare i liten grad bedrev om man går noen få hundre år tilbake. Vi har alltid reist, men ikke i det omfang som i dag, og reiseaktiviteten ser fortsatt ut til å øke. Vi finner hele tida på nye grunner til å reise. Vi reiser til steder vi ikke har vært, for å se og oppleve, og for å utøve de samme aktivitetene som vi utøver i hjemtraktene. Nordmenn går mye på tur i naturen. I våre dager gjør vi det også andre steder enn på egne trakter, og utlendingene kommer til oss for å utøve sine aktiviteter. Det finnes turoperatører som tilrettelegger for slikt, for eksempel for klatring, toppturer på ski, padling, jakt og fiske. De fleste fritidsinteresser kan utøves borte. Det tilbys i dag kurs innenfor de fleste interessefelt, ofte på eksotiske steder, for eksempel innen malerkunst og foto, og på de fleste sportsområder. En side ved den stadig mer omseggripende turismen er også at hva folk fordriver tida med der de bor, også endrer seg, i tråd og takt med nye trender både innen bruk av fritid og turisme. For eksempel har toppskikjøring mange steder blitt en lokal aktivitet, etter at denne aktiviteten i noen år først og fremst har vært bedrevet av folk utenfra. Alt dette krever etter hvert tilrettelegging, og jo mer man tilrettelegger, desto flere turister kommer. Ofte endrer dette både stedene og deres image. Det spektakulære eller idylliske ved stedene, som startet det hele, har en tendens til å forsvinne. Det er slike paradokser som løftes fram i denne boka.

De fleste kapitlene presenterer casestudier av turisme i norske bygdesamfunn samt en studie av tilrettelegging for turisme fra Svalbard. Studiene har blitt utført mellom 2009 og 2019. Sjøl om de fleste har lokal forankring, har mye av det som illustreres, i større eller mindre grad allmenngyldig relevans. Sentralisering, fjerneierskap og utfordringer knyttet til bruk av natur og fellesgoder er fenomener som opptrer over hele landet. Det samme gjelder positive trender knyttet til lokalsamfunn, lokale nettverk og lokale drivkrefter. Reiselivet i Norge har stort sett hatt en positiv utvikling. Næringa har vært et viktig bidrag i mange bygdesamfunn, og det har skapt eller omskapt både steder, byer og regioner som en del 
av samfunnsdynamikken. Men som utvikling i de fleste sammenhenger bidrar næringa til nye utfordringer.

I dette innledningskapitlet skal vi se på hva det innebærer at turister er fremmede i de områdene de skal utøve aktiviteter og hente opplevelser. En rekke ting må tilrettelegges. Vi skal videre se på hvordan turismen gjenspeiler store samfunnsspørsmål, og hvordan den inngår i diskurser som omhandler disse spørsmålene. Den viktigste i så måte er turismen som en bærebjelke i forbrukersamfunnet. Den representerer nye kommersielle aktivitetsfelter. Vi skal også viser hvordan tilrettelegging for turisme både er påkrevd og en problemskaper, og hvordan reiselivsutvikling kan være et kontraproduktivt felt. Paradoksene står i kø når turismen underkastes et kritisk blikk. Vi avslutter kapitlet med å understreke bokas hovedperspektiv og en kort presentasjon av dens kapitler.

\section{Turister er fremmede}

Som fremmede beveger og oppholder turister seg på steder hvor de ikke hører til, hvor de ofte ikke kjenner reglene for alminnelig atferd, hvor de ikke er en del av kulturen. Turistene er inntrengere i andres samfunn og kultur. Derfor har det grodd fram systemer for å ordne tilværelsen til de reisende, altså en reiselivsnæring. Den gjør at fremmede har et sted å bo, at de får mat, og atferden deres kanaliseres inn i aktiviteter og til arenaer hvor deres manglende tilhørighet ikke betyr mye. Det hevdes at turistrollen til tider representerer frigjøring, og at turister nå og da slipper alle hemninger, lar normer falle og lever ut sine primitive behov som turister. Hvert år strømmer det inn fortellinger om normløse tilstander på steder med mye ungdom, om ville fester og løssluppen rus- og sexatferd - det er gjerne det som fanger medienes oppmerksomhet. Dette er det ekstreme. Turister flest er vanlige mennesker med vanlig dannet oppførsel. Likevel må turistene styres og deres tilværelse ordnes (jf. Franklin 2012). Vi skal i denne boka vise hvordan de normene som har vokst fram for fastboende, ofte er utilstrekkelig når et sted blir gjenstand for massive besøk utenfra. Folk som bor et sted, har vært gjennom langvarige og omfattende sosialiseringsprosesser. Disse dekker både universelle og partikulære normer og regler. Fordi mange av normene er universelle og gjelder på tvers av landegrenser, religioner og kulturer, skaper ikke turismen alt for mange utfordringer. 
Men fordi det også er mange særegne normer, både nasjonalt og lokalt, er det mye turister ikke kan eller vet om stedene de besøker, og hva slags atferd som er gangbar der. Jo fjernere kulturene er fra hverandre, jo mer må turistene geleides gjennom landskapet. Vi nordmenn flirer av kinesere på reise i landet vårt. De går i flokk, har med seg teutstyr og drikker te, bruker munnbind og tror at brunost er dessert. Både naturen og kulturen er svært forskjellig fra det mange utlendinger er vant til. Derfor må man fortelle dem hva som forventes, hva som er lov og ikke lov, for å gi dem et godt og uprovoserende opphold på stedene de besøker.

For at turismen skal fungere, trengs det en del institusjoner. Noen må skape og drive en infrastruktur, yte informasjon og tilrettelegge de reisendes tilværelse. Turismen fungerer best der tilgangen på samfunnsinstitusjoner, eller det vi kaller offentlig infrastruktur, er stor. Reiselivet kan også betraktes som en slags struktur, eller en næring som kompenserer for manglende offentlige institusjoner. Som turist i Oslo klarer man seg på egen hånd, fordi det er et velorganisert samfunn med en infrastruktur beregnet på mange mennesker. På Svalbard er det verre, der finnes nesten intet av det man trenger, i alle fall ikke utenfor de tre-fire bosettingene. Likevel ordner det seg, fordi det finnes en reiselivsnæring som har spesialisert seg på å eskortere og pleie de reisende. Turismen er altså både en forbruker av eksisterende samfunnsorganer og en tilrettelegger der slike ikke finnes.

At reiselivet benytter seg av eksisterende infrastruktur, har vært ansett som en naturlig del av samfunnslivet. Det har alltid vært en del reisende de fleste steder; reisende er en slags funksjon av boende. Folk kommer på besøk, driver handel, utveksler kunnskap og kultur, og de reisende beriker livet til de boende. Det finnes en naturlig dimensjonert reiselivsnæring, basert på mennesker som reiser til og fra. Når det såkalte reiselivet legger seg i selen for å skape turisme ut over dette nivået, endrer problemstillingene seg. Turister som kommer for å tilfredsstille egne behov for forlystelser eller opplevelser, representerer en belastning for samfunnets infrastruktur, og for folk flest. De betaler ikke skatt, og det er få spesialavgifter. Men dette er ikke hele bildet, turisme er næring og betyr sysselsetting og lokal omsetning, penger i kassa både for næringsliv og myndigheter. På steder med ekstra stor trafikk kan turistbelastningen likevel bli i meste laget. Det er mange små steder som til tider opplever det slik når tre-fire store cruiseskip ligger til kai samtidig; røyken ligger som teppe over stedet, og 
gatebildet preges av trengsel og fremmede. Somrene 2018 og 2019 var det nesten daglig innslag i mediene om det som kalles «overturisme». Altså står reiselivsnæringa og samfunnet overfor en rekke utfordringer. Av og til er det rett og slett for mange turister. Eller er det det? Kanskje er det først og fremst organisering og regulering som mangler. Dette er problemstillinger som blir adressert i denne boka.

\section{Turisme som diskursivt felt}

Turismen utspinner seg ikke i et vakuum. Den er en del av samfunnet. Den gjenspeiler også hvordan vi mennesker forstår verden. For eksempel er vår horisont ikke lenger landets grenser eller Europa, vi er fortrolige med tanken på å besøke all verdens steder. Og mange gjør det. For noen århundrer siden var kunnskapen om den store verden begrenset, og reisen var en måte å skaffe seg slik kunnskap på. I enkelte perioder var også helsebot en viktig grunn for å reise, folk oppsøkte steder med rent vann, ren luft og tilrettelagte spa for helbredens eller velværets skyld. I våre dager er all verdens informasjon om utenverdenen tilgjengelig, og helsen pleies daglig. Likevel appellerer reklamen til trangen til å lære og å vite, og til helsehensyn. De gamle reisemotivene lever altså videre, men mange nye har kommet til. Vi reiser nå mest for å forlyste oss. Det er både akseptert og ønsket og et viktig bidrag til vår økonomi.

Mange av reisemotivene reflekterer de store debattene i samfunnet. En måte å formulere dette på er å si at reiselivet reflekterer og bidrar til offentlige diskurser og metanarrativer (Somers 1994). Slik har det nok alltid vært. Turismen er i seg sjøl en diskurs. Det er en massiv vegg av informasjon $\mathrm{i}$ alle medier og kanaler som på forskjellig vis forteller oss at vi skal ut og reise. Vi sosialiseres til å reise, i barnehager, hvor barna ofte er på tur, i skolen, hvor klasseturer er en del av hverdagen, og i arbeidslivet, hvor det forutsettes at vi kan og skal gjøre jobbreiser (jf. Abram 2014). Arbeidet foregår ikke lenger bare der vi bor, men rundt omkring. Som akademikere forutsettes det at vi samarbeider med kolleger i andre land, hvilket også tilsier at vi må reise. Og når vi har fri, eller ferie, forventes det at vi skal reise bort. Barn som ikke får «reise på ferie», synes vi synd på. Altså blir vi overalt tilpasset en forståelse av at samfunnet er i bevegelse, og at reisen 
er en nødvendighet. Underliggende krefter i dette spillet er sjølsagt vårt økonomiske system, som er basert på fri flyt av varer, tjenester, mennesker og ideer blant annet om vekst (Viken 2014). Reiseliv er big business. Men all reisingen setter spor, og reiselivet er en vesentlig bidragsyter til klodens miljøproblemer. Åtte prosent av luftforurensningen tilskrives turismen (Giæver 2018). Paradokset er imidlertid at uten disse reisene ville vårt økonomiske system trolig bryte sammen. Det arbeides for at man skal komme ut av dette sporet. Politikerne og offentligheten snakker om det grønne skiftet, om produksjon og konsum som ikke er klimabelastende. Noen ser også for seg en utvikling hvor stordrift og økonomisk vekst ikke er styrende for alle aktiviteter, innbefattet at vi reiser mindre. Klimautfordringene er et av reiselivets største paradokser.

Folks vitebehov og utforskertrang har alltid generert reiser. Det var for eksempel en sterk hang til å utforske de arktiske områdene på 1800-tallet. Det var et av de gjenværende uutforskede og udokumenterte områdene i verden. Tidsånden tilsa at verden skulle funderes på kunnskap. Utforskningen gjorde områdene kjent, og i kjølvannet av utforskerne kom de første turistene. Sjøl om de reisende i den første tida var få, satte de spor - de banet vei for moderne turisme. Interessen for å reise økte og ble gjort mulig. Med dampskipenes inntog ble Norge og Arktis populære reisemål. Fortsatt er trangen til å utforske områder et sentralt turistmotiv, men det er ikke lenger på vegne av verden eller for å framskaffe ny kunnskap at utforskningen skjer, men på egne vegne. Folk vil med selvsyn se verden. De vil se Arktis, Antarktis, Afrika og Asia. Den samme interessen har gitt grunnlag for all verdens filmer, dokumentarer og reiseskildringer. Fordi dokumentasjonen av alle verdenshjørner er så god, skulle man tro at reisetrangen gikk ned. Tallenes tale tilsier imidlertid det omvendte, aldri har så mange reist så mye som nå (https://norsk-reiseliv.no/reiseliv-i-tall-ogfakta/), kunnskap synes altså å øke reiselysten.

En annen diskursiv plattform for reiselivet er distriktspolitikk. Lenge var dette et anerkjent politisk område, og turismen ble betraktet som et av virkemidlene. Etter hvert ble denne politikken avløst av et fokus på regional utvikling, hvor alle regionene skulle utvikles, ikke bare i de såkalte distriktene (Eikeland 2009). Også i den sammenhengen har turismen hatt en plass. Sjøl om de distriktspolitiske virkemidlene har blitt redusert, disponerer myndighetene fortsatt en sentral institusjon for næringsutvikling, Innovasjon Norge. Dette organet er imidlertid preget av en neoliberal 
tankegang, hvor forretningsdrift, avkastning og vekst er de viktigste betingelsene for støtte. Eksisterende tenkning er altså at næringslivet skal stå for vekst, mens myndighetene skal tilrettelegge. Derfor har man hatt diverse programmer blant annet for å skape eller styrke næringsklynger, i tillegg til programmer som primært har støttet kompetansefremmende tiltak, og som skaper vekst, en vekst som ikke er uten utfordringer.

Det er mange diskurser i samfunnet som fremmer reiselivet. Man diskuterer klimaendringene, og folk reiser for å se dem med selvsyn, oppleve nye muligheter som følger derav, eller for å oppleve noe før det er for seint (Lemlin et al. 2013). Det virker som om de fleste debatter kan snus til noe man kan oppleve. Paradokset er at den samfunnsutviklinga som har skapt klimaendringene, om man skal tro forskningen, skaper en reisetrang som mest trolig gjør tilstanden - altså verdens klimaproblemer - verre. Norge, med all sin natur, nyter godt av, eller er et offer for dette, alt etter hvordan man betrakter det. Det er sjølsagt også andre diskurser som favoriserer reisemål som Norge, for eksempel de som er knyttet til helse og et aktivt liv. Norge er en god arena for slikt. En sterk internasjonal diskurs er også knyttet til verdens kultur- og naturarv. Også i den sammenhengen har Norge mye å by på. Blant annet står Bergen, Røros, Vega, Alta, Geiranger og Flåm på den internasjonale lista over steder med verdensarv.

\section{Tilrettelegging}

Tilrettelegging for turisme skjer altså på to plan, gjennom den generelle samfunnsorganiseringa og gjennom en spesiell tilrettelegging for turister. Den generelle tilrettelegginga er alminnelig infrastruktur og fellesgoder. Den spesielle tilrettelegginga dreier seg om å informere, skilte, skape parkeringsplasser, etablere attraksjoner og aktivitetsarenaer, organisere transport og besøk og sørge for at det finnes overnatting og bespisningstilbud. Reiselivsnæringa tar seg av dette.

Tilrettelegginga som trengs, er for det første informasjon. Dette omfatter karter og vei- og stedsbeskrivelser og bør forefinnes i ulike medier. Det er et slags bedrifts- og destinasjonsminimum å være på Internett, at man har egen hjemmeside, er nevnt i den regionale eller nasjonale markedsføringen, blir omtalt på TripAdvisor og så videre. I tillegg trengs det en stedlig informasjon i form av skilter og merking av veier og stier. For det 
andre kreves det mange steder en fysisk tilrettelegging. Det lages besøkssentre og attraksjoner, veier og stier for bedre tilgjengelighet, plattformer for bedre utsyn, gjerder for å øke sikkerheten, klopper for bedre passering av våtområder, og toaletter og søppelsystemer der det er mest trafikk. De siste åra har det for eksempel blitt bygd såkalte sherpastier (steintrapper bygd av sherpaer fra Nepal) i mange trafikkerte fjellområder, til steder som Preikestolen, Ulriken (Bergen), Hallingskarvet (ved Geilo), Fløya (Tromsø) og Reinebringen (Lofoten). For det tredje er det ofte behov for regulering, altså at man lager regler for hvordan turister eller operatører skal oppføre seg, eller fysisk tilrettelegging som styrer (veier) og sikrer de besøkende (klopper, tau og gelendre langs naturstier). Dette kan skje i regi av myndighetene eller av reiselivsnæringa sjøl. For eksempel har vernemyndighetene bestemt hvordan man skal opptre i nasjonalparker og naturreservater, mens cruisenæringa sjøl har etablert regler for turisme i arktiske områder. Og overalt etableres veier, stier, trapper og andre transportsystemer for besøkende, alt for at turismen skal fungere bedre. Det er som regel en tilrettelegging som også lokalbefolkningen nyter godt av. For det fjerde må alt dette organiseres og administreres.

\section{Turismeutvikling}

Turismen er svært dynamisk. Den utvikler seg både innenfra og utenfra, slik vi har antydet over. Hvordan dette skjer, varierer sjølsagt. De akademiske diskusjonene om turismeutvikling er preget av ulike faglige ståsteder, og de er lite samstemte. Et sentralt tema er om utviklinga er noe som bare skjer, eller om det er resultater av intensjoner og innovasjoner. Det er mye ved norsk turisme som ikke er resultat av noens bevisste strategier, altså at aktørene bak en utvikling kan identifiseres. For eksempel gjelder det den tidlige turismeutviklinga - som utviklinga av sightseeingsturismen eller hytteferier. Det var noe som skjedde ved at folk var nysgjerrige, kunnskaps- eller opplevelseshungrige og dro i vei til ukjente farvann, eller de la ferien til bygdene de eller deres forfedre kom fra. På en måte var denne utviklinga betinget av fortida, men representerte en ny tid. Fjellturismen derimot var mer intensjonell, i den forstand at man etablerte en forening til denne turismens fremme (Den Norske Turistforening, 1868), og tilpasset infrastruktur i form av hytter og stier. Ofte er det en 
blanding, noen har intensjoner om noe, og så skjer det mye mer eller noe annet enn det tiltenkte. Det som skjer i Norge, trender ute i verden og tida det skjer i. Utviklinga skjer, men ikke uavhengig av fortida, ei heller av verden omkring, og sjølsagt finnes det alltid noen aktører involvert i det som skjer. Ma og Hassink (2013) konstaterer at turismeutvikling som regel både er stiavhengig eller historisk betinget, kontekstavhengig og satt ut i live av mennesker. Terrenget turismen skjer i, blir ofte omtalt som komplekst. Næringsaktørene og utviklinga er påvirket av svært sammensatte kunnskaps- og teknologisystemer som er mer eller mindre åpne, mer eller mindre påvirket av samfunnet omkring. Derfor er turisme et tema i mange fag: ledelse, planlegging, markedsføring, forretningsutvikling, produktutvikling, kvalitetstenkning, nettverksorganisering, osv. (Pavlovich 2014). Og den er basert på all slags teknologi for bygging, transport og informasjonsflyt. Uten bil, buss, skip, tog, fly og avanserte datasystemer ville turismen sett ganske så annerledes ut. Kompleksiteten består altså av mennesker, materialiteter, informasjon og ideer, og av bevegelser og møter i et uoversiktlig spill og samspill.

En annet teoretisk tilnærming til turismeutviklinga omfatter relasjonelle teorier. Bathelt og Glückler (2003) beskriver hvordan et relasjonelt geografisk perspektiv er forskjellig fra en tradisjonell forståelse. De illustrerer forskjellen på måter man betrakter materielle ressurser, kunnskap, makt og sosial kapital på. Tradisjonelt har ressurser og kunnskap blitt sett på som noe forhåndsdefinert, sosial kapital som en ressurs å søke, og makt som innskrevet kapasitet (ibid., s. 1547). I en relasjonell tilnærming betraktes ressurser som muligheter, kunnskap som kollektive fortolkninger preget av faglige ståsteder, sosial kapital som energi produsert mellom aktører, og makt som følge av nettverk og mobilisering (ibid., s. 1547). Dette kan demonstreres av turismeutvikling fra Nord-Norge som ståsted. Nordlyset er et naturfenomen, men ikke sett som en ressurs for turisme før noen satte det inn i en turistisk ramme så seint som på begynnelsen av 2000-tallet. I Tromsø ble ideen tatt opp av en rekke entreprenører, støttet av institusjoner som Hurtigruten, det lokale destinasjonsselskapet og forskningsmiljøet (Heimtun \& Viken 2016). Flere kunnskapsfelter har vært sentrale, og både nordlysforskere og andre fra forskningsmiljøene ble brukt for å bygge opp fortellingene og identiteten rundt fenomenet. Dessuten har de største aktørene jobbet sammen om utviklinga i mer eller mindre formaliserte nettverk som har styrket næringas posisjon og konkurransekraft, kanskje 
på bekostning av nabodestinasjonene. Altså er nordlysturismen et resultat av relasjoner mellom et naturfenomen og aktører med ulik bakgrunn, relasjoner som har skapt det som i dag framstår som en bærekraftig næring. Utviklinga av turismen er ikke bare kompleks, den er også et relasjonelt anliggende.

\section{Bokas hovedperspektiv: turismens paradokser}

I boka pekes det på et svært broket turistisk landskap. Dette rommer både muligheter, utfordringer og paradokser. Et paradoks står som regel som en kontrast eller motsetning til en gjengs oppfatning av noe, i en del teoretiske sammenhenger kalt «doxa». Samfunnsvitere som Roland Barthes og Pierre Bourdieu var begge opptatt av doxa. Det er altså relativt lite presise oppfatninger om verden omkring oss eller av begreper, eksempler kan være forestillinger om demokratiet som en ideell styreform, trykkefrihet som en menneskerett, bærekraft som et overordnet miljøperspektiv, nyliberalismen som et rasjonelt økonomisk system. For alle disse prinsippene finnes det minussider og diskutable aspekter. Det er mange paradokser knyttet til demokratiet; mange deltar ikke, noen faller utenfor, det gir rom for eliter. Når noen vinner valg, kan det være store grupper som taper, og som står langt fra den politikken vinnerne vil føre. Bourdieu var særlig opptatt av nyliberalismen som doxa. Den framstilles som en åpenbar sannhet om samfunnet. Men på det grunnlaget er ikke staten lenger en garantist for de sosiale profilene til utdannings-, helse- eller velferdssystemene i Europa (Chopra 2003), og under dekke av globalisering utvannes arbeidslivssystemene som har vært utviklet. Bourdieu betraktet nyliberalismen som en altomfattende kolonialisering (Bourdieu 1998). Som vi skal vise i denne boka, er det en rekke paradokser knyttet til en turisme underlagt en slik nyliberalistisk tankegang. Det betyr at staten har en svekket rolle i utviklinga, det betyr kapitalens frie spill, noe som gjerne medfører at lokalsamfunns inntekter, styring og makt reduseres, og eksterne aktører overtar. Samfunnet er fullt av paradokser, det samme er turismen (Dann 2017). Paradoksene kan ha karakter av ord som står i motsetning til hverandre, som arbeidsferie, feriestress og stressferie. Det kan også være begreper som ikke stemmer med virkeligheten, altså et misforhold mellom tegn og det som betegnes: fiskevær, landsbyidyll kontrastert med horder av turister, 
lokalsamfunn eller landsbyer preget av turistvirksomhet og deres symboler og kunder, altså ikke det lokale. Og det kan være virkelighetsoppfatninger som står mot hverandre. Doxa, slik Bourdieu, ser det, henger sammen med habitus og kulturell kapital (Chopra 2003). Det som fortoner seg som doxa for noen, er et paradoks for andre. Reiselivsnæringa ser på turistifiseringen som en naturlig og ønsket utvikling, for eksempel i Lofoten eller Tromsø, mens andre ser det som noe negativt. Utvikling betyr vekst på måter som ikke nødvendigvis tjener lokalsamfunnene. Dette er ett av paradoksene ved turismen, sier Shanks (2016) i en tekst om temaet.

Turismen er et paradoks i seg sjøl. Turisme er reiser for fornøyelsens skyld. Men reisen er ofte en påkjenning. Det engelske ordet «travel» har samme opprinnelse som det franske ordet for arbeid, «traveil». Under den tidlige turismen var det mange som syntes det å være turist på moderne vis var å bli fraktet rundt som en pakke. Det var ikke en ordentlig reise, slik de så det. Men det er mange andre paradokser i turismen. Den har skapt utvikling mange steder, men tenderer mot å innta imperialistiske eller koloniale former når den er særs vellykket. Utvikling som begynner $\mathrm{i}$ det små, ender opp som fjernstyrte operasjoner kontrollert av og fra finanssentre. Og turismeutvikling som har hatt som mål å skape økonomisk utvikling, har ofte ført til miljømessige problemer, eller at utviklinga ikke løser problemene. Folk begynner med turismeutvikling for å skape aktivitet og arbeidsplasser i bygda, men ender ofte opp med bare utenlandske tilsatte. Cruiseskipene, som representerte starten på sightseeingsturismen i Norge, var fylt med folk fra bemidlede klasser i Europa som oppsøkte fjorder og landlig idyll. I våre dager har idyllen falmet. Cruiseturisme er det nærmeste vi kommer masseturisme her til lands. Skipene er blitt så store og passasjerene så mange at de formelig tråkker ned og fortrenger det som en gang skapte trafikken. Begrepet «overturisme» er et godt uttrykk for dette paradokset.

$\AA ̊$ være turist representerer en aktivitet som i utgangspunktet ikke er kommersielt motivert. Trangen til å se, oppleve og utforske er ikke kommersiell. Men slike aktiviteter lar seg bare realisere gjennom kjøp og salg av tjenester. Sjøl om dette kan fortone seg som et paradoks, er det kanskje ikke så spesielt. De fleste behov og ønsker lar seg imøtekomme kommersielt. Forholdet mellom det kommersielle og alternative verdier representerer i seg sjøl en spenning. I boka tar vi opp slike spenninger gjennom å dokumentere og analysere turistiske forskjeller mellom store og små 
aktører, by og land, sentrum og periferi, økonomiske og ikke-økonomiske verdier. Mantraet innen dagens næringspolitikk - hverdagsoppfatningen (doxa) - er at stor er bedre enn liten, by bedre enn land, sentrum bedre enn utkant. Men alle er ikke enige i dette, og noen demonstrerer alternative muligheter og motarbeider disse tendensene. Reiselivsutviklinga har både sine kritikere og forsvarere. Også det er et dilemma; det er vanskelig å gjøre alle til lags. Reiselivet representerer en viktig økonomisk sektor, det sysselsetter og bidrar til økonomien i mange lokalsamfunn, og ikke minst er det en distriktsnæring. Men turisme tar plass, er synlig og til tider forbundet med brautende og støyende aktiviteter. Den vil alltid ha sine kritikere og motstandere. Derfor er et av de fremste paradoksene at mange av oss misliker turismen, men liker å reise.

Mange av de debattene som her er tatt opp, er ikke nye. I Norge har man drøftet utbygging av tog og veier, vern av natur og kulturminner, friluftsliv, cruiseturisme og organisering av reiselivet i alle fall siden sist på 1800-tallet. Da som nå var man for eksempel opptatt av at cruiseskipene, de flytende hotellene som de ofte ble kalt, ikke ga inntekter på land. Men da som nå var det noen som tjente penger også på denne aktiviteten. Vi skal, først og fremst som en kontekst, begynne denne boka med å sette vår tid inn $\mathrm{i}$ en tidsmessig ramme, gjennom å presentere noen trekk ved og begivenheter som karakteriserer turismeutviklinga i Norge. Nordmenn har alltid reist. Helt fra vikingtida er vi kjent som et reisende folk, og statistikken forteller at vi i dag er blant de mest reisende.

\section{Bokas kapitler}

Boka er basert på forskning som har foregått de seinere åra, først og fremst ved UiT Norges arktiske universitet. Forskningen har i hovedsak vært casestudier og studier basert på bruk av kvalitative metoder. I varierende grad er de metodiske sidene ved arbeidene presentert og diskutert i kapitlene. Fokus er på funn, hva våre studier kan lære oss om turisme- og samfunnsutvikling.

Boka starter med dette innledende kapitlet (1) som påpeker en del paradoksale sider ved norsk turisme, dens vesen og uvesen. I kapittel 2 tar vi for oss reisende nordmenn i gammel tid, fra før vikingetida og fram til 
seinmiddelalderen. Det viser først og fremst at nordmenn lenge har vært et reisende folk, og at disse reisene har satt spor. Mot slutten av kapitlet presenteres forløperne til dagens turisme, hvordan man begynte å ta fjellene i bruk for fritidsmål, hvordan sightseeingsturismen begynte, hvordan byfolket begynte å feriere på landet. I tilknytning til kapitler som omhandler noen viktige destinasjoner, som Odda, Lofoten og Svalbard, har vi lagt inn små beskrivelser av den lokale turismeutviklinga.

I del II av boka er perspektivet på noen sentrale spenninger i feltet. Først (kapittel 3) ser vi på relasjonen mellom store og små bedrifter, og hva størrelse har å si for opplevelsene. Dernest (kapittel 4) diskuteres campingdrift, som en marginal aktivitet mellom sosiale og økonomiske systemer. Uten dugnader og uformelle økonomiske systemer ville mange campingplasser ikke vært liv laga, antydes det. Men de kan ha viktige sosiale funksjoner i bygdene. I kapitlet deretter (5) ser vi på utviklinga av hvalsafari på Andøya. Utviklinga av denne attraksjonen hadde forankring i flere definerte fag - både biologiske og utstillingsfaglige. Som et element i en destinasjonsutvikling gikk det atskillig tregere. Vi antyder at forskjellen har å gjøre med kunnskapstyper, som ikke er særlig klare eller aksepterte for destinasjonsutvikling. I kapitlet deretter (6) ser vi på turismen på Nordkapp som er et godt eksempel på fjerndrift. Denne typen turisme har høstet misnøye lokalt. Sjøl om lover og regler følges, framstår det som en drift med et umiskjennelig kolonialt preg. Det samme kan man kanskje si om det som følger, et kapittel (7) som særlig fokuserer på eierforhold innen rorbuturismen i Lofoten, hvor eksternt eierskap blir mer og mer vanlig.

Del III drøfter reiselivets rolle i en del samfunnsprosesser. Først (kapittel 8) drøftes Hurtigrutens rolle som katalysator for turismen på Nordkinn. Hurtigruten var i dette tilfellet helt avgjørende, men dermed har man også et tilfelle av avhengighet og skjørhet. Hva skjer om Hurtigrutens seilingsplan endres? I kapitlet etter (9) vises det hva som er næringsgrunnlaget to i Badderen og Årviksand i Nord-Troms. Turismen har bare en marginal rolle, men representerer samtidig en mulighet, $i$ alle fall på det ene stedet. Om dette er en ønskelig utvikling, er en annen sak. I et kapittel (10) som tar for seg utkanten av en utkant, Langfjorden i Alta kommune, er nettopp det en problemstilling: Er turisme den eneste framtidsutsikten, eller finnes det alternative næringsveier? Også i dette kapitlet er turismen bare en del av tematikken, problemstillingen er også her hva som holder stedet i gang, 
og om lokal omstilling og tilpasning til en politikk som helst så slike steder forsvinne. I neste kapittel (11) vises det at turisme er en sterk kraft, og en kanal for drøfting og realisering av alternative utviklingsstrategier - i kapitlet vises hvordan utviklinga av et skisted løste opp i en gammel konflikt om en vei mellom to skytefelt, gjennom et reinbeite.

I del IV av boka tar vi for oss friluftsliv og naturbasert turisme. I det ene kapitlet (12) vises det til behov for mer omfattende styring og regulering. Det virker som om turismen mange steder har kommet som julekvelden på kjerringa, man er ikke helt forberedt, særlig ikke for veksten i naturbaserte aktiviteter, som paradoksalt nok er det man frister med i markedsføringen av norske destinasjoner i utlandet. I det andre kapitlet (13) i denne bolken beskrives en prosess der retningslinjer for bruk av konkrete besøkssteder på Svalbard ble skapt -. Dette skjedde i regi av reiselivsnæringa og representerer et eksempel på sjølregulering.

I en epilog, i bokas siste kapittel (14), drøftes noen av utfordringene i dagens turisme, om det finnes alternativer til vekst og stordrift, om fjerneierskap er uunngåelig, om vi trenger cruiseturismen, og de utfordringene allemannsretten står overfor. Kapitlet avsluttes med å konstatere at en bærekraftig utvikling krever handling.

\section{Litteratur}

Abram, S. (2014). Destination development performances: Or how we learn to love tourism. I A. Viken \& B. Granås (red.), Tourism destination dynamics. Turns and tactics. Farnham: Ashgate.

Bathelt, H. \& Glückler, J. (2003). Toward a relational economic geography. Journal of Economic Geography, 3 (2), 117-144. https://doi.org/10.1093/ jeg/3.2.117

Bourdieu, P. (1998). Practical Reason. Stanford: Stanford University Press.

Butler, R. (1980). The Concept of a Tourist Area Cycle of Evolution: Implications for Management of Resources. Canadian Geographer, 24 (1), 5-12. https://doi.org/10.1111/j.1541-0064.1980.tb00970.x 
Chopra, R. (2003). Neoliberalism as doxa: Bourdieu's theory of the state and the contemporary Indian discourse on globalization and liberalization, Cultural Studies, 17, 419-444. https://doi.org/10.1080/0950238032000083881

Dann, G. (2017). Unearthing the paradoxes and oxymora of tourism. Tourism Recreation Research, 42 (1), 2-10. https://doi.org/10.1080/02508281.2016.1 222651

Eikeland, S. (2009). Frå stat til region - og tilbake? I E. Angell, S. Eikeland \& P. Selle (red.), Nordomradepolitikken sett fra nord (s. 98-117). Bergen: Fagbokforlaget.

Franklin, A. (2012). Ordering. I R. van der Duim, C. Ren \& G. T. Johannesson (red.), Actor-network theory and tourism. Ordering, materiality and multiplicity. Oxon: Routledge.

Giæver, O. P. (2018). Turisme står for $8 \%$ av globale $\mathrm{CO}_{2}$-utslipp. ABC Nyheter. https://www.abcnyheter.no/reise/reisenyheter/2018/05/08/195394270/ turisme-star-for-8-prosent-av-globale-co2-utslipp

Heimtun, B. \& Viken, A. (2016). Nordlysturismen - en institusjonelt betinget utvikling? I A. Viken (red.) Turisme. Destinasjonsutvikling (s. 175-197). Oslo: Gyldendal Akademisk.

Lemelin, H., Dawson, J. \& Stewart, E. J. (2013). Last chance tourism: adapting tourism opportunities in a changing world. London: Routledge. https://doi.org/10.4324/9780203828939

Ma, M. \& Hassink, R. (2013). An evolutionary perspective on tourism area development. Annals of Tourism Research, 41, 89-109. https://doi.org/10.1016/j.annals.2012.12.004

Pavlovich, K. (2014). A rhizomic approach to tourism destination evolution and transformation. Tourism Management, 41, 1-8. https://doi.org/10.1016/j. tourman.2013.08.004

Shanks, C. (2016). Paradoxes of modern tourism. www.matadornetwork.com/bnt/ the-9-paradoxes-of-moderntourism

Somers, M. (1994). The narrative constitution of identity - relational and network approach. Theory and Society, 23 (5), 605-649. https://doi.org/10.1007/BF00992905

Viken, A. (2014). Destinations discourses and the growth paradigm. I A. Viken $\&$ B. Granås (red.), Tourism destination dynamics. Turns and tactics. Farnham: Ashgate. 



\section{REISENDE I NORGE GJENNOM TIDENE}

Ola Sletvold og Arvid Viken

\section{Innledning}

I Norge som ellers i verden er reiselivet et gammelt fenomen. Landet vårt har vært gjenstand for utforskning og kartlegging, vikingene var kjent som et reisende folk, vi har vært avhengige av hjemlige og fremmede handelsreisende, våre forfedre valfartet og deltok i korstogene, militære og sivile øvrighetspersoner og kirkeautoriteter har reist rundt og sikret makten og styrket troen. Våre områder har vært gjenstand for fremmedes ekspedisjoner og kartlegging og deres økonomiske virketrang. Og i moderne tid ble Norge tidlig et mål både for folk som søkte utfordringer i naturen som fjellturister, og for dem som først og fremst ville beskue naturen, altså bedrive en eller annet form for sightseeing. I dette kapitlet drar vi opp noen hovedlinjer i utviklinga av reiselivet i Norge. De første delene av kapitlet trekker en linje fra den første tida vi kjenner til, nordmenns førhistoriske og tidlige tiders reiser, deriblant om reisene til Ottar, vikingene, pilegrimer og hanseater. De siste delene gjelder den moderne reiselivsutviklinga i Norge fram mot dagens turisme. Kapitlet starter med å dvele ved begrensningene som ligger i denne typen tekster, kildene er temmelig spredte og ikke alltid like gode eller av samme slag. Vi beskriver sider ved reisens utvikling som på noe vis omhandler Norge og nordmenn, fra Ottar på 800-tallet til romantikken nesten tusen år seinere. Deretter ser vi på de tydeligste og mest vedvarende trekkene ved reiselivet i Norge i moderne tid. 


\section{Tidslinjer og historie}

«Fortida er et fremmed land», sier Lowenthal (1985), og akkurat som turistreisenes midlertidige forflytninger resulterer i stykkevis og delte inntrykk av fremmede steder, består historieskrivning gjerne av utvalgte hovedtrekk eller avgrensede dypdykk i fortida. Dette er en verden som enhver generasjon forstår gjennom sin tids blikk og termer. Så langt historikeres narrativer kan representere sannhet (Sandmo 2015, s. 181 f.), vil for eksempel framstillinger av reiselivet før vår tids turisme være avhengig av leserens aksept av at en slik tynn reim av fortidas virkelighet lar seg fortelle. Man må gå med på skrivernes emplotment (Hayden \& White 1978). Målet med og formålet for reisene var trolig ikke alltid klart, like lite som det er for våre dagers turister. Den hermeneutiske innsikten i hvordan man møter beretninger fra fortida med sine egne forforståelser, kan spores allerede hos Augustin (354-430) (Sandmo 2015): Det er umulig å overskride helt den forskjelligheten som skapes av vår egen tids rammer. Kulturforståelse langs tidsdimensjonen møter problemer som er parallelle til dem Cohen og Cohen (2015) peker på for studier for turismen i ikke-vestlige områder, der man hittil har anvendt det vestlig-moderne blikket på fenomener som trenger andre blikk. Rendyrket gjelder dette det synkrone versus det diakrone perspektivet, det vil si det samtidige versus det tidsutspente. For historikere er det nettopp tidsavstanden som gir fascinasjon og fortryllelse (Sandmo 2013). Mens sosialantropologien heller i retning det synkrone (Barth 1970; Bråten 2013) og dermed mener å unngå determinismen, er sosiologien i større grad opptatt av tidsdimensjonen i samfunnets utviklingsprosesser. Til grunn for de ulike perspektivene ligger syn på «tid» som fenomen og filosofisk problem (jf. Sandmo 2015). Denne teksten rommer ikke en videre drøfting av dette, den er pragmatisk orientert mot et riss av fortidig reising. Og med det vide perspektivet skissert ovenfor dreier det seg i mange sammenhenger om mobilitet mer enn om turisme.

Det lar seg ikke nekte at kildene for å belegge nordlige reiselivshistoriske linjer fra førhistorisk tid, altså før de skriftlige beretningene utgjør et dominerende kunnskapsgrunnlag, og fram til for 200 år siden, er både få og spredte, og de som finnes, er ikke studert med fenomenet turisme for øyet. Mye kunnskap kommer fra arkeologien. Faren for å miste den 
historiske konteksten er imidlertid overhengende. Fortellingen om reisene i og til våre egner vil måtte henge sammen med den store fortellingen om menneskers mobilitet, enten forflytningen er av tvang eller frivillighet, av nysgjerrighet eller nødvendighet, og gamle tiders reiser som en blanding av trang til utforskning, eventyr, økonomisk vinning eller makt, eller for å glede seg sjøl og andre. I tråd med ønsket om å unngå determinisme kan man betrakte gløttene av fortidig reiseliv i nord som noe kontrapunktisk til dagens turisme, som deler av andre livsverdener, men også som elementer i den konstruksjonen av kontinuitet og brudd som historieskrivningen bedriver.

\section{Reisemålet Thule}

Turismehistorie som innslag i samfunnsvitenskapelige turismefag starter ofte med The Grand Tour, de europeiske elitenes dannelsesreiser i perioden cirka 1600-1800 (Walton 2009; Towner 1991). Beskrivelser av reiseliv før denne tid består gjerne i glimt fra den klassiske antikken, for eksempel romernes interesse for det gamle Egypt (Casson 1994). Garay og Cànoves (2011) tar i bruk termen "proto-turisme» for den reisevirksomheten som bærer i seg kimen til en sammenhengende utviklingslinje fram til i dag. Det følgende griper tilbake til en tid da det man i dag mener er «Reisemål Norge», ble et sted andre enn de som bodde der, visste litt om, og hviler på den vide forståelsen at turisme er å oppsøke eller besøke det som ligger bortenfor heimen. «Nordlig» er en relativ størrelse, og det tar århundrer før Skandinavia nord for Skagerrak blir steder for annet enn de innfødtes egen reising. De forholdsvis få som streifet og bodde langs våre kalde kyster før skriftkulturen, hadde sine kontakter og bytter, sammenstøt og sammenkomster, og arkeologien påviser ganske bastant deres mobilitet gjennom gjenstander, materielle tegn som må ha reist fra fjerne strøk til nordlige utkanter, som del av menneskers forflytning. Men den skriftlig dokumenterte starten på at dette nordlige skulle bli en del av den verden man reiste til og i, ble gjort av grekeren Pytheas cirka 330 f.Kr. Han påsto å ha sett midnattssol og drivis, han fant 'øya Thule' (Casson 1994, s. 118), som moderne beregninger plasserer på norskekysten mellom 63 og 66 grader nord, det vil si mellom Smøla og Dønna. 


\section{Med Norðweg på babord side}

Det ligger 1200 år mellom Pytheas og Ottar - en nordboer - og hans fortelling om sitt land og om en handelsekspedisjon derfra til det mer sofistikerte England (Bammberger 2010; Bately 2014). En skriver hos kong Alfred gjengir (cirka 890) Ottars reiseberetninger, både om reisen østover kysten til Kvitsjøen og Dvina, og om den lange ferden gjennom 'Norðweg' til Kaupang i Vestfold, via søndre Danmark til England. Man må anta at dette ikke var den eneste reisen Ottar foretok. Fra sitt sete på en av øyene i Troms har denne farmannen (Moseng et al. 1999, s. 242; Storli 2018)) drevet fangst av sjøpattedyr og krevd inn avgift eller byttet til seg gaver fra samer, og med dette muliggjort også eksport sørover. Han forteller om 'finner', kvener og andre finsk-ugrisktalende folkegrupper, og fortellingen påviser en tidlig fase av handelsreiselivet sørover og østover langs de nordlige kystene. Noen vil kunne se Ottar som representant for den norrøne kolonialismen. Da han fortalte om sin reise og sin handelsvirksomhet, ga det mottakerne en kunnskapsutvidelse eksotisk nok til å bli tatt med i en bearbeidelse av en grunnbok i historie og geografi fra 400-tallet (Bately 2014, s. 15).

Ottar var én av flere høvdinger. Andre høvdingseter fra samme periode (200-900) i Nord-Norge er lokalisert eksempelvis på Borg og Vågar i Lofoten, Bjarkøy i Troms og Tjøtta på Helgeland. Disse sentrene ble steder der økonomisk makt ble samlet, noe arkeologene avleder av størrelsen og mengden av båthus og gårdsanlegg. Båthus store nok til å romme skip på størrelse med Osebergskipet tyder på kapasitet til å forflytte militære styrker og godsmengder (Perdikaris 1999). I tillegg hadde man også nærliggende steder for lokale eller regionale ting, som samlet folk til forhandlinger om juridiske og politiske saker (Storli 2010). Størrelsen av anlegget på Borg og funn der tyder på at slike høvdingseter også var regionale sentre dit folk reiste for å delta i hedensk kult (Nielsen 1993; Resi 2004).

Ottar sto i forbindelse med det omfattende handelsnettverket rundt Nordsjøen og Østersjøen, der mer sørlige høvdinger var sentrale (Christiansen 2002, s. 209 f.). Man har gjort funn av reinsdyrhorn fra før 800 i Ribe i Danmark og betydelige funn i Nord-Skandinavia av frankiske mynter og glass fra 700-tallet og framover (Roslund 2015; Melleno 2014). Frankiske sverd og pyntesaker som draktspenner og brosjer og glass fra 
Rhin-området og England viser at eliten for eksempel på Borg var i jevnlig reise- eller handelsmessig kontakt med tilsvarende eliter sør i Skandinavia, England og på kontinentet (Resi 2004). Over 80000 mynter fra islamske kulturer er funnet i Norden og vitner om et omfattende handelsreiseliv til Svartehavs-området over Baltikum og langs russiske elver (Moseng 1999, s. 32). Mynter og drikkeglass betyr at mennesker møttes: Handel impliserer kommunikasjon og interaksjon, språkpåvirkning og giftermål, observasjon av og tilpasning til andres skikker og ritualer. Det er vanskelig å få noe særlig bilde av individer som sto for handelsreiselivet. Kanskje var det liten status forbundet med slikt arbeid, der mange var involvert i allsidige transportformer - per båt på elvene og per karavane over land. Handelsvirksomheten nordfra til Bysants hadde også sine risikofylte sider, man måtte kunne forsvare seg sjøl og fraktgodset både på tur og retur (Christiansen 2002, s. 212). Det nordboereliten bidro med i handelen, var statusfremmende luksusvarer i sør: dun, fine skinn, huder og hvalolje, i tillegg til mindre forgjengelige ting som bein fra hval, hvalross og rein, og kleberstein og slipesteiner (Storli 2010). Etter hvert ble tørrfisk den dominerende varen, som vi skal se.

Pytheas og Ottar seilte, men folk flest tok seg fram over land. Karavanerutene er eldre enn vikingferdene, og hvor tidlig stier i Norge ble «veier», er uklart, men de norske landsdelslovene fra tida før 900 og Magnus Lagabøtes landslov fra 1274 omfattet bestemmelser om kollektiv innsats for å vedlikeholde det som var av veier: «... den næraste vyrkedagen før jonsokaftan skal alle våpenføre menn vøla vegar ... og over alle tverråer gjera bruer» (Hagland \& Sandnes 1994, s. 46). Man har i Trøndelag funnet kavlebruer, det vil si stokker lagt ned i myra som brulegning, datert til tidsrommet 900-1100, og varding over fjell mellom Jämtland og Norge fra begynnelsen av 1000-tallet (Smestad 1996).

En ubehagelig vare sett med vår tids øyne var slavene, de livegne, på norrønt prall (trell). Datidas samfunn var basert på at noen mennesker var andres eiendom, og dermed gjenstand for kjøp og salg. Treller skaffet man seg på røvertokt i nabofjorden, på den andre siden av havet eller fjellet, eller i Baltikum på vei til Bysants. Mange av dem var kvinner som endte som konkubiner for stormenn og småkonger, noe som la grunnlag for arvestrider (Karras 1990). Det er ikke utforsket hvorvidt slave-varen ble omsatt på markeder i særlig grad (Holm 1986), som del av vikingøkonomien ble de sannsynligvis heller utvekslet mot løsepenger. Trellene kunne 
imidlertid utgjøre en slags diaspora, slik som kristne slaver i det hedenske Birka. De betød varige kulturimpulser utenfra og kunne kommunisere med frivillig reisende som kom som misjonærer, og representerte noe kjent for disse (Melleno 2014, s. 77). Reisevirksomheten var likevel en forholdsvis profesjonalisert aktivitet, mest tydelig for det kirkelige kommunikasjonssystemet mellom Roma og de perifere kirkelige sentra. Det var sårbart og tørket ut hvis viktige ledd forsvant, veien fra struktur til kollaps var bare noen steg lang (Sindbæk 2007).

Roesdahl (1991, s. 78 f.) gir en oppsummering av hva reiseliv på denne tida dreide seg om: 'Folk reiste til lokale og nasjonale ting og religiøse fester, til familiefeiringer og markeder. Handel, krig og diplomatiske oppdrag brakte dem utenlands' (forf. overs.). Bortsett fra at fritidsreiselivet ikke fantes, ettersom 'fritid' er et moderne begrep, ser det ut til at reisegrunnene var de samme da som nå. Skalden Sigvat Tordsson, utsending fra Olav Haraldsson til Ragnvald Jarl, omtaler i diktet 'Austrfararvisur' de gjenkjennelige utfordringene som møtte reisende også den gang: såre føtter og mangel på søvn, en lekk båt, problemer med å finne nattely (Roesdahl 1991, s. 82).

\section{Vikingene: ransmenn, handelsmenn, migranter}

På Ottars tid hadde det mest bemerkelsesverdige av alt reiseliv som nordboerne noen gang har bedrevet, allerede pågått i minst hundre år, nemlig vikingferdene. Årsakene til denne ekspansive reisingen er både mangfoldige og omstridte - en økonomisk blomstringstid der voldsbruk var det normale for å skaffe seg rikdom. I det ustabile europeiske bildet, der frankerrikets ekspansjon ble møtt av dansk motstand, kunne vikingene briljere i teknologisk-taktisk overlegenhet (Moseng 1999, s. 35 f.). Deres suverene båtteknologi og navigasjonskompetanse var deres store fortrinn. I den norrøne kulturens utferdstrang lå en oppfatning av det romlige, der havet ble opphevet som et reisehinder (Laget 2013). Både vikingraidene og koloniseringen i Nord-Atlanteren representerer eksempler på at teknologiforsprang gir grunnlag for endret reiseliv (Walton 2009, s. 788).

Vikingenes stridsferdigheter i raske, nådeløse raid var åpenbart skremmende. Men det som først hadde en definitiv karakter av plyndring og vold, endret over tid både de reisende sjøl og stedene de kom til. Kri- 
gere ble kolonister, eventuelt landnåmsmenn. Røvere ble handelsmenn og kjøpmenn. Reisende ble bofaste, det som først var sesongmessige tokt, ble migrasjon. Dublin og Jorvik (York) var byer preget av vikingkultur. Vikingenes ferder koloniserte en ny verden i vest - Island, Grønland, Vinland. Svenske vikinger dro østover og ga navn til Russland - navnet henger sammen med at vikingene rodde opp elvene (Christiansen 1999, s. 115). Hedendom møtte kristendom. Vikinger på tokt eller utenlandsopphold - eksempelvis Olav Haraldsson - ble omvendt og brakte med seg hjem også prester til nye nordlige misjonsmarker. Grimkjell omtales som Olavs «hirdbiskop». Slik fikk kirke og statsmakt i løpet av 1000- og 1100-tallet mer eller mindre samme autoritetsbasis, statlig i form av arverett etter Olav Haraldsson og kirkelig som tilbedelse av St. Olav, og det var nærværet av konge- og kirkemakt som ga grunnlaget for byutvikling (Moseng 199, s. 234). Denne autoriteten ga også grunnlag for den mest omfattende langdistanse reisevirksomheten på denne tida som ikke er handels- eller statsmaktbasert, nemlig pilegrimsfarten til Nidaros.

\section{Pilegrimsattraksjon: «Olavsskrinets magnetiserende nådekraft»}

Det er anakronistisk å bruke termen destinasjon om pilegrimsmål i middelalderen, og det kan fortone seg som en variant av medievalisme, altså konstruksjoner av det middelalderske som ledd i identitetsbygging (Aavitsland 2006). Pilegrimsreiser tjener likevel som tematisk fordypning av fenomenet turisme, ettersom konsentrasjonen av pilegrimene, tilreisende med en ikke-yrkesmessig begrunnelse for sin reise, dannet basis for det man i dag gjenkjenner som betingelser for at et sted blir et reisemål: overnattings- og serveringstilbud i kroer og vertshus, transportløsninger som konsesjonerte pilegrimsskip (for eksempel fra England til Spania) og å tilkjenne beiterettighet til ridende pilegrimer, reisehåndbøker med rute og praktiske anbefalinger på veien til valfartsmålet, salg av pilegrimsutstyr og -effekter, alle mulige hjelpende og utnyttende hender. Og en pilegrim var gjenkjennelig antrukket i sin kappe og hatt. Det avgjørende elementet var pilegrimsmålenes severdigheter: relikvier og feiringene av helgenenes døds- og helliggjøringsdager. 
Til å begynne med synes pilegrimsreisene å ha vært begrunnet med ønsker om å oppsøke helbredelse. Danbolt (1997, s. 198) taler om «Olavsskrinets magnetiserende nådekraft». Å være pilegrim var i utgangspunktet ikke den typen frivillige valg som vi mener å se i dagens fritidsreiseliv. Det lå kirkelig anbefaling eller pålegg bak, men begrunnelsen for pilegrimsfarten endret seg over tid. I takt med kirkens økte rolle i folks hverdag og dens behov for finansiering ble valfarten gjerne pålagt av en prestelig autoritet som bot og knyttet til gaver og frikjøp fra syndige gjerninger. «Man laget på 1300-tallet et slags åndelig bokholderi av avlat og skjærsild», sier Danbolt (1997, s. 202). «For Rom og de andre mest besøkte valfartsstedene var pilegrimstrafikken big business ... store beløp i ofringer og ... prydgjenstander i gull og sølv. Hele byer kunne leve stort gjennom denne middelalderlige form for turisttrafikk», heter det hos Blom (1992, s. 13). I det katolske hierarkiet av pilegrimsdestinasjoner i høymiddelalderen, der toppserien besto av Jerusalem, Roma og Compostela, hører feiringen av St. Olav til i nest øverste divisjon. Olav Haraldsson tapte slaget på Stiklestad den 29. juli, et gunstig festivaltidspunkt i en nordlig klimasone. Olsok i Nidaros (Trondheim) ble en gedigen internasjonal (i alle fall skandinavisk) hendelse, massesammenstimling av lokale og tilreisende, kjeltringer og fromme, kropp og sinn, opptog og musikk, skjemt og alvor, hysteri og mysterier. Det er betydelige problemer med å fastslå omfanget av trafikken til Nidaros. Byen hadde cirka tre tusen innbyggere og Norge under en halv million mennesker i høymiddelalderen. Dersom en prosent av nordmennene valfartet til olsokfest, ble folkemengden i Nidaros altså fordoblet (Næss 2011, s. 119).

Mange steder kunne høste av pilegrimsfarten til Nidaros. Det er påfallende mange kirker langs de tradisjonelle ledene som var viet til St. Olav (Blom 1992, s. 10). Ytreberg (1930) omtaler 22 bilder eller figurer av St. Olav i nordnorske kirker. Mens denne helgenen hadde høy status internasjonalt, fantes også helliggjorte mennesker av mer lokale dimensjoner og som grunnlag for mer avgrenset regional trafikk. I Europa fikk man etter hvert flere hundre pilegrimsmål, så konkurransen disse stedene imellom var hard. Dagens trønderske turisme prøver også å trekke veksler på pilegrimstrafikken. Pilegrimsledene fra sør, øst og nord er tilrettelagte vandringsleder (http://pilegrimsleden.no/), og programmene til sommerfestivalen Olavsfestdagene blander en gjenoppliving av kirkelige og verdslige middelalderskikker med samtidsmusikk og kommersielle show (http:// www.olavsfestdagene.no/). 
Pilegrimsbetegnelsen har fått en generalisert anvendelse i en forståelsesmåte av også dagens turisme, lansert av Turner (1978) og videreført av MacCannell (1989). Her ses pilegrimsreisen som et treleddet overgangsritual, der man først skilles fra hverdagslivet, for å tre inn i grensetilstanden under selve reisen og oppholdet på det hellige stedet, før hjemreisen medfører gjeninntredelse i hverdagslivet. Pilegrimsferden er preget av at vanlige sosiale bånd er midlertidig opphevet, symbolisert ved spesielle klær, asketiske øvelser og ulike restriksjoner, og erstattet av et sterkt fellesskap pilegrimene imellom. Generaliseres dette, avdempes det trosmessige religiøse grunnlaget og blir i moderniteten erstattet av en eksistensiell søken og identitetsbygging gjennom turistiske handlinger.

\section{Kirkelig-vitenskapelig dokumentasjon: Olaus Magnus}

Pavekirken ble i reformasjonstida med rette kritisert for avlatshandelen, men den sto også bak den til da mest spektakulære kartleggingen av de nordlige egne. Olaus Magnus kombinerte avlatshandel med et slags etnografisk arbeid. Han var en kirkelig utsending som i 1518-1519 gjorde en lengre reise fra Nord-Tyskland til Uppsala - Jämtland - Trøndelag - Nordland - Bottniska viken - Tornio - Stockholm, i alt 7200 kilometer. Han dekte altså både nordisk-katolsk kjerneland og sameland. I Nidaros traff han den siste katolske erkebiskopen Erik Valkendorf. Hans etnografiske innsats var like mye historie og kartografi, godt blandet med folketro. I ettertid må det betegnes som en vitenskapelig, kirkelig/politisk, men også sentimental reise. Den resulterte etter tolv års arbeid i et berømt kart, Carta Marina, og en svær bok, Historia de gentribus septentrionalibus, som beskriver eksotiske landskaper, klimatiske og geografiske særegenheter og uvanlige fenomener for datidas lesere. For de nordligste områdene er det et kart over fortida like mye som samtida. Det var en region med hedensk religion og skikker, men der folk driver jakt og fiske og bygger skip for handel og forflytning. Olaus Magnus støtter seg mer på egne reiseerfaringer enn tidligere beskrivelsers ganske mytebefengte oppfatninger av samene. De blir de gode og ville, og der det uutforskede Norden blir en slags nye verden (Balzamo 2013). 


\section{«Mens Bønderne seilte og Jægterne for»}

Pilegrimsreiselivet i Norge fortsatte fram til reformasjonen i 1537, sjøl om omfanget ble påvirket av den store pestepidemien i 1349 og de til sammen ti andre epidemiene før 1500. Det reiselivet som gjelder næringsvirksomhet, står for kontinuitet fram til vår tid. Tørrfiskeksporten la grunnlaget for et tydelig norsk reisemål. En av prosessene i samlingen av nordmennenes områder til staten Norge var framveksten av byer, og hvis Nidaros var sentrum for det religiøst motiverte reiselivet, ble Bergen etter hvert sentrum for reising knyttet til økonomi og handel. Torskefisket som salgsfiske og dermed som grunnlag for eksport fikk betydning fra tidlig 1100-tallet (Moseng 1999, s. 227; Hoffmann 2001). Bergen, mer enn de andre byene, ble i takt med tørrfiskens økte betydning stedet som handelsmenn ikke bare dro til, men også bodde. "Byen ble et oppsamlings- og omsetningssted for eksportvarer fra de mindre byene og tettstedene i vest og nord og fra skattlandene, hvor fremmede og norske skip kunne hente varer og bringe dem ut til markedene» (Moseng 1999, s. 242). Bergen ble Norges mest internasjonale by. Dit kom for eksempel islendinger fra vest, tyskere fra sør og gotlendere fra øst. Bergenfahrer fra Lübeck og Rostock utkonkurrerte i løpet av 150 år fra midt på 1100-tallet de fleste andre i tørrfiskeksporten, og tysk korn kom inn i stedet for engelsk (Hybel 2002). Hansaen i de nordtyske byene profesjonaliserte handelsreiselivet, først i familiebaserte nettverk, seinere i tros- og tillitsbaserte lukkede laug (Burkhardt 2010). I motsetning til norske fiskekjøperes sesongvirksomhet drev hansaene hele året, med flere slags varer, større kapital og bedre organisasjon (Opsahl 2003, s. 72), og deres handelssystem strakk seg på 1200-tallet fra London i vest til Novgorod i øst, seinere til Portugal, Venezia og Lvov. Handelsreiselivet omfattet mange slags folk: selgere, grossister, detaljister, aristokrater, byråkrater, korsfarere, kirkelige utsendinger, håndverkere som skipsbyggere, treskjærere og pottemakere (Gaimster 2014).

Dagens langtidsopphold i Syden (Haug et al. 2007) betinges av bosted hjemme for at man ikke skal miste rettigheter i hjemlandet og regnes som utflyttet. Middelalderens versjon i markering av grensen mellom reiseliv og migrasjon var opprinnelig ikke svært annerledes: Hvis utlendinger oppholdt seg over ett år i Norge, ble de pliktig til å delta i militærtjeneste 
(leidangen) (Opsahl 2003, s. 61 f.). Dette passet bra også for handelen med norske varer. Seilingssesongen var sommerhalvåret, med hovedmarkeder for tørrfiskhandelen i mai og august (Burkhardt 2010), og reisemålene fikk være i fred om vinteren. Hanseatenes kreativitet og pågående forretningssans la imidlertid grunnlaget for et langvarig gnisningsforhold mellom norske myndigheter og de tilreisende, da deres virksomhet førte til at de mot slutten av 1200-tallet også ble "vintersittere» eller «residerende fremmede». Ordningen ble institusjonalisert som «Kontoret», inntil hansaperiodens slutt omkring 1750 .

Bergen ble varig merket av hanseatene. Deres karakteristiske bryggeanlegg preger bybildet og utgjør en av dagens Turist-Norges fremste attraksjoner. Bryggen var nærmest en getto, og hanseatene utgjorde et diasporasamfunn. Tyske kjøpmenn og assistenter hadde kontor og bolig der (kun $28 \mathrm{~m}^{2}$ ), menget seg ikke unødig med de norske, lærte seg stort sett ikke norsk, hadde egen kirke, unndro seg norsk skattlegging og jus (Burkhardt 2010, s. 63; Myrvoll 2010; Opsahl 2003, s. 74 f.). Kulturell kontakt, for eksempel gjennom tyske skomakere, og passiv tospråklighet har likevel ført til enkelte særmerker i bergensdialekten, og tyskerne utgjorde opptil en femtedel (2000 mennesker) av byens befolkning (Nesse 2003). Utlendingene hadde ikke lov til å drive handel i Nord-Norge, dette forble en innenlands trafikk under kontroll av norske eliter. Nedkvitne (1988, s. 13) siterer Petter Dass: «Mens Bønderne seilte og Jægterne for». Likevel mener man å spore mellomnedertysk innflytelse på nordnorske dialekter (Skancke 2001). Med i kulturpåvirkningen fulgte også kirkekunst, altertavler og prekestoler, orgler og hymner. Når italieneren Querini, som etter et forlis drev i land på Røst i 1432, forteller om folket der, skriver han om deres brød, bakt på korn importert til Bergen, og om ullklær fra England, som trolig kom samme vei (Opsahl 2003, s. 191 f.). Kulturutvekslingen skjedde også den andre veien, når hanseatenes nettverk styrket St. Olavskulten sentrert i Nidaros inntil reformasjonen (Arnórsdóttir 2015).

En annen av Norges ressurser som ble mer interessant for markeder i Europa i det kommersielle oppsvinget etter svartedauden, var tømmer og trelast. Dette ble grunnlaget for reising fra og til andre markeder, med andre kunder og krav. Denne handelen ga aldri grunnlag for samme type konsentrert byutvikling som tørrfisken gjorde for Bergen. Fra begynnelsen av 1300-tallet og fram til 1800 er det dokumentert frakt av trelast 
fra mange norske steder langs kysten fra Hordaland og sør- og østover til Akershus, til havner i England, Skottland og Nederland (Lokalhistorisk Stiftelse 1999). Vannsager representerte et teknologisprang, en ny aksling på vannmølla, tidligst fra 1520-tallet, og de norske bøndene hadde både skogen, vannkraften og fløtingsveien. Mens de til å begynne med sjøl hadde direkte kontakt med utlandet, ble salgsarbeidet og dermed kommunikasjonen etter hvert et borgerlig privilegium, styrt av nordmenn og innflyttere rundt om i småbyer, en forsiktig urbanisering. Betegnelsene «skottetid» og «hollendertid» forteller hva som var de dominerende reiserutene og handelspartnerne (Sogner 2003, s. 286).

\section{Barbariske, gjestfrie og vakre mennesker $\mathrm{i}$ ydmykende natur}

Hvordan utlendingene så på Norge, vet man bare lite om. De pragmatiske hanseatene greide trolig å se forbi sin landsmann Mikael Beheims oppfatning fra 1450: Han hadde aldri sett et «fælere, villere og mer forunderlig land», en oppfatning som iallfall går tilbake til 1200-tallet om «et fælt, stenet land, alle vegne oppfylt med golde fjelle og klipper ... kun ødemarker og bjerge» (Opsahl 2003, s. 198). Tyskeren Augustin zu Mörsberg mente han på sin reise i 1593 var 'en Johannes-ridder blant barbarer', og å seile norske fjorder var som å reise mellom to høye vegger, en ydmykende opplevelse. Samene spiste røtter og planter, og det var bare den kongelige beskyttelsen, mente han, som berget ham fra å bli varulv. De nordlige områdene sto i kontrast til den europeiske ordenen og sivilisasjonen (Donecker 2013). Franske reisende på omtrent samme tid forteller om hvordan det var å kjenne vinterkulden på kroppen (Schnakenbourg 2013, s. 87), og la vekt på at guider og oversettere var en nødvendighet. Det ga kontakt med de lokale, som jevnt over var gjestfrie og bød både på rom og mat. I det hele, menneskene kompenserer for naturens hardhet. Det samme sier Querini etter sitt forlis (1432): Nordmennene var få, bodde spredt, men hadde rikelig med kjøtt og fisk, melk og øl. Han savnet vin og frukt, sjøl om han befant seg 'i paradisets første krets' (Wold 2005).

Dansketida vil her ellers bli mer eller mindre forbigått i stillhet. Det var en betydelig reiseaktivitet i denne perioden, både av mennesker som 
administrerte det dansk-norske riket (for eksempel var kong Christian IV med stort følge helt nord til Kola i 1599), av handelsfolk og fram forbi reformasjonen også av pilegrimer, men ut over dette var reisevirksomheten svært begrenset. Svartedauden reduserte folketallet i Norge med kanskje to tredeler og tynnet ut samfunnsveven for lange tider. Folk levde i lokale samfunn som stort sett var sjølberget, og fattigdom var den normale tilstanden i strevsomme liv. Men det finnes ingen gode og samlende beskrivelser av reisene i denne perioden.

I 1798-1799 gjorde italieneren Acerbi en reise til Arktis og beretter om anstrengelser og farer. Han mente at ingen er så avansert i kultur at man ikke kan se det fordelaktige $\mathrm{i}$ å gjøre seg kjent med andre lands kunst og vitenskap, sjøl de mest barbariske. Men reiser i nord ville bare bli gjort av mennesker med en maskulin smak for natur, mente han (Barton 1996, s. 2). Andre hadde en mer romantisk og følsom holdning til nordiske landskaper og folkeliv. Venezuelaneren Francesco de Mirandas reise i 1787 (Barton 1996, s. 4) viser bevissthet både for tid og sted, en entusiasme for folkeliv og kultur. De nordiske bygdene representerte Europas siste idyll, et nordisk Arkadia (landskap i Hellas).

Det er grunn til å tro at fritidsreiser på denne tida ikke var et særlig omfattende fenomen $\mathrm{i}$ et land med en så begrenset overklasse som Norge. Men denne deltok nok i sin tids reiseliv, for eksempel i The Grand Tour. Löfgren (1999) viser for eksempel både til nordmenn og svensker som beretter fra sine reiser på 1700-tallet. Det er fra denne tida og framover at det blir grunnlag for, og mer hensiktsmessig, å sondre mellom ulike typer turisme. I Norge som i resten av verden kan dette betraktes som starten på det moderne reiselivet, og man kan se en kopling mellom den innenlandske tradisjonelle bruken av naturen og den voksende interessen og begeistringen utenfra for norsk natur, særlig for våre fjorder og fjell. I den resterende delen av dette kapitlet skal vi se på noen aspekter av hvordan samvirket mellom det norske og det internasjonale har tedd seg, og hvordan dette står i sammenheng med kulturutviklinga generelt. Det var først og fremst cruiseturismen og fjellturismen som representerte Norge i denne forbindelse. 


\section{Fjellturisme og friluftsliv}

En viktig del av den norske, innenlandske turismen har dreid seg om å dra til fjells. Det begynte med at overklassemennesker fra Oslo var blitt inspirert av sine engelske klassefrender til å dra opp i fjellene. De på sin side hadde søkt til skotske høyfjell og til Alpene for å utøve fjellsportsaktiviteter, blant annet fjellklatring. Sveits ble beundret og besøkt, først og fremst på grunn av sine fjell, men også ved sin heroiske og demokratiske historie (Löfgren 1999). Etter hvert kastet man sine øyne på Norge. «Den europeiske alpintørsten omformet Norges fjellområder til Skandinavias første internasjonale turistattraksjon [...]», sier Löfgren (ibid., s. 34). Og nordmennene tok etter, gjennom den sosialiseringen de fikk i oppveksten, «lærte borgerne den kulturelle turistkoden som fortalte hva slags opplevelser man skulle søke, hva man burde føle, og ikke minst hvordan man skulle oppføre seg», sier Richardson (1994, s. 10). Orienteringen mot fjellene henger sammen med romantikkens endringer i synet på vill natur - den var ikke lenger stygg og utilgjengelig, men vakker, utfordrende og eksotisk. «Norge er et av de mest fjellrike landene i verden, og er i dag anerkjent som et av de flotteste av de alpine tumleplasser», sier Slingsby (1904, s. 104). Det var trolig på 1700-tallet man begynte å vandre i naturen for vandringens skyld, om mennesket ikke alltid har gjort det. På 1830-tallet utviklet Claude Francois Denecourt naturstier i skogen rundt Fontainbleu utenfor Paris (Löfgren 1999). Kanskje var dette starten på tilrettelegging av stier.

For engelskmennene var fjellklatring det edleste man kunne foreta seg i naturen, men i Norge fikk denne sporten aldri stor utbredelse. I stedet utviklet man andre former for fjellsport, særlig det å gå i fjellet, bestige topper og etter hvert vandre fra hytte til hytte. Det begynte på 1860-tallet (Aarnes 1999). Mens inspirasjonen kom utenfra, hentet man mye lærdom fra lokalbefolkningen. De første fjellturistene benyttet seg mye av fjellførere, helst fjellbønder som var kjent i områdene. Det finnes beretninger som viser at de både ble beundret og kritisert, blant annet for ikke å være dristige nok. De gikk gjerne der de var kjent, men vegret seg mot å gå inn i det ukjente (jf. Richardson 1994). Fjellturistene skulle imidlertid gjerne erobre toppene. En av dem var William Slingsby, som gjorde en rekke førstebestigninger i den norske fjellheimen, blant annet i Jotunheimen og i Lyngen. Han var imidlertid opptatt av at det var turen som var det egent- 
lige målet (Slingsby 1904), mens andre framhever at det var opplevelsene som var selve målet (Goksøyr 1994). Sjøl om Slingsby - han ble utnevnt til æresmedlem i Turistforeningen - og andre utlendinger var viktige for etablering og utbredelse av det norske friluftslivet, var norsk friluftsliv like mye bygget på tradisjoner i norsk bygde- og bondekultur (Pedersen 1999, s. 37). Folk hadde alltid høstet fra naturen, hogd ved, plukket bær, fisket og jaktet, tradisjoner som på landsbygda aldri har opphørt. Man kalte ikke dette friluftsliv, det var arbeid og mer beslektet med næring enn med fritid. Det moderne friluftslivet har tatt disse aktivitetene opp i seg. Friluftslivet må ikke utelukkende utøves på byens premisser, sier Breivik (1978). Likevel var friluftsliv først og fremst et byfenomen. En del byfolk fikk fritid som skulle fylles med noe, og det var i byen man fant de intellektuelle og borgerskapet som fanget opp internasjonale strømninger. Det var her man følte savnet og byens fremmedgjøring i forhold til natur. For eksempel var det studenten Baltazar Mathias Keilhau som i sin tid «oppdaget» "Jotunfjeldene» - han beskrev området både i akvareller og vitenskapelige publikasjoner (Sars 1872), men det var dikteren Aasmund Olavsson Vinje som ga fjellområdet navnet Jotunheimen.

Beundringen av de norske fjellene var en del av den norske identitetsbygginga på 1800-tallet. Fjell, daler, fjorder og fjellbønder ble vitale symboler blant dem som forberedte etableringen av en sjølstendig nasjonalstat (Aarnes 1999). I Norge som mange andre steder var kunstnere viktige formidlere av de romantiske og nasjonale verdiene, og dermed naturen. Malere med I.C. Dahl, Thomas Fearnley, Tidemand og Gude i spissen festet det nye synet på naturen på lerret og skapte det Aarnes har kalt en «nasjonal ikonografi», ifølge idrettsfilosofen Matti Goksøyr (1994). Og fjellfolket - fjellbønder og deres folkeliv - ble gjenstand for romantisering og mytologisering. Konkrete skikkelser var modeller både i Henrik Ibsens og Bjørnstjerne Bjørnsons diktning, og i Edvard Griegs komposisjoner. Men ikke bare kunstnere bidro, også vitenskapsmenn og oppdagelsesreisende som Roald Amundsen og Fridtjof Nansen ytte sine bidrag, særlig Nansen, som gjorde seg til talsmann for friluftslivet. I nasjonsbestrebelsene ble den norske naturen romantisert og særlig bøndene i innlandets daler glorifisert fordi de ikke var blitt preget av moderniseringa og representerte det mange mente var historiske forbindelseslinjer tilbake til sagatida (Øverland 1896). Det er ikke å undres at friluftslivet fikk en oppsving med den reklamen som landsbygda og fjellene fikk i siste halvdel av det 19. og 
ut i det 20. århundre. Men sjølsagt var det også andre forhold som bidro til vekst i friluftslivet: økt fritid og bedrede kommunikasjoner ga økt trafikk. Den økte bruken av naturen førte med seg et nett av stier og hytter, og alt i 1868 organiserte fjellfolket seg i Den Norske Turistforening. Fjellvandrerne anså seg altså den gang som turister, noe mange friluftsmennesker i dag vil protestere mot $-\mathrm{i}$ egne øyne driver de friluftsliv og distanserer seg fra turisme.

Byfolkets tilstrømming til landsbygda kan også betraktes som erobring eller kolonisering. Livet i naturen ble i 1957 kronet med en egen lov - friluftsloven - som sikret allmennheten tilgang til all utmark, uavhengig av hvem som eier den (Reusch 2012). Lenge før dette hadde prinsippene den bygger på, allemannsretten, fått aksept på tvers av sosiale lag og politiske partier. Ifølge Goksøyr ble natur- og friluftslivsinteressen «overraskende hurtig annektert av de brede lag av folket, slik at når man snakker om et begynnende friluftsliv i andre halvdel av 1800-tallet, så var det noe mer enn en moteretning i borgerskapet» (Goksøyr 1999, s. 185). Stimulering av friluftslivet var etter hvert et nasjonalt moralsk prosjekt, om man skal tro Richardson (1994), som blant annet viser til at arbeiderpartilederen Martin Tranmæl i sin tid skrev i Årboka for Den Norske Turistforening.

Tordsson (2006) nevner fire faser i denne utviklinga. I den første fasen, fram til første verdenskrig, skulle man møte naturen i ensomhet og i pakt med den utvikle sin personlighet. I mellomkrigstida var det fellesskapsideen som sto fremst - arbeiderbevegelsen trykket friluftslivet til sitt bryst, naturen var en arena hvor man kunne oppleve frihet, og friluftslivet representerte en kontrast til arbeidslivets og klassesamfunnets åk. Om den tredje fasen, tida etter krigen, sier Tordsson (2006) at friluftslivet ble marginalisert. Det var ideer om industri, økonomisk vekst og institusjonsbygging som dominerte debattene, og naturen ble omgjort til en ressurs for industriell utvikling. I dette bildet var det idretten og ikke friluftslivet som passet inn. I en fjerde periode, etter 1970, har friluftslivet hatt skiftende oppmerksomhet, men det har blitt anerkjent som en viktig trivsels- og helsefaktor og er blitt gjenstand for politikk. Friluftslivet har blitt institusjonalisert. Vi er nå inne i en femte fase i utviklinga, der friluftslivet er blitt teknifisert og kommersialisert. Friluftsliv har alltid vært turisme, men bruken av tekniske hjelpemidler og salg av aktiviteter i naturen har fått helt andre dimensjoner enn tidligere. Med teknifiseringen har forskjellene mellom by og land hva angår måter å møte naturen på, trolig blitt redusert. 
Ideene om naturens storhet og friluftslivets fortreffelighet brakte altså mange mennesker til fjells, ut på landet og på ferier som etter hvert antok spesielle former. For eksempel ble det ganske vanlig for byfolk å dra på landet i ferien, mange bygde seg hytte der, mens andre søkte mot fjellene. Ferietida ble i stort monn brukt til aktiviteter i naturen. For eksempel søndagsturen, som for svært mange skal foregå i naturen som skogstur, fjelltur, fisketur, bærtur eller bare det å gå. Et relativt omfattende nettverk av hytter er etablert, dels for å betjene dagsturbesøkende fra nærmeste tettsted, dels for å betjene folk som gjør rundturer på ski eller til fots. I mange områder kan man gå i dagevis, og det er alltid en kommersiell hytte innen rekkevidde, betjent eller ubetjent. Og det arrangeres turmarsjer og skirenn hvor poenget er å delta, ikke nødvendigvis å nå langt. Myndighetene har ved flere anledninger laget utredninger og vedtatt politiske mål for friluftslivet. Det er et politikkfelt i like stor grad som turismen er det, og friluftsliv er en viktig del av den innenlandske turismen i Norge.

Men med økt utbredelse var mange som dro ut i naturen, ikke like orientert mot toppene som pionerene hadde vært. Komfort ble også etterspurt på fjellet, og med bedre transportsystemer dro folk lenger vekk. Löfgren forteller i sine beretninger om denne utviklinga om John Muir, den kjente amerikanske naturforkjemperen og skribenten, som klagde over den nye typen turister som fløt sakte omkring i bunnen av dalene og møttes på hoteller og i salooner. De søkte ikke egentlig etter villmarken, mente Muir (Löfgren 1999). Etter hvert som folk i det 20. århundret fikk biler, ble biltur den nye formen for «friluftsliv». Det ble ikke oppfattet som friluftsliv, snarere dets motstykke; en heller passiv form for å konsumere landskap og kultur på. Blant de formene for turisme som dette innebar i sin begynnelse, var campingtur, i Amerika først i det 20. århundret, i Norge noen tiår seinere, og i mindre omfang. Det var først i etterkrigstidas Norge at bilen fikk særlig utbredelse og rundturturismen vokste fram. Etter som man fikk et bedre organisasjonsmessig grep om turismen, ble også bussbaserte rundturer med overnatting på hotell en vanlig pakketur. Dette har helt siden 1960-tallet kanskje vært en av de vanligste turismeformene i Norge. 


\section{Cruiseturisme og sightseeing}

I Norge er det sightseeing som er grunnlaget for turisme i store volum. Særlig om sommeren kommer folk for å oppleve den norske naturen. Turismeformens utvikling kan knyttes til romantikkens natursyn, fjellturismen, vegutbygging og cruisevirksomheten. Cruiseturismen er ved siden av fjellturismen en av forløperne til dagens sightseeingsturisme.

Norge er nærmest blitt definert gjennom sin lange kyst, og landet har til alle tider vært lettest tilgjengelig fra sjøsiden. Landet ble tidlig en cruisedestinasjon. Det første moderne cruiset sies å ha gått fra England til vestlandsfjordene og Nordkapp i 1882. Men da hadde man allerede i noen tiår kunnet ta seg fram langs kysten med lokalbåter, for eksempel kom den første dampbåtruten mellom Christiania og Hammerfest i 1841. Med konkurranse fra utenlandske cruiseskip opprettet flere norske rederier egne turistruter fra Bergen til vestlandsfjordene og til Nordkapp (Löfgren 1999). Fra og med 1894 ble også Svalbard inkludert i rutetrafikken (se nedenfor). Bergenske Dampskibsselskap og Nordenfjeldske Dampskibsselskap var de dominerende norske. Etter en lav aktivitet under første verdenskrig ble cruisene på norskekysten tatt opp igjen, og norske redere begynte med cruise til andre farvann, blant annet Middelhavet. «Bergenske» var fortsatt det mest aktive rederiet og anskaffet skip som utelukkende var tiltenkt turistfart, som Stella Polaris, brukt på turer til det sørlige Stillehavet for det amerikanske markedet (Nordgård \& Pettersen 1986). Også Den norske Amerikalinje, opprettet for å drive passasjerbefordring mellom Norge og USA, begynte med cruisetrafikk til vestlandsfordene og Nordkapp på 1920-tallet, blant annet som følge av at immigrasjonsbegrensninger i USA reduserte behovet i den transatlantiske farten. Selskapet innførte en såkalt turistklasse på sine skip, for å møte middelklassens behov (ibid.).

Hurtigruteselskapene har omtrent siden starten i 1894 representert et turisttilbud som likner på cruisefarten. I de første tiåra utstyrte man sesongmessig skipene med turistfasiliteter. Selskapene har alltid forsøkt å holde avstand til cruisemarkedene gjennom å presentere sine turer langs kysten som coastal voyages, der småstedsanløp og working ship lenge har vært attraktive elementer. Først i de siste 30 åra har turisttrafikken blitt dominerende, med landbaserte attraksjoner og opplevelser som supplementer til det å beskue landskapet som glir forbi. 
Bergens sentrale posisjon for kysttrafikken opp igjennom historien er kjent. En «Statistisk topografisk beskrivelse over Bergen» viser at i 1911 besøkte sju britiske «turistdampere» byen - de hadde til sammen 25 anløp - og fem tyske med til sammen ti besøk, altså til sammen 35 anløp. I tillegg besøkte elleve britiske, fire tyske, to franske, to amerikanske, en østerriksk og en egyptisk yacht byen. På landsbasis hadde cruisetrafikken gode tider i mellomkrigstida; anløpene av utenlandske cruiseskip økte fra cirka 20 i 1923 til 90 i 1938, og antallet cruisepassasjerer økte fra cirka 8000 til cirka 45000 i samme periode, ifølge Kolltveit (1980, s. 5). Andre verdenskrig satte en midlertidig stopper for cruiseturismen, og antallet cruiseturister var noen år relativt lavt, blant annet som følge av vekst i den transatlantiske rutetrafikken. Men på 1960-tallet tok denne passasjertransporten slutt, og rederiene flyttet store deler av sin virksomhet til USA, hvor cruisemarkedet både var stort og voksende. Norske redere var tidlig med i cruisetrafikken i Karibia, men dette er mer sentralt i norsk skipsfartshistorie enn i norsk turismesammenheng.

Cruisetrafikken til Norge skjer både gjennom norskeide og utenlandske cruiserederier, agenter og turoperatører. Cruisetrafikken er langt på vei helt uavhengig av ytelser fra land, men det har blitt stadig vanligere å selge landprogrammer for havneoppholdene. De siste åras vekst i denne turismen har derfor ført til en oppblomstring av lokale aktivitetstilbud. Det er altså skapt et vinn-vinn-forhold mellom den landbaserte reiselivsnæringa og cruiseskipene. Denne utviklinga gir også større utbud av opplevelser også for andre turistsegmenter. Men økninga har sin pris, og den har aktualisert en mer omfattende regulering.

\section{Hytte på landet}

Norsk fritidsreiseliv er en viktig del av landets turisme. Den omfatter nordmenns bruk både av sjøen og fjellet som aktivitetsarena, og ikke minst vår hyttekultur. Det er flere forklaringer på hyttepraksisens framvekst, og begrepene «hytte» og «fritidshus» er heller ikke entydige. Og om hyttefolket er turister, er også en diskusjon. Overklassen hadde allerede på 1600-tallet landeiendommer eller sommertun utenfor byene der de bodde (Hald 1992). Mot midten av 1800-tallet flyttet fritidsinteressen seg mot havet, hevder Rosander (1992), under påvirkning fra utlandet. Det er på samme 
tid som badeturismen vokser fram for eksempel i England, og sommerhus ved sjøen ble også vanlig i Norge. Rosander mener også at hytteferien kan knyttes tilbake til fjellturismen. Etter at overklassen på 1800-tallet «oppdaget» fjellet, varte det ikke så lenge før de første skaffet seg hytte på fjellet, i den tidligste perioden først og fremst for bruk i forbindelse med jakt og fiske (Pihl Atmer 1998). Først på 1900-tallet begynte man å bygge såkalte sportshytter - enkle overnattingssteder hvor man beholdt tomtene i sin naturlige form. «Ut fra disse røtter trer den tradisjonelle norske hytta fram, utført i tømmer, vinterkledd, rustikt utformet med innvendig furupanel og med tida med høyere standard», uttaler Pihl Altmer (ibid., s. 89). Trolig finnes det også en annen utviklingsbane som førte til hyttebebyggelse. Tidlig på 1900-tallet ble det stadig mer vanlig for byborgere å søke mot landsbygda i sine ferier. De skulle «på landet», sa bergenserne når ferietida nærmet seg (Andolf 1990). Det man siktet til, var at familien, eller i det minste mor og barn, skulle reise til et sted i omlandet hvor man hadde leid seg inn for barnas skoleferie. Det var to varianter av dette, enten leide man seg inn hos private, eller så bodde man på et pensjonat eller gjestgiveri. På landsbygda var det en kjærkommen ekstrainntekt å leie ut til byfolk om sommeren. Dette var også en vanlig ferieform i Sverige, og her er den bedre beskrevet (Sahlberg \& Vidén 1990). Ofte var det kulturmøter som eksponerte forskjellene mellom byenes borgerlighet og landsbygdlivets jordnærhet. De som huset turistene, følte seg nok ofte som gjestenes tjenere, de arbeidet mens byfolket sov til langt på dag, badet og koste seg (ibid.). Etter hvert som velstanden økte ut over på 1900-tallet, ble behovet for ekstrainntekter mindre, og de ferierende måtte se seg om etter andre måter å tilbringe sommeren på. For mange ble alternativet å bygge seg en hytte. Det var ikke lenger et privilegium for borgerskapet og overklassen å ha hytte. Også for middelklassen og arbeiderklassen ble hytte på landet et mål og en vanlig ferieform.

Det utviklet seg tidlig noen standarder for hvordan disse hyttene skulle være, og modellen for den norske sportshytta spredte seg både til Skottland og Sverige. Det var to varianter av disse hyttene, den ene svært primitiv, den andre var formet etter modell av norske hjem og hadde høyere komfort, ifølge Pihl Atmer (1998). Mer eller mindre kan man vel si at begge disse modellene har eksistert helt til i våre dager.

Når det gjelder byene, finnes også en annen hyttekultur, de såkalte kolonihagene. Dette var små hyttegrender som ble anlagt i utkanten av 
noen av våre byer. Også denne ideen kom fra England, hvor arbeiderne rundt de store industribyene ble tilbudt en jordlapp utenfor byen til å dyrke på. Men det var også kjent fra andre land. Første gang slike ble anlagt i Norge, var i Halden i 1896 (Jor 1996). De var opprinnelig tenkt som en hageflekk til dem som ikke hadde ferie og derfor ikke kunne reise vekk, men det ble fort vanlig å bygge en liten hytte på sin parsell. For mange var det en slags sommerbolig, hvor de bodde der fra mai til september. Men hyttene var små, og man bodde mer eller mindre i friluft sommeren igjennom, i stor kontrast til vinterens inneliv (Grimstad \& Lynge 1993). Folk levde to liv, et industri- og byliv om vinteren, et ute- og i naturen-liv om sommeren. Kolonihagene ble etter hvert populære, og de utviklet seg til villabyer i miniatyr, sier Jor (1996). Hagene er ikke lenger nyttehager, men prydhager, og beboerne ikke arbeidere, men middelklassemennesker og andre som har råd til å skaffe seg denne luksusen. Kolonihagehyttene eksisterer også i dag.

Hyttekulturen er fortsatt sterk i Norge. I 1970 fantes det 191000 fritidsboliger i Norge. Etter sigende var dette den tetteste hyttefrekvensen i Europa (Rosander 1999). Siden har det vært en vekst på fra 4000-8000 fritidsboliger i året, til cirka 370000 i 2005 (Ericson, Arnesen \& Overvåg 2005). Utviklinga i denne perioden har gitt en større konsentrasjon - Sør-Østlandet er det dominerende hytteregionen - og hyttene er blitt større og mer komfortable, derfor har nye begreper som «fritidsboliger» og «sekundærboliger» blitt tatt i bruk. Hytta er blitt hus (Toldnes 2003).

\section{Oppsummering}

I kapitlet har vi gitt et riss av reiselivsutviklinga i Norge. Store perioder er utelatt, for eksempel er dansketida mer eller mindre forbigått i stillhet. Det var en betydelig reiseaktivitet i denne perioden, både av mennesker som administrerte det dansk-norske riket, av handelsfolk og av pilegrimer, men ut over dette var reisevirksomheten svært begrenset. Folk levde i lokale samfunn som stort sett var sjølberget, og fattigdom var den normale tilstanden i strevsomme liv. Men det finnes ingen gode og samlende beskrivelser av reisene i denne perioden. Det er grunn til å tro at fritidsreiser ikke var et særlig omfattende fenomen i et land med en så begrenset overklasse som Norge. Det er imidlertid all grunn til å tro at denne deltok i sin tids 
reiseliv. I Norge som i resten av verden kan dette betraktes som starten på det moderne reiselivet. Men først og fremst var det fjellturismen og cruiseturismen som representerte den begynnende turismen i Norge, altså mennesker som tilbringer fritida utenfor hjemstedet og oppholder seg eller fartet rundt i landet vårt.

I kapitlet fortelles det videre at turistpionerene i Norge var utlendinger, først og fremst engelskmenn og tyskere, men at landet relativt tidlig ble besøkt av mennesker fra mange land og fra fjerne strøk. Særlig var cruiseturismen et utenlandsk anliggende; til dels skipene og de fleste turistene var i hovedsak fra andre land. De første norske moderne turistene var fra byene og fra overklassen og intelligentsiaen. Særlig gjelder det fjellturismen, som det argumenteres for var en av forløperne til den bil- og bussbaserte sightseeingsturismen ved siden av cruiseturismen. Men arbeiderbevegelsen var også sentral i etableringen av norsk reiseliv; den sto bak kravene om kortere arbeidstid og lengre ferier, viktige forutsetninger for et mer demokratisk reiseliv. Alt i første halvdel av det 20. århundret synes det å ha vært stor politisk enighet om at friluftsliv og ferieliv var til gode for alle parter og burde stimuleres og tilrettelegges. Norsk turismepolitikk, om man kan si at den har eksistert, har stimulert til bruk av norsk natur og vært tilrettelagt gjennom å bygge veier til fjells, etableringer av private hytter ved hav eller på fjell og av campingplasser med relativt billig overnatting.

\section{Litteratur}

Andolf, G. (1990). Turismen i historien. I B. Sahlberg \& L. Vidén, Längtan til landet annolunda. Om turisme i historia og nutid. Värnamo: Gidluns Forlag.

Arnórsdóttir, A.S. (2015). 'Ecclesia Nidrosiensis' and 'Noregs Veldi'. The role of the church in the making of Norwegian domination in the Norse world. Scandinavian Journal of History, 40 (3), 478-484. https://doi.org/10.1080/03 468755.2015 .1042291

Balzamo, E. (2014). The geopolitical laplander: From Olaus Magnus to Johannes Schefferus. Journal of Northern Studies, 8, 29-43.

Barth. F. (1970). Synkron komparasjon: Syntese, analyse, komparasjon. Studier $i$ historisk metode (s. 19-35). Oslo: Universitetsforlaget.

Barton, H. A. (1996). Iter Scandinavicum. Foreign travelers' views of the late eighteen-century north. Scandinavian Studies, 68 (1), 1-18. 
Bately, J. (2014). Othere's voyages. I S. M. Sindbæk \& A. Trakadas (red.), The world in the Viking Age. Roskilde: The Viking Ship Museum.

Blom, G. A. (1992). Norge i union på 1300-tallet: Kongedømme, politikk, administrasjon og forvaltning 1319-1380. Trondheim: Tapir.

Breivik, G. (1978). Friluftsliv fra Fridtjof Nansen til våre dager. Oslo: Universitetsforlaget.

Bråthen, E. (2013). Introduksjon - Den gang da: Synkrone og diakrone perspektiver på «fortid». Norsk Antropologisk Tidsskrift, 3-4, 157-168.

Burkhardt, M. (2010). The German Hanse and Bergen - new perspectives on an old subject, Scandinavian Economic History Review, (58) 1, 60-79. https://doi.org/10.1080/03585520903561201

Casson, L. (1994). Travel in the ancient world. Baltimore: Johns Hopkins University Press.

Cohen, E. \& Cohen, S. C. (2014). A mobilities approach to tourism from emerging world regions. Current Issues in tourism, 18 (1), 11-43. https://doi.org/10.1080/13683500.2014.898617

Christiansen, E. (2002). The Norsemen in the Viking Age. Oxford: Blackwell.

Danbolt, G. (1997). Nidarosdomen fra Kristkirke til nasjonalmonument. Oslo: Andresen \& Butenschøn.

Donecker, S. (2013). Stranger in a strange land: The Scandinavian journey of Augustin zu Mörsberg und Beffort. I S. Gaupseth, M.-T. Federhofer \& P. P. Aspaas (red.), Travels in the North. A Multi-Disciplinary Approach to the Long History of Northern Travel Writing. Hannover: Wehrlahn Verlag.

Ericsson, B., Arnesen, T. \& Overvåg K. (2005). Fra hyttefolk til sekundarbosatte. Et forprosjekt. ØF-rapport 04. Lillehammer: Østlandsforskning.

Framke, W. (2002). The destination as a concept: A discussion of the businessrelated perspective versus the socio-cultural approach in tourism theory. Scandinavian Journal of Hospitality and Tourism, 2, 92-108. https://doi.org/10.1080/15022250216287

Gaimster, D. (2014). The Hanseatic cultural signature: exploring globalization on the micro-scale in late Medieval Northern Europe, European Journal of Archaeology, 17 (1), 60-81. https://doi.org/10.1179/14619571 13Y.0000000044

Garay, L. \& Cànoves, G. (2011). Life cycle, stages and tourism history. The Catalonia (Spain) experience. Annals of Tourism Research, 38 (2), 651-671. https://doi.org/10.1016/j.annals.2010.12.006 
Goksøyr, M. (1994). Nasjonal identitetsbygging gjennom idrett og friluftsliv. Nytt Norsk Tidsskrift, 11, 182-203.

Grimstad, I. \& I. J. Lynge (1993). The pleasure of the holiday cabin. Ethnologia Scandinavia, 23, 45-57.

Hagland, J. R. \& Sandnes, J. (red.) (1994). Frostatingslova. Oslo: Samlaget \& Frosta historielag.

Hald, S. (1992). Norske lokkelandsteder 1630 til 1830: udsnitt af borgerskabets tegnunivers. Oslo: Avdeling for etnologi ved Institutt for kultur- og samfunnsfag, Universitetet i Oslo og Stiftelsen Norsk etnologisk gransking. Hardanger Folkeblad (1910). Odda: Hardanger Folkeblad.

Jor, F. (1996). Om å drømme seg - bort. I G. Stangeland (red.), På hytta. Oslo: Boksenteret.

Haug, B., Dann, G. M. S. \& Mehmetoglu, M. (2007). Little Norway in Spain. Annals of Tourism Research, 34 (1), 202-223. https://doi.org/10.1016/j. annals.2006.07.011

Hoffmann, R. (2001). Frontier foods for late medieval consumers: Culture, economy, ecology. Environment and History, 7 (2), 131-167. https://doi.org/10.3197/096734001129342432

Holm, P. (1998). The slave trade of Dublin. Peritia, 5, 317-345. https://doi.org/10.1484/J.Peri.3.139

Hybel, N. (2002). The grain trade in Northern Europe before 1350. The Economic History Review, 55 (2), 219-247. https://doi.org/10.1111/1468-0289.00219

Karras, R. M. (1990). Concubinage and slavery in the Viking age. Scandinavian Studies, 62, 141-162.

Kolltveit, B. (1980). Over fjord og fjell. Bergen: Universitetet i Bergen.

Laget, F. (2013). Travelling Along the Sixtieth Parallel North: The Vinland Sagas from Norway to Newfoundland. I S. Gaupseth, M.-T. Federhofer \& P. P. Aspaas (red.), Travels in the North. A Multi-Disciplinary Approach to the Long History of Northern Travel Writing. Hannover: Wehrlahn Verlag.

Lokalhistorisk Stiftelse (1999). Timber and trade. Nr. 1. Rogaland: Lokalhistorisk Stiftelse.

Lowenthal, D. (1985). The past is a foreign country. Cambridge: Cambridge University Press.

Löfgren, O. (1999). On Holiday. A history of vacationing. London: University of California Press. https://doi.org/10.1525/california/9780520217676.001.0001 MacCannell, D. (1989). The tourist. A new theory of the leisure class. Berkeley: University of California Press. 
Marx, C. (2014). Lokalisierung von Pytheas' und Ptolemaios' Thule. ZFVZeitschrift von Geodäsie, Geoinformation und Landmanagement, 139 (3), 197-203.

Melleno, D. (2014). North Sea networks: trade and communication from the seventh to the tenth century. Comitatus: A Journal of Medieval and Renaissance Studies, 45, 65-89. https://doi.org/10.1353/cjm.2014.0055

Moseng, O. G., Opsahl, E., Pettersen, G. I. \& Sandmo, E. (1999). Norsk historie 1. 750-1537. Oslo: Tano-Aschehoug.

Myrvoll, S. (1987). Archaeological investigations in Bergen 1980-1986: Some new aspects on the development of the town. Norwegian Archaeological Review, 20 (2), 100-109. https://doi.org/10.1080/00293652.1987.9965456

Nedkvitne, A. (1988). «Mens Bønderne seilte og Jagterne for». Nordnorsk og vestnorsk kystøkonomi 1500-1730. Oslo: Universitetsforlaget.

Nesse, A. (2003). Written and spoken languages in Bergen in the Hansa era. I K. Brumüller \& G. Ferraresi (red.), Aspects of multilingualism in European language history. Philadelphia: John Benjamins Publishing. https://doi.org/10.1075/hsm.2.04nes

Nielsen, A. R. (1993). Viking age chieftains in Lofoten in the medieval literature. Acta Borealia: A Nordic Journal of Circumpolar Societies, 10 (2), 19-31. https://doi.org/10.1080/08003839308580427

Nordgaard, L. \& Pettersen, B.-C. (1986). Cruisefart: Hotelldrift og reiseliv. Arbeidsnotat. Stavanger: Rogalandsforskning.

Næss, A. (2011). Nidarosdomen. En biografi om Norges nasjonalmonument og menneskene som bygde det. Oslo: Gyldendal.

Opsahl, E. (2003). I kongenes tid. Del 1. I K. Kjelstadli (red.), Norsk innvandringshistorie 1-3. Bind 1. Oslo: Pax Forlag.

Pedersen, K. (1999). "Det har bare vart naturlig». Friluftsliv, kjønn og kulturelle betydninger. ["It has always been natural». Outdoor recreation, gender and cultural meanings]. Doktoravhandling, Norges Idrettshøgskole. Alta: Høgskolen i Finnmark.

Perdikaris, S. (1999). From chiefly provisioning to commercial fishery: Long-term economic change in Arctic Norway. World Archaeology, (20) 3, 388-402. https://doi.org/10.1080/00438243.1999.9980419

Pihl Atmer, A. K. (1998). Livet som leves där måste smaka vildmark. Sporstugor ock friluftsliv (1900-1945). Stockholm: Stockholmia förlag. 
Resi, H. G. (2004). Book review. Stamsø Munch, G., Olav Sverre Johansen \& Else Roesdahl (red.) 2003. A chieftain's farm in North Norway. Arkeologisk Skriftserie 1. Lofotr. Vikingmuseet på Borg. Trondheim: Tapir. Norwegian Archaeological Review, 37 (2), 135-138. https://doi.org/10.1365/s10337-004-0363-0

Richardson, H. (1994). Kraftanstrengelse og ensombet: en analyse av det norske friluftslivets kulturelle konstruksjoner. Hovedoppgave. Bergen: Institutt for etnologi, Universitetet i Bergen.

Roesdahl, E. (1991). The Vikings. London: Penguin.

Rosander, G. (1992). Rotfast turism. Om hyttelivet som finit betydelsesområde.

Avdeling for etnologi ved Institutt for kultur- og samfunnsfag, Universitetet i

Oslo og Stiftelsen Norsk etnologisk gransking.

Sandmo, E. (2013). Avstandens fortryllelse. Scandia, 79, 59-67.

Sandmo, E. (2015). Tid for historie. En bok om historiske spørsmål. Oslo: Universitetsforlaget.

Sahlberg, B. \& Vidén, L. (1990). Längtan til landet annolunda. Om turisme i historia og nutid. Värnamo: Gidluns Forlag.

Sars, E. (1872). Keilhaus opdagelse af Jotunheimen. Den norske turistforenings årbog for 1872. Kristiania: Den norske turistforening.

Schnakenbourg, E. (2013). Travelling to Scandinavia: The French Visitors' Experience of the North, 17th-18th Centuries. I S. Gaupseth, M.-T. Federhofer \& P.P. Aspaas (red.), Travels in the North. A Multi-Disciplinary Approach to the Long History of Northern Travel Writing. Hannover: Wehrlahn Verlag.

Sindbæk, S. M. (2007). The small world of the Vikings: Networks in early Medieval communication and exchange. Norwegian Archaeological Review, 40(1), 59-74. https://doi.org/10.1080/00293650701327619

Skancke, K. (2001). Mellomnedertysk påvirkning på nordnorske dialekter. København: Nordisk Ministerråd.

Slingsby, W. C. (1904). Norway, the Northern playground. Edinburgh: David Douglas.

Smestad, I. (1996). Kommunikasjonsforhold i Trøndelag i vikingtid og middelalder. I Ø. Walberg (red.), Før og etter Stiklestad 1030. Religionsskifte, kulturforhold, politisk makt. Stiklestad Nasjonale Kultursenter.

Sogner, S. (2003). I kongenes tid. Del 2. I K. Kjelstadli (red.), Norsk innvandringshistorie 1-3. Bind 1. Oslo: Pax Forlag.

Steinsland, G. (2005). Norrøn religion. Myter, riter, samfunn. Oslo: Pax. 
Storli, I. (2010 Court Sites of Arctic Norway: Remains of Thing Sites and Representations of Political Consolidation Processes in the Northern Germanic World during the First Millennium ad? Norwegian Archaeological Review, 43 (2), 128-144.

Storli, I. (2018). Ottars verden. En reiseberetning fra 800-tallet. Stamsund: Orkana Akademisk. https://doi.org/10.1080/00293652.2010.531586

Toldnes, J. P. (2003). Historien om hyttelivet. Natur og miljø, 1, 42-43.

Tordsson, B. (2006). Perspektiv på friluftslivets pedagogik. Haderslev: CVU Sønderjylland.

Towner, J. (1988). Approaches to tourism history. Annals of Tourism Research, 15, 47-62. https://doi.org/10.1016/0160-7383(88)90070-9

Towner, J. \& Wall, G. (1991). History and Tourism. Annals of Tourism Research, 18, 71-84. https://doi.org/10.1016/0160-7383(91)90040-I

Turner, V. (1978). Image and pilgrimage in Christian culture: anthropological perspective. Oxford: Blackwell.

Viken, A. \& Granås, B. (2014). Destination development. Turns and tactics. Farnham: Ashgate.

Walton, J. K. (2009). Prospects in tourism history. Evolution, state of play and future developments. Tourism Management, 30, 783-793. https://doi.org/10.1016/j.tourman.2009.05.010

White, H. (1978/2001). The Historical Text as Literary Artifact. I G. Roberts (red.), The History and Narrative Reader. London: Routledge.

Wold, H. (2005). Querinis reise / Il vaggio di Querini. Stamsund: Orkana.

Ytreberg, N. A. (1930). St. Olav i Haalogalands kirker. Særtrykk av «Tromsø» 22. november 1930.

Øverland, O. A. (1896). Jotunheimens oppdagelseshistorie. Kristiania: Alb. Cammermeyers forlag.

Aarnes, S. Aa. (1999). Hu, hei kor er det vel frisk tog lett uppå fjellet [Hi, how fresh and easy all is, her up in the mountains]. Nytt Norsk Tidsskrift, 8, 78-83.

Aavitsland, K. B. (2006). Middelalder og norsk identitet. Litterære og visuelle eksempler på norsk medievalisme. Konsthistorisk Tidskrift, 75(1), 38-49. https://doi.org/10.1080/00233600500469719 


\section{Turistresorten Odda - en velorganisert cruisedestinasjon på 1800-tallet}

Odda innerst i Sørfjorden i Hardanger var ett av de tidlige turiststedene i Norge. Det begynte rundt 1860. Oddas turisthistorie viser de fleste sidene av turismen, for eksempel betydningen av gode attraksjoner og av infrastruktur, og hvordan reiselivet skaper grunnlag for et mangfold av næringsaktiviteter. Og allerede den gang var også samspillet mellom markedsutvikling og stedlig reiselivsutvikling sentralt. Men utviklinga i Odda viser også hvordan reiselivet er påvirket av andre næringer og endrede konjunkturer. Da Odda ble et industristed, ble det relativt fort slutt på turismen. Først og fremst er det imidlertid slående hvordan sentrale sider ved reiselivet også eksisterte i turismens første tid. Det finnes en del dokumentasjon og arbeider hvor turismens utvikling er beskrevet, særlig et studentarbeid fra 1984 (Bårtvedt 1984), hvor det meste i denne beskrivelsen er hentet fra.

Odda er både en fjord- og ei fjellbygd, og by, som stedet er benevnt i dag. Folketellingsmateriale viser at det i 1865 bodde cirka 1600 mennesker i Odda, de fleste bønder eller husmenn. Etter hvert som turismen vokste - det startet smått om senn på 1830- og 40-tallet, ble turistrelatert virke kjærkommen attåtnæring for mange om sommeren. For turismen begrenset seg til sommeren. Opprettelse av diverse innenlandske og utenlandske skipsruter fra 1850 og framover var en viktig forutsetning for den økende turisttrafikken til Hardanger; «[...] turistferdsla på Vestlandet fekk sitt store gjennombrot og si utvikling parallelt med den rutegåande dampskipstrafikken», hevder Kolltveit (1984). Fra 1861 gikk det en fast dampskipsrute fra Bergen til Odda, først med båten «Vøringen», et navn som ikke var tilfeldig, ifølge Kolltveit, men valgt fordi framsynte mennesker så kom- 


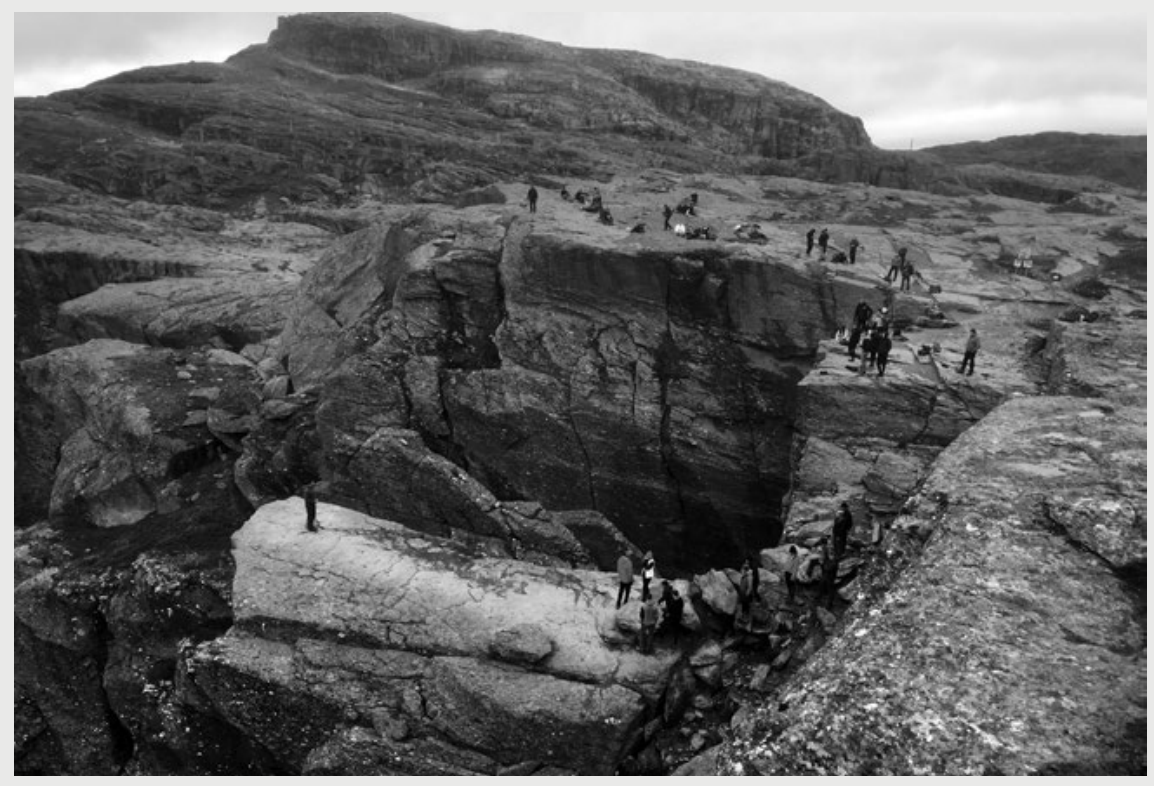

mersielle potensialer i Vøringsfossen og turismen. Det hjalp også på trafikken at man i 1857 påbegynte arbeidet med en vegforbindelse mellom Odda og Østlandet gjennom Telemark. Noe seinere ble også en annen turistveg fra Odda etablert, over Røldal til Sand og Suldal i Ryfylke. Dette gjorde sitt til at Odda fikk skysstasjoner og skysskarer til å betjene de reisende.

Odda fikk sitt forste hotell i 1851, Monsens Hotel, og hadde tolv hotell på det meste, de fleste familiedrevet. Hotellene holdt åpent fra slutten av

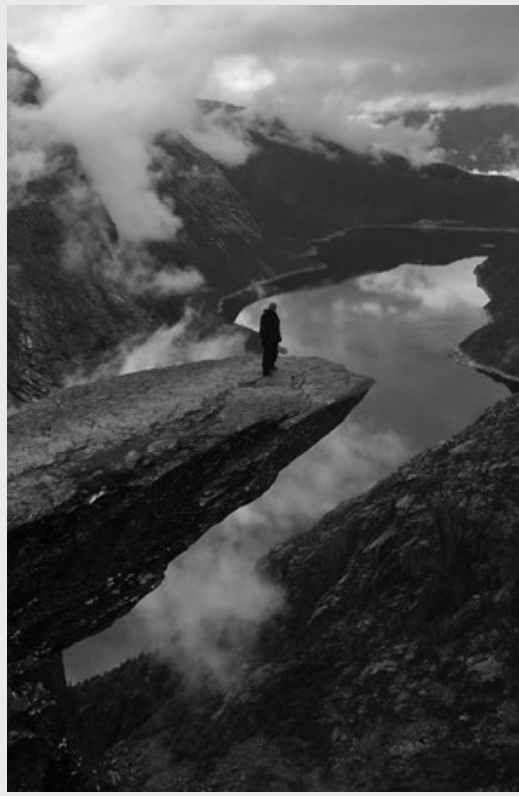

Det startet i Odda. Trolltunga er stadig spektakulært - etter en time i kø. Foto: Arvid Viken. mai til midt i september. Bår- 
tvedt (1984) skriver at de fleste som drev hotell, var oddinger som hadde vært ute i verden, flere hadde utvandret til USA, men kommet hjem igjen. Eierne støttet seg til eller gikk i kompaniskap med folk med hotellbakgrunn, og søkte råd hos kjente reiselivsstørrelser som for eksempel Thomas Bennett, som hadde etablert reisebyrå i Kristiania alt i 1851. Det var heller ikke uvanlig at de reisende leide rom rundt på gårdene. Hotell Hardanger var lenge det største hotellet, og eieren M. Tollefsen den største skatteyteren i kommunen. Etter en brann i 1895 ble hotellet gjenoppbygd med 110 rom, 170 senger og med plass til 250 gjester i spisesalen.

Odda ble med de nye veiene et viktig kommunikasjonsknutepunkt. Men det var også et anerkjent reisemål i seg sjøl, det var rosinen i pølsa for turister som kom båtveien. Landskapet bød på mye av det typisk norske; den trange fjorden, høye og steile fjell, brearmer og fosser. Også i dag er dette attraksjoner, Folgefonna, Buarbreen, Låtefossen, Skjeggedalsfossen og Ringedalsvannet (under Trolltunga), og i tillegg selve Odda med sin utsikt, sine restauranter og suvenirbutikker. For å få med seg de viktigste turistattraksjonene trengte man tre dager. Bårtvedt (1984) beskriver en relativt avansert og organisert turistdestinasjon. Utfluktene var relativt dyre i forhold til hva det kostet å overnatte. Mens helpensjon på hotell i 1900 kostet seks kroner, kostet en dagstur til Skjeggedalsfossen fem kroner, altså nesten like mye. For leie av fører over Folgefonna måtte man betale 12-16 kroner, og slike tjenester ble tilbudt; det fantes guider og skyssfolk som brakte turistene til attraksjonene. | 1903 ble det utstedt 137 skyssløyver. | 1898-1999 oppga 34 bønder at de hadde skyssinntekter, men det var mange flere som også hadde slike inntekter (Bårtvedt 1984). I materialet fra folketellingene finnes yrkestitler som turistkjørere, turistførere, hotellpiker og tjenestejenter. Også barn og ungdom fant seg arbeid i tilknytning til turismen. Noen var grindegutter - de åpnet og lukket de mange grindene på veiene, andre solgte blomster og bær til turistene (ibid.). 
I den første tida var det engelskmennene som dominerte turisttrafikken, men etter 1900 kom også mange tyskere - i kjølvannet av keiser Wilhelm II, som rundt forrige hundreårsskifte gjorde flere reiser til Norge (Skotheim 2011). De fleste som kom var velstående mennesker. Omfanget på turismen er ikke helt klart, men det finnes en del tall som gir indikasjoner (Kolltveit 1984). I 1904 ble Odda besøkt av 37 skip med til sammen 88 anløp, hvorav 83 utenlandske, og 7719 turister. I tillegg hadde fjorddampskipene med Odda som endestasjon 4400 passasjerer. Til sammen blir dette 2019 turister, skriver Kolltveit (1984). Om de i gjennomsnitt var der i fire døgn, blir dette altså nærmere 50000 besøkendedøgn i 1904. Dette var ikke det man i hotellsektoren kaller gjestedøgn, de fleste var cruiseturister som bodde om bord i båtene.

Moderne industri tok etter hvert knekken på turismen i Odda. I 1906 ble «halve Odda solgt» til et selskap som skulle produsere kunstgjødsel. I en uttalelse i Hardanger Folkeblad (1906) het det:

Odda har længe været et Sentralpunkt for Reiseog Turisttrafikken i vore Bygder. Og efterhånden Faat god og sikker Klang. [...] Og det kan saamenn hænde, at den gamle bondebygd Odda blir snart forvandlet til et Ladested ....

Avisa fikk rett. Fabrikken kom i gang i 1908. Og i 1910 siterer Hardanger Folkeblad reisehåndboka Baedecker: «Odda er malerisk, men skjemmes av Fabrikvirksomhet, som har betat Landskapet all dets Charme.» I Hardanger Folkeblad (1910) het det videre i en omtale av en innmeldt rettssak:

Hotellerne paastaar, at deres Næring i høi og stigende Grad forringes av Stanken. Ogsaa stedets Befolkning udenfor de direkte Hotellinteresserte lider meget. «Turisterne - dem er det ikke saa farligt for,» siger de, «men det er verre for os som maa være her, [...].» 
Etter hvert stengte hotellene, det sist anlagte Hotell Odda ble etter en rettssak overtatt av fabrikken og gjort om til arbeiderboliger. Odda mistet også sin posisjon som trafikkknutepunkt i og med at Bergensbanen var etablert, og en alternativ ruten mellom Bergen og Oslo ble foretrukket. I 1914 var det slutt på Oddas storhetstid som turistresort.

Eksemplet Odda viser betydningen av markedet, men og noen av dilemmaene knyttet til turisme. For det første at cruiseturismen ofte har skapt grunnlag for en stedlig turismenæring, samtidig som det også er en form for turisme som begrenser de lokale ringvirkningene av turismen. Hotellnæringa klagde over at mange av turistene bodde om bord i skipene under oppholdet. Det andre interessante aspektet ved oddaturismens historie er dens endelikt, som viser at turisme ikke går så godt sammen med konvensjonell industri - i alle fall ikke slik den foregikk i tidligere tider. Turismen ble kort og godt fortrengt av moderne prosessindustri, som både luktet og skjemmet landskapet. Turisme er industri basert på estetikk og uberørt natur, mens tradisjonell industri gjerne er basert på å utnytte naturressursene gjennom skjemmende inngrep. Ellers viser eksemplet at man tidlig utviklet en reiselivsnæring som både sto på egne bein, og som representerte attåtnæring for bønder og husmenn. Eksemplet forteller også om et attraksjonssystem med alle de ingrediensene en kjenner fra i dag: attraksjoner, fasiliteter for overnatting og bespisning, folk som levde av å være veivisere og formidlere, og myndigheter som skaffet til veie infrastruktur av vital betydning for reiselivsutviklinga. Til sist viser også eksemplet at turismen skapte både konflikter og lokale diskurser, noe avisoppslagene vitner om. 


\section{Litteratur}

Bårtvedt, R. (1984). «Vore gode bræ også i sommer beskuet av høitfornemme øine». Møtet mellom turistar og bygdefolk i Odda 1860-1914. Hovedoppgave i folkelivsgranskning. Bergen: Universitetet i Bergen.

Hardanger Folkeblad (1906). Odda: Hardanger Folkeblad. Hardanger Folkeblad (1910). Odda: Hardanger Folkeblad.

Kolltveit, B. (1980). Over fjord og fjell. Bergen: Universitetet i Bergen.

Kolltveit, B. (1984). Amerikabåtene. Oslo: Norsk sjøfartsmuseum. Skotheim, S. (2011). Keiser Wilhelm i Norge. Oslo: Spartacus 

DEL II: REISELIV - DYNAMIKK OG DRAGKAMPER 



\section{STORE SKIP OG SMÅ STEDER - EMOSJON, INTERESSE OG DYNAMIKKER I DESTINASJONSUTVIKLING}

Christian Ekeland og Arvid Viken

\section{Innledning}

I turismelitteraturen er John Urrys (1990) The Tourist Gaze en klassiker. Her utviklet han et skille mellom det romantiske og det kollektive blikket. Blikkene refererer til turistenes orientering, det kollektive turistblikket er representert av turister som foretrekker å være én blant mange - i en by, på en bar, på en festival. Det romantiske turistblikket assosieres med fravær av slike sammenstimlinger og vil ofte preges av at turisten føler nærhet til natur eller delaktighet i en kultur. For det kollektive blikket kan opplevelser masseproduseres og standardiseres, mens det romantiske blikket foretrekker mindre regisserte eller skriptede opplegg. I dette kapitlet ser vi på potensielle forskjeller mellom store og små turistoperatører med hensyn til opplevelsesproduksjon og opplevelsesmuligheter.

De fleste bedriftene i reiselivet er små, mens de fleste som arbeider i næringa, er å finne i større bedrifter. Dette gjelder både i Norge og resten av verden. Forskningen og teoretiseringen innen feltet har hatt en tendens til å fokusere på sistnevnte gruppe, mens småbedriftsforskningen er både sjelden og mangelfull. Stort sett har småbedriftene vært sett på som avvikende og uinteressante. Erkjennelsen av antall og mangfold har 
imidlertid gjort at det tross alt foregår en viss småbedriftsforskning i turismefeltet. Det foregår også en relativt omfattende småbedriftsforskning i sin alminnelighet, tross alt dominerer småbedriftene mange sektorer, som i landbruk, fiskeri og i mange service- og handelsnæringer (Smith 2006). I dette kapitlet er det forholdet mellom de store og de små bedriftene som vil bli analysert, med fokus på hva størrelse har å si for de opplevelsene som tilbys, og hva turistene kan oppleve i kontekster med henholdsvis små og store bedrifter.

Vi skal altså se på hvordan bedriftsstørrelse og forhold som henger sammen med denne, innvirker på opplevelsen til turistene. Er det slik at smått er godt i alle henseender? Betyr småskala produksjon mer hands-on, mer intime og trivelige turistmiljøer, og innebærer det bedre kontakt mellom produsenter og konsumenter? Og er det slik at de store er mer profesjonelle, kunnskapsorienterte og har bedre kvalitet og service? Svarene man får gjennom litteraturen, er ikke entydige, og understreker vel først og fremst at det i begge leirer er store variasjoner. Selvfølgelig har det også å gjøre med hvilke kvaliteter turistene søker - noen søker de smås kvaliteter og andre de stores. Vi skal illustrere forskjellene ved å referere til to studier, en av turistopplevelser på Hurtigruten - et eksempel på stordriftsturisme, en annen av kiteopplevelser på Ekkerøya, et lite sted på Finnmarkskysten (Ekeland 2016). I kapitlet vil vi altså basere oss på litteratur som tar opp hva som er de stores og smås styrker, hvordan kundene ofte blir betjent både av store og små aktører, og undersøkelser som viser hvordan størrelse heller mot å bli reflektert i de opplevelsene turistene får med seg.

\section{Store og små bedrifter}

\section{Karakter og komplementaritet}

Forestillingen om at stordrift og vekst gir de beste resultatene i forretningsverdenen, står sterkt (Viken 2014). Storskala operasjoner omtales ofte som fordistisk produksjon (Amin 1994). Fordisme er preget av stordrift (masseproduksjon), hierarkisk styring, sentralisert styring (administrert fra utsiden), en nasjonalt regulert økonomi (ekstern eierskap), et smalt spekter av produkter, bransjebestemte produkter (bestemt av turoperatører og hotellkjeder) og en konsentrert produksjon (Ioannides \& Debbage 1997, 
s. 232; Lafferty \& Fossen 2001). Innen turisme er en spesialisert pakketur et typisk fordistisk produkt. Imidlertid eksisterer ofte store og små bedrifter side om side. Undersøkelser har vist at storskala fordistiske operasjoner ofte gjør vei for en konkurrerende og mindre anlagt reiselivsnæring (Viken \& Aarsether 2012; Ioannides \& Debbage 1997, s. 231). Og mange av de små er det fordi de ikke (så langt) har lykkes i å bli større. Til tross for de mange små er stordrift det sterkeste mantraet i næringslivet generelt, også i reiselivet.

Det finnes motrøster til stordriftstenkningen. Mest kjent er Schumacher (1973), som konstaterte at small is beautiful, at smått også kan være godt. For som han sa, mennesket er lite, og produksjonen burde være menneskesentrert og fremme menneskelig kreativitet. Kanskje var dette først og fremst et politisk manifest, men det sies å ha hatt stor betydning for tenkning omkring alternativer til (stor-)skalaproduksjon og i forbindelse med utviklingspolitikk. I mange tilfeller der man trenger utvikling, er det naturlig å ta utgangspunkt i situasjonen og den lokale ressurssituasjonen. Det gjelder også ofte i reiselivet, at den eneste muligheten er å satse i det små. Derfor er det gjerne mange små reiselivsbedrifter, og særlig i områder med et skrint næringsliv. Reiseliv kan utøves på et relativt beskjedent ressursgrunnlag (Shaw \& Williams 2004), og i hovedsak vil overskuddet fra produksjonen forbrukes eller reinvesteres på stedet, sier Harrison (2012). Han nevner også en rekke andre fordeler ved småbedrifter, blant disse at det er en type bedrifter mange turister foretrekker. Småbedriftene kan ha eksistert lenge, og mange skriver seg fra en førfordistisk periode, en tid da familiedrift og kombinasjonsdrift dominerte. Også i denne studien foregår turismeproduksjonen på et førfordistisk produksjonssted, og den moderne driften er preget av små enheter tett på lokalsamfunnet. Driften er imidlertid også en del av den nye tida, basert på moderne teknologi som internett og eksemplet kiter.

Den viktigste kritikken (ibid.) mot smått-er-godt-tenkningen er kanskje at det ikke nødvendigvis er noen motsetning mellom små og store bedrifter, og at de strategisk sett bør ses i sammenheng. For det første er det mye som skjer rundt småbedriftsproduksjonen - for eksempel et lite hotell eller en liten opplevelsesbedrift - som har skalakarakter; flyselskapene, kredittkortselskapene, turoperatørene og andre som er en del av reiselivssystemet disse bedriftene støtter seg til, er som regel store. For det andre 
ligger ofte små og store bedrifter side om side, konkurrerer og samarbeider på samme tid. Alternativ turisme og masseturismen påvirker hverandre og utgjør mange steder en integrert helhet, hevder Weaver (2012). De store setter de store standardene, som de små tar etter. I norsk reiseliv har retorikken vært at man trenger fyrtårn, lokomotiver eller drahjelp i utviklinga av lokalt reiseliv - og at det er de store som kan stå for det. Men ikke i alle henseender. For eksempel foregår mye av opplevelsesproduksjonen i småbedrifter. En undersøkelse av reiselivet på Nordkapp viser en diversifisering av produktene, en utvikling som synes å skje i et vekselspill mellom store og små bedrifter (Viken \& Aarsether 2012). Undersøkelsen viste også at noen av småbedriftene hadde utviklet seg i samarbeid med den store og dominante bedriften på stedet, og at flere småbedriftsledere hadde lært sitt reiselivsyrke som ansatt der. Tendensen er altså at man tar opp i seg hverandres fordeler, og at man tilpasser seg og utfyller hverandre. Tilsynelatende er også dette et av feltets paradokser, de store bedriftene trenger de små, og de små trenger de store. På den annen side viste studien av Nordkapp at det på mange måter finnes to reiselivsnæringer der, en basert på virksomhet knyttet til stedets store attraksjon, og en som fungerte mer eller mindre uavhengig av denne. Særlig er fisketurisme en slik næring (ibid.). Ulikhetene i opplevelsesønsker og produksjon kan altså være så store at relasjonene blir svake. Forholdet mellom store og små bedrifter er komplekst.

\section{Bedriftsstørrelse og opplevelser}

Noe av ideen med stordrift eller skalaproduksjon er spesialisering og rutinisering. Det gir billigere produkter og massesalg. Produksjonen er preget av standardiserte operasjoner, hvor alt og alle behandles likt. I turismesammenheng betyr det at aktiviteten er skriptet, og at alle mer eller mindre gjør det samme. Produksjonen følger en oppskrift, opplevelsen er som regel beskrevet på forhånd, og denne beskrivelsen danner grunnlaget for kjøp og salg. De ansatte gjør det samme gang etter gang på et avgrenset område, og det blir de som regel gode til, og kvaliteten på deres ytelser er høye. Men den som betjenes av organisasjoner der arbeidsorganiseringa er slik, mottar tjenestene av ulike mennesker som bare møter dem i de korte øyeblikkene tjenesten ytes; en tar imot i resepsjonen, en annen serverer i baren, en 
tredje steller rommet, og atter andre formidler utflukter eller vokter bassenget. Kunnskapen om hvordan slike bedrifter skal og kan ledes, forvaltes hos ledelsen, ikke hos den enkelte ansatte. Slik er ikke arbeidshverdagen i små reiselivsbedrifter. Her er det mangesysleri og multitasking som gjelder. Valtonen (2009) viser hvordan ansatte i småbedrifter gjennom sin praksis erverver et mangfold av kunnskaper og ferdigheter, og hvordan deres forankring i lokal kultur representerer verdifull kunnskap i reiselivsproduksjonen. Gjennom mangesidig betjening fra en og samme person utvikles servicerelasjonen til noe mer enn kun det, og dette representerer en slags relasjonsbygging mellom produsent og kunde, hevder Valtonen (ibid.). I disse møtene genereres kunnskap - det foregår læring gjennom observasjoner, lytting, samtaler og opptredener - om hvordan opplevelser skapes, og om omsorgsfunksjoner som bidrar til å utvikle turismearbeiderens ferdigheter i å håndtere kunder. I småbedriftene er dessuten som regel skillet mellom arbeid og fritid diffust. Denne diffusheten bringes også inn i kunderelasjonene og gjør at turisten ofte får ta del i lokalt hverdagsliv på en helt annen måte enn man opplever i store bedrifter. Wanhill (2000) hevder derfor at besøk på småbedrifter som bed-and-breakfast-hoteller, gårdsbesøk og liknende, gir en sterkere følelse av autentiske møter, altså møter mellom mennesker, ikke bare mellom roller. Hovedpoenget er altså at småbedrifter innbyr til mye tettere relasjoner mellom turist og vert, mellom turisten og vertssamfunnet. I forskningen er dette omtalt som spørsmål om nærhet eller intimitet (Trauer \& Ryan 2005). Trauer og Ryan (ibid., s. 482) hevder at dersom man blir mottatt av en som har et nært forhold til det aktuelle stedet, får man helt andre opplevelser enn dersom «verten» er fremmed på stedet. I stordrift tenderer turismen mot å redusere menneskelige relasjoner til funksjonelle byttesituasjoner (Stokowski 2002) og transaksjoner. Moderne turister ønsker ikke bare å bivåne den Andre, men også å bli en del av den Andres liv, blir det hevdet (Conran 2006). Heri ligger et paradoks: For mange er målet å tre ut av rollen som turist når man kommer til nye omgivelser, mens verter og vertssamfunn nettopp innskriver dem i denne rollen (jf. Simoni 2014). Muligheten for å unnslippe turistrollen er trolig mindre jo større virksomheten er. Derfor representerer også småbedriftene og de som arbeider i disse, ofte mellomposisjoner mellom den internasjonale reiselivskulturen og lokalsamfunnene. 


\section{Opplevelse som interesse}

Opplevelsesbegrepet har blitt forsøkt dissekert innen turismefeltet på forskjellige måter. Pine og Gilmore (1999) skilte imellom aktive og passive opplevelser, mellom det å være involvert og distansert. Tagg (1993) argumenterer for at tilskueropplevelsen ikke trenger å være passiv, da kunnskap utvikles. Bigné og Andreu (2004) på sin side viser hvordan deltakelse og aktiviteter bidrar til opplevelsen, mens en passiv opplevelsesproduksjon ikke har tilsvarende opplevelsespotensial. Prebensen og Foss (2011) omtaler turistene som medprodusenter av egne opplevelser. Innen turismefeltet har det i mindre grad blitt forsket på turisters læringsopplevelser (Ekeland 2011), men i et beslektet felt har et begrep som edutainment blitt brukt for å fange inn hvordan meningsfulle og positive opplevelser skapes, for eksempel i forbindelse med dataspill. I stedet for å operere med det vide opplevelsesbegrepet skal vi her i dette kapitlet ta for oss emosjonen interesse. Dette begrepet omfatter læring og emosjonell kvalitet.

I studier gjort av turistenes motivasjoner for å reise mot nord er funnene svært klare (Ekeland 2011). Nordlyset er den sterkeste motivasjonsfaktoren. Turistene ønsker å lære om og se nye fenomener, bli kjent med norsk kystkultur og delta i aktiviteter som for eksempel hundesledekjøring. Turistene er fortsatt en slags explorers, altså utforskere. Som vi skal se, skaper to forskjellige kontekster, småstedet Ekkerøy og skipet Hurtigruten, to svært forskjellige dynamikker med hensyn til interesseutvikling.

\section{Interesse i store og små reiselivsbedrifter}

Mennesket kan ikke gjøre seg opp meninger, formulere fremtidige mål og handlinger uten tilstedeværelsen av følelser (Lazarus 1991). Ren rasjonell tanke eller handling finnes ikke, den er alltid påvirket av det emosjonelle (Zajonz 1980). Emosjonen "glede» oppstår av mange grunner; når en bit sjokolade smelter i munnen, når man står på toppen av et fjell etter å ha brukt timer på å bestige det, eller når man tar inn over seg en vakker utsikt. Emosjonen springer ut av evalueringer som du gjør av deg sjøl i forhold til dine omgivelser - at selvet gjør det bra i verden (D’Andrade 1995). For å oppnå glede gjør vi derfor ofte ting som har vist seg vellykkede i fortida 
(Silvia 2006). Glede kan ses på som en hedonistisk belønning av egne behov, til tross for at vi også har evne til å glede oss over andres lykke. Selve gledesfølelsen som oppstår etter slike evalueringer, forvandler kroppen. Hormoner frigjør energi som ligger lagret i musklene, man føler velvære i kroppen, og smilet og latteren sitter løst (Janig 2003). Den subjektive følelsen vil variere fra situasjon til situasjon, men kan beskrives som eksempelvis opprømthet, økt energi og velvære. Når man er lykkelig, formuleres mer positive hypoteser om verden og hvordan du sjøl gjør det i forhold til denne, hevdes det også (Schwartz \& Bless 1991). Følelse av glede kan dermed være med på å gjøre sjøltilliten mer robust (Taylor \& Fiske 1991).

Der glede er konservativ og bidrar til reproduksjon av handlinger som har vist seg positive i tidligere situasjoner, representerer interesse et emosjonelt begjær etter å utforske nye ting (Silvia 2006). Man engasjerer seg i nye situasjoner, blir nysgjerrig på nye landskap, objekter eller mennesker. Det eksisterer flere teorier om hvordan interesse utvikles, som har relevans for turismeforskningen. I dette kapitlet skal vi se på to forskjellige dynamikker som produkter av hver sin særegne kontekst representert igjennom en større og en mindre bedrift. Den ene teorien forklarer hvordan mennesker utvikler potensielle livslange relasjoner med sine interesseobjekter gjennom gjentatt engasjering. Man endres i en turistopplevelse gjennom læring (Hidi \& Renninger 2011). Den andre teorien er at motsatte dynamikker også kan skape intense interesser; når fraværet av et ønsket objekt vedvarer tross gjentatte forsøk på engasjering (Ekeland \& Dahl 2016).

\section{Interesse som læring}

Ifølge Hidi og Renninger (2011) bidrar gjentagende konfrontasjon (eller involvering) med et interesseobjekt til en utdypning av følelsen; man lærer mer om interesseobjektet, og det blir også mer viktig for selvet. Når vi utsettes for nye ting, er det viktig at vi evner å forstå kompleksiteten av dette nye, ellers legger vi ikke merke til det eller forstår ikke at dette kan være av interesse. Videre må man kunne håndtere kompleksiteten eller utfordringen som en situasjon eller aktivitet representerer. Blir aktiviteten for vanskelig eller for kjedelig, kan interessen dø ut (Csikszentmihalyi 2002). Interesseutvikling fordrer tid, som Hidi og Renninger (2006) sier, til å utforske og lære seg mer om disse objektene eller aktivitetene. De fleste 
av oss har allerede utviklet livslange interesser for akademia, matlaging, fjellvandring, musikk og så videre, som er med på å forme den personen vi er eller forsøker å være. Jo mer utviklet denne relasjonen er, gjennom mer kunnskap og økt verditilskriving for objektet, desto dypere og sterkere blir emosjonen (ibid.). Den subjektive følelsen av interesse blir beskrevet som en oppslukthet, oppmerksomhet, opprømthet og så videre (Izzard 1977). Når interesse er blitt aktivert, bidrar dette fokuset til begjær til å utforske, og til at man lærer raskere (Silvia 2006; Hidi \& Renninger 2006). Kritisk for denne teorien er at i begynnerstadiet til interesse, når turistene vet lite om et fenomen, er de mer avhengige av hva Hidi og Renninger (ibid.) kaller ekstern støtte for å klare å gjøre seg opp en mening, og dermed utvikle interesse. Ekstern støtte kan være en guide, Hurtigrutens oppbygging av opplevelser eller en instruksjonsbok. Disse hjelper deg med å forstå ny eller kompleks informasjon når interesse for et spesifikt interesseobjekt blir trigget for første gang, og man har liten kunnskap om det og enda mindre tilknytning til det. Med en velutviklet interesse kan du mer, og du evner å stille egne spørsmål og å finne fram til hva som trengs for å drive interessen framover og lære mer. Det er en sammenheng mellom det vi har kalt glede og interesse. Interesse skaper gledesfølelser. Man finner glede i å oppdage eller lære om nye ting, i situasjoner som er meningsfulle for en sjøl, som bidrar til realisering av ens egen (sanne) natur.

\section{Interesse som wanting}

I hjertet av interesseforskningen ligger premisset om at interesse er en emosjon som skaper begjær etter å utforske objekter. Hva skjer når noe du er blitt lovet, ikke dukker opp? Emosjoner påvirker hvordan vi tenker og forventer. Ofte er det noe vi ønsker oss veldig sterkt, som for eksempel å få se nordlyset. Dette kalles wanting. Når så dette ikke dukker opp, øker verdien på interesseobjektet - nordlyset - enda mer. Dette kan bli ytterligere forsterket ved at andre gir uttrykk for tilsvarende ønsker (Ekeland \& Dahl 2016). På den måten blir mennesker som en deler opplevelsen med, samskapere av den (Prebensen \& Foss 2011). Altså er det ikke bare varige relasjoner som bygges opp gjennom gjentatte forhandlinger med et interesseobjekt, fraværet av interesseobjektet skaper subjektive opplevelser av wanting, som ofte er sterkere enn noen annen form for interesse (Litman 
2005). Som vi skal se, blir slike dynamikker også viktig for verdiskaping i nordnorsk vinterturisme.

Interesse som emosjon kan dermed være et fruktbart analytisk rammeverk for å forstå møtene turister imellom og bedrifters måte å skape opplevelser på. De spesifikke kontekstene, her representert ved Ekkerøy og Hurtigruten, er avgjørende for muligheten til å utvikle disse emosjonene.

\section{Studieobjekter og metode}

\section{Hurtigruten}

Grunnlaget for fokuset på interesse kommer fra tre sett spørreundersøkelser gjort på Hurtigruten samt opplysninger fra Hurtigrutens egen markedsavdeling. Alle disse dataene forteller at primærmotivasjonen som ligger bak det å reise nordover og oppleve den arktiske vinteren, handler om å se nordlyset. Turistene vil dessuten lære om norsk kystkultur og delta i aktiviteter. Intervjuene som ligger til grunn for denne analysen, støtter disse funnene, men viser også at turistene ønsker å lære nye ting og å delta i settinger som kan gi dem ny kunnskap.

Hurtigruten er en av driverne for utviklinga av turismen i Nord-Norge. Hurtigruten er altså en slags hybrid mellom en lokalbåt og et cruiseskip, som med avgang hver dag trafikkerer strekningen Bergen-Kirkenes. Båtene tar i dag opptil 600 passasjerer. Dette er en form for masseproduksjon med tung skripting og standardisering.

Turistene som bestiller en tur med Hurtigruten om vinteren, er primært ute etter å oppleve nordlyset. I tillegg tilbyr skipet underholdning om bord i form av filmer, quizer, tørrfisksmaking, foredrag med mer. Hurtigruten forholder seg til en avtale med staten som regulerer mye av skipenes bevegelser, og hvor lenge disse blir liggende i havn. For Hurtigruten er ikke bare et cruise, det er et arbeidsskip som i over 120 år har levert personale, gods og post oppover og nedover norskekysten. Dette påvirker Hurtigrutens tredje opplevelsesmoment, som er ekskursjoner i land. Eksempler på dette er turer opp til Nordkapp eller hundesledekjøring i Tromsø og Kirkenes. Slike ekskursjoner varer toppen tre timer, da skipet må videre i sin stramme tidsplan. Alle disse opplevelsene på skipet og i land er nøye koreografert, tilpasset tid og mange mennesker. Filmskaper Nils Gaup har var med på 
å utforme dramaturgien $\mathrm{i}$ noen av disse opplevelsene. Hver dag ankommer et nytt skip en av disse havnene, med nøyaktig samme agenda, noe som peker på den repetitive naturen i industrialisert turisme.

\section{Ekkerøy}

Det andre eksemplet forteller om et besøk på Ekkerøya, en halvøy en mil utenfor Vadsø i Finnmark, et område der et sterkt kitemiljø har oppstått. Hvert år arrangeres Varanger Arctic Kite Enduro (VAKE) i området. Kiting blir et eksempel på en lavskriptet og dynamisk turisme, der vi møter
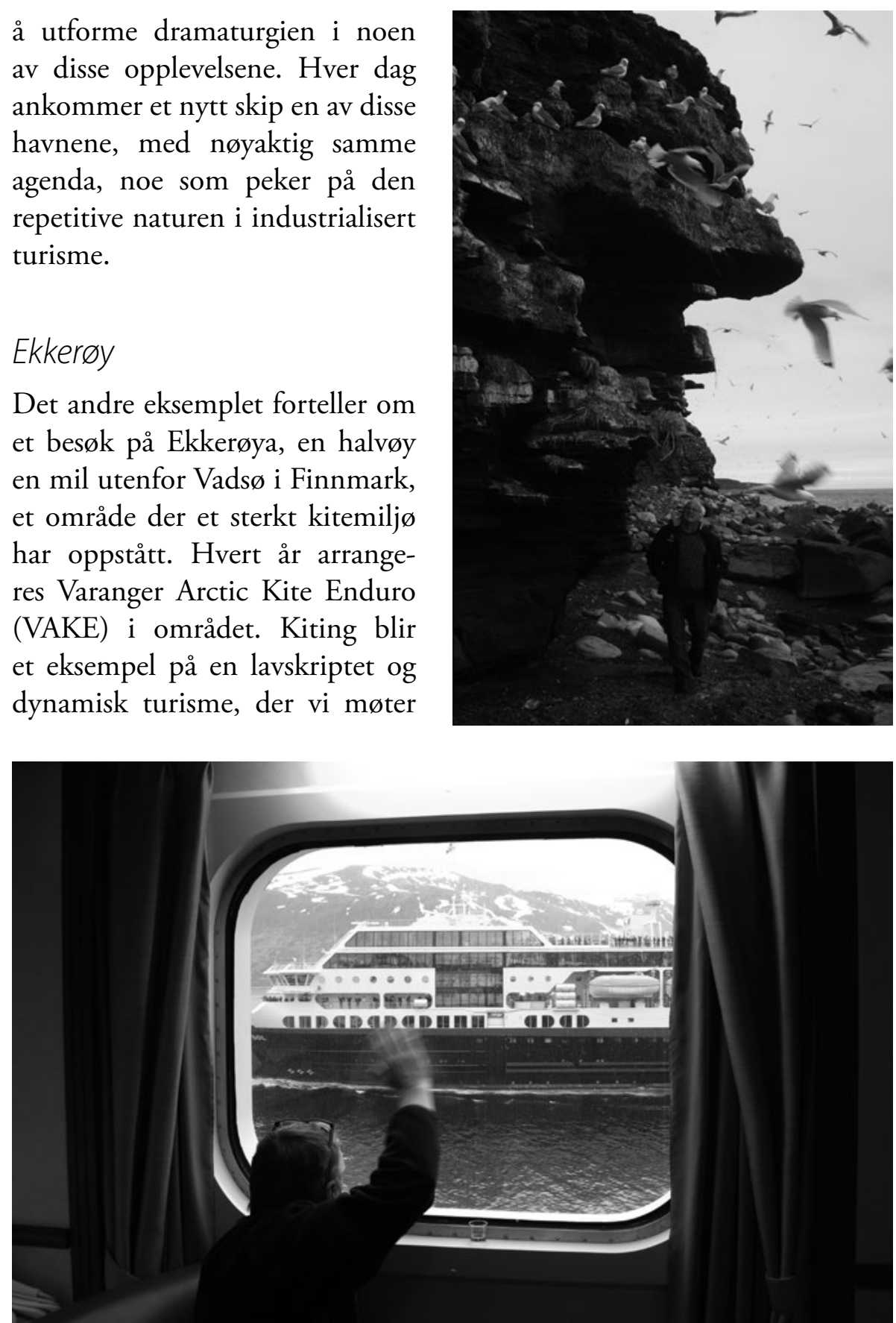

Hurtigruten og Ekkerøya, turistiske motsatser. Foto: Ole Magnus Rapp. 
små bedrifter i vår higen etter å engasjere oss i en spesifikk aktivitet. Ekkerøya har flere turismetilbud. Rorbuer leies ut til turister, og restauranten Havhesten tilbyr spiseopplevelser med vakker utsikt. I løpet av sommermånedene tiltrekker Ekkerøya seg fuglekikkere til fuglefjellet som befinner seg noen hundre meter fra bebyggelsen, og folk flytter inn i sommerhusene sine. Det lille lokalsamfunnet syder av mennesker. Vi kommer dit i oktober idet vinteren er i ferd med å ta tak. Vekk er både turister og deltidsboende. Bare en håndfull av mennesker bor der året gjennom. Gjennom aktiviteten kiting treffer vi Hanne, som styrer rorbuene, og Roald, Hannes onkel, som styrer Havhesten. Dette er et innblikk i små turismebedrifters fleksibilitet, men også hvordan interesser får handlingsrom under slike forhold.

\section{Data}

Implisitt i sammenlikningen av store og små bedrifter ligger et metodisk dilemma. Metoder en kan anvende for store bedrifter, er vanskelig å bruke på de små. I datagrunnlaget for analyse av Hurtigruten inngår spørreskjemaet som turistene har fylt ut sjøl. I alt 260 turister har svart på et slikt skjema i løpet av to turer i 2008 og 2012. Dataene dette gir, er kvantitative uttrykk for det vi studerer. Det er imidlertid meningsløst å anvende denne metoden på en småskala operasjon hvor kundene er svært få. I studien av Hurtigruten er det også brukt kvalitative intervjuer og deltakende observasjon over tid for å avdekke det temporale, som er kritisk for å forstå emosjoner (Ekeland 2011; Ekeland \& Dahl 2016; Ekeland 2016). For studiet av Ekkerøy ble analytisk autoetnografi benyttet, hvor forskeren ser på emosjonelle prosesser fra posisjonen til selvet, der samtidig andre mennesker, objekter og landskap inngår i slike analyser. Autoetnografi er en refleksiv etnografi som i grunnen minner svært om tradisjonell etnografi, men at fokuset på hvordan forskeren er en medprodusent av data, blir mer eksplisitt debattert (Boylorn \& Orbe 2014; Anderson 2006). Spørreskjema og autoetnografi skaper også svært forskjellige måter å representere kontekst og interesse på - og en forskjell i nærhet til det som analyseres, som også påvirker skrive- og fortellerstilen. I analysen som ligger til grunn for kapitlet, ble disse metodene anvendt, slik at dataene styrker hverandre og analysen. 


\section{Hurtigrutens to opplevelsesproduksjoner}

Hurtigruten er i stadig utvikling. Analysen i dette kapitlet er basert på data innhentet mellom 2010 og 2016. Gjennom disse studiene har vi blitt bevisst på at man må skille mellom to typer opplevelser som trigger og utvikler interesse på forskjellige måter. Som nevnt har Hurtigruten skriptede opplevelser som gjentas hver dag, der interesse forsøkes, trigges og utvikles på måten Hidi og Renninger (2006) argumenterer på ovenfor. Dette krever at Hurtigruten støtter denne gryende interessen, gir meningsfull informasjon og mulighet til utforskning gjennom gjentagende interaksjon med interesseobjektet. På den andre siden tilbyr Hurtigruten uskriptede og ukontrollerbare opplevelser i form av nordlysjakten. Dette skaper andre former for interesse, der fraværet av interesseobjekt skaper et sterkt begjær etter å utforske, såkalt wanting.

\section{Skripting og kontroll}

Hurtigrutens skip er bygd for å romme mange mennesker. De største kunne ta om lag 600 passasjerer på den tida vi gjorde våre undersøkelser. For at eierkonsernet skal gå i økonomisk balanse, kreves det at man klarer å fylle det meste av kapasiteten. Derfor er det også en form for masseproduksjon om bord. Reisen og dagene er nøye beskrevet og regissert, hva vi her har kalt skriptet. Bare i liten grad gis alternative muligheter. Dagene er derfor også like for alle. Hver dag tilbys eskorterte turer på land - også de er skriptet. Et eksempel på en sånn dag kan være dag to på tur nordover fra Tromsø. Skipet ankommer Honningsvåg utpå formiddagen. Turistene rekker å spise frokost før ekskursjonen til Nordkapp. Tre timer er satt av til denne. Turistene blir geleidet til ventende busser og en førti minutters guidet tur til platået. Et tog av busser slanger seg opp til Nordkapp-platået gjennom det arktiske landskapet. Fremme har turistene rundt en time på å oppleve Nordkapp: Turistene tar inn den majestetiske utsikten på platået, akkompagnert av summingen av alle turistene som snakker et mangfold av forskjellige språk. Nede i Nordkapphallen må man som regel stå i kø for å komme inn i filmsalen, på do, i kafeen og foran kassa i butikken. I Nordkapphallen kan de også se en ti minutters panoramafilm om området, få 
med seg utstillingene inne i hallen og shoppe i suvenirbutikken. Turistene transporteres tilbake til skipene på nok en guidet tur. Nesten umiddelbart etter at skipet begynner å bevege seg, vises en film om samisk kultur i ett av konferanserommene. Turistene får deretter to timer med hvile før skipet seiler forbi en klippeformasjon kalt Finnkirka - en samisk offerplass og et spektakulært landskap - mens høyttalere spiller en slags joik og klippen lyssettes i nordlysets farger. Klippene er en gammel samisk offerplass, steder og praksiser de fleste turistene vet lite om. Deretter blir Hurtigruten bordet av en eller to lokale aktører som har med kongekrabbe, som vises fram og fortelles om ute på dekk. Middagen med sine to bordsettinger følger så. Dagen avsluttes med en quiz i en av barene. Dagen har vært fylt av opplevelser, turistene har besøkt en markant turistattraksjon og fătt en rekke visuelle inntrykk. På resten av turen er opplegget mye av det samme, med landekskursjoner og landaktiviteter. Få av tilbudene er reelle aktiviteter i fysisk forstand, unntakene er hundekjøring i Tromsø eller Kirkenes og snøskuterkjøring i Mehamn. Men også her er standardiseringen og skriptingen til å ta og føle på. Før hundekjøringa samles alle turistene som skal kjøre, og de får en kjapp intro om hvordan man starter og stopper sleden. Så samles alle sledene i kø og følger etter guiden i en forhåndsinnkjørt rute. Guiden bestemmer tempoet, og hundene følger etter - de vet hvordan det skal foregå. Det eneste turistene trenger å kunne, er å trykke på bremsen sånn at hundene ikke vikler seg inn i spannet foran. Det hersker med andre ord en «one size fits all»-ideologi også her - med enkle utfordringer og én fart - guidens. Turistene får ikke prøve å kontrollere hundene, svinge eller øke tempoet, man kjører bare i ring etter hverandre i samme spor.

Hurtigruten er en dyktig leverandør av hygienefaktorer, altså av det som skal til for at leveransene fungerer. Lugarene er relativt romslige, og natten fortoner seg svært stille når skipet sklir gjennom mørket. Kun små avbrudd der skipet stopper i havner for å losse, og man kan høre kraner jobbe. Servicepersonalet er hyggelige og profesjonelle, og maten holder høy standard. Til og med i storm, når skipet duver i de store bølgene, står kokkene og tilbereder maten foran gjestene. Skipene har trygge rom og forutsigbare tidsskjemaer for mat og opplevelser. Som nevnt, det å skape glede og trygghet for turistene kan ligge i et godt måltid, vakre omgivelser, men å trigge interessefølelsen og utvikle denne, er noe helt annet. To undersøkelser på Hurtigruten i 2008 og 2012 avdekket et mønster. 
Hurtigruten tilbyr langturer som går fra Bergen til Kirkenes og tilbake. Disse turene er lagt opp med en dramaturgi der turistene blir introdusert til forskjellige aspekter ved norsk kystkultur. Det tilbys også korte turer som fra Tromsø til Kirkenes eller tur-retur Tromsø. Når disse turistene entrer skipet, får de ikke vite noe om regionen eller opplevelsene som venter. De har, ifølge interesseteorien, få mentale knagger å henge den nye informasjonen på. For eksempel tilbys tørrfisksmaking på dekk seint første dag. Denne opplevelsen om bord har ved begge anledningene vært sparsomt besøkt. Kapteinen banker tørrfisk, og turisten kan smake og i tillegg få en historisk innføring i tørrfiskens betydning for regionen. Men mange av turistene vet lite om hva tørrfisk er, så hvorfor skulle de være interessert i dette? Et annet og kanskje bedre eksempel handler om turistenes primærmotivasjon, nordlyset. Skipet seiler forbi Altafjorden og Haldetoppen, hvor nordlysforsker Birkeland, som lenge var avbildet på den norske 200-kronersseddelen, gjorde sin første nordlysforskning. Han bygde også verdens første nordlysobservatorium her. Dette er kunnskap som ville underbygge primærmotivasjonen for turistene, men ikke et ord nevnes om dette på turen. Med andre ord var Hurtigrutens kunnskapsformidling dårlig med hensyn til å vekke interesse. Svært mange mennesker og liten tid til utforskning gjør at dette ikke vektlegges. Turistene blir for det meste stående i flokk og lytte til en guide snakke om landskap eller objekter. Turistene blir gjort til tilskuere, noe som reduserer læringseffekten, som er vital for utviklinga av interesse. Når aktivitetene først finner sted, som for eksempel hundekjøringa, er denne såpass kort og lite utfordrende på grunn av one size fits all-ideologien, at det blir lite læring. Dette kan fort avstedkomme kjedsomhet, interessens nemesis, på grunn av manglende utfordringer. Kort fortalt: Turistene blir utsatt for mange nye landskap, mennesker og objekter, men lite gjøres for å bygge opp en interesse. Forholdene om bord er svært lite tilpasset turistenes behov for utforskning. ${ }^{1}$

Dette er forhold som Hurtigruten har jobbet med å forbedre. Kapitlet gjelder altså Hurtigruten slik den var fram mot 2012. Problemstillingene som tas opp, har imidlertid generell relevans, og de viser hvordan forskjellene mellom en storskala og skriptet og en småskala og lavskriptet produksjon kan fortone seg. 


\section{Jakten på nordlyset og eudaimonia}

Som nevnt er å se nordlyset primærmotivet for de fleste. Det å reise langt på leiting etter primærinteressen, uten at det lykkes, kan imidlertid medføre sterk interesseutvikling. I en tidligere analyse viser Ekeland og Dahl (2016) hvordan wanting-konflikt eskalerer etter hvert som tida går om bord og turistene ikke får sett nordlyset. Kort fortalt viser denne analysen hvordan turistene som allerede er interessert i nordlys, i økende grad opplever dette begjæret etter å utforske fenomenet de ikke lykkes i å få se. Emosjonen interesse påvirker også hvordan turistene formulerer fremtidige forventninger. De blir mer negative i sin tro på å få se nordlyset, som igjen øker dets verdi. Dette kaller vi styrket wanting, som også styrkes av medturistene som åpent klager fordi det bare er kort tid igjen av turen de har betalt tusenvis for uten å se nordlyset, og deres hvileløse vandring på båten mens de skanner horisonten for tegn på grønt lys. Da nordlyset endelig kommer, blir de emosjonelle uttrykkene sterke, sett fra vår observasjonspost. Turister kommer løpende opp trappene for å komme på dekk, noen snubler og faller, kryper på alle fire for så å løpe videre. Andre kommer løpende på dekk bare iført T-skjorte i minus ni grader og blåsende vind. Til slutt, når nordlyset danser kraftig over himmelen, bryter de 200-300 turistene ut i jubel og applaus, noen gråter.

Når turistene opplever en sterk emosjonell "peak» midt i reisen, som i vårt eksempel, kan de oppleve å bli mettet av å jakte på nordlyset. De søker da andre kilder til interesse, og Hurtigruten må da ha noe å tilby, ellers kan dette fort føre til kjedsomhet. Følgende svar i intervju ble foretatt under et døgn etter at de samme turistene hadde vært henrykt:

Innsiden av skipet er bare passivt. Jeg tror nok noen gjester liker å være med andre gjester, ha en fast måltidsrytme og ha ferdigplanlagte ekskursjoner - jeg vil heller være nærmere til naturen. Innsiden oppildner meg ikke - bare en måte å komme seg fra A til $\mathrm{B}$ på, komfortabelt, men ikke viktig. 
Her må det nevnes at «innsiden» utgjør det meste av turen.

Jeg har aldri vært på et cruise før. Miljøet og landskapet har gledet meg, samt introduksjonen til kultur. Mindre har jeg likt livet om bord. Det er ikke min ting. Jeg ønsker en aktiv livsførsel mer enn en passiv.

Uttalelsene sier noe om hvordan en fordistisk eller industriell opplevelsesproduksjon posisjonerer turistene som tilskuere - noe som oppleves som passivt.

Å være om bord føles som en tvangstrøye! Det var ikke mye å gjøre og jeg satt hele tida å bare ventet på å komme meg av skipet.

Det er ikke nok tid på land, når vi besøker nye steder. Jeg vil ut og utforske, ut av byene og inn i de frie landskapene, men det er ikke tid. Jeg liker ideen om å gå om bord i et skip og reise til forskjellige plasser - men jeg vil ha mer tid på de forskjellige stedene.

Å kunne snakke med de lokale, se hvordan ting fungerer, byene, hva folk gjør. Du kan ikke finne dette ut her inne, du trenger å være der ute. Båt konseptet kjører deg til hundesledekjøringseventen, du drar ut på den lille turen og du blir transportert tilbake, du klarer ikke se hvordan ting fungerer, å lære å kjenne hundene, stedene og landskapene.

Ingen ting om bord er av interesse.

Det er ganske tunge skyts turistene her kommer med. Det viser viktigheten av et temporalt perspektiv når man prøver å forstå emosjoner og turistopplevelser. Ifølge Kahneman og kolleger (1997) er det viktig å bygge opplevelsesdramaturgien slik at den ender på en «high note». Dette er fordi at slutten av en opplevelse, og den emosjonelle tilstanden man var i da, huskes best, og det er disse minnene som avgjør om turistene kommer tilbake eller ikke, og om de oppfatter helheten av turen som positiv. Dette er den såkalte "peak end rule». Det skriptede og kontrollerbare oppleves som uinteressant av turistene, mens det ukontrollerbare kan skape sterk interesse, påpeker altså Kahneman og kolleger (1997). 


\section{Ekkerøya: smått, godt, tilpasset og levd}

Opplevelsesproduksjonen på et lite sted som Ekkerøya er ganske så forskjellig fra den på Hurtigruten. Fortellingen under gir på autoetnografisk vis et inntrykk:

Å våkne opp på Ekkerøy uten å vite hva dagen bringer, til lukten av kaffe som trekker på kjøkkenet. Den kvinnelig guiden, som seinere skal introdusere oss for kiten har allerede stått opp og frokosten er klar. Vi blir enig om å starte dagen med en gåtur opp på fuglefjellet som overser halvøya. Tidsbruket blir til ettersom vi beveger oss i landskapet basert på forhandlinger. Turen opp tar ikke mer enn tjue minutter og fra toppen har vi utsikt over alle stedets bygninger og veien som fører inn, flankert av to perlehvite tvillingstrender (en på hver side av halvøya). Det er på en av disse vi skal kite seinere. Å bevege seg i landskapet bringer opp historier, store og små. Tyske kanonstillinger minner om andre verdenskrig. Ekkerøy var en av de få plassene som ble spart tyskernes brente jords taktikk på grunn av russernes hurtige invasjon. Tomme hus og forlatte fiskebruk forteller om en tid da Ekkerøy var en livlig bygd basert på fiske. Lik så mange slike bygder langsmed kysten står disse nakne og forlatte bygningene som et testamente på norsk sentraliseringspolitikk. Husene forteller sjøl denne historien. Men disse små plassene gir seg ikke uten kamp. Kreativt bruker man de ressursene man har og forvandler de tradisjonelle stedene til noe nytt - knyttet til turisme. For Ekkerøy er dette primært fokusert mot fugleturisme og kiting. Etter å ha tatt innover utsikten og reflektert over disse historiene går vi ned fjellet. Vi har en avtale med Roald, Hannes onkel, om å få omvisning i restauranten Havhesten før vi skal ut å fiske dagens middag. Tida flyter her og vi har nok av den, den er fleksibel, men må forhandles om siden vi er flere.

Når Trine skal lære fra seg kiting starter hun med en treningskite. Den minner litt om dragene man brukte å leke med om barn, bare at denne er litt større og styres med en «bar» - en stav der de tre settene med tau som fører opp til kiten kommer sammen. Trekker man i det midterste tauet kollapser kiten, noe som kan være viktig å vite da en stor kite kan ha vanvittig trekk- 
kraft. Over en time coacher Trine om hvordan man kontrollerer kiten og hvordan man kan lese vinden og finne maksimal trekkkraft. Den lille kiten har liten trekkraft og man har muligheter til å leke seg med denne vingen og lære seg hvordan den oppfører seg i vindkastene. Etter hvert pakker Trine ut den skikkelige kiten, som er designet til å trekke mennesker over landskap. Når man kiter i snø har man enten snowboard eller gode ski med stålkanter. Her på stranda læres baseferdighetene til denne ekstremsporten uten brett på bena. Å kjenne for første gang, når du er festet til kiten i en sele, den voldsomme trekkraften til kiten kan være en skremmende opplevelse. Man må her både lære å temme kiten, unngå facials og kitemares, men ikke minst temme sin egen frykt. Her har man et eksempel på en form for tilpasset opplæring der man lærer seg gradvis og kite ved hjelp av instruksjon og hjelp. Etter hvert som man mestrer økes utfordringene, til et punkt der man virkelig kjenner på fryktfølelsen, en type erkjennelse på at man lever.

Den etnografiske fortellingen viser til forskjellige landskap. Fuglefjellet bevandres akkompagnert av guidens (Trines) fortellinger, hvor store historier om krig og fraflytting knyttes inn i de personlige. Kitesesjonen er et eksempel på hvordan læringen blir tilpasset det kontinuerlig endrede ferdighetsnivået, der turisten får lov til å utfolde seg i aktivitet og lek. Det er veldig liten grad av skripting av disse opplevelsene - tida flyter, og den omforhandles blant dem som er til stede. Alle i den lille gruppen blir til medprodusenter av sin egen opplevelse - i varierende grad. Historien forteller om hvordan forskjellige interesseobjekter har en synergisk læringseffekt. Når man står der på stranda og skal kite, kjenner man allerede landskapet og dets historier, som man er blitt fascinert og rørt av. Gjennom møtet med forskjellige landskap som fuglefjellet, Havhesten restaurant og stranda blir man også bedre kjent med guiden, verten og instruktøren Trine - som hele tida fungerer som en ekstern support i turistenes streben etter å mestre og forstå. I slike prosesser blir relasjonene endret, man blir bedre kjent og slipper seg løs. Ulikt Hurtigrutens uniplekse servicerelasjon mellom personale og turistene, er relasjonene på Ekkerøya multiplekse og dynamiske. Kiten på sin side er også et interesseobjekt som du i økende grad lærer om og knytter deg til, etter hvert som du engasjerer deg. Og etter hvert som man mestrer, øker Trine utfordringsnivået, til et punkt der utfordringene blir for store, og vi 
Tabell 3.1: Generative dynamikker som forekommer i forholdsvis store og små turistbedrifter

\section{Hurtigruten Elkkerøya}

\section{Unipleks produksjon}

Transaksjonsrelasjoner

\section{Masseproduksjon}

Samme opplegg for alle, forhåndsbestemt

«One size fits all»-ideologi

Alle får samme tilbud, dog med valgmuligheter

\section{Høyskriptet}

Program som følger oppsatte tider for hver del av programmet, alle gjør det samme

\section{Begrenset i tid}

Fire timer tur, spising 1,5 timer, tidsskjema

Bestemt av produsent

Passiv tilskuer, lav involvering

Turistene er tilskuere og tilhørere, lite dialog, få forsøk på involvering

\section{De-destinering}

Skaper liten involvering i stedene som besøkes Turen er en reise, skipet og landet det nærmeste en kommer destinasjonsinvolvering

\section{Multipleks produksjon}

Utvikling av sosiale bånd

\section{Stykkproduksjon}

Tilpassede, omforhandlede opplegg

\section{Spesialtilpasset}

Alt tilpasses den enkelte besøkende

\section{Lavskriptet}

Lite skriptet, temaet gitt, fleksibilitet Ingen gjør det samme

\section{Ubegrenset tid}

Tida planlegges sammen, og underveis, avhengig av vær, form og stemning
Aktivitet og høy involvering Ideen er at man skal aktiviseres, fysisk og mentalt
Man deltar i livet på stedet, men dette er tilpasset turistene

\section{Skaper stedstilhørighet}
Skaper forståelse for og tilknytning til stedet
Turisten blir en del av stedets liv da dette er mye sentrert om turismen

Bærenholdt og Granås (2008) argumenterer med at turiststeder strategisk utspiller (enacts) seg sjøl gjennom markedsføring og møter imellom turister 
og turisttilbydere, på måter som understreker hvor unike de er. Gjennom å presentere to typer empiri, som er svært forskjellige, får man innblikk i hvordan store og små bedrifter utspiller seg svært forskjellig med hensyn til produksjonsforhold, som igjen făr store konsekvenser for disse møtene, og da hvordan interesse trigges og utvikles. Det sentrale spørsmålet er da om disse funnene kan generaliseres? Hvilke dynamikker risikerer vi å miste i en nordnorsk vinterturisme i eksplosiv utvikling, der høyskriptingen for lengst er i gang? Vi foreslår visse generative endringer i opplevelsesdynamikker etter hvert som produktet vokser, og en nødvendig skripting inngår.

Større bedrifter ønsker kontroll over produksjonsformene. Med en avansert logistikk og potensielt store masser med turister øker graden av skripting og industrialisering. Programmene blir tidsregulert, innholdsregulert og repetitive, slik som på Hurtigruten. Fleksible små bedrifter, som ofte er familie- og livsstilsbaserte og situerte på bestemte steder, utviser større mangfold og fleksibilitet i sine tilbud til turistene. Økene grad av skripting og repetisjon skaper stor avhengighet til innholdet i skriptingen. For å skape nysgjerrighet og interesse må informasjon distribueres til rett tid, og personalet må ha tid og tilstrekkelig kompetanse. For Hurtigruten viste funnene at den relevante informasjonen uteble, og turistene fikk ikke den kompetente støtten til å utvikle interessen.

Skriptingen innebærer også at man har svært lite rom for å tilpasse opplevelsene til den enkeltes ferdighetsnivå. For Hurtigruten og dens hundesledekjøring frarøves dermed turistene såpass mange mulighetsrom, for å holde kontroll på spetakkelet og utfordringsnivået nede, at man kan stille spørsmål ved hvor aktiv denne opplevelsen blir. Det motsatte bildet blir representert på Ekkerøy gjennom kitingen, der tett oppfølging og gradvis økning i utfordring skreddersys turistens ferdighetsnivå, noe som øker interessen og evnen til læring.

En annen sentral del av interesse er hvordan skriptede opplevelser hindrer utviklinga av sosiale bånd. For Hurtigruten kjennetegnes interaksjonen mellom turist og servicepersonellet mer som transaksjoner. Eksemplet fra Ekkerøy viser hvordan utvikling av sosiale bånd er sentral for interessesynergiene. Småbedriftenes multitasking bidrar potensielt til at turistene får se flere sider av verten. og dermed skapes det mulighetsrom for å etablere sosiale bånd.

I eksemplet fra Ekkerøy knyttes turisten til stedet gjennom utviklet interesse til multiple objekter. Forskjellige landskap læres igjennom forskjellige former for performativitet samt kontinuerlig storytelling. Disse 
landskapene blir interesseobjekter som styrker videre opplevelser på stedet. Når etnografen og Trine står på stranden og pakker ut kiten, er man ikke lenger den man var før man ankom stedet; fuglefjellet som ble besøkt for få timer siden har fått ny mening gjennom performativitet og narrasjon. Det samme gjelder havet vi fisket på. Relasjonen til Trine endres også gjennom disse endrede interrelasjonene. Kiten som interesseobjekt blir også styrket gjennom den læringen som finner sted. Vi kan si at det foregår en interessesynergi der landskap, menneske og objekt samspiller for å skape interesse i forhold til multiple objekter som skaper sterk stedstilknytning, som både kan endre deg som person og dine fremtidige valg. Den sterke opplevelsen av interesse som skaper denne formen for nostalgi, lokker deg tilbake. For Hurtigruten, som alltid er i bevegelse, syntes skriptingen å skape en travelhet som hemmet utviklinga av interesse, og som ga lite rom for a skape noen form for stedsnysgjerrighet.

\section{Konklusjon}

Vi har i dette kapitlet pekt på endringer i opplevelsesdynamikker relatert til interesse i små og store reiselivsbedrifter. Vi har fokusert på hvor viktig læring er for utviklinga av interesse og ikke minst stedstilknytning. Er det slik at større bedrifter med sine skriptede produksjonsformer kan begrense interesseutvikling, og da evnen til å knytte seg til bestemte steder? Parallelt har vi også vist hvordan disse større bedriftene kan skape former for interesseutvikling som har mindre med læring å gjøre, men som allikevel kan skape sterke opplevelser av interesse og påfølgende sterke positive emosjoner. En økt forståelse av emosjonen interesse, og da læring, gir analytiske innblikk i de effektene forskjellige former for opplevelsesproduksjon skaper. Dette gjør at man kan diskutere hva en gryende arktisk vinterturisme skal bestå av.

Må store reiselivsbedrifter, som kjører store volum med turister, under strenge tidsskjemaer, nødvendigvis ha en slik skripting vi har skissert fra Hurtigruten? Kanskje ikke, men denne empirien, produsert igjennom tre feltarbeider fra 2008 til 2012, representerer data som er verdt å reflektere rundt. Hurtigruten har bedrevet en imponerende produktutvikling siden 2006. Antall reisende har økt dramatisk, og parallelt med dette ser man at multinasjonale selskaper posisjonerer seg. Selskapets hovedaksjo- 
nær er i skrivende stund London-baserte TDR Capital. Eierskapet flyttes med andre ord stadig lenger vekk fra regionen selskapet skal representere, samtidig som tungskriptingen tiltar. Det er verdt å nevne at Hurtigrutens grunnlegger, Richard With, som ønsket å forbedre infrastrukturen særlig i Nord-Norge, opprinnelig kom fra Vesterålen.

Små bedrifter, som ofte representerer de stedene de selger, som er deltakere i lokalsamfunnet og sjøl har stedstilknytning, trenger ei heller å nødvendigvis kunne skape slike læringssynergier som skissert her. Som vi har nevnt, bærer, i likhet med de store bedriftene, mange av de små også preg av å ha begrenset kunnskap om opplevelsens dynamikker, her presentert som interesse. Men med en slik stedstilknytning, lokalkunnskap og mulighetsrom for utforskning som små bedrifter har, der alle deltakerne samskaper sine egne opplevelser (sammen med den multitaskende operatøren), er mulighetene for turistopplevelser som i større grad endrer turisten - skaper læring og interesse - mye større. Vi ser at sjøl om forskningen på opplevelsesbegrepet har skutt fart de siste åra, så trengs det fortsatt en del nyansering av dette arbeidet. Interessebegrepet, håper vi, er et bidrag i en slik prosess.

\section{Litteratur}

Anderson, L. (2006). Analytic autoethnography. Journal of Contemporary Ethnography, 35 (4), 373-395. https://doi.org/10.1177/0891241605280449

Amin, A. (1994). Post-Fordism: models, fantasies and phantoms of transition. London: Wiley. https://doi.org/10.1002/9780470712726

Ateljevic, J. \& Doorne, S. (2004). Diseconomies of scale: A study of development constraints in small tourism firms in central New Zealand. Tourism and Hospitality Research, 5-4, 5-21. https://doi.org/10.1057/palgrave.thr.6040002 Bigné, J. E. \& Andreu, L. (2004). Emotions in segmentation: An Empirical Study. Annals of Tourism Research, 31, 682-696. https://doi.org/10.1016/j. annals.2003.12.018

Boylorn, R. \& Orbe, M. (2014). Critical autoethnography. Intersecting cultural identities in everyday life. Walnut Creek, CA: Left Coast Press.

Butler, R. (2012). Small is beautiful, but size can be important. I T. V. Sing (red.), Critical debates in tourism (s. 90-93). Bristol: Channel View Publications. Bærenholdt, J. \& Granås, B. (2008). Places and mobilities beyond the periphery. Mobilities and place: Enacting Northern European peripheries. Oslo: Cappelen. 
Conran, M. (2006). Commentary: Beyond Authenticity: Exploring intimacy in the touristic encounter in Thailand. Tourism Geographies, 8, 274-285. https://doi.org/10.1080/14616680600765230

Csikszentmihalyi, M. (2002). Flow. London: CPI Group.

D'Andrade, R. (1995). The development of cognitive anthropology. New York: Cambridge University Press. https://doi.org/10.1017/CBO9781139166645

Ekeland, C. B. (2011). 'Hunting the light'. A study of a tourist group and its learning experiences on-board the Norwegian coastal steamer Hurtigruten. Acta Agriculturae Scandinavica, 61 (1), 38-51. https://doi.org/10.1080/09064 710.2011 .627375

Ekeland, C. B. \& Dahl, T. I. (2016). Hunting the Light in the High Arctic: Interest Development Among English Tourists Aboard the Coastal Steamer Hurtigruten. Tourism Culture \& Communication, 16 (1-2), 33-58. https://doi.org/10.3727/109830416X14655571061719

Ekeland, C. B. (2016). High as a kite: exploring the positive emotion of interest through extreme sporting in the arctic. International Journal of Tourism Anthropology, 5(3-4), 276-298. https://doi.org/10.1504/IJTA.2016.081744

Harrison, D. (2012). Tourism: Is small beautiful? I T. V. Sing (red.), Critical debates in tourism (s. 80-84). Bristol: Channel View Publications.

Hidi, S. \& Renninger, A. (2006). The four-phase model of interest development. Educational Psychologist, 41 (2), 111-127. https://doi.org/10.1207/ s15326985ep4102_4

Ioannides, C. \& Debbage, K. (1997). Post-Fordism and flexibility: the travel industry polyglot. Tourism Management, 18, 229-241. https://doi.org/10.1016/S0261-5177(97)00019-8

Kahneman, D., Wakker, P. \& Sarin, R. (1997). Back to Bentham. Explorations of experience utility. The Quarterly Journal of Economics, 112 (2), 375-406. https://doi.org/10.1162/003355397555235

Lazaruz, R. S. (1991). Emotion and adaption. New York, NY: Oxford University Press.

Litman, J. (2005). Curiosity and the pleasures of learning: Wanting and liking new information. Cognition \& Emotion, 19 (6), 793-814. https://doi.org/10.1080/02699930541000101

Pine, B. J. \& Gilmore, J. H. (1999). The experience economy: Work is theatre and every business a stage. Boston, MA: Harvard Business Review Press. 
Prebensen, N. K. \& Foss, L. (2011). Coping and co-creating in tourist experiences. International Journal of Tourism Research, 13, 54-67. https://doi.org/10.1002/jtr.799

Renninger, A. \& Hidi, S. (2011). Revisiting the conceptualization, measurement, and generation of interest. Educational Psychologist, 46 (3), 168-184. https:// doi.org/10.1080/00461520.2011.587723

Schumacher, E. F. (1973). Small is beautiful: a study of ecomonics as if people mattered. New York: Harper and Row.

Schwartz, N. \& Bless, H. (1991). Happy and mindless, but sad and smart? The impact of affective states on analytic reasoning. I E. Forgas (red.), Emotion and social judgments (s. 51-70). London: Pergamon Press.

Shaw, G. \& Williams, A. M. (2004). From lifestyle consumption to lifestyle production: changing patterns of tourism entrepreneurship. I R. Thomas (red.), Small firms in tourism: International perspectives (s. 99-113). Oxford: Pergamon. https://doi.org/10.1016/B978-0-08-044132-0.50010-1

Silvia, J. P. (2006). Exploring the psychology of interest. New York, NY: Oxford University Press. https://doi.org/10.1093/acprof: oso/9780195158557.001.0001

Simoni, V. (2014). From tourist to person: the value of intimacy in touristic Cuba. Journal of Tourism and Cultural Change, 12, 280-292. https://doi.org/1 $0.1080 / 14766825.2014 .934054$

Smith, S. L. J. (2006). How big? How many? Enterprise size distributions in tourism and other industries. Journal of Travel Research, 45, 53-58. https://doi.org/10.1177/0047287506288886

Stokowski, P. A. (2002). Languages of place and discourses of power:

Constructing new sense of place. Journal of Leisure Research, 34, 368-382. https://doi.org/10.1080/00222216.2002.11949977

Fiske, S. T. \& Taylor, S. E. (1991). Social Cognition (2. utg., s. 717 f.). New York, NY, England: Mcgraw-Hill Book Company.

Tagg, J. (1993). The burden of representation: Essays on photographies and histories. Minneapolis: University of Minnesota Press.

Thomas, R., Shaw, G. \& Page, S. J. (2011). Understanding small firms in tourism: A perspective on research trends and challenges. Tourism Management, 32, 963-976. https://doi.org/10.1016/j.tourman.2011.02.003

Trauer, B. \& Ryan, C. (2005). Destination image, romance and place experience - an application of intimacy theory in tourism. Tourism Management, 26, 481-491. https://doi.org/10.1016/j.tourman.2004.02.014 
Urry. J. (1990). The tourist gaze. London: Sage.

Valtonen, A. (2009). Small Tourism Firms as Agents of Critical Knowledge. Tourist Studies, 9, 127-143. https://doi.org/10.1177/1468797609360600

Viken, A. (2014). Destination discourses and the growth paradigm. I A. Viken \& B. Granås (red.), Destination Development in Tourism: Turns and Tactics. Farnham: Ashgate.

Viken, A. \& Aarsæther, N. (2012). North Cape: Transforming an iconic attraction into a diversified destination. Scandinavian Journal of Hospitality and Tourism, 13 (1), 38-54. https://doi.org/10.1080/15022250.2013.771994

Wanhill, S. (2000). Small and Medium Tourism Enterprise. Annals of Tourism Research, 27 (1), 132-147. https://doi.org/10.1016/S0160-7383(99)00072-9

Weaver, D. (2006). Sustainable tourism: Theory and practice. London: Butterworth-Heinemann.

Weaver, D. (2012). Small can beautiful, but big can be beautiful too - and complementary: Towards mass/alternative tourism synergy. I T. V. Sing (red.), Critical debates in tourism (s. 85-89). Bristol: Channel View Publications.

Zajonc, B. (1980). Feeling and thinking: Preferences need no inferences. American Psychologist, 35 (2), 151-175. https://doi.org/10.1037/0003-066X.35.2.151 



\section{CAMPINGDRIFT I GRENSELANDET MELLOM ØKONOMISKE OG SOSIALE SYSTEMER}

Arvid Viken

\section{Innledning}

Dette kapitlet handler om hvordan små reiselivsbedrifter overlever og utvikler seg gjennom å være integrert i lokalsamfunn, og utgjøre dynamiske sosiale enheter. Campingdrift er ofte attåtnæring for bønder og andre som har eiendommer langs veien. Jeg skal i kapitlet vise at campingdrift kan være del av sosiale nettverk og lokal kultur, og at det ofte er dette som gjør at mange småbedrifter overlever. Dette skal vises gjennom å beskrive en bestemt campingplass i X-fjord i Nord-Norge. Campingplassen er en familiebedrift, etablert på 1960-tallet. I generasjoner har slekten hatt kyr, sau og høns og drevet bærproduksjon. Men eierne har gjerne også hatt andre inntekter, som fiskere og ansatte i det offentlige. De siste tiåra har campingdrift blitt en stadig viktigere del av gårdsdriften. Dagens eier driver campingplassen i kombinasjon med en jobb som informasjonsarbeider. Campingplassen er en av bygdas møteplasser og bidrar både til samhold og utvikling i bygda. I kapitlet skal jeg se nærmere på dette, hvordan en slik campingplass representerer en institusjon og et bindemiddel i lokalsamfunnet.

I kapitlet viser jeg hvordan dugnad og det som kalles nyttevennskap, utgjør viktige bidrag til driften. Dette er kjente fenomener, i Norge er dug- 
naden både høyt verdsatt og en mye brukt institusjon (Haugstad 2005), oftest i forbindelse med at man tar et tak for noe man har felles interesse i, som å drive, skaffe penger til eller bygge et idrettsanlegg, utføre vårarbeid i barnehage, arrangere en festival eller liknende. Men man kan også innby til dugnad for å realisere et individuelt prosjekt, for eksempel i forbindelse med flytting eller oppussing i heimen. I dette kapitlet blir det vist hvordan det å stille opp for hverandre også skjer i miljøer rundt småbedrifter i reiselivet. Forretningskulturer der man stiller opp for hverandre, er kjent fra mange land og økonomiske systemer. For eksempel sies dette være svært sentralt i Østens kulturer, og for eksempel i kinesisk økonomi. I deler av diskusjonen blir fenomenet satt inn i en ramme som kalles bytte- eller barterøkonomi, som det argumenteres for er en del av vårt økonomiske system. Det er kanskje et paradoks at vår økonomi, den formelle delen av den, ofte er tett flettet sammen med samfunnsaktiviteter som ikke anses som økonomiske, eller transaksjoner som ikke registreres i vårt formelle økonomisystem. Kapitlet er basert på en etnografisk studie av en campingplass og ei bygd som er anonymisert i den presenterte fortellingen. Hvem og hvor er ikke poenget, men det antas, uten at det kan forskningsmessig bevises, at det som beskrives, er ganske typisk for norsk bygdeturisme.

\section{X-fjord Camping}

Camping er i dag en mangslungen sektor. Det begynte som teltplasser, og sykkelturister har alltid vært en viktig kundegruppe. Etter som bilturisten vokste fram, ble stadig nye campingplasser etablert, etter hvert også med hytter for innendørs overnatting. Campingplassene er stadig i endring. Mange steder både langs kysten og på fjellet har campingplassene blitt til feriesteder hvor folk oppholder seg over lengre tid, gjerne hele ferien. Andre steder rommer campingplassene «helgehytter». Folk parkerer sine campingvogner for vinteren, ofte med et lite tilbygg kalt spikertelt - og er der i helgene. X-fjord Campings viktigste kundegruppe er imidlertid tradisjonelle sightseeingsturister, på vei mot nord eller på retur, med bil, motorsykkel eller sykkel. Sommerturistene er viktige for økonomien, mens vinteroppsitterne inngår i nettverk viktige for drift og vedlikehold.

X-fjord Camping ligger i X-fjord. Det er en familiedrevet bedrift som mannen i familien har overtatt etter sin far. Mannen bor på plassen halve 
året, men bor i byen om vinteren. Øvrige familie har ulike rolle og bidrar i ulik grad. Campingplassen har 34 hytter, hvorav 14 har dusj og do, mens resten har en enklere standard. Det finnes et romslig servicebygg med ymse fasiliteter, et annet hus med et forsamlingslokale med kapasitet til å bespise 40-50 mennesker og en grillhytte. Sesongen for camping er sommeren, men i tillegg til ordinære campinghytter, oppstillingsplasser for campingvogner og teltplasser finnes 20 langtids oppstillingsplasser for campingvogner med såkalt spikertelt, en flyttbar trehytte som står inntil campingvogna. Plassen leies for hele året, men brukes lite om sommeren. Fra tunet går det veier, stier og skiløyper opp i fjellet, og i sjøkanten er det en kai med båter som det er mulig å leie. Turterrenget innbyr til turgåing, fiske, jakt og bærplukking, rekreasjonsmuligheter som er særs viktige for vinteroppstillerne.

Kapitlet er basert på observasjoner og et feltarbeid over en rekke år. Forfatteren har i perioder oppholdt seg på campingplassen. Dataene rommer derfor også deltakende observasjon; i noen grad har forfatteren vært en del av den virkeligheten som beskrives. Tematikken i kapitlet er drøftet over kjøkkenbordet hos eieren, både med han, hans familie, folk fra bygda og med representanter for de langtidsboende camperne. Og tematikken er diskutert med fagkolleger og bygdefolk. Kapitlet er skrevet i et fugleperspektiv, altså med en viss distanse, og ikke som en autoetnografisk fortelling.

\section{Nyttevenner og nettverk}

Som mennesker samler vi på vennskap og venner. Noen av våre vennskapsforhold er nytteorientert. Derfor forstås vi som mer eller mindre rasjonelle aktører, et syn den norske sosialantropologen Fredrik Barth (1966) har vært en eksponent for. Men hva som er «til nytte», hevder Sahlins (1976), er også kulturelt betinget. Implisitt i denne tenkningen ligger at vi handler og utvikler sosiale relasjoner som i tillegg til å være nytteorienterte, har i seg andre verdier. Perspektivet her er at det gjerne er en blanding, at vi både har rasjonelle og andre motiver. På norsk har man ikke et velutviklet begrepssett for det at forretning og sosialt liv er vevd sammen, og uttrykkene vi bruker, har ofte en odiøs klang, som for eksempel kameraderi og gutteklubb. Men vi har og mer nøytrale begreper som vennetjenester, dugnad og samfunnsansvar. Jeg velger her å bruke begrepet «nyttevenner» og «nyttevennskap», hentet fra den samiske institusjonen «verdde». «Nyt- 
tevenn» er et relativt tykt begrep - altså kan det ligge mye bak. Tilsvarende finnes i mange kulturer, for eksempel den kinesiske, men det er lite forsket på (se Qi 2013).

Elementer som tillit og gjensidighet er også sentrale i forståelsen av nettverk, som gjerne brukes til å forklare strukturer i reiselivet (Leiper 2008). Castells (2004, s. 3-4) refererer til nettverk som et «sett av sammenkoblede noder. En node er et punkt hvor kurver krysses. Et nettverk har intet sentrum, bare noder.» Nettverk består av aktører med mer eller mindre tette, mer eller mindre formelt definerte relasjoner. Prats og kolleger (2008, s. 182) framhever de viktigste områdene hvor nettverk kan ha en rolle i reiselivssammenheng; de kan representere et makromiljø (politisk, økonomisk, teknologisk, sosialt og historisk); kople turismebedrifter i et område; utgjøre en relasjonell struktur og kvalitet; produsere kollektiv kunnskap og læring og representere innovasjonskapasitet. Nettverksteori er også nær knyttet til teorier om sosial kapital (Coleman 1988; Putnam 2000). De sistnevnte teoriene fokuserer på bånd, forpliktelser og tillit mellom aktører (Granovetter 1973; Nahapiet \& Ghoshal 1998). I dette kapitlet vil vi bruke elementer fra teorier om nettverk og sosial kapital som ulike typer bånd og brobygging. I slike relasjoner er gjensidighet og tillit sentrale elementer. Nettverk dreier seg om å knytte bånd til andre mennesker, relasjoner man både kan ha nytte og glede av. I nettverksteorien omtales dette som bånd. Granovetter $(1973,1983)$ skriver om sterke og svake bånd. Sterke både finnes mellom familiemedlemmer og nære venner, svake bånd er alle andre kontakter man har, med arbeidskolleger, naboer og andre. Han hevder at de svake båndene er svært viktige, det er ofte disse som utgjør nettverksrelasjonene, mens de sterke båndene ofte har sine begrensninger. I Putnams (2000) håndtering av sosial kapital er det de svake båndene som analyseres. Andre peker på at ved siden å ha bånd inn i de miljøene man opererer i til vanlig, er det også viktig å ha forbindelser som går ut av de vante miljøene (kalt bridging eller brobygging). Sjansene for at man når ut, er langt flere gjennom svake bånd - altså at man ikke er for tett involvert med sine forbindelser, ifølge Granovetters logikk.

Nytten man har av å være del av nettverk av ymse slag, er utveksling av varer og tjenester, kunnskap, et sosialt liv og å bli møtt med godvilje og hjelpsomhet. Det er for eksempel vist hvordan relasjonene til lokalsamfunn i sterk grad påvirker handlingsrommet til reiselivsaktører i små lokalsamfunn (Svensson 2014). Altså dersom man hjelper en person - for 
eksempel med å reparere huset - kan man påregne en motytelse en gang. Dette er ofte det vi legger i «godt naboskap» eller «gode lokalsamfunnsrelasjoner». Noe av det som også utveksles, er tillit. Tillit kan grovt sies å være forventninger man har til mennesker man kjenner, om et gitt handlingsmønster i bestemte situasjoner (jf. Coleman 1988; Quandt 2012). Når man låner ut redskaper eller penger, forventer man å få dem igjen. Dersom man stiller opp og hjelper en nabo, kan man påregne en eller annen form for motytelse. Det er en viss gjensidighet i et tillitsforhold. I tillegg til at vi har tillit til mennesker, har vi det også til institusjoner. Mangel på tillit er ofte et krisetegn for en institusjon. Quandt (2012) viser til ulike sider ved et tillitsforhold. For at man skal ha tillit til en annen aktør, må en ha god kjennskap til vedkommende. Tilliten er også avhengig av kontekst eller situasjon, inklusive betydningen av en tredje part.

Også gjensidighet har vært gjenstand for analyser. Basert på tidligere arbeid av Mauss og Polanyi drøfter Sahlins (1972) gjensidighetsteori (en teori om resiprositet) (se også Gaughan \& Ferman 1987). Mauss' (2011 [1954]) verk om gaveutveksling har vært skjellsettende for forståelsen av ikke-kommersielle bytterelasjoner i samfunnet. Sahlins bygger på dette. Han gjør et skille mellom tre ulike former for gjensidighet: generalisert, balansert og negativ. Sahlins (ibid., s. 194) anser generalisert gjensidighet som ekstremt solidarisk, forbundet med deling, gjestfrihet, hjelp og sjenerøsitet. Man vet ikke når og i hvilken form gjenytelsen kommer, og det finnes ingen standardiserte oppfatninger av hva det skal være. Balansert gjensidighet, på den annen side, refererer til direkte utveksling eller bytte. Sahlins karakteriserer det som «mindre personlig enn generalisert gjensidighet», og dessuten «mer økonomisk» (ibid., s. 195). Handel - kjøp og salg - er et eksempel på balansert gjensidighet i henhold til Sahlins, og det nærmer seg alminnelige transaksjonsforhold. Å avvise eller å avstå fra gjengjeldelse karakteriserer den tredje formen - negativ gjensidighet. Dette er en situasjon der en av deltakerne er «ute etter å maksimere en nytte på den andres bekostning.» (ibid., s. 195; se også Walsh 2009). Gjensidighet og tillit er fenomener som er vevd inn i hverandre, og som er elementer $\mathrm{i}$ nær sagt alt sosialt liv. I mange sammenhenger er det innebygd i formelle systemer og institusjoner, som i markedsøkonomien, og i våre relasjoner til myndigheter. I andre sammenhenger kan tillit og gjensidighet kompensere for manglende formalisering av forbindelsene, som for eksempel i det man kaller barter- eller bytteøkonomi. 


\section{Bytteøkonomi}

Nyttevennskap finnes både innenfor og utenfor formelle økonomiske systemer. Innen det som kalles uformell økonomi er det en rekke former for utveksling av varer og tjenester, som svart arbeid, frivillighetsarbeid, dugnad, og kanskje tyveri og annen kriminalitet (Gaugen \& Ferman 1987, s. 16). Det som her diskuteres, er relasjonsbasert bytting av varer og tjenester, herunder ubetalt arbeid. Dette er internasjonalt kjent som barter-økonomi. «Barter kan defineres som en prosess hvor det foregår direkte utveksling av varer og tjenester uten pengetransaksjoner», sier Williams (1996, s. 85). Barter eller bytte skjer altså uten referanse til en nøytral standard som penger. Williams peker på at dette var den førmoderne handelsformen og er mer eller mindre forsvunnet i moderne industri- eller bysamfunn. Men det er ikke helt borte, og det er fortsatt en del av hverdagen mange steder, for eksempel i utviklingsland, på mindre steder og i perifere strøk. Mange steder vil «... partene i barter-handel forholde seg til sine individuelle og umiddelbare behov, ikke til abstrakte verdier», sier Ingham (1996, s. 517). Han hevder også at det finnes moderne varianter av uformell økonomi også i byer, særlig blant marginaliserte grupper. Barter-relasjoner har vist seg, sier han, å være viktige i prosjekter og prosesser knyttet til utvikling av lokalsamfunn. Gaugen og Ferman (1987) understreker også at den uformelle økonomien som regel er viklet inn i den formelle. Det er nesten alltid elementer som håndteres i formelle kanaler, som har preg av uformell økonomi. Det er derfor snakk om grader av (u-)formalitet, og ikke distinkte grenser. Gaugen og Ferman (1987) hevder også at generalisert gjensidighet ofte er sentralt i uformelle økonomiske systemer. De kaller dette en sosial $ø$ konomi, men peker på at den har sin grenser, og at det finnes en rekke tilfeller som best kan karakteriseres som negativ gjensidighet, og som kan tendere mot kriminalitet.

At skillet mellom formell og uformell økonomi er flytende, gjelder trolig alle samfunn. Innen familien er bytte uten penger standarden. Og ofte gjør man slike bytter med slekt og naboer, uten at noen tenker på det som grå eller svart økonomi - det er vennetjenester. Gjelder det folk man kjenner mindre, eller lokalsamfunnet, kalles det gjerne dugnad. Dugnad er å gjøre noe sammen, kanskje først og fremst for et kollektiv, det er «et redskap for kollektiv produksjon av fellesgoder», sier Haugestad (2003; 
se også Klepp 2001). Men det er også ganske vanlig å arrangere private dugnader, for eksempel i forbindelse med flytting, eller for å få ryddet en tomt eller reist en grunnmur. Dette er også kjent internasjonalt, for eksempel som «barn raising» (låvebygging) (Mc Cormick \& Kahn 1982); skulle man i gamle dager sette opp en làve, deltok naboer eller folk fra bygda. Barth (1981) beskriver dugnadsinstitusjonen ut fra studier i Darfur, hvor han også fant at institusjonen hadde sine begrensninger, illustrert med et eksempel kjent som «tomatmannen». Tomatmannen var innflytter, og som sådan fikk han i tråd med tradisjonen er jordflekk til å bo og dyrke hirse på. En annen tradisjon var å avholde dugnad for å hjelpe folk i gang med livet på stedet, og dyrkingen. Tomatmannen kjøpte i stedet hirse, laget $ø$ l, arrangerte dugnad og belønte deltakerne med rikelig med øl laget på hirsen. Men i stedet for å bygge hus eller låve satte han dugnadsgjengen til å dyrke tomater. Dette tjente han godt på. Da lokalsamfunnet oppdaget dette, dalte interessen for å delta i dugnader, og praksisen med å gi jord til innflyttere opphørte. Altså, å utnytte et sosiokulturelt system som omfatter nyttevennskap, til personlig berikelse utfordrer systemet. Relasjoner basert på vennskap, tillit og generalisert gjensidighet rommer komplekse sosiale forpliktelser og forventninger, men er ikke beregnet på forretningssfæren.

I norsk politisk sammenheng appelleres det relativt ofte til dugnadsånden, dugnad brukt mer eller mindre som en metafor. Det dreier seg da om å dra lasset sammen for å nå noen mål. Altså, uformell økonomi er en legitim del av det formelle og politiske samfunnet vi lever i, i alle fall på symbolsk plan. Det interessante oppstår først og fremst når forretningsdrift veves sammen med slike systemer - også det en ganske vanlig foreteelse - da oppstår en rekke grensetilfeller og dilemmaer.

For det første vil jeg se på forholdet mellom bytte og kommersielle transaksjoner. Bytte nær knyttet til gaver og sosiale relasjoner og kommersielle transaksjoner er basert på en formell pengeøkonomi. For det andre vil jeg se nærmere på tillit og gjensidighet. Hvor sentrale er den generaliserte gjensidigheten, og har vi tilfeller av negativ gjensidighet? Hvordan håndteres i tilfelle det? Inn i denne diskusjonen hører også styrken på relasjonene, av det Granovetter (1983) har kalt sterke og svake bånd. Dette er et forhold jeg også vil se på. Og gjennomgående rommer disse perspektivene en diskusjon av grenser. 


\section{Campingliv i X-fjord}

\section{Internt samhold}

Livet på X-fford Camping er ganske forskjellig sommer og vinter. Om sommeren er det preget av flyktighet, mennesker som kommer og går, korte og overflatiske møter. Utenom sommeren er det helt annerledes, da er campingplassen som et lite lokalsamfunn, med mennesker som kjenner hverandre, som er venner, og som utøver et sosialt liv sammen, og som har sitt sett av normer og verdier. De med langtidsplass er primært helgegjester, men kommer igjen helg etter helg, og noen ganger er de der lenger. For slike brukere er campingplassen et relativt komplekst sosialt system, som regel utstyrt med egne verdier og normer (se Angell 1999). Det er beboere fra mange samfunnssektorer og lag, men hovedvekten er arbeider- og middelklassemennesker. Her er offentlig ansatte, bankansatte, gravemaskinkjørere, snekkere, elektrikere, mekanikere og rørleggere. Beboerne møtes hos hverandre over en kaffe eller en drink, besøker hverandre, og de lager større fester, for eksempel i grillhuset. Det sosiale livet på campingplassen er derfor viktig. Beboerne har også en viss identitet knyttet til stedet, og de er opptatt av hvordan campingplassen skal drives og utvikles. Reguleringen er ikke streng, men det finnes både noen skrevne regler, basert på diskusjoner og møter mellom eier og beboere, og uskrevne normer. Det sosiale livet er for en stor del basert på tillit til at folk kan oppføre seg - frihet under ansvar, og at man lærer av dem som har bodd der før. Skrevne regler finnes for hvordan og når man skal gjøre opp for seg, og for bruk av kjøretøy inne på plassen og for bruk av fellesanleggene. En gang $\mathrm{i}$ året avholder eieren møte med beboerne hvor slikt diskuteres. For eksempel har man drøftet hvordan man skal få ned strømutgiftene, i slike møter. Blant de uskrevne reglene er for eksempel at sjenerende festing og fyll ikke er akseptert. På dette området gjelder gruppejustisen. Brudd på normene anses som et tillitsbrudd. Mange av dem som bor der, kjenner hverandre fra før, dels har de blitt rekruttert gjennom slike forbindelser, mens eieren ofte ikke kjenner dem. Noen av beboerne har egentlig bare et kundeforhold til eieren, og egentlig ikke et tillitsforhold. Det er mange eksempler på at folk har tatt seg til rette, lånt verktøy og maskiner, ikke alltid ved å spørre først. Noen 
synes å tro at dette inngår i det man har betalt for, eller at kulturen er slik at man bare henter og bruker det man trenger. Uforstandig bruk har flere ganger ført til havari på eierens maskiner. De mest graverende tilfellene har egentlig skjedd med mennesker som ikke kjenner kulturen overhodet, som da en gruppe gjestearbeidere som arbeidet på et anlegg lenger inne i fjorden, bodde der. Ved flere anledninger ble de observert sterkt beruset, og det hendte de forsynte seg av et matlager. De var åpenbart ikke fortrolige med eller en del av det tillitsforholdet som campingens sosiale liv er basert på. Eksemplet illustrerer trolig at norsk campingliv er tett koplet til norsk hyttekultur, som ikke alle kjenner.

Mange av dem som bor på campingen, liker å ha noe å henge fingrene $\mathrm{i}$ - de er som norske hytteeiere flest - liker å stulle og stelle. Derfor er de ikke sene med å trå til når det er behov for å gjøre noe, når ei grøft må graves eller strømanlegget trenger reparasjon. Når det er behov for det, tar man tak, avhengig av tid, motivasjon og kompetanse. Mange utbedringer skjer dermed uten store utgifter. Beboerne er innforstått med at camping er en marginal økonomisk virksomhet. Da eierens firhjuling brøt sammen, samlet en gruppe kyndige seg, skrudde den fra hverandre, fant et brudd, sveiset og skrudde den sammen igjen, og hadde mange trivelige stunder med dette. Firhjulingen ble som ny. Som et annet eksempel ble badstuen laget på dugnad. De som deltar i slikt, får goodwill, og effekten er økt trivsel på plassen. Eierens gevinst er modernisering og verdiøkning. Beboere som har nedlagt en ekstra innsats, kan oppleve at deres opphold ikke blir fakturert det året. På denne måten har også oppstillingsplasser for campingvogner blitt laget, veien utbedret og plenene blitt klipt. Slike tiltak utvikler relasjonen mellom dem som bor der, innbefattet eieren, nyttevennskap skapes og utvikles. Til tross for mange nyttevennrelasjoner som mer eller mindre er aktive, er det så vidt driften går i balanse. Men driften er viklet inn i et etter måten komplisert sosialt system, som gjør det vanskelig å legge ned. Det har flere ganger vært drøftet. Fortsatt drift blir en slags sosial forpliktelse, en slags gjenytelse, så lenge hjulene går rundt. En annen måte å oppsummere dette på er at campingen er et sosioøkonomisk system av komplekse og resiproke relasjoner som både gir den stabilitet og utvikling. 


\section{Integrasjon og institusjon i bygda}

X-fjord er ei bygd der man prøver å dra i lag. Man har et aktivt bygdelag som årlig arrangerer X-fjorddager, hvor bygda setter seg sjøl i fokus. Man hjelper hverandre, låner av hverandre og gjør ting på dugnad. Derfor føler også folk tilhørighet til bygda. At man ordner opp utenfor den kommersielle sfæren, er det flere eksempler på. Da selskapet som la bredbånd rundt i kommunen, fant ut at det ikke lønte seg å gjøre det i X-fjord, så gjorde bygdefolket det sjøl. Bygda hadde kompetansen som skulle til. Dermed fikk alle, inklusive campingplassen, førsteklasses nettforbindelse. Den kollektive holdningen i bygda synes også å favne om campingen. Folk synes å være interessert $\mathrm{i}$ at den klarer seg og utvikles. Som kompensasjon for en ødelagt strandlinje i forbindelse med en veiutbygging fikk campingen for noen år siden anlagt en kai. For å kunne utnyttes bedre burde den utvides med en flytebrygge. To av bygdas nevenyttige herrer satte i gang. Gjennom sine nettverk skaffet de utdaterte mærer som ble brukt til flottører, sveiset og skrudde, og i løpet av et par sommermåneder var flytebrygga ferdig - for en sum som trolig ikke er mer enn ti prosent av hva den kunne ha kostet om alt skulle vært gjort kommersielt. En av motytelsene er at de som trådte til, får ha båtene sine der. Brygga er også blitt en stangfiskeplass for campingturistene og for bygda. Og alle synes å ha tillit til at brygga blir brukt til beste for alle parter. Men det vil kanskje være problematisk å leie ut båtplasser kommersielt, til det er brygga for sterkt forankret i dugnad og andre former for nyttevennskap. Et annet eksempel på en relativt stor ting realisert med hjelp fra bygda er et redskapshus som ble reist på dugnad. En mann fra bygda tok på seg ansvaret med å få opp bygget og gjorde mye av jobben sammen med andre venner av campingen. En nabo laget tegningene som skulle gi grunnlag for byggetillatelse. Noen snekret vegger, noen monterte porter, andre installerte det elektriske anlegget. Dugnadsinnsatsen går inn som egeninnsats og matchingskapital i prosjektet, som også fikk en god del offentlig støtte. Dugnad er ulønnet arbeid som inngår som et legalt element i prosjektregnskap. Begge disse eksemplene betyr at campingen har fătt forbedrede fasiliteter og en betydelig verdiøkning. Bare i en situasjon preget av generalisert gjensidighet - altså uklare nytte- og gjengjeldelsesforhold - kunne dette la seg gjøre.

Det er flere religiøse grupperinger i bygda. De representerer ulike trosretninger og går ikke alltid godt i lag. Campingplassen merker lite til det, men opplevde en gang at en mann som sto for snørydding, sa fra seg 
oppdraget, fordi eieren ikke står i statskirka. Etter hvert kom han tilbake og ba om godt vær - tilsynelatende trengte han oppdraget. Da en av de religiøse gruppene så seg nødt å avhende et lite bedehus i nabolaget, ble campingeieren spurt om han ville overta det - de hadde tillit til at han ikke ville ødelegge noe de hadde et spesielt (religiøst) forhold til. Han har siden hengt opp en fotomontasje fra det religiøse miljøet i bedehuset og brukt lokalet til konserter. Også det gir tillit. Dette kan også være eksempel på at eieren ikke har for sterke bånd til bygda, det var trolig ikke et alternativ for gruppen å selge til andre lokale - på godt og vondt var relasjonene for tette. Campingeieren har en tillit som kanskje er basert på at båndene tross alt ikke er for tette.

En campingplass er ikke et stille sted. Noen ganger har det kommet klager på bråk, men stort sett går det bra. Campingen står også for aktiviteter hvor bygdefolket inviteres, som for eksempel skirenn i påsken. Og på brygga har det vært avholdt fiskekonkurranser. Når folk i bygda skal samle familien - ha konfirmasjon, bryllup eller slektstreff - hender det at de leier eller låner lokaler. Campingens lille kiosk betjener tidvis også lokalbefolkningen. Her kan man få tjenester som ellers ikke finnes i bygda - og det til overkommelige priser. Campingens offentlige funksjoner er ikke store og mange, men viktige. Campingplassen gir liv til bygda gjennom sine gjester og aktiviteter på plassen, den betyr små hendelser i lokalsamfunnet, for eksempel i forbindelse med bygdelagets årlige festival, eller konserter og utstillinger, og den brukes til familiebegivenheter og annet. Tidligere var den også et viktig bidrag til opprettholdelse av lokalbutikken. Alt dette er stabiliserende faktorer i bygda. Stort sett er relasjonene lite preget av forretningstenkning. Det har åpenbart med eieren å gjøre - han er ikke først og fremst forretningsmann. Han er romslig og imøtekommende, låner ut redskaper og lokaler, og trår til når noen har behov for hjelp. Men han får igjen for det. I sitt andre yrke som informasjonskonsulent - og tidligere som journalist - har han nytte av å ha kjennskap til livet i bygdene omkring. Campingplassen, dens lokalisering i en tett liten bygd, gir altså eieren en rekke fordeler i utøvelsen av sitt andre yrke. Forholdet til bygda er preget av gjensidighet.

Alt i alt har campingen visse institusjonelle trekk; den er et verdisystem, den er en kommunikasjonsarena, den representerer stabilitet og inngår i lokale identitetsforhandlinger. Innvevd i dette, og som en premiss, er både gjensidighet og tillit, og en viss distanse - kalt svake bånd - som ikke gjør 
relasjonene for kompliserte. Men campingen har ingen formell posisjon i bygda, og det er i så måte skjøre relasjoner som omtales. Altså er det en institusjon med lav formaliseringsgrad, lite struktur og lav regulering, men den representerer kontinuitet og har symbolsk verdi. Og plassen er avhengig av sin eier og driver - han representerer institusjonens motor.

\section{Diskusjon}

Som det framgår foran, er nyttevennskap en del av hverdagen på denne campingplassen. Et interessant aspekt ved campingplassen og dens eier er om den kan sies å være nettverksbasert. Det er åpenbart at det finnes en rekke forbindelser til omgivelsene som er mer eller mindre etablert og formalisert. Men det kan diskuteres om dette er nettverk. Kanskje er det - slik det er observert også i andre kulturer - like mye et sett av tosidige relasjoner eller dyader som et egentlig nettverk (Chen \& Chen 2004). Relasjonene som den analyserte campingplassen har til omgivelsene, er mer dyadiske, det er kontakter til mennesker som seg imellom ikke har et forhold (eller vet om) til hverandre. Trolig er dette et kjennetegn ved relasjoner i mange bygdesamfunn, man har kontakter med flere, også utad, men ikke primært som kollektiver. Der kontaktene skjer gjennom bygdelag, idrettslag og liknende, er nettverkskarakteren klarere. Men dyadene har også betydning gjennom at de ofte er kjent for andre, eller tredjeparter, som Qi (2013) kaller det. Relasjonene gir anerkjennelse, kanskje også en viss status, som kan ha verdi i mange sammenhenger.

Nettverk er ofte analysert som varianter av sosial kapital, både som en individuell og en kollektiv størrelse (Castellfranchi et al. 2006). Det er åpenbart at alle båndene campingplasseieren har, er en uvurderlig ressurs. Gjennom sine forbindelser kan mye ordnes utenfor markedet. Dette er viktig, driften er marginal, og mange av prosjektene ville ikke latt seg gjøre utelukkende med formelle transaksjoner - det ville simpelthen blitt for dyrt. Altså må de mange relasjonene kunne ses på som «generell kapital» (Smart 1993), de ulike formene for kapital Bourdieu skiller mellom - økonomisk, sosial, symbolsk og kulturell - glir over i hverandre og sammen til en helhet, slik Smart (1993) ser det. Men casen rommer også eksempler på brobygging (bridging), altså at forbindelser i en sammenheng overføres til en annen. Campingplassen og dens lokalisering og eierens forbindelser 
i bygda har gitt han mange fordeler som informasjonsarbeider, og vice versa. For bygda er campingen en viktig institusjon. Som nevnt er det en møteplass og et dynamisk element; et sted hvor noe skjer. Campingen er dermed både en arena for og et symbol på livskraft og utvikling. Den representerer derfor også et tilfelle av sosial kapital i kollektiv forstand.

Betydningen av tillit og gjensidighet i det sosiale systemet som campingplassen og dens omgivelser utgjør, er ubestridelig. Det er forhold som er bygd opp over tid. Likevel er grenseproblematikken den vanskeligste å håndtere, og noe som er gjenstand for forhandlinger på et mer eller mindre subtilt plan. Normer for hva som er rett og galt, oppfattes forskjellig, det samme gjelder synet på sanksjoner. Problemet er at stedet er organisk og dynamisk, uten formelle regler for hva som er tillatt eller tilforlatelig. På samme tid er campingplassen en forretningsenhet, som er avhengig av inntekter, og at det betales for de tjenestene som tas ut. Som sosialt system er det en blanding av generalisert og balansert gjensidighet. En rekke forhold befinner seg i grenselandet mellom hva som er rimelig å låne, og hva som er normalt å betale for som kunde. Denne uklarheten blir til tider misforstått og utnyttet. Derfor har man også tilfeller som tenderer mot det som er blitt kalt negativ gjensidighet. Dette blir av eieren sett på som forhold man må håndtere nennsomt dersom plassen skal drives med regler a la kardemommeloven; du skal ikke plage andre, du skal være snill og grei, og for øvrig kan du gjøre hva du vil.

X-fjord Camping er altså vevd inn i et dugnads- og nyttevennskapssystem som har trekk av uformell økonomi. Noen vil kunne hevde at det som er beskrevet, er et eksempel på svart eller grå økonomi. Det kan sikkert ha elementer av dette i seg, men drivere av slike plasser har samme regler som andre og er gjenstand for beskatning og revisjon som alle andre. Og de er klar over at de blir kikket i kortene. På den andre siden følger de tradisjoner som står sterkt i det norske samfunn, som dugnad og vennetjenester, som anses for viktige sider ved normal sosial omgang. Det vanskeligste i dette tilfellet er at virksomheten i fokus er kommersiell, mens vennetjenestene ikke er det. Våre normer er slik at det er greit å gi og få hjelp så lenge det ikke er til inntekts ervervelse. Tomatmann-dilemmaet (Barth 1981) opptrer til stadighet i norsk virkelighet, og er illustrert også gjennom casen som her er presentert. Det har også en parallell som er kjent i den offentlige debatten, hvor det i de seinere åra har vært drøftet hvordan frivillighet (altså dugnad) skal håndteres i kommersielle festivaler. Det finnes intet klart svar. Trolig 
er løsningen på dilemmaet at man er refleksiv og transparent om saken; at temaet tas opp og diskuteres, men ikke nødvendigvis med en etterfølgende formalisering.

I kapitlet har jeg presentert et nyttevennsystem med klare likhetstrekk til fenomener kjent i andre kulturer, som for eksempel kinesiske guanxi, som enkelt definert er sosiale relasjoner og nettverk basert på gjensidig tillit. Qi (2013) argumenterer for at guanxi representerer et universelt fenomen, og at når det ikke har vært fokusert slike relasjoner, så er det snarere en unnlatelsessynd blant sosiologer enn noe annet. Slike relasjoner er viktige for å forstå hvordan lokalsamfunn fungerer. Samtidig viser eksemplet at reiselivet og en reiselivsbedrift hvor en slik institusjon er skattet - inngår i dynamikken i slike lokalsamfunn.

\section{Konklusjon}

I dette kapitlet har jeg presentert livet på en campingplass i forhold til samfunnet omkring og til sine langtidsbeboere. Det er pekt på at det er et organisk og dynamisk system, med lav formaliseringsgrad. Dette gir en del utfordringer for eier og driver, en balansegang mellom å holde på dette trekket og mer regulering og formalisering. Hvorvidt dette er typisk for campingplasser, skal være usagt, men det er noe i deres vesen som skulle tilsi at dette ikke er den eneste plassen med slike dilemmaer. Men det er også sikkert at det finnes forretningsområder med langt flere forordninger og regler.

\section{Litteratur}

Angell, E. (1999). Campingplassen og modernitetens nomader. I J. K. S. Jacobsen \& A. Viken (red.), Turisme. Stedet i en bevegelig verden (s. 199-207). Oslo: Universitetsforlaget.

Barth, F. (1966). Models of social organisation. London: Royal Anthropological Institute.

Barth, F. (1981). Process and form in social Life. Selected essays of Fredrik Barth. London: Routledge. 
Castellfranchi, C., Falcone, R. \& Morzo, F. (2006). Being trusted in a social network: Trust as relational capital (s. 19-32). Heidelberg: Springer-Verlag Berlin. https://doi.org/10.1007/11755593_3

Castells, M. (red.) (2004). The Network society: a cross-cultural perspective. Cheltenham: Edward Elgar. https://doi.org/10.4337/9781845421663

Chen, X.-P. \& Chen, C. C. (2004). On the intricacies of the Chinese Guanxi: A process model of gunaxi development. Asia Pacific Journal of Management, 21, 305-324. https://doi.org/10.1023/B:APJM.0000036465.19102.d5

Coleman, J. S. (1988). Social capital in the creation of human capital, American Journal of Sociology, 94, 95-120. https://doi.org/10.1086/228943

Gaughan, J. P. \& Ferman, L. A. (1987). Science toward an understanding of the informal economy. Annals of the American Academy of Political and Social Science, 493, 15-25. https://doi.org/10.1177/0002716287493001002

Granovetter, M. S. (1973). The strength of weak ties. American Journal of Sociology, 78, 1360-1380. https://doi.org/10.1086/225469

Granovetter, M. S. (1983). The strength of weak ties: A network theory revisited. Sociological Theory, 1, 201-233. https://doi.org/10.2307/202051

Haugestad, A. K. (2003). The Dugnad: Sustainable Development and Sustainable Consumption in Norway. 6th Nordic Conference on Environmental Social Sciences (NESS), juni, Turku/Åbo, Finland.

Ingham, G. (1996). Money is a Social Relation. Review of Social Economy, 54, 507-529. https://doi.org/10.1080/00346769600000031

Klepp, A. (2001). From neighbourly duty to national rhetoric: An analysis of the shifting meanings of Norwegian dugnad. Ethnologia Scandinavica, 31, 82-98.

Leiper, N. (2008). Why 'the tourism industry' is misleading as a generic expression: The case for the plural variation, 'tourism industries'. Tourism Management, 29, 237-251. https://doi.org/10.1016/j.tourman.2007.03.015

Mc Cormick, D. \& Kahn, M. (1982). Collaborative group process in seminars. Exchange. The Organisational Behavior Teacing Journal, VII, 16-22. https://doi.org/10.1177/105256298200700404

Prats, L., Guia, J. \& Molina F. X. (2008). How tourism destinations evolve: The notion of tourism local innovation system. Tourism and Hospitality Research, 8, 178-191. https://doi.org/10.1057/thr.2008.24

Putnam, R. D. (2000). Bowling alone. The Collapse and Revival of American Community. New York: Simon \& Schuster. https://doi.org/10.1145/358916.361990 
Mauss, M. (2011). The gift: the form and reason for exchange in archaic societies. Mansfield, Conn.: Martino publishing.

Nahapiet, J. \& Ghoshal, S. (1998). Social capital, intellectual capital, and the organizational advantage. Academy of Management Review, 23 (2), 242-266. https://doi.org/10.5465/amr.1998.533225

Quandt, T. (2012). What's left of trust in a network society? An evolutionary model and critical discussion of trust and societal communication. European Journal of Communication, 27 (1), 7-21. https://doi.org/10.1177/0267323111434452

Qi, X. (2013). Guanxi, social capital theory and beyond: toward a globalized social science. The British Journal of Sociology, 64, 308-324. https://doi.org/10.1111/1468-4446.12019

Sahlins, M. (1972). Stone age economics. Chicago: Aldine Atherton.

Sahlins, M. (1976). Culture and practical reason. Chicago: Aldline.

Smart, A. (1993). Gifts, bribes and guanxi: A reconsideration of Bourdieu's social capital. Cultural Anthropology, 8, 388-408. https://doi.org/10.1525/ can.1993.8.3.02a00060

Svensson, G. (2014). Exchange and Change in Northern Norway: On Reciprocity in Nature Based Tourism. Tourism, Culture and Communication, under utgivelse. https://doi.org/10.3727/109830415X14213698267352

Walsh, A. (2009). The Grift: Getting Burned in the Northern Malagasy Sapphire Trade. I K. E. Brown \& B. L. Milgram (red.), Economics and morality: Anthropological approaches (s. 59-76). Ventura: California State University Channel Islands.

Williams, C. C. (1996). The new barter economy: An appraisal of local exchange and trading systems Journal of Public Policy, 16, 85-101. https://doi.org/10.1017/S0143814X0000787X 


\section{HVALSAFARI ANDENES - REISELIVSETABLERING I MØTE MELLOM IDEALISME, VITENSKAP OG FORRETNINGSDRIFT}

Anniken Førde og Arvid Viken

\section{Innledning}

Turisme basert på møter med hval har siden starten hatt kunnskapsformidling om hval og marint liv som sentralt element. Hvalsafari er en utbredt turismeaktivitet, og det finnes over 500 tilbud verden over. Ifølge en rapport fra International Fund for Animal Welfare (2009) ble det tilbudt hvalturisme i California alt på 1950-tallet. Men ideen hadde ikke særlig utbredelse før etter at hvalfangsten var blitt bannlyst i 1982, og man hadde begynt å diskutere ikke-konsumerende måter å forholde seg til hval på. I denne diskusjonen deltok også International Whaling Commission (IWC) og NGO-er med dyrevern på sine agendaer. Disse organisasjonene har siden deltatt i utviklinga av møter med hval som turismeaktivitet og i forskning både knyttet til tilrettelegging og til aktivitetens betydning for dyr og samfunn (Hoyt \& Hvenegaard 2002). Som nasjon har Norge sammen med Island og Japan holdt fast ved hvalfangsten og ikke deltatt $\mathrm{i}$ de internasjonale organisasjonene og debattene. Men Norge har ikke vært upåvirket av de internasjonale strømningene og interessen for hval, og etter hvert har vi fått mange tilbydere av hvalturisme langs norskekysten. 


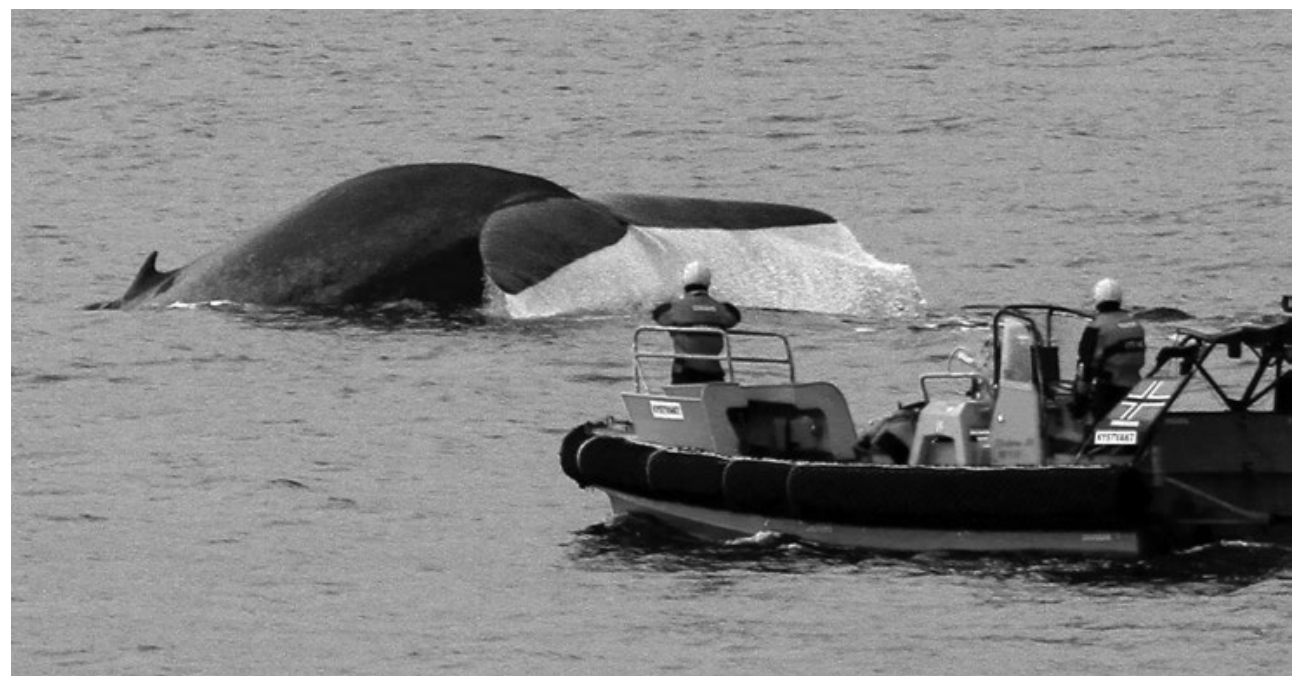

Myndigheter på hvalsafari? Foto: Ole Magnus Rapp.

Andenes har vært det mest kjente stedet for denne aktiviteten, hvor de har drevet med hvalsafari i 30 år.

Andøya ligger ytterst i Vesterålen, tett på Eggakanten, som er et førsteklasses fiskefelt, og derfor et stabilt og godt beiteområde for hval. Fra båt kan man se mest spermhval, men også vågehval, grindhval, spekkhogger og knølhval. Siden 1989 har turister kommet til Andøya fra inn- og utland for å oppleve hval på nært hold. I dag er det flere selskaper som tilbyr hvalturisme på Andøya, men den bedriften som har holdt på siden starten, er Hvalsafari AS. De omtaler seg sjøl som den første, største og mest erfarne tilbyderen av hvalsafari i Norge og lover sine besøkende «100 \% hvalgaranti» (www.whalesafari.no). Å oppleve levende hval er kjernen i attraksjonen, men den omfatter også et hvalsenter på land med utstillinger, restaurant og butikk. Det som starta som et idealistisk prosjekt for noen tilreisende hvalforskere, er blitt en betydelig attraksjon. Med cirka 15000 besøkende i året er Hvalsafari AS den største reiselivsattraksjonen i regionen. Selskapet har en ambisjon om å være en sentral aktør i utvikling og formidling av kunnskap om marint dyreliv. I dette kapitlet vil vi se nærmere på innovasjonsprosessen som leda til etableringa av Hvalsafari AS, og prosessen mot en etablert reiselivsvirksomhet. Vi er særlig opptatt av møtet mellom idealisme, forskning og forretningsdrift og kunnskapens plass i disse prosessene. 
Utviklinga av Hvalsafari AS på Andenes blir i dette kapitlet analysert som en kompleks entreprenørskapsprosess som involverer ulike aktører, institusjoner og kunnskapstyper. Vi argumenterer for et relasjonelt perspektiv på entreprenørskap og destinasjonsutvikling, hvor tradisjonelle forståelser av attraksjoner og destinasjoner som produkter utfordres. I nyere, kunnskapskritiske perspektiver forstås entreprenørskap som relasjonelle prosesser (Ingold \& Hallam 2007; Johannesson 2012; Førde 2014). Også destinasjonsforskningen utfordres av mer relasjonelle forståelser. En utbredt måte å betrakte destinasjoner på, har vært som attraksjonsansamlinger innen et område eller en region; bestående av en rekke attraksjoner, aktivitetstilbud, fasiliteter og infrastruktur (Gunn 1993). De seinere åra har mange argumentert for et bredere perspektiv, hvor destinasjoner forstås i sammenheng med andre lokale utviklingsprosesser i det landskapet de inngår i (Ringer 1998; Saarinen \& Kask 2008; Viken \& Granås 2014). Det innebærer et fokus på forholdet mellom reiselivsutvikling og omliggende stedlige strukturer og prosesser som både spenninger, muligheter og utfordringer.

\section{Andenes: 30 år med hvalsafari}

Andenes er et lite tettsted i Andøy kommune i Vesterålen, ytterst mot Nordishavet. Kommunen har et areal på 656 kvadratkilometer og en befolkning på rundt 5000 . Omtrent halvparten av innbyggerne bor i kommunesenteret Andenes, nord på øya. Naturen på Andøya er storslagen, med bratte fjell, store myrområder, hvite strender, storhavet og kontinuerlig skiftende lys. Øya rommer flere naturreservater og er kjent for rikt fiske, store forekomster av hval og et rikt fugleliv. Andenes er kommunens handelssentrum, kommunikasjonssentrum og administrasjonssentrum, og har et variert næringsliv. Det er både et fiskevær og et turistvær. Innerst i havna, like ved fyrtårnet, ligger hvalsenteret. Det omfatter et hvalmuseum, en resepsjon, butikk, kafé og restaurant. Og på kaien nedenfor ligger båtene som frakter turister ut til hvalen.

Andøy er primært en fiskerikommune, og Andenes er et av landets største fiskevær med et stort havneanlegg. Under den kalde krigen bygde Forsvaret seg opp på Andøya, med base for Forsvarets store overvåkingsfly. Jordbruk og etter hvert reiseliv er også viktige næringer. Stedet er videre kjent for å romme Norges eneste rakettoppskytingsfelt, som også er en 
del av landets beskjedne romforskning. Andøy står overfor mange av de samme utfordringene som andre kystsamfunn, med strukturering og rasjonalisering i tradisjonelle næringer som fiskeri og landbruk. I tillegg står de overfor store omstillingsoppgaver, etter at Stortinget i 2016, gjennom den nye langtidsplanen for Forsvaret, vedtok nedlegging av Andøya flystasjon. De maritime patruljeringsflyene skal flyttes fra Andenes til Evenes, noe som er ventet vil medføre tap av over 300 arbeidsplasser (over 16 prosent av total sysselsetting). Nedlegginga er også venta å ha store negative ringvirkninger for andre næringer og sektorer i kommunen. ${ }^{2}$ Som et resultat av dette fikk Andøy i 2017 status som omstillingskommune, og etablerte omstillingsprogrammet Samskap. I tillegg til naturbaserte næringer som sjømat og landbruk, rom- og droneteknologi er reiseliv løfta fram som et sentralt satsingsområde for framtidas Andøy. Innen reiselivet ses hvalturisme som en bærebjelke, og et nytt hvalsenter i verdensklasse - The Whale - er under etablering. Turismen på Andøy har de senere åra opplevd vekst. I tillegg til hvalsafari byr reiselivet på fugletitting, fisketurer, gårdsturisme, padling og fotturer, eller en tur i verdensrommet med romskipet Aurora (et besøkssenter knyttet til virksomheten på Andøya Space Center). Øya har flere museer, et hvalsenter, gallerier og et aktivt kulturliv. Her finnes flere serveringssteder, hoteller, rorbuer, campingplasser og en rekke private overnattingstilbud. Kommunen har hurtigruteanløp, fastlandsforbindelse, flyplass og fergeforbindelse til Senja. I 2012 åpnet Nasjonal turistveg langs yttersida av Andøya. Denne står kommunen i 2020 i fare for å miste på grunn av planlagte utbygginger for rom- og droneteknologi. Det uroer reiselivsnæringa, som er avhengig av at turister til Lofoten eller Nordkapp tar en omvei for å komme til Andøy. Etableringa av Hvalsafari AS ses som starten på reiselivsutviklinga i kommunen og er den desidert største reiselivsbedriften. I 2019 feiret bedriften 30-årsjubileum, men den er i stadig utvikling. Turistsesongen har i hovedsak vært fra slutten av mai til midten av september, men de seinere åra har Hvalsafari AS hatt helårsdrift. Virksomheten ses som en viktig trafikkgenerator for reiselivet i Andøy og Vesterålen.

Tall hentet fra rapporten Situasjons- og konsekvensanalyse ved nedlegging av Andøya flystasjon, Nordland Fylkeskommune 2017. http://www.andoy.kommune.no/handlers/fh.ashx?FilId=21190 


\section{Entreprenørskap og kunnskapsmøter}

Med et relasjonelt perspektiv på entreprenørskap, kunnskap og attraksjonsog destinasjonsutvikling er oppstartsprosessen til hvalsafariaktivitetene på Andenes særlig interessant. Ifølge Rotefoss og Kolvereid (2005) har de fleste oppstartsstudier fokus på enten den enkelte entreprenør, prosessens kontekstuelle karakter eller de faktiske aktiviteter eller hendelser som er viktige for oppstartsprosessen. Et relasjonelt inntak til analysen tilsier imidlertid at vi i stedet for på å se på disse elementene hver for seg har fokus på samspillet mellom dem. Entreprenørskap ses som sosialt situerte prosesser, avhengig av samspill i og mellom nettverk. Entreprenørers kreativitet kan ikke skilles fra de relasjonene de er forankret i, og disse relasjonene er igjen situert i spesifikke kontekster (Hall \& Williams 2000). En slik relasjonell tilnærming til entreprenørskap innebærer et skifte i fokus fra innovasjon som produkt til komplekse innovative prosesser (Ingold \& Hallam 2007). For å forstå innovasjonsprosesser i reiselivet må vi derfor skifte fokus fra resultat til prosessene som skaper dem.

Etablering av reiselivsbedrifter bidrar til å skape turiststeder eller turistdestinasjoner. Men stedene slike destinasjoner befinner seg på, er ikke bare det; de har sin historie og spesifikke utvikling og består også av en rekke andre relasjoner, nettverk og praksiser. Det å skape turiststeder involverer ulike aktører som drar med seg ulike historier, verdier og livsstiler inn i produktet (Burns \& Novelli 2006). Turismeforskningen har blitt kritisert for å være lite opptatt av relasjonene mellom reiselivsutvikling og videre lokale utviklingsprosesser. De senere åra har stadig flere prøvd å møte denne kritikken, blant annet ved å argumentere for at også destinasjoner må forstås som prosesser snarere enn produkt, da de kontinuerlig forhandles og reforhandles (se blant annet MacLeod 2011; Saraniemi \& Kylänen 2011; Førde 2014). Som van der Duim, Ren og Jóhannesson (2012) vil vi argumentere for at destinasjoner må ses som ledd i komplekse prosesser hvor en rekke sosiale praksiser, diskurser, objekter og teknologier er involvert.

Innovasjonsprosesser, som etableringa av nye reiselivsbedrifter og -produkter, setter steder i bevegelse. Kreative prosesser utfoldes i samhandling og involverer nye sammenstillinger innenfor et mangfold av allerede etablerte relasjoner. Det medfører gjerne spenninger, hvor normer og normalitet blir utfordra og gjøres til gjenstand for forhandling. Ste- 
det reproduseres kontinuerlig som natur, sosiale relasjoner og diskursive forestillinger (Bærenholdt et al. 2004). Reiselivsutvikling innebærer for eksempel konstruksjoner av nye stedsbilder og innebærer reforhandling av stedsidentiteter. Slike prosesser fører både til endring og ivaretagelse av lokale praksiser, da utvikling oppstår i samspill mellom konvensjon og innovasjon.

Med et relasjonelt perspektiv på entreprenørskap, attraksjons- og destinasjonsutvikling forstås innovasjon som samspill mellom spesifikke aktører og kontekster. Vi må studere kreative praksiser, nettverk og forhandlinger. Et slikt perspektiv gir innsikt i repertoarer av kunnskap og relasjoner som entreprenører bringer med seg, og hvordan disse kan plasseres inn i nye prosjekter. Ved å studere hvordan entreprenørskap inngår i komplekse relasjoner mellom situerte aktører og kontekster, og hvordan aktører bringer sammen tradisjonelle og nye praksiser, kan vi gripe hvordan reiselivsutvikling bidrar til både vedlikehold og transformasjon av lokale praksiser, representasjoner og omgivelser. Som Førde (2009) har vist, inntreffer ofte entreprenørskap i reiselivet gjennom nye og ukonvensjonelle forbindelser og arbeidsmetoder. Disse innebære ofte nye lokale allianser og utvidede nettverk, men også nye kombinasjoner av tradisjon og innovasjon, av natur og kultur, av det lokale og det globale og av ulike typer kunnskap.

I dette kapitlet vil vi konsentrere oss om denne kunnskapsbasen; hva slags kunnskap som var involvert i prosessen med å etablere hvalsafari på Andenes, og hva slags kunnskap som er sentral i driften av en slik attraksjon. Et spørsmål som reises, er hva slags kunnskap og modeller som ble introdusert av entreprenørene som var involvert. Det er alltid noen forkunnskaper som ligger til grunn for entreprenørskapsprosesser. Folk flest opererer innenfor en «kunnskapskorridor», som gjør det mulig å se visse muligheter, men ikke andre, hevdes det (Shane 2000, s. 452; Venkataraman 1997). Entreprenørenes bakgrunn og erfaringer er altså førende for hvilke muligheter de ser og bidrar til å skape. Det vil for eksempel være stor forskjell på om de som leder utviklinga av en bedrift eller aktivitet, er naturvitere, økonomer eller har en turismefaglig eller en mer praktisk bakgrunn. Kunnskapens rolle i utviklinga av turismen er et tema som i økende grad er blitt diskutert. Flere av dem som har diskutert dette, har framhevet betydningen av ikke-eksplisitt kunnskap, taus kunnskap (Weidenfeld et al. 2010) eller praktisk kunnskap (Tribe 2005). Turismefeltet krever mange slags tilpasninger og er sterkt preget av folks evne til å finne praktiske 
løsninger. Det er også en del eksempler på at attraksjoner formet etter fagfolks anvisninger ikke har overlevd fordi de ikke har hatt tilstrekkelig appell i markedet, eller fordi markedsaspekter har vært for lite tilgodesett (Frost 2011). Et eksempel er norske nasjonalparksentre, formet av naturvitere, som etter noen år blir gjort om i henhold til mer markedsorienterte prinsipper for å overleve.

I etableringen av naturbaserte attraksjoner vil kjernekunnskapen ofte være naturvitenskapelig. Det gjelder attraksjoner som nasjonalparksentre og naturvitenskapelige museer. Samtidig er de ofte også preget av andre typer kunnskap og ferdigheter, knyttet til det å utforme og sette opp utstillinger. Aristoteles opererte med en inndeling i tre typer kunnskap, en som vi i dag vil kalle akademisk kunnskap (episteme), ferdigheter (techne) og praktisk kunnskap (fronesis) (se Flyvbjerg 2004; Flyvbjerg et al. 2012). Den praktiske kunnskapen er gjerne erfaringsbasert, handlingsorientert, konteksttilpasset og innbefatter moralske vurderinger. Nonanka og Toyana $(2007$, s. 378, vår oversettelse) sier det slik: «Praktisk kunnskap er en intellektuell dyd. Grovt oversatt som klokskap, etikk, praktisk visdom eller praktisk rasjonalitet, er praktisk kunnskap generelt forstått som evnen til å bestemme og gjennomføre tiltak som i størst mulig grad oppfyller mål og tjener et fellesskap.» I utviklinga av turismeprosjekter er den praktiske kunnskapen ofte sentral. Den omfatter det å kjenne feltet, vite hva slags kunnskap man skal etterspørre, ha nettverkskompetanse, kjenne forretningsverdenens og offentlighetens irrganger (Viken 2014). I denne studien fokuserer vi på hvordan et naturvitenskapelig og idealistisk prosjekt ble koplet til bestemte kunnskapsmodeller og ferdigheter og etter hvert overtatt av aktører med praktisk erfaring fra næringslivet i regionen. Vi ser på forhandlinger og spenninger i slike kunnskapsmøter.

\section{Studiens metodikk}

I dette kapitlet forsøker vi å skrive fram kompleksiteten i et konkret utviklingsforløp. Analysene baserer seg på en casestudie i hovedsak gjennomført fra 2011 til 2014, med oppfølgingsbesøk i seinere år. Vi har intervjuet aktører som har vært deltakende i utviklinga av attraksjonen Hvalsafari AS, fra oppstarten og fram til drifta i dag. Dette innebærer de som i dag arbeider med drift, kunnskapsproduksjon og formidling, aktører 
innen lokale styresmakter og administrasjon og folk som var med som ildsjeler da ideen om hvalsafari på Andøya ble etablert, både tilreisende og lokale. For å fange kompleksiteten i destinasjonsutviklingsprosessene som fulgte etableringen av hvalsafari, har vi videre gjennomført en rekke intervjuer og fokusgruppesamtaler med ulike lokale aktører: reiselivsaktører fra ulike steder på Andøya, representanter for øvrig næringsliv, offentlige institusjoner, fiskere, pensjonister og ungdommer. Tema for disse gruppesamtalene har vært lokal utvikling generelt og reiselivsutvikling spesielt, med fokus på mangfoldet av nettverksrelasjoner. I tillegg har vi deltatt på møter i reiselivsnæringa, hvor utfordringer, muligheter og samarbeid har vært diskutert.

I hovedsak baserer vi vår framstilling på involverte aktørers fortellinger om hva som skjedde i de tidligere fasene av prosessen. Vi var ikke der og deltok i møtene, de kreative praksisene og samarbeidet som fant sted fra slutten av 1980-tallet. Å studere «nåtidas fortid» krever følsomhet overfor hva Huyssen (2003) kaller hukommelsespolitikken; hvilke aspekter av fortida som blir understreket, av hvem og for hvilket formål. Historier fra fortida brukes ofte til å legitimere maktforhold (ibid.). Derfor har vi forsøkt å inkludere historier fra aktører med ulik tilknytning til prosjektet. Dette har vi gjort både gjennom individuelle intervjuer og fokusgrupper. Det å samle folk i fokusgrupper gjør at både delte fortellinger og motsetninger om attraksjons- og destinasjonsutviklingsprosesser blir gjort eksplisitte, og vi får et innblikk i hvordan kunnskap og lokale virkeligheter forhandles (Viken 2013). Ved å initiere og delta i arenaer for diskusjon om reiselivsutvikling blir også vi en del av disse diskusjonene. Våre metoder er dermed ikke uskyldige teknikker, men inngår i de prosessene vi forsøker å avdekke (Law 2004). Gjennom et bredt inntak til feltet har vi prøvd å fange ulike aktørers perspektiver på utviklinga og å anerkjenne kompleksiteten av relasjoner og nettverk som er involvert. En utvidet kontekst for å forstå reiselivsutvikling mener vi kan bidra til å utfordre implisitte forståelser av hva som er relevante relasjoner og sammenhenger i slike prosesser.

\section{Oppstarten av Hvalsafari AS}

«Den spermasetthvalen - det var jo svenske, danske og finske forskere som fortalte oss at det var dyr uti havet som de mente fremmedfolk kunne 
komme hit og betale for å se. Det var det som var utgangspunktet.» Slik forteller daværende næringskonsulent hvordan det hele startet.

Året var 1987. Da ankom en seilbåt med representanter for The Swedish Centre for Studies on Whale and Dolphin (CSWD). De kalte seg et nettverk, opprettet for dette formålet - å starte hvalsturisme i Norge, forklarer den første lederen av Hvalsafari AS. Det var altså en organisasjon skapt for anledningen. Om bord i båten var det marinbiologer, biologistudenter og andre som var fascinert av hval. En av studentene fra den gang sier: «Vi var en håndfull entusiaster, sånn som meg sjøl. Det var basert på frivillig arbeid, og opplevelsen ved å skape noe ...» De fleste var fra Sverige, men det var også noen fra Danmark og Finland. Turen var delvis finansiert av Verdens naturfond (WWF). De var på jakt etter et sted man kunne se hval. I utgangspunktet var de på jakt etter spekkhoggere i Lofoten, men dårlig vær og lokal motstand i fiskevær hvor hvalfangst sto sterkt, gjorde at strandhogget der var lite vellykket. De kom så til Vesterålen og møtte på store flokker spermhval utenfor Andøya. «Spermhvalen var ikke av interesse for hvalfangst lenger, så ingen i Norge hadde lagt merke til dem», forteller en av lederne for prosjektet. I Andenes ble de møtt med «litt skepsis», av folk som trodde hvalsturisme «var en vits», men ikke med samme motstand som i Lofoten. Ideen om å etablere hvalsafari ble lansert helt fra starten og fikk støtte fra både kommunen, fylkeskommunen, Vesterålen regionråd og Vesterålen reiselivslag - som bidro til å få i gang et prøveprosjekt med kommersiell hvalsafari året etter. Til tross for en viss skepsis lokalt møtte de tilreisende enkelte lokale aktører som syntes ideen var spennende og tok godt imot dem. Næringskonsulenten i kommunen tok de tilreisende med hjem og serverte dem fiskesuppe, og en av de lokale entusiastene som deltok i prosjektet, mener det må være «den mest lønnsomme fiskesuppa som har vært servert i Andøys historie». Sammen med noen få lokale aktører skapte de den første hvalsafaribedriften i Norge. Hvalsafari AS ble stiftet med støtte fra WWF i 1989. Det var to hovedkomponenter i satsingen: den ene var turene på havet hvor en fikk møte hvalen, den andre et hvalsenter for formidling av kunnskap om hvalen. De allierte seg med en hvalfanger fra Lofoten og leide inn hvalfangstskuta hans for å frakte turister ut. Etter hvert leide de inn en hvalfangstskute til, før de etter hvert investerte i egne og mer tilpassa båter. Hvalsenteret med utstillinger og bildefremvisninger var først lokalisert til stedets ungdomsklubb, før de kjøpte et nedlagt fiskebruk som ble gjort om til hvalsenter. 
Nærheten til hvalen var hovedelementet: «Det å være ute på sjøen der og lukte ånden - altså, du kommer så nær at du kan lukte hva den har spist. Og ser muskelspillet over ryggen på hvalen når den dykker. Det forandrer folk.» Slik beskriver en som har hatt ansvar for markedsføringen av Hvalsafari AS, hva de ville formidle. «Møt Moby Dick» ble tidlig et slagord, hvor en spilte på Herman Melvilles legendariske bok om nettopp en spermasetthval. "Vi forsto etter hvert hvor stor Moby Dick var internasjonalt ... i vår felles litteraturarv.» Det vises til hvordan det å møte så mektige dyr har en egen tiltrekningskraft, og de ville formidle opplevelsen av et slikt møte med "giganten på havet», sammen med kunnskap om hvalen. Her spilte en både på mytologi og vitenskap.

Den første turen de hadde, var i samarbeid med den svenske turistforeningen. De hadde en rekke turoperatører med, og det ble en stor suksess: «Det var hvaler overalt.» Det ble invitert til en lokal konferanse, hvor de hentet inn en hvalsafarientreprenør fra Florida, som hadde tjent seg rik på denne aktiviteten. Flere av pionerene mener dette var en avgjørende faktor for å få lokal støtte. Han ble «et sannhetsvitne på at dette var business». Den eksklusive retten til å bruke WWFs logo i markedsføringa dras også fram: «Det ga oss status å ha pandabjørnen.» Den oppstarten vi får beskrevet i de mange historiene fra 1980- og 90-tallet, var ikke preget av enkeltaktører, men av en rekke relasjoner mellom et mangfold av aktører med ulike utgangspunkt. Her møttes naturvitenskap og kunst, globale miljøinteresser og lokale fangsttradisjoner, ung idealisme og lokale næringsutviklingsinteresser. I disse møtene oppsto det en rekke nye nettverk og allianser, men også brytninger og forhandlinger. Det er i disse komplekse relasjonene attraksjonen og destinasjonen ble drevet fram.

\section{Møte mellom kunst og vitenskap}

De som var med fra starten, snakker om en fantastisk tid, med mye idealisme, entusiasme og kreativitet. Men også mye arbeid. Det var folk som var opptatt av hval og marint liv, og som så hvalsenteret som et unikt prosjekt for å skape engasjement rundt dette. En av de tilreisende studentene forteller at saken hadde stor tiltrekning på ungdommer: «Det stedet tiltrakk unge mennesker fra hele verden: Mexico, Australia, Italia, USA, Brasil, alle land i Europa jeg kan komme på. Unge mennesker som ville gi 
sin høyre arm for å komme opp dit. Fordi det var et levende og spennende prosjekt.» Flere omtaler pionertida nærmest som et «hippiekollektiv». Her bodde, arbeidet og festet de sammen, og det ble etablerte mange vennskap og også parforhold. Prosjektet var preget av entusiaster som sto på for å skape attraksjonen, uten lønn. En representant fra kommunen forteller at deres bidrag var å betale regninger slik at «de kunne bo, spise og drikke», og at den første regninga kommunen betalte, var tre kasser øl. Som en av de lokale deltakerne uttrykker det: «Det var folk som blir lett begeistra, lett forelska. Det var fantastisk artige fester. Ei artig tid, men også ei arbeidsom tid. Folk jobba knallhardt.» De hadde en ledelse som bygde opp under engasjementet og turte å ta risikoen med å «bare la ting skje». Vi blir fortalt historier om folk som jobbet til langt på natt, og at det for noen gikk på helsa løs. En av dem forklarer at drivkraften lå i det å få være med å skape noe unikt, og at det å være med i et pionerprosjekt «får folk til å arbeide 26 timer i døgnet».

I tillegg til det de som var med, beskriver som et sterkt fagmiljø på hval, vokste det fram et kreativt miljø rundt hvalsafariene. Det besto av forskere og studenter, men også fotografer, designere, reklamefolk, teaterfolk og illustratører. Denne kombinasjonen av forskere, studenter og folk fra kunst- og kultursektoren ser ut til å ha vært svært fruktbart, og miljøet som ble skapt, beskrives av dem som var med, som raust og inkluderende. De utviklet «et sterkt indre liv».

Samtidig var relasjonene til lokalsamfunnet begrensa. Sjøl om de aldri følte seg uvelkomne, mener flere at de ble sett på med skepsis - og ansett som «en flokk hippier». En lokal reiselivsaktør som ble med på prosjektet, sier: «Folk trodde vi var gale.» Og en av studentene fra pionertida tror folk syntes hele ideen med hvalsafari var litt «åndssvakt». Hun forteller om en ung, norsk jente som arbeidet i den første turistinformasjonen (som var på kjøkkenet deres), som ikke ville nevne hvalsafari når turister spurte om hva som skjedde på stedet; det synes hun var for pinlig! De hadde noen få lokale ansatte i turistinformasjonen, men miljøet tiltrakk få norske studenter og forskere.

I dag har de fleste pionerene forlatt Andøya. En av de utenlandske forskerne som var med fra starten, forklarer det slik; «Vi var folk som kom langveisfra. På et tidspunkt vil man hjem igjen.» Men de har fortsatt et forhold til Andenes. Nettverket de etablerte, er fremdeles viktig for mange; de holder kontakt og snakker om denne tida som noe de «savner helt vilt». 
I det pågående arbeidet med etableringen av The Whale, et nytt hvalsenter av langt større dimensjoner, er flere av dem involvert.

\section{Fra idealisme til forretning}

Det kunstneriske sto sterkt i oppstarten av Hvalsafari AS, og da særlig gjennom utviklinga av utstillingene på Hvalsenteret og etter hvert Andøy natursenter og Hisnakul, et kulturhus primært for ungdom. Flere av svenskene som kom med CSWD, var kunstnere, som gjennom utarbeiding av utstillinger fikk brukt sin kunstneriske kompetanse. Her involverte en også noen lokale aktører fra kulturfeltet. En av dem forteller at tanken bak natursenteret og Hisnakul var at når så mange var interessert i å komme og se hval, måtte de også være interessert $\mathrm{i}$ alt det andre stedet hadde å by på. En ønsket derfor å utvide attraksjonstilbudet. Natursenteret var tenkt som et dokumentasjonssenter for fugl og de spesielle naturforholdene på Andøya, etter samme grunnfilosofi som Hvalsenteret. Hisnakul ble konsertlokale og scene. Det ble satt opp over 20 teaterstykker, og noen år ble det spilt teater hver hele time i sommersesongen. Estetikken sto høyt i kurs, og det ble etablert et kunstnerisk råd som skulle godkjenne alt som ble skapt. En som var med i rådet, sier de fungerte som en slags «åndelige vaktmestre», som til og med utviklet et eget språk; «hisnakulsk». Kommersielt ble disse satsingene aldri noen suksess, og for noen år siden ble Hisnakul stengt. En lokal deltaker omtaler det som en litt trist historie, men påpeker at det likevel kom mye ut av det: «Det var en økonomisk katastrofe, men en kulturell kjempesuksess!» Hisnakul var et sted hvor unge mennesker fikk sommerjobb som skuespillere, og unge komponister fikk lage musikk for teater. Noe han mener har hatt stor betydning for det blomstrende kulturlivet Andøy har i dag.

Driften av hvalsafarien var heller ingen stor økonomisk suksess de første åra. Hvalsafari AS var en bedrift med sterkt islett av offentlig eierskap, ved etableringa hadde kommunen en eierandel på 40 prosent, fylkeskommunen 20 prosent, mens lokalt næringsliv hadde 20 prosent og CSWD 20 prosent (Ris 1993). De idealistiske initiativtakerne som var med, hadde liten tilgang til kapital. Da de manglet penger for å komme i mål med museet, gikk de ut for å selge aksjene. En lokal forretningsmann kom da inn som investor. Etter hvert solgte også fylkeskommunen og kommunen 
seg ut, og det som er dagens eier, ble sittende med majoriteten av aksjene. «Det ble aldri noen store overskudd før vi tok over. Fikk tatt over i privat regi. Da ble det litt mer fart i det, men det går sakte.» Dagens eier forteller hvordan de har vært opptatt av å utvikle bedriften i små steg. De har utvidet drifta med nye båter og nye landanlegg, og de har overtatt campingplassen på stedet.

Når bedriften ble overtatt av lokale næringslivsinteresser, sier flere som var involvert i den tidlige fasen, at det var en lettelse. Mange poengterer også betydninga av at det var en lokal investor som kom inn og overtok ansvaret for drift og utvikling; en som kjente stedet. Det ble «velfungerende, strukturert og ordentlig». Men også «veldig kommersielt». Flere av dem som var med i starten, mener mye av filosofien fra den første tida er gått tapt i utviklinga mot et mer kommersielt produkt. En av pionerene uttrykker det slik: «Poesien som var på stedet, er blitt borte.» Hvalfangstmuseet er blitt erstatta av en dansebar. Fra å være et sted med drivved og handlaga, signerte møbler har senteret fătt et mer kommersielt uttrykk, "med vegg-til-vegg-tepper, exit through the giftshop og plysjhvaler ..." Samtidig som flere av pionerene uttrykker en viss skuffelse over denne utviklinga, har de forståelse for at kommersialisering er nødvendig, med den profesjonaliseringa og strømlinjeforminga det innebærer. «Den pionerånden, den får du ikke tilbake. Det skal inn i bedriftsmodus.» Flere av dem hevder at kvaliteten ved andre sider av drifta enn det som går på utstillinger og estetikk, har blitt bedre. Det gjelder forhold som sikkerhet og service om bord. De uttrykker også stor respekt for at Hvalsafari AS har holdt fast ved det å ha kvalifiserte guider. Dette kan på mange måter ses som et klassisk utviklingsforløp, hvor aktører med praktisk forretningserfaring tar over etter entusiastiske, verdiorienterte entreprenører. Idealisme blir erstattet av økonomisk rasjonalitet og praktisk sans. Det har berget aktiviteten økonomisk. Og sjøl om noen av kvalitetene fra startfasen kan se ut til å ha gått tapt, har en forsøkt gjennom kommersiell drift å holde fast på grunnpilaren i det idealistiske utgangspunktet som handler om kunnskapsformidling som en sentral del av produktet. Og fascinasjonen for hvalen er fortsatt det bærende elementet i bedriften. 


\section{Kunnskapens plass i attraksjonen}

Kjernekunnskapen i en attraksjon som Hvalsafari AS vil naturlig nok være naturvitenskapelig. En tidligere faglig leder sier at sjøl om det var svært naturvitenskaplig orientert, la de vekt på bredde ved ansettelser: «Om det var en som var marinbiolog og seilmaker, eller marinbiolog og sirkusartist, så valte vi han.» Profesjonalitet - både teoretisk og praktisk kunnskap - er høyt verdsatt. I tidlig fase var naturvitenskaplig kunnskap og ferdigheter knyttet til det å lage utstillinger, sentralt. Kunnskapen var ikke bare av naturvitenskapelig art. Men det var en overvekt av folk med marinbiologisk bakgrunn - dette framkommer i stadig referering til forskere og studenter. Stabens CV-er var en form for faglig garanti. Det ble også nedsatt et faglig råd til å ha overoppsyn med utviklinga. En av dem som var med her, sier de fremdeles konsulteres av og til, men mener de mangler et slikt i råd dag, og at det vitenskapelige fundamentet er svekket.

Internasjonalt har hvalsafari vært motivert av å finne fram til ikke-konsumerende bruk av hvalen og av å øke kunnskapen om hval og marint liv. For Hvalsafari AS på Andøya har utdanning og kunnskapsformidling stått sentralt helt fra starten. «Konseptet, som CSWD presenterte, handlet om å kombinere kunnskapsformidling og forskning med reiseliv», sier den første lederen. De la stor vekt på å ha kvalifiserte guider, og gjennom nettverket til CSWD rekrutterte de biologer og studenter fra mange land. Hvalsafari AS har opp igjennom rekruttert en rekke marinbiologer og marinbiologistudenter, og det er skrevet mange studentoppgaver og avhandlinger ved universiteter i mange land basert på studieopphold og data fra Andøya. Kunnskapsformidling har vært sentralt både i guiding av turister og i måten de innredet hvalsenteret og natursenteret på. En av forskerne fra oppstartsåra sier de i hovedsak drev naturformidling, hvor de presenterte basal kunnskap om hvalen og naturhistorien. Natursenteret var tenkt som et formidlingssenter for lokal naturkunnskap, hvor man skulle formidle kunnskap ikke bare om hval, men også om lokalt fugleliv og den spesielle geologiske historien til stedet. Det ble også holdt en rekke forelesninger om kveldene: «Du kunne stikke innom, og så kunne du få en presentasjon av en topp kvalifisert internasjonal lydforsker, som på en populærvitenskapelig måte dro alle mulige folk som hadde lyst til å komme inn i den verdenen de jobba med ...» Denne koplinga til vitenskap har man holdt fast ved hele vegen. 
«Det skal være kvalitet over det som presenteres», fastslår dagens ledelse. Hvalsafari AS skal først og fremst gi turister gode opplevelser, men har også som mål å bidra til finansiering og utøving av forskning og kunnskapsformidling. Sentralt i arbeidet som gjøres på Hvalsenteret, er en spermhvalkatalog som inneholder data fra så langt tilbake til som 1987. «Vi har så langt identifisert nesten 500 individer. Omtrent 30-40 nye spermhvaler hvert år. Den (spermhvalkatalogen) kan brukes til å studere populasjonen her ute, og hvalens migrasjonsmønster», forklarer forskningskoordinatoren. Gjennom slike data vet man at mange av hvalene kommer igjen år etter år, «Glen» for eksempel, en 13-14 meter lang spermasetthval, hadde de i 2012 observert i 17 år. Studenter og forskere som vil ha et opphold ved senteret, må presentere sin forskning og sitt forskningsmiljø. Forskningens plass ser ut til å ha gått litt i bølger. Det var svært sentralt i starten, så var den noen år at det var mindre forskningsaktivitet tilknyttet bedriften, før de i 2010 igjen styrket dette fokuset - blant annet gjennom å ansette en person som har forskningskontakt som sitt ansvarsområde.

Forskningen har også en plass i opplevelsesproduksjonen. På deres hjemmeside kunngjør Hvalsafari AS at mange guider er «hvalforskere eller studerer marinbiologi» (whalesafari.no). Noen har hatt ordninger med forskning og guiding annenhver uke, mens andre har hatt sommerjobber som guider og arbeidet med sine oppgaver eller avhandlinger ellers i året. Forskningskoordinatoren forklarer at de har prøvd forskjellige modeller, da det er en utfordring å være forsker og veileder samtidig: «Hvis du er på båten som en guide, må du ta vare på turister. Og hvis du er der som forsker, må du ta bildene og gjøre det som kreves av deg som forsker.» Nåværende leder sier at de fortsatt insisterer på å kombinere forskning og formidling, det er noe som «styrker vårt produkt». I 2012 var åtte av elleve guider biologer. For å dekke flere språk tilsetter de guider fra forskjellige land. De har som regel både spanske, russiske og polske guider. Ansatte refererer til den positive tilbakemeldingen fra turister som uttrykker at å ha en forsker som guide gir dem en bedre opplevelse: «... det var herlig å oppleve henne (guiden og forskeren), fordi hun signaliserte at dette var noe hun jobbet med, ... hun bygde det inn i hele sin guiding.»

Tilknytninga til forskning er også en viktig del av markedsføringa. Hvalsenteret tilbyr ulike opplevelsesprodukter med forskningselementer i seg. Blant annet arrangerer de fotokurs, da fotografier er en viktig del av forskningsmaterialet de samler inn. Ellers tilbyr Hvalsafari AS produkter som å være «forsker for en dag», hvor man kan lære å identifisere hva- 
ler. Man kan også «adoptere» en spermasetthval, støtte hvalforskningen gjennom kjøp av suvenirer eller man kan «gi navn til en hval» (det kostet 10000 kroner i 2011). Dette er eksempler på produkter man har etablert for å skaffe penger til forskningsvirksomheten ved hvalsenteret.

Sjøl om man har holdt fast ved betydningen av forskningsbasert kunnskap, er det flere som mener forskningsbiten er utfordrende. En av forskerne som har hatt tilknytning til senteret over mange år, sier det har vært et produktivt miljø, fungert som et slags forskningshotell, som har produsert mange oppgaver og avhandlinger - i samarbeid med universiteter rundt om, men påpeker også utfordringene med å drive et forskningssenter uten å være knyttet til et universitet. En forsker sa det slik: «For å fungere som et forskningssenter må du være tilknyttet et universitet. Det må være et sett med vitenskapelige problemer som skal undersøkes. ID-merkingen er flott og kan danne grunnlag for forskning, men selve merkingen er ikke forskning.» Forskeren mener derfor de burde hatt sterkere bånd til forskningsinstitusjoner og nasjonale og internasjonale akademiske miljøer. Nåværende formidlingsansvarlig anerkjenner denne utfordringen og sier at: «Et av målene mine er å integrere deler av det vi gjør her i universitetsmiljøer. Det er et mål å få Andenes involvert i institusjoner som Havforskningsinstituttet eller Universitetet i Tromsø (...). Gode ambisjoner, men ikke så lett å få til.»

\section{Forholdet til hvalfangst}

Hvalturismen på Andøya oppsto i en periode hvor det var et betydelig fokus på miljøspørsmål, og hvalsaken hadde stor aktualitet. Det var store internasjonale protester mot hvalfangst. Tidligere forskning har vist hvordan oppbygginga av hvalturismen har stått i konflikt med hvalfangsten (Kalland 1992; Ris 1993; Lawrence \& Phillips 2004). Ris hevder at introduksjonen av hvalturisme på Andøya hadde en klar anti-hvalfangst dimensjon, og at målet var å bringe hvalen bort fra sin tradisjonelle, kulturelle kontekst ved å bygge opp det han kaller «an alien image» av hvalen - ikke som et objekt for konsum, men for opplevelser (Ris 1993). I en studie av hvalfangst i Nord-Amerika viser Lawrence og Phillips (2004) hvordan kommersiell hvalturisme er gjort mulig gjennom en radikal endring av hvordan vi konseptualiserer hvalen. I den nye diskursive konstruksjonen 
som vokste fram, gikk hval fra å være en ressurs som skulle høstes og forvaltes, eller en art som skulle reddes, til å være individuelle dyr med nesten menneskelig atferd (ibid.). I denne diskursen har man gått fra å snakke om hval i flertall til å snakke om «The Whale» (entall), og hvalen er blitt «the humans of the sea», hevder Kalland (1992). Han mener CSWD gjennom sin forskning (som han setter i hermetegn) bidro sterkt til denne redefineringa og individualiseringa av hvalen.

I våre forsøk på å utforske denne konflikten opplevde vi ofte at de involverte unndro seg oppmerksomhet. De fleste vi har snakket med, mener den er så godt som fraværende på Andøya. Likevel finnes det fortellinger om konfrontasjoner. Lokalt ble båten med svenske, danske og finske marinbiologer og andre idealister i starten omtalt som «Green Peace-båten». Sjøl om de møtte mindre motstand på Andøya enn de gjorde i Lofoten, hvor noen sier de ble «kasta ut», ble de utfordra av hvalfangstnæringa i landsdelen. Den første lederen forteller at hvalfangstlaget så på etableringa av hvalturisme som en trussel, og var spesielt kritiske til koplinga til WWF. Sjøl om pionerene som kom til Andøya, hadde tilknytning til organisasjoner som WWF og CSWD, som var mot hvalfangst, tok de offisielt ikke standpunkt i denne saken. En av dem som da var student om bord, og som seinere har hatt en sentral posisjon i utviklinga av Hvalsafari AS, sier deres anliggende var å bygge bro mellom de ulike holdningene i hvalfangstspørsmålet gjennom å opplyse og skape dialog. For noen av dem som var med, var det et motiv å få slutt på hvalfangsten, mens det for andre ikke var så kontroversielt.

Det ble av og til servert hvalkjøtt på Hvalsenterets kafé. Dette opplevdes ikke som et problem blant dem som var med, ifølge våre informanter. En av de lokale aktørene som var med fra starten, sier at det nok lå en tanke i bunnen hos mange om at turismen skulle erstatte hvalfangsten, «men det brydde jo ikke vi oss noe om. For oss var dette næringsutvikling i Andøy.» Han sier de var veldig tydelige på at det ikke skulle formidles et anti-hvalfangstbudskap ved hvalsenteret, og at deltakerne var lojale mot dette. Dette bekreftes av andre, en annen lokal deltaker sier han aldri hørte noen predike mot hvalfangst. Arbeidet var snarere preget av en fascinasjon for hvalen: «De var opptatt av - de elsket det flytende vesenet.»

En av pionerene sier at de i møte med turister ikke hadde fokus på hvalfangst, men at det ofte ble tematisert av de besøkende. Hun hevder de i formidlinga av den norske hvalfangsten la vekt på å skille etikk og bestand; at fangsten var forsvarlig i forhold til bestanden, men at det var 
opp til hver enkelt å vurdere om det var «moralsk forsvarlig». I arbeidet med å bygge bro inviterte de også hvalfangere til hvalsenteret, hvor de fikk møte forskere fra andre land som var sterke motstandere av hvalfangst. Som regel gikk debatten i rolige former.

Det ble laget et lite hvalfangstmuseum i Hvalsenteret for å skape balanse i fortellingene. Hvalfangstmuseet ble seinere lagt ned og gjort om til dansebar. Når vi spør om forholdet mellom hvalturisme og hvalfangst lokalt, blir vi ofte fortalt at en aldri har hatt hvalfangst på Andenes - det har foregått andre steder i kommunen og regionen.

Hvalfangsthistorien gjøres dermed marginal på Andøya. Og gjennom å insistere på en nøytral posisjon i hvalfangstspørsmålet ser det ut til at Hvalsafari AS har manøvrert klar av de sterkeste konfrontasjonene i møte med hvalfangsten. Forskeren som vi intervjuet, i sin tid tilknyttet CSWD og Hvalsafari AS, mener de den gang ikke forsøkte å skape et bilde av «The Whale» (fra Herman Melvilles roman), slik man gjør i et prosjekt i 2020. Like fullt har det å identifisere, og også navngi enkelthvaler vært - og er fremdeles - et viktig anliggende, en aktivitet som sjølsagt inngår i slike diskursive transformasjoner.

\section{Fra attraksjon til destinasjon?}

I tillegg til å undersøke kunnskapsformer og kontroverser i utviklinga av Hvalsafari AS på Andenes som attraksjon, har vi også sett på destinasjonsutviklinga av Andøya. Vi har særlig vært interessert i hvilken rolle hvalsafari har hatt i denne utviklinga. I samtalene snakket mange om skiftet som skjedde for 30 år siden, i hvalsafarienes spede begynnelse. Før dette kom få turister til Andøya, det var i liten grad et turistmål: «Vi husker hvordan det var før; turistene som kom, ble nevnt med navn i lokalavisa. Slik er det ikke nå lenger.» Siden midten av 1990-tallet har Hvalsafari AS årlig mottatt mellom 10000 og 15000 turister, med en topp i 2004, med 16019 besøkende, i 201414 855, i 201513565 besøkende (informasjon fra Hvalsafari AS). Mens destinasjoner som Nordkapp og Lofoten har hatt stor vekst, har det ikke vært noen markant økning i antall besøkende til Hvalsafari AS på Andøya mellom begynnelsen av 1990-tallet og 2015. Utviklinga har heller ikke ført til stor industri rundt hvalturisme, slik vi for eksempel har sett på Victoria Island i Canada. Der ble pionerforetaket innen hvalturisme 
kopiert, og en hel industri knyttet til hvalsafari ble utviklet (Lawrence \& Phillips 2004). Hvalsafari AS var i mange år det eneste hvalsafariselskapet i regionen, og sjøl om flere selskaper som i vintermånedene driver hvalsafari i Tromsø-regionen og Nord-Troms, nå også sikter seg inn mot Andøya, var det i 2018 bare to hvalsafarioperatører lokalt.

Fokuset i oppstartperioden var å etablere hvalsafari som en attraksjon og ikke å utvikle regionen som en destinasjon. De involverte var sterkt opptatt av ideen om å skape en god og robust hvalattraksjon, mens «kontaktene med lokalsamfunnet var svake», innrømmer en av pionerene. Initiativet om å etablere en hvalsafariattraksjon ble også møtt «med en svært moderat interesse» $\mathrm{i}$ det lokale forretningsmiljøet, forteller kommunens næringskonsulent. Men de første åra var kommunen en viktig dialogpartner og støttespiller for Hvalsafari AS. Sammen med fylket var kommunen en hovedaksjonær, og ordføreren var den første styrelederen i selskapet. Når en lokal forretningsmann seinere overtok selskapet og kjøpte de offentlige aksjene, ble forholdet til kommunen svekket. Nåværende eier hevder i et intervju at virksomheten får liten støtte fra kommunale og regionale organer, og mener Hvalsafari AS i liten grad løftes fram som spydspiss i kommunen og regionens destinasjonsutviklingsarbeid. Samtidig mener flere mindre turismeentreprenører vi har snakket med, at Hvalsafari AS $\mathrm{i}$ årene rundt tusenårsskiftet hadde en for sentral posisjon i reiselivsbransjen. I turismesammenheng er Andøy hvalsafari både i offentlighetens og myndighetenes øyne, og flere mener det har vært vanskelig å få støtte til andre tiltak. I arbeidet med å markedsføre Andøy som destinasjon har kommunen forsøkt så selge Andøya som magisk og rundt tusenårsskiftet som nordlyskommunen, The Northern Lights Municipality. Dette er et merkenavn få av turismeentreprenørene på Andøya identifiserte seg med (Førde 2014). Til tross for et stadig mer variert reiselivstilbud er hvalsafari fortsatt den største og mest kjente attraksjonen i Andøy.

Lenge manglet Andøya en veletablert destinasjonsselskap (DMO). Dermed var det ingen som hadde ansvar for destinasjonsutviklinga, og heller ingen som organiserte reiselivsnæringa. Dette er et velkjent problem i destinasjonsutviklingsprosesser (Garnes 2014). Under vårt feltarbeid på Andøya ble spørsmålet om destinasjonsorganisering diskutert i flere fokusgrupper og offentlige møter. Hvalsafari AS har i perioder hatt oppgaven med å drive turistinformasjonen i kommunen. Dette har ført til misnøye blant småskalabedrifter, som følte at én bedrift ble for dominerende i kommunen og turistene i for liten grad distribuert rundt til ulike tilbud i 
Andøy. I 2014 ble Andøy Reiseliv etablert som et samvirkeforetak, et destinasjonsselskap som tar seg av organisering og utvikling. En av de største satsingene de arbeider med, er etableringen av The Whale, et hvalsenter «i verdensklasse», som har som ambisjon å gjøre Andøy til en internasjonalt ledende destinasjon for hvalturisme, men også å bidra til lokal stedsutvikling og destinasjonsutvikling i regionen og landsdelen.

Vi har i dette kapitlet diskutert hvordan ulike typer kunnskaper, ferdigheter og relasjoner har vært sentrale i utviklinga av hvalsafari. Når det gjelder destinasjonsutvikling, er det vanskeligere å identifisere viktige kunnskapselementer og nettverksrelasjoner. Hvalsafari AS har vært den viktigste bedriften og en forløper og et symbol på turisme som en mulighet. En aktør fra det lokale kulturlivet snakker om det han kaller de mange «usynlige ringvirkningene» av hvalsafariaktiviteten. Han mener at mye på Andøya på mange måter har vært påvirket av det som skjedde i hvalsafariens oppstartstid, og refererer til øyas aktive kulturliv, de mange kjente artistene som kommer fra øya, og opprettelsen av nye institusjoner både innen turisme og i kulturfeltet. «Disse tingene handler ikke om hval, men om sjenerøsitet», sier han, og påpeker at arbeidsmetoder og pågangsmot, kunnskap, erfaringer og nettvert som ble utviklet i denne perioden, har generert mange nye prosjekter.

\section{Avslutning}

I dette kapitlet har vi analysert utviklinga av hvalturisme på Andøya, sett som dynamiske og relasjonelle prosesser. Med et relasjonelt perspektiv på entreprenørskap har vi lagt vekt på hvordan attraksjonen Hvalsafari AS har utviklet seg gjennom komplekse nettverksrelasjoner, med involvering av og forhandlinger om - ulike typer kunnskaper. Initiativet til hvalturisme på Andenes kom fra folk utenfra, fra idealister, forskere og studenter som alle delte et engasjement for hval. I tillegg til kunnskap om hval og marint liv inkluderte gruppen også personer med kunstnerisk kompetanse og ferdigheter. Etter hvert som turismeaktiviteten ble større, ble selskapet overtatt av en lokal investor med kompetanse innen forretningsdrift. Over tid har dette resultert i en endret profil. Ulike typer kunnskaper har dermed både supplert og utfordret hverandre. Hvalturisme er også forankret i makro- 
kulturelle diskurser som dreier seg om hvalens eksistens og utryddelse som art, hvalen sett som en ressurs som må reguleres, og om de etiske aspektene både ved hvalfangst og hvalsafari (Lawrence \& Phillips 2004; Kramvig et al. 2016). Hvalsafari AS på Andenes fokuserte på hvaler som dyr og objekter for forskning, og ikke så mye på ressursaspektet, dyrevelferd eller hvalfangstpolitikk. Men over tid har de merkantile sidene av hvalsafari fått en sterkere posisjon. Med bevegelsen mot et mer kommersielt produkt og en mer solid økonomisk base er en del av "poesien blitt borte», slik en av pionerene uttrykte det. Dette er et velkjent utviklingsmønster; over tid må ikke-økonomiske verdier vike plass for sterkere fokus på avkastning og kontroll, også i bedrifter som viser fram dyreliv (Duffus \& Deaden 1990). Det handler også om motsetninger knyttet til kreativitet, ledelse og kontroll i kreative næringer. Eikhof og Haunschild (2006) diskuterer det de kaller den bohemske livsstilen blant kunstnere, hvor økonomiske verdier bevisst ignoreres. I vårt tilfelle karakteriserer pionerene $\mathrm{i}$ hvalsafarivirksomheten seg som «et hippiekollektiv», som hadde sterkere fokus på kreative arbeidsprosesser enn på økonomi. Et viktig aspekt ved slike kreative prosesser er å produsere fantasifulle horisonter - som krever improvisasjon og fleksibilitet (Førde \& Kramvig 2017). Vi har også identifisert dette som et spørsmål om kunnskapsutvikling, hvor ulike kunnskapsformer, fra vitenskap, kunst, økonomi og lokal utvikling, forenes, forhandles og noen ganger leder til konfrontasjoner. Andre studier fra dette feltet har hevdet at balansering av ikke-økonomisk og økonomisk kunnskap er avgjørende i turismeutvikling (Ateljevic \& Doorne 2000; Walker \& Brown 2004; DeFillippi, Grabher \& Jones 2007). Vår studie illustrerer kompleksiteten av slike kunnskapsprosesser. Gjennom forhandlingsprosesser har forretningsmotiver vært balansert mot kunnskapsproduksjon og formidling knyttet til hval, som fortsatt er et sentralt element for hvalsafarien.

Vår analyse fra Andøya illustrerer hvordan prosessen med å utvikle hvalsafari som en attraksjon ble drevet av et samspill mellom ulike typer kunnskaper. En blanding av idealisme og forskning gjorde det mulig å realisere hvalen som et opplevelsesprodukt. Kunnskapsformidling har vært en bærebjelke i utviklinga av hvalsafari som virksomhet. Vi ser også at god attraksjonsutvikling ikke nødvendigvis fører til sterk destinasjonsutvikling. Dette er et paradoks i reiselivsutviklinga; man kan ha en god attraksjon, men slite med å utvikle destinasjonen. Mens attraksjonsutvikling forankres i møter mellom ulike fagområder, inkludert både faglig kompetanse 
og praktiske ferdigheter, er den kunnskapen som trengs i en destinasjonsutviklingsprosess, vanskeligere å identifisere. Dette er et mer politisk felt som krever andre typer organisering, praktisk erfaring og institusjonell forankring. I destinasjonsutvikling er det framfor noe et behov for samarbeid mellom flere og svært ulike aktører med ulike kunnskapsbaser (Mariani et al. 2014). Mens den første fasen av utviklinga av hvalsturismen var preget av idealisme og dynamiske kunnskapssamfunn knyttet til marinbiologi og kunst, med fokus på de kreative prosessene, ble det i implementeringsfasen brukt mer konvensjonelle modeller for næringsutvikling. Utfordringen for videre utvikling av både attraksjon og destinasjon er å finne måter å kombinere disse kunnskapsformene på. Å utvikle økonomisk bærekraftige attraksjoner med god lokal forankring, samtidig som en sikrer nødvendige vilkår for idealismen, de kreative og kunstneriske aspektene slike opplevelsesprodukter krever - at poesien og evnen til å produsere fantasifulle horisonter hvor møter med hvalen kan fortsette å engasjere, ikke forsvinner.

\section{Litteratur}

Ateljevic, I. \& Doorne, S. (2000). 'Staying within the fence': lifestyle entrepreneurship in tourism. Journal of Sustainable Tourism, 8 (5), 378-392. https://doi.org/10.1080/09669580008667374

Burns, P. \& Novelli, M. (2006). Tourism and social identities: Introduction. I P. Burns \& M. Novelli (red.), Tourism and social identities. Global frameworks and local realities (s. 1-12). Oxford: Elsevier. https://doi.org/10.1016/B9780-08-045074-2.50004-7

Bærenholdt, J. O., Haldrup, M., Larsen, J. \& Urry, J. (2004). Performing tourist places. Aldershot: Ashgate.

DeFillippi, R., Grabher, G. \& Jones, J.C. (2007). Introduction to paradoxes of creativity: managerial and organizational challenges in the cultural economy. Journal of Organizational Behavior, 28 (5), 511-521. https://doi.org/10.1002/job.466

Duffus, D. A. \& Dearden, P. (1990). Non-consumptive wildlife-oriented recreation: a conceptual framework. Biological Conservation, 53, 213-231. https://doi.org/10.1016/0006-3207(90)90087-6

Eikhof, D. R. \& Haunschild, A. (2006). Lifestyle meets market: Bohemian entrepreneurs in creative Industries. Creativity and Innovation Management, 15 (3), 234-241. https://doi.org/10.1111/j.1467-8691.2006.00392.x 
Flognfeldt, T. (2007). Developing tourism products in the shadow of primary attractions. Tourism, Culture \& Communication, 7, 133-135. https://doi.org/10.3727/109830407780339026

Flyvbjerg, B. (2004). Phronetic planning research: theoretical and methodological reflections. Planning Theory \& Practice, 5, 283-306. https://doi.org/10.1080/1464935042000250195

Flyvbjerg, B., Landman, T. \& Schram (red.) (2012). Real Social Science: Applied Phronesis, Cambridge, UK: Cambridge University Press. https://doi.org/10.1017/CBO9780511719912

Frost, W. (2011). Zoos and Tourism in a Changing World. I W. Frost (red.), Zoos and tourism: conservation, education, entertainment? (s. 227-235). Bristol: Channel View. https://doi.org/10.21832/9781845411657-025

Førde, A. (2009). Creating the land of the big fish. A study of rural tourism innovation. I T. Nyseth \& A. Viken (red.), Place reinvention. Northern perspectives (s. 93-110). Aldershot: Ashgate. https://doi. org/10.4324/9781315600574-6

Førde, A. (2014). Integrated tourism development? When places of the ordinary are transformed to destinations. I A. Viken \& B. Granås (red.), Tourism Destination Development. Turns and tactics (s. 153-170). Farnham: Asghate.

Førde, A. \& Kramvig, B. (2017). Cultural industries as a base for local development; the challenges of planning for the un-known. I A. Hamdouch, T. Nyseth, C. Demaziere, A. Førde, J. Serrano \& N. Aarsæther (red.), Creative Approaches to Planning and Local Development in Small \& Medium Sized Town (s. 81-96). Farnham: Ashgate.

Garnes, S. (2014). Tourist organizations and the power of the public sector: A corporate governance perspective. Scandinavian Journal of Public Administration, 18, 41-62.

Gunn, C. (1993). Tourism planning: basics, concepts and cases. Washington: Francis and Taylor.

Hall, C. M. \& Williams, A. (2000). Tourism and innovation. Oxon: Routledge. Hoyt, E. \& Hvenegaard, G. T. (2002). A review of whale watching and whaling with applications for the Caribbean. Coastal Management, 30, 381-399. https://doi.org/10.1080/089207502900273

Huyssen, A. (2003). Present pasts: Urban palimpsests and the politics of memory. Stanford: Stanford University Press.

Ingold, T. \& Hallam, E. (2007). Creativity and cultural improvisation: An introduction. I E. Hallam \& T. Ingold (red.), Creativity and Cultural Improvisation. Oxford: Berg. 
Johannesson, G. T. (2012). «To get things done»: A relational approach to entrepreneurship. Scandinavian Journal of Hospitality and Tourism, 12, 181-196. https://doi.org/10.1080/15022250.2012.695463

Kalland, A. (1992). Whose whale is that? Diverting the Commodity Path. Nordic Institute of Asian Studies. København: Copenhagen Publishers.

Kramvig, B., Kristoffersen, B. \& Førde, A. (2016). Responsible cohabitation in Arctic waters: The promise of a spectacle tourist whale. I S. Abram \& K. A. Lund (red.), Green Ice. London: Macmillian Publishers. https://doi.org/10.1057/978-1-137-58736-7_2

Law, J. (2004). After method; Mess in social science research. London: Routledge. https://doi.org/10.4324/9780203481141

Lawrence, T. B. \& Phillips, N. (2004). From Moby Dick to Free Willy:

Macro-cultural discourse and institutional entrepreneurship in emerging institutional fields. Organization, 11 (5), 689-711.

https://doi.org/10.1177/1350508404046457

MacLeod, D. (2011). Introduction. I D. MacLeod \& S. Gillespie (red.), Sustainable tourism in rural Europe. Approaches to development. London: Routledge. https://doi.org/10.4324/9780203844212

Mariani, M., Buhalis, D., Longhi, C. \& Vitouladiti, O. (2014).

Managing change in tourism destinations: Key issues and current trends. Journal of Destination Marketing \& Management, 2, 269-272. https://doi.org/10.1016/j.jdmm.2013.11.003

Nonaka, I. \& Toyama, R. (2007). Strategic management as distributed practical wisdom (phronesis). Industrial and Corporate Change, 16, 371-394. https://doi.org/10.1093/icc/dtm014

Ringer, G. (red.) (1998). Destinations: cultural landscapes of tourism. London: Routledge.

Ris, M. (1993). Conflicting cultural values: Whale tourism in Northern Norway. Arctic, 46, 156-163. https://doi.org/10.14430/arctic1337

Rotefoss, R. \& Kolvereid, L. (2005). Aspiring, nascent and fledging entrepreneurs; and investigation of the business start-up process. Entrepreneurship \& Regional Development, 17, 109-127. https://doi.org/10.1080/08985620500074049

Saarinen, J. \& Kask, T. (2008). Transforming tourism spaces in changing socio-political contexts: The case of Pärnu, Estonia, as a tourist destination. Tourism Geographies, 10, 452-473. https://doi.org/10.1080/14616680802434072 
Saraniemi, S. \& Kylänen, M. (2011). Problematizing the concept of tourist destinations. Tourist Studies, 4 (2), 161-179.

Shane, S. (2000). Prior knowledge and the discovery of entrepreneurial opportunities. Organization Science, 11, 448-469. https://doi.org/10.1287/ orsc.11.4.448.14602

Smed, K. M. (2016). Culture in nature - exploring the role of 'culture' in the destination of Ilulissat, Greenland. I A. Viken \& D. Müller (red.), Tourism and indigeneity. Diversifying or othering the Arctic? London: Channel View Publications. https://doi.org/10.21832/9781845416102-011

Tribe, J. (2005). New Tourism Research. Tourism Recreation Research, 30, 5-8. https://doi.org/10.1080/02508281.2005.11081468

Van der Duim, R., Ren, C. \& Johannesson, G. T. (2012). Tourismscapes, entrepreneurs and sustainability; enacting ANT in tourism studies. I R. van der Duim, C. Ren \& G. T. Johannesson (red.), Actor-Network Theory and tourism. Ordering, materiality and multiplicity. London: Routledge. https://doi.org/10.4324/9780203122976

Viken, A. (2013). Fokusgruppesamtaler. I A. Førde, B. Kramvig, N.G. Berg \& B. Dale (red.), Å forske på sted (s. 205-220). Trondheim: Akademisk forlag. Viken, A. (2014). Ski resort development; scripts and phronesis. I A. Viken \& B. Granås (red.), Destination Development in Tourism: Turns and Tactics. Farnham: Ashgate.

Viken, A. \& Granås, B. (red.) (2014). Destination Development in Tourism: Turns and Tactics. Farnham: Ashgate.

Viken, A. \& Aarsæther, N. (2013). North Cape: Transforming an iconic attraction into a diversified destination. Scandinavian Journal of Hospitality and Tourism, 13, 38-54. https://doi.org/10.1080/15022250.2013.771994

Venkatarman, S. (1997). The distinctive domain of entrepreneurship re-search: an editor's perspective. I J. Katz \& R. Brockhaus (red.), Advances in Entrepreneurship, firm emergence, and growth (s. 119-138). Greenwich, CT: JAI Press.

Walker, E. \& Brown, A. (2004). What success factors are important to small business owners? International Small Business Journal, 22, 577-594. https://doi.org/10.1177/0266242604047411

Weidenfeld, A., Williams, A. M. \& Butler, R. W. (2010). Knowledge transfer and innovation among attractions. Annals of Tourism Research, 37(3), 604-626. https://doi.org/10.1016/j.annals.2009.12.001 



\section{NORDKAPP - ANNEKTERT AV TURISMEN $^{3}$}

Arvid Viken

\section{Innledning}

Nordkapp er Norges og Europas nordligste reisemål med fastlandsforbindelse. Stedet ligger på Magerøya, som har veiforbindelse i land, men den kom først i 1996. Nordkapp er både en destinasjon og en attraksjon. Hva som er attraksjonen her, er det delte meninger om, om det er klippen som sådan, eller Nordkapphallen, som rommer både friområder, kafeer, toaletter, butikker og opplevelseselementer, eller om det faktisk er selve beliggenheten på planeten og kartet? Et pragmatisk svar er at det er alt dette til sammen som er attraktivt. Det er også et sted som er skapt av turismen, drevet og forvaltet av reiselivsaktører. For folk på Magerøya er det en arbeidsplass, men også i så måte er det først og fremst et sted for tilreisende - de fleste ansatte er ikke fra bygda. I dette kapitlet beskriver vi noen av utviklings- og karaktertrekkene til stedet.

Fra gammelt av har Nordkapp åpenbart vært et reinbeite og et rundingspunkt og landemerke for sjøfarende. Siden 1500-tallet, da britiske Richard Chancellor satte Nordkapp på kartet og navnga det, i 1553, har det vært et internasjonalt reisemål. Italieneren Francesco Negri (1663)

Kapitlet er skrevet i 2018-2019. Regimet for Nordkapplatået var da under sterk debatt og det foregikk forhandlinger. Ved kommunevalget i 2019 vant kritikerne av regimet, og i 2020 pågår forhandlinger om hvordan stedet skal forvaltes i åra som kommer. Casen, som altså beskriver utviklinga fram til nå, er fortsatt en god illustrasjon på fjerneie og fjernstyring innen turismen i Norge. 
laget den første kjente reiseskildringen fra stedet, og siden har det blitt ganske mange beretninger. Stedets nordlighet kan ikke bestrides, og det er ikke det nordligste punktet verken på Magerøya eller på Fastlands-Norge. Knivskjellodden noen kilometer lenger vest er lenger nord, og noen mil lenger øst befinner Kinnarodden seg, som det nordligste fastlandspunktet. Dessuten er det mange øyer som er lenger nord i verden. Offentligheten har altså bestemt at dette er den nordlige endestasjonen, og et egnet sted å feire nordligheten på. Dette forholder turistverdenen seg til, og mer enn 250000 mennesker besøker stedet årlig. Lokalt er det et større næringsfokus på fiske og i 2018 på mulighetene for å bli en oljebase (som ikke ser ut til å bli noe av), enn på det faktum at kommunen rommer et internasjonalt ikonisk turiststed. Lokalbefolkningen lever sine liv slik alle andre gjør det i Norge, med arbeid, familier og fritidsaktiviteter, hvor nordligheten er et romlig og klimatisk hverdagselement. Paradoksalt nok er Nordkapplatået perifert i lokalbefolkningens hverdagsliv, og det turistattraksjonen skaper, er bare en av flere inntektskilder for kommunen. Men folk er likevel opptatt av hva som skjer der, og hvordan stedet forvaltes.

I dette kapitlet skal vi altså underkaste Nordkapp en analyse, med fokus på fjerneierskap, fjernstyring og eksklusjon av lokale interessenter fra inntektsgivende virksomhet, som et hovedfokus. Vi skal se på prosessen hvorigjennom stedet har blitt konstruert som sådant, som sted og som reisemål, av aktører utenfra, og prøve å angi hvordan denne utenfrahåndteringen har preget og preger den turistattraksjonen vi her har fokus på. Mot slutten ses forvaltningen av stedet i lys av moderne prinsipper for hvordan industri og reiselivsbedrifter basert på naturressurser forventes å forholde seg til og involvere omkringliggende lokalsamfunn.

\section{Et teoretisk bakteppe: imperialisme}

Mye av turismen i Norge, slik den på Nordkapp, er råvarebasert produksjon, eller som det også benevnes; industri basert på naturressurser. Råvaren er natur, produksjonen består av tilrettelegging av attraksjoner og aktiviteter, overnatting og bespisning. I andre sammenhenger kalles dette ekstraktiv industri. Som regel krever slik industri tilgang til kapital som langt overskrider det man har til rådighet lokalt. Derfor er det gjerne eksterne investorer - fra kapitalens sentra - som realiserer slik industri, 

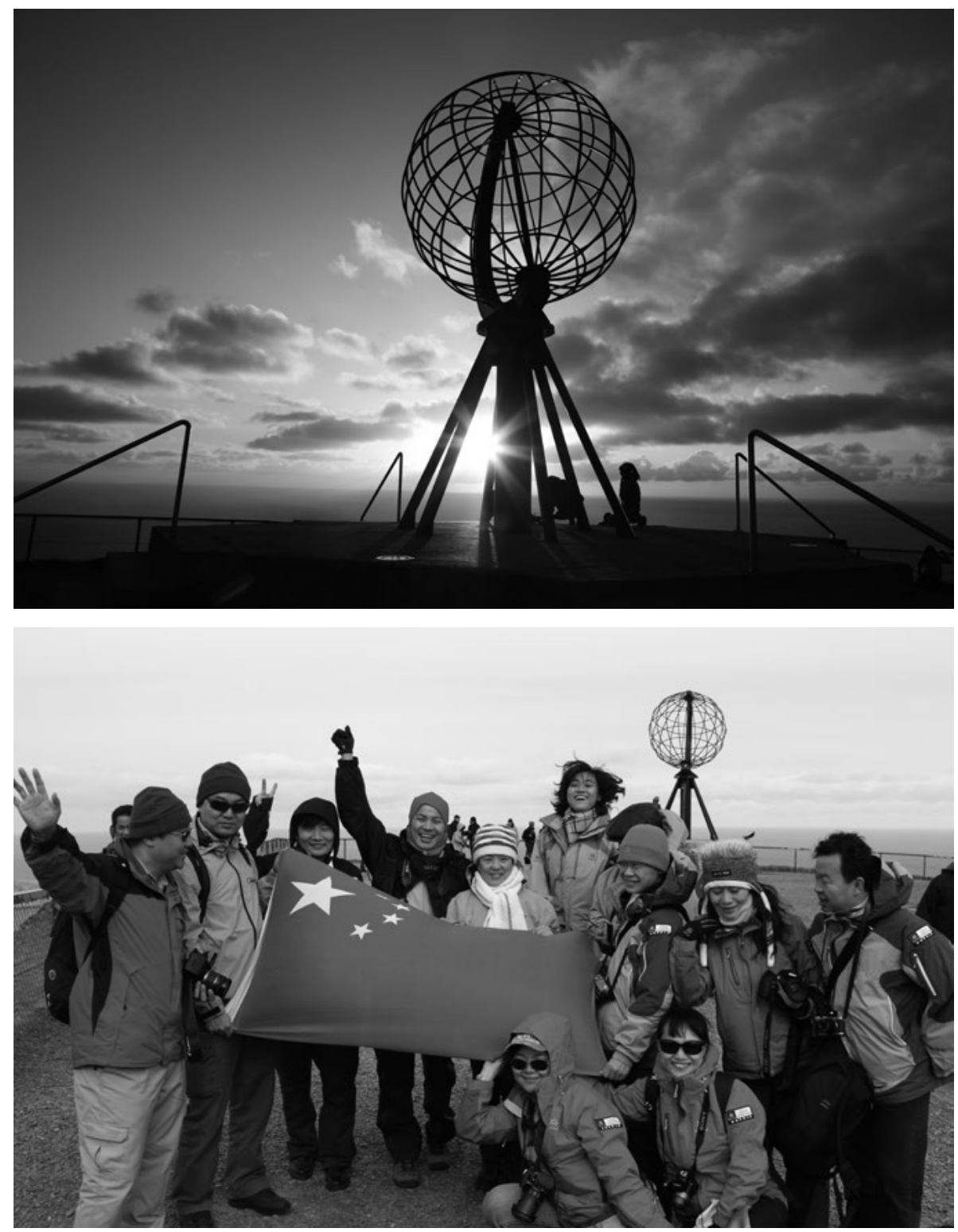

Nordkapp: hvem skal ha verdiene som skapes? Foto: Ole Magnus Rapp.

som regel understøttet av myndighetene (Freitag 2006). Det er ikke uvanlig at produsentene skaffer seg enerett til ressursene på stedet. Slik enerett gitt til eksterne industriutviklere betyr eksklusjon av andre aktører - også 
de lokale. Dermed får produksjonen en kolonial struktur, hvor aktører fra finanssentrene gjør seg rike på å utnytte råvarer i periferien (Britton 1982), mens lokale aktører holdes utenfor. Dette er det enkle teoretiske bakteppet for det som har utviklet seg på Nordkapp. Om det finnes eller fantes noe alternativ, er et åpent spørsmål. Det kunne kanskje ikke ha skjedd på annet vis fordi turisme i sin tidlige periode aldri var tilbudsdrevet, men basert på reisende og aktører i markedet som satte nye reisemål på kartet, også steder uten produksjons- og infrastruktur. Disse strukturene måtte dermed etableres, og det ble ofte gjort av dem som besørget organisering av reisene og befordringen av de reisende. Men sjøl om utviklinga kan forklares, legitimerer det ikke at næringa hadde en kolonial struktur fram til 2019. I dag framstår slike eksterne operasjoner som eksempler på konsentrasjonstendensene i markedsøkonomien, og slik noen ser det, som anakronismer. Modellen har gått ut på dato.

Johan Galtung kalte i sin tid slik relasjoner for imperialisme (Galtung 1971). Begrepet «imperialisme» kan tilbakeføres til Lenin og Marx, men har også vært anvendt for å karakterisere våre dagers forhold mellom den rike og den fattige verden (Galtung 1971), hvor den rike verden øker sin rikdom på bekostning av den fattige verden. Sjøl om dette først og fremst er en teori anvendt på utviklingsland, har modellen også anvendelse på forholdet mellom nasjonale sentra og periferi, hvor poenget er at sentrum $ø$ ker sin rikdom gjennom å utnytte verdier i periferien. Turismen har sjølsagt vært kritisert for å ha en slik karakter (Britton 1982). Sinclair-Maragh og Gursoy (2015) skiller i forbindelse med turisme mellom økonomisk, politisk og kulturell imperialisme. Den økonomiske siden av imperialismen består i at sentrumsplasserte investorer deltar i finansieringen av prosjekter i periferien. Som regel betyr det også sentralisering av leveranser og kompetanse, handelslekkasje og økt bruk av ekstern arbeidskraft. Det politiske elementet består gjerne i myndigheter som inviterer til og tilrettelegger for investorer utenfra, det være seg internasjonal eller nasjonal kapital, fordi de ser muligheter i turismen, men mangler kapital. I slik sammenheng er det også tendenser til at myndighetene på ulike vis beskytter slike investeringer. Et av resultatene er marginalisering av lokale aktører (ibid.; Hall \& Tucker 2015). Kulturell imperialisme er et iboende karaktertrekk ved turismen som sådan. Turismen er påtrengende i sitt vesen, den bringer med seg verdier og atferdsmønstre som kan avvike fra dem som råder i vertssamfunnet, og føre til endringer i disse. Turismen virker både 
moderniserende, globaliserende og kommersialiserende på lokale kulturer. I denne presentasjonen vil de kulturelle påvirkningene av turismen ikke bli belyst.

Det finnes måter å organisere turismen på som maksimerer fortjenesten for investorene, og som forsterker preget av imperialisme. Det som gir mest inntjening for investorene, er når turistene bruker alle pengene på de anleggene de har investert i. Derfor har man utviklet modeller for hvor dette kan skje, for eksempel gjennom etablering av såkalte resorter. Disse fungerer i sine ekstremutgaver som lukkede systemer, enklaver, hvor de aller fleste aktivitetene foregår (Kohtari 2015). Som regel dreier det seg om velorganiserte, luksuriøse resorter, hvor kundene blir tilbudt alle de tjenestene de trenger for et behagelig opphold, og i tillegg gjerne sikkerhet og velsmurt logistikk. Modellen gjør også at operasjonen kan drives forretningsmessig i alle ledd, ut fra helhetlige strategier og konsepter. Som regel fungerer slike resorter også som enklaver i romlig forstand, de er lukket for omverdenen. Altså er det en modell som på en rekke måter markerer avstand og forskjeller mellom turistene og lokalbefolkningen. Som det er blitt påpekt, er dette en sosial organisering som minner om den man hadde i mange kolonier (ibid.). Men det finnes mellomvarianter, der avsondringen fra lokalsamfunnet er mindre bastant. Nordkapp har islett av enklavemodellen, gjennom at turistene er håndtert av turoperatører som bringer dem dit, og til hotellene, og hvor andre aktører i liten grad slipper til med sine tilbud. Men det finnes også turisme på øya som ikke skjer innenfor enklaven, for eksempel fisketurisme (Viken \& Aarsaether 2013).

\section{Hva slags sted er Nordkapp?}

Geografisk er Nordkapp et av de nordligste punktene på det europeiske kontinentet - vel 71 grader nord. Det er også endepunktet for mange turister i Norge. Det innebærer at nordkapptrafikken - det dreier seg om cirka 300000 turister - er viktig for reiselivsnæringa i store deler av landet. Turistene er også turister underveis, de overnatter, spiser og oppsøker attraksjoner og opplevelsesbedrifter langs reiseruta. Men for mange er Nordkapp det ultimate målet. Nordkapp er altså både en destinasjon og en attraksjon. 
Turiststeder kan karakteriseres med fysiske attributter (denotasjoner) eller gjennom de konnotasjonene de gir, sier Berger (2013), i sin gjennomgang av ikoniske destinasjoner. Topografisk er Nordkapp en klippe som strekker seg loddrett 307 meter opp fra havet. Beliggenheten gjør at stedet har midnattssol om sommeren og mørketid om vinteren, men 60-70 prosent av tida er platået dekket av tåke eller skyer. Stedet er langt fra sentrum, men langt fra isolert. Det er vevd inn i ulike slags nettverk, både av romlig, diskursiv og turistisk karakter. Denne involveringen, men også andre karakteristikker av steder, kan best betraktes som sosiale konstruksjoner. En av de sosiale konstruksjonene er at det er nordligst, sjøl om mange steder befinner seg lenger nord. Beskrivelsene av stedet preges gjerne av ståstedet til beskriveren. For Francesco Negri var Nordkapp så langt som han anså det mulig å komme; der «hvor verden ender, ender også min nysgjerrighet og jeg vender tilfreds hjem», skrev han til og med (sitert av Favero 2000, s. 4). I nyere tid har turistoperatører klagd over at når turistene har vært på Nordkapp, har de bare en ting i tankene, å komme seg fortest mulig hjem. Nordkapp er altså et sentralt referansepunkt i den norsk turismen. Jacobsen (2016) har gått gjennom en del moderne reisehåndbøker og konkluderer med at mange steder i Norge, og særlig i Nord-Norge, omtales som steder på reisen mot Nordkapp. Han refererer også til at noen av bøkene er kritiske til Nordkapp - det er et kommersielt sted - og anbefaler turistene å gjøre avstikkere fra hovedveien, og oppleve ro og ensomhet i kontrast til hva som venter dem på Nordkapp.

Når det gjelder konnotasjonene som Nordkapp gir, er lista svært lang. Stedet har en rekke symbolske betydninger. Det er verdens eller Europas ende, en symbolikk som er understreket av klippens form, den stuper rett ned i havet. Favero (2000) kommenterer området som et månelandskap, som et liminalt sted langt fra hverdagens plikter og bekymringer, som en sivilisasjonens utkant, som et spirituelt og hellig sted, et sted med en sublim skjønnhet, hvor en kan få en «tilbake-til-naturen»-opplevelse. Favero (2000) og Birkeland (2006) skriver om hvordan termen «nord» har en spesiell betydning i henholdsvis Italia og Spania. I Italia er konnotasjonene «bedre», «mer utviklet», «annerledes», mens i Spania brukes uttrykket «har du mistet ditt nord?» i betydningen «har du gått fra vettet?». Nord har altså også en metaforisk betydning i disse landene. I Norge har det snarere vært en merkelapp som folk har forbundet med det ukjente, periferi og problemer. De som har stått for slike beskrivelser av Nordkapp, kommer 
utenfra, som handelsreisende eller utforskere for flere hundre år siden, eller «turister» som kom nordover i kjølvannet av utforskningen av de arktiske områdene på 1800-tallet, og deres reiseberetninger, eller medieomtaler av besøkende konger og andre selebriteter i samme periode. Siden 1800-tallet har malere, fotografer, forfattere, reiselivsaktører og ymse medier på ulike vis bidratt til markedsføringen av Nordkapp. I tråd med dette vil mange også hevde at Nordkapp ikke er et lokalt sted.

\section{Et tilbakeblikk på den turistiske annekteringen av Nordkapp}

Cruiseturismen i Norge vokste fram på siste halvdel av 1800-tallet. Nordkapp ble fort ett av målene og ilandstigningspunktene. Turistene gikk i land i Hornvika nær ved og klatret opp til platået, for de fleste en strabasiøs bestigning. På 1920-tallet gikk hurtigruteselskapene i bresjen for etableringen av et selskap, Nordkaps Vel, som skulle stå for utvikling av nødvendig tilrettelegging for de besøkende. I den forbindelse krevde etablererne å få kontroll over arealene mellom Hornvika og klippekanten. Alt på slutten av 1920-tallet framsto dette som en provokasjon for nordkappsamfunnet, som protesterte høylytt, men ble avvist (Holmgreen \& Richter-Hansen 2016). Kommunestyret var satt på sidelinjen, og har stort sett vært det siden, slik det beskrives av Holmgreen og Richter-Hansen (ibid.). Dette skapte misnøye, sies det, og var en av grunnene til at Honningsvåg og Omegn Turistforening ble etablert i 1927. Sammen med kommunen arbeidet denne organisasjonen for etablering av vei til platået, en vei som sto ferdig i 1956, finansiert gjennom kommunal forskuttering og bompenger. Det første bygget på platået var det man kalte Champagne-paviljongen, fra 1890-tallet. Den første Nordkapphallen sto ferdig i 1959, med Nordkaps Vel som eier av fasilitetene og leier av grunnen, og med statseide Nordnorsk Hotelldrift som driver. Kommunen ble fortsatt holdt på avstand, og vant ikke fram da den ville endre konsesjonsbetingelsene i 1958. Dermed ble leieforholdet forlenget i 30 år til, og atter en gang i 1988. Derfor ble det i 2017 startet forhandlinger om hva som skal gjelde de neste 30 åra. Mens det før var Finnmarks Jordsalsstyre som var motpart, er det i 2018 det halvoffentlige selskapet Finnmarkseiendommen (Fefo) som står som grunneier og forhandlingspart. Kommunen prøvde ved flere anledninger 
å forbedre sin posisjon, blant annet i 1974, da Nordkaps Vel innførte en inngangsbillett, og i 1981 da staten solgte sine eierinteresser i Nordnorsk Hotelldrift. Kommunen ville overta, men ble ikke hørt, og SAS fikk kjøpe hotellene (ibid.).

1980-tallet var et vendepunkt for turismen på Nordkapp. Finnmarkshotellene var nå blitt til SAS-hoteller, og selskapet så muligheter for en helt annen turisme på Nordkapp. Trafikken hadde økt, men man antok at ved å etablere en ny attraksjon der, i første rekke en forbedring av fasilitetene, ville trafikken kunne økes ytterligere. Det var særlig hotelldirektør Rolf Holmen i Honningsvåg som hadde dette blikket. Han rykket opp som sjef for alle SAS-hotellene i Finnmark og satte i gang et prosjekt som ble kalt «Nordkapp 1990». Det innebar etableringen av en stor hall, toaletter, en stor butikk, flere serveringssteder og opplevelsespunkter, med en film som viser ulike årstider på stedet, og et eukumenisk kapell som de viktigste. Utbyggingen representerte en voldsom forbedring for alle besøkende, med innearealer og døgnåpne toalettfasiliteter. Det siste var viktig, da mange lenge hadde valgt å stå parkert på stedet over natten, noe driftsselskapet hadde tillatt, uten at det var tilrettelagt for det med toaletter eller annet. Prosjektet var budsjettert til 65 millioner kroner, men regningen kom på langt over 100 millioner. Overskridelsen gjorde at hovedeieren av Nordkaps Vel, Kosmos, som hadde overtatt hurtigruteselskapenes eierandeler, ville selge seg ut. Kommunen var interessert i å overta, men klarte ikke å komme fram til en finansieringsmodell. Det antydes at kommunen hadde liten støtte i Finnmark fylke - som på den tida var et såkalt frifylke. Det var relativt tette bånd mellom fylkeskommunen og SAS, som fikk tilslaget på aksjeposten. Det hører også med at statens mann i fylket, fylkesmann Anders Aune, satt i styret for Nordkaps Vel, samtidig som han var den som skulle godkjenne eventuelle kommunale disposisjoner. Staten og fylket sto åpenbart i ledtog med kapitalinteressene og holdt den lille kommunen utenfor.

Nordkapp har etter 1990 blitt en pengemaskin. Den gang ble inngangspengene satt til 90 kroner per person, men har siden økt jevnt og trutt (Lindkvist 2017), og var i 2020 på 290 kroner per person. Nordkaps Vel gjorde relativt store investeringer i 1998, men seinere har det bare skjedd mindre justeringer i anlegget. Inntektene, som har steget, legitimeres som tilbakebetaling av lån, avskriving og avkastningskrav. Det antydes at det 
dreier seg om 400-500 millioner kroner over en 20-årsperiode (ibid.). Dette har blitt omtalt som ran og tyveri, og profittørene som umoralske. Det er i alle fall snakk om utbytting.

Rettsgrunnlaget for inngangsavgiften er omstridt. På 1970-tallet prøvde kommunen å få forståelse for at en inngangsavgift måtte hjemles i friluftslovens $₫ 14$, som gir kommunene adgang til å innføre avgifter for tilrettelegging av naturområder, med de begrensningene loven setter. Kommunen ble ikke hørt i saken. Miljøverndepartementet har behandlet avgiften på Nordkapp flere ganger, men har aldri sagt klart ifra om hva de anser som gjeldende regler. Først i 2014, etter påtrykk fra friluftslivsorganisasjonene, ble Nordkaps Vel bedt om vise fram et løyve fra kommunen. Dette ble gitt, men ordlyden er slik at kommunen kan trekke det tilbake dersom avgiften anses å bryte med gjeldende lover og regler. Det har altså vært bevegelser i saken, og på slutten av 2019 ble dagens regime underkjent av fylkesmannen.

Nordkapps eiere og drivere har altså navigert slik at kommunen og det lokale næringslivet har vært holdt utenfor, både med hensyn til eierskap, styring og forretning. Inntektene man har hatt de siste 20 åra, har ikke gått til reinvesteringer. Nordkappturismen framstår derfor som stabil, men servil, og bidrar i liten grad til en dynamisk utvikling av vertskommunen. Likevel har det skjedd endringer i turismen på Magerøya. Reiselivet er blitt mer mangfoldig, med flere aktører som lever av nordkapptrafikken, en gryende opplevelsesnæring og en voksende fisketurismenæring. Dette er blitt omtalt som en diversifisering (Viken \& Aarsæther 2013). Den lokale nytten av fisketurismen er imidlertid begrenset, da også den mer og mer er overtatt av eksterne eiere som ikke deltar eller bruker pengene de tjener i lokalsamfunnet (Holmgren \& Lindkvist 2017).

Eierskapet til Nordkapphallen og området rundt har skiftet i tråd skiftene i kjedetilknytning og disse selskapenes forretningsstrategier. Hele tida har Nordkaps Vel stått som den formelle eieren, slik at det er dette selskapets aksjer som har skiftet hender, og det har skjedd relativt ofte. Selskapet ble altså etablert i 1928 av de tre hurtigruteselskapene, Ofoten og Vesterålens Dampskibsselskap, Nordenfjeldske Dampskibsselskap, Det Bergenske Dampskibsselskap, og reisebyråene Thomas Cook, Berg-Hansen og Bennett. Hurtigruteselskapene var fortsatt eiere på 1980-tallet, men solgte da aksjene sine til SAS-selskapet North Cape Hotels, som hadde overtatt 
Nord-Norsk Hotelldrift i 1980. Utbyggingen på 1980-tallet skjedde i regi av et eget selskap, ANS Nordkapp 1990. Nordkaps Vel hadde garantert for budsjettoverskridelser. Det ble det, blant annet fordi grunnarbeidene ble vesentlig dyrere enn budsjettert, og Nordkaps Vel solgte Nordkapphallen til ANS Nordkapp 1990 som del av redningsaksjonen. Da Kosmos litt seinere trakk seg ut, overtok SAS North Cape Hotels eieransvaret for Nordkapp (i 1988). I 1994 ble SAS North Cape Hotels solgt til en ny eiergruppe anført av Rolf Holmen, som hadde stått for moderniseringa noen år tidligere. Dette eierskapet ble kortvarig og i 1997 overført til hotellkjeden Rica, som dermed også ble driver av Nordkapplatået. I 2018 er Rica Eiendom Holding fortsatt eier av Nordkaps Vel og dermed også av Nordkapphallen. Rica solgte imidlertid hotelldriftsselskapet sitt til hotellkjeden Scandic i 2014. For første gang er også driften satt bort til et selskap som ikke er norsk.

Da Nordkapphallen ble ombygd på slutten av 1980-tallet, var det en av de første gangene en «ren» turistattraksjon ble anlagt i Norge. Man reiste et bygg som skulle bidra til adspredelse av turister, gi dem tak over hodet og betjene dem. Reiselivet har i Norge stort sett alltid rommet anlegg for overnatting og bespisning, mens adspredelsen eller underholdningen har skjedd i naturen, eller i anlegg som har hatt mer allmenne hensikter, som kirker, museer og minnesmerker. Da man utvidet, og i realiteten laget en helt ny attraksjon sist på 1980-tallet, fantes det færre modeller for attraksjonsutvikling, men man hentet inspirasjon utenfra, blant annet fra Disneys temaparker. Som utelukkende beregnet på turister var Nordkapphallen noe nytt i det norske attraksjonslandskapet. Noen vil mene at det hadde Nordkapp alt vært i flere hundre år, men den «kunstige» attraksjonsdelen var ny. Den skapte en trend, og det ble i tida etter etablert en rekke slike attraksjoner i Norge, for eksempel Polarsirkelsenteret på Saltfjellet, Alta Museum, Lofotr Viking Museum på Borg, Polaria i Tromsø og Samelandssenteret i Karasjok. Alle er stort sett bygd opp om en opplevelseskjerne som det koster å oppleve, butikker som selger suvenirer knyttet til attraksjonens tema, serveringssteder og gode toalettfasiliteter. Turisme inngikk som argument og i finansieringsoppleggene (Viken 2001). Turisme er å gjøre forretning på de reisende, hvor adgang til turistattraksjoner er blant tjenestene som selges. Nordkapp var en trendsetter. 


\section{Monopolisering og eksklusjon}

Nordkaps Vel krevde og fikk - om enn ikke uten protester - enerett til området da selskapet framforhandlet en avtale med Finnmark Jordsalsstyre i 1927. Siden har Nordkaps Vel blitt innlemmet i de konsernene som har stått for hotelldriften på Magerøya. Dette innebærer at Nordkaps Vel, og i rekkefølge, Nord Norsk Hotelldrift, SAS, North Cape Hotels, Rica og Scandic har hatt monopolposisjon på øya. Dette har ikke gått upåaktet hen lokalt. Og det har en rekke konsekvenser. Den viktigste er at andre har vært avskåret fra å drive forretningsvirksomhet på platået. I 1927 gikk det for eksempel ut over en lokal bardriver som ble fortrengt. Også reindrifta, hvori det alltid har inngått duodjiproduksjon (samisk håndverk) og som har vært en næring på øya og platået siden reinen ble domestisert, er holdt utenfor. Reindriverne solgte sine suvenirer på platåt på slutten av 1800-tallet, men ble ved Nordkaps Vels inntog fortrengt fra sitt eget beiteland. I dag holder de til ved sin sommerboplass, cirka fem kilometer før platået. Her har de et utsalgssted laget av teltduk, utstyrt med samiske symboler. Utenfor står samen, iført samiske tradisjonsklær, leiende på en rein, klar for fotografering. Autentisk er det nok på et vis, men ikke for det moderne livet reineieren og hans familie lever, og knapt noen god kulturreklame. Stereotypiene om kommersialiserte urfolk - the noble savage som tyner og tynes av turismen, er nærliggende. Det er ganske uforståelig at denne aktøren ikke er invitert inn som en del av attraksjonen på platået. At det samiske ikke er en del av attraksjonen, er en skamplett for driverne, sies det. Men det er altså bare driftsselskapet til Nordkapphallen som har virksomhet på platået. Det preger kanskje stedet. Det kjøres i samme spor år etter år, uten vesentlige fornyelser. Konseptet for stedet er globalt og nasjonalt, og det er nesten ingen plass til lokale elementer. Tidvis har man solgt lokale suvenirer, men også det har vært problematisk, fordi stedet krever store leveranser, om produktene er gode.

Monopolstatusen har altså stor symbolsk kraft og er et tegn på en vedvarende kolonisering, noe som stort sett irriterer store deler av lokalbefolkningen. Men monopolsituasjonen har trolig gitt økonomiske muskler til å utvikle Nordkapp. Men det har også sine minussider. Monopoler antar normalt en bestemt atferd, slik Semmler (1982, s. 109) ser det, for eksempel ved å pålegge monopolpriser for å øke profittratene. Inngangsbilletten 
på Nordkapp (275 kroner i 2018, i 2020290 kroner) er et eksempel på dette. Viktigst er det at monopolet har makt, og de på utsiden er mer eller mindre er avmektige. Monopoltendenser har vært studert under ulike etiketter (Mbaiwa 2005), for eksempel som enklaveturisme (Britton 1982; Freitag 1995). Hotell- og turoperatørkjeder har skapt turismeanlegg som gir turister alt de trenger for oppholdet - Club Med er et eksempel, men modellen er også kjent innen skiturisme og i cruiseskipssektoren. Mbaiwa (2005, s. 159) hevder at dette har en tendens til å være en type turisme hvor «... [n]aturressurser $\mathrm{i}$ en vertsregion utnyttes av noen fra utsiden, mens de fleste i lokalbefolkningen har liten eller ingen fordeler av det». Det nærliggende samfunnets behov og ønsker blir mer eller mindre ignorert. Slike relasjoner finner man først og fremst i fjerntliggende områder, sier Lascurain (1996). Karakteriseringen passer bra for Nordkapp, som er et fjerntliggende sted for de fleste. I tillegg har monopolene noen andre problematiske egenskaper; de pleier å være late og passive og å kontrollere og holde tilbake informasjon. Også det er trekk som nordkappsamfunnet kjenner igjen. Det har ikke skjedd mye på Nordkapp siden 1998, og driverne har vært tilbakeholdne med informasjon, slik mange lokalt ser det.

\section{Angår Nordkapp lokalbefolkningen?}

Turisme er et eksempel på en ekstraktiv næring, altså en næring hvor man utnytter en naturressurs for industrielle formål. Turismen på Nordkapp, og i store deler av Norge, har likhetstrekk med både fiskeri og gruvevirksomhet. Det er en råvarebasert virksomhet. Det er allment akseptert at slik næringsvirksomhet bør ha en lokal forankring og gi noe tilbake til lokalsamfunnet hvor virksomheten foregår. Det er særlig to teorifelt som har hatt fokus på dette. Det ene feltet er kalt SLO og dreier seg om sosial aksept - social licence to operate, det andre er kalt CSR - corporate social responsibility, og dreier seg om bedrifters samfunnsansvar, altså hvordan virksomheten tilgodeser samfunnet omkring. Begge prinsippene har relevans på Nordkapp, og særlig i situasjoner hvor premissene for driften reforhandles.

De som skriver om SLO-feltet, hevder at det er fire nivåer av aksept; avvisning eller tilbaketrekking, aksept, godkjenning og identifikasjon med prosjektet (Prno \& Slocum 2012). Aksept har man når et lokalsamfunn 
mener at et industriselskap bør få fortsette med sitt ekstraktive prosjekt. Miljødepartementet har ikke hindret Rica å ta en høy inngangsavgift på Nordkapp, hvilket må betraktes som en formell aksept. Men det er ikke full aksept, eller lokal godkjenning av driften. Og det er langt fra at nordkappsamfunnet identifiserer seg med turistmaskinen på platået. Navneadopteringen skjedde mens turismen var av liten omfang, og utbyttingen likeså. Identifikasjoner er basert på normative elementer som legitimitet, troverdighet og tillit, argumenteres det (Boutilier et al. 2012).

Legitimitet er en tro på at «myndigheter, institusjoner og sosiale arrangementer er passende, riktige og rettferdige», hevder Tyler (2006, s. 376). Videre bunner legitimiteten i tro på økonomiske fordeler for samfunnet, tro på at prosjektet bidrar til trivsel for lokalbefolkningen, at driverne respekterer lokale skikker og livsstiler, og at prosjektet er i samsvar med lover og regler (Koivurova et al. 2015). De fleste på Nordkapp vet at lokalsamfunnet tjener på turismen. Det er få tegn på at trivselsaspektet er negativt, sjøl om det kan være litt trengsel i gater og butikker om sommeren. Heller ikke er kulturen særlig utfordret - som et kyst- og fiskerisamfunn har Nordkapp alltid vært et samfunn med stor kontakt med omverdenen. Det siste legitimitetspunktet sliter man med; det er svært mange som mener at eier og driver bryter lover slik som stedet opereres i 2019, særlig friluftsloven.

Troverdighet handler om å overholde løfter, opptre ærlig og med åpenhet, forhold som i stor grad er premisser for tillit (Thomson \& Boutilier 2011). Utbyggerne på Nordkapp har først og fremst unngått å gi løfter. Når man skulle selge inn ideene om Nordkapp 1990, skjedde det med brask og bram og med store vyer, men knapt nok med «lovnader». Men det var stor åpenhet om planene. Men siden har driften vært preget av lukkethet, angående leiekontrakter, eiendomsutvikling og økonomiforvaltning. Strategien har vært å holde lokalsamfunnet og dets representanter - kommunen - utenfor (Holmgren \& Richter-Hansen 2016). Lokalsamfunnet har aldri følt på åpenhet og ærlighet, og de har følt seg utbyttet i økonomisk forstand. Derfor har man i 2017 og 2018, i forbindelse med at leiekontraktene skulle reforhandles, hatt diverse møter, også protestmøter, angående drift og forvaltning av Nordkapplatået.

Tillit er basert på kommunikasjon mellom prosjektet og samfunnet omkring, om det er en reell dialog, om respons er gitt og løfter holdes, og det er gjensidighet i samspillet (Koivurova et al. 2015). Relasjonene 
som har eksistert når det gjelder Nordkapp, har knapt vært basert på tillit, og måten involverte selskaper og myndigheter opptrådte på rundt 1990, ga god grunn for mistillit. Da driftsselskapet hadde økonomiske problemer tidlig på 1990-tallet, hadde kommunen fått de tre nordnorske fylkeskommunene med på en modell hvor de skulle overta aksjene, men fylkesordføreren i Finnmark forpurret det hele. I et intervju antyder Odd Holmgren, som var ordfører på den tida, at «vi ble regelrett dolket i ryggen av fylkesmannen og fylkeskommunen!» (ibid., s. 85). Tilliten som måtte ha eksistert, ble altså undergravd av fylkesordføreren og fylkesmannen, slik den tidligere ordføreren i ettertid så det. Disse menneskene synes å ha vært vel plassert i lomma til SAS, som den gang var hovedaktøren lokalt. Om forholdet har blitt ryddigere siden, skal være usagt. Lokalt ledes virksomheten i dag av en fra stedet, men som sjølsagt er prisgitt sine eiere og drivere, som driver butikk og ikke veldedighet. Verken eier- eller driftsselskap har i årene fram til 2020 hatt stor tillit lokalt.

Det er likevel ikke gitt hvordan forretningsdrifta skal foregå. Det er relativt anerkjent at foretak har et ansvar som omfatter mer enn sine eiere. De har også et ansvar overfor sine ansatte, samfunnet og miljøet. Hva dette omfatter og innebærer, har også utviklet seg til et teorifelt. Internasjonalt kalles det altså CSR - Corporate Social Responsibility. På norsk omtales det som bedrifters samfunnsansvar. Begrepet er basert på et syn hvor forretningsvirksomheter tillegges et bredere ansvar enn å tjene penger. Chandler og Werter (2011) opererer med tre typer virksomhetsansvar: økonomisk, lovmessig og etisk ansvar. De hevder videre at virksomheter har ansvar overfor tre typer interessenter: økonomiske (eiere, kunder osv.), organisatoriske (tilsatte, fagforeninger osv.) og sosiale (myndigheter, lokalsamfunn, NGO-er osv.). Andre har føyd til en fjerde interessentgruppe, nemlig miljøet (Cole, Fenclova \& Dinan 2013). Slik utviklinga har vært, er miljøet hovedfokus for en del selskapers CSR. Fokus innen CSR varierer og kan både dreie seg om hva virksomhetene produserer, om produktenes betydning for samfunnet, men også om hvordan produksjonen foregår og ledes (ibid.). Det er først og fremst hensynet til ansatte og miljøet, men særlig samfunnet omkring, som det siktes til når man i Norge taler om bedrifters samfunnsansvar (CSR). Motivene for å ta samfunnsansvar er at det anses som en plikt, men det hevdes også å være en lønnsom strategi (Bohdanowicz \& Zientara 2008), for eksempel vil både redusert vannforbruk og strømforbruk lønne seg i det lange løp. Og slike miljøtiltak skaper 
et fordelaktig image (ibid.) $\AA$ ta samfunnsansvar dreier seg som regel om å skape gode relasjoner, skaffe seg «venner» i omgivelsene, men også om å dempe reguleringslysten i omgivelsene. Samfunnsansvar vil kunne være en del av en bedriftsfilosofi som gjennomsyrer en organisasjon, slik det hevdes å være i hotellkjeden Scandic (Bohdanowicz \& Zientara 2008).

To av bedriftene som er involvert i turismen på Nordkapp, er høyprofilerte samfunnsansvarsselskaper: Scandic Hotel, driveren både av de store hotellene og hovedattraksjonen på Nordkapp, og TUI, som er Europas største turoperatør og en cruiseoperatør. Scandic Hotels har gjennomført en rekke tiltak både overfor ansatte, samfunnet omkring og ikke minst miljømessig. Tiltakene overfor ansatte har gjort hotellkjeden til en attraktiv arbeidsplass, hevdes det (Bohdanowicz \& Zientara 2008; Heesbeen 2014). Det tilbys opplæring hvor de ansatte også blir satt inn i CSR-tenkningen og strategiene. De ansatte omtales som teammedlemmer (ibid.). Selskapet har også hatt et program kalt Scandic in Society. Man har hatt flere fokus innen dette programmet, som å samle inn penger til kreftforskning, bistå i kampen mot barnearbeid, støtte WWF, tilrettelegging for funksjonshemmede og et relativt omfattende program for å fremme bærekraft. Lokalt ble det i en periode diskutert med hotellenes ansatte hva selskapet kunne og burde gjøre overfor lokalsamfunnet. Dette kunne dreie seg om å gi restemat til trengende, gi bort utrangert inventar og utstyr til dem som ville ha, sponsing av ulike arrangementer osv. Det viktigste i dette arbeidet er kanskje en ledelsesstrategi som involverer alle ansatte i arbeidet med samfunnsansvar, og ledelsesstrategier for å redusere barrierene mellom hotellene og samfunnene omkring. En leder i North Cape Hotels forteller at etter at hotellene ble en del av Scandic Hotels i 2014, har fokuset på samfunnskontakt og miljø blitt både større og mer systematisk, og rapporteringen mer omfattende - og som han sa, «mer svensk». I 2018 arbeidet man med å få hotellene svanemerket. En styrket miljøprofil har også betydd at man har måttet skape endringer i omgivelsene, som for eksempel de lokale mottakssystemene for søppel, som mange steder ikke fyller Svanemerkets krav til søppelhåndtering. Derfor måtte selskapet også gripe inn i kommunenes søppelhåndtering. Man har også skapt nye tiltak, som å invitere vanskeligstilte grupper eller pensjonister på middag. I 2018 var det et sterkt fokus på matavfall og hvordan dette kan komme til nytte. Når det gjelder støtte til lokale lag og tiltak, er endringene små. Lederen antyder at eierskiftet heller ikke har betydd så mye for driften 
av Nordkapphallen. Det er heller ikke noe som tyder på at miljøengasjementet er særlig stort, snarere tvert imot. Man har for eksempel de seinere åra tillatt helikopterlandinger på platået, altså innenfor et vernet område. Man tillater også telting på området, hvilket representerer konkurranse for stedets campingplasser, og bryter med reguleringsplanen for platået. Det er utvilsomt et paradoks at forholdet til lokalsamfunnet i beste fall er svært varierende, for en kjede som profilerer seg på samfunnsansvar.

Turoperatørene har alltid vært sentrale i nordkappturismen. Også noen av dem profilerer seg på CSR, og i særdeleshet på miljø. Blant disse er TUI, Europas største turoperatør. Deres motto er i 2018 «Better Holidays, Better World». Selskapet selger seg som miljøvennlig og sier de lever etter følgene retningslinjer:

Our Code of Conduct adopts the principles of the UN Global Compact Initiative and formulates minimum standards in five major areas: TUI's basic values, respect and honesty, adherence to the law, ethical standards and business methods, and social responsibility.

Dette er en krevende retningslinje. Selskapet står for en rekke prosjekter som har som mål å skape en bedre verden der de opererer, særlig i Afrika. Hva de gjør for å leve opp til retningslinjene sine i destinasjoner som Nordkapp, er uklart. Lederen i Scandic North Cape Hotels opplever imidlertid ofte at kravene er langt større fra for eksempel en del offentlige kunder. SLO og CSR representerer moderne krav til forretningsvirksomhet; man skal ta hensyn til samfunnet omkring, og man skal ha blikk for framtida. Disse prinsippene er på vei inn, men har ikke funnet sin form i alle bedrifter og destinasjoner, ei heller i den norsk bedriftsverdenen eller offentligheten. Scandic tok over Nordkapp i 2014 og har i årene etter forsvart seg med at det tar tid å snu strategier og å innføre nye driftsprinsipper. Men det bør skapes forventninger om endringer, slik dette selskapet profilerer seg. Nordkapp drives i dag knapt etter prinsipper om bærekraft, ei heller med et mål for øye å skape et bedre samfunn lokalt. På Nordkapp framstår Scandic som en aktør som suger på den gamle karamellen så lenge det går. Dels kan de skylde på eierskapsselskapet, som krever svært høy avkastning. Men det er en dårlig unnskyldning. Det er en del av CSR-strategien å gå i dialog med sine handelspartnere, om nødvendig for å skape en bedre verden. 


\section{Forvaltningen av Nordkapp}

«Besøksforvaltning» er et nytt fagfelt i Norge, men er velkjent internasjonalt. Det dreier seg om forvaltning av områder for rekreasjon, friluftsliv og turisme, og handler om å forhindre eller redusere negativ påvirkning av besøk og å optimalisere opplevelsen for de besøkende. I dette inngår tilrettelegging, overvåking og kontroll av natur. I Norge betyr det områder som er definert som utmark, eller som på noe vis er vernet. Nordkapp var tidlig ute med besøksforvaltning, uten at det begrepet ble brukt. Etableringen av Champagne-paviljongen på 1890-tallet, og seinere etableringen av Nordkapphallen i flere omganger, kan ses på som besøksforvaltning. Prosjektet Nordkapp 1990 hadde også dette elementet i seg. På 1980-tallet ble bilturistene gjerne over natta på platået, uten tilgjengelige toaletter, vann eller godt nok søppelsystem. Det var grisete der, slik flere husker det, og behovet for tilrettelegging var stort. Det nye anlegget innfridde disse behovene; toalettene ble døgnåpne og tilgjengelige fra utsiden, søppelsystemer ble etablert, og turistene fikk innendørs tumleplass. Derfor framsto anlegget som et eksempel på hvordan utmark med mange besøkende kan forvaltes. Modellen, som andre kan ta lærdom av, er å kanalisere turistene gjennom en bom hvor man betaler for de tjenestene man får.

Nordkapplatået ble i 1924 fredet, uten at det har hindret utbygging og masseturisme. Det er også et område for reindrift, og hvor reindriftsloven har gyldighet. Det har også vært hevdet at loven om motorferdsel i utmark gjelder, men i så fall bare utenfor selve veien og parkeringsanlegget, og der er det ikke trafikk. ${ }^{4} \mathrm{Hjemmelen} \mathrm{for} \mathrm{forvaltningsregimet} \mathrm{ligger} \mathrm{i} \mathrm{at}$ Nordkapp er utmark, og et område hvor friluftsloven og allemannsretten gjelder. Friluftslovens $₫ 14$ gir kommunen rett til å regulere adkomst til naturområder og å ta seg betalt for det. Det er intet juridiske hinder for at denne forvaltningen settes bort til private aktører slik tilfellet er på Nordkapp, men det er kommunen som skal bestemme nivået på avgiften man tar. Grunnlaget for beregning av avgiften slik den har vært i årene fram mot 2020, sies det, er at det er satt et kapitalavkastningskrav på 11,7 prosent per år med utgangspunkt i gjenskaffelsesverdien, i 2012 satt til 325 millioner kroner, og ikke anskaffelsesverdien på under 150 millioner

Nordkapphallen er endepunktet til Europavei 18, og formelt er veibommen satt opp før veien slutter. Dette er klanderverdig, slik noen ser det, men i et større perspektiv er dette flisespikkeri. 
(inkludert statsstøtte). Dette beregningsgrunnlaget er ansett som urimelig høyt, både av departement, friluftsorganisasjonene og andre (Norsk Friluftsliv 2017; Lindkvist 2017). Avgiften er formelt todelt, en for dem som skal inn i hallen, og en lavere for dem som bare skal inn på uteområdet. Delingen ble gjort etter påtrykk fra Miljøverndepartementet. Oppsplittingen er imidlertid underkommunisert, og de fleste blir ikke opplyst om det, noe som kan være brudd på opplysningsplikten knyttet til kommunale avgifter i utmark. Avgiftsregimet ble i 2019 underkjent av fylkesmannen for Troms og Finnmark.

Nordkapp, slik det framsto i 2018, er et funksjonelt anlegg sett ut fra snevre besøksforvaltningsprinsipper. Det finnes velfungerende inneområder, toaletter og bespisningsmuligheter. Men anlegget har ikke vært gjennom store forandringer siden 1998, da hallen ble utvidet. Anlegget hevdes å være slitt. Det er gjort små endringer som har redusert estetikken, blant annet ved å stenge utsikten til havet i en underjordisk bar. Man har heller aldri gjort noe med estetikken i parkeringsanlegget, og som ifølge lokale aktører framstår som lurvete (Lindkvist 2017). Og som en bemerket, så snublet han i den samme vaieren i 2016 som han hadde gjort i 1996. Derfor bør man kanskje også tenke på hvordan anlegget skal utvikles, og ikke overlate det til den private driveren, som åpenbart ikke setter estetikk eller utvikling i hovedsetet. Når det gjelder området omkring, var kommunen i gang med en områderegulering i 2018. Det har også vært antydet at man burde omgjøre Nordkapp til nasjonalpark, noe som også har vært foreslått tidligere (Rapp 1997). Fredning i tilknytning til turistdestinasjoner er ikke ukjent. I sin tid ble nasjonalparkene etablert for å vise fram og bevare særpreget natur (Vistad 1999), ikke for å gjemme vekk naturen. Det finnes også mange nasjonalparker som er mye besøkt. Det som kreves, er først og fremst en litt romsligere norsk tenkning.

I 2019, etter at dette kapitlet ble skrevet, har det pågått forhandlinger, og endringer er varslet. Festekontrakten mellom Finnmarkseiendommen og Rica er forlenget med en leie på 3,45 millioner i året, samtidig som Rica/Scandics arealer reduseres fra 900 til 115 dekar. Dette betyr trolig at monopolet er svekket, og siden billettregimet er underkjent av fylkesmannen, må et nytt utvikles. Det gjenstår fortsatt forhandlinger om hva som blir det nye regimet. 


\section{Konklusjon: skapt og styrt utenfra}

En oppsummering av dette kapitlet er at Nordkapp har vært styrt utenfra så lenge det har vært et moderne turistmål. «Oppdagerne» var utlendinger, de som reiste Champagne-paviljongen, var utenfra, stifterne av Nordkaps Vel var nasjonale selskaper og et utenlandsk et, det nordiske flyselskapet SAS sto for utbygging på siste halvpart av 1980-tallet, mens dagens leier og eier av grunnen og bygningene er et nasjonalt norsk selskap, og driftsselskapet er svensk. Slik er reiselivet, og slik er markedsøkonomien, og slik tenker den neoliberale staten at det skal være. Framstillingen over viser at nordkappturismen både har koloniale og imperialistiske trekk; den drives av nasjonale og internasjonale selskaper som maksimerer utbyttet fra sine ekstraktive turismeoperasjoner i periferien. Profitten går til finansselskap som i liten grad reinvesterer der verdiene skapes. Vi har også vist til et annet trekk, at lokale aktører, både næringsdrivende og kommunale myndigheter, holdes utenfor, og bare tjener på den sysselsettingseffekten og de ringvirkningene som turismen har.

I dette kapitlet har vi analysert Nordkapp som et turiststed. Noen vil kanskje bestride at det er det, at det i det hele tatt er et sted, siden det knapt bor noen der. Men det er mange mennesker der, turister og ansatte, sjøl om de som jobber der, stort sett bor flere mil unna. Slik vi har omskrevet stedet her, framgår det som et sted med en tidslinje, og som er bundet sammen av diverse romlige systemer bestående av mennesker, reiselivsselskaper, kapital og myndigheter. Ikke minst har vi vist til de endringene som har skjedd med stedet. Det er all grunn til å tro at endringer også vil finne sted i framtida. Steder skjer og skapes. Kanskje har Nordkapp «skjedd» mer enn det har blitt skapt. Det er i dag større krav til at stedsutviklinga skal skje i prosesser som er gjennomtenkte og omdiskuterte, og hvor mangfoldet av interessenter deltar. Eksklusjonsstrategienes tid bør være forbi. Nordkapp er ikke bare et globalt sted, det er også et sted som angår offentligheten, og et sted som betyr noe for dem som er nærmest. Nordkapp bør forvaltes nasjonalt og globalt, men tjene lokalsamfunnet. 


\section{Litteratur}

Berger, A. A. (2013). Theorizing tourism. Walnut Creek: Left Coast Publishing. Birkeland, I. (1999). The motho-poetics in northern travel. I D. Crouch (red.), Leisure/tourism geographies: Practices and geographical knowledge (s. 17-33). London: Routledge.

Birkeland, I. (2006). Sensing places: The ethics of authentic place. Mobility and place. Enacting Northern European. https://www.researchgate.net/ publication/277801590

Bohdanowicz, P. \& Zientara, P. (2008). Corporate social responsibility in hospitality: Issues and implications. A case study of Scandic. Scandinavian Journal of Hospitality and Tourism, 8 (4), 271-293. https://doi.org/10.1080/15022250802504814

Boutilier, R. G., Black, L. \& Thomson, I. (2012). From metaphor to management tool: How the social licences to operate can stabilise the sociopolitical environment for business. International Mine Management 2012. Proceedings (s. 227-237). Melbourne: Australian Institute of Mining and Metallurgy.

Britton, S. G. (1982). The political economy of tourism in the third world. Annals of Tourism Research, 9, 331-356. https://doi.org/10.1016/01607383(82)90018-4

Chandler, D. \& Werther, W. B. jr. (2011). Strategic Corporate Social Responsibility: Stakeholders, Globalization, and sustainable value creation. New York: Sage Publications.

Coles, T., Fenclova, E. \& Dinan, C. (2013). Tourism and corporate social responsibility: A critical review and research agenda. Tourism Management Perspectives, 6, 122-141. https://doi.org/10.1016/j.tmp.2013.02.001

Favero, P. (2000). «O’ Sole Mio»: Italian Charter Tourists' Experiences of the Midnight Sun in North Cape, Norway. Anthropological Quarterly, 73 (1), $1-18$.

Freitag, T. G. (1994). Enclave tourism development for whom the benefits roll? Annals of Tourism Research, 21, 538-554. https://doi.org/10.1016/01607383(94)90119-8

Galtung, J. (1971). A Structural Theory of Imperialism. Paper. Oslo: International Peace Research Institute. https://doi.org/10.1177/002234337100800201 
Gustavsen, J. (2016). Kampen om Nordkapp. Intervju med tidligere ordfører Odd Holmgren. I

K. B. Lindkvist (red.), Årbok for Nordkapp 2016. Honningsvåg: Nordkapp historielag.

Heesbeen, L. (2014). Corporate social responsibility: A case study of Scandic Hotel. Bachelor Thesis. Helsinki: Haga-Helia University of Applied Sciences.

Hall, C. M. \& Tucker, H. (2004). Tourism and postcolonialism: Contested discourses, identities and representations. London: Routledge. https://doi.org/10.4324/9780203392270

Holmgren, H. \& Lindkvist, K. B. (2016). Resource management regimes and innovation in peripheral nature-based tourism: The case of North Cape tourism and seafishing tourism. Norsk Geografisk Tidsskrift - Norwegian Journal of Geography, 70 (4), 203-215. https://doi.org/10.1080/00291951.20 16.1168481

Holmgren, H. \& Richter-Hanssen, E. (2016). Tilskuer og deltager i forvaltningen av Nordkapp. I K. B. Lindkvist (red.), Arbok for Nordkapp 2016.

Honningsvåg: Nordkapp historielag og Nordkappmuseet.

Jacobsen, J. K. S. (2016). North Cape: In the land of the midnight sun.

I N. Herrero \& S. R. Roseman, The tourism imaginary and pilgrimages to the edges of the world. Bristol: Channel View Publications. https://doi.org/10.21832/9781845415242-008

Koivurova, T., Buanes, A., Riabova, L., Didyk, V., Ejdemo, T., Poelzer, G., ATaavo, P. \& Lesser, P. (2015). 'Social licence to aoperate': a relevant term in Northern European mining? Polar Geography, 38, 194-227. https://doi.org/1 0.1080/1088937X.2015.1056859

Kothari, U. (2015). Reworking colonial imaginaries in post-colonial tourist enclaves. Tourist Studies, 15, 248-266. https://doi.org/10.1177/1468797615579566

Lawrence, R. \& Åhrén, M. (2016). Mining as Colonisation: The Need for Restorative Justice and Restitution of Traditional Sami Lands. I L. Head, S. Saltzman, G. Setten \& M. Stenseke (red.), Nature, Temporality and Environmental Management: Scandinavian and Australian Perspectives on Landscapes and Peoples. London: Taylor and Francis.

Lindkvist, K. B. (2017). Nordkapp - utvikling og muligheter. Notat. Honningsvåg: Forfatteren.

Mbaiwa, J. E. (2005). Enclave tourism and its socio-economic impacts in the Okavango Delta, Botswana. Tourism Management, 26, 157-172. https://doi.org/10.1016/j.tourman.2003.11.005 
Mehmetoglu, M. \& Olsen, K. (2007). From cultural consumer at home to heritage tourist away. I J. S. Chen (red.), Advances in Hospitality and Leisure (s. 19-37) Volume 3. New York: Emerald Group Publishing Limited. https://doi.org/10.1016/S1745-3542(06)03002-5

Norsk Friluftsliv (2017). Internt notat om Nordkapp. Oslo: Norsk Friluftsliv. Prno, J. \& Slocombe, D.S. (2012). Exploring the origins of 'soccial licence to operate' in the mining sector. Perspectives from governance and sustainability theories. Resourse Policy, 37, 346-357. https://doi.org/10.1016/j. resourpol.2012.04.002

Rapp, O. M. (2002). Nordkapp som nasjonalpark. Oslo: Aftenposten.

Richter-Hanssen, E. (1990). Nordkapp - en fiskerikommune. Fra eldste tider til i dag. Honningsvåg: Nordkapp kommune.

Semmler, W. (1982). Theories of competition and monopoly. Capital \& Class, 6, 91-116. https://doi.org/10.1177/030981688201800106

Sinclair-Maragh, G. \& Gursoy, D. (2015). Imperialism and tourism: the case of developing island countries. Annals of Tourism Research, 50,143-158. https://doi.org/10.1016/j.annals.2014.12.001

Thomson, I. \& Bouttelier, R. G. (2011). Social license to operate. I P. Darling (red.), SME mining engineering handbook (s. 1779-1790). Denver, Colorado: Society for mining, metallurgy and exploration.

Tyler, T. (2006). Psychological Perspectives on Legitimacy and Legitimation. Annual Review of Psychology, 57, 375-400. https://doi.org/10.1146/annurev. psych.57.102904.190038

Viken, A. (2001). Turismeutvikling i Lofoten. I A. Viken (red.), Turisme. Tradisjoner og trender (s. 91-108). Oslo: Gyldendal.

Viken, A. (2011). Naturbasert turisme i nord. Ytre påvirkning - lokal tilpasning. I S. Jentoft, J.-I. Nergård \& K. A. Rørvik (red.), Hvor går Nord-Norge. Tidsbilder fra en landsdel i forandring. Stamsund: Orkana Forlag.

Viken, A. \& Aarsaether, N. (2013). Transforming an iconic attraction into a diversified destination: The case of North Cape tourism. Scandinavian Journal of Hospitality and Tourism, 13, 38-54. https://doi.org/10.1080/15022250.20 13.771994

Vistad, O. I. (1999). Nasjonalparken. I J. K. Jacobsen \& A. Viken, Turisme. Sted $i$ en bevegelig verden. Oslo: Gyldendal. 


\section{FRA LOKALT TIL EKSTERNT EIERSKAP - EKSEMPEL PÅ FINANSIALISERING I NORSK TURISME}

Arvid Viken, Ragnar Nilsen og Carina Olufsen

\section{Innledning}

Hensikten med dette kapitlet er å peke på omstillingsprosesser i reiselivet i Lofoten, som reflekterer restrukturering innen det økonomiske systemet i retning av fjerneierskap og ytre kontroll, men også noen motreaksjoner. Det er tidligere vist hvordan det er tendenser til at flere og flere av reiselivsbedriftene i Nord-Norge blir kjøpt opp av aktører utenfra (Viken 2011). Både Hurtigruten og de fleste hotellene er eid av investorer utenfor landsdelen. Og at dette skjer, er ikke noe særsyn. Det samme skjer også i fiskeriene og i oppdrettsnæringa og er altså en del av den allmenne investorovertakelsen eller investordominansen (også kalt finansialisering) i norsk næringsliv. Dette er prosesser som er beskrevet av klassiske samfunnsanalytikere som Marx, Polanyi, Granovetter, Giddens, Schumpeter, Harvey og andre. Vi skal knytte an til noen av disse teoretikerne og vise at prosesser de har beskrevet, synes å ha gyldighet også i Lofoten, både i forholdet mellom fiskeriene og reiselivet, og innen reiselivsnæringa. Poenget i teorien til Polanyi er at når markedsøkonomien får råde, så betyr dette at innsatsfaktorer som ikke hører hjemme i markedssfæren - som kultur og lokalsamfunn - blir dratt inn i denne. Dette kalles varegjøring. Jordbruk og fiske har vært viktige sosiale og kulturelle arenaer. Varegjøring i form av såkalt fri omsetning av dyrkingsjord eller rett til fiske vil undergrave de 
samfunnene disse næringselementene har skapt. På tilsvarende måte kan turistisk varegjøring eller kommersialisering endre den lokale kulturen og ikke minst dens kulturlandskap. Vi skal vise hvordan slike mekanismer har gjort seg gjeldende blant småbedrifter, som rorbuanlegg i Lofoten. Mens disse inntil nylig var solid forankret i regionens lokalsamfunn, er de i dag i større og større grad eid utenfra. Vi skal også vise til motkrefter mot en slik utvikling og drøfte implikasjonene av dem.

Kapitlet starter med to teoretiske avsnitt, ett om nyliberal økonomi og det som er kalt kreative destruksjon og motbevegelser, og ett om forankringsteori. Dernest brukes perspektivene fra denne teorien i en presentasjon av turismeutviklinga i Lofoten, med empiri fra opplevelsesnæringa i Moskenes, og ett om utviklinga av et bestemt rorbuanlegg i Vestvågøy. Dette dras sammen i en konklusjon som antyder at det finnes middelveier og kombinasjoner, at tradisjonell og moderne drift lar seg gjennomføre side om side. Kapitlet er basert på flere runder med datainnsamling fra 1990-tallet og fram til 2018.

\section{Økonomisk utvikling: liberalisme og finansialisering}

Turisme som næring rommer alt fra store kapitalkrevende virksomheter til små enkeltforetak som nesten ikke krever økonomiske investeringer. Næringsanalyser av Lofoten kan fortelle at virksomhetene stort sett har vært basert på lokalsamfunnets bruksrettigheter til regionens ressurser, folks egen arbeidsinnsats og begrensede investeringer. Tendensen er imidlertid at en stadig større andel av fiskeriene og turismen håndteres av kapitalinteresser. Når de små reiselivsbedriftene vokser, blir de interessante investeringsobjekter. Vekst er bransjens mantra (Viken 2014). Dessuten er det kanskje like viktig at turismen ofte er å finne i grenselandet mellom ulike industrier, blant pådriverne for utvikling er både investorer, eiendomsutviklere, byggefirmaer, transportselskaper og andre, sammen med det man til vanlig regner som reiselivsaktører (Bianchi 2009). Stadig utvikles nye turistresorter fordi noen, som eiendomsutviklere og investorer, forsøker å tjene på selve utviklingsprosjektene, og stadig skjer det overtakelser og sammenslåinger av bedrifter og kjeder for å oppnå større økonomisk gevinst. Når nye markeder utvikles og nye konsumenter ankommer, følger kapitalen etter. Dette er kapitalismens vesen. 

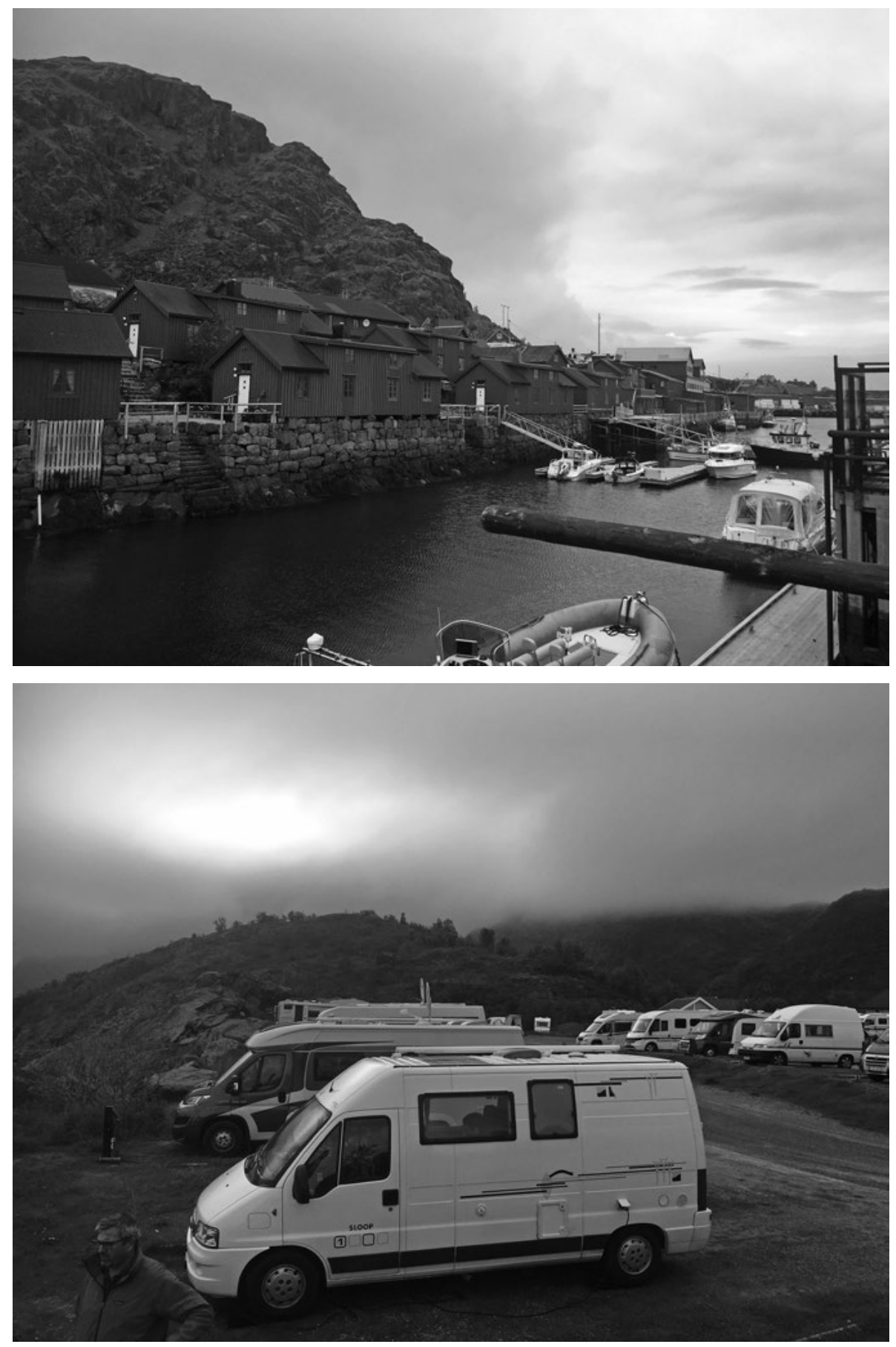

Lofoten, idyll og trafikk. Foto: Ole Magnus Rapp. 
Harvey (2006) knytter an til Shumpeters begrep 'kreativ destruksjon' i sin beskrivelse av den neoliberale økonomien som dominerer i vår tid. Innen denne økonomien skapes sentra for akkumulasjon og produksjon som ender i destruksjon - altså at det som var grunnlaget for utviklinga, går til grunne. Dette er en syklisk utvikling. Modellen ble opprinnelig anvendt på industrisamfunn, men har også blitt brukt i analyser av turisme og kulturarv (Mitchell 1998, 2009). Harvey (2006) identifiserte fire tendenser i denne økonomien: privatisering, finansialisering, krisehåndtering og statsregulert redistribusjon. Privatisering er kjernen i neoliberal tenkning: Statlig virksomhet og tjenester skal privatiseres. En konsekvens av dette er et dårligere klima for offentlig støtte til næringsutvikling. Finansialisering gjør eierskap til produksjonsmidler og råvarer til varer i et marked - vi kaller det varegjøring. I et slikt system er det legitimt å investere, spekulere og tenke finans foran andre hensyn. En konsekvens er at investorer fokuserer på muligheter til fortjeneste, mens lojaliteten og innrettingen mot spesifikke bransjer svekkes. Derfor hender det ofte at reiselivsbedrifter kjøpes opp av investorer fra helt andre bransjer. I en økonomi som stadig viser seg ikke å fungere perfekt, er imidlertid krisehåndtering et tilbakevendende behov, og en rolle som offentlige myndigheter påtar seg. Myndighetene har stadig måttet redde det økonomiske systemet, også på lokalt plan - og blant annet derfor har vi en distriktspolitisk institusjon som Innovasjon Norge. Statlig redistribusjon fra arbeid til kapital, hevder Harvey, skjer gjennom at folk fra landsbygda på ulike vis presses ut av tradisjonell og arbeidsintensiv virksomhet, og inn til byer, lønnsarbeid eller arbeidsledighet. Jorda eller andre naturressurser kan da overtas av større aktører som produserer mat eller bruker ressursene på det som regnes som mer effektivt innenfor rammen av en neoliberal diskurs. Et annet eksempel er privatisering av eiendom. Skjer det, følger ofte spekulasjon i eiendom, og folk fristes til salg, for eksempel av fritidseiendommer. Harveys teorier er makro-orienterte, men vi skal vise at det også gjelder på mikronivå. Vi mener imidlertid at Harveys teorier har en kulturell slagside. De er særlig preget av erfaringer og tenkning i den angloamerikanske kulturkretsen. Vi tar det derfor ikke for gitt at alle sidene ved teorien treffer vårt norske og nordnorske materiale like godt, men vil problematisere dette underveis.

Mitchell (2009) har brukt Harveys teorier som grunnlag for observasjoner i reiselivssammenheng. På eiersiden i St. Jacobs i Canada, sier Mitchell, har det skjedd en bevegelse fra ledelsesorientering til entreprenørånd, hvor ideen er at utvikling skapes gjennom innovasjon. En annen bølge, 
mener hun, har vært at urbane middelklassemennesker søker til hva hun kaller den «idealiserte rurale landsbygda» (ibid.: 157). En tredje bølge er at det er blitt skapt "et post-industrielt rasjonelt akkumulasjonslandskap» (ibid.), som også fører til en utskiftning av involverte aktører. Som vi skal se, kan disse utviklingsmodellene gjenfinnes i Lofoten. Forestillingen om «den rurale idyllen» er først og fremst engelsk, sier Cruickshank (2009). Begrepet har dels sin basis i en kulturelt hegemonisk, urban middelklasse sine forestillinger om hva som er landsbygdas fortinn i kontrast til det britiske bylivet. Og dels har begrepet sin basis i en avmektiggjort engelsk landsbygd, der det pittoreske framstår som det eneste fortrinnet eller styrken i forhold til det urbane.

Til tross for det mønsteret Mitchell tegner, så finnes det motkrefter (Harvey 2006). Det er mange eksempler på at utviklinga ikke har fulgt modellen med kreativ destruksjon. På individuelt plan har dette skjedd gjennom oppgradering og omstilling av bedrifter, især ser eiere av småbedrifter tendenser som de ikke liker, og som de motarbeider. Også i Lofoten finnes det, som mange andre steder i verden, kollektive motbevegelser mot en slik utvikling. I Lofoten har slike bevegelser tatt til motmæle mot det man kaller strukturering i fiskeriene, mot en bebudet oljevirksomhet og mot en utvikling som desavuerer kystsamfunnet mer generelt. Et eksempel er Kystpartiet, et politisk parti som også har hatt representanter på Stortinget. Norges Kystfiskarlag, som organiserer kystfiskere, med hovedsete i Ramberg, er et annet eksempel. Disse motbevegelsene har sin viktigste styrke i et næringsliv som drives av lokale aktører som har bygd opp egen virksomhet basert på institusjonelt nedfelte rettigheter til naturressursene. Rettighetene har tradisjonelt blitt fordelt etter et bruksrettsprinsipp; det er aktive brukere som skal ha rett til naturressursene. Dette gjaldt både en individuell eiendomsrett til jord og høstingsrett til havets fellesressurser.

I sin anvendelse av Harveys teori karakteriserte Mitchell (1998) det som hadde skjedd i St. Jacobs utenfor Toronto, som kreativ destruksjon. I en ny analyse av casen i 2009 stiller hun spørsmålstegn om hvorvidt casen passer til modellen. Som kulturarvsted har St. Jacobs blitt destruert, men ikke som bosted og turiststed. Nye grupper mennesker har flyttet til stedet, og andre typer turister, som hun kaller post-turister, har tatt stedet i bruk. De er mindre opptatt av kulturarven og den idyllen som den i sin tid representerte. I en artikkel fra 2013 anvender hun begrepet «kreativ forbedring» for å beskrive endringer fra ensidige produksjonssamfunn til multifunksjonelle lokalsamfunn. Hennes observasjon er at det i mange 
av disse samfunnene skjer innovasjoner, og nye plattformer for næringsvirksomhet skapes. Kulturarv, fritidsrelatert virksomhet og turisme er slike eksempler. Dette gjør stedene mer hybride. Men det, understreker Michell, kan også gi grunnlag for nye produkter og ny produksjon i de opprinnelige næringene. Følgelig, sier Mitchell, fører kreativiteten både til destruksjon og konstruksjon, og den skaper dynamiske steder og rom.

\section{Forankring og avforankring}

Det finnes mange eksempler på kreativ destruksjon, men også på kreativ forbedring langs norskekysten. Bygdebyene har ofte vært sett på som destruksjon, men det finnes også mange kreative endringer. I disse prosessene skjer det også endringer med hensyn til eierskap og maktforhold. Ofte går eierskapet ut av lokalsamfunnet. Moderniseringa og utviklinga krever større kapitalinnsprøytninger enn det lokalsamfunnet kan makte, og eierskap og styring overføres til eksterne aktører. Altså, i mange kystsamfunn har det fra 1990-tallet og fram til i dag funnet sted en prosess som kan karakteriseres som avforankring (disembedding). Avforankring er et begrep som brukes på forskjellige måter. De to kanskje mest kjente teoretiske diskusjonene av begrepet har Polanyi ([1944] 2012) og Granovetter (1985, Hess 2004) stått for. Polanyi skrev Den store transformasjonen i 1944 ([1944] 2012) som en kritikk av den dominerende økonomiske utviklinga innen politikk og vitenskap, nemlig utviklinga mot et totalt fritt og sjølregulerende marked. Han setter denne utviklinga opp mot økonomien i tradisjonelle samfunn som var forankret i sosiale relasjoner gjennom systemer av gjensidighet og omfordeling basert på felles verdier og normer. Samfunnet kontrollerte markedet, og transaksjoner var alltid basert på eksisterende sosiale relasjoner. Idealet for det sjølregulerende markedet er at det skal fungere uten innblanding fra samfunnet. Men stort sett er det motsatt: Ulike sosiale og politiske mekanismer er ofte avgjørende for at markedet skal fungere. Sosiale relasjoner er altså innebygd i det økonomiske systemet, mener Polanyi ([1944] 2012). Men idealet var og er like fullt sosial avforankring av økonomien.

Avforankringen må også forstås i lys av Polanyis ([1944] 2012) teori om at jord (land), arbeidskraft og kapital i økende grad blir betraktet som varer. Han mener det er en fiksjon å forstå disse tre innsatsfaktorene som 
styrt av separate markeder. For at det industrielle markedet skal fungere effektivt, må det være separate markeder for alle innsatsfaktorene, ifølge Polanyi ([1944] 2012). At dette er en fiksjon, blir tydelig når man innser at begrepet arbeid egentlig refererer til erfaringer fra de menneskene som samfunnet består av. Uttrykket «jord» brukes med henvisning til naturen rundt samfunnet, men kan ikke forstås uavhengig av sosiale systemer. $\AA$ omgjøre disse faktorene til råvarer for et marked blir av Polanyi ([1944] 2012) sett på som det samme som å regulere samfunnet etter reglene $\mathrm{i}$ markedet eller innlemme samfunnet i det økonomiske systemet (Polanyi [1944] 2012). Han mener altså at næringslivet arbeider etter slike modeller. Gjennom kvotesystemet for kystflåten slik vi kjenner det fra fiskeriene, blir rettighetene til naturressursene gjort om til varer som også kan selges ut av regionen. ${ }^{5}$ Dette betyr at fiskeriene blir avforankret. Samfunnet sitter imidlertid igjen med aktører som stritter imot, og ofte må staten trå til fordi systemene ikke virker ideelt. Arbeids- og næringslivet er innvevd i kultur- og samfunnsliv slik at markedet ikke fungerer som en isolert arena. Det finnes mange eksempler på dette i norsk kyst- og fiskeripolitisk historie.

Førti år etter Polanyis bidrag ble avforankringsbegrepet brukt av Granovetter (1985), men på en litt annen måte. Han bruker begrepet i en debatt om den sosiale forankringen av økonomisk atferd på individnivå (Hess 2004). Ifølge Granovetter (1985) kan ikke økonomiske handlinger, enten av selskaper eller av individer, forstås uten å se dem i lys av sosiale mekanismer. Ifølge hans teori opptrer ikke økonomiske aktører utelukkende på rasjonelt grunnlag, og heller ikke utelukkende ut fra sosiale regler. Alle handlinger, økonomiske eller motivert på andre måter, må forstås ut fra hva aktøren håper på å oppnå, og på bakgrunn av de sosiale strukturene som former handlingene. Det er for eksempel vist hvordan fiskerinæringa er innvevd i lokale sosiale nettverk (Apostle et al. 1998; Jentoft 2001). En lokalt forankret aktør vil, forstått på denne måten, ha omsorg for de menneskene, ressursene og mekanismene som danner grunnlaget for hans eller hennes virksomhet. Med forankring i lokalsamfunnet vil næringsdrivende opptre på en mer bærekraftig måte. Gjennom lokalsamfunnsmedlemskap aktiveres et ansvar for bruk av de lokale fellesressursene som lettere vil gå tapt $\mathrm{i}$ en reint individorientert eller markedsorientert tilnærming. Gran-

Det er viktig å understreke at det ikke er markedet eller tydelige, tunge kapitalinteresser som har iverksatt dette kvotesystemet. Det har den norske staten ved Fiskeridepartementet med en nordnorsk statsråd i spissen stått for. Rett nok sterkt oppmuntret av aktører med store lommebøker innen fiskerinæringa. 
ovetter (1985) advarer mot at tillit også fremmer større muligheter for misbruk - altså at vekst blir viktigere enn å forvalte ressursene fornuftig. I tillegg vil lokale aktører kunne mangle tilgang på ekstern kunnskap og dermed være mindre innovative og markedsorienterte (Saxenian et al. 2007). Dette er ofte brukt i reiselivet som argument for kjedetilknytning og salg til store aktører.

En tredje samfunnsforsker som har vært opptatt av denne problematikken, er Giddens. Mens Polanyi ([1944] 2012) og Granovetter (1985) først og fremst refererte til sosiale relasjoner, har forankringsteorien hos Giddens (1990) også en romlig dimensjon. Avforankring blir mulig gjennom det som Giddens (1990) kaller tid-rom-distansering. Atskillelsen av tid fra rom skaper grunnlag for nye former for sosial aktivitet og nye relasjonsmønstre. Giddens (1990, s. 21) har beskrevet dette som å «løfte ut» samhandling fra sosiale relasjoner og lokale kontekster. Det skjer altså en restrukturering over et uendelig spenn av tid-rom, slik Giddens ibid.) ser det, altså det vi kan kalle globalisering. Tendensen har ifølge Jentoft (op.cit.) også ført til at norske kystsamfunn blir påvirket av ytre trender i mye høyere grad enn tidligere. Sjøl om dette er en situasjon som kan føre til nye muligheter for økonomisk utvikling, kan det føre til bortfall av mange av de tradisjonelle kulturelle og sosiale sidene ved kystsamfunnene i Nord-Norge. Det mest interessante ved Giddens teoretisering av avforankring er kanskje hans fokusering på mulighetene det innebærer for en reforankring. Avforankring er ikke en tilstand som nødvendigvis vil vedvare. Det vil inntreffe nye forankringer, forankring på nye måter og på tvers av tid og rom, slik Mitchell (2013) fant for St. Jacobs. I forhold til kystsamfunn betyr dette at prosessen der fiskeriene avforankres, kan gi rom for nye former for forankring, som for eksempel innen reiseliv. Vi skal i det påfølgende vise prosesser der avforankring i én næring blir fulgt av prosesser med reforankring av andre, men også at ny avforankring synes å skje dersom det reforankrede blir en økonomisk suksess.

\section{Moskenes: finansialisering og motmakt}

Turismen i Lofoten er sentrert rundt en spektakulær natur og et landskap med rorbuer. Rorbuene ble tatt i bruk for turistformål på slutten av 1950-tallet. I det som antakelig var den første nordnorske turismeutredningen, ble det i 1958 tatt til orde for å øke denne bruken. Dette ble 
gjentatt i et "Aksjonsprogram for utbygging av turistnæringa i Lofoten", i 1964. I 1961 fikk Lofoten sin første turistsjef, noe som bidro til mer helhetlig og systematisk markedsføring av regionen. Turistsjef (fra 1964) Terje Henriksen ivret for utvidet bruk av rorbuene i reiselivssammenheng. Han var også sentral i utformingen av det nevnte aksjonsprogrammet. Det var flere av rorbueierne som hadde sett muligheten, og både på Brettesnes, Nesland, Mortsund, Ballstad og Hamnøy var man tidlig ute med mer bevisst satsing på turisme. De fleste som sto for dette, drev også handel, fiskebruk og hadde fiskere boende i buene under lofotfisket. Rorbuene inngikk allerede på 1960-tallet i et samarbeid og solgte seg delvis gjennom reiselivsforeningen og KNA (Kongelig Norsk Automobilforbund). Prisen per rorbu var midt på 1980-tallet 40 kroner per døgn.

'Rorbuer' ble tidlig et begrep som symboliserte en egenartet boform; overnatting i buer som om vinteren eller i tidligere tider hadde vært brukt av fiskere. Tegnene på dette kunne være et forrom eller et hjørne med egnestamper og annet utstyr som fiskerne trengte for å forberede neste dags fiske. At reisebyråene og turoperatørene tok rorbuferie inn i sine programmer, er et første tegn på ekstern innflytelse i rorbunæringa. Rorbuene er seinere blitt interessante for nasjonale investorer. Når rorbuer legges ut for salg, er der en tendens til at folk med økonomiske muskler overtar. Dette er sjelden folk fra stedet. Dette har skjedd med flere av de eldste rorbuanleggene, blant annet i Moskenes. Ved en anledning døde eieren, og hennes sønn, som hadde vært driver i noen år, så seg ikke i stand til å kjøpe ut søsknene - prisen på anlegget var mange millioner. Derfor ble rorbuene lagt ut for salg og kjøpt av en gruppe investorer. De har seinere modernisert buene, som innvending er til forveksling lik nye hytter hvor som helst i Norge. De nye eierne forsøkte å utvikle en tidsdelingsmodell (time share), hvor de som selger hyttene (eller et annet selskap), leier dem tilbake for deler av året, for utleieformål. Tilsynelatende var det ikke marked for dette, og modellen ble forlatt.

Et annet eksempel er når eiere går konkurs. I ett slikt tilfelle fikk en regionbank kontroll over et rorbuanlegg og solgte det til høystbydende. Kjøper var en skipsreder fra Oslo-regionen og en investorgruppe rundt han. De kontrollerer anleggene, men han ansatte lokale drivere med relativ stor handlefrihet. For eierne er det et fristed de bruker en sjelden gang. I et tredje eksempel var nåværende eier flyttet til Oslo-regionen da han arvet stedet. Han drev anlegget på familie- og sommerbasis i noen år, men leide noen år ut fasilitetene til et driftsselskap som drev tilsvarende anlegg andre 
steder. Anlegget har i perioder vært uten lokal ledelse, og rorbuutleien håndteres gjennom et elektronisk booking- og innsjekkingssystem. Bare rengjøringspersonale var da sysselsatt lokalt. Felles for alle de tre anleggene er at kontrollen over utvikling og disposisjoner har gått ut av regionen. Et annet eksempel er fra slutten av 1990-tallet, da man opplevede et målrettet forsøk med fjerneierskap i Lofoten. En gruppe reiselivsaktører med noen investorer i ryggen dannet et selskap som de kalte Top Destination. Selskapet skulle drive reiselivsdestinasjoner etter en forretningsmodell a la hotellkjeder. De skulle sentralstyre og markedsføre de destinasjonene de rådde over, blant annet gjaldt det Kabelvåg og Reine. De sleit fort med lokal aksept og tillit, med drivere som hadde liten råderett i en uferdig organisasjon, og som ikke kjente lokalsamfunnene de var lokalisert til. Selskapet feilet. I ettertid kan man si at det feilet på grunn av at de kanskje ikke tok hensyn til behovet for lokal forankring av selskapene, og at finansialisering ofte er knyttet til en profittfokusering som gjør at man ikke er villig til å betale kostnadene ved å ansette gode drivere, og at investorene ikke var fornøyd med inntjeningsnivåt i reiselivet. Finansialiseringsmodellen i Lofoten er altså som følger: rorbuer som investeringsobjekt og objekter i finansmarkedet for folk som ikke har et røtter i sted og region, en modell som altså teoretikerne mener overser kapitalens sosiale implikasjoner.

En annen trend er at rorbuer som har blitt brukt i reiselivssammenheng, blir gjort om til private hytter eller fritidsboliger. Dette skjer for eksempel når noen $\mathrm{d} ø \mathrm{r}, \mathrm{og}$ barna deler arven gjennom å ta over hver sin eller sine hytter. Dermed splitter de opp arven, og rorbuene omgjøres til private hytter. Dette reflekterer et kjent problem knyttet til generasjonsskifte hvor arveloven presser arvinger til å dele opp eller avhende virksomheter. Slik oppsplitting kan og skje ved at eieren, ved behov for penger, selger rorbuene til private, en for en. Vi fant også et slikt tilfelle under våre feltarbeid i Lofoten. En åpenbar effekt av privatiseringsmodellen er at det er færre hytter i utleiemarkedet i sommersesongen.

Mot disse modellene framstår noen rorbuanlegg som har vært i eierfamiliens hender i generasjoner og er det fortsatt. Og slik mener mange det bør være. Rorbuene er bevart, men modernisert, og fortsatt drevet av folk for stedene. En rorbueier beskriver driften som opp- og nedturer, forhandlinger med bankene og om ulike finansieringsmodeller og modeller for drift, restaurering og modernisering. Eieren har brakt flere av hyttene tilbake til sin opprinnelige form, men satt inn moderne kjøkken og bad. Rorbuene ser utenfra ut som de alltid har gjort, men har høy klasse og høy 
pris. I ett av de tidligere produksjonslokalene var det i 2018 restaurant, og man har flere andre restaureringsprosjekter gående, for eksempel en gammel butikk (landhandel). Det er også et lite museum og en bruktbutikk på anlegget. En fiskeforedlingsfabrikk like ved er fortsatt i drift, og fiskehjeller er en markant del av landskapet rundt rorbuene. Rorbuanlegget har en ny resepsjon. Denne er også resepsjon for flere aktivitetstilbydere. Filosofien til eieren er at jo mer aktivitet, jo mer attraktivt er stedet og rorbuene. Det er flere anlegg som drives etter samme modell i kommunen, også de arvet etter foreldre, i ett av tilfellene en fiskefabrikkeier, en annen var tørrfiskhandler. Begge måtte forlate fiskerisektoren på grunn av gammeldags teknologi og dårlige havneforhold for moderne fiskebåter. Tørrfiskhandleren har forvandlet fasilitetene til et tørrfiskmuseum og bevart og modernisert rorbuene. Disse eierne har åpenbart, også uttalt, et annet grunnlag for sin drift enn bare økonomiske mål. De snakker både om kulturarv, lokale tradisjoner og forpliktelser, og om et ønske om lokal kontroll. De uttrykker også skepsis til utviklinga slik de oppfatter den i noen av de andre anleggene, og mener at fjerneierskapet utarmer miljøet og svekker den lokal forankringa. Det finnes altså en lokalsamfunnsbasert eier- og driftsmodell som kontrasterer finansialiseringsmodellen.

\section{Reforankring i Moskenes: en voksende opplevelsesnæring}

Det er flere entreprenører enn rorbueierne som har vært engasjert i utviklinga av turismen i Moskenes. En av dem er en typisk sosialentreprenør. Han kom til kommunen som lærer, ble skoleleder, men var opptatt både av regionens kulturarv og av avfolkingen. Eieren av et nedlagt fiskeforedlingsanlegg fant ut at han var best tjent med å overlate deler av sine anlegg til kommunen. Skolelederen ble ansatt for å utvikle dette til et museum (i dag Norsk Fiskeværsmuseum). Han hadde mange jern i ilden og sto også sentralt i en tilrettelegging av parkering på det trange stedet. For å sikre arbeidskraft og tilgang på ungdom startet han på slutten av 1980-tallet en reiselivsskole støttet av arbeidskraftmyndighetene. I løpet av noen få år fikk mer enn hundre ungdommer (17-22 år) utdanning innen turisme, mennesker som ofte ble gode ambassadører for kommunen. seinere var han drivkraften bak et årsstudium på universitetsnivå innen bærekraftig turisme. Sosialentreprenøren hadde også etter at han ble pensjonist en fin- 
ger med i ulike prosjekter, for eksempel et som hadde som mål å etablere en nasjonalpark for ytre Lofoten. Lofotodden nasjonalpark ble en realitet i 2019. Entreprenøren har alltid vært en entusiastisk nettverksbygger, flink i markedsføring av sine prosjekter, og ofte lyktes han i å få dem finansiert og gjennomført. Han har bidratt sterkt til at det finnes flere attraksjoner og en moderne reiselivsinfrastruktur i kommunen.

En annen entreprenør selger aktive naturopplevelser: fotturer, kajakkpadling, sykling og ski. Han startet sin karriere som skiboms i Alpene og ble etter hvert guide innen ski og sykling. Han kom til Lofoten for første gang ansatt som sykkelguide for et britisk selskap. Han forelsket seg i området, tok kona si med tilbake for et ferieopphold, og de bestemte seg for å bosette seg i Moskenes Noen år etter drev de en av de viktigste opplevelsesbedriftene i regionen. I sesongen engasjerer de guider, fortrinnsvis nordmenn som mannen kjenner fra sin tid som en guide rundt i Europa og andre steder. Han har også vært medeier i et liknende selskap i Marokko. Guidene han hyrer, driver private firmaer, som han kjøper guidetjenester fra. Dette reduserer administrasjonen. Selskapet måtte ikke vokse for mye, mente han, han ville ikke ende opp som en leder som sitter på kontoret sitt og administrerer folk og penger. Eieren er også selektiv i hvem han samarbeider med; familieeide og lokalsamfunnsforankrede rorbuer er den typen han tilbyr sine kunder.

Moskenes er et lite sted hvor folk kjenner hverandre. Som nevnt har noen av aktørene en klar linje på hvem de samarbeider med, og hvilke verdier de mener skal gjelde for utviklinga. Flere av disse aktørene er relativt unge mennesker, og de er mer eller mindre i samme livssituasjon, flere av dem er tilflyttere som prøver å skape seg et levebrød av sine fritidsinteresser. De utgjør et lite, kreativt miljø eller næringsklynge, som sender kunder til hverandre, hjelper hverandre og møtes privat.

\section{Statles Rorbuer: tradisjon og innovasjon}

Det andre utgangspunktet for folkelig motmakt mot finansialisering og utenfraeie er at lokale aktører har modernisert egen virksomhet og med det klart å holde motstandskraften ved like. Både i Lofoten og i andre distrikter i Nord-Norge har et element i denne moderniseringa vært utvikling av nye former for yrkeskombinasjoner med utgangspunkt i de tradisjonelle primærnæringene jordbruk og fiske (Nilsen 1997, 2002). Et av områdene 
for slik yrkesblanding i Lofoten er turisme. Når vi bruker et begrep som «motmakt», eksemplifisert med delvis vedlikehold av etablerte bruksrettigheter og med nye yrkeskombinasjoner, er det fordi det ser ut til å være sterkere krefter i gang den andre veien, noe som preger så å si alle de viktige nordnorske private næringene (Jentoft, Nergård \& Røvik 2011). Finansielt basert ekspansjon inn i dette næringslivet har sammen med statlige tiltak bidratt til økende avstand mellom næring og sosialt liv.

Statles Rorbuer er imidlertid et eksempel på det motsatte. Det er et lokalt initiert og eid turistanlegg. Den familieeide bedriften er et eksempel på at fiskeriaktiviteter har skapt grobunn for reiselivsutvikling. Starten var at en i familien Statle kjøpte et av fiskebrukene i Mortsund etter andre verdenskrig. Det var gode lofotsesonger og gode markeder for tørrfisk. Statle-eieren hadde som leveregel at i de åra det ble overskudd av drifta, ble det bygd en ny rorbu. Stort sett betød dette en ny rorbu i året. Det var hele seks fiskekjøpere i drift i Mortsund og derfor et lokalt marked for romutleie. Med denne strategien ble inntektene fra de rike naturressursene reinvestert lokalt. Overskudd kan karakteriseres som grunnrentehøsting produksjon og inntjening basert på fiske i nære farvann. Fiskerne leverte til brukseieren i Mortsund. Markedet, de rike naturressursene, fiskernes relativt lave kostnader $\mathrm{i}$ et kystnært fiske med mindre båter og fiskebrukeierens evne til å få overskudd av drifta sikret grunnrenterealisering av naturressursfangsten. Resultatet var vekst i lokal verdiskaping, som ble reinvestert i nye rorbuer rundt fiskebruket.

En viktig impuls for satsing på rorbuturisme som egen virksomhet kom ifølge representanter for Statle-familien fra forsikringsselskapet de var kunde hos, som ønsket et opphold i Lofoten for de viktigste kundene sine. Dette var i 1961. Da hadde familien fătt bygd ut så mange rorbuer at de kunne huse en slik gruppe. Arrangementet var vellykket og omfattet også matservering på fiskebruket som ennå var i drift. Ideen om å bruke rorbuene til mer organisert turismevirksomhet var dermed sådd, og i ettertid kan man si at satsingen lyktes. I 2012 hadde bedriften 64 rorbuer og 40 rom i det gamle, ombygde fiskebruket. De kunne ta opptil tre busslaster av gangen til overnatting og matservering. En blanding av nye og eldre rorbuer finnes rundt kaianlegget med det gamle fiskebruket som sentrum. Familiebedriften omfatter også et trandamperi som fortsatt er i drift. Tranen er på to store tanker godt synlige i landskapet, og det ble fremstilt om lag 400000 liter tran i 2013. Dette er en viktig del av bedriftens inntekter. Trandampingen representerer fortsettelsen av den opprinnelige fiskerivirk- 
somheten og gir bedriften to bein å stå på. Trandampingen og rorbuvirksomheten ga grunnlag for fire helårlige arbeidsplasser i 2012. Etter det har reiselivsvirksomheten bli videreutviklet. Fiskeripreget vedlikeholdes også ved at den nærmeste naboen driver en kombinasjon av lakseoppdrett med slakteri, og tørrfiskproduksjon. Nye fiskehjeller var nettopp satt opp. Driften i begge bedriftene er eksempel på kontinuitet og brudd, og at tradisjon $\mathrm{og}$ innovasjon kan gå hånd $\mathrm{i}$ hånd.

\section{Reforankring i turisme og mangesysleri}

De omfattende næringsendringene som har preget Lofoten de siste tiåra, kan leses ut av et omskapt landskap. Mange endringer kan tas som tegn på det Joseph Schumpeter kalte «kreativ destruksjon»; moderne, standardiserte hytter kalt rorbuer, hoteller, museer og andre reiselivsattraksjoner. Som nevnt innledningsvis identifiserte Harvey (2006) fire tendenser i disse destruksjonsprosessene: privatisering, finansialisering, krisehåndtering og statsregulert redistribusjon. Vår gjennomgang har vist at alle disse tendensene kan spores i turismeutviklinga i Lofoten. Det første punktet, privatisering, gjennom at myndighetene, for eksempel Moskenes kommune, i 2012 var svært lite engasjert i reiselivsutviklinga. Vi fant mange tilfeller av finansialisering, for eksempel i flere rorbuanlegg. Dette er i tråd med de generelle tendensene i nordnorske private næringer (Jentoft, Nergård \& Rørvik 2011). Den finansielt baserte ekspansjonen i næringslivet har sammen med statlige tiltak svekket de nære båndene som tidligere eksisterte mellom næring og lokalt sosialt liv. Rorbukonseptet står svakere enn moderne funksjonalitet og inntjeningsmuligheter. Vi mener også å se en av ulempene av det - altså kreativ destruksjon - i hvordan noen av de eksterne aktørene har utviklet sine rorbuer, standardiserte konsepter og moderne databasert fjernbetjening. «Rorbuer» er for disse aktørene først og fremst en kommersiell retorikk og et objekt i finansmarkedet: I varierende grad er destruksjonen påtakelig. Og trolig representerer tendensen lav kreativitet og innovasjonsgrad.

Et av forholdene som har bevegd rorbuene i denne retningen, er også kriser, for eksempel innen fiskeriene. Behovene for strukturendringer i fiskeriene har framstått som lokale kriser som har tvunget fram endringer, hvor turisme som regel har stått fram som det mest aktuelle alternativet. Noen av endringene kan også tilbakeføres til det fjerde punktet til Harvey 
- statsregulert redistribusjon. Først og fremst har det skjedd gjennom å favorisere andre typer fiske enn det som tidligere kjennetegnet næringa, altså overgang til større og havgående fiskebåter. Dermed har fisket mistet noe av sitt fotfeste i Lofoten, og folk har måtte finne seg annet arbeid. Det har de blant annet funnet i reiselivet. Noen - som Statle-familien i Mortsund - har klart å kombinere de to feltene, noe som viser at tradisjon og innovasjon ikke behøver å være motsetninger. Slik utviklinga har vært i Lofoten, er det vanskelig å påstå at det generelt sett har foregått en kreativ destruksjon. Med utgangspunkt i rorbuer og annen historie er det skapt mye nytt, regionen har blitt modernisert, i tråd med den generelle samfunnsutviklinga. Vi kan altså se det samme som Mitchell (2013) har funnet i sine studier, en prosess som sies å være karakterisert av kreativ fornying eller konstruksjon, om man vil.

Omstillingen i Lofoten kan også ses i lys av en av teoriene til den andre klassiske nasjonaløkonomen vi har introdusert, Karl Polanyi. Omstilling av næringslivet er flere steder forankret i familie- og lokalsamfunnsrelasjoner og i et verdigrunnlag som omfatter mer enn krav til profitt. Vi har funnet flere varianter av dette. Først og fremst er det rorbuanlegg som har blitt renovert, og kulturarv som er gjort om til attraksjoner. Dernest har vi fokusert på en bedrift som gradvis ble omstilt fra fiskeri til fiskeri kombinert med turisme. Det er blitt en tidsmessig mønsterbedrift som gjenspeiler en utvikling preget både av moderne tilpasning og motmakt. Her har man stått imot finansialiseringfristelsene. I stedet er tradisjonelle bruksrettigheter i noen grad vedlikeholdt i nye yrkeskombinasjoner. Det sosiale livet som følger av en utvidet reiselivsnæring, rommer nyinnflyttede og pendlende mennesker, men preges også av nye impulser og innovasjon. Turismen er en global næring, med mange tråder inn i lokale kontekster. Flere av disse trådene har brakt inn innovative mennesker. Lenge savnet man en entreprenørskapsånd i regionen. Lite skjedde ut over rorbudrift. Dette har altså endret seg. Båndene mellom de «nye» menneskene og de som representerer tradisjonene, gjør at det som skjer i dagens reiseliv, kan karakteriseres som reforankringsprosesser. Eksternt etablert kompetanse kombineres med lokal forankring til en helhet som gjør at Lofoten framstår som en komplett reiselivsdestinasjon, der man tjener penger både på overnatting, bespisning og opplevelser, ikke bare overnatting i rorbuer, slik det var tidligere. Men de sosiale båndene som skapes, går i våre dager like mye ut av som inn mot lokalsamfunnene for øvrig. Lofoten er i så måte gjenstand for allmenne globaliseringstendenser, på godt og ondt. 


\section{Konklusjon}

Vi har i kapitlet også vist hvordan eksterne aktører med tilgjengelig kapital kommer inn og utnytter de stedlige lofotfortrinnene gjennom å investere i rorbuer og andre virksomheter, uten forankring. I flere tilfeller har dette gått galt - aktørene har ikke lykkes og har trukket seg ut. Men noen har fătt det til, og i noen av tilfellene fordi de har ansatt ledere med lokal forankring. Våre funn er i tråd med Polanyis skepsis til varegjøringen og Granovetters idé om at også økonomiske entreprenører er sosiale aktører. For noen er dette relativt åpenbart, for andre kan det fortone seg som et paradoks, altså at økonomiske systemer og verdier er basert på sosiale systemer. Dette tilsier at en fullstendig finansialisering ikke har skjedd og kanskje heller ikke vil skje, så lenge Lofoten er en region av småsteder. Lokalsamfunnene er komplekse, og kompleksiteten er nedfelt i lokale tradisjoner og globale nettverk. Det er et sosialt system hvor det å rendyrke profittmaksimering som forretningskonsept kan være vanskelig. Men som vår analyse har vist, finnes det også annerledestenkende aktører, som dyrker verdier knyttet til tradisjoner og lokalsamfunn. Turismevirksomhet er mer enn forretning og forrentning, det er også forvaltning av samfunnsrelasjoner og rotfestet samfunnsansvar.

\section{Litteratur}

Apostle, R.A., Barrett, G., Holm, P., Jentoft, S., Mazany, L., McCay, B. \&

Mikalsen, K. (1998). Community, state, and market on the North Atlantic rim:

Challenges in the fisheries. Toronto: University of Toronto Press. https://doi.org/10.3138/9781442673151

Bianchi, R. V. (2009). The 'critical turn' in tourism studies: A radical critique.

Tourism Geographies, 11, 484-504.

https://doi.org/10.1080/14616680903262653

Cruickshank, J. (2009). A play for rurality - Modernization versus local autonomy. Journal of Rural Studies, 25 (1), 98-107. https://doi.org/10.1016/j. jrurstud.2008.06.005 
Giddens, A. (1990). The consequence of modernity. Cambridge: Polity Press.

Granovetter, M. (1985). Economic action and social structure: The problem of embeddedness. American Journal of Sociology, 91, 481-510.

https://doi.org/10.1086/228311

Harvey, D. (2006). Spaces of global capitalism. London: Verso.

Hess, M. (2004). 'Spatial' relationships? Towards a reconceptualisation of embeddedness. Progress in Human Geography, 28, 165-186. https://doi.org/10.1191/0309132504ph479oa

Jentoft, S. (2001). Røtter og vinger. Kystkulturen i globalsamfunnet. Stamsund: Orkana Forlag.

Jentoft, S., Nergård, J.-I. \& Røvik, K. A. (red.) (2011). Hvor går Nord-Norge? Tidsbilder fra en landsdel i forandring. Stamsund: Orkana Akademisk.

Mitchell, C. J. A. (1998). Entrepreneurialism, commodification and creative destruction: a model of post-modern community development. Journal of Rural Studies, 14, 273-286. https://doi.org/10.1016/S0743-0167(98)00013-8

Mitchell, C. J. A. (2009). Revisiting the model of creative destruction: St. Jacobs, Ontario, a decade later. Journal of Rural Studies, 25, 156-167.

https://doi.org/10.1016/j.jrurstud.2008.09.003

Mitchell, C. J. A. (2013). Creative destruction or creative enhancement? Understanding the transformation of rural spaces. Journal of Rural Studies, 32, 375-387. https://doi.org/10.1016/j.jrurstud.2013.09.005

Nilsen, R. (1997). Fjordfiskere og ressursbruk i nord. Oslo: Ad Notam, Gyldendal.

Nilsen, R. (2002). Makt og motmakt på kysten. Makt og demokratiutredningen. Rapport nr. 45. Oslo: Universitetet i Oslo.

Polanyi, K. (2012 [1944]). Den liberale utopi. Oslo: Res Publica.

Saxenian, A. L. (2007). The new argonauts: Regional advantage in a global economy. London: Harvard University Press.

Viken, A. (2011). Naturbasert turisme i nord. Ytre påvirkning - lokal tilpasning. I S. Jentoft, J.-I. Nergård \& K. A. Røvik (red.), Hvor går Nord-Norge? Tidsbilder fra en landsdel i forandring (s. 175-188). Stamsund: Orkana Akademisk.

Viken, A. (2014). Destination discourses and the growth paradigm. I A. Viken \& B. Granås (red.), Tourism destinations development. Turns and tactics. Farnham: Ashgate. 


\section{Lofoten: rorbuer, rorbuferie og turistindustri}

Lofoten er blant Norges fremste reisemål. Den mest systematiske gjennomgangen av regionens turisme gjennom tidene finnes i en hovedoppgave i historie (Fossum 2000), som er hovedkilden for denne beskrivelsen. Da turismen gjorde sitt inntog, hadde man i Nord-Norge allerede tradisjoner for å håndtere reisende, særlig da på storgårder og handelssteder. I 1838 begynte man å trafikkere strekningen Bergen-Hammerfest med dampskip (Kleppa (https://leksikon.fylkesarkivet.no/ article/53ec17c3-90df-455e-95b4-e2079ac40088/)), noe som innvarslet en ny tid. Den nye transportteknologien som etter hvert også omfattet jernbanen - Ofotbanen mellom Narvik og Kiruna sto ferdig i 1902 - beredte grunnen for den første turistbølgen innover landet, en bølge som også rakk helt opp til Nord-Norge. I kjølvannet av romantikken ble Lofoten fort anerkjent som et vakkert og spesielt reismål, og her som andre steder bidro ulike typer kunstnere til markedsføringen av området: Bjørnstjerne Bjørnson, Christian Krohg, Jonas Lie, Knut Hamsun, Theodor Kittelsen, Thorolf Holmboe og ikke minst den lokale maleren Gunnar Berg ytte alle sine bidrag til å gjøre Lofoten kjent (ibid. s. 28). Men Lofoten ble også markedsført av reisebyråer, turoperatører og reisehåndbøker (ibid. s. 30). Lofoten var først og fremst et turistmål hvor man tok seg fram med båt, og cruiseturismen var derfor lenge den viktigste. Derfor er kanskje etterkrigstidas turismehistorie den mest interessante i Lofoten, særlig på grunn av den populariteten og utbredelsen rorbuturismen fikk. Forutsetningen for denne var at Lofoten tilpasset seg bilismen, først med et omfattende nett av ferger og veier, dernest også av broer og tunneler som binder øyene sammen. I 2007 blir på en måte prosjektet ferdigstilt - fastlandsforbindelsen ble åpnet. I tillegg viser kanskje også tilfellet Lofoten betydningen av at reiselivet er organisert. Mye av utviklinga sprang ut av planer 
utviklet av reiselivsorganisasjoner, og prosjekter mer eller mindre i regi av det offentlige. Det startet på 1960-tallet.

På den tida fantes det hoteller eller gjestgiverier på de største stedene, og rorbuene rommet 13 000-14 000 senger. Man begynte å ta disse i bruk for turistformål på slutten av 1950-tallet. I en turismeutredning fra1958 og et aksjonsprogram fra 1964, ble det tatt til orde for å øke denne bruken (Fossum 2007, s. 39).I 1961 fikk Lofoten sin første turistsjef, noe som bidro til en mer helhetlig og systematisk markedsføring av regionen, og ikke minst turistsjef (fra 1964) Terje Henriksen ivret for utvidet bruk av rorbuene i reiselivssammenheng. Han var også sentral i utformingen av det nevnte aksjonsprogrammet. Det var flere av rorbueierne som hadde sett poenget og som bevisst satset på turisme, sjøl om de fleste som sto for dette, også drev handel, fiskebruk og hadde fiskere boende i buene under Lofotfisket (ibid., s. 56-57). Rorbuene inngikk allerede på 1960-tallet i et samarbeid og solgte seg delvis gjennom reiselivsforeningen Kongelig Norsk Automobilforbund (KNA). Prisen per rorbu var midt på 1980-tallet kroner 40 (ibid., s. 57).

Til å begynne med var det «rorbucamping» som ble tilbudt, og ordet «rorbuferie» ble trolig ikke brukt før på 1970-tallet. Men rorbuene ble tidlige et begrep som symboliserte en egenartet boform; overnatting i buer som om vinteren eller i tidligere tider har vært brukt av fiskere. Reisebyråene og turoperatørene tok rorbuferie inn i sine programmer midt på 1960-tallet, blant annet var Bennett tidlig ute, men også svenske Reso hadde rorbuferie på sitt program alt i 1964 (ibid., s. 58). Lokalt utviklet man den første rorbubrosjyren i 1965. På slutten av 1960-tallet ble rorbutilbud inkludert i katalogene til Norsk Hytteformidling og inngikk i nasjonalt produserte brosjyrer som ble trykt på tre språk (ibid., s. 59).

Omfanget av rorbuturismen var kanskje ganske beskjeden i starten. I 1964 rommet rorbuene bare cirka 3000 av de 41000 
kommersielle sommerovernattingene i regionen, tre år etter 10000 av 50 000, dette ifølge statistikken. Men rorbusuksessen er først og fremst av nyere dato. I 1999 rommet rorbuene cirka 118000 av i alt cirka 250000 overnattinger på årsbasis i regionen (Viken 2001). Men rorbuferie er blitt et begrep som har god klang, og på mange måter gjenspeilte trafikken rundt tusenårsskiftet kapasiteten i regionen.

Turismeutviklinga i Lofoten er først og fremst et resultat av en natur og et naturlandskap som gitt dagens normer framstår som relativt unik. Det er også et eksempel på at kommunikasjoner, organisering og planmessig arbeid gir resultater. Kanskje er det imidlertid først og fremst et eksempel på betydningen av å skaffe seg et godt image, eller det man i dag kaller merkenavn. Både Lofoten som reisemål og rorbuene som overnattingsform er kjente begreper. Uten de mange budbringerne hadde man trolig ikke lykkes i samme grad. Tross alt er det områdets omdømme i markedet - blant potensielle turister - som er den viktigste grunnen til at tre til fem hundre tusen besøker området hvert år (jf. Viken, Evjemo, Akselsen \& Hansen 2004).

Lofoten er også blitt et viktig reisemål for de cruisene langs norskekysten som strekker seg til Tromsø og Nordkapp (Sletvold 2016). Denne trafikken representerer et delvis separat utviklingsløp og bringer med seg store grupper turister - anslagsvis 60 000-70 000 - som kommer i tillegg til den landbaserte ferdselen. Man kan se tendenser til fortrengningsvirkninger mellom de to delene av turismen, fordi cruiseturistenes attraksjonsbesøk gjerne er planlagt og avtalt flere år i forveien, noe den øvrige sommerturismen ikke er. De fleste cruiseanløpene skjer på Leknes, sentralt for halv- og heldags turer til attraksjoner og landskaper i resten av Lofoten. Cruiseturismen er avhengig av nitid planlegging og bruk av et stort antall guider og busser, der forarbeidet gjøres av en lokal entreprenør og agent, som i samarbeid med sentrale nasjonale aktører har bygd opp trafikken over de siste 
par tiåra. For mange forholdsvis små bedrifter gir cruisebesøkene en økonomisk langsiktighet og relativ trygghet som de ellers vanskelig kunne oppnå. På den annen side har de vært gjenstand for strenge, standardiserende kvalitetskrav fra cruisenæringa, krav de sjøl mener har vært til fordel for driften, samtidig som de har vært utsatt for et sterkt prispress (Sletvold 2016). Et bevisst lokalt samarbeid i møte med cruisebransjen har vært bevissthetsskapende og har bidratt til den suksessen man mener å ha hatt.

\section{Litteratur}

Fossum, H. (2000). Utror og in-sted. Reiseliv og reiselivsorganisering i Lofoten 1960-1995. Hovedoppgave i historie. Institutt for historie. Tromsø: Troms $\varnothing$ universitet.

Sletvold, O. (2016). Cruise i Lofoten. I A. Viken (red.), Turisme. Destinasjonsutvikling. Oslo: Gyldendal.

Viken, A. (2001). Turismeutvikling i Lofoten. I A. Viken (red.), Turisme. Tradisjoner og trender. Oslo: Gyldendal. Viken, A., Akselsen, S. Evjemo, B. \& Hansen, A.A. (2004). Lofotundersøkelsen 2004. FoU R 27. Oslo: Telenor. 



\section{DEL III: REISELIVET I SAMFUNNSUTVIKLINGSPROSESSER}





\section{HURTIGRUTEN SOM DESTINASJONSKATALYSATOR}

Arvid Viken

\section{Innledning}

Øst for Nordkapp ligger Nordkyn, halvøya hvor Norges og Europas nordligste fastlandspunkt, Kinnarodden, befinner seg. Det er strabasiøst å ta seg fram til Kinnarodden, og det er et reisemål for de veltrente og spesielt interesserte. Halvøya som sådan har imidlertid i noen tiår hatt en viss sommerturisme på grunn av sin beliggenhet og som en spinoff av nordkapptrafikken. Dette bildet har imidlertid endret seg noe. I dag er halvøya også ilandstigningssted for hurtigruteturister som blant annet tilbys en overlandstur mellom Kjøllefjord og Mehamn, om vinteren med en innlagt snøskutertur, om sommeren med et besøk i en sameleir. I dette kapitlet vil vi ta for oss utviklinga mellom 2006 og 2018. Det dreier seg om en svært liten destinasjons tilblivelsesprosess. Hurtigruten har vært sentral i denne prosessen, som initiativtaker, innspiller, inspirasjon og institusjon. Selskapet skiftet strategi tidlig på 2000-tallet og gjorde vinteren om fra lav- til høysesong. Til det trengte man nye aktiviteter i land. I Kjøllefjord svarte man på invitasjonen som selskapet hadde sendt ut, og ballen begynte å rulle. I kapitlet skal vi se nærmere på prosessen, produktene, aktørene og utfordringene dette har gitt.

Det er mange måter å betrakte Hurtigrutens rolle på. Hurtigruten er en av de største aktørene i norsk reiseliv. Selskapet har siden slutten av 
1800-tallet seilt langs kysten mellom Bergen og Kirkenes - for tida med elleve skip. «Hurtigruta» var «lokalbåt» og langtransportør, viktig for persontrafikken og for vareforsyningene mellom nord og sør og mellom de mange stedene langs kysten. I de siste tiåra av det 20. århundret ble den sommerlige turisttrafikken en stadig viktigere del av virksomheten. I perioden fram mot 2010 ble det også satt fokus på vinterturismen, noe man lykkes med. I dette arbeidet har også nye reiselivsprodukter og destinasjoner på land blitt utviklet. Derfor er turismen blitt langt viktigere i mange av Hurtigrutens havner. En av dem er Kjøllefjord. Hurtigruten har vært en stimulator, en katalysator, en innovativ pådriver og en sosialiserende kraft i prosessen. Jeg velger her å benytte begrepet «katalysator». En slik betegnelse har vært brukt i liknende sammenhenger før (Moscardo 2014; Viken \& Granås 2014). En katalysator er en aktør med hovedfokus på egen virksomhet, men som i sitt arbeid drar med seg andre, som viser vei og/eller setter standarder gjennom å lykkes med å rekruttere turister (Moscardo 2014). En katalysator bringer impulser utenfra inn i lokale prosesser. I en turismeproduksjon oppstår ofte behov som best kan dekkes av andre aktører. Altså vil den enes initiativ eller innovasjon kunne gi arbeid og inntekter også til andre, som underleverandører. Når Hurtigruten satset på vinterturisme, tok selskapet ansvar for også å utvikle opplevelsestilbud i land. En side ved katalysatorrollen er at man mer eller mindre tilsiktet forventer at vellykkede satsinger blir kopiert eller imitert. Det har for eksempel skjedd innen nordlysturismen i Tromsø (Heimtun \& Viken 2016). Ofte skaper en satsing aktiviteter også i tilstøtende næringer (Sharif \& Lonik 2014). Det kanskje mest interessante ved slike katalysatorer er derfor hvilke prosesser som følger i kjølvannet av deres inntreden, for eksempel i form av tro på at det er mulig å få til noe, og som idéstimulator. Katalysatorer er imidlertid ikke det samme som fasilitatorer. En fasilitator er en tilrettelegger, en som gir råd eller finansiell støtte, eller utvikler nødvendig infrastruktur (Ateljevic \& Doorne 2000). Bak innovasjoner står det gjerne både katalysatorer og fasilitatorer.

I dette kapitlet analyseres det som skjedde i prosesser der en liten turistdestinasjon ble til. Det dreier seg om næringsutvikling der nye produkter skapes for salg i et marked, basert på lokale ressurser, i dette tilfellet vinterforhold og samisk kultur. Dette har skjedd på et sted hvor man tradisjonelt og fortsatt har et sterkt fokus på fiskerier. Det sies at slike ensidige ressursbaserte og eksportbaserte industrier ikke er ideelle omgivelser 
for utvikling av ny lokal næringsvirksomhet (Carson \& Carson 2017). Likevel har noe skjedd i Kjøllefjord, om enn i liten målestokk, ved hjelp av Hurtigruten, som sjøl må sies å representere ressursbasert eksport - selskapets forretningsområde er salg av norsk natur og kultur, og i tillegg noe varetransport. Vi skal ha fokus på forholdet mellom det store skipsrederiet og et lite lokalsamfunn som rommer noen entreprenører som hadde sett muligheter i reiselivet.

Analysen knytter an til økonomisk geografi og det man der kaller utviklingsgeografi, der fokus er på entreprenører, institusjoner, gamle vaner og relasjoner. Etter presentasjonen av denne tilnærminga skal forholdet mellom store og små bedrifter drøftes. De store er «motorene» i reiselivsutviklinga, sies det ofte. Jeg skal dvele ved denne motorkraften gjennom presentasjon av en casestudie. Resultatene deles i to seksjoner: en som drøfter utviklingsfasen, og en som vurderer dynamikken på stedet og relasjonene internt og eksternt. I diskusjonen peker vi på skjørheten i systemet og argumenterer for at man må skape større uavhengighet til den store eksterne samarbeidspartneren, og at den - sammen med sine institusjonelle kontakter - kanskje bør gjøre endringer som vil gjøre turismen både større og mer bærekraftig på Nordkyn.

\section{En teoretisk ramme: et evolusjonsperspektiv}

Analysen er som nevnt inspirert av evolusjonsøkonomisk geografi (Bathelt \& Glückler 2005; Brouder, Clavé, Gill \& Ioannides 2017). Flere har argumentert for at perspektivet er særlig egnet til å studere hvordan destinasjoner endrer seg over tid (Brouder \& Eriksson 2013a; Ioannides \& Petersen 2003). Med dette som bakgrunn argumenterer Sanz-Ibáńez og Clavé (2014) for og demonstrerer nytten av å forstå utvikling i lys av forhold som menneskelig handlingsvalg (buman agency), institusjonalisering (som de også kaller contextuality) og sporavhengighet (path dependency). Dette er grove kategorier, men de har vist seg anvendelige også i forståelsen av destinasjonsutvikling i Norge (Heimtun \& Viken 2016). Deres «modell» er også inspirert av andre fag som sosiologi og mikroøkonomi, der atferd på individnivå og entreprenørskap er kjente temaer.

Menneskelig handlingskraft kan observeres gjennom individuelle og kollektive handlinger. Handlingskraften er ofte en av årsakene til ulike utvi- 
klingsløp (Sanz-Ibáñez \& Clavé 2014, s. 571) og henspiller på hvor viktige entreprenører har vært i mange destinasjons- og attraksjonsutviklingsprosesser, som for eksempel i Nord-Norge (Viken 2011). Destinasjonsutvikling preges av hvilke aktører eller miljøer som driver fram eller mobiliseres i prosessene. Entreprenørskap er viktig i denne sammenhengen. Entreprenører er mennesker som har skapt «en virksomhet for å tjene penger eller for å dyrke en interesse og som utnytter en oppfattet markedsmulighet» (Koh \& Hatten 2002, s. 25). Ofte fokuserer man på «entreprenørskap», fordi entreprenørene sjelden opptrer aleine og er avhengige av sin kontekst for å lykkes. Komppula (2014) viser at tilpasningsdyktige småbedrifter og støttende kommuner er forutsetninger for vellykket destinasjonsutvikling. Andre har vist hvordan det også finnes slike entreprenører både innen store bedrifter og i det offentlige, gjerne omtalt som sosialentreprenører (se Santos 2012).

Entreprenørskap innen turismen, for eksempel i resortutvikling, krever mye og varierende kunnskap, og i særdeleshet praktisk erfaring (Viken 2014). Det er et lite skriptet arbeidsfelt. Deres kunnskap er det de gjør, snarere enn noe de har, sier Valtonen (2010) om dette. Dermed setter entreprenørene ofte sitt preg på produktene de utvikler. I reiselivet er det også tendenser til at små entreprenører mer eller mindre er produktet eller «produksjonsteknologien», det er de sjøl som er den gode fortelleren, eller som har alle kontaktene som gjør at de får ting til. Arbeidet tenderer da mot å bli en livsstil, og det er ofte flytende overganger mellom fritid og arbeid (Valtonen 2010).

Det er gjort mange forsøk på å utvikle en typologi for entreprenørskap. Schumpeter gjorde det på 1930-tallet, og i våre dager har dette også vært gjort i turismesammenheng. Koh og Hatten (2002) har for eksempel utledet følgende kategorier: inventive eller nyskapende entreprenører, innovative entreprenører som skaper ny virksomhet basert på kjente modeller, imitative entreprenører som etteraper andre, sosiale entreprenører som skaper ikke-forretningsmessige foretak (som for eksempel et museum), livsstilsenterprenører som lager forretning av en spesiell interesse, ferdighet (som hundekjøring) eller bostedsønske (Ioannides \& Petersen 2003), marginale entreprenører som befinner seg i gråsonen mot forretning (som hjemmebakeri eller suvenirsalg), deltidsentreprenører som har en fast jobb ved siden av (som hytteutleie på gård), og oppstarts- og serieentreprenører. Det er ikke vanskelig å finne disse igjen i nordnorsk reiseliv. Entrepre- 
nørene har ulik kunnskap og erfaring og utvikler derfor ulike produkter. Dette bidrar til at destinasjonene framstår som sammensatte og forskjellige. Forskningen har også hatt fokus på hvordan entreprenører samhandler. På små steder synes det ofte å være en nødvendighet; de står hver for seg for smale produktelementer som til sammen utgjør den helheten som tilbys turistene. Overnatting, bespisning, opplevelser og transport er ulike bransjer, og de er ofte håndtert av ulike bedrifter. Hvordan relasjonene er, vil variere, men aktørene utgjør nesten alltid mer eller mindre formelle nettverk (Koh \& Hatten 2002). Ofte vil disse nettverkene ha tråder ut til større eksterne nettverk og globale systemer (Saarinen 2004; Thomas, Shaw \& Page 2011). Dersom det i en destinasjon også befinner seg en eller flere store bedrifter, vil relasjonene bli annerledes, med en tendens til en hierarkisk nettverkverksstruktur. Slike strukturer representerer muligheter, men kan skape uheldig avhengighet. Vi skal komme tilbake til dette.

Entreprenørånden er ofte ikke bare fundert i økonomi. Forskningen har vist at det særlig gjelder småbedrifter, og at det er utbredt i perifere områder (Ioannides \& Petersen 2003). Man driver på for å overleve eller for å dyrke en interesse eller verdi. Spesialinteresse, livsstil, familiedrift og ideologi er kjente ikke-kommersielle motiver for entreprenører i reiselivet (Thomas, Shaw \& Page 2011). Det har vist seg at ikke-kommersielle entreprenører er lite vekstorientert, noe som kan være et problem for samarbeidende bedrifter med vekstønsker. Ofte er de heller ikke veldrevne i konvensjonell forstand. De investerer ikke ut over de midlene de sjøl rår over, de har ikke langsiktige planer eller nitid økonomistyring, hevdes det, og ofte er det aktører som har slengt seg på en trend - på noe de ser andre tjener penger på (Ioannides \& Petersen 2003). Det hevdes derfor at majoriteten av disse firmaene ikke egentlig er entreprenørielle i økonomisk forstand (Getz \& Paterson 2005). Både aktørene og nettverk av slike bedrifter vil ofte være skjøre, andelen som overlever sine først to år, er relativt lav (Li 2008). Men småbedriftene er ikke desto mindre i flertall innen reiselivsnæringa.

Sanz-Ibánez og Clavés (2014) andre hovedforklaring på utvikling er institusjonell kontekst. Institusjoner er nedfelt i folks måter å tenke på, som tidsånd og «elementer som muliggjør og begrenser stakeholdernes strategiske valg i gitte situasjoner» (ibid., s. 571). Som en del av dette inngår aktørers systemkunnskap, norm- og verdifellesskap og tilhørighet, men også organisering og fysisk materialisering. For eksempel muliggjør aktører og allianser strategier for realisering og finansiering av utviklingsprosjek- 
ter, både på destinasjons- og attraksjonsnivå. Lofotr Vikingmuseum og Alta museum (et helleristningsmuseum) er eksempler på utvikling drevet fram av aktører med god systeminnsikt og som inngikk riktige og viktige allianser (Viken 2001). Det hevdes også at institusjonell tykkelse (Amin \& Thrift 1995) er en sentral forklaring på ulike utviklingsforløp. Enkelt sagt henspiller begrepet på hvor mange og solide institusjonene er. «Institusjonell tykkelse har betydelige implikasjoner for organiseringa av turismen og for forståelsen av hvordan produksjonen av en 'lokal' destinasjonsidentitet skapes», hevder Dredge og Jenkins (2003, s. 387). Videre sier de at "tykkelse' skaper legitimitet, og kollektive holdninger, og den stimulerer til deling av kunnskap om og utvikling av gjensidig tillit og felles siktepunkt» (ibid.). Et sentralt institusjonelt og mye omdiskutert element i reiselivet er næringas territorielle organisering, destinasjonsselskapene. Slike selskaper er bindeledd mellom og møteplass for aktørene i reiselivet. Mange steder i Nord-Norge har man slitt med å få dem på plass (se Viken \& Svensson 2016), og legitimiteten har ofte vært lav. Dette gjelder særlig mindre steder, slik som Nordkyn.

Det tredje elementet hos Sanz-Ibáñez og Clavé (2014) er sporavhengighet, både som en form for beskrankning eller innelåsthet (lock-in) og som et fasiliterende element. Norsk turisme har i hovedsak vært basert på ressursmessige forutsetninger knyttet til natur. Lenge tenkte man at det var nok at slike fellesgoder eksisterte, at de ikke trengte foredling. Turistene kom for å oppleve norsk natur, rå og uforedlet. Denne holdningen førte til lav foredlingsgrad og at vinteren forble lavsesong. Først i våre dager har man kommet ut av dette sporet og økt foredlingsgraden - og skapt en vinterturisme. Sporavhengighet kan også føre til stagnasjon eller at man suger for lenge på karamellen, slik det antydes om den nordfinske turismen (Kajan \& Saarinen 2014). I ressursene som skaper sporavhengighet, ligger imidlertid også kimen til nyorientering og produktutvikling. Derfor omhandler teorifeltet også sporkreasjoner og sporplastisitet (Strambach \& Halkier 2013). Man kan altså vende sporene i nye retninger. Dette skjer når gamle og stivnede destinasjoner reorienterer seg og skaper ny utvikling.

I tillegg til det som er nevnt, framhever evolusjonsgeografene betydningen av relasjoner. Relasjoner inngår som forutsetninger i teorier om nettverk, forankring, gjensidighet og tillit, men dreier seg om hvordan dynamikken mellom aktører ofte fører til prosesser som de hver især ikke ville ha utviklet. For eksempel oppstår og utvikles ideer ofte i dialog. Men- 
nesker møtes og skaper noe sammen. Det er mange eksempler på dette innen norsk reiseliv. Et eksempel er Lyngsfjord Adventure, som ble til etter at tre aktører ble enige om å satse sammen (Viken \& Svensson 2016). Ofte vil et nytt blikk på et område bringe fram nye ideer om hvordan det kan brukes. Målselv Fjellandsby, en alpin vinterdestinasjon, ble til etter et møte om utvikling av sommerturisme (Viken 2014a). Som vi skal se, har møter og relasjoner vært sentralt i utviklinga av Nordkyn som destinasjon.

Denne teoretiske modellen gir altså fire hoveddimensjoner for analysen: betydningen av menneskelige handlingsvalg, institusjonaliseringsprosesser og sporavhengighet samt samspillet mellom disse faktorene. Modellen angir en grov teoretisk ramme, en bakgrunn for å forstå utvikling. I analysene vil vi også tangere eller anvende modeller og begreper som representerer tunge alternative tilnærmingsmåter til studier av utvikling (jf. Brouder \& Eriksson 2013a). Innovasjon, kunnskap og nettverk er eksempler på tilnærmingsmåter som ikke brukes eksplisitt, eller i full tyngde i denne analysen.

\section{Store og små bedrifter}

Forestillingen om at stordrift og vekst gir de beste resultatene i forretningsverdenen, står sterkt (Viken 2014b). Storskala operasjoner omtales ofte som fordistisk produksjon (Amin \& Thrift 1995). Fordisme er preget av masseproduksjon, hierarkisk styring, sentralisert styring (administrert fra utsiden), en nasjonalt regulert økonomi (ekstern eierskap), et smalt spekter av produkter, bransjebestemte produkter (bestemt av turoperat $\varnothing$ rer og hotellkjeder) og en konsentrert produksjon (Ioannides \& Debbage 1997; Lafferty \& Fossen 2001). Innen turisme er en spesialisert pakketur et typisk fordistisk produkt. Undersøkelser har imidlertid vist at storskala operasjoner ofte gjør vei for en konkurrerende og mindre anlagt reiselivsnæring (Viken \& Aarsether 2012; Ioannides \& Debbage (1997, s. 231). Og mange av dem som framstår som mindre, er det fordi de ikke (så langt) har lykkes i å bli større. Reiselivsbedriftene i Norge er stort sett små.

Sjøl om motrøstene til stordriftstenkningen finnes, er det en massiv skepsis mot små bedrifter (se Ateljevic \& Doorne 2004; Morrison \& Teixeira 2004; Thomas, Shaw \& Page 2011). (Se kapittel 3 i denne boka.) I Norge finner man store og små reiselivsbedrifter side om side. Det er 
ikke nødvendigvis noen motsetning mellom små og store bedrifter og det at de strategisk sett bør ses i sammenheng. Småbedriftene er som regel en del av store selskapers nettverk: Flyselskapene, kredittkortselskapene, turoperatørene og andre som inngår i reiselivssystemet, er også viktige for småbedriftene. For det andre ligger ofte små og store bedrifter side om side, de konkurrerer og samarbeider og betjener til dels samme, til dels forskjellige markeder. Hva er det så de store bedriftene katalyserer? For det første er det ideer, ideer om produkt- og markedsmuligheter - impulser fra internasjonale markeder. For den andre kan de representere et finansielt fundament, ofte en innsats som er liten for den store aktøren, men stor for den lille. For det tredje representerer de profesjonalitet og krav om kvalitet. For det fjerde har store selskaper en posisjon i markedet som gjør at de kan ofte kanalisere sine kunder i retning av mindre selskaper som tilbyr opplevelser. Hotellene gjør ofte det, cruiseskip likeså. Og sist, men ikke minst representerer de store makt, som kan settes inn mot en tredje part, for eksempel en finansieringskilde som Innovasjon Norge.

\section{Metode}

I arbeidet med dette prosjektet er relativt velkjente metoder blitt brukt. Arbeidet har vært organisert i tre faser. I første fase ble problematikken gjenstand for litteraturstudier og orienteringsarbeid på internett. I neste fase ble stedet i fokus besøkt, og det ble foretatt intervjuer med nøkkelinformanter knyttet til bransjen. De to viktigste lokale entreprenørene ble intervjuet, to offentlig ansatte, en kulturansatt, samt kortere samtaler med tre andre aktører i reiselivet. Konturene av stedet og reiselivet ble klarere, og ideen om hva som skulle bli fortellingen fra stedet, begynte å ta form. For eksempel ble det relativt klart at det er et veldig ujevnt maktforhold i relasjonen mellom Hurtigruten og lokalsamfunnet, og at dette burde fokuseres i den videre datainnsamlingen. En annen erkjennelse var at reiselivet også burde ses fra lokalsamfunnets ståsted. Derfor ble det ved hjelp av lokalkjente organisert fire fokusgruppeintervjuer (samtaler), en med ungdom (fem deltakere), en med pensjonister (fire deltakere), en med offentlige ansatte (tre deltakere) og en med næringslivsrepresentanter (fire deltakere). Gruppesamtalene fant sted i kommunens rådhus. Kommunens karakter og utvikling, næringsarbeid, og dernest reiselivets rolle, aktører og 
arbeid i bygda, var temaer. Til sist ble det foretatt en rundreise i området, der samtaler med tilfeldige mennesker ble gjennomført, alle med fokus på reiselivsutviklinga. I tillegg er Hurtigrutens produktutvikler og interne entreprenør intervjuet. All datainnsamling skjedde i løpet av en firemånedersperiode vinteren og våren 2017.

Dataene er brukt til å bygge opp fortellingen om tilblivelsen av en liten destinasjon. Plottet er kronologi, og fokus er på institusjonelle forhold, entreprenørskap, stiavhengighet og relasjoner, ut fra den teoretiske forankringen som er valgt. Fortellingen er skapt av forfatteren, men er også forelagt flere av casens aktører, som har kommet med mindre korreksjoner.

\section{Nordkyn}

Nordkyn er halvøya mellom Tanafjorden og Laksefjorden i Finnmark og rommer kommunene Lebesby og Gamvik. Begge kommunene er fiskerikommuner. Halvøya er neste fastland for Hurtigruten på sin ferd østover fra Nordkapp. Kjøllefjord er sentrum i Lebesby kommune. Kommunen har cirka 1400 innbyggere. Stedet var før siste verdenskrig mer et handelssted enn et fiskevær og var ikke kommunesentrum. Etter krigen bestemte sentrale myndigheter at Kjøllefjord skulle være sentrum for gjenreisningen i kommunen. Fiskeanlegg som hadde hatt konsesjoner før krigen, ble gjenoppbygd. I dag er det ingen fiskeforedlingsbedrifter igjen, men to mottak. Kommunen er største arbeidsgiver. I privat sektor er fiskeoppdrett størst med tre store konsern som til sammen sysselsetter 70-80 personer i kommunen. Det er også vekst i fisket, hvor særlig krabbefisket sies å ha virket rekrutterende. Vårtorskefisket er det største sesongfisket, ved siden av kongekrabbefisket. Fiskeridirektoratet har kontor i bygda. Havna er en drivkraft i utviklinga av stedet. Det er ingen andre offentlige eller halvoffentlige arbeidsplasser, med unntak av Foldalbruket, som i dag er museum, med en person ansatt.

Mehamn er i dag sentrum i Gamvik kommune, som har 1200 innbyggere. Utviklinga i fiskeriene er omtrent den samme som for Lebesby, men Gamvik har flere fiskeindustribedrifter med til sammen mer enn 100 arbeidsplasser, samt mellom 100 og 200 fiskere. Kommunen er også her en stor arbeidsgiver. Mehamn lufthavn, som også betjener Kjøllefjord, er en viktig halvoffentlig arbeidsplass, og viktig for forbindelsene ut i verden. 
Det er langt til hovedveiene gjennom fylket. Fra Kjøllefjord er det 198 kilometer til Tana, 233 kilometer til Lakselv og 435 kilometer til Nordkapp, som årlig besøkes av nærmere 300000 turister.

\section{Nordkyn-turismens utvikling}

Turismen i Kjøllefjord bidro i 2017 med cirka ti årsverk. Fem av årsverkene er knyttet til turer for passasjerer som tas i land i den ene havna (primært Kjøllefjord) og bringes over til den neste. Hovedproduktet er en overlandstur med snøskuter og/eller buss mellom Kjøllefjord og Mehamn, som i prinsippet tilbys både på nordgående (om ettermiddagen) og sørgående skip (om natta). Denne produksjonen innbefatter året igjennom en bedrift i Kjøllefjord, om vinteren en i Mehamn og om sommeren en langs veien imellom, hvor attraksjonen er en samisk kulturpresentasjon. Produktet organiseres av en lokal turprodusent, som med noen avbrudd har vært i turismebransjen siden 1990-tallet. Andre produkter er presentasjon av kongekrabben om bord på Hurtigruten den siste halvtimen før Kjøllefjord, et gratistilbud for alle om bord. Foruten dette finnes det i Kjøllefjord en fisketurismebedrift som også tilbyr overnatting, og et hotell. For øvrig er det en del mindre reiselivsbedrifter andre steder i kommunen, som strekker seg langt inn i Laksefjorden.

Ut over hotellet og et gjestehus har Mehamn en markant reiselivsaktør som opererer skuterdelen av turene mellom Kjøllefjord og Mehamn. Han driver imidlertid også en fisketurismebedrift og har andre skuterbaserte tilbud. Hovedattraksjonen på Nordkyn og i Gamvik kommune er Slettnes fyr og et tilliggende fuglereservat samt et museum (i Gamvik), alt innenfor en avstand på cirka tre kilometer. Fuglereservatet, som er et vernet område, har en stor variasjon i fuglearter og er et mål for fugletittere. Slettnes har også utviklet seg som en yndet oppstillingsplass for bobiler. I tillegg har Gamvik kommune flere fraflyttede bosteder av kulturhistorisk interesse (blant annet Losvik og Finnkongkeila), og det tilbys fisketurisme på tre steder i tillegg til i Mehamn. For hele Nordkyn er naturen viktigste trekkplaster og profileringspunkt, hvilket reflekteres i slagordet til Visit Nordkyn: «Nordkyn - where nature rules».

Reiselivsnæringa er ikke ny på Nordkyn. Før krigen, men også på 1960-tallet, var det flere hoteller i Kjøllefjord. Etter hvert ble de imidlertid 
lagt ned. Dagens hotell er fra 1970-åra. Da som nå var forretningsreisende det viktigste segmentet for hotellene. Som et veiløst fiskevær var sjøen tilkomstveien både til Kjøllefjord og Mehamn. Etter at forbindelsen til det nasjonale veinettet sto ferdig i 1989, har Nordkyn også vært et mål for veifarende. Men regionen er utenfor den turistiske allfartsveien. Likevel har det flere ganger vært forsøkt å utvikle turisme. Rundt 1990 ble det gjort et forsøk med et busstilbud - en tur for hurtigruteturistene fra Kjøllefjord til Slettnes fyr og om bord igjen på skipet i Mehamn. Etter fem prøveturer sa Hurtigruten stopp. Bussoperatøren som hadde satset, fikk økonomiske vanskeligheter og måtte avvikle. Han uttrykker det slik: «Det virket som om at det var en forestilling om at strekningen Nordkapp-Kirkenes var en ikke-strekning opplevelsesmessig.» Men verken denne mannen eller den andre hovedentreprenøren ga slipp på sine ideer om turismevirksomhet på stedet.

En viktig begivenhet i turismeutviklinga ble et møte i Lakselv i 2006, der Hurtigrutens produktansvarlige holdt et foredrag om selskapets nye strategi og behov for aktører som kunne bidra med opplevelser i land. Han kom i snakk med en person fra Kjøllefjord som markerte interesse for det som hadde blitt formidlet. I første omgang satset man på noe man kalte "A taste of Lapland», en samisk opplevelse. Samiske opplevelser har siden vært et viktig element i overlandsturismen. I prosessen hadde man dialog med to samiske familier. En av familiene gikk etter hvert inn som partnere i utviklinga av en sameleir. Produktet har seinere vært gjennomgått av forskere. Dette sies å ha vært bevisstgjørende med hensyn til ordvalg og spørsmålet om autentisitet, og særlig for betydningen av og spørsmålet om hvordan man skal framstille samisk kultur som moderne. Særlig viktig var det å utvikle produktet slik at det skulle framstå fjernt fra «dverg i bur»-forestillinger, sier en av aktørene. Det erkjennes at balansegangen mellom å betone tradisjonene og den moderne samiskheten er utfordrende.

Besøk i sameleir og bussturen over fra Kjøllefjord til Mehamn ble en suksess. Året etter at man startet med dette, bestemte man seg for å tilby snøskuterturer på deler av strekningen om vinteren. Også det viste seg å være et godt produkt. Turistene kles opp på kaien, går om bord i en buss som frakter dem nærmere to mil opp på fjellet. Derfra kjører turistene snøskuter resten av strekningen. Produktet håndteres av et firma i Kjølleford som står for kontakten og administrasjonen vis-a-vis Hurtigruten. 
Skuteroperatøren er underleverandør. Dette er et samarbeid som i 2017 har fungert i nærmere ti år.

En av dem som hadde vært på møtet i Lakselv, ble også spurt om han kunne tenke seg å prøve et produkt som gikk ut på å vise fram og fortelle om kongekrabben for passasjerene. Det ble en suksess, og det har vært et produkt siden. I samme periode hadde ideen om å lyssette et samisk offersted, Finnkirka, en fjellklippe ytterst i Kjøllefjorden, kommet opp. Ideen var ikke ny og tilskrives en lokal innovatør, men fikk ny fart da filmskaperen Nils Gaup ble involvert i Hurtigrutens produktutvikling. Det ble også forsøkt med andre produkter, som å være med på en profesjonell fiskebåt og servering av lokal mat i lavvu.

En viktig institusjon i Kjøllefjord er Foldalbruket. Dette var et fiskebruk som hadde hatt handelstillatelse før krigen, og som drev tranproduksjon (damperi) og salting av fisk inntil 1980-tallet. Flere generasjoners trandamperi er intakt, og seinere har det i flere runder blitt laget tranmaling i regi av dem som har forvaltet stedet etter at den kommersielle produksjonen opphørte. Etter nedleggelsen ble anlegget overtatt av Forbundet Kysten (1990), seinere omgjort til Stiftelsen Foldal med Kystlaget i Kjøllefjord som viktigste eier. Det ble ansatt daglig leder, samme mann som hadde forsøkt bussdrift på 1990-tallet. Han skaffet finansiering til vedlikehold og oppgradering, blant annet et sprinkelanlegg. Som daglig leder utviklet han et turprodukt for hurtigrutepassasjerene som startet med et besøk på Foldalbruket, og som fortsatte med buss til en sameleir på fjellet og endte opp i Mehamn. Dette produktet mente imidlertid styret i Foldalbruket var på siden av brukets naturlige aktivitetsområde. Den ansatte valgte da å slutte og ta med seg porteføljen over i et eget selskap. Etter hvert falt besøket på Foldalbruket ut av turproduktet. I dag er Foldalbruket innlemmet i Museene for kystkultur og gjenreisning i Finnmark (Kystmuseene), fortsatt med Kystlaget som eier av bygningsmassen. Daglig leder er fra 2017 fulltidsansatt i Kystmuseene. Kommunene har støttet bruket med årlige 100000 koner, og på prosjektbasis. Institusjonen har stadig vært en del av turismesatsinga.

Man har også ved flere anledninger prøvd å få til en destinasjonsorganisering av og på Nordkyn. På 1990-tallet skjedde dette gjennom et planprosjekt, man laget en reiselivsplan for Nordkyn. Seinere ble Visit Nordkyn stiftet. Starten var at man ønsket å være med i et nasjonalt designprogram for reiselivsbedrifter, og trengte et selskap som tok seg av denne 
kontakten. Prosjektet samlet folk og skapte kontakter mellom bedriftene og forståelse for regionen som en destinasjon, og resulterte i en dynamisk nettlogo som skifter form med været. En av erkjennelsene i prosjektet var at stedene Mehamn og Kjøllefjord hadde nokså forskjellige turisttilbud og utfyller hverandre. Destinasjonen er Nordkyn og ikke stedene, og overlandsturismen tjener alle parter. Både da man laget reiselivsplanen og ved etableringen av Visit Nordkyn, hadde man ekstern finansiering, og ved begge anledninger varte satsingen så lenge man hadde prosjektmidler. Visit Nordkyn har eksistert i noen år, men med et lavt aktivitetsnivå, ble det sagt. Det har altså vist seg at utviklingsarbeid av destinasjonen krever en institusjonell ramme som ikke finnes internt i kommunene. Det var i 2017 en viss uenighet om veien videre. Samarbeid med eller innlemming i Visit Nordkapp er stadig et tema, men et fylkessamarbeid har også lenge vært en problemstilling. Flere ser fordeler i å være en del av større enheter, mens andre er imot.

Hurtigruten la i starten vekt på å ha god tone med lokalsamfunnet. Da selskapet bestemte seg for å satse på Kjøllefjord (og Mehamn), ble det avholdt folkemøte og møter på skolen. Turistene måtte føle seg velkomne, var en viktig grunnide og budskap til bygda fra Hurtigrutens side. I ettertid anses dette som viktige begivenheter. Hurtigrutens produktutvikler understreker sjøl at han var bevisst på at disse prosessene var viktige, og at de kunne ta tid. Resultatet, mener flere, er at folk fikk en større forståelse for reiselivet, og for det å skulle motta turister.

Vi spurte også om hvilken støtte man har i næringsutvikling i Kjøllefjord. Kommunen har i sine strategiarbeider prioritert fiske og jordbruk. Kommunen har et eget næringsfond for fiskeri, og et for andre næringer. Her kan man få veiledning og støtte til forundersøkelser. Det er ulike meninger om hvor god støtten fra kommunen er. Innovasjon Norge støtter reiseliv, men lite annet, ble det hevdet. Og bankene er lite villige til å gi lån, sies det. Altså er det vanskelig å få i gang ny virksomhet dersom man ikke har en solid egenkapital. Likevel vises det til en viss nyutvikling av næringsvirksomhet, blant annet at stedet har mange butikker, flere gallerier og en ny kafé. Og fiskerisektoren er i vekst med stadig flere fiskere bosatt i kommunen, og et nytt fiskemottak. Men det trekkes også fram et eksempel på en fiskeoppdrettsbedrift som ikke har fått lov å skifte lokalitet, av miljøhensyn. 
Oppsummert er Kjøllefjord et lite sted med en liten turisme. En fisketurismebedrift ligger midt i bygda. Siden 2007 har det imidlertid funnet sted en positiv utvikling, der en allianse mellom Hurtigruten og lokale entreprenører har skapt en viss dynamikk. Ellers har veksten vært beskjeden, og det nevnes at flere forsøk på å skape noe nytt har strandet. Hotellet prøvde å tilrettelegge for turer til fots og med sykkel, men klarte ikke å skape etterspørsel. En prøvde med båtutleie, men hadde for liten omsetning til at det lønte seg. Forsøk på å lage en tilrettelagt oppstillingsplass for bobiler har heller ikke fungert. Målet for sommerturistene på Nordkyn er stadig først og fremst Slettnes fyr, og fuglekikking der, mens de færreste tar turen om Kjøllefjord. Det har vært forsøkt med en turistinformasjon på fjellet der veien til Mehamn og Kjøllefjord skilles, men det var ingen suksess. Alt i alt er det lite nytt, og fortsatt er det entreprenørene som begynte etter Hurtigrutens initiativ som synes stå for tenkningen. «Vi trenger noen som kommer utenfra og setter i gang nye greier», sies det, og: «Vi mangler gründere.» En viktig årsak til at turismen ikke har blitt større, mener flere er den noe avsides beliggenheten. Nordkyn er en lang omvei for dem som har Nordkapp som mål. Det var i sin tid snakk om en sommerferge mellom Honningsvåg og Nordkyn, men prosjektet ble ikke realisert. Det har ikke vært fylkeskommunal vilje til å prioritere en slik sammenkopling. Alle mener at den omtalte fergen både ville gitt effekter og hadde hatt et marked. Det har vært gjort tilsvarende andre steder, sier man, og peker på forbindelsen mellom Andenes og Gryllefjord på Senja.

\section{Diskusjon}

Vi har innledningsvis plassert denne studien innen rammen av en utviklingsorientert geografi. Institusjonell kontekst er en av faktorene. Det har også vært en hovedfaktor på Nordkyn. Hurtigrutens institusjonelle betydning framstår som helt sentral. Det var Hurtigruten som inviterte til lokale initiativ. Tidligere, på 1990-tallet, hadde selskapet blitt forespurt av en lokal aktør, men ikke vist interesse ut over noen få forsøk, og den lokale aktøren måtte gi opp. Uten den institusjonelle støtten var det altså vanskelig å få noe til. For det andre er det Hurtigruten som har vært markedet for de lokale aktørene. Men det er også en større institusjonell ramme, som også styrer Hurtigruten. Skipsruten er konsesjonsbelagt og støttet av 


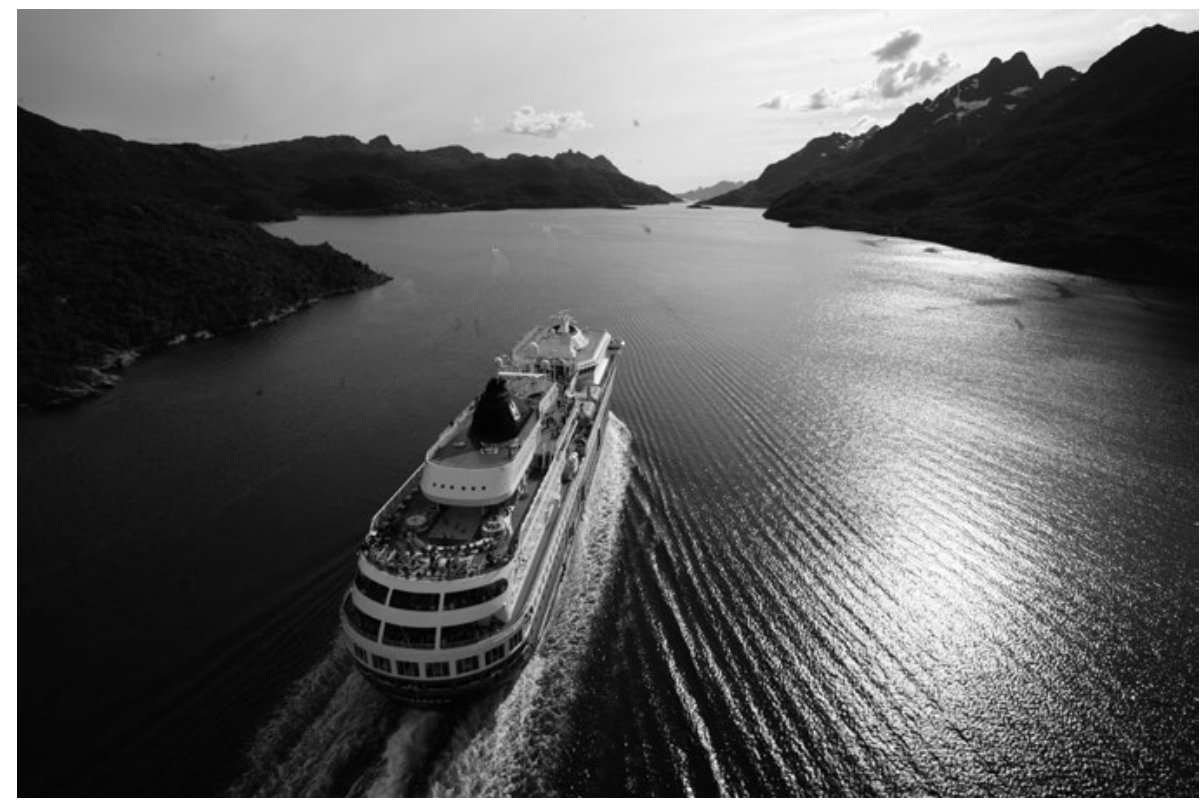

Hurtigruten i en norsk ford. Foto: Ole Magnus Rapp.

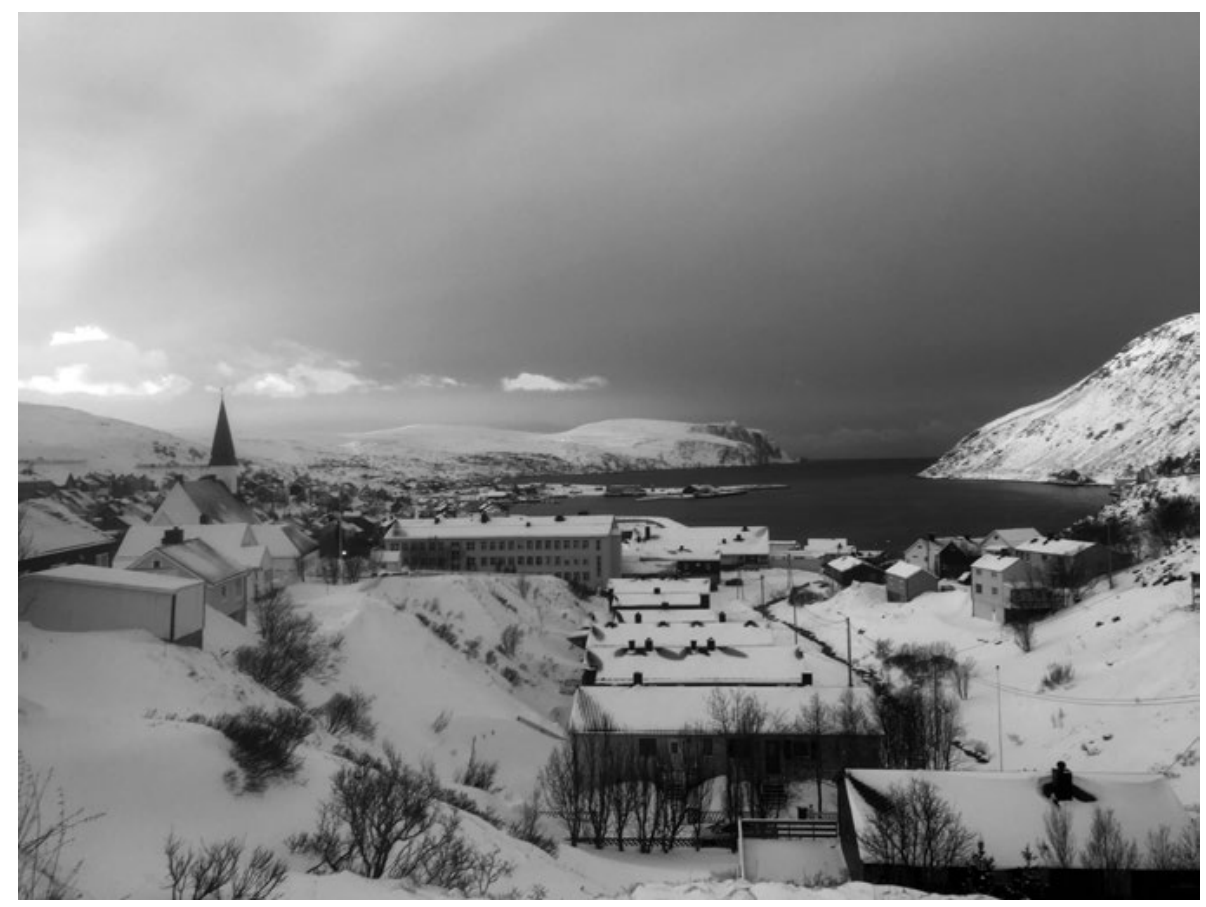

Kjøllefjord: turisme på nåde? Foto: Arvid Viken. 
staten, som også har et ord med i laget når anløpsstedene bestemmes. $\mathrm{Og}$ når det gjelder det spørsmålet, vil både lokale og nasjonale politikere ha et ord med i laget. Til syvende og sist er det imidlertid Stortinget som bestemmer. Dette gir en viss trygghet, men også Stortinget er opptatt av markedstenkning, kostnadsbesparelser og lønnsomhet. Framtidas seilingsmønster kan ikke lenger tas for gitt, hevdet en sentral næringsaktør.

En annen institusjonell ramme for utvikling er næringsklimaet, om det er rom for gründere, og om de støttes. Her er bildet noe uklart, det er litt både og. Holdningene til gründere er positive, men de institusjonelle rammene begrenset, dersom det ikke dreier seg om fiske. Ved flere anledninger prøvde man å utvide rammene for turismeutviklinga. Hurtigruteforbindelsen er det beste eksemplet på at man lyktes. Deltakelse i diskusjonen om et fylkesdekkende destinasjonsselskap og samarbeid med nabokommunen Nordkapp er et eksempel på at man har slitt med å få det til. Noen av aktørene har hatt et samarbeid med forskere som både har evaluert og foreslått forbedringer av produktene. Det er en produktiv relasjon, ifølge aktørene. Samfunnet var også svært imøtekommende i forbindelse med forskningen som ligger til grunn for dette kapitlet. Men noen peker på at det burde vært større permanens i slike forbindelser. Trolig må de institusjonelle rammene sies å være tynne. Det er ikke lag på lag med institusjoner og mennesker som bryr seg om reiselivsutviklinga, entreprenørene synes å stå nokså aleine.

Et annet punkt i teorien dreier seg om menneskelige handlinger og entreprenørskap. Entreprenørene har vært viktige for utviklinga, og de har befunnet seg både innen hurtigruteselskapet og lokalt. Hurtigruten hadde et sterkt fokus på produktutvikling, og de representerte et innovativt miljø og var en pådriver for innovasjon fra 2006 og utover. Selskapet var representert med individer som så muligheter, og som kommuniserte med folk lokalt. Det dreier seg altså om mennesker som kjenner landsdelen, folket og kulturen, og som så mulighetene som nordnorsk kultur og natur rommer, og som evnet å gi impulser til lokalsamfunnene, og å finne fram til samarbeidspartnere. Lokalt i Kjøllefjord kan også entreprenørene identifiseres, det gjelder særlig to aktører som sto for kontakten med Hurtigruten, men som også klarte å skape lokale allianser som til sammen ga flere nye reiselivstilbud. Men slike nettverk er skjøre, og samarbeidet strandet etter at to av partene følte seg ført bak lyset av en tredje, og tilliten dem imellom ble brutt. Skal slike små nettverk fungere, er gjensidig åpenhet en 
betingelse. Det er imidlertid vanskelig å se at entreprenørenes arbeid har hatt smitteeffekt. Ingen har tatt etter, men noen mener at det finnes slike effekter om en ser på kommunen som helhet; at de har inspirert flere av dem som har etablert seg siden, for eksempel med fisketurisme. Det ble også observert vegring og angst for nyetableringer, da dette ble ansett som konkurranse og trussel mot det som i dag er en relativt velfungerende produksjon. Angsten for konkurranse fra nabobedriften er et velkjent fenomen, men representerer som regel en lite gagnlig tenkning. Små steder som Kjøllefjord trenger flere aktører og større aktivitet for å bli lagt merke til som en turistdestinasjon.

De to mest sentrale entreprenørene har hatt et komplementært forhold til hverandre. Den ene er den kreative, i teorien kalt en håndverksorientert (artisan) entreprenør (Shaw 2014). Han har satt og setter stadig spor etter seg i Kjøllefjord. Han er kunst- og kulturinteressert og skaper nye produkter og bedrifter, og overlever på prosjekter og reiselivsproduksjon. Den andre er av organisasjonstypen (managerial), som lager prosjekter, får dem finansiert og er en driver, en som er opptatt av markedssignaler og kalkulerer kritisk masse, før han setter i gang. Begge har et blikk for kultur og har vært involvert i sosiale entreprenørprosesser. Begge kan sies å være innovative, den ene for sine nyskapinger (inventions), den andre gjennom å snappe opp kjente konsepter og tilpasse dem lokalt. Et godt team, kan man si, bortsett fra at de ikke arbeider i lag. Men det er ingen dans på roser for noen av dem. Som så mange andre steder er det å drive småbedrift i en periferi en kamp for å overleve (Shaw 2014).

Det tredje elementet i vårt teoretiske utgangspunkt er sporavhengighet, altså om man fortsetter i samme spor som tidligere. På et vis gjør man det. Kjøllefjord har alltid vært et fiskerisamfunn og er det fortsatt. Statistikken viser oppgang både for fangst og oppdrett, og det har i 2017 kommet et nytt fiskemottak på stedet. Kjøllefjord er et fiskevær, slik alle ser det, både unge og gamle, og fiskeri anses også som det viktigste satsingsområdet for dem som ble intervjuet. Fiskesporet er kjent og kjært og en naturlig satsing. Ofte bugner det med fisk i fjorden og havet utenfor. Dette kan imidlertid være et hinder for annerledestenkende, sjøl om synspunktene varierer. De to entreprenørene sier begge at de har opplevd mye støtte fra omgivelsene, deriblant kommunen, gjennom åra de har holdt på.

Kjøllefjords reiseliv er i høyeste grad småskala. Det er det man også kaller mikroturisme, og stedet er en mikrodestinasjon. EU definerer 
virksomheter med færre enn ti ansatte som mikrobedrifter (Brouder \& Eriksson 2013b). Turismen er så liten at turistene ikke ses i bybildet, sies det. Hurtigruteturistene - 26 stykker i snitt - går rett om bord i en buss på hurtigrutekaien og synes ikke i bygda. Da hurtigrutekaien i Mehamn i 2014 var under reparasjon, lå Hurtigruten i bygda i mer enn en time, og man merket turistene, ble det sagt. Flere sier at det ville gitt bedre effekt lokalt om skipet hadde ligget lenger på bekostning av Mehamn. Grunnet havneforholdene tror ingen at Kjøllefjord ville blitt sløyfet om Hurtigruten skulle endre på seilingsplanen. Å sløyfe den ene havnen, eller bare gå til Mehamn på sørgående, og med 1,5 timers landligge i Kjøllefjord på nordgående, ville selskapet utvilsomt bli en katalysator for en langt større anlagt turisme på stedet. Uansett er Hurtigrutens gjøren og laden ansett å være av stor betydning. Det oppleves som en avhengighet. Derfor er det mye snakk om hvordan man skulle kunne utvikle en alternativ turisme. Man ser visse muligheter i smale nisjer, knyttet til spesialinteresser som fiske, arktisk friluftsliv og ekstremsport.

Et annet trekk ved utviklinga er at den har vært preget av noen begivenheter eller momenter (Sanz-Ibáńez, Wilson \& Clavé (2017), hvor sporet ble korrigert. Først og fremst gjelder dette møtet med Hurtigruten i 2006, da noen fant å ville satse. Siden har det bare vært gjort mindre justeringer, som for eksempel å endre på programmet for overlandsturen, eller forestå kvalitetsforbedring i dialog med forskere. Nye, store innovasjoner har ikke funnet sted, men man hadde i 2017 flere produktideer. Reiselivet er imidlertid marginalt, og nye produkter kan være vanskelige å realisere.

\section{Konklusjon}

I dette kapitlet har vi presentert turismeutviklinga på et sted som før 2005 nesten ikke hadde turisme. Stedet er av de mest avsidesliggende i Norge og Europa. Sjøl om stedet har flyplass, er det både tidkrevende og dyrt å ta seg fram dit. Stedets egenart er arktisk natur og et særegent landskap. Stedet minner knapt om andre steder på kysten, her er det karrig, men ikke fattigslig. Fiskeriene har gitt inntekter i generasjoner og satt sine spor. Dette er flotte kulisser, men stedet har ingen særegne attraksjoner, slik det er i dag. Den turismen som har utviklet seg, er skapt av og sammen med Hurtigruten, skipet som daglig farer forbi på sin ferd fra Bergen til 
Kirkenes eller omvendt. Noen lever av å ta med 20-30 av disse turistene på tur, fortrinnsvis mellom Kjøllefford og Mehamn, som er neste havn. Dette er en turisme preget av små aktørers avhengighet til en større. Hurtigruten har bukta og begge endene for denne turismen. Det kan fortone seg som paradoksalt: Hurtigruten har bidratt til utvikling, men representerer en usikker framtid. Det er vanskelig å se alternative utviklingsforløp, men stedet kunne være et utgangspunkt for ekstreme aktiviteter, fortrinnsvis satt i system av livsstilsoperatører. Så langt har ikke de meldt seg. Derfor ligger det an til at turismen forblir på mikronivå, at stedet fortsetter som fiskevær, og at sidesporet turistfiskevær blir av begrenset betydning.

Hurtigruten har utvilsomt vært en katalysator for et utvidet reiseliv på Nordkyn. Flere av innovasjonene som har funnet sted, har enten vært etterspurt av eller utviklet i dialog med selskapet. De påtok seg rollen som destinasjonsinnovatør og innovasjonsleder, roller som man lokalt ikke kunne ta eller ha. Men uten de lokale entreprenørene og innovatørene ville Hurtigruten ikke ha lykkes med å skape opplevelser på en strekning som tidligere og stadig er en transportetappe. Det er gjensidighet i relasjonene. Man har satt i gang noe som har potensial til noe langt mer, om man tør å gå ut av det seilingsmønsteret man har hatt til nå. Små endringer kan gjøre en stor forskjell for turismen på Nordkyn.

\section{Litteratur}

Amin, A. \& Thrift, N. (1995). Living in the global. I A. Amin \& N. Thrift (red.), Globalization, Institutions, and Regional Development in Europe (s. 1-22).

Oxford: Oxford University Press.

Ateljevic, I. \& Doorne, S. (2000). 'Staying within the fence': lifestyle entrepreneurship in tourism. Journal of Sustainable Tourism, 8 (5), 378-392. https://doi.org/10.1080/09669580008667374

Ateljevic, J. \& Doorne, S. (2004). Diseconomiwes of scale: A study of development constraints in small tourism firms in centra New Zealand. Tourism and Hospitality Research, 5, 5-21. https://doi.org/10.1057/palgrave.thr.6040002

Bathelt, H. \& Glückler, J. (2005). Resources in economic geography: From substantive concepts towards a relational perspective. Environment and Planning, 37 (9), 1545-1563. https://doi.org/10.1068/a37109 
Brouder, P. \& Eriksson, R. H. (2013a). Tourism evolution: on the synergies of tourism studies and evolutionary economic geography. Annals of Tourism Research, 43, 370-389. https://doi.org/10.1016/j.annals.2013.07.001

Brouder P. \& Eriksson, R. H. (2013b). Staying Power: What influences microfirm survival in tourism? Tourism Geographies, 15, 125-144. https://doi.org/1 $0.1080 / 14616688.2011 .647326$

Brouder, P., Clavé, S.-A., Gill, A. \& Ionnides, D. (red.) (2017). Tourism destination evolution (s. 103-122). London: Routledge. https://doi. org/10.4324/9781315550749

Carson, D. A. \& Carson, D. B. (2017). Path dependence in remote area tourism development: why institutional legacies matter. I P. Brouder, S.-A. Clavé, A. Gill \& D. Ionnides (red.), Tourism destination evolution (s. 103-122). London: Routledge.

Dredge, D. \& Jenkins, J. (2003). Destination place identity and regional tourism policy. Tourism Geographies, 5 (4), 383-407. https://doi.org/10.1080/1461668032000129137

Getz, D. \& Paterson, T. (2005). Growth and profitorientated entrepreneurship among family business owners in the tourism and hospitality industry. International Journal of Hospitality Management, 24 (2), 219-242. https://doi.org/10.1016/j.ijhm.2004.06.007

Heimtun, B. \& Viken, A. (2016). Nordlysturismen - en institusjonell betinget utvikling. I A. Viken (red.), Turisme. Destinasjonsutvikling (s. 175-197). Oslo: Gyldendal Akademisk.

Ioannides, C. \& Debbage, K. (1997). Post-Fordism and flexibility: the travel industry polyglot. Tourism Management, 18, 229-241. https://doi.org/10.1016/S0261-5177(97)00019-8

Ioannides, D. \& Petersen, T. (2003). Tourism 'non-entrepreneurship' in peripheral destinations: a case study of small and medium tourism enterprises on Bornholm, Denmark. Tourism Geographies, 5, 408-435. https://doi.org/10 $.1080 / 1461668032000129146$

Kajan, E. \& Saarinen, J. (2014). Transforming visions of pathways in destination development. Local perceptions and adaptation strategies to changing environment in Finnish Lapland. I A. Viken \& B. Granås (red.), Destination Development in Tourism: Turns and Tactics (s. 189-208). Farnham: Ashgate.

Koh, K. Y. \& Hatten, T. S. (2002). The Tourism Entrepreneur. International Journal of Hospitality \& Tourism Administration, 3 (1), 21-48. https://doi.org/10.1300/J149v03n01_02 
Komppula, R. (2014). The role of individual entrepreneurs in the development of competitiveness for a rural tourism destination - A case study. Tourism Management, 40, 361-371. https://doi.org/10.1016/j.tourman.2013.07.007

Lafferty, G. \& van Fossen, A. (2001). Integrating the tourism industry: problems and strategies. Tourism Management, 22, 11-19. https://doi.org/10.1016/ S0261-5177(00)00021-2

Li, L. (2008). A review of entrepreneurship research published in the hospitality and tourism management journals. Tourism Management, 29 (5), 1013-1022. https://doi.org/10.1016/j.tourman.2008.01.003

Morrison, A. \& Teixeira, R. (2004). Small business performance: a tourism sector focus. Journal of Small Business and Enterprise Development, 11, 166-173. https://doi.org/10.1108/14626000410537100

Moscardo, G. (2014). Tourism and community leadership in rural regions: Linking mobility, entrepreneurship, tourism development and community well-being. Tourism Planning \& Development, 11, 354-370. https://doi.org/1 $0.1080 / 21568316.2014 .890129$

Saarinen, J. (2004). Destinations in change. The transformation process of tourist destinations. Tourist Studies, 4, 161-179. https://doi.org/10.1177/1468797604054381

Santos, F. M. (2012). A Positive Theory of Social Entrepreneurship. Journal of Business Ethics, 111 (3), 335-351. https://doi.org/10.1007/s10551-012-1413-4

Sanz-Ibáńez, C. \& Clavé, S. A. (2014). The evolution of destinations: towards an evolutionary and relational economic geography approach. Tourism Geographies: An International Journal of Tourism, Space, Place and Environment, 16, 563-574. https://doi.org/10.1080/14616688.2014.925965

Schumpeter, J. J. (1943). Capitalism, Socialism and Democracy. New York: Harper and Row.

Sharif, N. \& Lonik, K. A. T. (2014). Entrepreneurship as a Catalyst for Rural Tourism Development. SHS Web of Conferences, 12. https://doi.org/10.1051/shsconf/20141201087

Shaw, G. \& Williams, A. M. (2004). From lifestyle consumption to lifestyle production: changing patterns of tourism entrepreneurship. I R. Thomas (red.), Small firms in tourism: International perspectives (s. 99-114). Oxford: Pergamon. https://doi.org/10.1016/B978-0-08-044132-0.50010-1

Stokowski, P. A. (2002). Languages of place and discourses of power: Constructing new sense of place. Journal of Leisure Research, 34, 368-382. https://doi.org/10.1080/00222216.2002.11949977 
Strambach, S. \& Halkier, H. (2013). Reconceptualising change. Path dependency, path plasticity and knowledge combination. Zeitschrift fuer Wirtschaftsgeographie, 57 (1-2), 1-14. https://doi.org/10.1515/zfw.2013.0001

Thomas, R., Shaw, G. \& Page, S. J. (2011). Understanding small firms in tourism: A perspective on research trends and challenges. Tourism Management, 3, 963-976. https://doi.org/10.1016/j.tourman.2011.02.003

Valtonen, A. (2009). Small Tourism Firms as Agents of Critical Knowledge. Tourist Studies, 9, 127-143. https://doi.org/10.1177/1468797609360600

Viken, A. (2001). Turismeutvikling i Lofoten. I A. Viken (red.), Turisme. Tradisjoner og trender (s. 91-108). Oslo: Gyldendal Akademisk.

Viken, A. (2011). Naturbasert turisme i nord; ytre påvirkning - lokal tilpasning. I S. Jentoft, J.-I. Nergård \& K. A. Røvik (red.), Hvor går Nord-Norge? Tidsbilder fra en landsdel i forandring. Stamsund: Orkana Akademisk.

Viken, A. (2014a). Ski resort development; scripts and phronesis. I A. Viken \& B. Granås (red.), Destination Development in Tourism: Turns and Tactics (s. 113-130). Farnham: Ashgate.

Viken, A. (2014b). Destination discourses and the growth paradigm. I A. Viken \& B. Granås (red.), Destination Development in Tourism: Turns and Tactics (s. 21-46). Farnham: Ashgate.

Viken, A. \& Granås, B. (red.) (2014). Destination Development in Tourism: Turns and Tactics. Farnham: Ashgate.

Viken, A. \& Aarsæther, N. (2012). North Cape: Transforming an iconic attraction into a diversified destination. Scandinavian Journal of Hospitality and Tourism, 13, 38-54. https://doi.org/10.1080/15022250.2013.771994

Viken, A. \& Svensson, G. (2016). Organisering av reiselivet - DMO-er, disiplinering dialog og partnerskap. I A. Viken (red.), Turisme. Destinasjonsutvikling (s. 73-95). Oslo: Gyldendal Akademisk.

Weaver, D. (2012). Small can be beautiful, but big can be beautiful too - and complementary: Towards mass/alternative tourism synergy. I T.V. Sing (red.), Critical debates in tourism (s. 85-89). Bristol: Channel View Publications. 


\section{KONTINUITET OG BRUDD: FISKEVARET ÅRVIKSAND OG BOSTEDET BADDEREN ${ }^{\circ}$}

Arvid Viken

\section{Innledning}

Dette kapitlet dreier seg om hva man lever av i Utkant-Norge, eller i utkanten av utkanten, på steder som Årviksand i Skjervøy og Badderen i Kvænangen. Skjervøy og Kvænangen er to nabokommuner i Nord-Troms. Folketallet har vært nedadgående i flere tiår, men utviklinga er ikke bare negativ. Det kommer litt an på øynene som ser, og hva slags kontekst man tolker utviklinga inn i, og hva man verdsetter. Og konteksten er både nasjonal og internasjonal. Nasjonalt har man de siste åra vært opptatt av å skape større enheter, sammenslåing av kommuner, etablering av nye regioner. Småsteder ser imidlertid ut til å overleve uansett hva slags strukturer og politikk som utvikles. De færreste småsteder er i våre dager isolerte, om de i Norge noensinne har vært det. De er som regel deler av større steder, deler av større regioner, de inngår i nettverk, og ofte har de glidd sammen med nabostedene. At steder er dynamiske og inngår i og representerer krysninger av globale nettverk og bevegelser, er en etter hvert vanlig oppfatning (Massey 2005). Samtidig oppfattes steder ulikt av ulike aktører og

$6 \quad$ Kapitlet er skapt i dialog med mine forskerkolleger, især Inga Marie Skavhaug og Gaute Svensson, som også deltok i datainnsamlingene, samt Anniken Førde og Ragnar Nilsen. Lisbeth Holm, Trude Indrebø, Rune Benonisen, Odd Rudberg, Silje Karlsen, Anne-Berit Bær deltok også i forskningsprosessen. Takk til alle, også til dem som satte sammen gruppeintervjuene for oss. Forfatteren står aleine ansvarlig for teksten. 
fra ulike perspektiver. En side ved utviklinga er at man de siste to tiåra har foretrukket å bruke «sted» og ikke lokalsamfunn. Det skyldes, sies det, at lokalsamfunnsbegrepet på 1970- og 80-tallet ble brukt politisk og ga visse romantiske eller romantiserende konnotasjoner (se Altern 1996; Jentoft 1996). Jeg velger likevel å bruke lokalsamfunnsbegrepet. ${ }^{7}$

Jeg vil begynne denne analysen med et sideblikk til internasjonale tendenser når det gjelder bygdeutvikling. En av de viktige debattene er definisjonene av og forholdet mellom det rurale og det urbane, og hvordan utviklinga har vært for disse to typene samfunn. Ifølge Cloke (2006) kan det rurale ses fra tre konseptuelle ståsteder: et funksjonelt, et politisk-økonomisk og et sosialkonstruksjonistisk. I det funksjonelle perspektivet defineres det rurale ut fra sted, landskap og samfunnstyper samt forhold som tilgjengelighet, sysselsetting, bosetting, mv. Det politisk-økonomiske perspektivet vokste fram av ideologiske forståelsesrammer på 1970-tallet, der landsbygda ble sett i sammenheng med endringer i politiske ideer og systemer, inkludert statens rolle. Teoriene om landsbygda som sosialt konstruert kom som en naturlig følge av en allmenn samfunnsvitenskapelig trend i 1990-åra. Ifølge dette synet er landsbygda først og fremst skapt gjennom måtene den blir framstilt på, i ulike diskurser, gjennom forskning og i mediene. Brauer og Dimitrow (2014) peker for eksempel på at oppfatningene av bygdeutviklinga preges av hvordan den konseptualiseres, altså hvordan den beskrives og omtales, hva slags ideologier som råder, og den materielle utviklinga. Leter man etter stordrift, vekst og skalafordeler, vil landsbygda ofte framstå som mislykket, leter man etter små tette samfunn, er den ofte et mønster. Den dominerende ideologien i dag er hva man kaller nyliberalisme. I tråd med denne tenkningen har det vokst fram en produksjonsstruktur som stort sett er basert på stordrift og vekst, og som ikke har rom for små aktører eller steder. Bare storgårder overlever, fiskebåtredere eier store deler av fiskeflåten, store konsern dominerer innen fiskeoppdrett og hotelldrift, og eierne er store internasjonale investorer. For små bygdesamfunn innebærer det at de sjøl må skape utvikling, og at myndighetene i beste fall er en tilrettelegger. Ikke alle er like begeistret for denne utviklinga. «Det er et konstant overfokus på økonomisk orienterte aspekter», kommenterer Brauer og Dimitrow (2014, s. 44), og det finnes mennesker og miljøer som representerer alternative verdier. Kanskje bør

I kapitlene veksles det mellom å bruke «vi» og «jeg». Dette kapitlet er basert på en undersøkelse der flere har deltatt. Gaute Svensson og Inga Marie Skavhaug har vært med på datainnsamlinga, og mange har vært med i prosessen, derfor er begge formene naturlig, men kapitlet er i sin helhet skrevet av Arvid Viken. 
man også i større grad diskutere hva utvikling er, hva som kan være alternativer til vekst. Men slik det er i dag, blir det meste presset inn i en veksttenkning, også utviklinga på landsbygda. Det er imidlertid mange eksempler på små samfunn, med små bedrifter og små ambisjoner som overlever. Sjøl om de nyliberale strømningene er viktige pådrivere og kontekst også for forskningen, bør forskningen også omfatte bedrifter, steder og regioner som står imot denne utviklinga. For eksempel finnes det forskningsmiljøer som fokuserer på de-growth. Dette kapitlet skal ikke ha fokus på dette, men på hva som er grunnlaget for bosetting på små steder. Kanskje ligger det i alternative verdier?

Kapitlet begynner med å forklare bakgrunnen for studien - at den tar opp en problematikk man lokalt er opptatt av. Dernest gis det et innblikk i det som kan kalles «den nye bygdeøkonomien», før vi diskuterer den anvendte metoden i studien. Dataene fra de to stedene presenteres ett for ett, fulgt av en sammenfattende drøfting og en konklusjon.

\section{Bakgrunn for studien}

Kapitlet har sin bakgrunn i oppfatninger om næringsutvikling og lokal mobilisering på bygdene i Nord-Troms. På et seminar avholdt i Olderdalen april $2016^{8}$ var dette tema. Det ble snakket om manglende næringsinitiativ og lav innovasjonsgrad. Statistikken viser en viss nedgang i folketallet, og flytte- og fødselsstatistikken er negativ. Det er fylkessentrene Tromsø og Alta som har vekst.

Likevel blir mange boende i bygdene. På seminaret ble det fokusert på hva som skal til for å skape vekst i små samfunn. I to av gruppesamtalene som ble avholdt, var man opptatt av allmenne spørsmål som næring og bosetting:

Hva er næringsgrunnlaget på småsteder i regionen, hvilke fortrinn har man? Er den lokale kulturen hemmende, for eksempel vet at man ikke skal stikke seg fram? Altså, hvordan er klimaet for nyetableringer? Hvordan mobiliserer man lokalt, drar man i lag, og hvordan er samholdet i bygdene? Hvorfor bor man på de små stedene i den norske utkanten? 
Altså ble to hovedspørsmål reist i oppsummeringen; det første dreier seg om hva slags næringer det er som holder liv i bygdene - og hvorfor folk velger å bo der de bor? Problemstillingen er ikke ny. Ottar Brox (1968) stilte omtrent de samme spørsmålene på 1960-tallet, og har arbeidet med slike spørsmål gjennom hele sin karriere; hvordan går det med småstedene i Nord-Norge sett i lys av markedsøkonomiske trender og politiske skifter. Mye av hans funn og analyser er like aktuelle i dag som for noen tiår siden. Vi har også lagt til spørsmålet om hva nye næringer som for eksempel er basert på kultur og reiseliv, betyr i denne sammenhengen? Og som et annet hovedspørsmål i fortsettelsen av dette: Hvordan er samholdet og dugnadsånden i bygdene - skaper man noe på egen hånd, og drar man i lag?

Dette er spørsmål som også er stilt av norske myndigheter. I 2005 ble det lagt fram en stortingsmelding som lanserte en småsamfunnssatsing, som blant annet innebar et pilotprosjekt i en antall utvalgte kommuner. Pilotene omfattet stimulering av nettverk, entreprenørprogram, kompetansehus, IKT-senter, kultursatsinger, hyttesatsing og internshipordninger (Holm \& Villa 2010). En evaluering fra Senter fra Bygdeforskning (ibid.) karakteriserer satsingen som vellykket. Dette kan altså tas som et tegn på at utviklinga i småsamfunn kan påvirkes, men utredningen gir ikke svar på hva som er rett vei å gå for et enkelt lokalsamfunn eller sted. Ei heller er det en analyse av hva som hindrer utvikling. Vi vil i dette prosjektet skjele både til positive og negative sider ved utviklinga.

\section{Den nye bygdeøkonomien}

Den nyliberale filosofien betyr at næringsidealene er markedsøkonomi, skala- og vekstmodeller. På landsbygda er det imidlertid også mange virksomheter og mennesker som ikke lever og driver i tråd med denne tenkningen. Deres virkelighet er småbedrifter (SMB-er), ofte drevet på deltid, med fokus på hvordan bedriften skal overleve til neste dag, en virkelighet som er svært langt unna det meste som omtales i det dominerende bedriftsøkonomiske teorifeltet. Småbedriftene representerer ofte et alternativt næringsliv, som er relativt sett viktigere i landlige enn i urbane områder, og i fjerntliggende områder hvor det forretningsmessige potensialet ofte er begrenset. Ulempene med SMB-er er beskrevet i mange sammenhenger. De sies å være mindre profesjonelle, ha lavere kvalitet og å være mindre 
forutsigbare (Ateljevic \& Doorne 2004; Morrison \& Teixeira 2004). Men å grave i disse problemene er ofte ufruktbart (Jacobsen 2016). Og det er heller ikke hele historien. Distriktene og bygdene har også sine fordeler.

Forskjellene mellom det urbane og det landlige hverdagslivet er blitt vesentlig mindre enn de en gang var, hevdes det (Munkjord 2009). Tenkningen omkring by og land har både i politikk, kunst og forskning vært knyttet til en rekke stereotype dikotomier; som at mens landsbygda er natur, er byene sivilisasjon og kultur, at landsbygda representerer tradisjoner og byene modernitet, at på landsbygda er alt smått og trått, mens i byene er det stort og godt. Slik har det aldri vært, og i beste fall er dette ytterpunkter på skalaer. Ifølge Brauer og Dimitrow (2014) har de siste tiåra vært preget av at man har brutt ned en del tidligere forestillinger, blant annet om skillet mellom by og land, og mellom natur og kultur, mellom det abstrakte og det konkrete. De peker også på at mens man lenge hadde et hovedfokus på landsbygda som en produksjonsarena - for eksempel knyttet til landbruk og fiske - er landsbygda i dag også anerkjent som en arena for konsum, et konsum som både den rurale og den urbane befolkningen tar del i. Landsbygda skal både være et attraktivt sted å bo og å besøke, slik dagens politiske regimer vil ha det (Woods 2011). I tillegg danner tettere relasjoner mellom by og land mer enhetlige regioner der byene er sentra, men hvor byene og deres omgivelser utgjør industrielle distrikter (Hjalager 1997). Det er ikke alltid en balansert integrasjon, fortsatt er byene maktsentra, men de integrerte regionene representerer muligheter også for aktører fra periferien, og dikotomien by-land bør kanskje erstattes med grader av komplementaritet. Den stedlige spesialiseringen gjenspeiler ikke by-land-skiller i samme grad som tidligere.

Som andre har påpekt, har også landsbygda blitt modernisert, i takt med byene, men til dels med en annen og alternativ modernitet (Bringslid 2012). Med moderniseringa har byene og deres omland både fysisk (trafikalt) og mentalt nærmet seg hverandre (Brox 1984, 2006). Allerede i 1980-tallets Nord-Norge fungerte byene og deres omland som integrerte arbeidsmarkedsregioner. Til tross for slike tendenser finner det også sted en moturbanisering eller ruralisering, som består i at mennesker flytter fra byene til landsbygda. Mange foretrekker å bo på landet, og for noen er valg av bosted viktigere enn å ha en jobb på stedet. Forbindelsene mellom bolig og arbeid har blitt svekket. Folk velger bosted og tar de jobbene de får, pendler eller skaper seg egne arbeidsplasser (Herslund 2012), blant annet i «nye» 
næringer som reiseliv og kulturnæringer. Kanskje er det enklere å skape seg et levebrød på landsbygda? Og folk pendler, på daglig, ukentlig eller månedlig basis, eller de jobber hjemmefra på fjernarbeidsordning. Dette er en del av hva geografene har kalt en frikopling mellom tid og rom (Harvey 1989); vi mennesker velger sjøl hvilke koplinger vi gjør, om arbeidet skal få bestemme bosted eller ikke, hvor sentrale andre hensyn og verdier skal være.

Enda viktigere er at man kan se konturene av en ny økonomi både i urbane og rurale områder, eksisterende på siden av skalaproduksjon og vekstorientert virksomhet (Herslund 2012). På den nordnorske landsbygda er landbruk og fiske ikke like viktig som før, den er supplert med nisjeproduksjon, kulturvirksomhet og turisme, ofte basert på SMB-er eller mikrobedrifter. Allerede i 1984 beskrev Brox (1984) bortfallet av det tradisjonelle næringsgrunnlaget i nordnorske bygder, mens andre på 1990-tallet skrev om et mer differensiert arbeidsliv (Nilsen 1996). Internasjonalt snakker man om den differensierte landsbygda (Murdoch et al. 2003). Kanskje har landsbygda alltid vært det, lenge ble de fleste behov og oppgaver løst med lokal produksjon, og nærings- og arbeidsliv var tilsvarende variert. Bygdene trengte både smed, skomaker og hårklipper. Lokal næringstilpasning var vanlig. Men dette endret seg mye i tiåra før tusenårsskiftet. Lokalproduksjon ble mer og mer erstattet med import både av varer og tjenester. På 1990-tallet registrerte Brox (2006) - i motsetning til hva han hadde spådd et par tiår tidligere - at folk fortsatt levde langs kysten av Nord-Norge, men bare et fătall arbeidet med sjølbergingsjordbruk og lokalt fiske, som tradisjonene var tidligere. På 1990-tallet jobbet de i «lokale tjenester, som skole, vegsystemet, lokal transport og andre offentlige funksjoner» (ibid., s. 57). En av forskjellene fra tidligere tider, som også Brox har påpekt, er hvor viktig offentlig virksomhet er for bygdeøkonomien. I Troms i 2015 var 44 prosent av arbeidsstokken ansatt i det offentlige, ifølge statistikken. Det offentliges rolle, og særlig dets rolle som partnere i ulike typer institusjoner og prosjekter, er derfor et viktig tema i bygdesosiologien. Også halvoffentlige institusjoner har vist seg å stå sentralt i bygdeutviklinga mange steder. «Sosiale bedrifter er hybride organisasjoner som kombinerer profittorientert virksomhet og samfunnstjenester ...", sier Eversole og kolleger (2013). Etter hvert har vi fått ganske mange slike virksomheter i Norge. Nærliggende eksempler er kommunale næringsparker, vernede bedrifter og omsorgsinstitusjoner. 
Et annet element i den nye økonomien er bygdene som rekreasjonsområder for byfolk. Tradisjoner og landskap har blitt gjort om til konsumvarer i opplevelsesøkonomien (Larsen 2012). Overalt i Norge har det for eksempel vært gitt rom for en omfattende hyttebygging de seinere åra (Overvåg \& Ericsson 2016). Også et bredere anlagt reiseliv har fått innpass mange steder. Dette er en utvikling som ikke alle ser udelt positivt på. Det skrives både om Mac-ruralisering og disneyfisering av landsbygda, altså at den blir gjort om til tumleplass (eller lekeplass) for byfolk og andre tilreisende (Figueiredo 2013). Transformasjonen til hyttebygder der store deler av boligmassen eies av folk som primært bor andre steder, kan føre til at bygdene blir avfolket og passivisert, sies det (ibid.). På den annen side, mange steder inngår hyttene i levende lokalsamfunn og utgjør et viktig bidrag til den lokale økonomien.

Etter noen tiår med sterk spesialisering innen landbruket, hvor blant andre fiskerbonden har måttet vike, er det i dag tendenser til økt mangesysleri på landsbygda. Den omtales som et multifunksjonelt sosialt rom (Figueiredo 2013) og en hybrid økonomi. Altman (2001) argumenterer for tre viktige komponenter i den hybride økonomien: marked, stat og tradisjonell bytteøkonomi. Markedsdelen omfatter all slags forretningsvirksomhet, staten driver offentlige institusjoner eller er partnere i sosiale virksomheter. Offentlige institusjoner gir arbeidsplasser, representerer lokal omsetning og bidrar med ressurspersoner til lokalsamfunnene. Bytteøkonomien omfatter også sjølhushold, ikke-kommersiell utveksling av varer og tjenester utenom den formelle økonomien. Innen den uformelle økonomien er det en rekke former for utveksling av varer og tjenester, som svart arbeid, frivillighetsarbeid, dugnad, kanskje også en økonomi på kanten av hva som er lovlig (Gaugen \& Ferman 1987, s. 16). Bytting av varer og tjenester, herunder ubetalt arbeid, er internasjonalt kjent som barter-økonomi. «Barter kan defineres som en prosess hvor det foregår direkte utveksling av varer og tjenester uten pengetransaksjoner», sier Williams (1996, s. 85). Barter eller bytte skjer altså uten referanse til en nøytral standard (som penger). Williams peker på at dette var den førmoderne handelsformen, som mer eller mindre er forsvunnet i moderne industri- eller bysamfunn. Men handelsformen er ikke helt borte, den er fortsatt en del av hverdagen mange steder, for eksempel i svært mange nabolag, på mindre steder og $\mathrm{i}$ perifere strøk. Mange steder vil «partene i barter-handel forholde seg til 
sine individuelle og umiddelbare behov, ikke til abstrakte verdier», sier Ingham (1996, s. 517). Han hevder også at det finnes moderne varianter av uformell økonomi også i byer, særlig blant marginaliserte grupper. Og dette har vist seg, sier han, å være viktig i prosjekter og prosesser knyttet til lokalsamfunnsutvikling. Gaugen og Ferman (1987) understreker også at den uformelle økonomien som regel er viklet inn i den formelle. Det er nesten alltid elementer som håndteres i formelle kanaler, som for eksempel innkjøp av mange slag. Det er derfor snakk om grader av (u-)formalitet og ikke distinkte grenser. Gaugen og Ferman (1987) kaller dette en sosial økonomi, men peker på at den har sine grenser, og at det finnes negative sider ved den. Den er viktig for lokalt liv, men når bytterelasjonene gjelder større økonomiske verdier, blir det ofte problematisk.

Den nevnte småsatsingspolitikken til de norske myndighetene omfattet en rekke piloter i det som i evalueringen ble kalt lokal mobilisering (Holm \& Villa 2010). Lokal mobilisering er også en side ved det som ovenfor ble kalt sosiale bedrifter. De har som regel til hensikt å mobilisere både lokale og ikke-lokale ressurser og opptrer gjerne på tvers av tradisjonelle sektorer (Eversole, Barraket \& Luke 2013). Slike organisasjoner eller selskaper bidrar til styrket sosial kapital og kompetanse, men også til økt økonomisk aktivitet. Men mobilisering har også vært analysert som en forutsetning for utvikling av småbedrifter, blant annet i Sverige og Norge (Spilling 2011). Disse studiene har både påvist betydningen av kulturelementer og av formell organisering. Lokal mobilisering «må tilpasses til situasjonen et lokalsamfunn befinner seg i, og det er særlig viktig at samfunnsmedlemmene sjøl analyserer situasjonen og tar ansvar for å implementere de ulike initiativene», sier Spilling (2011, s. 28). Han viser til forskningen til Bengt Johannisson, som har studert lokal mobilisering i Sverige (Johannisson 2009). Johannisson viser både til lokale mekanismer som skaper stagnasjon og blinder lokalsamfunnet, og hvordan dette kan bekjempes. Det er også gjort studier av norske fiskevær som viser at tilpasning kan være en nøkkelfaktor i steders overlevelsesprosesser (Hovelsrud et al. 2010). Ofte er det Johannisson kaller sosiale entreprenører, sentrale i slike prosesser. Lokal mobilisering innebærer å styrke den sosiale orienteringen i lokalsamfunnet. I slike prosesser kan også forskere ha viktige roller, hevder Johannisson. Lokalsamfunnet er en arena og et handlingsfelt både for individuelle og samhandlende entreprenører, men tilførsel av kunnskap kan være nødvendig for å utløse slike potensialer. Det dreier seg også om å skape positive 
verdier og å få lokalsamfunnet til å erkjenne sitt verdigrunnlag, og hvordan verdier og holdninger påvirker samfunnsånd og næringsorientering. Entreprenørskap kan i seg sjøl ses på som en form for verdi.

\section{Problemstilling og metode}

På bakgrunn av diskusjonen over er det to hovedproblemstillinger som utkrystalliserer seg. Den første hovedproblemstillingen er den samme som utgangspunktet for undersøkelsen: Hva lever folk av på små plasser i Norges utkant? Slik vi har forankret det teoretisk, forventer vi å finne en mye mer sammensatt næringsbakgrunn enn hva som gjaldt noen tiår tilbake. Problemstillingen er derfor hva denne sammensetningen består av, og hvor sentralt offentlige arbeidsplasser og arbeid i næringslivet er for denne overlevelsen? Og hvor viktig er pendling, og kan man finne spirer til «nye» næringer?

Den andre hovedproblemstillingen tar utgangspunkt i det faktum at statistikken viser nedgang i folketallet i disse områdene, samtidig som det finnes teorier om samhold og dugnadsånd på små, tette steder (Sanden, Thulesius \& Harrysson 2015). Spørsmålet vårt er dermed om man lokalt gjør noe for å skape aktiviteter som kan bedre denne statistikken: Tas det lokale initiativer, skjer det vi kan kalle lokal mobilisering? Og hvis ikke, hva skyldes det? Disse problemstillingene vil bli belyst i det følgende, basert på datainnsamling i Årviksand og Badderen. Stort sett sammenfaller disse problemstillingene med det diskursive engasjementet som Woods og McDonagh (2011) har identifisert i forskningsfeltet: a) å finne ut hva slags problemer og utfordringer bygdene står overfor, b) evaluere områdenes muligheter, og c) bidra til å skape visjoner for framtida til disse områdene. Om forskningen også kan bidra til det siste punktet, er det fint. Herværende prosjekt er skapt i dialog med dem som bor der, og informantene er plukket ut av lokale aktører som synes å ha valgt ut posisjons- og meningssterke mennesker. Mange har visjoner for framtida. I tillegg til dette er en del av den anvendte metodikken teori, altså det man fra andre undersøkelser vet om den typen samfunn vi skulle studere. Vi gikk altså ikke til verket med blanke ark.

I utgangspunktet gjorde vi gruppeintervjuer, en metode som både har fordeler og ulemper (Viken 2015). Blant fordelene er at vi får samtaler 
og meningsutvekslinger om temaene vi tar opp, ikke bare individuelle synspunkter. En ulempe er at vi ikke kan forfølge temaer som har å gjøre med individene som deltar, for eksempel knyttet til ildsjelene. Det ville vært interessant å vite hva som driver dem, hvor viktig konteksten de inngår $\mathrm{i}$, er, og så videre. Men dette ville kreve individuelle dybdeintervjuer. Den metoden har vi ikke anvendt. Gruppedeltakerne var både kvinner og menn, folk i arbeidsalder og eldre, ingen ungdommer, men noen unge voksne. Særlig har vi i ettertid sett at yngre utflyttede under utdanning ville ha vært en interessant gruppe, men de er altså ikke med.

Intervjuene i Badderen fant sted 4.-6. april 2017 i lokalene til Kvænangshagen Verdde, Sørstraumen. Rekrutteringen til intervjuene var gjort av folk knyttet til næringshagen. Til sammen 28 mennesker deltok, en i et enkeltintervju, resten i gruppeintervjuer med fra to til seks deltakere. Det viste seg alt i utplukkingen av informanter at stedet Badderen ikke hadde en entydig avgrensning, det kom folk både fra Dorras, Sørstraumen og Kjækan, steder som egentlig ikke er en del av Badderen. Men vi fikk et klart inntrykk av at de på mange måter bodde på samme sted, stedet er altså Badderen med omland, eller kanskje stedet Kvænangen? Dette kan ses på som et tegn på det som har skjedd overalt i Norge, steder har glidd sammen og nye storbygder har oppstått.

I Årvik foregikk intervjuingen de siste dagene i mai 2017 i skolens lokaler. Til sammen elleve personer deltok. Rekrutteringen av informanter ble gjort av en lokal representant, som også satte informantene sammen i grupper. Intervjuene varte begge steder i en-to timer. Det ble gjort opptak av intervjuene. Alle informantene bodde i bygda. Årvik har ikke i samme grad som Badderen vokst sammen med nabobygda, men tendensen til at stedet inngår i større enheter, kan også merkes her.

Det er mange måter å nærme seg den underliggende problematikken på. Jeg har her valgt å fokusere på lokalsamfunnsutvikling fra et bygdesosiologisk ståsted. Et alternativ kunne vært å fokusere på entreprenørskap. Dette ville vært et naturlig valg i et sosialantropologisk perspektiv, hvor individet som økonomisk aktør ofte har vært satt i fokus (Barth 1981). Med fokus på dugnad og mobilisering ville man også kunne valgt et sosialpsykologisk utgangspunkt. Det gjorde man i en nylig publisert artikkel i Sverige, hvor et lokalsamfunn i Vesterålen (kalt Polarfjorden) ble satt under lupen (Sandén, Thulesius \& Harrysson 2015), med omtrent samme 
problemstilling som i herværende studie. De finner at folk er godt fornøyd med tilstanden, og kaller det «nuets fornøjsamhet». Folk er relativt tilfreds med tilstanden og bekymrer seg i hverdagen verken om fortid eller framtid mer enn høyst nødvendig, hevdes det i artikkelen. De peker så på årsakene til dette, noe som de har fått fram gjennom lange feltarbeid på stedet. Vårt perspektiv er hvordan utkantsteder består i en tid hvor sentraliseringspresset er stort, og hva folk ser som de viktigste årsakene til at man har en positiv eller negativ utvikling på sitt sted. Dette avdekket vi med en helt annen form for datainnsamling, som snarere kan kalles episodisk, og som mangler feltarbeidets modnende fortrolighet og potensial. Men også vi oppfatter steder som dynamiske prosesser like mye som geografiske lokaliteter, og som punkter i nettverk som forbinder stedene med den store verden, og som mer eller mindre tilfeldige møteplasser for ulike strømmer av mennesker, penger, varer og kunnskap. Vårt utgangspunkt kan dermed også sies å være inspirert av relasjonell økonomisk geografi (Bathelt \& Glücker 2003; Massey 2005).

Til tross for skepsis til veksttenkningen stilte vi spørsmål preget av dette paradigmet. Vi stilte først spørsmål om næring, utvikling, endring, drivkrefter og omstilling. Spørsmål om bolyst, trivsel og verdier ble på en måte underordnet disse. Når det da ikke er vekst eller utvikling, blir fortellingen vår fra Badderen negativ, sjøl om vi også får fram at det er et godt sted å bo. Grunnen til at det er slik, tilskrives for eksempel kommunen, som i likhet med andre moderne kommuner har satt næringsutvikling på dagsordenen. Men er det egentlig kommunens ansvar å skape næringsutvikling? Og kanskje er det takket være kommunen at det ikke er verre? Dette er metodiske forbehold som vi må ta. Vi er ikke objektive måleinstrumenter, men forskere med en betydelig ballast. Det kan ha vridd utspørringen og vår fortelling.

Sjøl om vårt utgangpunkt var teoretisk og epistemologisk farget av vår samfunnsfaglige bakgrunn, har også empirien til dels fått styre vårt teoretiske arbeid. Det betyr at vi underveis har oppdaget andre teoretiske felter enn dem som dannet vårt utgangspunkt, som har stor relevans for det vi holder på med, som følge av vinklinger hos informantene. Det handler om kultur og historie, og det dreier seg særlig om forankring og tilpasning og om sjøl å ta styring over sin situasjon, eller ikke å gjøre det. 
Fra et metodologisk ståsted kan man spørre hva verdien av en slik undersøkelse er. Den kan sikkert reise aktuelle problemstillinger for stedene som er i fokus, men har den gyldighet ut over det? Dette går inn i ett av kjernespørsmålene knyttet til kvalitative og narrative metoder. Vårt mål er å sette ord på hva folk lever av, hva som er dynamikken på småsteder, og å forstå positive og negative prosesser. Til slike formål er kvalitative metoder hvor en snakker med folk, å anbefale.

\section{Nord-Troms: fiskerbønder og sjøsamer}

Nord-Troms var tidligere bebodd av fiskerbønder; jordbruk kombinert med fiske var næringsgrunnlaget. Det var havet som bandt bygdene sammen helt til i siste halvdel av forrige århundre. Steder som Årvik var langt fra isolerte så lenge hovedtrafikkåren var havet, slik det av og til sies (Sandén, Thulesius \& Harrysson 2015). Årviksand fikk sine veier ferdigstilt i 1968. Dette var omtrent samtidig med den store utdanningsreformen, med ungdomsskole og tilbud om videregående utdanning. Den politikken hadde dramatiske konsekvenser for små steder; ungdommen måtte reise ut for å ta utdanning. Dette førte til lavere rekruttering til fiskeriene. Seinere, rundt 1990, skjedde det endringer i både fiske og landbruk, og det ble innført kvotesystemer på begge områder. Mange hadde for liten melkeproduksjon til å få fortsette med melkeleveranser, mens fangsten var for liten til å få kvote som fiskere. Dessuten ble frafallet fra fiskeriene og jordbruket forsterket av et skolesystem som bygde ned statusen til disse yrkesfeltene, hevdet våre informanter. Fiskerbonden passet ikke inn i den offentlige politikken fra 1970-tallet og framover og ble mer eller mindre utradert (Brox 1984). Brox (1984) har beskrevet hvordan levestandarden økte, sjølhusholdet forsvant, og behovet for penger steg. Dette var også understøttet av en landbrukspolitikk som favoriserte større bruk med produksjon for salg, og i fiskeriene var det stadig mindre rom for sjarkfiske og fiske som deltidsarbeid. Folk ville ha lønnet arbeid, og mange flyttet fra «utværene» til byene. Mentalt og politisk ble fiskerbonden omgjort til et problem, påpekte en av våre informanter. I disse prosessene forsvant også mye av kunnskapene til fiskerbonden, ble det sagt. Disse prosessene er godt beskrevet av andre, men beskrives også av de eldre informantene våre, som sjøl hadde opplevd dem, og som ser det som prosesser som stadig pågår. 
Prosessen har ikke vært omstilling, men et forsøk på avvikling, slik en av informantene omtalte det. Uansett, det har lenge vært en negativ utvikling i regionen målt i folketall, flytting og fødselstall. De fleste fiskerbøndene var av samisk avstamming. Folketellingene fra 1910 viste dette (Bjørklund 1985). Men fornorskningen satte dype spor, og ved folketellingen i 1970 var det bare et fåtall som anså seg som samer i for eksempel Kvænangen. Men fornorskningen medførte også modernisering og integrering i velferdsstaten. Det betød blant annet et godt utbygd utdanningssystem. Utdanning førte imidlertid til utflytting, da alle skoler på videregånde nivå og høyere var lokalisert til kommune- og fylkessentra. De færreste av ungdommene som har dratt ut for å utdanne seg, har kommet tilbake og bosatt seg der de vokste opp. Modernisering og velferd har hatt sin pris og blir omtalt som tveeggede sverd på begge de stedene vi har studert.

Altså, både Årviksand og Badderen har vært hardt rammet av sentraliseringspolitikken, både den som lå implisitt i utdanningsrevolusjonen, og den som dreide seg om omstrukturering av fiskeri og jordbruk. Som vi skal vise i det følgende, har man taklet dette på ulikt vis på de to stedene.

\section{Årviksand: tradisjon for å ordne opp}

Årviksand, eller Årvik som man oftest sier, ligger i den nordøstlige hjørnet av Troms, på Arnøya i Skjervøy kommune, på grensa til Finnmark. Stedet som i 2017 hadde 118 innbyggere, er et fiskevær, noe det alltid har vært. Inntil de siste tiåra av 1900-tallet var beboerne fiskere og fiskerbønder. Det betød stort sett at mennene fisket og kvinnene var bønder. Med strukturendringene i fiskeriene ble fiskeriene et mer ensidig næringsgrunnlag, og jordbruket forsvant. I dag er det igjen én bonde, og fiskerbonden er havnet på museum, en av attraksjonene i bygda. Det er en velkjent postmoderne foreteelse at fortidas næringsfasiliteter tilrettelegges for moderne konsum og turisme (Urry 1990). Fiskebruket har overlevd historiens mange fiskerikriser og er i dag bygdas største arbeidsplass, med 40-50 ansatte - i 2017 besto arbeidsstokken blant annet av mange rumenere. Bruket kjøper fisk fra kystfiskeflåten, produserer og selger saltfisk og skiper ut ferskfisk. I tillegg rommer stedet et mekanisk verksted med fem ansatte, en butikk, to fisketurismebedrifter og noen fiskere som alle egentlig er pensjonister. Det er ingen moderne fiskebåter på stedet. Lakseoppdrett er den største virk- 
somheten på Arnøya, og noen få fra Årviksand arbeider der. Hele Arnøya er sommerbeite for rein, men man har lite kontakt med reindrifta, sies det. Det er en del fritidshus i bygda, de fleste eid av utflyttede årvikværinger, eller hus arvet av folk som bor andre steder. Flere informanter understreket at de helst så at det var fastboende i husene, og man ønsket ikke at for mange hus blir gjort om til fritidsboliger. Folk vil gjerne tilrettelegge hyttefelt, men på utsida av bygda. Det hadde vært planer om et på nordsida, men dette ble stoppet av kulturminnevernet. Det er relativt mange vernede groper etter tidlige tiders oljenæring - hvalkoking - i området. Hyttefolket og turistene sies å utgjøre viktige bidrag til omsetningen i den lokale butikken, og de besøkende skaper liv i bygda. Flere av de vi snakket med, hadde gjerne sett at det var flere som prøvde å etablere nye virksomheter i bygda, for eksempel knyttet til turismen.

Som på mange andre steder betyr de offentlige og halvoffentlige arbeidsplassene mye for sysselsettingen. På Årviksand er det skolen og barnehagen som først og fremst utgjør kategorien. Skolen er privat, men har solid offentlig støtte. Ellers finnes det noen som pendler til Skjervøy og jobber i kommunen. Det finnes også sjøfolk på turnusordning, og noen få som ukependler til Tromsø.

\section{Samhold og samhandling}

Årvik har hatt nedgang i folketallet de siste tiåra. Tre til fire ganger så mange bodde der på 1970-tallet. Likevel oppleves bosettingen som relativt stabil, det er verken en påtakelig utflytting fra eller innflytting til stedet. Når vi spurte om hva som holder dem der, framheves det at det er et godt sted å bo, med et godt samhold. Stedet er et godt sted å vokse opp, har store friluftslivsmuligheter og vakre omgivelser. Folk kjenner hverandre, bryr seg om hverandre og har mye kontakt. Man låser verken hus eller bil. Og man går på besøk til hverandre uanmeldt. Er døra ulåst, anses man som velkommen.

Samholdet utfolder seg på ulike måter og på ulike arenaer. På et lite sted kjenner alle, og man møtes på veien og butikken, og i møter i foreninger. Det hender også at folk stikker innom kantinene på fiskebruket eller verkstedet for å slå av en prat. Og man hjelper hverandre, om det trengs. En maskinentreprenør berømmes for eksempel fordi han hjalp til hos folk når de trengte det. Ellers møtes man på en del arrangementer som gjennom 
året er samlingspunkter både i tid og rom. Kvinneforeningen og Ungdomslaget, som har sitt eget ungdomshus, avholder en del arrangementer i løpet av året, som jule- og påskefester, 17. mai-fester, møljekalas og restaurantkvelder. Viktig har også Årvikdagene vært, et helgearrangement en gang om sommeren. Arrangementet ble ikke avholdt i 2017. Ildsjelene var slitne, ble det sagt. Det snakkes en hel del om disse ildsjelene. Det er de som holder mange aktiviteter i gang. For eksempel barneidretten. Som organisert tilbud er den mer eller mindre lagt ned. Foreldre og barn må til Skjervøy for turn- og fotballtrening. Det betyr at man må dra i tretida om ettermiddagen og er tilbake klokka ni om kvelden - for en times trening. Dette sliter. Og det sliter enda mer fordi man må stille opp tidlig i fergekø for å komme med, og på grunn av veien som oppleves som utrygg, og som av og til er stengt på grunn av været. Det er mye vær i Årvik. Været og infrastrukturen er minussidene ved å bo i Årviksand. Flere nevner at den etablerte veioverbygningen er for kort, og at man drømmer om fastlandsforbindelse (via Skjervøy). Det finnes planer for et undersjøisk tunnel der man i dag må ta ferge. De tunge argumentene for denne forbindelsen er ikke ungene, men fiskeri og lakseoppdrett. Det går flere trailere med fisk fra øya hver dag, året gjennom. Vi trenger noen som sentralt (i det politiske Norge) jobber for tunnelen, sies det.

Samholdet har også reddet flere av de sentrale institusjonene i bygda. Med nedgang i fiske og folketall har kommunen ikke sett seg råd til å holde i gang barnehage og skole. Da man la ned barnehagen, overtok bygdefolket, og da man la ned skolen, startet foreldrene en Montessori-skole. Og da fiskebruket sto i ferd med å stenge, gikk folk fra bygda sammen og kjøpte det, sammen med en fiskeriaktør fra Senja, og da butikken var i fare, kjøpte en fra bygda den, for å drive videre. Alt dette har skjedd ved at man drar i lag, eller har støtte fra andre. Det snakkes altså først og fremst om samhold, men også om dugnadsånd. Den gjelder også i private sammenhenger - at man hjelper hverandre. Bygdefolket gjør også ting sammen - for bygda, gjerne initiert av noen ildsjeler i en av de frivillige foreningene. Det er tilrettelagt flere kulturstier i området, for eksempel i Årvikmarka, hvor man har arbeidet i lag - på dugnad - for å få det til. Man har stasjonert en hjertestarter på skolen, og noen har gått på kurs og trår til når det er nødvendig. Og man har et brannkorps av frivillige - som en sa om mannen sin: «Han kunne ikke akkurat si nei», da han ble forespurt. Og fiskebruket vurderes som en institusjon som er viktig for bygda, ikke bare 
som en forretning og ut fra profitthensyn. Det er forskjellen fra forrige eier, sies det, som bare drev forretning og ikke var en samfunnsaktør. Alt dette øker trivselen og styrker samholdet. Og gjør Årviksand til et bra sted å bo.

Nesten alle våre informanter hadde $\mathrm{i}$ faser av livet bodd andre steder, blant annet i Tromsø, som er «byen». De reflekterte over hva de savnet, eller ikke savnet ved å bo i Årvik. Slik det var i 2017, var det båtforbindelse til byen hver dag, og fergen går hver time. Det er altså ikke en stor sak å dra til byen, det synes å være mer belastende at dersom de skal til lege eller et kommunekontor, så må man til Skjervøy, og det tar mer eller mindre en hel dag. Ting tar tid når man bor i en slik utkant. De opplever heller ikke de store forskjellene mellom hverdagslivet i byen og på landet. Forskjellene var langt større før. Internettverdenen og -kulturen er den samme for alle, mente man. Kanskje er ungene likevel flinkere til å sysselsette seg sjøl enn unger i byen. Det er mye å holde på med i nærmiljøet, i fjæra, på kaien og på veien - fisking, fotball og all slags lek. Å vokse opp på Arnøya er bra, slik det alltid har vært, sies det. Og det har mange fordeler. Det er mye som er billigere enn i byen. «Det er bedre å bo her, og ha råd til å dra til byen og benytte dens tilbud nå og da, enn å bo i byen og ikke ha råd til å bruke tilbudene som er der», sa en av informantene.

Det er altså tradisjon for å ordne opp sjøl i Årvik, når omverdenen opptrer ublidt. Som det ble sagt, så har man lange tradisjoner for å måtte klare seg sjøl, plassert langt fra andre, og med veiforbindelse først i 1968. Det er en del av kulturen på øya, at man tar et tak for fellesskapet og ordner i stand tiltrengte tiltak, som skole, barnehage og butikk. Det antydes også at dette kan være en sovepute for kommunen, som vet at folk "der ute» ordner opp sjøl. Og kanskje har det også enkelte ganger ført til at man ikke har stått på krava. "Vi står litt med lua i hånda, her ute», ble det sagt om forholdet til overordnede myndigheter. Men man løser altså problemene når de oppstår. Flere av våre informanter virket relativt bevisst på sin retoriske måte å snakke om stedet sitt på. «Vi står'an av»-holdningen har en stor symbolsk betydning i skapingen av positive stedsbilder og fortellinger (jf. Sandén, Thulesius \& Harrisson 2015). Slike fortellinger representerer samtidig en oppskrift for hvordan man kan eller skal opptre i kritiske situasjoner, i kulturen ligger det en beredskap til å håndtere kritiske tider (ibid.). Man tilpasser seg situasjonen, slik man alltid har gjort, og som gjør at man har stått gjennom kriser og trusler av ulike slag, fra havet og det sentralpolitiske systemet. 


\section{Badderen: utfasing eller innlemming i et større sted?}

Badderen er en av bygdene i Kvænangen kommune. Området som var inkludert $\mathrm{i}$ vår undersøkelse, er de vestlige delen av kommunen, fra Baddereidet og forbi Sekkemo-krysset. Dermed inngår stedene Badderen, Dorras og Sørstraumen. Kommunen har cirka 1200 innbyggere. Det er cirka 440 hytter i kommunen, hvorav cirka 330 sies å være i bruk. Kvænangen er grensekommune til Finnmark. Kommunens innbyggere gikk imot sammenslåing av kommunen med andre under en folkeavstemning i 2015. Både Nordreisa og Alta har vært inne i dette bildet. Uansett skjer det en sentralisering, også innad i kommunen, til kommunesenteret Burfjord. Det gis uttrykk for at det er en stor kommunal uvilje mot å lokalisere til steder som Badderen. Alt skal skje i sentrum, hvor man bygger ny skole, hvor idrettslaget er lokalisert, hvor kommunale kontorer og tjenester stort sett er lokalisert, og det meste foregår. Skolen i Badderen var lagt ned, og ungene i Badderen hadde inntil 2016 kunnet velge mellom å gå på skole i Burfjord eller i Kjækan, som ligger tolv kilometer inn mot Kvænangsbotn. Kjækan skole som i 2017 hadde ni elever, skulle nedlegges $\mathrm{da}$ vi gjorde vår datainnsamling, til stor frustrasjon for noen av informantene. Men som det ble sagt, det synes ikke å være noen vei utenom, og skolen ble lagt ned.

De vi snakket med, hadde enten alltid bodd der, flyttet tilbake til stedet de var oppvokst på, eller flyttet dit på grunn av en partner med røtter på stedet. Noen flytter til stedet

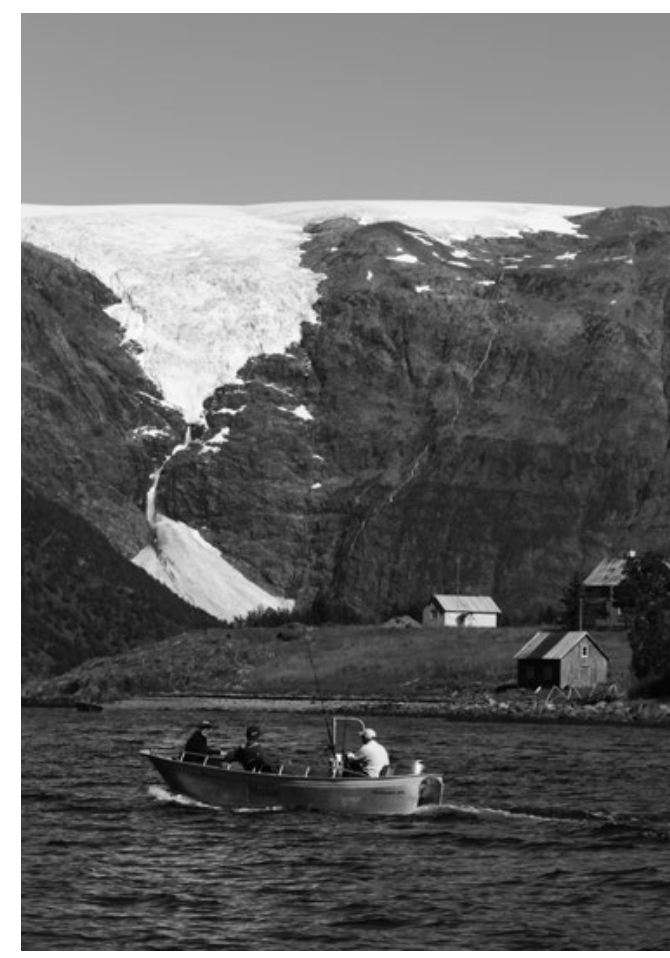

Kvænangen - fra fiskarbønder til turistbønder? Foto: Ole Magnus Rapp. 
fordi de får jobb der. Noen vi intervjuet, jobbet i det offentlige, i likhet med 60 prosent av kommunens arbeidstakere. Også på stedet Badderen er en offentlig eid arbeidsplass sentral, en vernet produksjonsbedrift. Kraftverket, som har hovedsete i Kvænangsbotn noen kilometer unna, er også en arbeidsplass for folk fra Badderen og en inntektskilde for kommunen. Største private arbeidsplass i kommunen er Marine Harvest, et konsern som driver lakseoppdrett på åtte lokasjoner og et lakseslakteri i Jøkelfjord. Til sammen utgjør dette om lag 30 arbeidsplasser på sjøanleggene og 25-50 på slakteriet i Jøkelfjord (avhengig av om det er ett eller to skift). I tillegg skaper fiskeoppdrett en del aktivitet i servicebedrifter som leverer tjenester til anleggene. Fiskeoppdrett er i særdeleshet den viktigste arbeidsplassen blant yngre mennesker. Fiskeriene har lenge vært i nedgang, men det finnes et fătall fiskere i kommunen, særlig på Spildra og i Burfjord, hvor det også kan leveres fisk. I selve Badderen er det i tillegg til den vernede bedriften et bilverksted, en liten produksjonsbedrift, en stall og en nystartet pub i en nedlagt butikk. Det er dessuten fire bedrifter som tilbyr overnatting på den aktuelle strekningen. Det pekes ellers på en del nyetableringer i kommunen, for eksempel innen bygningsservice, men det er i kommunesenteret Burfjord. Flere fra Badderen dag- eller ukependler til Alta og Storslett. Dessuten er det en hel del som langtidspendler, særlig sjøfolk, og noen som arbeider i større transportfirmaer lokalisert andre steder. Det er også en del mennesker som er på trygd, og gjennomsnittsalderen er høy. Man trenger nye arbeidsplasser, men folk har ikke lett for å se hvordan de skal komme. Hovedinntrykket er et lokalsamfunn som er svært avhengig av ytre krefter og aktører. En informant på nærmere 90 år mener at det så lenge hun kan huske, har vært nedgangstider, og at denne trenden bare synes å fortsette. Noen ser muligheter i nye næringer, og særlig da knyttet til lakseoppdrett, hytteservice og turisme. Det mest interessante er kanskje imidlertid at stedet og kommunen synes å være et godt sted å bo.

Næringsutvikling har vist seg vanskelig i Badderen. Det trekkes fram eksempler på at man ikke har fått det til - ideer som ikke har blitt til virkelighet. Kulturen har vært slik at man vil ha lønnet arbeid, på arbeidsplasser som andre har skapt, altså at de færreste har skaffet seg en bakgrunn som gjør dem til entreprenører. «Vi tør ikke», sies det, altså er man lite villig til å ta sjansen og starte for seg sjøl. Det ble også hevdet at jantelov og avundsyke var utbredte fenomener. Man skal ikke stikke seg ut, og bedriftsetableringer kan bli oppfattet slik. Det er altså ikke en entreprenørånd på stedet. En 
annen faktor som nevnes, er at det er flere typer byråkratiske hindringer mot bedriftsetablering. Noen nevner skjemaveldet og det byråkratiske arbeidet man må gjøre både for å starte opp, og for å drive bedrift. Andre peker på kommunen, som de opplever som negativ til bedriftsetableringer. Saksbehandlerne ser «bare» hindringer, som for eksempel samfunns- og arealplaner som enten ikke finnes, eller som er prioritert andre formål enn det folk har hatt ideer om, for et område. I flere tilfeller har folk opplevd at man viser til at det foreslåtte vil komme i konflikt med reindrifta, og dermed avvist. Inntrykket fra datainnsamlingen er at kommunen ikke fungerer som en fasilitator, men som et hinder for næringsutvikling. Et fjerde problem er forholdet til andre næringer, og særlig til reindrifta. Til og med en idé om fisketurismebedrift hadde blitt stoppet av reindriftshensyn, ble det sagt. Samtidig etterlyses det dialog med reindrifta, «dialog begge veier», som en uttrykte det.

Blant dem som hadde startet bedrifter, ble en etablererskole de hadde gått på, trukket fram. Den hadde vært god og til stor hjelp for flere av informantene. Kurset hadde blant annet gjort det lettere å hanskes med alt papirarbeidet. Altså synes det som om offentlig tilrettelegging kan ha vært viktig for flere av småbedriftene på stedet. Det kom samtidig fram eksempler på nye ideer og forsøk med ny virksomhet. En hadde begynt med villsau, en med mekanisk verksted, og puben var også ny. Det finnes ett gårdsbruk i bygda, og kommunen er viktig sommerbeite for reindrifta. Flere av informantene mente at man burde revitalisere både jordbruk og fiske. Særlig uttrykker flere det paradoksale i at det nesten ikke finnes fiskere i bygda. Man reflekterer også over hvorfor fisket på 2000-tallet har vært så dårlig i Kvænangen, som tradisjonelt var et fiskerisamfunn. Kan det skyldes fiskeoppdrettet, spør noen? Flere peker på trålerfiske som hovedårsak, at trålere eller andre store fiskebåter har «tømt» fjorden. Av «nye» næringer er turisme stadig et tema. Det finnes litt av det, og særlig er det en viss mengde hytter, med folk fra Alta som den største gruppen. Det var flere som var inne på at dette måtte kunne være et satsingsområde framover, og at det kan være en viss «vaktmesterøkonomi» knyttet til dette. Når det gjelder andre former for turisme i Kvænangen, så er det noen campingplasser, noen nye hytteutleiebedrifter og noen fisketurismebedrifter, men ingen hoteller. Det største og fineste overnattingsstedet Gildetun på Kvænangsfjellet noen kilometer unna - drives på lavbluss, ble det hevdet. Den såkalte opplevelsesnæringa er også representert med et 
par aktivitetsbedrifter i Jøkelfjord og en sportsutstyrsprodusent i Burfjord. Opplevelsesnæringa er altså liten, til tross for en stor enighet om at mulighetene i naturen er store og mange, og at tilgjengeligheten også er god. Man mangler entreprenører, sies det.

Hovedinntrykket er at det er langt mellom nye bedriftsetableringer. Det virker som om de fleste sitter og venter på at noe skal skje, uten at de sjøl skal bidra. Flere nevnte at de ønsker seg at en sterk person skal komme til bygda og sette i gang noe. Svært mange har imidlertid liten tro på at det vil skje, og antyder at nedgangen i folketallet vil fortsette. Næringene man hadde, er stort sett forsvunnet. Overgangen fra fiskerbondetida til i dag har bare gitt en ny næring: lakseoppdrett. Altså har tilpasningen til nye tider vært svak.

\section{Omå drailag}

Vi spurte innledningsvis om hva slags sted Badderen er. De fleste svarte at det var et godt sted å bo, både sosialt og når det gjelder sosial service; man hadde fortsatt barnehage, grendehus og et fungerende grendelag, men ikke skole. En kvinnelig informant snakket særlig varmt om Badderen som bosted; her bryr man seg om hverandre, støtter hverandre, har nytte av hverandre og nyter godt av naboer som bryr seg, sa hun. Hun holdt dette opp mot en småby på Østlandet, hvor hun hadde bodd i mange år, men hvor hun hadde følt på avstanden mellom folk, til tross for tette nabolag. Flere viser til at Badderen er et sted hvor man fortsatt kan gå på besøk til hverandre uten å melde fra på forhånd, uten å være invitert. Men noen mener dette er i ferd med å endre seg, at man gjør det sjeldnere enn før. Noen mener at mye av den lokale informasjonsflyten i dag skjer gjennom sosiale medier, og at man holder seg godt orientert uten å møtes. Det er blitt lettere å følge med på hva som skjer, og framfor alt er det blitt lettere å organisere ting. Men de sosiale mediene er også blitt arenaer for kanalisering av uoverensstemmelser, uthenging og hets. For eksempel er det en arena for å eksponere misnøye med reindrifta, og mye annet. Den viktigste møteplassen i bygda synes å være butikken. Den har en kaffekrok hvor folk møtes og diskuterer «verdensproblemene», og har en viktig sosial funksjon. I tillegg nevnes også puben som et positivt sosialt tilskudd.

Badderen og Kvænangen har mange lag og foreninger som er relativt aktive, og kommunen har hele ni grendelag med hver sitt grendehus. 
Grendelagene sies å være svært avhengige av ildsjeler, folk som tar initiativ og organiserer. Ofte er det også disse menneskene som gjør det meste av jobben. Grendelaget i Badderen organiserte i mange år Baddertreffet, hvor utflyttere og de som bodde der, møttes rundt en del arrangementer; fiskekonkurranse, idrett, grilling og fest på kvelden. Planleggingen og forberedelsene til dette arrangementet ble også nevnt som viktige sosiale arenaer, men man hadde i det siste slitt med å få folk til å stille opp, for eksempel i styret. I 2017 valgte man derfor å flytte arrangementet til sankthans og «konsentrere det om en fest». Ellers ble Verdde-turneringa i fotball nevnt som en av årets viktigste hendelser. Den er både en begivenhet, en anledning til å møte samene og en fest både med positive og negative innslag, blant annet slåssing.

Også når det gjelder frivillig arbeid og organisasjonsarbeid, skjer det en sentralisering. De fleste organisasjonene har sete og hovedaktiviteter i Burfjord. Det er en sterk gravitasjonskraft i bygda, uttrykte en informant, og den er sentrert rundt Burfjord. Et eksempel er idrettslaget. En diskusjon om å endre navnet fra Burfjord til Kvænangen idrettslag hadde stoppet opp. Burfjord er altså en kilde til frustrasjon, sjøl om mange arbeider der. En annen kilde til irritasjon er reindrifta. Den går på at reinen invaderer bygda og forstyrrer landbruket, at hensynet til reindrifta hindrer andre aktiviteter, samt at reindrifta har særrettigheter i forhold til bruk av utmark og verneområder. Reindrifta har rett til fri motorisert ferdsel og bruk av naturen der andre har sterke begrensninger. Dette oppleves som urettferdig.

\section{Etsted å bo}

Analysen så langt er at det synes å være vanskelig å få til næringsutvikling både i Badderen og Kvænangen som kommune. Noen er pessimistiske også når det gjelder det man har, fiskeoppdrett og kommunale arbeidsplasser. Oppdrettsnæringa kan bli dratt til havs eller på land, tror noen, og med en eventuell kommunesammenslåing vil mange arbeidsplasser forsvinne, antas det. Man ser muligheter i bedre tilrettelegging for friluftsliv, hyttebygging og turisme. Dette står i stor kontrast til det faktum at folk trives, og at både Badderen og kommunen synes å være et utmerket sted å bo.

Altså er det nærliggende å se for seg at Badderen eller Kvænangen i framtida først og fremst vil være et sted å bo. Dette er i tråd med nyere forskning. Det er ikke uvanlig at folk finner seg steder de vil bo, flytter dit, 
og så finner seg et arbeid, eller tar med seg det arbeidet man hadde fra før. Som det ble sagt i flere grupper, svært mange utfører i dag sitt arbeid på PC og over nett, noe som i prinsippet er stedsuavhengig. I gruppene kom det opp flere eksempler på dette, og på ideer om prosjekter hvor dette var fokus. Dette ble også knyttet til hyttelivet. Hyttene er som hus, og man kan godt arbeide fra hytta. Trolig blir det derfor mer vanlig at man er på hytta flere dager i slengen. Skjer det, blir hyttefolket også viktigere for lokalsamfunnet.

Framtida for et sted som Badderen, og kanskje hele Kvænangen, kan likevel ligge i at man blir del av større enheter. For eksempel vil Kvænangen kunne vokse atskillig som hytteområde, først og fremst for altafolk. Dette vil også kunne være et insentiv til økt satsing på turisme med overnatting i dagens kommune. Innlemming i en større kommune kunne bety nedbryting av mentale barrierer; for eksempel vil de som driver turisme i og fra Alta, kunne utvide sine revir til også å omfatte Kvænangen. Dernest vil innlemming i større systemer, for eksempel for næringsutvikling, kunne bli en fordel. Skal man få noe til i dag, må man inngå i nettverk, ble det sagt, og kanskje er de å finne utenfor dagens kommunegrenser.

\section{Sammenfattende diskusjon}

Det vi har funnet ut om småsteder i Nord-Troms i dette arbeidet, er at det er ganske store forskjeller med hensyn til bosetting og næringsutvikling. I Årvik, som folk som bor der, beskriver som et fiskevær, er det privat næringsvirksomhet, først og fremst fiskebruket og et mekanisk verksted, som er kjernen i sysselsettingen og bosettingen, dernest flere halvoffentlige arbeidsplasser. På det andre stedet, Badderen, er de offentlige eller halvoffentlige arbeidsplassene hovedkilden til folks inntekt, dernest pendling, dels til oppdrettsanleggene på ulike steder i kommunen og til kommunesenteret, samt pendling til steder utenfor kommunen. Dernest finnes noen små virksomheter, som en gård og et par mekaniske verksteder. Et kraftverk i nærheten er også en viktig arbeidsplass og kommunal inntektskilde. Relativt mange mennesker har Badderen som bosted, men arbeider et annet sted. Det finnes også en del mennesker som har sitt andre hus på stedet, og som tidvis arbeider derfra. Også dette er et kjent fenomen fra andre steder. I sum er Årvik et sted med en heller tradisjonelt sammensatt 
økonomi, mens lokaløkonomien i Badderen er langt mer variert og mangfoldig, og i mindre grad lokal.

Årviksand synes å ha blitt mindre påvirket av moderniseringas omstruktureringseffekt. Slik forankring skaper lokalt handlingsrom. I Årviksand har lokalbefolkningen over lang tid skapt seg slikt handlingsrom. Gjennom historien har man lært seg å ta ansvar og ordne opp sjøl. Det har vært nødvendig for å overleve. Det er grunn til å tro at den lokale mentaliteten har vært påvirket av at stedet, sjøl om det er isolert, har hatt forbindelser til og stadig har fått impulser fra verden utenfor. I nabobygda (Lauksletta) omstilte man til lakseoppdrett da fiskebruket ikke lenger var liv laga (i 1985). I Årvik har fisket, fiskerbonden, fiskebruket og verkstedet vært og er fortsatt grunnpilaren i næring og samfunnsliv. Man har klart å omstille og modernisere disse virksomhetene, men har samtidig sett muligheter i modernitetsutviklinga. Grunn har blitt til hyttetomter, og elementer fra fiskerbondekulturen har blitt til rorbuer og museum, altså tilpasset den globale opplevelsesøkonomien. I Badderen har bunnen falt ut litt etter litt, ettersom som både fiskeriene og fiskerbonden har blitt avviklet, og arbeidsalternativer i bygdene omkring har vokst fram, først og fremst representert ved kraftverk, fiskeoppdrett og offentlig virksomhet. Behovet for å ordne opp på stedet har ikke vært det samme. Da står det igjen en hovedfortelling om Årvik som et fiskevær og Badderen som et hybrid sted (Altman 2001), hvor mulighetene kanskje er å finne i opplevelsesøkonomien. I tilfelle trengs det et en ny giv der man tar opp konkurransen med andre attraktive opplevelsessteder. Kanskje sliter Badderen og Kvænangen også med et nedslitt omdømme, basert på en økonomisk virkelighet som ikke lenger eksisterer. Kommunen trenger kanskje å bli sosialt rekonstruert? Det burde være fullt mulig.

Nord-Troms er åpenbart preget av de siste tiåras sentraliserings- og finansialiseringspolitikk, omstruktureringer i fiskeriene og i jordbruket og allmenne nyliberale strømninger. Det er langt fra unikt. Mange steder langs kysten har opplevd det samme, og tilsvarende har skjedd ute i Europa og i USA (Copus \& Skuras 2006; Besser \& Miller 2013). Stedene og kommunene vi har studert, er små, og virksomhetene som har vært der, har også vært små. Gårdene var for små til å få melkekvoter og fiskebåtene for små til å få fiskekvoter. Så godt hjulpet av myndighetene er det banet vei for at større aktører skal kunne utnytte de lokale ressursene på antatt mer effektive måter. Dette har i liten grad skjedd innen jordbruket på 
stedene for vår undersøkelse - jordbruket er stort sett bare lagt brakk, det er bare én gård igjen på hvert av stedene. Fiskeriene har derimot blitt omstrukturert, som man kaller det. Fiske fra større og fjerneide båter har tatt over. For mange av de lokale fortoner dette seg som tyveri, de har blitt fratatt sine lokale ressursfordeler. Og med hensyn til ny virksomhet er det bare fiskeoppdrett som har utviklet seg i lukrativ retning.

I begge kommunene begynte lakseoppdrett med lokale gründere på 1980-tallet. Men utviklinga innen næringa har hatt forskjellige utviklingsforløp. På Arnøya (i Skjervøy), hvor Årvik ligger, var det i 2018 samme eierne av oppdrettsbedriften som de som startet virksomheten på 1980-tallet, mens i resten av Skjervøy og i Kvænangen er alle anleggene kjøpt opp av store konserner. På Arnøya har eierne fornyet og utviklet bedriften, mens resten av Kvænangen sitter igjen med noen millionærer som bare delvis opptrer som aktive investorer, og med fiskeoppdrettsanlegg som er fjerneide og fjernstyrte. Også i denne sektoren har man i Kvænangen mistet råderetten over lokale ressurser. Det tradisjonelle fiskebruket er av stor betydning for Årvik, lokalt eid og stedets største arbeidsplass. Eierne er svært bevisst sitt samfunnsansvar. Tilsvarende finnes ikke i Badderen, men det finnes fiskemottak på to andre steder i kommunen. Kjernen i forskjellen mellom de to stedene er at i Årvik gjør man sjøl noe med problemene som oppstår, i Badderen venter man på at andre skal gjøre det, eller lener seg på det som blir skapt og tilbys i områdene omkring. Tilsynelatende reflekterer dette to ulike kulturer, en aktiv stå-på-og-ordne-opp-kultur i Årvik, en nokså passiv la-andre-ordne-opp-kultur i Badderen. Hva som er den beste modellen, kommer an på øynene som ser, men det å ordne opp sjøl ligger nok nærmest det norske bygdeidealet. Det finnes eksempler på at steder som har vært preget av en vente-på-at-andre-ordner-opp-holdning - altså staten - har endret strategi og tatt skjeen i egne hender. Blant annet har dette skjedd med Hasvik kommune for få år siden (Huseby 2016). Altså, om en ser negative tendenser på et sted, eller i en kommune, betyr det ikke at dette ikke kan snus. Men trolig krever det arbeid på mange plan, og at noen - inkludert kommunen - tar tak, slik man gjorde i Hasvik. Det finnes også mange internasjonale studier som tyder på at offentlig tilrettelegging kan hjelpe på utviklinga av lokalt næringsliv (Besser \& Miller 2013; Esparcia 2014). En utfordring for Badderen er at det knapt finnes noen å hjelpe. Ungdom som flytter ut for å gå på skole, vender sjelden hjem igjen. Eventuelle etablerere må altså komme utenfra. Derfor kan en 
annen eller supplerende strategi være å utvikle området som et attraktivt sted å bo. Som vist er trivselen høy, Badderen og Kvænangen er et sted som skårer høyt på velferdsmessige og sosiale faktorer, og mulighetene til personlig sjølrealisering er gode.

Hva som er årsaken til de to stedenes ulike utviklingsforløp, er ikke åpenbart. Prosesser knyttet til politikk og samfunnsmodernisering har ikke favorisert noen av disse stedene. Noe av forklaringen på forskjellene ligger trolig i institusjonenes varierende betydning, mangfold og soliditet. I Årvik har de mest sentrale institusjonene blitt opprettholdt, som skole, barnehage, butikk, fabrikk og bygdelag. Fabrikken er trolig særs viktig som en tradisjonsbærer og identitetsmarkør. Stedet er fortsatt oppfattet som et fiskevær. Det er altså flere lag med institusjoner som styrker stedet. I Badderen har folk et sterkere bilde av at institusjonene forsvinner en etter en, det siste var skolen i Kjækan i 2017. Igjen er én butikk, barnehagen, begge i nabobygda Sør-Straumen, grendelag og grendehus, en vernet bedrift og noen småbedrifter. De viktigste institusjonene som skole, helse- og sosialtjenester er lokalisert i kommunesenteret Burfjord. Det samme gjelder idrettslag. Den institusjonelle dimensjonen er altså mindre kompakt eller tykk i Badderen enn i Årviksand, noe som er kjent som en svakere samfunnsorganisering (Amin \& Thrift 1995).

Kanskje like viktig som selve institusjonene er hva slags fortellinger man legger rundt dem, og stedenes utvikling. Rundt 2000 ble det gjort en liknende analyse av Båtsfjord og Vardø (Moldenæs 2006), hvor forskjellene hadde tilsvarende mønster som jeg har vist til her: I Båtsfjord ordnet man opp og tok ansvar, i Vardø klagde man på alle andre, som også var forventet å skulle ordne opp. Det Moldenæs skriver om Båtsfjord, kunne godt anvendes på Årvik, hvor de «tror på seg sjøl og sine ledere, og de tror på dugnadsånden og samarbeidet som årsaker til lokalsamfunnets suksess» (ibid., s. 101), og som Moldenæs sier, de «konstruerer lokalsamfunnets 'suksess' som sin egen fortjeneste» (ibid.). Hennes fortelling om Vardø minner om den vi kan lage om Badderen, hvor man ikke ser særlige næringsmuligheter, men hvor folk trives. Moldenæs illustrerer det med noen sitater «Vi er uten jobb, vi stempler, men vi tar oss en fest» og «Det nytter ikke hva vi gjør, men vi står han av. Myndighetene må gjøre nokka». Man venter altså på at noen andre skal ordne opp. Moldenæs skriver om fortellingenes makt, hvordan positive fortellinger om Båtsfjord får ting til å skje, og om hvordan de negative fortellingene i Vardø skaper resignasjon, 
avmakt og handlingslammelse (ibid., s. 107). Og hun viser til teorier som forfekter at fortellinger - diskurser og snakk - «øker sannsynligheten for korresponderende handlinger ...» (ibid., s. 107; Barry \& Elmes 1997). Fortellingene i Årvik handler om at man ordner opp lokalt, i Badderen om at man ikke får det til, i alle fall ikke der. For å bruke et begrep fra en annen norsk samfunnsforsker så mangler Badderen kanskje et utviklingsskapende erfaringsrom (Rudi 2007). Erfaringsrommet som har vært skapt over tid, er at dette går galt, dette får vi ikke til. Dette er blitt til kultur, en kollektiv tro, væremåte og fortelling som er kontraproduktiv (jf. Førde 2010).

Trolig betinger omstillingsarbeidet i slike områder at man er villig til å ta opp de ubehagelig spørsmålene, og å drøfte hva verdigrunnlaget skal være. Kan omfordeling skape utvikling, hvordan kan man stabilisere samfunnet, hvilke verdier skal vi legge til grunn for lokalsamfunnet? Dessuten, gjennom samtalene opplevde vi relativt klart at å se på Badderen som en enhet for næringsutvikling kan være feil. Stedet er, som jeg har antydet, i ferd med å bli sosialt rekonstruert (Brauer \& Dimitryw 2014). På grunn av andre former for sosiale kontakter, og endrede kommunikasjoner, har de mange småstedene blitt fusjonert med den geografisk større enheten Kvænangen. Dette er en naturlig utvikling, gitt vår tids økonomiske systemer og politiske regimer. Derfor er det et betimelig spørsmål om lokaløkonomien som den i Årvik er levedyktig. Årvik kan på sett og vis være det skjøreste stedet - man har mest å miste der. I dag er stedet solid forankret i fiskeriene, men også avhengig av denne næringa. Det er imidlertid et vakkert sted, og fritidssamfunnet banker på døra. Foreløpig har man holdt den relativt lukket. Badderen har ikke en tilsvarende forankring og er mer basert på at det er et sted hvor folk ønsker å bo, uansett tilgangen på arbeid. Begge stedenes framtid kan altså ligge i at arbeid og bosted i økende grad frikoples, og utgjør næringsuavhengige steder. Svært mange bransjer har langtidspendlerordninger, og fjernarbeid er stadig mer akseptert. Da kan man velge å bo på steder som Årvik og Badderen. Det er bare en-to timers transport til nærmeste by eller tettsted. Vår undersøkelse forteller at folk er tilfreds med å bo der de bor, sjøl om næringskonteksten kunne vært bedre. Kanskje er den mest fornuftige strategien for slike steder å finne sin plass som gode steder å bo, som lykkelige periferier i større nabokommuner eller regioner? Dette er en strategi man har vondt for å svelge i dag, for eksempel stemte over 90 prosent av folket i Kvænangen imot at kommunen skulle slås sammen med en annen kommune. Men 
særlig for Badderen og Kvænangen er tanken likevel interessant. Sjøl om kommunen som institusjon forsvant i Kvænangen, ville mange av funksjonene måtte opprettholdes, og slik sett fortsatt gi arbeid til noen. Det er også grunn til å tro at næringsarbeidet kunne bli like godt ivaretatt som periferi i en større kommune, fordi næringsarbeidet da vil kunne være mer profesjonelt og ha større ressurser. Og kanskje kunne frigjorte skattepenger brukes på andre måter, for eksempel i målrettet utviklingsarbeid uten et hovedfokus på tradisjonell næringsutvikling.

Det vi har observert i Årvik og Badderen, er ganske sammensatte lokalsamfunn. De er dessuten viklet inn i nettverk av ulike slag, både kommunale, regionale, nasjonale og internasjonale. At røttene i primærnæringene er svekket, er en internasjonal tendens for rurale områder, det samme gjelder migrasjonsarbeidet (pendling), som blir mer og mer vanlig. Ikke-økonomiske verdier synes å få mer å si for hvor folk bosetter seg. Det eksisterer et mangfold av «komplementaritet mellom marked og ikke-marked, kapitalistisk og ikke-kapitalistisk, og mangfoldige urbane og rurale økonomier», sier Fairbairn og kolleger (2014, s. 660). Folk lever relativt urbane liv i rurale områder og inngår i komplekse, romlige systemer der grensene mellom by og land viskes ut. By-land-skillet framstår mer som dynamikk og som muligheter enn som skiller mellom ulike sosiale og økonomiske systemer. Dette kan være en god beskrivelse av virkeligheten, men gir få hint om hvordan veien vil gå videre, eller hva som kan være farbare utviklingsstrategier. Den rådende kulturen i Nord-Troms representerer ikke et reservoar av løsninger, slik noen svenske forskere observerte i Vesterålen noen år tidligere (jf. Sandén, Thulesius \& Harrysson 2015). Dette kan det sikkert gjøres noe med.

\section{Konklusjon}

Vi har i drøftingen over framstilt to helt forskjellig steder, Årvik, hvor man stoler på egne krefter og opptrer relativt uavhengig av offentlig politikk og de politiske systemer de er en del av. Men stedet er lite og skjørt. For det andre stedet, Badderen, er det litt omvendt; man tilskriver sine problemer strukturendringene i samfunnet, og hvordan det lille stedet har mistet sine posisjoner ved disse endringene, men samtidig blitt en del av en større enhet. Badderen er først og fremst et sted å leve og å bo. Men begge steder 
er det godt å bo, det er et betydelig lokalt samhold, og man drar i lag om lokale arrangementer og begivenheter. Likevel har jeg i drøftingen antydet at det kanskje kunne være bedre for Badderen og Kvænangen å være en utkant i en større kommune, enn å skulle forbli en sjølstendig liten enhet, noe befolkningen har uttrykt at de er sterkt imot. Så hvorfor lar jeg ikke det bli med det? Har ikke folket alltid rett? Til det kan man kanskje svare at det kan være tungt å stritte imot store trender: «If you can't beat them, join them», er et velkjent ordtak. Det som taler for at man skal stå på som liten, er først og fremst at det kanskje er trender på gang som vil kunne endre på forholdet, altså at man får et ideologisk skifte mer i retning av at smått er godt. Det er mange eksempler på at folk flytter på landet, men fortsetter sitt relativt urbane liv (Munkjord 2009). Overalt finnes det eksempler på unge mennesker som har dratt hjem igjen etter endt utdanning. Det finnes mange forsøk med nye driftsmodeller og spesialiteter i jordbruket, og bedre ordninger for inngang til fiskeriene drøftes. «Det grønne skiftet», som er en del av dagens politiske retorikk, varsler kanskje endrede holdninger til veksttenkningen. Ett av temaene er å utvikle nye og sterke regioner der sentrum og periferi skal utvikle seg sammen. Dagens kommuneinndeling (som er under endring) er tross alt en konstruksjon som er tilpasset en annen tid - 1960- og 70-tallet - forskjellig fra den som hadde vært gjeldende fra 1863, da Kvænangen ble utskilt fra Skjervøy. Samtidas region- eller kommuneinndeling er en naturlig debatt, og eventuelle endringsprosesser er tidkrevende. Steder som Badderen og Årvik må tåle debatter om stedenes infrastrukturer og tilhørighet, og kommuner som Kvænangen og Skjervøy slipper ikke unna viktige regionalpolitiske debatter og ideologier. Det bør imidlertid understrekes at vi verken har studert Kvænangen eller Skjervøy som kommuner, eller som steder.

I dette kapitlet har jeg som forsker analysert to relativt små lokalsamfunn. Som forskere kommer vi utenfra og fra en annen hverdagskontekst enn lokalbefolkningen. Vår kontekst er teorier og store fortellinger om utvikling, som også rommer fortellinger om småstedsutvikling. Slike fortellinger er blant våre fortolkningsrammer. Vi tolker altså den lokale utviklinga inn i eksisterende diskurser, samtidig som vi gjerne skulle bidra til at diskursene eller metafortellingene endret seg. En av disse er ideen om at vekst og stordrift er den foretrukne utviklinga. Årvik og Arnøya er eksempler på at det går an å stå imot disse kreftene, i alle fall har det gått så langt. Badderen representerer en annen utviklingsbane, hvor stedet er 
innlemmet i en større enhet, og egentlig representerer en tilpasning til en ønsket regionalpolitisk utvikling, og til veksttenkningen. I slike sosiale og politiske konstruksjoner sliter periferiene. Analysen forteller kanskje at det først og fremst er behov for å rekonstruere fortellingen om Badderen og Kvænangen. Det er i alle fall ingen grunn til å tro at den gamle tida kommer tilbake.Fiskerbondens tid er forbi. Nye næringer skimtes, og nye fortellinger må skapes.

\section{Litteratur}

Amin, A. \& Thrift, N. (1995). Living in the global. I Amin, A. \& Thrift N. (red.) Globalization, Institutions, and Regional Development in Europe (s. 1-22). Oxford: Oxford University Press.

Ateljevic, J. \& Doorne, S. (2004). Diseconomies of scale: A study of development constraints in small tourism firms in Central New Zealand. Tourism and Hospitality Research, 5, 5-21. https://doi.org/10.1057/palgrave.thr.6040002

Barry, D. \& Elmes, M. (1997). Strategy retold: Towards a narrative view of strategic discourse. The Academy of Management Review, 22 (2), 121-142. https://doi.org/10.2307/259329

Barth, F. (1981). Process and form in social life. Vol. 1. London: Kegan \& Paul. Bathelt, H. \& Glückler, J. (2003). Toward a relational economic geography. Journal of Economic Geography, 3 (2), 117-144. https://doi.org/10.1093/jeg/3.2.117

Besser, T. L. \& Miller, N. J. (2013). Community Matters: Successful Entrepreneurship in Remote Rural US Locations. Entrepreneurship and innovation, 14, 15-27. https://doi.org/10.5367/ijei.2013.0104

Bjørklund, I. (1985). Fjordfolket i Kvonangen: fra samisk samfunn til norsk utkant. Tromsø: Universitetsforlaget.

Brauer, R. \& Dimytrow, M. (2014). Quality of life in rural areas: A topic for the Rural Development policy? Bulletin of Geography. Socio-economic Series, 25, 25-54. https://doi.org/10.2478/bog-2014-0028

Bringslid, M. B. (2012). Bygdeutvikling når alternativet er avvikling. Innledning. I B. Bringslid (red.), Bygdeutviklingas paradoks. Oslo: Spartacus.

Brox, O. (1968). Hva skjer i Nord-Norge? Oslo: Pax.

Brox, O. (1984). Nord-Norge. Fra allmenning til koloni. Tromsø: Universitetsforlaget. Brox, O. (2006). The political economy of rural development. Modernisation without centralization? Delft: Eburon. 
Cloce, P. (2006). Conceptualizing rurality. I P. Cloke, T. Marsden \& P. Mooney, Handbook of rural studies. London: Sage.

Copus, A. \& Skuras, D. (2006). Accessibility, innovative milieu and the innovative activity of businesses in EU peripheral and lagging areas. I T. de Noronha Vaz, E. J. Morgan \& P. Nijkamp (red.), The New European Rurality: Strategies for Small Firms (s. 29-40). Aldershot: Ashgate.

Esparcia, J. (2014). Innovation and networks in rural areas. An analysis from European innovative projects. Journal of Rural Studies, 34, 1-14. https://doi.org/10.1016/j.jrurstud.2013.12.004

Eversole, R., Barraket, J. \& Luke, B. (2013). Social enterprises in rural community development. Community Development Journal. https://doi.org/10.1093/cdj/ bst030

Fairbairn, M., Fox, J., Ryan Isakson, S., Levien, M., Peluso, N., Razavi, S., Scoones, I. \& Sivaramakrishnan, K. (2014). Introduction: New directions in agrarian political economy. The Journal of Peasant Studies, 4, 653-666. https://doi.org/10.1080/03066150.2014.953490

Figueiredo, E. (2013). Mc.Rural, no rural or what rural? - Some reflections on rural reconfiguration processes based on the promotion of Schist Villages Network, Portugal. I L. Silva \& E. Figueiredo (red.), Shaping rural areas in Europe: Perceptions and outcomes of the present and the future. Dordrecht: Springer. https://doi.org/10.1007/978-94-007-6796-6_9

Førde, A. (2010). Nyskaping, brytningar og samspel. I O. J. Broch \& A. Førde (red.), Innovative bygdemiljø. Ildsjeler og nyskapingsarbeid. Bergen: Fagbokforlaget.

Gaughan J. P. \& Ferman L. A. (1987). Science Toward an Understanding of the Informal Economy. Annals of the American Academy of Political and Social Science, 493, 15-25. https://doi.org/10.1177/0002716287493001002

Harvey, D. (1989). The condition of postmodernity. London, Oxford: Blackwell. Herslund, L. (2012). The rural creative class: counterurbanisation and entrepreneurship in the Danish countryside. Sociologia Ruralis, 52, 235-255. https://doi.org/10.1111/j.1467-9523.2011.00560.x

Hjalager, A.-M. (1997). Tourism destinations and the concept of industrial districts. Paper for ERSA conference, Dublin, August 1999. Århus: Science Park.

Holm, F. E. \& Vila, M. (2010). Små samfunn tar sats - Sluttrapport fra folgeforskningen av Regjeringens småsamfunnssatsing. Rapport 5/10. Trondheim: Bygdeforskning. 
Hovelsrud, G. K., Dannevig, H., West, J. \& Amundsen, H. (2010). Adaptation in Fisheries and Municipalities: Three Communities in Northern Norway. I G. K. Hovelsrud \& B. Smit, Community Adaptation and Vulnerability in Arctic Regions (s. 23-62). London: Springer. https://doi.org/10.1007/978-90-481-9174-1_2 Huseby, E. (2016). Foredrag holdt på Olderdalen, 6.4.2016.

https://doi.org/10.3366/vic.2016.0237

Ingham, G. (1996). Money is a Social Relation. Review of Social Economy, 54, 507-529. https://doi.org/10.1080/00346769600000031

Jacobsen, D. (2016). Tourism enterprises beyond the margins: the relational practices of Aboriginal and Torres Strait Islander SMEs in remote Australia. Tourism Planning \& Development, 14, 31-49. https://doi.org/10.1080/2156831 6.2016 .1152290

Jentoft, S. (1996). Samfunnsforskningen og sjarkromantikken. I I. Altern (red.), Lokalsamfunn og lokalsamfunnsforskning $i$ endring. Artikkelsamling. Tromsø: Universitetet i Tromsø.

Johannisson, B. (2009). Networking and entrepreneurship in place.

I M.-A. Galindo, J. Guzman \& D. Ribeiro (red.), Entrepreneurship and business: A regional perspective (s. 137-162). Berlin: Springer. https://doi.org/10.1007/978-3-540-70902-2_8

Larsen, T. (2012). Et dobbelt syndefall. Etterord om moral og klassifikasjon. I M. B. Bringslid (red.), Bygdeutviklingas paradoks. Oslo: Spartacus.

Massey, D. (2005). For space. London: Sage. https://doi.org/10.12968/ sece.2005.1.361

Moldenæs, T. (2006). I sitt bilde? Identitet og identitetskonstruksjon i lokalsamfunn. Trondheim: Tapir.

Morrison, A. \& Teixeira, R. (2004). Small business performance: a tourism sector focus. https://doi.org/10.1108/14626000410537100

Journal of Small Business and Enterprise Development, 11, 166-173.

Munkjord, M. C. (2009). Reinventing rurality in the north. I T. Nyseth \& A. Viken (red.), Place reinvention. Northern perspectives (s. 203-220). Farnham: Ashgate. https://doi.org/10.4324/9781315600574-12

Murdoch, J., Lowe, P., Ward, N. \& Marsden, T. (2003). The differentiated countryside. London og New York: Routledge Studies in Human Geography.

Nilsen, R. (1996). Om å få orden på gjenstridige fjordfolk. Begreper og perspektiv i analyse av periferiutvikling. I I. Altern (red.), Lokalsamfunn og 
lokalsamfunnsforskning. Artikkelsamling. Tromsø: Universitetet i Tromsø, Institutt for samfunnsvitenskap.

Overvåg, K. \& Ericsson, B. (2016). Fritidsboligdestinasjoner og regional utvikling i fjellområdene. I A. Viken (red.), Turisme. Destinasjonsutvikling. Oslo: Gyldendal Akademisk.

Rudi, I. (2007). Kjønn og relasjonskvaliteter i et historisk forløp. Norsk Antropologisk Tidsskrift, 18 (2), 90-103.

Sandén, U., Thulesius, H. \& Harrysson, L. (2015). Nuets förnöjsamhet. En grundag teori om livsval og överlevnadsstrategier. Sociologisk Forskning, 52, 234-256.

Spilling, O. R. (2011). Mobilising the entrepreneurial potential in local community development. Entrepreneurship and Regional Development, 23 (1-2), 23-35.

Urry, J. (1990). The tourist gaze. London: Sage. https://doi.org/10.1080/08985626. 2011.540406

Viken, A. (2015). Gruppesamtaler som metode. I A. Førde, A. Kramvig, N. Gunnerud Berg \& B. Dale (red.), Å forske på sted. Trondheim: Tapir.

Williams, C. C. (1996). The new barter economy: An appraisal of local exchange and trading systems (LETS). Journal of Public Policy, 16, 85-101. https://doi.org/10.1017/S0143814X0000787X

Woods, M. \& Mc Donagh, J. (2011). Rural Europe and the world: Globalization and rural development (Editorial). European countryside: Journal of Mendel University in Brno, 3 (3), 153-163. https://doi.org/10.2478/v10091-0120001-z 


\section{LANGFJORDEN - UTVIKLING UTEN INSTITUSJONELL TILHØRIGHET ${ }^{9}$}

Arvid Viken

\section{Innledning}

Hva er det med de små stedene i Troms og Finnmark? Gjennom de siste tiåra har det vært mange forhold som skulle tilsi fraflytting, men fortsatt bor det folk der. Stedene eksisterer på tross av politiske og ideologiske strømninger, men kanskje litt på grunn av den utviklinga som disse strømningene har medført: gode veier, moderne kommunikasjonsnettverk, kortere fysiske og mentale avstander og delaktighet i velferdsstaten. Ingen har blitt tvangsflyttet, og velferdsgoder har også omfattet periferien, om enn ikke med samme tilgjengelighet som i sentrum. Altså, det er først og fremst næringspolitikken som har jobbet mot disse stedene, med utvikling av industri og servicenæringer lokalisert til sentrum. Men noen næringer og aktiviteter krever tilgang på naturressurser som først og fremst utkantene kan by på.

Vi har, med god hjelp av folk i disse distriktene, undersøkt hva det er som gjør at folk blir boende i det som kan kalles utkanten av utkanten i Norge. Blant spørsmålene er hvor viktig arbeid er for valg av bosted. Det er forskning som tyder på at bolysten, som har vært et offentlig og politisk begrep i noen år, er basert på flere forhold, hvor arbeid bare er ett. Mens våre forfedre bosatte seg der det var mulig å brødfø seg og sine familier, synes

Kapitlet er basert på forarbeidene til et foredrag avholdt under festivalen Langforddagene, juli 2018. Kapitlets presens er altså 2018. 
noen mennesker å bosette der de har lyst, ut fra en helhetsvurdering hvorav arbeid bare er en av flere faktorer.

Kapitlet er basert på etnografiske studier av stedet over lang tid samt noen intervjuer sommeren 2018. Kapitlet starter med en gjennomgang av teorier om steder, bolyst, arbeid og bostedsvalg. Deretter beskrives stedet Altafjord langs noen sentrale dimensjoner, etterfulgt av et avsnitt der stedet sammenliknes med andre bygder i nærheten, og en avsluttende diskusjon.

\section{Hva er et sted?}

«Sted» er slett ikke noe enkelt begrep. Det kan bety så mye, og det finnes mange teorier om hva et sted er, og mange tilnærmingsmåter til analyser av fenomenet, men alle erkjenner at det har noe å gjøre med en territorielt avgrenset lokalitet. Men der slutter enigheten. Mens man lenge var opptatt av det unike eller stedegne, har man en tid vært mer opptatt av steders flyktighet og avhengighet av ulike typer prosesser. Heri ligger en av debattene: I hvilken grad er steder stabile eller stabiliserende elementer i folks hverdagsliv? De fleste synes å mene at steder er det, men at de samtidig er dynamiske. Folk har tilhørighet til steder, men stedene er likevel i bevegelse - for eksempel fordi både natur og kultur er dynamiske størrelser. Steder er noe som skjer, og som blir til. Som regel er dette en tilblivelse preget av et mangfold av prosesser med så vel menneskelige som ikke-menneskelige elementer (Berg \& Dale 2015). Dermed framstår også steder som en slags ansamling av nokså ulike elementer - og prosesser - knyttet til natur, næringsliv og kultur, og bærer preg av ulike tidsepoker og maktforhold.

Steder kan altså fortone seg ganske forskjellig fra et tidspunkt til et annet. Men steder oppleves ulikt. For noen er et ulendt sted et tungdrevet bondeland, for andre er det flotte skibakker. For noen er et sted først og fremst et landskap, for andre rommer landskapet stier, rasteplasser, bærmyrer og tuer de har et forhold til. Menneskene kan både ha et rasjonelt eller funksjonelt og et emosjonelt forhold til et sted, stedet og dets natur og kultur er på en måte kroppens forlengelse (Vestby 2015). Dette blir omtalt på ulikt vis, for eksempel som tilhørighet, og er ofte erfaringsbasert. Det kan involvere flere sanser - steder er punkter, topografi, lyd og lukt. De kroppslige relasjonene til et sted kan altså både være knyttet til landskapet og de fysiske omgivelsene, og til sosiale og lokalkulturelle forhold, sier Vestby (ibid., s. 167). Ofte 
er kulturelle forhold svært viktige for tilhørigheten til et sted, for eksempel rommer kulturarv en tidsdimensjon og representerer en rotfestethet som mange kjenner på. For de fleste finnes det typer av steder, stedstyper man er mer fortrolig med og foretrekker framfor andre. Noen foretrekker fjell, andre flatmark. I en diskusjon med en ivrig multeplukker fra Finnmark kom det fram at et av hennes fremste reiseønsker var å dra på sjølplukk i en jordbæråker sørpå.

Steder er relasjonelle fenomener. Det er punkter hvor ulike prosesser møtes, og som Massey (2005) sier, er de preget av at ulike elementer fra ulike prosesser er blitt kastet sammen. Det er altså relasjonene mellom elementene, bestående både av mennesker, materialiteter og diskurser, som former stedene. Bestemte kombinasjoner gir stedene egenart. På noen av stedene er naturen dominerende, andre kulturen, noen steder har røtter i rurale tradisjoner, andre steder er basert på en moderne og urban utvikling. Det var lenge et påstått skille mellom by og land, byen som moderne, monden og profan, landsbygda som tradisjonsbasert og ofte preget av seder og skikker knyttet til arbeidsmetoder, kulturuttrykk og byggemåter (Osbaldiston 2012). Synet på landsbygda har imidlertid endret seg, også den er preget av prosesser og dynamikk, og av at stedene inngår i ymse typer nettverk. Slike nettverk representerer muligheter, men gjør steder mer avhengige av og påvirket av hendelser utenfor sin egen lille verden. En annen endring er at det er slutt på at landsens steder kan betraktes som helheter, enheter som rommet de fleste samfunnsfunksjonene og dekker de fleste menneskelige behovene. Slik betød steder ofte også en bestemt livsform der lokalsamfunnet dannet rammene for de flestes hverdagsliv. Slik er det ikke i dag. Man lever ikke utelukkende på stedet. Behov, eller funksjoner som tidligere ble dekket lokalt, blir fylt utenfor de lokale kontekstene. Lokalbefolkningen må ut av stedet sitt, ut av bygda for å gå i barnehage, gå på skole, for å handle og for å finne seg en make. Dette betyr samtidig at små steder innlemmes i større, og at stedet kanskje er et annet og større enn det var. Altså er stedet man hører til og identifiserer seg med, i endring. Dette blir også kalt for delokalisering, prosesser hvorigjennom lokalsamfunn blir tett bundet sammen med andre steder, og aktører derfra (Ojha et al. 2016). «Dagens lokalsamfunn er integrert i mange lag av nettverk, som medfører rekonfigurasjon av geografiske grenser og institusjonelle arrangementer som tidligere definerte lokalsamfunn", sier Ojha og kolleger (ibid., s. 275).

Landsbygda har altså endret seg på flere måter. For eksempel er befolkningssammensetningen annerledes. Mens folk tidligere som en tendens 
fødtes inn i steder og yrker, for eksempel til fiskerbønder som skulle bo hvor de ble født, er det blitt vanlig at ungdommen flytter ut for å ta utdanning. Ofte betyr det at de utdanner seg vekk fra stedet de trådte sine barnesko. Noen flytter imidlertid tilbake, og andre flytter til stedet. Mens det før var båndene til jord og hav som avgjorde bosted, er det ofte andre egenskaper ved stedene som motiverer dagens tilflyttere. For eksempel er mulighetene til å utøve en bestemt livsstil knyttet til kultur, religion eller friluftsliv blitt vanlige flyttemotiv. Det har også skjedd en idyllisering av landsbygda, som har tiltrekningskraft på bymennesker. Negative sider ved bylivet er deler av denne problematikken (Osbaldison 2012). Noen rømmer fra byen, andre flytter til landsbygda på grunn av dens kvaliteter. Naturkvaliteter som muliggjør turismevirksomhet, for eksempel skiturisme eller fjellturisme, har slike tiltrekningseffekter. Slike prosesser betyr endring i befolkningssammensetningen i retning av større innslag av middelklassemennesker (Milbourne \& Kitchen 2014). Nyinnflytterne deler ikke forankringen i tradisjoner og naturkvaliteter med dem som har hatt slekt der over generasjoner. Dynamikken som ligger i sammenkastetheten, kan bety at andre verdier enn de tradisjonelle gjør sitt inntog i bygdemiljøene. En del av de verdiene som er registrert i Bygde-Norge, er altså knyttet til den voksende fritidssektoren, som også representerer nye næringsmuligheter.

\section{Stedet Langfjorden}

Langfjordbotn er et sted innerst i en sidefjord til Altafjorden. Bosettingen har skjedd rundt botnen og inn i en sidedal, Bognelvdalen. Befolkningen har norske, finske og samiske røtter. Hva det reelle folketallet er, kommer an på hva slags kriterier en legger til grunn, og når på året en måler. Om vinteren er det cirka 100. De fleste tenker om stedet som ei landbruksbygd. Reindrifta er også sentral - det er to siidaer som har bygda som tilholdssted om sommeren, altså to bosettinger knyttet til reindrifta. I den tida, nesten halve året, er folketallet om lag det dobbelte. Blant innbyggerne er det i dag flere utlendinger. De har kommet til bygda på grunn av sine hundekjøringseller skiinteresser. I tillegg er det en del mennesker som har hytte, og på campingplassen er det cirka 20 spikertelt, altså mennesker som oppholder seg i Langfjorden i helgene eller korte perioder. Bygda alltid hatt en del turister, primært på campingen, men flere og flere turister kommer for å utøve en 

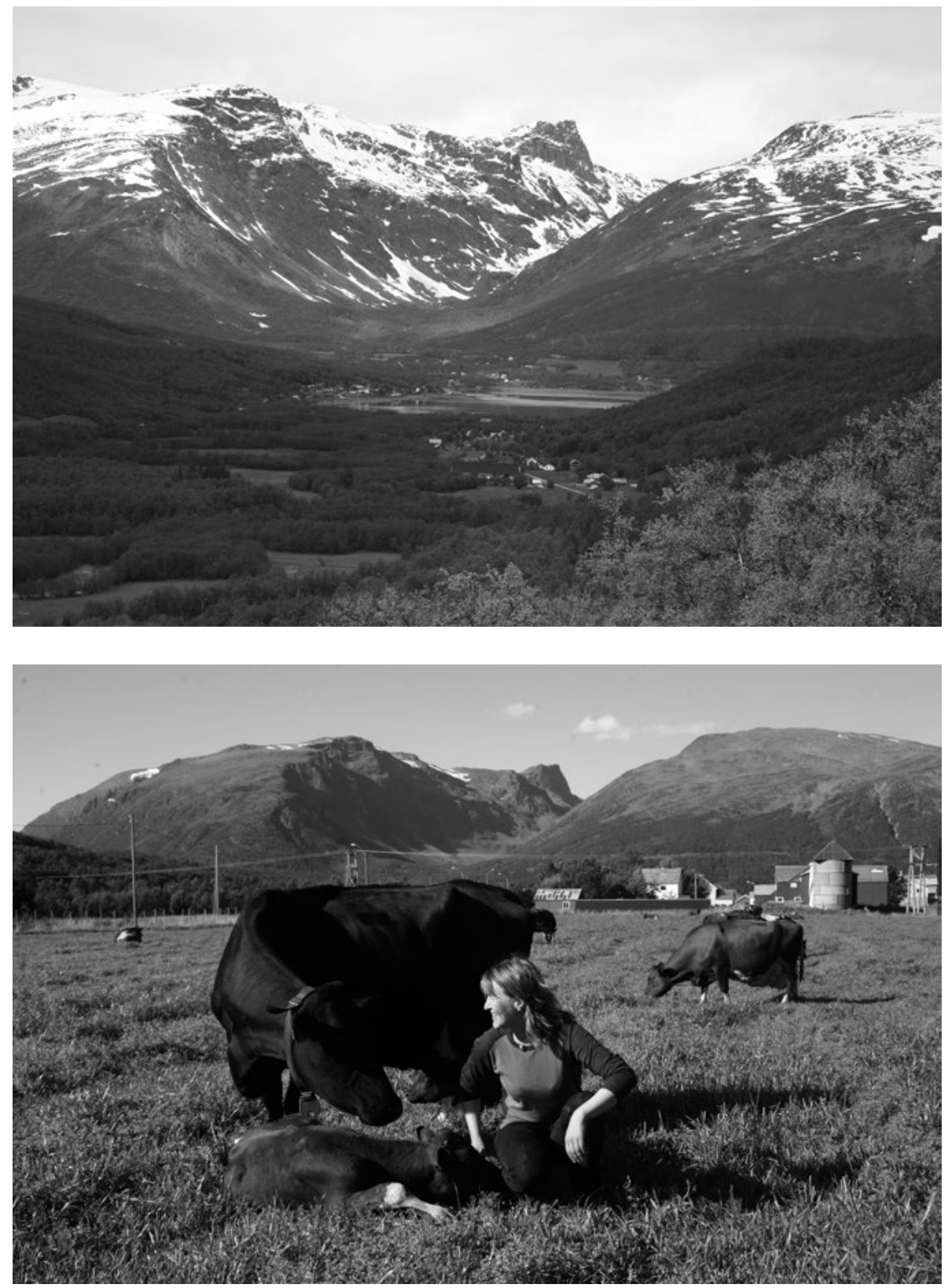

Langfjordbotn: truer turismen idyllen? Foto: Ole Magnus Rapp. 
eller annen aktivitet i området. De siste åra har det dreid seg om hunde- og toppskikjøring. Stedet er i ferd med å utvikle seg til et turiststed.

Som alle andre steder har stedet en historie med ulike typer forløp og hendelser. Noen av forfedrene til dagens langfjordinger deltok i de relativt kjente forsøkene med å bringe rein over til Alaska, og noen av dem deltok i gullgraving og kom hjem vel beslått. Noen mistet pengene sine under krakket på 1920-tallet, noe som også understreker stedets tilknytning til storsamfunnet. I våre dager har det vært laget reality-programmer for TV fra bygda. Fra nyere tid sirkulerer det fortellinger og sladder både knyttet til politikk, skolenedleggelser og sexaffærer. Små steder er relativt oversiktlige, så de fleste vet det meste. Slike fortellinger er med på å skape stedet, på godt og ondt, gi det karakter, om man vil.

Det understrekes både samhold og fred i samtalene om stedet. Men det ligger også under at det har vært, og kanskje pågår noe maktkamper, i alle fall en viss kiving. Dette synes være knyttet til to forhold: gårdsdrift og land- og dyrkningsarealer, og til forholdet mellom de to "polene» i bygda, mellom «botninga» og "dalinga». En botning forteller at han prøvde å kjøpe en eiendom på dalingssida, men dette ble forpurret av dalens maktpersoner. Det er kanskje også et nytt skille på gang, mellom «originale» langfjordinger og tilflyttere. Det sies at det er lite kontakt mellom dem som utøver turisme - mange av dem er utlendinger og har kommet gjennom forbindelser til den ene gården - og de andre i bygda. Utlendingene er dårlig integrert, sier noen.

\section{Hvor går stedets grenser?}

I gamle dager utgjorde det man i dag regner som Langfjorden, flere bygder, også de utover i fjorden. Og bygda har mer og mer tilknytning til Burfjord, som er sentrum i nabokommunen, Kvænangen. Ungene går på skole der, og der finnes nærmeste butikk. Men det er også sterkere og sterkere forbindelser til den andre nabokommunen, Loppa, hvor sentrum, Øksfjord, er fire mil unna. Skimiljøet opererer ikke med kommunegrenser, for disse menneskene er Langfjord, Øksfjord og deler av Kvænangen samme sted, det er de fine skifjellene som er kjernen i deres sted, og Langfjorden ser ut til å bli et slags sentrum i dette stedet.

Langfjorden er også et sted som lett lar seg innordne i det moderne synet på et sted. Stedet, og folkene der, inngår i mange slags nettverk. For det første 
er det mange som har arbeid som ikke er knyttet til stedet, de pendler eller jobber i virksomheter på fylkesnivå eller i nasjonale bedrifter. I skimiljøet er det flere som har sterk tilknytning til skimiljøer andre steder, for eksempel i Frankrike. Disse nettverkene har på mange måter skapt skimiljøet. For dem som driver hundekjøring, er lokaliteten viktigere, det har lenge vært dyktige hundekjørere i bygda og i Alta kommune for øvrig. Disse har skapt oppmerksomhet om stedet og har fristet andre til å etablere seg her. Flere av dagens hundekjørere kom første gang som turister. Dette er en god modell, sier en fra bygda. Altså er det noen som har kommet for å dyrke sin interesse, og som har gjort den til et yrke, og andre igjen som først og fremst har valgt Langfjorden som bosted. Noen av disse har valgt stedet som bosted fordi de er født her, føler de hører til her, og synes at livet her er bedre enn det de har prøvd ut andre steder.

\section{Hva lever man av?}

Langfjorden er ei gammel jordbruksbygd, hvor de fleste var bønder eller fiskerbønder. Foreldregenerasjonen til dem med røtter på stedet var det. Gårdsdriften av i dag er moderne, tre bønder dyrker all jorda. Den ene gården har flere hundre fordyr. Reindrifta er også en viktig næring, i den ene siidaen er det mer enn femti mennesker om sommeren, i den andre færre. Dessuten flytter flere flokker forbi vår og høst på vei til og fra sommerbeitene lenger ut på kysten. Det er én offentlig arbeidsplass i bygda, Finnmarkskollektivet, men den rekrutterer stort sett ikke ansatte lokalt. Den betyr imidlertid en viss aktivitet i bygda, og det forsyner campingen med kunder, både ansatte, studenter og pårørende, og er således et bidrag til den lokale økonomien. I tillegg er det flere som arbeider for det offentlige, som ansatt i kraftlaget eller på brøytekontrakter. Derfor utgjør det offentlige en vesentlig del av lokaløkonomien. De seinere åra har det vokst fram flere bedrifter innen reiselivsnæringa, basert på hundekjøring, fjell- og breguiding og toppskikjøring. Dette sysselsetter mer enn ti personer, men mest om vinteren. Ellers pendler folk, til Alta og Burfjord. Fiskeoppdrettsanlegg, både i Langfjorden og i Kvænangen, sysselsetter flere. Noen er også på langpendlerordninger og fjernarbeidsordninger. En er journalist, en arbeider i en fylkesorganisasjon.

Det er flere slags entreprenører på stedet, både innen landbruk og turisme. To av gårdsbrukene har vært modernisert og er stordriftsbaserte; 
fôringa er datastyrt, og melkinga er det roboter som tar seg av, og de høster flere steder i bygda. To brødre som er involvert i gårdsdrift, har begge startet reiselivsbedrifter, den ene basert på hundekjøring, den andre driver et fjell-, bre- og skiguidefirma. De synes å ha skapt et miljø for den slags virksomhet, da flere har flyttet til bygda for å drive tilsvarende virksomhet. Skibonden, som den ene bonden kalles, har på sin side skapt kontakter til Frankrike. En av disse kontaktene har nå et eget guidefirma i Langfjorden om vinteren. Det synes være en modell at de som kommer, starter eget firma og leverer tjenester til hverandre, etter behov. Man opererer altså sammen, men med egne firmaer.

Det lokale økonomiske systemet i Langfjorden er først og fremst integrert i større systemer. Fiskeoppdrettsselskapet er japanskeid og har både norske og utenlandske ansatte. Hundekjørerne er både norske, tyske og engelske, og i skimiljøet er det altså sterke kontakter til Frankrike. Det er en god del bytteøkonomi. I lokalsamfunnet som sådant ordnes det opp, og man hjelper hverandre. Innad på et sted som campingen byttes tjenester internt, gjennom at de som bor der, tar del i vedlikehold og drift, og bygda låner møtelokaler og redskaper når det trengs. Her arrangeres møter, familiebegivenheter og fester. Folk bytter ofte tjenester mot både fisk og reinkjøtt. Slik bytteøkonomi er intet særsyn, men er velkjent på landsbygda, og er en måte relasjoner vedlikeholdes på.

\section{Møter og motsetninger}

I gamle dager var kirka, butikken og skolen steder hvor man møttes, men bare kirka eksisterer i dag, og den har ikke samme standing som før. Det betyr at man har få plasser å møtes. Det finnes en kafé, den er møteplass for noen. For eksempel på torsdagspuben. Da drøftes viktige spørsmål for bygda. Eieren er både entreprenør og politiker og har en udefinert lederposisjon i bygda. Hun er både likt og mislikt, slik det gjerne blir når man stikker hodet fram. Samfunnshuset er en mer nøytral og ikke-kommersiell møteplass, folk møtes på arrangementer, men også gjennom å delta i drift og vedlikehold. Samfunnshuset drives som en forening, hvor de øvrige foreningene i bygda er medlemmer. Bygningen vedlikeholdes, dels på dugnad, dels gjennom kjøp av tjenester. Man har folk i foreningen som kjenner til finansieringskilder, og som kan pengesøkesystemet, som kommunen, fylket, Innovasjon 
Norge og andre. Samfunnshuset er en arena for arrangementer, private så vel som kollektive. Her holdes dåp, konfirmasjon, giftermål, gebursdager og begravelser. Kirka er som nevnt en annen møteplass, men gudstjenestene er sjeldne. Også på dette planet har Burfjord fått en rolle, der er det oftere gudstjenester. I tillegg har man en slags «næringshage», hvor småbedrifter tilbys kontorer. Lokalene er den gamle skolen, som kommunen egentlig ville selge. Det protesterte man på lokalt, og i 2018 fungerer den som møteplass for næringsdrivende. Skolens status er litt usikker, kommunen synes bare motvillig å holde på lokalene. Noen savner mer struktur rundt næringssatsinga og vil satse mer målrettet på å etablere Langfjorden som en turistdestinasjon. Også campingen er et sted man treffer folk, for noen i bygda er det et sted man stikker innom og drikker pulverkaffe. Når vi spør om møteplasser, svarer folk med å nevne anledninger, altså ulike kollektive arrangementer som fester, basarer og andre arrangementer på samfunnshuset. De fleste nevner også Langfjorddagan. Men ellers sier flere at de møtes rundt kjøkkenbordet hjemme hos hverandre. I våre dager er Facebook og andre sosiale medier viktige, både som møteerstatninger og for å avtale møter av ulike slag, for eksempel for å samles rundt bålet ved Bognelva en fredags kveld.

Det er også mange relasjoner som er gamle, man viser til at fedrene eller mødrene, eller også besteforeldrene var venner. «Våre fedre spilte fotball i lag», sa en. Dette gjelder både mellom norske - ofte godt blandet opp både med kvensk og samisk blod - og mellom norske og samiske. Man kjenner hverandre, har det en kaller verdderelasjoner - relasjoner som innebærer vennskap, gjensidig nytte og tillit - og har levd i lag over generasjoner. Vi snakker sammen, sies det, og derfor er det også lite konflikt mellom de som driver reindrift, og bøndene. Flere ga eksempler på hvordan man hadde snakket sammen og ordnet opp. Det snakkes en hel del om verdder, altså nyttevenner (jf. Svensson \& Viken 2017). For eksempel har reindrifta og campingen en slik relasjon. Reindrifta bruker campingens fasiliteter, dusj, badstue, vaskemaskin, møterom og av og til båt, mens gjenytelser består i reparasjoner, reinkjøtt og i 2016 bygging av et redskapsbygg (naust) på plassen. Dette regnes altså begge veier som nyttige vennskap. Det er ofte uklart hva gjenytelsene er eller vil bli, noe som underbygger relasjonens styrke, den er bygd på gjensidig tillit. I teorien kalles dette generalisert gjensidighet (Sahlins 1972; Svensson \& Viken 2017).

Likevel er det slik at noen ser noen motpoler i bygda. Det dreier seg trolig mer om status enn om makt. Det har for eksempel vært uenigheter om 
nydyrking og utmarksarealer. Det synes være noe som ligger og ulmer. Det går mest på forholdet bøndene imellom og sammenfaller med skillet mellom dalinga og botninga. I dag synes imidlertid samholdet å være sterkere enn skillelinjene.

At man har gode relasjoner seg imellom, betyr også at man holder sammen. Samholdet materialiserer seg i at man hjelper hverandre, stiller opp når noe skal arrangeres, og deltar i dugnader. Det er mye som ordnes på dugnadsbasis. Men det er ikke slik det en gang var, da man arrangerte dugnader for det meste. Det er her som mange andre steder, de eldre som stiller ved slike anledninger. Kanskje er dette et trekk ved fenomenet. Ungdommen møtes på annet vis.

\section{Stedsidentitet?}

Folk snakker om at de har en identitet knyttet til stedet. Det er her de hører til. Folk er verken altaværinger eller kvænangsværinger, de er langfjordinger, og gjerne dalinga og botninga. Identiteten er først og fremst knyttet til stedet, sjøl om det flyter sammen med nabostedene. Identiteten er også knyttet til jordbruket. Langfjorden er ei landbruksbygd, sier flere. Identiteten er dermed mindre knyttet til aktiviteter av fritidskarakter. Identitet er ansett som et sentralt element i etablering av territorielle enheter, sier Paasi (2009). Identiteten kan både være knyttet til stedets særpreg og er avgrensbart i henhold til geografi, topografi eller kultur. Kanskje er Langfjordbotn et eksempel, stedet er innerst i fjorden med høye fjell omkring, og et sted der kulturmøter mellom samer og nordmenn er en del av hverdagen. Folks identitet til stedet kan være knyttet til disse forholdene, men det er også en følelsesmessig sak. Folk føler seg som langfjordinger. Det er her de hører til, sier de. Og tilflytterne opplever at det tar tid å bli anerkjent, også det et trekk ved stedsidentiteter (Stedman 2002). Paasis andre regionelementer er navn, institusjoner og ytelser. Navnet er Langfjordbotn, men ofte sier man Langford eller Langfjorden. Sier man Langfjorden, regnes alle småstedene langs forden med. Institusjonselementet er et problem, institusjonene har blitt færre og færre, skolen er lagt ned, butikken er lagt ned, bedehuset er lagt ned, altså de institusjonene som ofte holder bygder eller steder sammen. Altså har stedet som sådant blitt tømt for institusjoner og funksjoner, noe som ofte virker nedbrytende. Men det synes ikke helt å ha skjedd i Langfjordbotn, 
folk fortsetter å bo der, og det er en ikke uvesentlig tilflytting. Noen tror at jordbruket vil ta seg opp igjen, at man vil se at det utvikles gårdsdrift knyttet til utradisjonelt jordbruk, og til produksjon av nærmat. I tillegg til gårdsbrukene har som nevnt en viss turisme vokst fram. Naturen er stort sett utmark, og er som sådan tilgjengelig for alle.

\section{Utvikling}

Skjer det noen utvikling? Spørsmålet må svares med et ja. Det skjer en utvikling, men den har en relativt anarkistisk karakter. Det har vært en betydelig utvikling i jordbruket, i tråd med nasjonale målsetninger; større og mer rasjonelle enheter. I dag er dette feil tenkning for steder som Langfjorden, hevder en informant. Et annet utviklingstrekk er framvekst av turisme. Det er også et mål for slike steder, men mål, strategier og virkemidler er uklare. Men vekst er ønsket, og det er en påtakelig vekst innen turismen også i Langfjorden. Noen av de som har uttalt seg, savner en mer samordnet satsing i sektoren; at man lager en utviklingsplan. Dette ble gjort for noen år siden, men det er uklart om planen hadde betydning for det som har skjedd.

Langfjorden synes å ha en rekke ressurssterke mennesker som bidrar til utvikling på og av stedet. Noen er åpenbare samfunnsaktører, mens de fleste er bedriftsentreprenører. Det er få arbeidsgivere på stedet, og dels etterspørres kompetanse som ikke finnes lokalt. Derfor er den eneste offentlige bedriften, en rusklinikk, bemannet med tilflyttere eller pendlere. Skal man bo i bygda, må man ha et levebrød, og man må helst skape det sjøl eller arbeide andre steder.

Det skjer en del utvikling på kollektivt plan basert på ildsjeler eller samfunnsentreprenører. De gjør en masse for bygda, basert på sin kompetanse og sine kontaktnett. Slik fikset man grendehuset, skaffet bygda bredbånd, skapte en flytebrygge utenfor moloen osv. Andre tar tak når det gjelder de årvisse arrangementene, som julestart, Langfjorddagan osv. Dette er ildsjeler, som har hjerte for stedet og vil at det skal pulsere i bygda. Og går en tilbake i tid, kan folk fortelle om diverse tiltak, for eksempel vedlikehold av kirka og etablering av parkeringsplasser, som er jobbet fram av ildsjeler, av «mennesker som tør å ta ordet i forsamlinger», som en av dem kalte det. Det har hjulpet å stille krav, stedet har åpenbart lav oppmerksomhet i kommunale fora. Kommunen vil for eksempel ikke tilrettelegge boligfelt. Kommunen 
tror ikke på bygda, virker det som. «De tror at det som skjer - avfolking og nedbygging av utkantene - er en naturlig følge av de økonomiske kreftene i samfunnet - at det ikke går an å få til noe her.» Slik uttrykte en av informantene opplevelsen av kommuneledelsen. Jordbruk og servicevirksomhet er ikke næring, slik kommunepampene ser det, sier en annen, og viser til utviklinga av et industriområde i en av nabobygdene (Isnestoften). Næringsutvikling er industriutvikling. Et eksempel på lavprioritering av området finner man også når det gjelder tilrettelegging for friluftslivet. I sentrum har man opparbeidet og merket stier, i Langfjorden er lite gjort ut over etablering av skuterløyper. Men her er det delte meninger om hva som trengs, og hva som er ønskelig. I Langfjordens nabolag, i Kvænangen kommune, er det merkede stier og parkeringsplasser. Verken Alta eller Finnmark friluftsråd har satset på Langfjorden. Som en uttalte: «Vi får stort sett leve i fred, på godt og vondt.» Men det betyr kanskje at man heller ikke får de store utviklingsprosjektene, eller forsøk på noe slikt. Markante samfunnsentreprenører som tenker helhetlig, og som får andre med seg, synes å mangle. Her trengs det ledelse, uttalte en informant. Vedkommende mente nok at dette burde være en som opptrådte på vegne av bygda, og som står ansvarlig overfor kommunen. De som prøver seg, risikerer å måtte slite både med bygdedyr og arvesynd. Gamle maktkonstellasjoner gjenoppstår når noen prøver å ta tak. Skal man lykkes med utviklingsprosjekter, må det både finnes ildsjeler og entreprenørielle miljøer. Entreprenørskap rommer en rekke roller, sies det (Broch \& Vestby 2010); ideer må lanseres og drives fram, prosjekter må administreres, folk i omgivelsene må overbevises og motiveres, og ikke minst vil de fleste samfunnsprosjekter være avhengige av at man makter å bygge broer mellom ulike interesser. Slik det er i Langforden, synes det som om bare noen av rollene ivaretas. Jo mer omfattende prosjektet er, jo flere roller er det som skal dekkes. Det synes som om folk som tar et overordnet ansvar, mangler. Kanskje kunne man trenge et bygdeutviklingsprosjekt hvor folk flest involveres.

\section{Diskusjon}

Tilfellet Langfjordbotn faller inn i et kjent mønster. Stedet er blitt delokalisert, knyttet til nasjonale og internasjonale nettverk, og er preget av globale trender. Dette betyr at stedet på mange måter ikke lenger er en lokal helhet, men inngår i større enheter. En slik enhet er et større sted, kanskje en region 
bestående av denne bygda og nabobygdene, eller av Alta-regionen. Andre enheter folk har tilknytning til, er arbeidsplasser som både er lokale, regionale og nasjonale. Institusjonene som betjener folket, er ikke lenger lokale, men befinner seg i nabokommunen, eller i Alta åtte mil unna. Institusjonstømming har både vært en konsekvens av og en pådriver for avfolking. Men avfolkingstendensen har stoppet opp, eller samtidig som folk flytter ut, flytter andre inn. De mest stabile sies det, er folk med røtter i jordbruket. Og folk har vent seg til å se på institusjoner utenfor bygda som sine.

Langfjorden står likevel fram som et sted. Det er riktignok litt uklart hva kjernen består i, og hvor grensene går, men folk er fortsatt fra Langfjorden, har følelser for og identitet til stedet. Steder er seige materier, sies det (Cruickschank 2015), noe også dette stedet vitner om. Folk snakker om fortida, men også om endringene, at det var tettere relasjoner før, at man traff hverandre mer og hadde flere møteplasser. Når institusjoner forsvinner fra byene, er det gjerne andre institusjoner som tar over. Når institusjoner forsvinner fra landsbygda, oppstår tomrom og forflytning av institusjonelle tyngdepunkt. Langfjorden bidrar til styrking av nabokommunen og dets sentrum, Burfjord. Alta er lite baktalt, men også lite omtalt. Det virker litt som om kommunen ikke er så viktig for stedet. Kommunen har på ett vis administrert stedet bort.

Likevel skjer det ting i bygda. Ny næringsvirksomhet, som turisme, er i gang, og noen ser muligheter i revitalisering av landbruket. Det skjer innovasjoner. Disse er først og fremst knyttet til at folk med andre blikk ser andre og nye muligheter. Ressurser for næring er ikke noe som bare ligger der, det er noe som mobiliseres i møter med mennesker som har andre erfaringer, andre blikk og er fortrolig med andre diskurser (Bathel \& Glückler 2003). Hundekjøring og toppskikjøring er eksempler på dette. Nyskaperne møter en viss motstand. Det kan være uforstand, redsel for det ukjente, jantelova eller det mye omtalte bygdedyret (Førde 2010). I innovative prosesser utfordres vante forestillinger og rådende diskurser. Slike forestillinger er normative, og normer er stabiliserende og trege. Også i Langfjorden. Her har bondekulturen og læstadianismen vært ordnende - kulturer som begge er konservative. Forskning viser imidlertid at en viss motstand mot innovasjon finnes overalt, også på steder hvor ildsjeler vinner fram, og det skjer ting. Og det finnes også undersøkelser som viser at innovasjon ofte skaper brytninger, og at det ikke nødvendigvis er usunt. Men likevel synes det ofte å være et visst handlingsrom (Førde 2010). Den gryende turismen i Langfjorden ønskes velkommen, men 
er også gjenstand for en viss skepsis. Folk har forestillinger om hva masseturisme er, og har lest om negative trekk ved turismen i Lofoten og Lyngen. Stort sett er dette basert på oppslag om uheldige hendelser, og en uventet stor vekst. Uansett betyr turismeutvikling stedsendring, eller om man vil, en ny dimensjon i stedsutviklinga. Dermed rokkes det både ved stedets mening, maktforhold og materialitet, sier Frisvoll (2015). En side ved dette er kommersialisering og det som for mange verre er, en varegjøring av stedet, naturen og kulturen. Det betyr at disse elementene tillegges kommersielle verdier, og verdsettingen skjer utenfor lokalsamfunnet. Noen har omtalt omstilling fra jordbruk til turisme som å ta et skritt fra et produksjonslandskap over i et konsumlandskap (Førde \& Magnussen 2012). Dette er en kulturkonservativ retorikk, som vi også møtte hos en informant i Langfjorden. Turistlandskapet er også et produksjonslandskap, og som regel er det slik det er i Langfjorden, lokale krefter som står bak slike endringer, og som ser for seg et nye muligheter for stedet sitt. Turistsatsinga bunner i en plan som ble laget for 20 år siden, hvor det også sto at bygda trenger en kafé. Det har man fått.

\section{Oppsummering}

Langfjorden, hva nå man måtte inkludere, hele fjorden eller bare dens indre ende, er et sted som gir mening for dem som bor der. Noen har røtter mange generasjoner tilbake, andre er nyinnflyttere. De med røtter, har en tilhørighet av både emosjonell og funksjonell karakter. De føler for stedet. og noen arbeider her. De nyinnflyttede reflekterer nye samfunnstrender, hvor interesser og opplevelsesmuligheter er bestemmende for hvor en bosetter seg. Det er gode forhold for både hundekjøring og toppski-, fjell- og brevandring i Langfjorden. Dette er etterspurt i vår tid og har altså gitt grunnlag for nye næringsaktiviteter. Det taler også til stedets fordel at det har en liten by bare 80 kilometer unna, og dermed har tilgang til moderne kulturtilbud, universitetsutdanninger og mange daglige flyavganger til Oslo. Stedet er således en integrert del av mangfoldige globale nettverk og strømninger. Folk er ikke bundet til Langfjorden om de vil smake på det stedet ikke rommer, om man vil på kino, restaurant eller konsert. Man kan smake både på det rurale og det urbane når man bor der. Man får både i pose og sekk.

Folk er opptatt av røttene og av hvordan det var før, og av at det er langt færre mennesker i bygda i dag. Stedet sliter med å komme seg fra en fase 
med avvikling og over i tilblivelse. Folk ser ikke helt hva tilblivelsen skal bli. De fleste har registrert turismeutviklinga og ser positivt på den. Om det er dette som skal være stien å følge, er det likevel tvil om. Slik det er i dag, er dette verken en helhetlig eller omforent strategi. Noen etterlyser strategisk tekning og systematikk i utviklingsarbeidet. Og noen er bekymret for måten det har startet på, med et sterkt innslag av utlendinger. Hva tjener bygda på at utenlandske eller utenbygds firmaer utvikler turisme her, pengene fra denne ressursutnyttelsen går da ut av bygda?

Langfjorden har mistet sine institusjoner og dermed mange av møtestedene man før hadde. Men nye har oppstått, som kafeen, samfunnshuset og Langfjorddagan. Sentrum er Burfjord, 20 kilometer unna, og i en annen kommune. Dagens utvikling har etablert et område rundt Langfjordbotn som omfatter deler av Kvænangen og Loppa. Det er i dag en funksjonell region for skiturisme, fjellguiding og hundekjøring. Regionen mangler navn. Den har identitet, institusjoner og ressurser. Mulighetene er der. Og folk trives her, og det skjer ting. Det trengs en del nybrottsarbeid og lederskap for å få det nye området til å fungere som en mer ordnet helhet.

\section{Litteratur}

Altman, J. C. (2001). Sustainable development options on Aboriginal land: The hybrid economy in the twenty-first century. Centre of Aboriginal Research. Discussion paper no. 226. digitalcollections.anu.edu.au

Bathelt, H. \& Glückler, J. (2003). Toward a relational economic geography. Journal of Economic Geography, 3 (2), 117-144. https://doi.org/10.1093/ jeg/3.2.117

Berg, N. G. \& Dale, B. (2015). Sted - noen nyere teoretiske tilnærminger og debatter. I M. Aure, N. G. Gunnerud Berg, J. Cruickschank \& B. Dale (red.), Med sans for sted. Nyere teorier (s. 31-46). Bergen: Fagbokforlaget.

Borch, O. J. \& Vestrum, I. (2010). Samfunnsentreprenøren og «de gode hjelperne». I O. J. Borch \& A. Førde (red.), Innovative bygdemiljø. Ildsjeler og nyskapingsarbeid (s. 84-94). Bergen: Fagbokforlaget.

Cruickschank, J. (2015). Hvordan forstå steders treghet? Betydningen av konflikt. I M. Aure, N. G. Gunnerud Berg, J. Cruickschank \& B. Dale (red.), Med sans for sted. Nyere teorier (s. 83-98). Bergen: Fagbokforlaget. 
Frisvoll S. (2015). Korleis analytisk fange staddanning mellom meining, makt, materialitet og menneske? I M. Aure, N. G. Gunnerud Berg, J. Cruickschank \& B. Dale (red.), Med sans for sted. Nyere teorier (s. 133-147). Bergen: Fagbokforlaget.

Førde, A. (2010). Nyskaping, brytningar og samspel. I O. J. Borch \& A. Førde (red.), Innovative bygdemiljø. Ildsjeler og nyskapingsarbeid (s. 155-170). Bergen: Fagbokforlaget.

Førde, A. \& Magnussen, T. (2012). Når hundekjeksen tar over - opplevinga av stad gjennom landskap. I M. B. Bringslid (red.), Bygdeutviklingas paradoks (s. 91-116). Oslo: Scandinavian Academic Press.

Massey, D. (2005). For space. London: Sage. https://doi.org/10.12968/ sece.2005.1.361

Milbourne, P. \& Kitchen, L. (2014). Rural mobilities: Connecting movement and fixity in rural places. Journal of Rural Studies, 34, 326-338. https://doi.org/10.1016/j.jrurstud.2014.01.004

Ojha, H. R., Ford, R., Keenan, R. J., Race, D., Vega, D. C., Baral, H. \& Sapkota, P. (2016). Delocalizing communities: changing forms of community engagement in natural resources governance. World Development, 87, 274-290. https://doi.org/10.1016/j.worlddev.2016.06.017

Osbaldiston, N. (2012). Seeking authenticity in place, culture, and the self. The great urban escape. New York: Palgrave Macmillan. https://doi.org/10.1057/9781137007636

Paasi, A. (2009). The resurgence of the 'region' and 'regional identity': Theoretical perspectives and empirical observations on regional dynamics in Europe. Review of International Studies, 35, 121-146. https://doi.org/10.1017/ S0260210509008456

Sahlins, M. D. (1972). Stone age economics. New York: Aldine de Gruyter.

Stedman, R. C. (2002). Toward a Social Psychology of Place. Environment and Behavior, 34 (5), 561-581. https://doi.org/10.1177/0013916502034005001

Svensson, G. \& Viken, A. (2017). Respect in the girdnu: The Sami verdde institution and tourism in Northern Norway. I A. Viken \& D. Müller (red.), Tourism and indigeneity in the Arctic (s. 61-280). Bristol: Channel View Publications. https://doi.org/10.21832/9781845416102-017

Vestby, G. M. (2015). Stedsutviklingas råstoff og resultat: Funksjonelle og emosjonelle relasjoner mellom mennesker og sted. I M. Aure, N. Gunnerud Berge, J. Cruickschank \& B. Dale (red.), Med sans for sted. Nyere teorier (s. 165-178). Bergen: Fagbokforlaget. 


\section{BÅLDIPLOMATI, GJENSIDIG AVHENGIGHET, DIALOG OG REFLEKSIVITET}

Torill Nyseth og Arvid Viken

\section{Innledning}

Samfunnsstyring er et dynamisk felt hvor nye styringsformer vokser fram. Begrepet samstyring eller nettverksstyring anvendes om nye styringsformer der samspillet mellom ulike aktører, sektorer og beslutningstakere er nødvendige (Sørensen \& Torfing 2005; Røiseland \& Vabo 2012). Dette gjelder også innenfor turisme (Bramwell \& Sharman 1999; Dredge 2006; Dredge \& Pfrorr 2008). De som utvikler reiselivet, er ofte svært avhengige av hva som besluttes og gjøres av andre aktører, og på andre beslutningsnivåer (Nordin \& Svensson 2007). Det som særlig kjennetegner samstyring, er gjensidig avhengighet mellom aktørene. I en metaanalyse av styring av turismen fant Ruhanen og kolleger (2010) at «gjensidig avhengighet» ikke har vært noe reiselivsforskningen har vært særlig opptatt av. Destinasjonsutvikling har for det meste blitt studert fra perspektiver som økonomisk vekst og bedriftsøkonomi (se for eksempel Flagestad \& Hope 2001; Haugland et al. 2011). Vårt utgangspunkt er at dette kan være noe snevert og ikke evner å fange inn viktige mekanismer og prosesser i utviklinga av en destinasjon, eller det vi kaller en turistresort, et sted hvor det gjøres en konsentrert satsing på de opplevelsene, aktivitetene og fasilitetene som da trengs. For å forstå en opp- 
startsprosess er det derfor behov for en tilnærming hvor man kan fange inn samspillet mellom mange interesser. Vi vil her særlig fokusere på betydningen av gjensidig avhengighet og dialoger i en slik prosess. Undersøkelser har vist at $\mathrm{i}$ et entreprenørorientert felt er det viktig hvordan gjensidig avhengighet håndteres, og hvordan dialoger mellom aktørgrupper utvikler seg (Innes \& Booher 2003). I slike prosesser blir lokale myndigheter forvandlet fra et system for tjenesteyting til responsive, innovative, markedsorienterte og tilretteleggende institusjoner. Målet med dette kapitlet er å undersøke hvordan dette fortonte seg i utviklinga av Måselv Fjellandsby, en ski- og hytteresort to timer fra Tromsø. Resorten ble utviklet gjennom et samarbeid som involverte et stort antall aktører, både offentlige og sivile aktører og næringsaktører. Av særlig interesse i denne sammenhengen er organisering av grunneiere og involvering av reindriftsutøvere og Norges forsvar, som er en tung statlig aktør i det aktuelle området. Kapitlet viser hvordan gjensidig avhengighet førte til samspill og samarbeid mellom aktørene og bidro til å framforhandle løsninger på fastlåste konflikter.

I samstyringslitteraturen er begrepet gjensidig avhengighet løftet fram som et sentralt begrep, et begrep som i tradisjonell styringslitteratur i liten grad er drøftet. Men hvordan skal gjensidig avhengighet forstås? Finnes det ulike former for gjensidig avhengighet? Hvilke dimensjoner er relevante? Fremmer avhengigheten felles løsninger? Hvor utsatt er gjensidigheten? Kapitlet starter med en presentasjon av teorifeltet gjensidig avhengighet og dialog som to aspekter ved moderne styring, etterfulgt av en presentasjon av metode og data som denne studien har anvendt, det vil si casestudien, og deretter en diskusjonsdel, hvor de observerte sammenhengene er oppsummert og knyttet til eksisterende teori.

\section{Gjensidig avhengighet}

Ideen om gjensidig avhengighet har blitt behandlet fra ulike teoretiske perspektiver, men særlig i organisasjonsstudier og samstyringsteori, som har gitt oss begrepet 'styringsnettverk' som et alternativ til det hierarkiske styringsperspektivet. Større avhengigheter mellom organisasjoner bunner i et behov for ressurser som andre råder over, for eksempel spesialisert kunnskap, kapital eller legitimitet. I et gjennomintegrert samfunn påvirkes den enes handlinger de andre. For aktører som arbeider med samfunnsproblemer, er samarbeid 
en viktig strategi, og å etablere nettverk er et av virkemidlene (Kickert et al. 1997). Svært mye samfunnsutvikling skjer $i$ «selvorganiserende, interorganisatoriske nettverk preget av gjensidig avhengighet, ressursutveksling, felles spilleregler, og en betydelig uavhengighet fra staten», hevder Rhodes (1997, s. 15, vår oversettelse). Rhodes definerer et politisk nettverk som en klynge eller samling av organisasjoner som er knyttet til hverandre i ressursavhengighet (1986). Ifølge Rhodes ville nettverk ikke bli dannet dersom aktørene på en eller annen måte ikke var innbyrdes avhengige. Slik Kickert og kolleger $(2007$, s. 6) ser det, er «[a]ktører i nettverk gjensidig avhengige fordi de ikke sjøl kan oppnå sine mål uten tilgang andre aktørers ressurser». Gjensidig avhengighet utvikles når flere involverte parter nyter godt av samarbeidet. Men hva som ligger i slik avhengighet, og hvordan gjensidighet skal tolkes, varierer mellom ulike faglige tilnærminger. To av disse er ressursavhengighetsstrategier og samarbeid gjennom dialog.

Ressursavhengighet som strategi er en tenkemåte lånt fra organisasjonsteori, først utviklet av Scharpf (1978), noen ganger referert til som ressursavhengighet eller utvekslingsperspektiv. Scharpf skiller mellom to dimensjoner; ressursens betydning og i hvilken grad den kan erstattes av en annen. En aktør er avhengig av en annen hvis hans forhold til den aktøren er preget av at ressursen er viktig og ikke kan erstattes. Hertting (2007) er spesielt interessert i hvordan gjensidig avhengighet er en insentivstruktur for dannelse av styringsnettverk. Han skiller mellom ressursavhengigheter og avhengighetsforhold som produserer strategiske allianser. Ressursavhengighet gjør at aktører investerer i nettverksforbindelser for å effektivisere ressursutvekslinger. Strategisk avhengighet er relatert til utfallet av handlinger fra andre aktørers side, og ikke ressursene de tar med seg til forhandlingsbordet. For eksempel vil kommunen være en strategisk alliansepartner i utviklinga av turismeprosjekter. Det er en rekke fordeler ved å ha kommunen med på laget, sjøl om den ikke bringer penger eller andre ressurser til bordet, som for eksempel beslutningskompetanse og offentlig støtte.

Avhengigheter utvikles når det er umulig for aktører å løse komplekse problemer på egen hånd. Når slik avhengighet er gjensidig, kan den bidra til å skape og opprettholde relasjonsmønstre. Som et resultat kan det oppstå samspillsmønstre rundt et bestemt politisk saksfelt som ligger der som en arena for håndtering av nye saker (jf. Koppenjahn et al. 2004, s. 10). Hertting (2007) bringer også inn betydningen av uformelle relasjoner i nettverk: «Uformelle nettverk gjør det mulig å håndtere gjensidig avhengighet mer 
effektivt uten å overgi formell autonomi, samtidig som det er mulig å unngå nettverket når det er ønskelig» (ibid., s. 59).

Gjensidig avhengighet er dynamisk; den erkjennes og forandres gjennom interaksjon (Crozier \& Friedberg 1980). Opplevelsen av gjensidig avhengighet er ikke nødvendigvis realiteter. «Det er oppfatninger sammen med ønsker, som stimulerer aktører til å bygge institusjonelle arrangementer for morgendagen, inkludert nettverk», sier Hertting (2007, s. 49). Slike oppfatninger utgjør altså en insentivstruktur. For å erkjenne gjensidig avhengighet er det ofte behov for dialog mellom partene. Sjøl om dette ikke er mye studert, hevder Innes og Booher (2000 s. 5) at «samarbeid og dialog har utvilsomt eksistert gjennom historien blant små grupper av likemenn som prøver å løse et problem, slik som i offentlig-politiske prosesser ...». I denne studien er det imidlertid også fokus på å initiere og administrere dialoger som et styringsaspekt. Ikke alle parter er nødvendigvis bevisst sine avhengighetsrelasjoner. Innes og Booher (2000) hevder at gjensidig avhengighet ikke nødvendigvis er erkjent i starten av en prosess, men noe som utvikler seg i prosessen etter som deltakere blir kjent med hverandre. Uten dialog kan de for eksempel ikke vite hva andre disponerer av det de sjøl trenger, eller hva de sjøl kan tilby som andre ønsker.

Interessenter begynner å lære om sin gjensidige avhengighet når de forklarer sin egen situasjon og behov, men de lærer mest om dette idet gruppen går gjennom de vanskelige oppgavene for å bli enige om hvordan man definerer og måler problemet og bestemmer seg for handlinger (ibid., s. 41). Dermed er gjensidig avhengighet et refleksivt anliggende. I noen tilfeller fant Innes og Booher (2010) at manglende anerkjennelse av gjensidig avhengighet var et sentralt hinder for samarbeid, og mot å nå fram til felles løsninger. For å finne løsninger på problemer trengs dialog.

Et av resultatene av dialoger vil ofte være en større forståelse for betydningen av gjensidig avhengighet og tillit. Gjennom gjensidig å engasjere seg trenes aktørene opp i å ta hensyn til andres interesser, ta ansvar for andre, som igjen skaper følelser av tilhørighet, og vilje til å akseptere beslutninger som ikke nødvendigvis er fordelaktig for en sjøl (Hillier 2002, s. 277). For dem som koordinerer slike prosesser, er refleksivitetsutvikling et virkemiddel, altså å få deltakerne til å erkjenne avhengigheten og gjensidigheten i den. Aktørenes interesser er som regel sosialt konstruert og modifiseres gjennom dialog og samhandling, og gjennom utvikling av kunnskap eller intellektuell kapital (Innes et al. 1994). 
Gjensidig avhengighet vil både utvikle og bygge på tillit. Tillit reduserer usikkerhet (Koppenjahn \& Klinj 2004, s. 84). Tillit letter samordningen og beslutningsprosessene i nettverk. Men tillit krever tid, den utvikles sakte og kan forsvinne raskt. Tillit er derfor mest kritisk i begynnelsen av en nettverksdannelse hvor partene ikke kjenner hverandre. En måte å redusere disse hindringene på er å involvere aktører som deler en historie, i stedet for å skape nye koplinger (Agranoff 1991; O’Toole 1995). Vellykkede nettverk er basert på tillit, forpliktelse og gjensidig anerkjennelse.

Partnerne i et nettverk er ikke like, heller ikke med hensyn til sin grad av avhengighet, eller når det gjelder hvilke ressurser eller statuser de bringer inn. Asymmetri kan forårsake problemer. Hertting (2007, s. 58) hevder at «[a]ktører som opplever den gjensidige avhengighet som sterkt asymmetrisk trolig vil foretrekke formaliserte former for koordinering». Aktører i nettverk har også ulik kapasitet til å overbevise sine partnere. Mektige aktører kan bruke trussel om exit for å vinne fram med sitt syn. Maktforskjeller kan påvirke muligheten til å oppnå felles mål. På den annen side kan det også være problematisk om partene er for like. Det ligger en viss dynamikk i ulikhet ved at man bringer inn ulike perspektiver, kompetanse og synspunkter.

\section{Casestudien Målselv Fjellandsby}

Det empiriske grunnlaget for dette kapitlet er en casestudie av kreftene bak og dynamikken i en resortutvikling av Målselv Fjellandsby, som hadde prosjektoppstart i 2006. Landsbyen rommer hytter, leiligheter, tomter, veier, skiløyper og skiheiser, kafé, bar og restaurant, og i starten også en attraksjon, "Blånisseland», som rettet seg mot barn (jf. Viken 2014). Denne ble ingen suksess og er i dag avviklet. Målselv Fjellandsby gikk konkurs i 2015, men er startet opp igjen med nye eiere. Oppstarten av Målselv Fjellandsby er likevel en interessant case for analyse av de komplekse prosessene en resortutvikling representerer, og særlig for hvordan aktørene sto i avhengighet til hverandre. For det første var stedet preget av en avhengighet til Forsvaret, som ikke var særlig gunstig med hensyn til tjeneste- og styringsstrukturer, eller entreprenørskap og nyskapende aktiviteter. Denne avhengigheten av imidlertid ikke gjensidig. Det som utløste en prosess der en erkjennelse av gjensidig avhengighet gradvis vokste fram, 
var i utviklinga av en vei mellom to skytefelt, som representerte en konflikt mellom militærmyndighetene og reindrifta i over 30 år. I løsningen av denne konflikten fikk turismeutviklinga en utilsiktet sentral rolle.
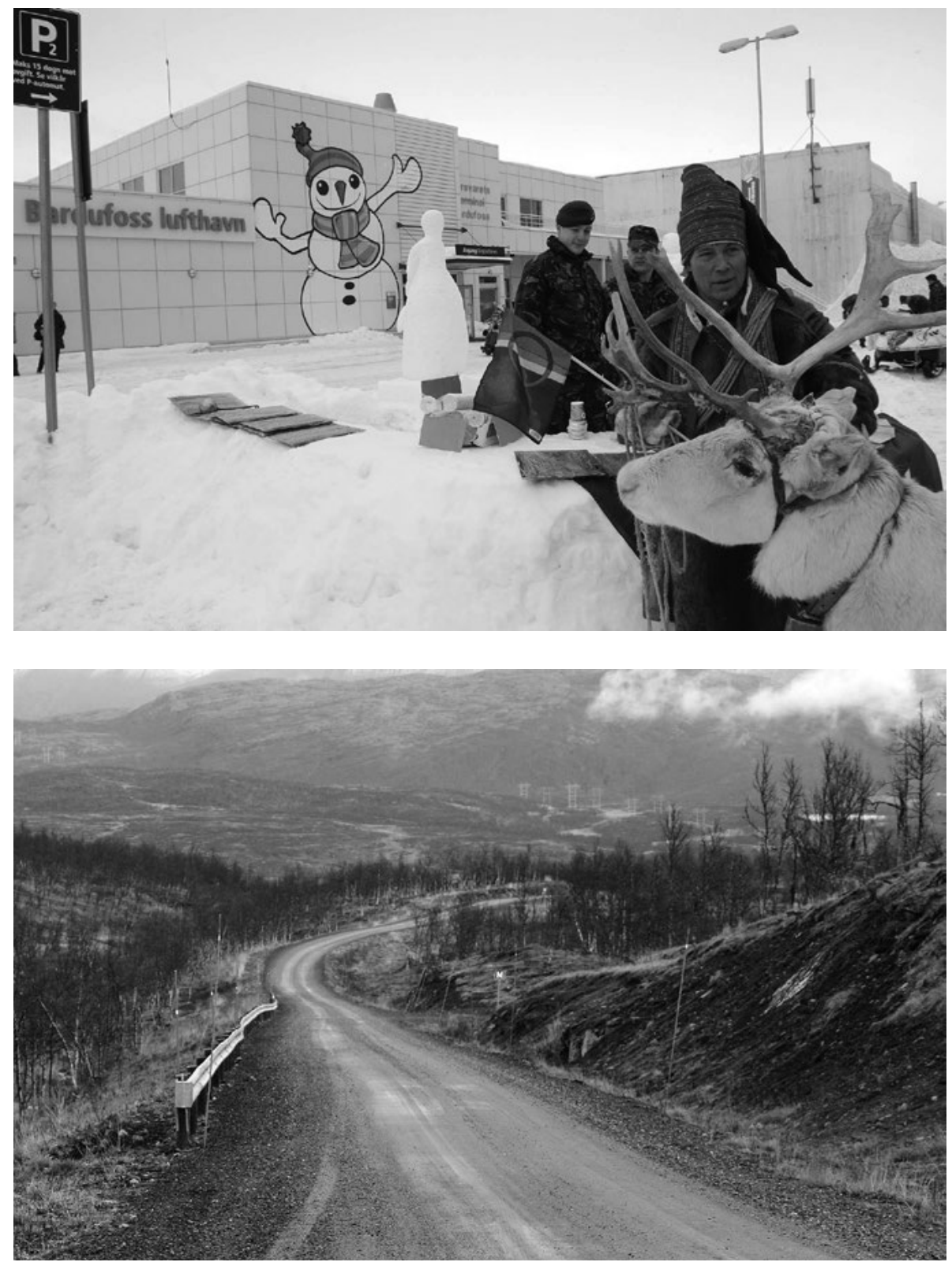

Turistsatsing som bidro til å løse en gammel veikonflikt mellom reindrift og militære. Foto: Ole Magnus Rapp. 
Tabell 11.1: Oversikt over intervjuer.

\begin{tabular}{|l|l|l|}
\hline Interessenter & Hvem representerer de & Hva er deres interesser \\
\hline Ordfører & Kommunen & Lokal utvikling og sysselsetting \\
\hline En tidligere ordfører & Lokalsamfunnet & Lokalsamfunnet \\
\hline Kommuneplanlegger & Kommunen & Regulering \\
\hline Næringskonsulent & Kommunen & Lokal næringsutvikling \\
\hline Militæransatte & Forsvarets sivile stab & Effektivisering av bruken av skytefeltene \\
\hline Ledere i entreprenørfirmaer & Byggebransjen & Forretningsinteresser \\
\hline $\begin{array}{l}\text { Entreprenøren for utviklinga } \\
\text { av Målselv Fjellandsby }\end{array}$ & Målselv Fjellandsby & Ski- og hyttedestinasjons-utvikling \\
\hline Ansatt i reiselivsselskap & DMO & Reiselivsmarkedsføring \\
\hline Private næringsdrivende & Private selskaper & Forretningsinteresser \\
\hline Bønder/landeiere & Jordbruket & Å tjene penger på grunnen \\
\hline Reindriftsutøver & Reindrifta & Bruksrettighet til beiter \\
\hline Representant for Statskog & Staten som grunneier & Forretningsdrift knyttet til statsgrunn \\
\hline
\end{tabular}

Dataene for casestudien ble samlet inn gjennom fire feltturer til området i 2011 og 2012 og gjennom en studie av ettervirkningene av en vei mellom to skytefelt i 2015 (Viken \& Svensso1.1n 2015). Dataene er basert på intervjuer med en rekke involverte interessenter. Interessenter $\left(\right.$ stakeholdere $\left.^{10}\right)$ kan være både aksjonærer, eiere eller bruksrettighetshavere, men også innehavere av kunnskap eller status (Schmitter 2002). De viktigste interessentene i denne sammenhengen er resortutviklingsselskapet, kommunen, entreprenørbransjen, reindriverne, bøndene, Forsvaret og Statskog. I intervjuene ble det særlig fokusert på relasjoner og roller blant disse interessentene. Disse ble dels intervjuet i grupper, dels individuelt.

I alt tolv dybdeintervjuer med ulike interessenter ble gjennomført i 2011-2012 og to gruppeintervjuer og seks dybdeintervjuer i 2015. Kommunens rolle i utviklinga har vært viktig, både den politiske støtten fra ordføreren og hans nettverk - for eksempel Forsvarsdepartementet, men også kommunens planleggingsavdeling. Den involverte ordføreren ble intervjuet ved to forskjellige anledninger. Også en representant for Måselv Fjellandsby ble intervjuet to ganger, andre gang i 2012, på et tidspunkt med mye turbulens. Den opprinnelige entreprenøren hadde da forlatt prosjektet, og en ny leder hadde overtatt. Med han hadde nye ideer blitt innført, både med

10 Stakeholdere er definert av Freeman (2006) som enhver gruppe eller individ som kan påvirke eller påvirkes av oppnåelsen av et selskaps formål. I dette kapitlet er det et spesielt fokus på de mest involverte partene i utviklingsprosessen. 
hensyn til prosjektets innhold og med hensyn til markedsføring av destinasjonen. En tidligere ordfører var også en viktig informant (som hadde vært ordfører i flere år, nå pensjonert) gjennom sin inngående kunnskap om samfunnet og på grunn av sitt engasjement i en rekke prosjekter over en lang periode. Representanter for reindrifta ble intervjuet i 2012. I tillegg ble det gjennomført flere fokusgruppeintervjuer (se tabell 11.1). I 2015 ble en del aktører intervjuet som ledd i en evaluering av veien mellom skytefeltene, blant annet ble to fokusgruppeintervjuer gjort, en bestående av grunneiere og en med hytteeiere. Disse ga en utvidet forstålse av deler av tematikken i dette kapitlet.

\section{Gjensidig avhengighet}

Et fellesskap og en kommune avhengig av nye næringsaktiviteter

Under den kalde krigen var Målselv et viktig sted for Norges forsvar. På stedet var det en militærbase med tusenvis av soldater, og innbyggertallet var over 8500. Etter Sovjetunionens fall ble det militære trusselbildet i nordområdene endret, og Målselv ble strategisk mindre viktig. På begynnelsen av 2000-tallet bestemte hæren seg for å flytte det meste av soldatopplæringen til Sør-Norge. Som følge av dette sank innbyggertallet fra 8500 til om lag 6000 . Følgelig sank også de kommunale skatteinntektene. Man var bekymret for lokalsamfunnets framtid. Noe måtte gjøres dersom tjenestetilbudene skulle opprettholdes. Nye virksomheter som kunne kompensere for tap av arbeidsplasser og inntektsskatten som militæret hadde representert, måtte utvikles. I diskusjonen om alternative næringer var kommunen særs aktiv. For denne innsatsen ble kommunen i 2008 tildelt en pris av Innovasjon Norge som den mest innovative kommunen det året. Hele prosessen forteller om en kommune sterkt avhengig av at noe måtte skje.

En av de nye næringene som ble diskutert, var turisme, delvis basert på Målselva, kjent for sin laksefiskturisme helt tilbake til 1800-tallet, og Målselvfossen, også et velkjent turistmål. Sjøl om disse attraksjonene tiltrekker seg mange turister, stopper de fleste bare et par timer på turen forbi, de fleste på vei til eller fra Nordkapp. For å vurdere om en mer lønnsom turisme kunne utvikles, inviterte kommunen en entreprenør sørfra til Måsselv, som hadde lang erfaring med å utvikle denne typen resorter andre steder $\mathrm{i}$ landet. I utgangspunktet var det potensialene knyttet til elva, fossen og tilstøtende 
innkvarteringsanlegg entreprenøren ble invitert til å vurdere. Entreprenøren så imidlertid ikke noe spesielt potensial i elva, men ble derimot fascinert av de omkringliggende fjella - de var egnet for skiturisme, slik han så det. Fra da av ble det fokus på å utvikle Målselv til et skisted, med den inviterte entreprenøren som ansvarlig for oppstarten. Han startet en prosess som bidro til å utvikle ulike former for gjensidig avhengighet mellom kommunen, grunneiere, reindrivere, Forsvaret og ulike investorgrupper.

\section{Kapitalog grunn}

For å utvikle en skiresort, etablerte entreprenøren (også kalt prosjektleder) et firma som het Målselv Utvikling. Selskapet hadde en ganske liten startkapital, 100000 kroner. Etter noen måneder ble det gjort en emisjon med utvidelse av denne kapitalen til 150000 kroner. De nye investorene måtte betale tolv millioner kroner for halvparten av selskapets aksjer. Seks lokale investorer som noen måneder tidligere hadde opprettet investeringsselskapet Målselv Invest, la åtte millioner kroner på bordet, og to investorer fra Tromsø de resterende fire. Dermed var 50 prosent av den nødvendige startkapitalen på plass verdt tolv millioner kroner, noe som medførte at Målselv Utvikling hadde en finansiell plattform på 24 millioner kroner. Involvering av lokale investorer var et viktig signal til allmennheten. Det var også penger som investorene kunne påregne å få tilbake; de var alle i bygge- eller eiendomsbransjen. Kommunen opptok et lån på 60 millioner kroner for utvikling av infrastruktur som vei, vann, kabler og skiheiser. Avtalen var at for hver hytte eller tomt som ble solgt, skulle en andel av pengene gå til innløsning av lånet. Hytter ble solgt på prospekter - altså tegninger og spesifikasjoner, som også var en del av finansieringsmodellen. Sjøl om prosjektet ble rammet av den internasjonale økonomikrisa i 2008/2009, ble det solgt rundt 250 enheter på kort tid. Per 2011 var 148 hytter og 48 leiligheter blitt bygget, og om lag 600 millioner kroner hadde blitt investert i løpet av de første fem åra.

For at prosjektet skulle kunne realiseres, måtte man få tilgang til grunnarealer. Kommunen, som hadde invitert og fikk entreprenøren involvert, eide ikke sjøl grunn i områdene man hadde blinket ut. En liten del var statlig eiendom, men det meste var beiteområder eid av bøndene i området. Grunneierne ble invitert til et møte der det ble informert om planene, og om hvordan man så for seg at eierforholdene kunne håndteres. Modellen 
som ble present og seinere fulgt, hadde også blitt brukt i Voss (Myrkdalen) og i Trysil, velkjente vintersportssteder i Norge. Et eiendomsselskap ble etablert, der alle de ti grunneierne (inklusiv Statskog) fikk en part hver. I tillegg fikk reineieren med beiterett i område en part. Eierne frasa seg råderetten over sin del, som nå disponeres av et felles driftsselskap, Målselv Fjellandsby. Modellen innebærer at all grunn har samme verdi uansett hva den brukes til, vei, tomt, skibakke, heis, eller bare er en skråning eller et åpent område. Partene får en tilbakebetaling etter en avtalt formel. For å overbevise partene arrangerte entreprenøren et besøk på Voss, hvor han hadde vært involvert i en liknende prosess. Entreprenøren brukte også andre metoder for å overbevise grunneierne, en kombinasjon av løfter om økonomisk fortjeneste og trusler om å velge en annen lokalitet. Prosessen bidro til å skape gjensidig avhengighet; man måtte finne fram til enighet dersom det som framsto som en god investering, skulle kunne realiseres. På denne måten ble entreprenøren en ressurs som grunneierne var avhengige av, om de skulle få inntekter fra området. Sauehold var mer eller mindre gitt opp i området, og det var behov for nye og alternative inntektskilder.

En tredje utfordring var forholdet til myndighetene. Prosjektlederen var avhengig av en rekke offentlige etaters medvirkning, engasjement og smidighet. Han gjorde seg kjent med fylkeskommunens administrasjon, og i kommuneadministrasjonen overvåket ordføreren prosessen. En av de formelle forutsetningene for oppstarten var å få på plass en detaljert reguleringsplan for området. Planen ble utformet i henhold til plan- og bygningslovens krav, der en privat konsulent sto for det meste av arbeidet. Planen, vedlagt flere konsekvensvurderinger, ble kvalitetssikret og godkjent av respektive myndigheter etter de nødvendige høringsprosedyrer. Reindriftas områdestyre (et organ som ikke lenger eksisterer) kunne stoppet prosessen dersom det mente at prosjektet var til skade for reindrifta. Kommunestyret måtte avvente sin godkjenning av reguleringsplanen til dette organet hadde uttalt seg. Denne avhengigheten var den mest risikable delen av prosjektet, slik prosjektlederen og den tidligere ordføreren i ettertid så det. Områdestyret hadde ikke innsigelser, og samme dag som dette ble klart, hadde kommunestyret møte, og utbyggingen av området kunne starte.

Prosessen beskrevet ovenfor var preget av forhandlinger mellom ulike interessenter, ofte mer på bakgrunn av løse ideer enn ferdige planer. Det dreide seg mye om forventede resultater. Det var mye lirking og tilpasning (se Viken 2014), eller bricolage, som Innes og Booher (2010, s. 136) sier 
kjennetegner autentiske dialoger. Det er prosesser fylt med gi og ta, som ikke er lineære eller alltid like rasjonelle. Prosessen var preget av pragmatiske forhandlinger mellom likeverdige samarbeidspartnere, i en relativt åpen prosess.

Oppsummert må en kunne si at entreprenøren var sterkt avhengig av sin evne til å overbevise ulike investorer og kommunen. De på sin side ble avhengige av entreprenøren, hans kunnskaper og ferdigheter, som kunne føre til hardt tiltrengt næringsutvikling. De lokale investorene og deres nyetablerte investorselskap var på søk etter noe å investere i, og kommunen, som fryktet en krise, var åpen for en investor med en solid erfaring fra liknende prosesser. Situasjonen kunne karakteriseres som en vinn-vinn-situasjon.

\section{Gjensidig avhengighet og dialoger: reindrivere, resortutviklere og} Forsvaret

De fleste utmarksområder i Nord-Norge er reinbeiter. Med noen få unntak er reindrift forbeholdt mennesker av samisk opprinnelse. Reindrift er en seminomadisk livsform, med migrasjon fra innlandet til kysten hver vår og tilbake igjen om høsten. Reineierne er ikke anerkjent som eiere av beitene, men har sterke rettigheter vedrørende bruk. Målselv Fjellandsby ligger i et slikt beiteområde. Dermed var entreprenøren avhengig av å utvikle et godt forhold til reindriverne. Tidlig i prosessen tok prosjektlederen og ordføreren kontakt. Noen av møtene med reineierne fant sted i reineiernes lavvu rundt bålet. Forhandlingene førte fram, og man entes om en økonomisk kompensasjon på cirka tolv millioner kroner til reindriverne for ulempene knyttet til resortutviklinga. Et annet viktig element for å få reindriftsutøvernes støtte til prosjektet var å gi dem en andel i Målselv Eiendom, hvor deres brukerrettigheter fikk samme status som for grunneierne. En del av avtalen var også en eksklusiv rett til å utvikle reinbaserte reiselivstilbud i anlegget, som reinkjøring, servering av samisk mat og underholdning i og rundt lavvoer. I ettertid karakteriserte begge partene forhandlingene som rettferdige og relativt åpne, hvor fordeler og ulemper for reindrifta hadde blitt diskutert, og hvor prosjektets avhengighet av reineiernes støtte ble drøftet. En konflikt kunne ha stoppe prosjektet, eller i det minste satt det på vent i mange år. Dette hadde skjedd med et annet prosjekt i området, som handlet om en veiforbindelse hæren ønsket å etablere mellom to av sine skytefelt i kommunen og nabokommunen, Blåtind og Mauken. 
Veiplanene hadde eksistert siden 1970. Reindriftsutøverne var sterkt kritiske til veietableringen. Dette var kjent som en hard, vanskelig og uforsonlig konflikt. Reindriverne ble betraktet som kompromissløse, representert ved en advokat som hadde spesialisert seg på reindriftsrelatert jus. Kontakten hadde $\mathrm{i}$ årevis gått gjennom advokater på begge sider. Ledelsen av Skjold Bataljon (ansvarlig for skytefeltene) hadde informert ordføreren om at de vurderte å flytte skyteopplæringen for soldatene til Sør-Norge. Om dette skjedde, ville Målselv miste mange arbeidsplasser. Ordføreren måtte derfor finne en løsning på veikonflikten. Et alternativ, og noe reindriftsutøverne var vel klar over, kunne være ekspropriasjon, en komplisert og tidkrevende prosess. Saken var vanskelig også for reindriverne. Hvis de tvang hæren til å flytte, følte de seg ansvarlige for antatt arbeidsledighet og nedgangstider i lokalsamfunnet. Vår informant og hans familie følte derfor behov for å finne en løsning på veikonflikten. Under diskusjonene mellom skiresortentreprenøren, ordføreren og reineierne kom veispørsmålet opp, og reingjeteren gjorde det klart at de ønsket en slutt på denne uenigheten. Ordføreren klarte å ordne møter mellom partene som var involvert, reindriverne og lederne av bataljonen, uten advokater til stede. De brakte også inn en veiingeniør, og alternative veitraseer ble diskutert, blant annet en som medførte langt færre ulemper for reindrifta. Ifølge en annen studie av denne prosessen (Haavet 2009) møtte også hæren med en annen tilnærming til forhandlingene enn hva man hadde gjort tidligere; med representanter som var mer åpne, og som møtte reineierne som likeverdige forhandlingsparter: «Det var flere møter. Forsvaret hadde signalisert vilje til å inngå kompromisser. Vi involverte ikke advokater ved disse anledninger, med hensikt, fra vår side» (ibid., s. 74), ifølge ordføreren på den tida. Partene møttes på en kafé i Øverbygd, og ordføreren forteller:

Vi satte oss ned med et kart som viste den gamle veitraseen, og tegnet en ny en som alle parter kunne akseptere. «Dette er historisk», hevdet jeg,» hvis vi alle signerer dette kartet har vi et fantastisk dokument». Og slik gjorde vi, og ble enige om å starte mer formelle forhandlinger. (Ibid., s. 75)

Alle de involverte ble av våre informanter berømmet for løsningen. I prosessen hadde ordføreren mobilisert sitt nettverk innenfor Arbeiderpartiet og hatt møte med forsvarsministeren. Her ble de mulige løsningene presentert og etter hvert akseptert av Forsvarsdepartementet. Et møte for signering av 
avtalen ble berammet. Ordføreren fryktet at reindriftsutøvernes advokat ikke ville anbefale den. Han ordnet det slik at han møtte advokaten i en uformell setting, fikk han i tale og la press på han. Det endte med at advokaten anbefalte reindriftsutøverne å signere dokumentet. Altså, flere saker ble løst i denne prosessen: Skiresorten kunne utvikles; hæren fikk sine skytefelt sammenkoplet; og reindriftsutøverne beholdt det meste av sitt beiteland, og ble i tillegg introdusert for et nytt forretningsområde - turisme. Målselv hadde fătt en ny næring vinterturisme. Slike oppsummerte ordføreren fra den aktuelle perioden saken:

Vi etablerte Målselv Fjellandsby (ski- og hytteresort), med samiske interesser og militære styrker, alle flettet inn i det samme store spørsmålet, og vi løste en rekke utfordringer i en stor jafs ... Det er et faktum at vi har funnet løsningene mye på grunn av at de militære styrkene var i ferd med å trekke seg tilbake. Tross alt gjorde de ikke det. (Ibid., s. 76).

I ettertid kan man skimte en hel rekke av innbyrdes avhengigheter i sakskomplekset. Det hadde oppstått et skjebnefellesskap. Både hæren og reindriftsutøverne var avhengige av noen som kunne ta tak i saken og å se på den med nye øyne. Ordføreren var avhengig av en løsning for ikke å miste arbeidsplasser. Entreprenøren for skiresorten var avhengig av et godt forhold til reindriftsutøverne. Han vant tillit gjennom å ta dem på alvor og som bisitter $\mathrm{i}$ dialogen mellom partene i den gamle veikonflikten. Ordførerens ressurser var hans entreprenørielle holdning, hans kommunikasjonsevner og hans nettverk innen det politiske systemet. Alle partene som var involvert, hadde mye å vinne og mye å tape, den gjensidige avhengigheten som eksisterte, er åpenbar og ble også erkjent av dem som sto i det. En tilsynelatende voksende refleksivitet omkring disse forholdene skapte en utbredt vilje til å løse konflikten.

Men det var også noen som var tapere i prosessen, eller som først og fremst følte seg overkjørt. Veitraseen man til slutt entes om, gikk gjennom områder som særlig hadde betydning for to grupper, bøndene og hytteeierne i området. Intervjuer foretatt i 2015 avdekket stor misnøye med prosessen fra disse hold (Viken \& Svensson 2015). Slik de så det, hadde det vært så viktig å oppnå enighet med reindrifta at alle andre hensyn ble skjøvet til side. Prosessen, slik de så det, hadde vært langt fra demokratisk. Kanskje illustrerer dette ytterligere viktigheten av avhengighet; koplingen mellom den gamle veikonflikten og skiresortutviklinga overskygget andre aspekter ved saken. 
Posisjonene og løsningene i denne prosessen ble utviklet gjennom dialoger. Flere av deltakerne brukte møtene og dialogene til å legge fram saker som ventet på løsninger. Faktisk, og særlig i veitilfellet, eksisterte det formelle rammer som blokkerte autentiske dialoger; formelle forhandlinger ført i et formelt (rettslig) språk og gjennom advokater og dokumenter. En slik ramme "... er måten folk ser et problem, situasjon og praksis på» (Innes \& Booher 2010, s. 124). Gjennom å rekontekstualisere, først og fremst gjennom å skape arenaer for autentiske dialoger, ble skiresorten realisert, og den gamle veikonflikten løst.

\section{Diskusjon}

Saken som presenteres i dette kapitlet, er et utmerket eksempel på ressursbasert gjensidig avhengighet, og betydningen av dialoger for å etablere et fruktbart forhandlingsklima mellom parter som tidligere hadde stått steilt mot hverandre. Utbygger var sterkt avhengig av andres landressurser (grunn) og av investorenes økonomiske midler. Bøndene ble invitert til å bruke sine landområder på nye måter, men var avhengige av at noen sto for organisering og utvikling. Kommunen var avhengig av ny næringsvirksomhet. Derfor omformet ordføreren langt på vei kommuneadministrasjonen til en tilrettelegger for skiresortprosjektet. Dette kan ses som en form for metastyring (Sørensen \& Torfing 2005) eller som ekstern nettverksstyring (Verdung 2006). Forsvaret hadde et sterkt behov for en løsning på konflikten om korridoren og veien mellom de to skytefeltene i området, mens kommunen mer eller mindre var avhengig av Forsvarets fortsatte tilstedeværelse. Den grunnleggende 'ressursen’ for reindriftsutøverne var deres bruksrett, men også de sterke juridiske rettighetene til beiteområdet. De kunne stoppe prosjektet, på samme måte som de hadde hindret byggingen av skytefeltveien. I sakskomplekset har vi altså identifisert en rekke avhengigheter til ressurser som andre kontrollerte, men også tilfeller av strategisk avhengighet (Hertting 2007). Utbyggeren var avhengig av kommunal velvillighet, sauebøndene fikk utkomme fra et landområde som ikke var veldig lønnsomt for dem, og kommunen reddet arbeidsplasser.

Gjennom diplomati - også utført rundt bål og i lavvuer - og anerkjennelse av avhengighet mellom aktørene kunne nye allianser bygges og konflikter løses. I skytefeltsaken opptrådte entreprenøren og ordføreren som mel- 
lommenn mellom partene. Deres tilnærming var ikke gjennom paragrafer, advokater og formelle møter, men dialoger. De oppsøkte reindriftsutøvere og omgikk dem som likeverdige forretningspartnere. Innes og Booher (2000, s. 5) kaller altså dette autentiske dialoger. Entreprenørens og ordførerens besøk ved reinflokken var symbolsk viktig; det signaliserte avhengighet av reindriftsutøverne og vilje til å lytte og forhandle på deres premisser. I dialoger er vilje til å inngå kompromisser sentralt. I gode dialoger, hevder Innes og Booher (2000, s.10), «kan aktører oppdage at de kan gjøre endring i sin atferd uten særlig kostnad eller betydning for dem, men til stor nytte for en annen aktør». Gjennom å modifisere veitraseen og korridoren ble den valgte løsningen akseptabel for både reindriftsutøverne og Forsvaret. Derfor kan man sannsynligvis si at denne saken ble forvandlet fra en interessekonflikt til en politisk og omsettelig utfordring. Men dette betyr ikke at løsningen var uten byrder; reindrifta har fătt redusert beitearealene med 126 kilometer $^{2}$ og en mer komplisert flytting vår og høst.

Casen er et også eksempel på håndtering av asymmetriske maktrelasjoner som følge av store forskjeller i hvilke ressurser partene bringer inn. I slike tilfeller er utjevningsmekanismer viktige (Hertting 2007). I en diskusjon av kollaborativ styring identifiserer Ansell og Gash (2008, s. 550) noen sentrale elementer i samarbeid om styringsprosesser. De tar også ressurs- og kunnskapsasymmetri som et «utgangspunkt» og viser til betydningen av dialoger ansikt-til-ansikt, tillitsbygging, forpliktelse til prosessen, felles forståelse av situasjonen og av mulige utfall, og av hva som gjensidig styrker partene. Dette er mer eller mindre hva vi har beskrevet i dette kapitlet.

Ansell og Gash (2008) anlegger i tillegg et kritisk syn på styringsprosessen som også er implisitt i det som kom fram i våre intervjuer. Det første Ansell og Gash nevner, er at mektige aktører kan manipulere prosessen. Dette har åpenbart funnet sted; hovedentreprenøren tråklet seg gjennom det politisk-administrative systemet ved hjelp av frekkhet, karisma, veltalenhet og kløkt. Målselvordføreren brukte sin posisjon til å få kommunen til å prioritere denne saken, noe som absolutt skapte forsinkelser på andre saksområder, for eksempel for regulering og boligspørsmål, eller i ordinær saksbehandling for kommunens innbyggere. Man kan også stille spørsmål ved fylkesmannens prioritering av denne saken, og om ordførerens uortodokse metoder for å få kontakt og legge press på reindriftsutøvernes advokat. Når det gjelder bøndene, var noen av dem først sterkt imot prosjektet, men de endret holdning i løpet av prosessen, og de endte opp med å få en ekstra inntekt og en løsning 
som ikke representerte problemer for gårdsdriften. Noen vil si at de ble «kjøpt»; både sauebønder og reineiere fikk betydelig økonomisk kompensasjon for å akseptere prosjektet. Et annet punkt i Ansell og Gashs kritiske analyse (2008) er at enkelte offentlige etater mangler engasjement. Det var etater i Målselv som hadde vært skeptiske, men de ble omvendt og overbevist i prosessen. Mistillit var også et problem i oppstartsperioden; grunneierne hadde ikke tillit til hverandre, og reindriftsutøverne var mistrodd både av kommunen og Forsvaret. Men de fant tonen i prosessen. Særlig viktig var trolig foreløpige oppsummeringer i prosessen, hvor interessentene ble enige om deler av den komplekse saken og innså at motpartene var forhandlingsvillige.

Ansell og Gash (2008) reiser også spørsmålet om maktforholdene i slike prosesser. Dette er også velkjent i reiselivsutviklingsprosjekter: «Makt styrer samspillet mellom enkeltpersoner, organisasjoner og etater som påvirker, eller prøver å påvirke, utformingen av reiselivspolitikken og måten den blir implementert på», sier Hall (1994, s. 52). Dette kan trolig også sies å karakterisere utviklingsprosessen i Målselv. En av reindriverne forteller om et møte med Forsvarsdepartementet som fant sted i lokalene til departementet, det vil si en arena som opplevdes som svært forskjellig fra hva de var vant til. I en lang sal var departementets representanter og advokater massivt plassert på den ene siden av bordet, og samtale avholdt $\mathrm{i}$ et helt og holdent formelt språk svært forskjellig fra det språket reindriftsutøverne normalt anvender, og i tillegg på norsk, ikke samisk (sjøl om det er pålegg om at man i Norge i møte med staten skal bli møtt på sitt eget målføre). Opplevelsen reindriftsutøverne hadde, var at måten forhandlingene ble avholdt på, var regissert for å skape avstand og over- og underdanighet. Disse beskrivelsene står i sterk kontrast til det bildet vi fikk av prosessen, som er beskrevet ovenfor, og som bidro til å løse konfliktene. Ifølge Jamal og Getz (1997, s. 567) «kan samarbeid overvinne maktforskjeller ved å involvere alle interessenter i en prosess som tilfredsstiller deres behov «. Eller kanskje mer riktig; i prosessen vi har beskrevet, var reindriftsutøvernes interesser, eller interessemotsetningene aldri dratt i tvil, men anerkjent som legitime. Sjøl om saken viser at samarbeid og dialog kan løse problemer, blant annet i en veisak, eksisterer det fortsatt interessekonflikter og motsetninger mellom partene. Som Innes og Booher ser det, kan imidlertid motsetninger ses på som «en viktig kilde til kreativitet som hindrer fastlåste situasjoner» (ibid., s. 104), og viktig «for fremtidig samarbeid og fremgang». 


\section{Konklusjon}

Dette kapitlet har vist hvordan en reiselivsutviklingsprosess ga en anledning til å løse andre problemer som i lang tid hadde skapt en fiendtlig atmosfære mellom reindrifta og Forsvaret. Et reiselivsprosjekt ga nye arenaer for dialog, nye former for kommunikasjon og en redefinering av statuser mellom lokale interessenter. Gjennom autentiske dialoger, tillit og gjensidighet ble en 30 års fastlåst konflikt løst. Saken viser og at en kommunikativ tilnærming kan være mer fruktbar, enn en juridisk. Den viser og hvor viktig kombinasjonen av profesjonalitet, entusiasme og bruk av kollaborativ rasjonalitet kan være. Planprofesjonalitet dreier seg blant annet om å utvikle modeller med likeverdige parter og vinn-vinn-situasjoner. Men det er også en sak som viser viktigheten av relasjonsbygging, refleksivitet og tillit. Prosesser som dette kan skape grunnlag for sjølstyre av lokalsamfunn. Prosessene bygger sosial, politisk og intellektuell kapital som kan brukes ikke bare for å løse det aktuelle problemet, men til problemløsning over tid (Innes \& Booher 2010: 7). Den generelle lærdommen fra dette er at refleksivitet og dialog lønner seg. I tillegg illustrerer casen at det i et nettverk av aktører, også finnes et nettverk av saker; at løsning av ett tilfelle kan avhenge av en løsning av et annet. Videre illustrerer saken at å anvende en interessent- eller stakeholdertilnærming sannsynligvis er mye mer fruktbart i denne typen saker, enn strengt å følge jussen på feltet. Til sist vil vi påpeke at det kan være noe å lære fra reiselivssektoren, det er en ganske gjennomsiktig og relasjonell næring; å bygge relasjoner gjennom å snakke og lytte til andre interessenter er en produktiv tilnærming for å få ting gjort og konflikter løst.

\section{Litteratur}

Agranoff, R. (1991). Human service integration; past and present challenges in public Administration. Public Administration Review, 51, 533-542. https://doi.org/10.2307/976604

Ansell, C. \& Gash, A. (2008). Collaborative governance in theory and practice. Journal of Public Administration Research and Theory, 18 (4), 543-571. https://doi.org/10.1093/jopart/mum032

Bramwell, B. \& Sharman, A. (1999). Collaboration in local tourism policymaking. Annals of Tourism Research, 26, 392-415. https://doi.org/10.1016/S01607383(98)00105-4 
Crozier, M. \& Friedberg, E. (1980). Actors and systems: The politics of collective action. Chicago: University of Chicago Press.

Dredge, D. (2006). Policy networks and the local organisation of tourism. Tourism Management, 27, 269-280. https://doi.org/10.1016/j.tourman.2004.10.003

Dredge, D. \& Pforr, C. (2008). Policy networks and tourism governance. I N. Scott, R. Baggio \& C. Cooper (red.), Network analysis and tourism: from theory to practice. Clevedon: Channel View Publications. https://doi.org/10.21832/9781845410896-008

Flagestad, A. \& Hope, C. A. (2001). Strategic success in winter sports destinations: a sustainable value creation perspective. Tourism Management, 22, 445-461. https:// doi.org/10.1016/S0261-5177(01)00010-3

Freeman, R. E. (2006). A stakeholder approach to strategic management. Working paper. No. 01-02. Darden graduate school of business administration. University of Virginia.

Haavet, K. M. (2009). Skytefelt til besvar. En analyse av forhandlingsprosessen i forbindelse med sammenslaingen av Mauken-Blätind. Masteroppgave. Institutt for planlegging og lokalsamfunnsforskning. Universitet i Tromsø.

Hall, C. M. (1994). Tourism and politics: Policy, power and place. Chichester: Wiley. Haugland, S. A., Ness, H., Grønseth, B.-O. \& Aarstad, J. (2011). Development of tourism destinations. An integreated multilevel perspective. Annals of Tourism Research, 38, 268-290. https://doi.org/10.1016/j.annals.2010.08.008

Hertting, N. (2007). Mechanisms of governance network formation - a contextual rational perspective. I E. Sørensen \& J. Torfing (red.), Theories of democratic network governance. Houndsmills: Palgrave Macmillan. https://doi.org/10.1057/9780230625006_3

Hillier, J. (2002). Shadows of power. An allegory of prudence in land-use planning. London: Routledge. https://doi.org/10.4324/9780203167298

Innes, J. E. \& Booher, D. E. (2000). Public participation in planning; new strategies for the $21^{\text {st }}$ century. Paper for the annual conference of the Association of Collegitae Schools of Planning, Nov. 2-5. https://doi.org/10.1080/1464935042000293170

Innes, J. E. \& Booher, D. E. (2003). Collaborative policymaking: governance through dialogue. I M. J. Hajer \& H. Wagenaar (red.), Deliberative policy analyses. Cambridge: Cambridge University Press. https://doi.org/10.1017/CBO9780511490934.003

Innes, J. E. \& Booher, D. E. (2010). Planning with complexity: An introduction to collaborative rationality for public policy. New York: Routledge.

https://doi.org/10.4324/9780203864302

Innes, J.E., Gruber, J., Neuman, M. \& Thompson, R. (1994). Coordinating growth and environmental management through consensus building. Policy Research Program Report. California Policy Seminar. Berkeley: University of California. 
Jamal, T. B. \& Getz, D. (1997). «Visioning» for sustainable tourism development: Community-based collaborations. I P. E. Murphy (red.), Quality management in urban tourism (s. 199-220). Chichester: Wiley.

Kickert, W., Klijn, H.E. \& Koppenjan, J. (red.) (2007). Managing complex networks. Strategies for the public sector. London: Sage Publications.

Koppenjahn, J. \& Klinj, H. E. (2004). Managing uncertainties in networks. London: Routledge. https://doi.org/10.4324/9780203643457

Nordin, S. \& Svensson, B. (2007). Innovative destination governance. Entrepreneurship and Innovation, 8, 53-66. https://doi.org/10.5367/000000007780007416

O'Toole, L. J. (1995). Rational choice and policy implementation: Implications for interorganizational network management. American Review of Public Administration, 25, 43-57. https://doi.org/10.1177/027507409502500103

Rhodes, R. (1986). The national world of local government. London: Allen and Unwin.

Rhodes, R. (1997). Understanding governance: Policy networks, governance, reflexivity and accountability. Buckingham: Open University Press.

Ruhanen, L., Scott, N., Ritchie, B. \& Tkaczynski, A. (2010). Governance; a review synthesis of the literature. Tourism Review, 65, 4-16.

https://doi.org/10.1108/16605371011093836

Røiseland, A. \& Vabo, S. I. (2012). Styring og samstyring - governance på norkk. Oslo: Fagbokforlaget.

Scharpf, F. W. (1978). Interorganizational policy studies: Issues, concepts and perspectives. I K. I. Hanf \& F. W. Scharpf (red.), Interorganizational Policy Making: Limits to Coordination and Central Control. London: Sage.

Schmitter, P. (2002). Participation in Governance arrangements: Is there a reason to expect it will achieve sustainable and innovative policies in a multi-level context? I J. R. Grote \& B. Gbikpi (red.), Participatory Governance (s. 51-69). Opladen: Leske-Budrich. https://doi.org/10.1007/978-3-663-11003-3_3

Sørensen, E. \& Torfing, J. (2005). Netvarksstyring: fra government til governance. Frederiksberg: Roskilde Universitetsforlag.

Vedung, E. (2006). Konsten att utvärdera nätverk [The Art of Evaluating Networks]. Helsinki: Stakes.

Viken, A. (2014). Ski resort development; Scripts and phronesis. I A. Viken \& B. Granås (red.), Destination Development in Tourism: Turns and Tactics. Farnham: Ashgate.

Viken, A. \& Svensson, G. (2015). Mauken og Blätind skyte- og øvingsfelt: Etablering av sammenbindingskorridor og utvidelse av Blatind skytefelt. Tematisk etterproving friluftsliv og hytter. Norut-rapport 24. Tromsø: Norut. 



\section{DEL IV: NATURBASERT TURISME - FORVALTNINGSUTFORDRINGER}





\section{DET USTYRLIGE FRILUFTSLIVET? ${ }^{11}$}

Arvid Viken, Rune Benonissen og Gaute Svensson

\section{Innledning}

Regjeringen la i 2017 fram en ny reiselivsmelding som dokumenterer at norsk reiseliv er i vekst. Det gjelder også turismen som foregår i naturen, og det gjelder i Nord-Norge, som øynene rettes mot i dette kapitlet. Veksten finner ikke sted uten å sette spor, sjøl om miljøproblemene som følger, ikke er ansett som store. Internasjonalt har Norge et godt omdømme som miljønasjon, og det forplikter. Det forventes at vi skal ivareta det som utgjør landsdelens attraksjonskraft - en natur som framstår som relativt uberørt. Men naturen er under press. I Lofoten og på Senja er det tiltagende problemer, om en skal tro rapporter i ymse medier. Også i Tromsø har slitasje på naturen blitt gjenstand for debatt.

Utfordringene knyttes til at flere mennesker bruker naturen. Det er flere som driver friluftsliv, og det er flere turister. Blant de konsekvensene dette har for naturen, er for det første slitasje, det rapporteres om breiere stier og økt erosjon, og nedtråkking av kulturminner som tufter, gravplasser, gamle bygninger og så videre, samt forstyrrelser av dyrelivet. En side ved denne problematikken er å bestemme hva som er tålegrensen, eller terskelverdiene. Gjennom overvåking kan man beskrive tilstanden og endringer i naturen, men det er ofte vanskelig å si om det som observeres,

11 Kapitlet er en omarbeiding av en rapport kalt «Besøksforvaltning - tilrettelegging og regulering av friluftsliv og naturbasert turisme» av samme forfattere (2018). 
er et problem, eller når det måtte bli det. På sett og vis er det et holdningsbasert eller politisk spørsmål. Det er derimot enighet om at naturen og bruken av den bør overvåkes. For det andre vil det til tider bli store opphopninger av mennesker på enkelte steder. Det er svært individuelt hvordan dette oppleves, og det er en lite målbar effekt. Opplevelsen av for mange mennesker er særlig aktuelt i forbindelse med nordlysturismen, hvor det hevdes å være vanskelig å finne steder å parkere langs veien, uten at det er mange andre der samtidig. Nordlysturister i kø er ingen idealsituasjon. For det tredje fører økt tilstrømming utenfra et endret bruksmønster også i lokalbefolkningen. Turismen påvirker hvordan man lokalt ser på naturen, og hvordan den brukes, for eksempel er det et økende antall lokale toppturskigåere. Det fjerde problemet er knyttet til risiko. Det finnes stadig flere aktuelle aktiviteter som er forbundet med risiko, og utfartsmål som det er forbundet med risiko å besøke. Dette er sjølsagt også et spørsmål om erfaring og kompetanse. Manglende kunnskap om turgåing og mangelfull utrustning førte for få år siden til diverse redningsaksjoner blant vandrere til Trolltunga i Hardanger. For det femte er det en utfordring at nye brukergrupper ser andre verdier i naturen, enn de tradisjonelle. Derfor kan det være interessekonflikter både internt i friluftslivs- og turismefeltet, og i forholdet mellom disse feltene og andre bruksområder. Et eksempel på dette er konflikter mellom turisme og verneinteresser, og mellom turisme og reindrift. Til sist skal nevnes at det er en del misnøye med, og debatt om hvordan naturen bør forvaltes. Utfordringene påpekes i mediene, og politikere presses til raske og ugjennomtenkte svar. Det er altså behov for grundige analyser og diskusjoner av hva problemene eller utfordringene består av, og hvem sitt ansvar det er?

I dette kapitlet peker vi først på utviklinga fra friluftsliv til naturbasert turisme, dernest presenteres noen overordnede begreper knyttet til styring, og besøksforvaltning defineres. I et eget avsnitt presenteres en undersøkelse som ligger til grunn for denne teksten. De empiriske delene består av en presentasjon av forvaltningssystemet, en presentasjon av de viktigste og gjennomgående problemene, en diskusjon av forholdet mellom Tromsø og omlandet, og en om hvordan allemannsretten er utfordret. Til sist presenteres kort tilstanden i Lofoten, til sammenlikning, før kapitlet avsluttes med en drøfting. 


\section{Fra friluftsliv til turisme}

Friluftslivet her til lands er solid forankret i norsk kultur - noen har hevdet at det er norsk kultur. Nordmenn går mye på tur, og nå mer enn noen gang, sies det. Friluftslivet er imidlertid først og fremst et moderne og urbant fenomen, knyttet til folks behov for frisk luft og aktivitet. ${ }^{12}$ I vår tid er helsemyndighetene en av de sterkeste pådriverne, for eksempel med tiltak som «Fysak» og «Ti på topp». Dette ser ut til å gi resultater. Det kryr av mennesker langs løyper og på topper. Nordmenn synes å gå mer på tur enn noensinne, mellom 90 og 95 prosent av befolkningen sier at de i løpet av et år utøver friluftsliv (https://www.miljostatus.no/ finn-tallene). Alle våre naturperler og naturområder tiltrekker også folk fra andre land. Den naturbaserte turismen er i vekst. Følgelig er det flere og flere som gjør det til næring å tilrettelegge for og å ledsage turister ut i norsk natur. Dette er ikke nytt, fjellguiding var også vanlig på slutten av 1800-tallet en rekke steder. Men det er blitt flere som tilbyr dette, og en mer variert næring. Det tilbys organiserte turer, transport, transport av bagasje, utstyrsleie og så videre. Og man tar seg betalt for det. Det innebærer også en vridning i verdigrunnlaget for aktivitetene i norsk natur. Friluftsliv og naturbasert turisme har fått større kommersiell verdi.

Verdigrunnlaget i det tradisjonelle norske friluftslivet er frihet, uberørt natur og en sunn sjel i et sunt legeme. Som vi beskrev i kapittel 2, har friluftslivet både bakgrunn i byfolks søken til land og fjell og i høstingstradisjoner. Mange bruker friluftslivsbegrepet svært vidt og innlemmer også motorisert ferdsel i utmark og på havet og andre teknologibaserte aktiviteter i begrepet, en betraktningsmåte som ligger opptil det som i amerikansk sammenheng omtales som outdoor recreation (Ingulfsvann 2013). Der finnes altså ingen omforent eller autoritativ avgrensning av fenomenet «friluftsliv».

Når turer i naturen er noe som man kan kjøpe, eller som styres politisk, skjer det noe med friluftslivets karakter. Dets verdigrunnlag utfordres og endres. Når man innfører Ti-på-topp-konseptet som turstimulans, slik man har gjort mange steder, innfører man et konkurranseelement. Det er snakk om antall turer, antall høydemeter, kartsystemer, dataregistrering

12 For en gjennomgang av grunnlaget for og varianter av norsk friluftsliv, se for eksempel Pedersen (1999) eller Ingulfsvann (2013). 
av bestigelser, premiering og liknende. Dette er tiltak som har vist seg å virke, det er tusenvis som bestiger fjellene. Men tilstrømmingen gjør noe med naturen; den er ikke lenger like uberørt (om den noen gang har vært det), og den konstrueres og rekonstrueres sosialt. Fortellingene fra turene er ikke bare om indre opplevelser og slit, men også om å ta de beste bildene, selfiene og nakenbildene fra toppene, og ikke minst om numeriske forhold som antall skritt og meter. Opplevelsen er blitt mer mangfoldig, om man vil. Verdigrunnlaget for friluftslivet er altså i endring, mange gjør ikke turene utelukkende for naturopplevelsens eller velværets skyld. På liknende vis endrer også turismen verdigrunnlaget. For gjesten er fortsatt det å oppleve naturen viktigst, men vurderinger av om opplegget svarer til forventningene og kostnadene, blir stadig mer sentrale. Altså er det en tendens til at friluftslivet blir gjenstand for en økonomisk verdisetting - det er blitt til en vare i et marked. Og med et stort inntog av turister har norske myndigheter fått noen nye utfordringer.

Grunnlaget for vårt friluftsliv har lange tradisjoner, men er også nedfelt i friluftsloven fra 1957. Lova stadfester allmennhetens rett til fri tilgang til utmarksområder. Denne allemannsretten ble etablert i en tid da folk flest gikk turer i områdene der de bodde, og ikke andre steder. Og i særdeleshet var ikke prinsippet tiltenkt en situasjon hvor all verdens mennesker har fri adgang til de fleste steder. I den moderne verdenen er det en slags universell rettighet å reise og oppholde seg der en ønsker. Sjøl om bare noen realiserer denne muligheten, er det langt flere som ferdes i norske naturområder, enn den gangen prinsippet om fri adgang ble etablert.

\section{Styring og forvaltning av turismens naturbruk}

I innledningen over antyder vi at det både kan være behov for politiske beslutninger og en mer aktiv forvaltning av relasjonen mellom friluftsliv og naturbasert turisme og naturen. Sagt på en annen måte er det behov både for styring og ledelse av denne relasjonen. Styring, eller governans, er ikke bare for en overordnet myndighet å ta noen beslutninger, som så settes ut i livet. I dagens samfunn er det store forventninger om at de som styres, skal ha et ord med i laget, og derfor involverer en rekke aktører (Sørensen \& Torfing 2009). Det er rom for både tradisjonell 
hierarkisk styring, sjølstyring og samstyring (Koiman 2003). Implisitt i dette ligger det at styring ofte er basert på forhandlinger mellom ulike aktører, og at man søker kompromisser dem imellom (Holmgren, Sandström \& Zachrisson 2017). Slike prosesser finner sted på flere nivåer, både nasjonalt, regionalt og lokalt, og gjelder både for prosesser der politikk - styringen - utformes, og for prosesser hvor politiske beslutninger iverksettes. Det er disse prosessene vi ofte kaller forvaltning. Når både styringen og forvaltningen utøves i dialog med de berørte partene, vil det bli vanskeligere å få igjennom endringer i politikken, og forvaltningen har til tider blir kritisert for å ha for stor makt i forhold til politikerne. Vår tids forvaltning er preget av det som kalles new public management, hvor fokus er mer på effektivitet enn på politisk innhold, blir det hevdet. Det er også et system hvor forvaltningen ofte drives etter bedriftsøkonomiske idealer, og hvor kommersielle aktører får stor betydning. Derfor hevder Nunkoo (2017) i en diskusjon av styring av reiselivet at « $\ldots$ gode governans-prinsipper må anerkjenne rollen til ikke-markedsbaserte krefter, slik som lokalsamfunn og det sivile samfunnet» (ibid., s. 277). Det ligger i dette at man på mange områder ikke kan forvente å finne entydige politiske mål for en sektor, og at myndighetene på et område ofte er stykket opp eller fragmentert. Det er mange som skal mene og ta del i styringen. Dermed blir kanskje de viktigste styringsimpulsene å finne på et relativt generelt nivå. I forbindelse med friluftsliv og naturbasert reiseliv blir dette verdier som tilgang til utmark, altså allemannsretten, friheten til å utøve aktiviteter og bærekraftig utvikling.

Styring og forvaltning er basert på en eller annen form for kunnskap. Med mange aktører involvert varierer også kunnskapsgrunnlaget. Det er ikke bare naturvitenskaplige målinger som kan legges til grunn (Nyseth \& Viken 2015), også kunnskapsgrunnlaget er gjenstand for forhandlinger. Det må ikke bare være gyldig, men også samfunnsmessig robust. Altså er et forvaltningsregime avhengig av legitimitet og tillit. «Tillit fremmer samarbeid og letter sosial interaksjon», sier Nunkoo (2017), uten tillit er det vanskelig å skape samfunnsmessig orden (Putnam 2000) eller å få til velfungerende regimer. Studier tyder på at tillit, og det vi kaller samfunnsmessig aksept, har vært et neglisjert område i reiselivet (Nunkoo 2017). Når grunnlaget for ens næringsaktiviteter er fellesgoder, blir dette viktig, og kanskje ligger det utfordringer i å utvikle systemer for å håndtere slike relasjoner både for friluftslivssektoren og reiselivet. 
Det ligger i resonnementene over at den hierarkiske styringa og det vi tradisjonelt har kalt regulering, må skje på andre måter enn tidligere. Det er ikke nok med fysisk tilrettelegging, regler og skilter som orienterer om forbud og påbud. Trenden er en overgang fra slike harde styringsmodeller til mykere former (Keskitalo, Juhola, Baron, Fyhn \& Klein 2016), som informasjon, kunnskapsformidling og utvikling av retningslinjer hvor styringselementet er mer implisitt. Tradisjonelt har normer for naturatferd vært de viktigste reguleringsmekanisme i Norge. Vi har en sterk friluftslivskultur. Men den er ikke kjent i utlandet, så jo flere turister, jo mer er det behov for eksplisitt informasjon og formell regulering. Mange vet ikke hvordan de skal kle eller sko seg for lange fjellturer, de har verken nødvendig utstyr eller kompetanse, ei heller innsikt i hva som er lovlig og ulovlig atferd. Folk må informeres og opplyses. Det fremste eksemplet på dette behovet er nevnte Trolltunga, hvor det i 2016 var nærmere 100 redningsaksjoner av slike grunner. Ved å lage en vei som alternativ til en bratt trapp opp og ned fra dalen, tilrettelegge stier, bedre skilting - blant annet som forteller at en bør snu dersom man ikke har nådd et visst punkt før klokka 13 - og ved å ha utplasserte veiledere langs løypa, har antall redningsaksjoner fra og med 2017 sunket betraktelig. Hvordan man skal unngå at folk forulykkes, hva slags beredskap for redning man skal ha, og hvem skal betale for det, er aktuelle temaer. Alt dette inngår i det vi kaller besøksledelse eller besøksforvaltning.

\section{Besøksforvaltning, besøksledelse}

Besøksforvaltning kalles «visitor management» på engelsk. Som fagfelt er det knyttet til forvaltning av verneområder eller områder for rekreasjon og friluftsliv. ${ }^{13}$ Besøksforvaltning omfatter den delen av den helhetlige forvaltningen som grovt sett handler om å forhindre eller redusere negativ påvirkning av besøk og optimalisere opplevelsen for de besøkende. Sjøl et lite besøkstall kan gi negative effekter på naturverdier. På den andre siden er det også som regel positive effekter som ønskes optimalisert gjennom slik forvaltning (lokal økonomi, sosiale effekter mv.) (Eagles, McCool, Haynes 2002). Definisjon av «besøk» og «besøkende» vil mest sannsynlig

13 Det finnes en alternativ måte å oppfatte begrepet på, som å tilrettelegge for den besøkende (se Hansen \& Lykkja 2018; Perace 2017). 
være noe ulikt alt etter hvilket område man tar utgangspunkt i. Parks Canada, det øverste styringsorganet for verneområder i Canada, definerer besøkende som "personer som trer inn i et verneområde for rekreasjon, undervisning eller kulturutøvelse» (Hyslop \& Eagles 2007). Dette omfatter også lokalbefolkningen, hvilket også er en fornuftig avgrensning også i Norge, besøksforvaltning omfatter i utgangspunktet alle brukere.

Besøksforvaltning består av svært mange temaer og innfallsvinkler som har forskningsmessig relevans. Friluftsforskning, turismeforskning, økologi/biologi, teknologi, planlegging og politikk/styringssystemer er bare noen av de fagområdene som tangerer besøksforvaltning. Et nærmere inntrykk av de aktuelle forskningstemaene får man gjennom den internasjonale konferansen "Monitoring and management of visitors in recreational and protected areas» (MMV) som har vært arrangert annethvert år siden 2002. To av konferansene, avholdt i Stockholm i 2012 og i Tallinn i 2014, omfattet mer enn 268 muntlige presentasjoner i tillegg til posterpresentasjoner (Fredman et al. 2012; Reimann et al. 2014). Temaene går fram av figur 12.1.

Figur 12.1: Ulike forskningstemaer innen besøksforvaltning.

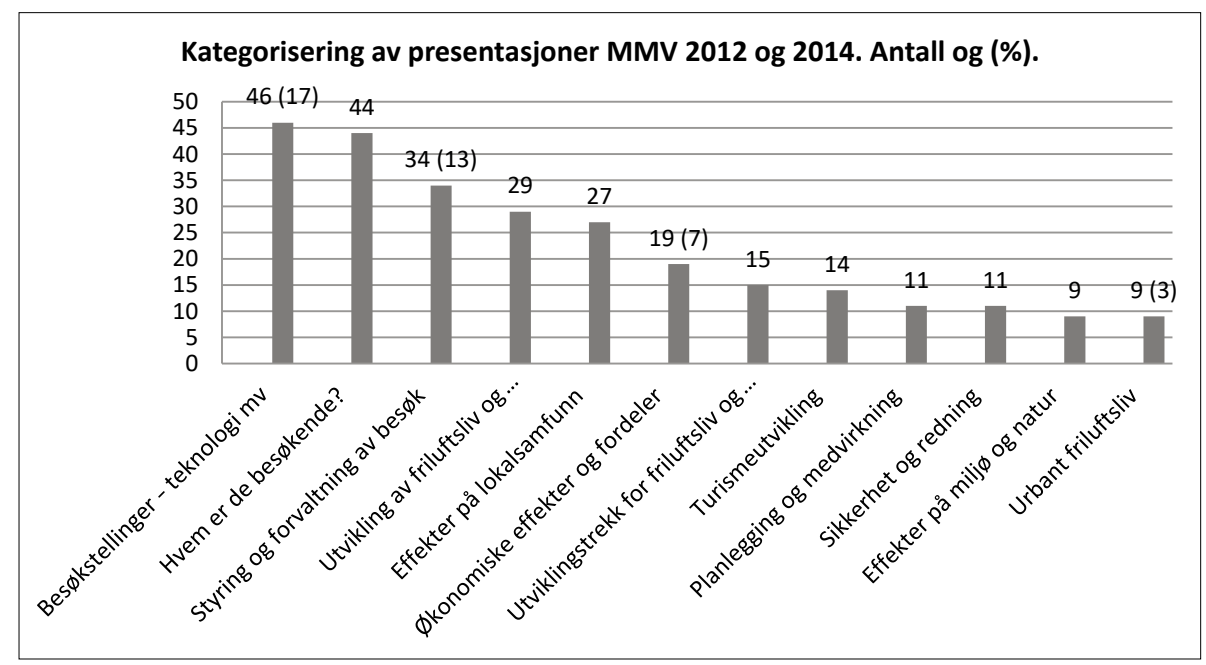

Kilde Monitoring and management of visitors in recreational and protected areas, 2012 og 2014. 
Figur 12.1 viser relativt sett at det finnes flest arbeider knyttet til «besøkstellinger», herunder teknologi, systemer, nytte og praktisk bruk, men det utgjør bare vel 17 prosent av det totale antallet. Videre er kunnskapsinnhenting rundt «hvem de besøkende er» godt representert i de arbeidene som er presentert fra 2012 og 2014. Her er kartlegging av atferd, verdier, preferanser, motivasjon, holdninger og erfaringer ved brukerne eller besøkende. «Styring og forvaltning av besøk» dreier seg om praktisk forvaltning og styring av de besøkendes påvirkning, mens «utvikling av friluftsliv og rekreasjon» omfatter andre aspekter som helse, barn og unge, læring mv. «Effekter av turisme og rekreasjon på lokalsamfunn» og "økonomiske effekter og fordeler» utgjør hver om lag ti prosent. Noe overraskende utgjør «planlegging og medvirkning» og «effekter/påvirkning av friluftsliv og rekreasjon på natur og miljø» bare noen få prosent av det totale antallet presentasjoner i 2012 og 2014. Dette er et paradoks, i hvert fall i norsk sammenheng, hvor "heldekkende» kunnskap om naturgrunnlaget og sårbarhet sies å være nødvendig for å drive god besøksforvaltning. Systemet Natur i Norge (NiN) er skapt av slike hensyn, det skal "danne et godt kunnskapsgrunnlag for forvaltning av naturmangfold» (brev til fylkesmenn datert 05.05.2015).

Besøksforvaltning er et begrep som for alvor har kommet inn som en del av den norske naturforvaltningen etter 2012, og myndighetene har tatt initiativ til ulike tiltak og programmer, for eksempel «Bærekraftig besøksforvaltning», hvor friluftsråd og organisasjoner kan søke støtte til stier, doer og liknende i tilknytning til populære naturområder. Men behovene for slik forvaltning er trolig mange steder vel så store utenom verneområdene.

En bedre utviklet og klarere besøksforvaltning er i reiselivets interesse. Men det er også et politisk ansvar. Derfor bør strategier og tiltak innen besøksforvaltningen utvikles i samarbeid mellom næringsaktører, kommuner, fylkeskommuner og fylkesmenn. Et problem i denne sammenhengen er at kommunene ikke tar et ansvar. Friluftsliv er blitt et kommunalt anliggende, men turisme er det ikke. Det anses for å være privat næringsvirksomhet. Naturen er fritt tilgjengelig, ikke bare for folk flest, men også for turoperatører og aktivitetsbedrifter. Det er ingen krav om beskatning av grunnrenta, svært varierende tilrettelegging, svært varierende rettledning, som nettsteder, retningslinjer og liknende. Det er behov for et forvaltningsapparat for å håndtere de utfordringene man er vant med, og de uforutsette problemene næringsaktivitet som regel medfører. 


\section{En undersøkelse av styring og forvaltning av friluftsliv og naturbasert turisme}

Etter samtaler med fylkesmyndighetene i Troms, ${ }^{14}$ formulerte vi en problemstilling som stilte spørsmål om hva folk i feltet oppfatter med begrepet besøksforvaltning, og hvilke arbeidsoppgaver de så for seg i dette feltet, og hvem de mente bør utføre dem? Vi plukket ut sentrale aktører i Troms og intervjuet cirka 30 av dem, enten i grupper eller individuelt. Vi valgte ut fire områder: Senja, indre Troms, Nord-Troms og Tromsø. I tillegg brukte vi Vest-Lofoten som en kontrollcase, for å sette egen region i perspektiv. De intervjuede representerte institusjoner og organisasjoner som er sentrale i arbeid med friluftsliv og turisme. I noen grad ble også folk vi ble tipset om underveis, intervjuet, særlig mennesker som hadde hatt karrierer som ildsjeler eller tillitsvalgte.

Metodologisk er undersøkelsen relativt tradisjonell. Vi valgte en kvalitativ tilnærming fordi vi ønsket å få brettet ut feltet, altså få oversikt over de viktigste problemene og problemstillingene. Undersøkelsene har derfor hatt et sterkere fokus på hva som er de viktige og riktige spørsmålene, enn på svarene. Men samtalene dreide seg en hel del om hva som må gjøres, og disse er inkludert i analysen. Med en kvalitativ tilnærming har vi ikke data som gjør det mulig å presentere vekting av de ulike temaene. Men når noen av temaene går igjen blant nesten alle informantene, så er det en pekepinn på at de er svært sentrale. Og slike temaer finnes i materialet.

\section{Forvaltningssystemet for friluftsliv og turisme}

Myndighetene har satset en del på å aktivisere folk - få folk ut på tur - og har derfor også etablert et forvaltningssystem for dette. Sentralt i dette systemet står både kommunene og de såkalte friluftsrådene. Friluftsrådene eies av kommunene eller av et regionråd. De har en til to ansatte, men i tillegg gjerne flere prosjektstillinger. Ansvarsfordelingen mellom de to hovedaktørene er ofte uklar. Det er rom for forskjellige løsninger. Friluftsrådene planlegger og utvikler tiltak for å øke eller forbedre tilretteleggingen for friluftsliv - følger med, søker penger og organiserer samarbeid, men har som regel ingen tilsatte «gjørere». Den praktiske tilrettelegginga faller derfor på kommunene eller et system av frivillige. De frivillige rekrutteres

14 Kapitlet er basert på en undersøkelse finansiert av Troms fylkeskommune. 
gjennom lokale lag og foreninger, eller lokale bekjentskaper. Ofte finnes ildsjeler som er vant til å ta et tak for bygda si. Noen ganger er de som organiserer de frivillige, ansatt eller engasjert av friluftsrådene, andre ganger er dette også ivaretatt av frivillige. Stivakter brukes svært mange steder, det er mennesker som ser til merking av stier, og som forvalter kodebrikkene som må på plass på fjelltoppene for Ti på topp-registreringen. Lokale bygdelag har noen steder også påtatt seg arbeidet med å sette ut og drifte toaletter. Dette fungerer mange steder svært godt, men for eksempel ikke sentralt i Tromsø. Dermed får kommunen en mer aktiv rolle.

Friluftsrådene har ingen formelle roller med hensyn til turismen, men erkjenner at når de tilrettelegger for lokalbefolkningen, vil tiltakene ofte også bli benyttet av tilreisende. Slik systemet er i dag, og med allemannsretten som rettsramme, er det vanskelig å ekskludere tilreisende. Heri ligger noen utfordringer. Særlig gjelder det frivilligheten. Systemet fungerer godt så lenge man betjener sambygdinger. Når det blir mange utenfra, synker motivasjonen, og særlig når kommersielle turoperatører tar stiene i bruk. Da er situasjonen den at ubetalte frivillige legger til rette for at noen skal tjene penger. Dette er et kjent fenomen; dugnad fungerer ikke dersom det viser seg at noen (utenfra) tjener penger på det som gjøres (Barth 1981; se kapittel 5 i denne boka). Dersom frivillighetssystemet bryter sammen, må noen andre ta over. Som regel betyr det myndighetene, eller en organisasjon som har som oppgave å tilrettelegge. Den Norske Turistforening (DNT) er en slik organisasjon, en organisasjon som både er basert på frivillighet og profesjonalitet. Man har imidlertid et godt eksempel på hvordan frivilligheten har mistet fotfeste i en annen sektor. For noen år siden innførte man en ny struktur i museumssektoren, som til da hadde hatt mange museumslag og frivillige i driften av kulturminner og lokale samlinger. Alle museene inngikk i en ny organisasjon, med en regional og profesjonell organisering, mange steder med bortfall av de frivillige, sies det. En konsekvens av dette er at det er mye som står til forfall, da de nye regimet ikke har kapasitet til å ivareta alt.

Friluftsrådene fungerer altså som bindeledd mellom utøverne av friluftslivet, folk flest og myndighetene. Også DNT er basert på frivillighet, og trolig modell for friluftsrådene, men er ikke en del av myndighetsapparatet. Til sammen utgjør disse organisasjonene et system som uten store kostnader rår over en ganske stor arbeidsstokk, som gjør at friluftslivet framstår som godt tilrettelagt. Men systemet er altså truet av turismen, 
kanskje også av ideer om profesjonalisering. Slik det er i dag, synes det å være et velfungerende system, som også er innovativt.

I tillegg til dette finnes det også flere styrings- og kontrollorganer for naturen og for verneområdene. Statens naturoppsyn overvåker tilstanden i naturen, og har også en viss politimyndighet overfor brukerne. Det samme gjelder Fjelltjenesten til Statskog, som er den største eieren av utmarksområder i Troms. I tilfelle av grov uaktsomhet rapporterer disse instansene til politiet, som vurderer sakene. Når det gjelder nasjonalparker, landskapsvernområder og naturreservater, har man fra 2010 hatt et system med regionalt oppnevnte vernestyrer og tilhørende sekretariater, i Troms i alt fem slike. Organiseringa har til hensikt å dra lokalsamfunnene inn i forvaltningen. Styrene skal fremme tiltak som både ivaretar vern, lokal bruk og naturbasert turisme. Formelt er sekretariatene underlagt fylkesmannen, som en overordnet miljøvernmyndighet i fylkene.

Det er altså flere instanser som har som oppgave å ha oppsyn med naturområdene. Og oppgavene er mange. Hyslop og Eagles (2007) opererer man med en liste med 30 temaer og arbeidsoppgaver for dem som driver planlegging av besøksforvaltning. Lista rommer målarbeid, planlegging, sonering, regulering, konflikthåndtering, fysisk tilrettelegging, betalingssystemer, produktutvikling og handel, informasjonsarbeid og markedsføring, kvalitetssikring, monitorering, analyse og forvaltningsbeslutninger. I Norge er det altså flere instanser som ivaretar oppgaven. Dagens forvaltningssystem er derfor relativt komplekst og uoversiktlig, og det er behov for koordinering, eller i det minste for samsnakking. Først og fremst kan det kanskje være behov for større gjennomsiktighet. Dette kan man løse gjennom fylkes- eller regionbasert informasjonsutveksling, kanskje også gjennom at man lager egnede fora for samsnakking både på nett og gjennom møter.

\section{Hva er problemet, og er det et problem?}

I hovedsak er det ikke store problemer i naturen som kan knyttes til friluftsliv og turisme i Troms. Det er en natur preget av bruk, men lite preget av misbruk. Men det kommer sjølsagt an på øynene som ser, det er mange spor etter menneskelig aktivitet, nær sagt overalt, og det moderne friluftslivet og turismen har gitt noen nye utfordringer. Det er mer bruk at teknologiske hjelpemidler, utstyret er blitt lettere, og langt flere bruker naturen 
enn tidligere, sies det. I alle fall noen steder. Det synes å tre fram bestemte steder og områder som har mer besøk, større belastning og større behov for forvaltning, enn andre. Dette gjelder særlig noen steder på Senja, i Lyngen, rundt Tromsø og i Lofoten. Mange av disse utfordringene må imøtekommes med stedsspesifikke tiltak. Dette er et arbeid som synes være startet, men som kanskje går for sakte, på grunn av manglende avklaringer av forvaltningsansvar. Det er i alle fall behov for samsnakking mellom friluftsrådene, destinasjonsselskapene, kommunene og fylkesmyndighetene.

Felles for alle stedene hvor vi har gjort intervjuer, er behov for parkeringsplasser, søppelsystemer og doer. Hvem sitt problem det er, kan diskuteres, og må diskuteres, det løser seg ikke sjøl. Å tilrettelegge for friluftsliv er kanskje myndighetenes oppgave, de oppfordrer folk til å komme seg ut, både av helsemessige og andre grunner. Og da oppstår det et tilretteleggingsbehov. DNT jobber også for at flere skal kunne ta seg ut i naturen, og gjør det primært gjennom tilrettelegging. Reiselivet er den mest pågående aktørgruppen når det gjelder å rekruttere utlendinger til vår natur, og gjør det vanligvis uten å tilrettelegge for det. Næringa anser fellesskapets infrastruktur også å være til avbenyttelse for kommersiell virksomhet. Det er delte meninger om dette. Noen vil mene at friluftsfolket og turistene bør betale for det, og da må man finne fram til ordninger som muliggjør det, for eksempel betalingsdoer eller bomstasjoner ved innfallsportene til mye brukte områder og stier. En del av problemene er knyttet til allmennhetens frie tilgang til vår natur, altså til allemannsretten.

Det er få konflikttema i det feltet vi har studert, men det er noen spenninger knyttet til verdigrunnlaget for forvaltningen. Dette gjelder særlig tre konflikttemaer, og det ene dreier seg om vern versus bruk. Noen aktører oppfatter fylkesmannsembetet som relativt rigid i spørsmål om vern. Vern går foran alle andre hensyn, også når det ikke er påvist negative effekter av bruk, sies det. For eksempel gjelder dette bruk av snøskuter i forbindelse med turlagenes tilrettelegging av hytter og stier. Myndighetene mener, sies det, at det skal brukes hundespann i stedet for snøskuter. Liten fleksibilitet er anklagen. Den andre konfliktlinjen bunner i dagens relativt sterke fokus på kommersialisering, som flere hevder bryter med de grunnleggende verdiene i friluftslivet. Skal alt måles i penger, vil fokus lett bli endret. Dette er ikke en ønsket utvikling, slik altså flere av våre informanter ser det. Et tredje spenningsfelt er knyttet til allemannsretten. Den er utfordret av det moderne friluftslivet og turismen, og meningene er mange. 


\section{Utfordringer knyttet til Tromsø og omland}

\section{Tromsø}

Tromsø har hatt en betydelig økt turisttilstrømming de seinere åra. Det har vært en stor økning uansett hvordan det måles, i antall virksomheter, sysselsetting og omsetning. Fra 2007 til 2016 hadde antall hotellbedrifter $ø$ kt fra 30 til 38, mens det nesten fant sted en fordobling av både av antall ansatte i hotellnæringa og i omsetninga. Turismen er åpenbart en næring i vekst.

Tabell 12.1: Hotellnæringa i Tromsø i perioden 2007-2016.

\begin{tabular}{|l|r|r|r|r|r|r|r|r|r|r|}
\hline År & 2007 & 2008 & 2009 & 2010 & 2011 & 2012 & 2013 & 2014 & 2015 & 2016 \\
\hline Foretak & 30 & 28 & 27 & 28 & 30 & 29 & 31 & 32 & 36 & 38 \\
\hline Sysselsatte & 557 & 578 & 530 & 559 & 624 & 645 & 686 & 791 & 860 & 1003 \\
\hline Omsetning (mill. kr) & 444,7 & 473 & 433,5 & 473,6 & 567,3 & 598,2 & 626,1 & 726,6 & 729,7 & 878,3 \\
\hline
\end{tabular}

Kilde: SSB Statistikkbanken

Turismen i Tromsø dreier seg om følgende. I mange år har det vært stor tilstrømming av mennesker som skal overvære konferanser og festivaler årvisse begivenheter som merkes i statistikken. Dernest er det en ganske omfattene regional trafikk. Når det gjelder turister, er Hurtigruten sentral året igjennom, mens cruiseturismen, særlig om sommeren, er en viktig kilde til inntekt for havnevesen, guide- og trafikkselskaper, attraksjoner og butikkene i sentrum. De siste åra har det vært en betydelig vekst i to typer turister: nordlysturister og toppturturister, hvor Lyngen-området er sentralt. Dessuten hadde man noen år en omfattende hvalbasert turisme. Hoveddelen av turistene drar ut av byen for sine opplevelser. Tromsø er altså kjernen i en baseturisme. Av det følger det noen klassiske problemer. Sentrum i dette systemet tjener pengene, mens periferien får belastningen og problemene.

I Tromsø har man også erfart at tilrettelegging kan gi nye utfordringer. Siden 2017 har det blitt bygget en sherpatrapp opp til et sentrumsnært område hvor det også går en privat drevet fjellheis. Heiseieren driver også en restaurant på toppen. Trappa førte minst til en femdobling av trafikken, til over 100000 oppstigninger iåret. I tillegg har heistrafikken økt. Kommunen, som er ansvarlig for trappa, har ikke bygd toaletter på toppen, slik at det er restauranten som får denne belastningen. I tillegg er det få parkerings- 
plasser der trappa starter, og man er bekymret for alt tråkket på toppen. Altså, trappa som ble etablert for å få bukt med stiproblemene, har gitt de impliserte partene en rekke nye utfordringer.

\section{Djupvik}

Djupvik er ei bygd i Kåford kommune, en snaut tre timers kjøretur fra Tromsø. Stedet ligger ved foten av fjellet Storhaugen. Fjellet er lett tilgjengelig, skredsikkert, og har fine nedkjøringer om vinteren. Det er et særlig yndet fjell for skiturister. De kommer i hovedsak via Tromsø, med bil eller som seil-og-skiturister. Starten skjer oftest fra Djupvik kirkegård, hvor det også er en liten parkeringsplass. Trafikken hit har økt betydelig de seinere åra, og den er til tider til irritasjon for lokalbefolkningen. De som kommer med seilbåt, kan bli satt $\mathrm{i}$ land $\mathrm{i}$ en havn, men mange blir satt i land $\mathrm{i}$ fjæra med gummibåter, da slipper operatøren å betale havneavgift. For å komme opp til veien og startstedet, og tilbake, må turistene gå over privat eiendom, noe som ikke er forbudt så lenge grunnen er snødekt. Turistene har også behov for å gå på do, og mange gjør fra seg bak husnovene eller i skogen rundt parkeringsplassen og kirkegården. Det sies til tider å være ganske utrivelig der. Når det skal være begravelser, har parkeringen ved enkelte anledninger vært fylt opp med turistenes biler. Kommunen har i 2019 bevilget penger til toaletter og utbedring av parkeringsplassen. Fjellets popularitet kan ganske sikkert i noen grad tilskrives Lyngen Lodge, en turarrangør og overnattingsbedrift som også ligger ved foten av fjellet - som for øvrig roses for å ha utviklet en miljøprofil. Det er også flere andre fjell i området som brukes av toppturturister. Djupvik er i ferd med å få et navn blant denne typen turister.

\section{Storfjord}

Storfjord er nabokommune til Tromsø og har lenge vært et populært område for hyttebygging og spikertelt blant tromsøværinger. I dag er bygdene Skibotn og Skibotndalen blant de mest brukte utfartsområdene for nordlysturistene i byen. Skibotn og Skibotndalen ligger på veien som går inn i Finland. Like over finskegrensa ligger Kilpesjärvi, som også er et mye brukt mål for disse turistene. Enten drar turistene denne veien med leiebil, eller de er med på en av de mange kommersielle buss- eller minibussturene 


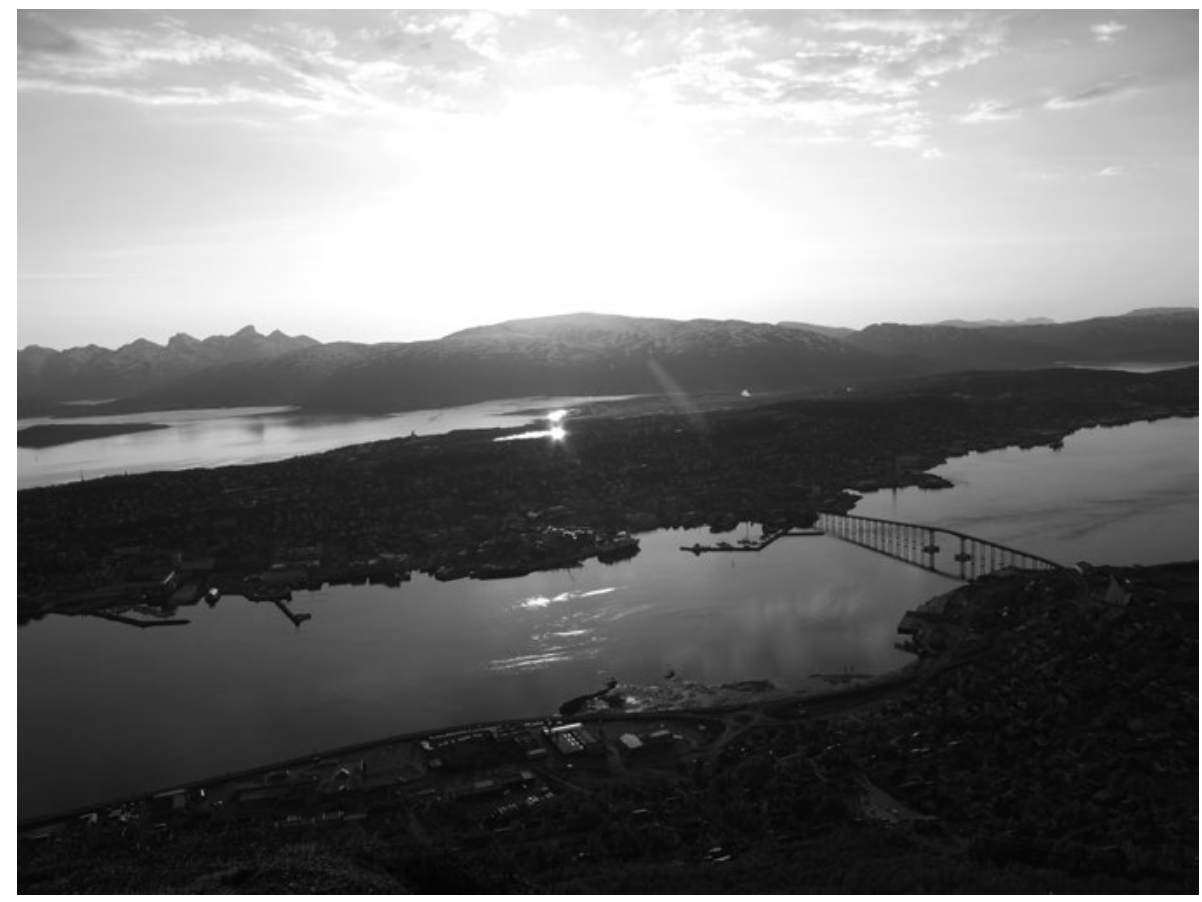

Tromsø - et turistmål i emning - besøksforvaltning i praksis. Foto: Ole Magnus Rapp.

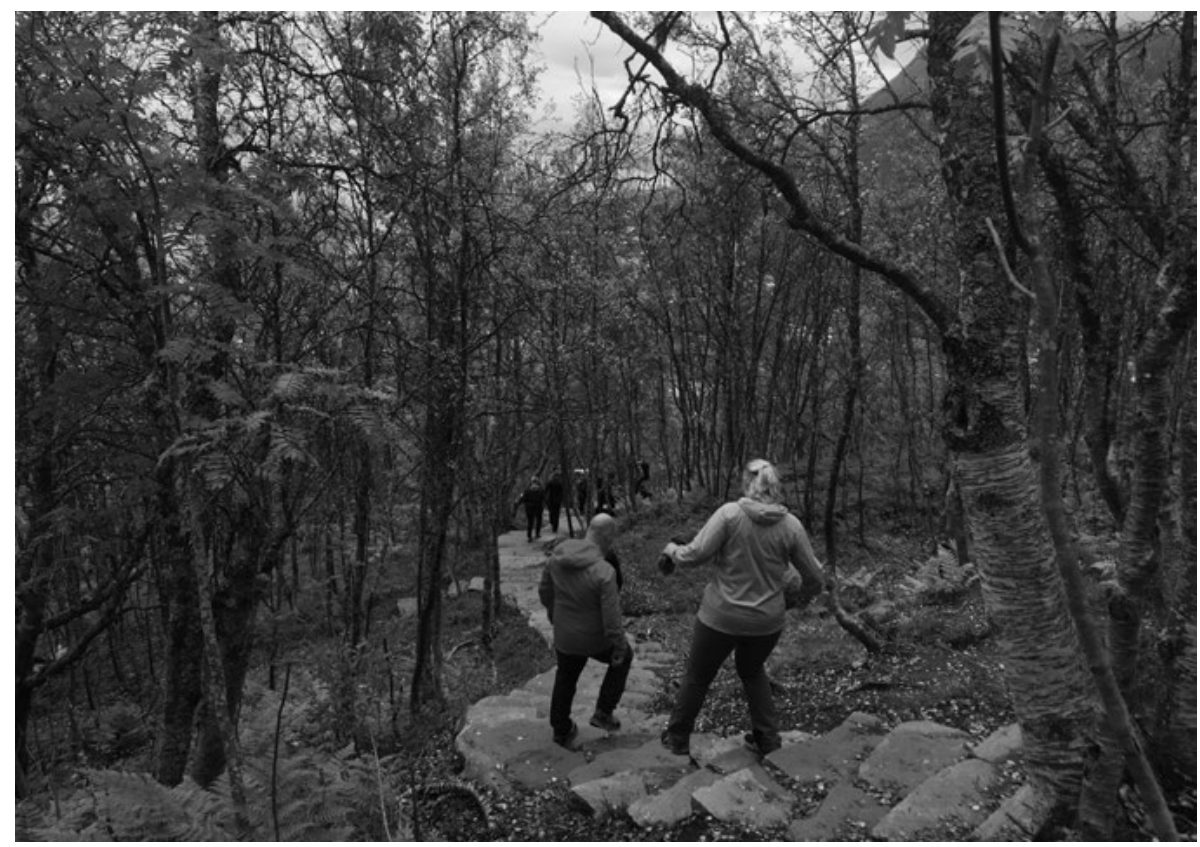

Tilrettelegging med sherpatrapp mangedoblet trafikken. Foto: Arvid Viken. 
som arrangeres fra Tromsø. Altså er det i Storfjord at mange tromsøturister får sine nordlysåpenbaringer. Bilene parkeres der det er mulig, og så står man der og venter på at nordlyset skal inntreffe. Det skjer imidlertid uten av Storfjord kommune eller dens innbyggere tjener på trafikken. Det er få parkeringsplasser langs veien og ingen kommersielt tilrettelagte plasser. Det er bare én kommersiell aktør som har tilrettelagt for å ta imot turister, et stykke oppe i dalen. I tillegg har UiT Norges arktiske universitet en forskningsstasjon som nå og da samarbeider med turismeoperatører. Det mangler altså en kommersialisering av mottak, både i form av private mottaksbedrifter og parkeringsanlegg. Derimot merker befolkningen en god del av problemene som følger derav. Det kan til tider være trangt langs veien på grunn av turistenes parkering. Mangelen på toaletter er heller ikke en trivselsfaktor. Hva er så problemet? Problemet er at Tromsø og dens næringsliv får nesten alle inntektene fra en virksomhet som foregår i en annen kommune, hvor man stort sett bare har merket ulempene. Det dreier seg kanskje om at kommunen - som institusjon, eller dens innbyggere - ikke har sett de kommersielle mulighetene. Kanskje kan man også bebreide Visit Tromsø, som ikke har tatt tak i problemet - de må være kjent med det. Og hva med de mange senter-omland-prosjektene man har hatt? Dette bør være et klassisk problem i en slik sammenheng.

\section{Allemannsretten er utfordret}

\section{Senja}

På Senja har turismen økt voldsomt de seinere åra. Ideen om Senja som et turistmål er gamle, men turistene har inntil nylig uteblitt. Det samme har tilretteleggingen. Derfor var det i 2018 åpenbart en del utfordringer. Turistene kommer stort sett med (leie-)bil eller bobil. Attraksjonen er den vakre naturen, ensomheten og turmulighetene på yttersida av øya. Et av de populære stedene er Ersfjordstranda i Berg kommune. Det er et lite sted. Stedet har strålende anmeldelser og er åpenbart et vakkert sted. Folk ligger i telt både på oversida og nedsida av veien - opptil 70 telt er registrert samtidig. Det fantes en fast do og to utsatte doer i $2018 .{ }^{15}$ Det skal også bygges et servicebygg på stranda. Det er et tilrettelagt utkikkspunkt på

Den faste doen - bare med en do og populært kalt Gulldoen (på grunn av sitt gylne eksteriør), er satt opp av Norske Turistveier, og den kostet nærmere fire millioner kroner. 

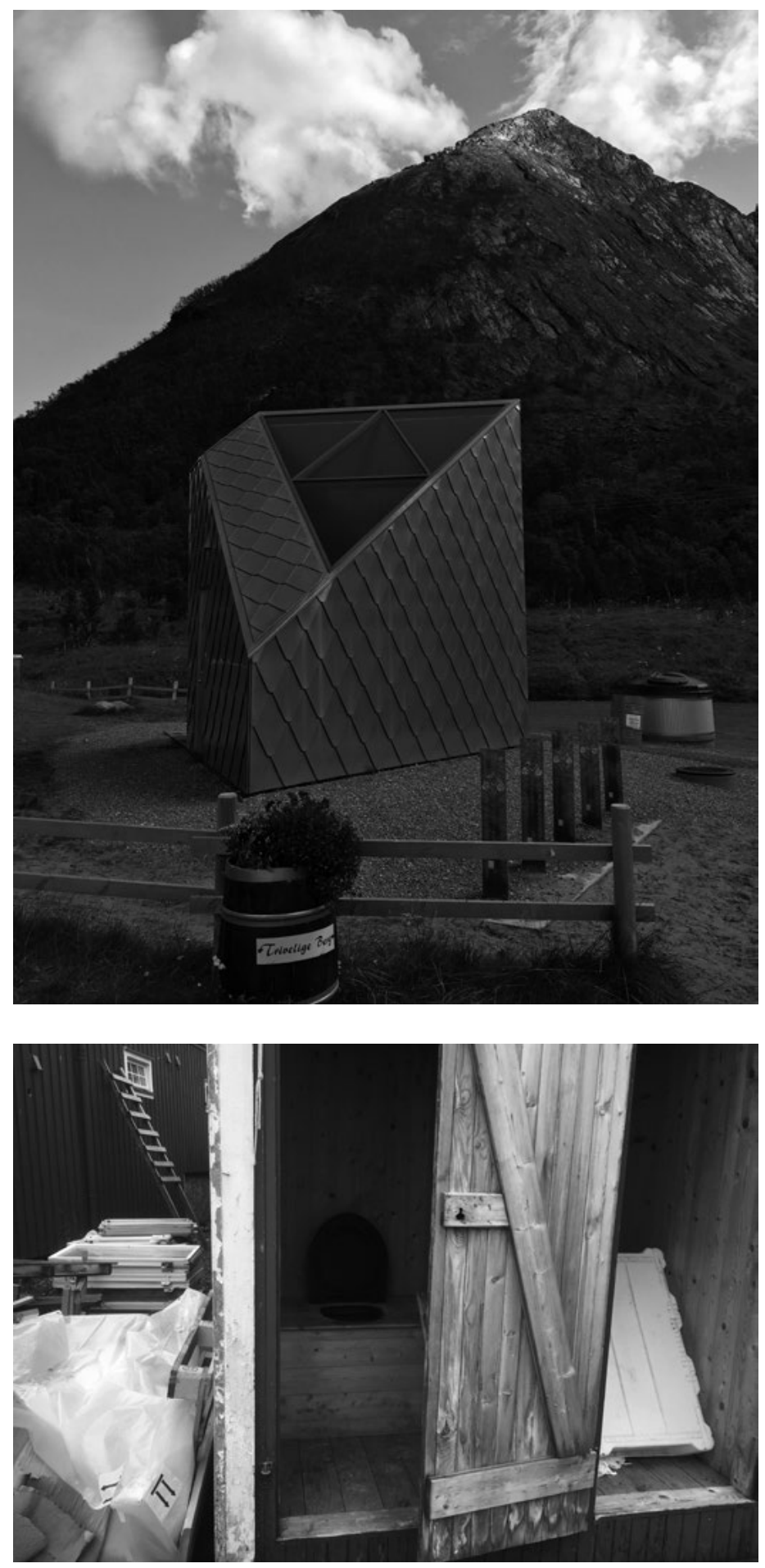

Toaletter må både bygges, drives og vedlikeholdes. Foto: Arvid Viken. 
Tungeneset, mindre enn fire kilometer unna - der er det to doer. Det er ingen campingplass i nærheten. Andre mye besøkte steder er Segla, Husfjellet og Sukkertoppen, utfartsmål både om sommeren og om vinteren på ski. Stiene slites, sies det. I tillegg til behov for tilrettelegging som parkering, doer og søppelsystem er også sikkerheten en utfordring.

Et hovedproblem er, sies det, at folk fra andre land og kulturer ikke vet hvordan de skal oppføre seg i naturen, hva slags utstyr de må ha, hvordan man går på do i det fri. Parkering i folks innkjørsler er heller ikke uvanlig. Telting nær bebyggelse er også et problem, det virker som om folk foretrekker å sette oppe teltene sine nær bebyggelsen, at man finner det tryggest. Men ofte er det for nær, og i strid med norsk lov. Dette illustrerer en av utfordringene ved allemannsretten. Informantene kritiserer også sentralmyndighetene, først og fremst Innovasjon Norge, som reklamerer med allemannsretten, men uten å si noe om hvilke forpliktelser som ligger i dette. Institusjonens evne og vilje til å løse problemene den bidrar til, er uklar.

Trengselen blant turistene på Senja illustrerer et annet problem. «Problemet» varer bare i fem-seks uker om sommeren. Da er behovene for tilrettelegging akutte. Investeringer i en infrastruktur som matcher toppsesongen, vil bli uforholdsmessig dyrt. Derfor bør en kanskje finne fram til andre løsninger, for eksempel etter modell fra festivalsektoren. Det pleier å fungere godt, er fleksibelt og kan drives av private aktører, dersom myndighetene tilrettelegger for det.

\section{Ersfjordbotn og Sandholmen}

Ersfordbotn ligger om lag 20 kilometer nord for Tromsø. Ersfjordbotn er et populært sted både å bo, dra på tur til og dra på tur ut fra. Fra gammelt av har det vært et fiskevær, men fiskemottaket er i dag ikke i drift og er omskapt til kafé, selskapslokaler og butikk. Bedriften har eksistert siden 1800-tallet, men har vært gjennom flere runder med omstilling. Fiskerivirksomheten, først og fremst eksport av tørrfisk og saltfisk, foregår fra et anlegg som bedriften eier på et annet sted. I gamle dager foregikk noe av virksomheten lenger ut i fjorden, på et sted kalt Sandholmen. En del av bygningsmassen i Sandholmen står fortsatt, men det meste av stedet er utmark. Fortsatt er området en del av væreierens eiendom. Det er et yndet 
utfartssted. Man kommer seg dit bare til fots eller med båt. Ersfjordbotn er også et populært startsted for turgåere og padlere. Kafeen ligger i enden av en sandstrand og har uteservering når været tillater det. Foruten kafeen er det to fisketurismebedrifter i bygda, og en som tilbyr sjøorienterte tjenester, først og fremst en kai. I de seinere åra har Sandholmen også blitt tatt i bruk av kommersielle aktører. En bruker stedet som basecamp for fjellturer, og en stor reiselivsbedrift bruker områder for piknik for opp mot 100 turister som fraktes i zodiaker (gummibåter) fra og til Ersfjordbotn fra et privat kaianlegg, om sommeren en til to ganger i uka. Foruten er Sandholmen et utfartsmål også for Tromsøs lokalbefolkning. Eieren har med en viss forundring sett at kommersielle aktører bruker stedet i sin virksomhet uten at han er forespurt, og uten at han får noen som helst kompensasjon for bruken. Minussidene har man imidlertid merket, som etterlatt søppel og ekskrementer. Det er imidlertid intet illegalt i det som foregår, slik lovverket er i dag, men kanskje er det i grenselandet for hva allemannsretten rommer. Dagens praksis bryter, slik eieren ser det. først og fremst med god folkeskikk, men illustrerer et av dilemmaene knyttet til allemannsretten.

\section{Til sammenlikning - Vest-Lofoten}

Lofoten er Nord-Norges mest populære reiselivsregion. Et sted mellom tre og fire hundre tusen turister besøker området årlig, og mer og mer skjer det gjennom hele året. Men fortsatt er sommeren toppsesong. Ikke alle besøker hele regionen, og hvor mange som drar til Vest-Lofoten, er ikke klart. Veien i de vestlige områdene er mange steder trang, og det er daglige stans i trafikken. Lofoten er et åpenbart mål for bobilturister, men det er lite tilrettelagt for dem. Og bobilene stiller seg opp overalt. En av rorbueierne i nærheten av Leknes sliter med at de kjører inn i hans anlegg og parkerer. Han har full hyre med å jage dem. Han har, som han sier, ikke plass til å opparbeide et kommersielt overnattingsanlegg for denne gruppen. Han tviler og på om turistene er innstilt på å betale. Det må tvang til, mener flere. Bobilene står på de få parkeringsplassene som eksisterer langs veien, og den store offentlige parkeringsplassen i $\AA$ er full av bobiler. Der er det også noen toaletter. Denne parkeringsplassen tar av mye av trykket. På Moskenes, like ved stedets fergekai, finnes en moderne og velutstyrt campingplass, også tilrettelagt for bobiler. Likevel er det mye villcamping, og det står bobiler nær sagt overalt. Problemet er imidlertid ikke først og 
fremst et naturbruksproblem, men at det er mangel på toaletter på sentrale besøkspunkter, som ved foten av Reinebringen, på Bøstranda og et fåtall andre utfartssteder, og på steder med villcamping i telt, for eksempel nær kommunens drikkevannskilde. Stiproblemene er ikke store, men stien mellom Torsfjorden (Fredvang) og Kvalvika var nedslitt, og tiltak - blant annet klopping - er satt inn. Reinebringen, en svært bratt oppstigning til et utkikkspunkt, er i 2019 i ferd med å bli tilrettelagt med en sherpasti, og det er lovet at det skal komme en parkeringsplass ved foten av stien. Et av de populære villcampstedene er ved Reinevannet, en drikkevannskilde. Massiv skilting ser ikke ut til å hindre villcamping i området. Når en googler Reine i Lofoten, kommer reklame for fricamp tidlig opp, men ingen formaninger eller retningslinjer. Til tross for mange toaletter har regionen et doproblem i de travleste periodene. Rorbueiere opplever ofte at turister, som ikke har vært eller er deres kunder, danner køer foran toalettene deres. Det er varierende reaksjoner på dette. En viss privat tilrettelegging er rimelig, slik en av aktørene ser det. Enkelte var mer opptatt av alle cruiseturistene, som enkelte ganger rettferdiggjør alt snakket om trengsel og overturisme. Som en rorbueier omtrent sa det: «Idyllen folk søker i Lofoten, forsvinner når området trakkes ned av flere tusen turister.» Passasjerene fra skip med over 3000 passasjerer busses omkring i regionen.

Under vår datainnsamling i 2018 hørte vi gjentatte ganger begrepet «Lofoten-tilstander» brukt som et eksempel til skrekk og advarsel. Det skyldes medieoppslag som alltid opptrer om sommeren, gjerne uttrykt av ordførere. Men dette er en helt ufortjent nedsnakking av en region hvor man har tatt tak, og hvor tilstanden er bedre enn de fleste andre steder. Man har ikke løst alle problemene, men gjør noe, og forholdene blir bedre. Derfor er problemene små, med unntak av i slutten juli. Problemet er av cirka fire ukers varighet. Da er det for mange mennesker der i forhold til regionens infrastruktur, og særlig da kapasiteten på veiene og sanitæranleggene. Derfor bør man først og fremst drøfte hvordan utfordringene i denne perioden skal løses. Trengs det faste installasjoner for å håndtere toppsesongen, eller kan dette løses med sesongløsninger, tilsvarende festivalverdenen? 


\section{Til sammenlikning - Canada og Finland}

Canada er et pionerland med hensyn til turisme i verneområder. I mange tilfeller er turisme selve årsaken til opprettelsen av nasjonalparker eller andre verneområder. I en artikkel fra 2017 sier man at det har vært tre faser i tenkningen rundt nasjonalparker i Canada og andre land knyttet til det britiske imperiet (Weaver \& Lawton 2017). I første fase var fokus på å tilrettelegge for besøk. I andre fase var fokus på besøksforvaltning, altså på å tilrettelegge for bruk, men samtidig beskytte naturen. I samme artikkel argumenteres det sterkt for en ny vending, hvor brukere av alle slag tar ansvar for naturen og bidrar til et konstruktivt og symbiotisk forhold mellom menneskene og naturen. Vi har alle et ansvar både for vår egen og naturens velbefinnende, sies det.

I Canada er Banff landets eldste nasjonalpark. Den ble etablert i 1885 i den kanadiske delen av Rocky Mountains. Parken, som ligger 110-180 kilometer fra Calgary i provinsen Alberta, dekker et areal på 6641 kilometer $^{2}$ fjellterreng med tallrike isbreer, tette barskoger og fjellandskap. Mye av den kommersielle virksomheten i parken er i byen Banff, i Bow River-dalen, men Lake Louise også er et viktig tettsted langs Highway One. Canadian Pacific Railway var svært viktig i de første åra for Banff, da de bygde både Banff Springs Hotel og Chateau Lake Louise, og trakk turister til stedet gjennom utstrakt annonsering. I begynnelsen av det 20. århundret ble det bygd veier i Banff. Siden 1960-åra har overnattingsstedene i parken vært åpne hele året, og antall gjestedøgn i Banff økte til over fem millioner i 1990-åra. Enda flere mennesker passerer gjennom parken på Trans-Canada Highway. Siden Banff er en av de mest besøkte nasjonalparkene i verden, er økosystemet i parken truet. På midten av 1990-tallet satte Parks Canada i gang en undersøkelse som har ledet fram til anbefalinger for forvaltningen av parken, og nye prinsipper som har som mål å bevare det økologiske mangfoldet. Først og fremst er parken styrt av Parks Canada, både naturen og de besøkende. De besøkende må følge anviste stier og veier og er gjenstand for ulike former for overvåking. Dette gjør at man vet hvor tilretteleggingen eller reguleringstiltakene må settes inn. Sjøl om økosystemene i parken er truet på grunn av høye besøkstall, oppleves nasjonalparken som betydelig mer «intakt» enn de fleste liknende økosystemer på det europeiske kontinentet. Hovedproblemet, slik Parks Canada ser det i dag, er trafikkreguleringen til, gjennom og fra parken. Det er flere verneområder som grenser til Banff. Noen av disse forvaltes av 
Alberta Parks. Dette er altså en provinsbasert forvaltning og har et svakere rettsgrunnlag enn det føderale Parks Canada.

Et mer nærliggende sammenlikningsland er Finland. Det er neppe en overdrivelse å hevde at Finland er «europamester» i verneområdeforvaltning. I dag er det finsk statskog - Metsähallitus - som eier all statlig grunn inkludert verneområder, og som tilrettelegger, forvalter og utvikler disse områdene. Fra 1990-tallet og fram til i dag har Metsähallitus, opprinnelig et skogforvaltningsorgan, blitt en sentral tilrettelegger for turisme. Metsähallitus håndterer alle aspekter ved besøksforvaltning. Den delen av organisasjonen som styrer med verneområder, er altså både grunneier og forvaltningsmyndighet på lokalt og regionalt nivå, både for naturressurser og kulturminner. Organisasjonen har på samme tid ansvar for naturvern og næringsutvikling og drifter en omfattende infrastruktur. Organisasjonen har også utarbeidet strategier og planer for hvordan effekter av turismen skal håndteres i praksis, hvilke naturverdier som skal bevares, og hvorfor.

I Finland som helhet var det i 2017 om lag tre millioner besøkende til landets nasjonalparker. I noen verneområder er det registrert 550000 besøkende. Den mest besøkte nasjonalparken i Finland er Pallas-Ylläsfjellene, som strekker seg fra Hætta til Äkäslompolo. Årlig gjøres det representative besøksundersøkelser med påfølgende beregninger av direkte økonomiske effekter og effekter for folkehelse i Finland. Den største forskjellen mellom Norge og Finland er systematikken i arbeidet med besøkshåndtering.

Et hovedskille mellom de kanadiske og finske forvaltningssystemene og norsk naturforvaltning er at de to landene har relativt enhetlige og hierarkiske systemer for håndtering av relasjonen mellom naturen og brukerne. Det norske systemet er langt mer fragmentert. I Norge er de samme oppgavene delt på tre forvaltningsnivåer (kommune, fylke og nasjon) og ulike organisasjoner som Fjelltjenesten i Statskog, Statens naturoppsyn, fylkesmannen, verneområdestyrer og kommunale myndigheter - et relativt komplekst system. Mens de kanadiske og finske systemene i hovedsak representer top-down-styring og forvaltning, har det norske systemet en langt sterkere bottom up-organisering. Det betyr også at de norske forvaltningsorganene har en mye mer begrenset myndighet, enn sine kanadiske og finske motparter. Særlig viktig er det at myndighetene i de to referanselandene i langt større grad enn i Norge brukes til å styre de besøkende og deres bevegelsesmønstre, noe som gjør forvaltningen enklere. Det norske systemet har også sine fordeler, det er trolig mer fleksibelt, det er mer 
brukerstyrt og mer demokratisk, og har et sterkt kulturelement som sitt grunnlag. Den norske friluftslivskulturen har en uvurderlig egenverdi.

\section{Hvordan kan utfordringene imøtekommes?}

Hvordan man kan løse problemene, vil variere. Det finnes ingen standardløsning. Mange av problemene som er antydet, dreier seg om mangel på besøksforvaltning. De vil trolig løse seg ved at slik forvaltning innføres. Men det vil også være nødvendig med en holdningsendring både hos dem som selger Norge, og i det internasjonale markedet. Man må få slutt på forestillingen om det er fritt fram i Norge. Da må Innovasjon Norge og andre organisasjoner endre sin markedsføring. Men det henger også sammen med hvordan vi i Norge vil at forretningsvirksomhet skal foregå. I dag er det fritt fram dersom det ikke er forbudt med lov. Prinsippet kan snus, at det er forbud mot kommersiell virksomhet i utmark, det vil si å innføre en konsesjonsordning, slik man har det i andre naturbaserte næringer.

Det finnes ulike måter å gruppere de kjente forvaltningsvirkemidlene på (Lascoumes \& Gales 2007). Harde og myke virkemidler er ett skille, hvor legale, fysiske, og økonomiske virkemidler er de harde, og hvor informasjon og stimulerings- og premieringstiltak er blant de myke. Et annet skille er mellom legale, økonomiske og fysiske tiltak (se Keskitalo et al. 2017). I det følgende velger vi denne inndelingen, hvor vi først ser på grunneieravtaler og regler og retningslinjer, dernest kommersiell tilrettelegging. Som det tredje, drøftes ulike former for fysiske inngrep og avbøtende tiltak i naturen, og som det fjerde holdningsskapende arbeid. Til sist nevnes kort hvordan dette har vært gjort andre steder.

\section{Grunneieravtaler}

Og til nå har det ikke vært forbudt å drive forretningsvirksomhet basert på allemannsretten. Likevel er det intet som hindrer aktørene å inngå avtaler med grunneierne. DNT sier de alltid inngår slike avtaler når de anlegger stier eller gjør annen tilrettelegging. I næringslivet synes det ikke å være regelen at slike avtaler finnes. Et mulig prinsipp kunne være å innføre et totalforbud mot kommersiell aktivitet $i$ annen manns utmark. Dermed ville man kunne innføre krav om grunneieravtaler. Men det kan og innføres ved 
at destinasjonsselskapene stiller krav om at slike avtaler kan dokumenteres for å inkludere bedriftene i sin markedsføring. Samarbeid med grunneiere vil dessuten være en måte å spre aktivitetene på. En av nordlysoperatørene i Tromsø opererer på denne måten. Firmaet har etablert satellitter - steder som bedriften reiser til for ulike typer opplevelser.

\section{Lover, regler og retningslinjer}

Lover og regler er den vanligste måten for myndigheter å regulere folks atferd på. Vårt samfunn er relativt gjennomregulert, det finnes regler for det meste. Men vårt regelverk er fundert på norsk kultur, som stort sett bare er kjent for oss nordmenn. I en tid med flere utenlandske besøkende $i$ året enn antall innbyggere kan det være et problem. Samtidig er rådende ideologi at man ikke skal regulere mer enn nødvendig. Derfor er det også mange områder som det ikke finnes regler for. Mens det finnes detaljerte internasjonale regler for hvordan vi skal oppføre oss langs veiene, finnes ikke noe tilsvarende for ferdsel utenfor veiene. Når det gjelder friluftsliv og naturbasert turisme, rommer friluftsloven noen regulerende bestemmelser, som regler for telting i utmark, for eksempel ikke mer enn to netter på samme sted, og ikke nærmere enn 150 meter fra bebyggelse. Lova gir også kommunene adgang til å lage regler for konkrete friluftslivsområder. Enkelte steder, som i Lofoten, finnes også retningslinjer, eller guidelines, utformet av reiselivsnæringa. En utfordring med slike regler er altså å gjøre dem kjent for turistene.

Det er ikke i tidas ånd å skulle innføre flere forbud og påbud. Vi mener imidlertid at dette også bør diskuteres. For eksempel ligger det et betydelig potensial i å forby villcamping mange steder. Det vil både ha økonomiske effekter og løse en del av miljøutfordringene. Men det må knyttes til økt kommersiell tilrettelegging. Telting i henhold til reglene i friluftsloven må imidlertid fortsatt kunne skje, i områder hvor dette ikke eksplisitt er innført forbud. En av utfordringene med forbud er at reglene må håndheves, noe som kan kreve at noen utøver den myndigheten.

Slik vi ser det, er det altså behov for retningslinjer som forteller om hva som forventes av atferd i norsk natur, hva som er lov og ikke, hva som er anbefalt utstyr, hva som er farer, og hva som er prosedyrer ved ulykker. Som regel har retningslinjene form av informasjon og anbefalinger og er verken forbud eller påbud. De finnes gjerne på nett, man kan 

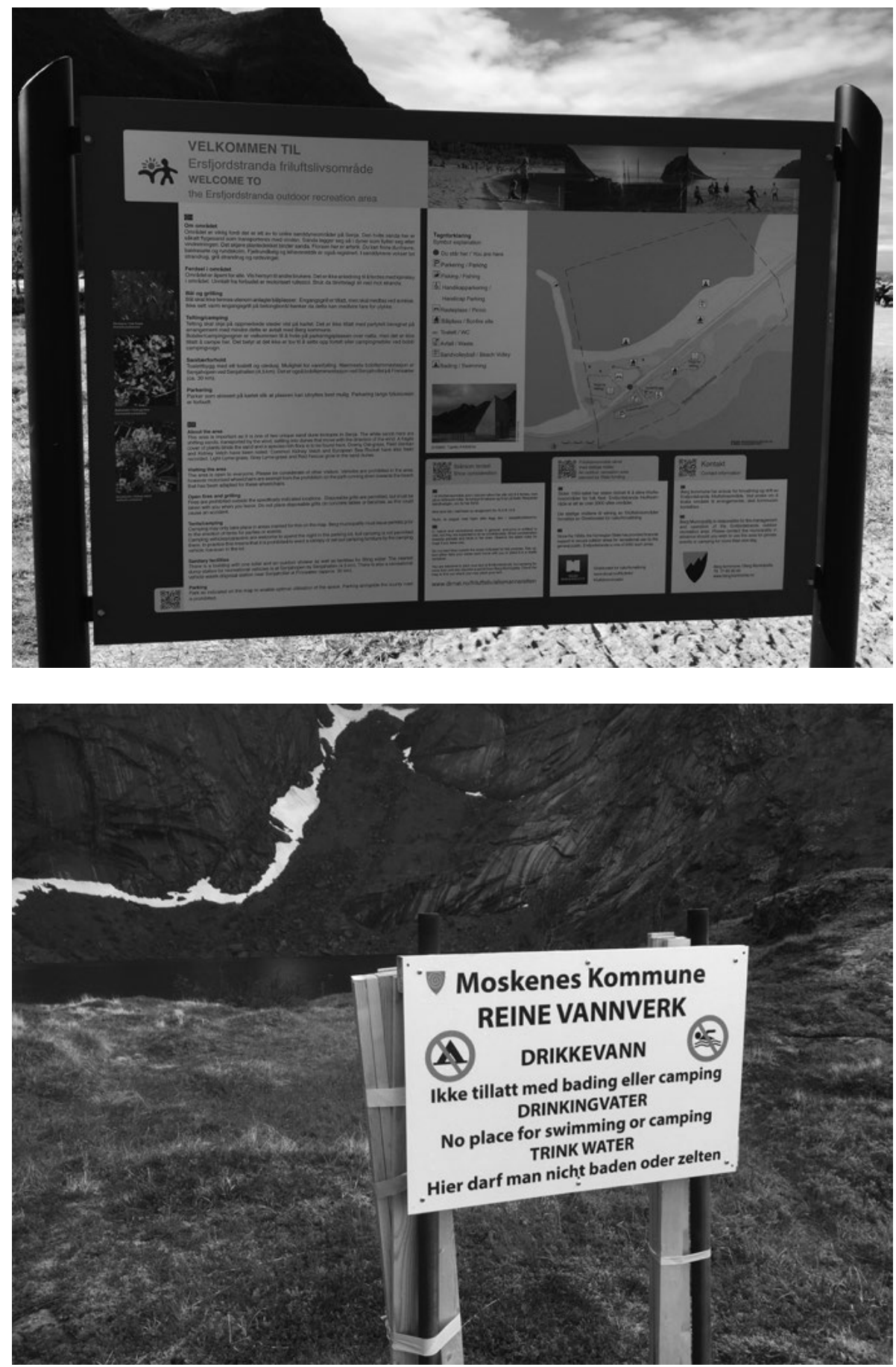

Tilrettelegging krever mange slags kompetanse. Foto: Arvid Viken. 
også være slått opp på stedet. I Lofoten har man laget slike retningslinjer, som er oppslått her og der. Retningslinjene vil fungere som oversettelser av norsk friluftslivskultur beregnet på eksterne brukere av naturen. De kan også gjøres spesifikke i forhold til bestemte aktivitetstyper, som toppskiturisme, eller kano- og kajakkpadling, fritidsfiske og liknende. Og de kan gjøres stedsspesifikke, altså fortelle om hvordan man skal oppføre seg på et bestemt sted. Til dels finnes dette, det er relativt vanlig med oppslag som informerer om regler for angjeldende område. Dette er gjort på Svalbard.

\section{Kommersiell og avgiftsbelagt tilrettelegging}

En måte å regulere på er å innføre en adgangsavgift som turistene må betale for kunne passere et bestemt punkt. Dette er først og fremst en finansieringsmodell for tilrettelegging, men kan også være en kilde til forretningsinntekter. Det kan for eksempel være en ilandstignings- eller passeringsavgift for ski- og fjellturister. Problemet er at dersom turistene trer inn på områder der allemannsretten gjelder, er det bare kommunen som kan ta en avgift, og den skal bare dekke kostnader. Altså gir regelverket ikke rom for en profitabel passeringsbetaling. Det finnes imidlertid unntak, som på Nordkapp. Der hadde man på 1980-tallet et parkerings-, do- og søppelproblem. Man bygde tiltrengte fasiliteter, satte opp en bom og økte inngangsavgiften (se også kapittel 7 i denne boka). Dette løste problemene. Tilfellet har vært kontroversielt fordi man satte avgiften svært høyt, altså rommer den også en betydelig profitt til den kommersielle forvalteren. Trolltunga er et annet eksempel, der har man laget en fire kilometer lang slyngevei (s-formet vei) til erstatning for en 1,4 kilometer lang trapp. Man kan også kjøre denne veien, mot en avgift som var på kr 500 per bil i 2017 . Dette er bare ett av tilretteleggingstiltakene. En ilandstigningsavgift som måtte betales uansett om man går i land på en tilrettelagt kai eller i fjæra, ville trolig løse problemet med seil-og-skiturister som vasser over privat eiendom i Djupvik i Lyngen og en del andre plasser. Avgifts- eller billetteringsregulering vil kunne dekke kostnader ved tilrettelegging, og kanskje hindre at turister invaderer privat grunn, men vil ikke virke begrensende på antall besøkende. Det har i alle fall ikke gjort det på Nordkapp. Det har det heller ikke gjort på Svalbard, hvor man siden 2002 har hatt en såkalt miljøavgift på 150 kroner som ilegges alle besøkende. Pengene går til et fond som man kan søke støtte hos, til tiltak som er miljøfremmende. Mye 
har gått til tilrettelegging for turisme. Dette har man gjort etter modell fra verneområder verden over, hvor nasjonalparkavgifter er vanlig. Det er altså lange tradisjoner for å ta betalt for å slippe inn i naturområder. Det er sjølsagt enklere å gjøre det der man har få og definerte innfallsporter, slik det gjerne er til øyer eller nasjonalparker. Poenget er at det er relativt enkelt å få til betalingsordninger på bruer, ferger, flyplasser eller andre passeringspunkter. På steder med særlig turistbelastning - Lofoten er et slikt område - eller steder med særlig tander natur bør slike ordninger vurderes. Men ikke overalt. De aller fleste steder utgjør turistene en del av brukerne av stedenes infrastruktur, uten at de belastes for det. Nordmenn er en relativt stor slik brukergruppe av andres fellesgoder i forhold til folketallet. Da kan vi ikke klage over at andre bruker våre fellesgoder. Det er altså ikke rimelig å innføre slike avgifter overalt.

\section{Fysisk tilrettelegging}

Det norske friluftslivet har tradisjonelt vært basert på lav grad av fysisk tilrettelegging. Stier, klopper, broer, stimerking, skilter og av og til tilrettelagte rasteplasser er dominerende modeller. Men det er en utvikling mot mer tilrettelegging. Den enkleste formen for tilrettelegging er at stier merkes og «sertifiseres» innen ordninger som Fysak, Ti på topp eller Ut i Nord, for å nevne noen slike offentlig initierte tiltak. Stort sett er tilretteleggingen knyttet til dette, kartverk, stedlig merking og nettsted og besøkskoder for nettregistrering. Andre eksempler på fysisk tilrettelegging er toaletter og søppelhåndtering. I Norge har vi de seinere åra etablert såkalte sherpastier (steinlagte trapper), for eksempel opp til Preikestolen, til Ulriken i Bergen, Reinebringen og til Fløya i Tromsø. Som nevnt kan slik tilrettelegging utløse andre tilretteleggingsbehov, særlig for parkeringsplasser, doer og søppelsystemer. Hvert år opplever man både klager fra turistene og politisk sutring over mangelfull tilrettelegging. Er det reiselivsnæringa, friluftsorganisasjonene eller kommunene sitt ansvar? Hva med staten, som reklamerer for fri tilgang i norsk natur? Og hvem skal betale? Når det gjelder toaletter og søppelsystemer, er det behov for konseptutvikling, altså at man finner fram til standardiserte løsninger både rent utformingsmessig, driftsmessig og finansielt. Det er stor enighet om at brukerne bør betale, men det mangler gode løsninger. Ulike automat- eller Vipps-liknende (Vipps er per i dag bare for norske bankkunder) ordninger diskuteres. På mange måter 
har man utviklet en virksomhet - reiseliv - som impliserer mengder av mennesker, uten å tilrettelegge for det faktum at vi mennesker har jevnlige dobehov. Det er som å bygge et sykehus eller universitet uten toaletter. Altså må man si at ansvaret kan tillegges dem som står bak utviklinga av turismen, reiselivsnæringa assistert av myndighetene.

\section{Holdningsskaping}

Som nevnt går det et skille mellom harde og myke virkemidler i forvaltningen. Det meste av det vi har beskrevet så langt, er av det harde slaget. Retningslinjer har vi nevnt som et virkemiddel som er av den myke sorten, og det aller viktigste, den norske friluftslivskulturen. Blant de retningslinjene vi ser for oss, er nedskriving og oversettelser av denne kulturen. Men friluftslivskulturen er ikke statisk, den påvirkes av ulike diskurser og trender, og den kan påvirkes gjennom strategier og virkemidler. For eksempel har friluftslivet hatt et oppsving som følge av myndighetenes satsing på folkehelse. Friluftsliv og tiltak som Fysak- og Ti på topp-varianter har skapt aktiviteter og rekruttert nye brukere av naturen. Bakgrunnen er stortingsmeldinger både om friluftslivet og helse fra rundt tusenårsskiftet. Det er altså en nasjonal satsing som har gitt lokale effekter. Et mer omfattende friluftsliv skaper positive holdninger til naturen, men også behov for og krav om mer tilrettelegging. Tilretteleggingsbehov er en funksjon av aktivitetsomfang. Men det viktigste er at folk flest tar ansvar - både for seg sjøl og for naturen (se Weaver \& Lawton 2017). Dette kan styrkes av kampanjer som skaper oppmerksomhet. Dagens mange kampanjer for å bli kvitt plasten som slenger rundt, har forhåpentligvis både oppmerksomhetsskapende og holdningsskapende effekter, i tillegg til at det ryddes opp. Holdningsarbeid er et sentralt arbeidsfelt i all besøksforvaltning.

Ofte er det en del paradokser knyttet til politiske satsinger. Folkehelsepolitikken er bra for folk, men ikke bare bra for miljøet. Vi har fått mer tråkk og trengsel, som igjen skaper behov for politikk og tiltak. Noen av virkemidlene $\mathrm{i}$ folkehelse- og friluftslivssammenheng representerer både sportifisering og kommersialisering, og verdier som står fjernt fra de tradisjonelle friluftslivsverdiene og naturens egenverdi. Vi har kanskje fått flere i aktivitet, men verdiene endres. Det er ikke nødvendigvis slik at besøksforvaltning fremmer naturens egenverdi. Fokuset på besøksforvaltning er ofte motivert av helt andre hensyn; et ønske om å styrke mulighetene for 
økonomisk verdiskaping. Også dette er forhold som bør diskuteres når besøksforvaltning settes på dagsorden. I iveren etter en bedre forvaltning må ikke naturens egenverdi glemmes. Friluftslivet og naturbasert turisme trenger en verdidebatt.

\section{Ulike modeller: Nordkapp, Trolltunga og Preikestolen}

På Nordkapp har man altså sperret av veien, og turistene betaler en avgift for å komme inn. Dette er dagens forklaring, mens det opprinnelig ble oppfattet som en legitim betaling for å få tilgang til en moderne attraksjon. Anlegget som ble ferdigstilt i 1989, løste problemene man hadde hatt knyttet det som er problemet overalt: ekskrementer, søppel og parkering. Andre steder er problemene mer kompliserte og omfatter en rekke andre ting. Det mest interessante er kanskje Preikestolen og Trolltunga.

Preikestolen forvaltes av en stiftelse. Stedet er et verdenskjent utsikts- og besøkspunkt 600 meter over Lysefjorden i Rogaland, to timer fra Stavanger. Stedet nås langs en 3,4 kilometer lang sti, tilrettelagt med sherpatrapper og klopper. Der stien starter, er det gratis parkering og en campingplass og en fjellstue drevet av DNT. Det er et middels tilrettelagt sted. Man har gjennom åra hatt en del redningsaksjoner for å få ned skadede og mennesker som ikke har vært skikket eller kledd for turen. Man uttrykker et ønske om ikke å skulle måtte regulere for mye. Det er et tilrettelagt turistmål, men lite regulert.

Trolltunga er et tredje sted hvor spørsmålet om besøksforvaltning har blitt aktualisert. Stedet, nær Odda i Hardanger, opplevde å gå fra å være ukjent til å tiltrekke seg 100000 turister i året i løpet av få år. Attraksjonen er en klippe som stikker ut fra terrenget, ovenfor Ringedalsvannet, og opplevelsen, eller fotomotivet, er å stå ute på tunga. Men slik det er blitt, får man bare gjøre det et minutt eller to, fordi det er en massiv kø bak, som skal gjøre det samme. Turen inn er på 11 eller 13 kilometer, alt etter hvor en starter, og det samme tilbake. Starter en nede i dalen, har turen cirka 600 meter stigning, mindre om en starter oppe, etter å ha kjørt opp til et nytt startpunkt på fjellkanten (ferdigstilt i 2017). Man har laget veien opp av flere årsaker, blant annet finnes det et hyttefelt på kanten over dalen. Turistene anmodes om å gå den veien ned igjen, den er mindre krevende enn den alternative stien. Man har stiverter som gir råd, skilt med anbefaling, og man har satt opp redningshytter et par steder. Stedet ble 
kjent gjennom sosiale medier. Gjennom disse kanalene har åpenbart også informasjonen om at turen er krevende, spredd seg. De første åra var det nesten daglig redningsaksjoner. Disse er blitt atskillig færre etter at man satte inn ulike tiltak. Så langt har man ikke anvendt nordkappmodellen, med å kanalisere folk gjennom en hovedport. Det kunne man gjort, og man kunne tatt en avgift for å dekke tilretteleggingen og en forsikring. Det er åpenbart at man vegrer seg mot dette. Allemannsretten er fortsatt relativ hellig i Norge.

\section{Diskusjon: Hva styres, og hva bør styres mer?}

Som vi skrev i den teoretiske introduksjonen, er dagens samfunnsstyring preget at mange impliserte parter (Sørensen \& Torfing 2009). Det har også den empiriske gjennomgangen av besøksforvaltningen vist, det er mange aktører og kanskje enda flere interesser. Slik våre informanter opplever det, er feltet uoversiktlig, og mange mener at det er behov for mer koordinering. Systemet består av flere likeverdige parter, og noen mener at hierarkisering ville være en måte å samordne på. Men trolig vil ikke det skje, slik at det er mer sannsynlig at man vil kunne utvikle ulike varianter av samstyring. Det er også en del tilfeller av sjølstyring, representert ved sterke og relativt sjølstendige aktører, som for eksempel Den Norske Turistforening. Men også denne organisasjonen inngår i mange samstyringsrelasjoner (Koiman 2003). En av aktørene, friluftsrådene, er basert på selve ideen om samstyring. Disse må samarbeide med kommunene og fungerer som et bindeledd til dem som styres, de mange frivillige aktørene i feltet. Dette betyr sjølsagt at det er mange kompromisser representert i de vedtakene som gjøres, og ordninger en etablerer (Holmgren, Sandström \& Zachrisson 2017). Mest problematisk i dette tilfellet er reiselivets mange aktører. I mange sammenhenger er det reiselivet som utfordrer det systemet som har eksistert til nå, og som ofte vil være skeptisk til nye forvaltningstiltak som de oppfatter som begrensende. Turismen representerer mange steder enn ny vinkling og nye forvaltningsbehov. Men næringa er sammensatt i seg sjøl og rommer motstridende interesser. Cruisenæringa og de små bedriftene på små steder går ofte dårlig i hop, og de krever helt forskjellig tilrettelegging. Når vi har kunnet registrere en viss unnfallenhet og sendrektighet når det gjelder utvikling av forvaltningstiltak, så kan det bunne i slike motsetninger. Mest 
skadelidende har Lofoten vært, hvor næringslivsorganisasjonene har motarbeidet nye forvaltningsordninger. Hadde de blitt innført, ville ganske sikkert noen ha tapt på det. Dette er et resultat av at forvaltningen utøves i dialog med de berørte partene, det blir fort vanskelig å få til endringer som tilsidesetter økonomiske verdier. Flere av de små aktørene vi snakket med i Lofoten, erkjente denne verdikonflikten, mellom økonomisk profitt og verdier knyttet til tradisjoner og lokalsamfunn.

Våre informanter klager relativt mye over kommunene. De er ofte sendrektige og lite handlingsorienterte, om vi skal tro informantene. Kan det være så vanskelig å lage parkeringsplasser, sette ut doer og søppelkontainere? En av våre informanter gir oss en forklaring på dette. Det er ikke en del av den kommunale infrastrukturtenkningen å skulle ordne dette, og enda mindre finnes det rom for drift av dette i dagens budsjetter. Dersom man skal sette opp offentlige doer, vil det måtte skje der det finnes vann og kloakk lett tilgjengelig. Og likevel vil man ha et driftsproblem, man har ikke ansatt den typen mennesker som trengs for oppgaven. Altså trengs det kommunal nytenkning til for å få orden på disse sakene, slik vår informant ser det.

Vår gjennomgang av hva som regnes som besøksforvaltning, viste et relativt sterkt fokus på besøkstellinger, kundeundersøkelser, med styring og forvaltning, utvikling av friluftsliv og virkninger på lokalsamfunn deretter. Vår undersøkelse har vist at særlig de tre siste punktene er sentrale temaer i Troms og Lofoten. Slik vi formulerte vår undersøkelse, måtte styring og forvaltning bli sentralt, det var det som var vårt utgangspunkt. Men dette er både koplet til utvikling av friluftslivet og til å håndtere denne utviklinga overfor lokalsamfunnet. Det vi finner lokalt, gjenspeiler altså internasjonale teoretiske trender. Dette er også tegn på at feltet er umodent - forvaltning og samfunnseffekter er relativt nye temaer, fordi den fritidsbaserte bruken av natur er i sterk utvikling, både i Norge og ute i verden.

\section{Konklusjon}

Vi har i dette kapitlet vist hva slags utfordringer som er knyttet til et utvidet friluftsliv og en økende naturbasert turisme i Norge. Det er flere mennesker i norsk natur enn tidligere, som gir større miljøvirkninger, flere som ikke kjenner den norsk friluftlivskulturen, og større risiko for ulykker. Undersøkelsen vår har påvist en behov for bedre tilrettelegging med hen- 
syn til parkering, toaletter og søppelhåndtering samt et behov for en større satsing på utkantene av sentrale turiststeder. En særlig utfordring ligger i å håndtere toppsesongene. Disse må kunne håndteres med sesongbaserte løsninger. Først og fremst har undersøkelsen avdekket at feltet mangler en fastere organisering. Det er mange aktører i feltet, som alle gjør en viktig jobb, men dagens system er ukoordinert og med uavklarte ansvarsforhold. Men det er et felt i utvikling. Det diskuteres, forskning blir satt i gang, møter og seminarer avholdt og nye forvaltningstiltak blir diskutert og innført. Besøksforvaltning er i ferd med å bli en ny offentlig sektor.

Turisme representerer økt kommersialisering som gir nye forvaltningsutfordringer, og kan på sikt bety mindre frihet for friluftslivet. Allemannsretten er utfordret, og prinsippet trenger å bli diskutert. Kanskje den største utfordringen i å organisere nasjonale, regionale og lokale systemer for besøksforvaltning, er derfor en utbredt skepsis mot å rokke ved de lovmessige rammene for slik forvaltning. Det trengs både kunnskapsinnhenting, forskning og folkeopplysning på dette feltet.

\section{Litteratur}

Barth, F. (1981). Process and form in social life. Vol. 1. London: Kegan \& Paul. Eagles, P. F. J., Coburn J. \& Swartman, B. (2014). Plan qality and plan detail of visitor and tourism policies in Ontario Provincial Park management plans. Journal of Outdoor Recreation and Tourism, 7-8, 44-54. https://doi.org/10.1016/j.jort.2014.09.006

Eagles P. F. J., McCool, S. F. \& Haynes C. D. (2002). Sustainable tourism in protected areas. Guidelines for planning and Management. IUCN Gland, Switzerland and Cambridge, UK.

Fredman, P., Stenseke, M., Liljendahl, H., Mossing, A. \& Laven D. (2012).

Proceedings. The 6th International Conference on Monitoring and Management of Visitors in Recreational and Protected Areas. Outdoor Recreation in Change - Current Knowledge and Future Challenges. 21.-24. august 2002. Stockholm, Sverige.

Hansen, A. H. \& Lykkja, H. (2018). Hvordan gjør vi lokalsamfunnet i stand til å ta imot besøkende. https://lofoten.info/sites///lofoten.info/files/ besoeksforvaltning__ reiselivskonferansen_lofoten_7_feb_2018.pdf (nedlastet oktober 2019). 
Hyslop, K. E. \& Eagles, P. F. J. (2007). Visitor Management policy of national parks, National wildlife areas and refuges in Canada and the United States: A policy analysis of public documents. Leisure/Loisir, 31 (2), 475-499. https://doi.org/10.1080/14927713.2007.9651392

Holmgren, L., Sandstrøm, C. \& Zachrisson, A. (2017). Protected area governance in Sweden: new modes of governance or business as usual? Local Environment, 22, 22-37. https://doi.org/10.1080/13549839.2016.1154518

Keskitalo, E. C. H., Juhola, S., Baron, N., Fyhn, H. \& Klein, J. (2016). Implementing Local Climate Change Adaptation and Mitigation Actions: The Role of Various Policy Instruments in a Multi-Level Governance Context. Climate, 4 (1), 7. https://doi.org/10.3390/cli4010007

Koiman, (2003). Governing as governance. London: Sage Publications.

Kaltenborn, B. P. (2012). Bruk og vern i utmarksområder. Sluttrapport. Strategisk instituttprogram for perioden 2009-2011. NINA Temahefte 50. Lillehammer: NINA.

Lascoumes, P. \& Le Gales, P. (2007). Introduction: Understanding public policy through its instruments - From the nature of instruments of the sociology of public policy instrumentation. Governance, 20, 1-21. https://doi.org/10.1111/ j.1468-0491.2007.00342.x

Nunkoo, R. (2017). Governance and sustainable tourism: What is the role of trust, power and social capital. Journal of Destination Marketing \& Management, 6, 277-286. https://doi.org/10.1016/j.jdmm.2017.10.003

Nyseth, T. \& Viken, A. (2015). Communities of practice in the management of an Arctic environment: Monitoring knowledge as complementary to scientific knowledge and the precautionary principle? Polar Record, i trykken. https://doi.org/10.1017/S003224741500039X

Pearce, D. (2017). Destination management and visitor management: Nonconvergent litteratures but complementary. I J. N. Albrecht (red.), Visitor management in tourism destinations (s. 9-21). Wallingford: Cabi. https://doi. org/10.1079/9781780647357.0009

Pedersen, K. (1999). «Det har bare vart naturlig». Friluftsliv, kjønn og kulturelle brytninger. Doktoravhandling. Oslo/Alta: Norges Idrettshøgskole.

Peters, B. G. (2017). Management, management everywhere: whatever happened to governance. International Journal of Public Sector Management, 30, 606-614. https://doi.org/10.1108/IJPSM-05-2017-0146

Putnam, R. D. (2000). Bowling alone: America's declining social capital. London: Springer. https://doi.org/10.1007/978-1-349-62397-6_12 
Reimann, M., Sepp, K., Pärna, E. \& Tuula, R. (2014). Proceedings. The 7th International Conference on Monitoring and Management of Visitors in Recreational and Protected Areas (MMV). Local Community and Outdoor Recreation. 20.-23. august 2014. Tallinn, Estland.

Sørensen, E. \& Torfing, J. (2009). Making governance networks effective and democratic through metagovernance. Public Administration, 87, 234-258. https://doi.org/10.1111/j.1467-9299.2009.01753.x

Vorkinn, M. (2014). Nasjonal standard for besøksregistreringer i nasjonalparker. Oppsummering av norske og internasjonale erfaringer, anbefalinger for et norsk system. Notat. Upublisert.

Weaver, D. B. \& Lawton, L. J. (2017). A new visitation paradigm for protected areas. Tourism Management, 60, 140-146. https://doi.org/10.1016/j. tourman.2016.11.018

Wenger, E. (1998). Communities of practice and social learning systems. Organization, 7, 225-246. https://doi.org/10.1177/135050840072002 


\section{TURISME, KUNNSKAPSHEGEMONIER OG SJØLREGULERING PÅ SVALBARD}

Arvid Viken

\section{Introduksjon}

Det er i dag et anerkjent prinsipp at de som er gjenstand for offentlig styring, bør delta i styringsprosessene (Rohdes 1997; Kooimann 2003). Dette har også vært forfektet for reiselivsutviklinga på Svalbard, der reguleringsanordninger for turismen ofte har blitt utviklet i samarbeid mellom myndighetene og reiselivsnæringa (Viken 2006, 2011). Men det finnes også eksempler på det motsatte; statlige organer som unnlater å involvere reiselivsnæringa. Reiselivet blir ikke alltid ansett som en legitim lokal interessent (McKercher 1992, s. 468) og blir derfor ikke alltid tatt med på råd. Et eksempel på dette opplevde man på Svalbard i 2006, da et forslag til en altomfattende regulering av Øst-Svalbard ble foreslått, bestemmelser som nærmest ville sette en stopper for turismen i området. Reiselivsnæringa protesterte, fikk støtte fra mange andre, og ble hørt. En modell med utvikling av en forvaltningsplan ble valgt i stedet. En av strategiene fra reiselivsnæringas side for å unngå slike situasjoner er å opptre ansvarlig og i realiteten sjøl stå for en aktiv regulering av feltet. I dette kapitlet skal vi beskrive denne prosessen, som illustrerer at tradisjonell hierarkisk forvaltning vil møte motbør i våre dager. De som styres, forventer å få delta i styringsprosessene.

Styring er basert på kunnskap. Men kunnskap eller vitenskap er et komplekst felt. Sjøl om disiplin- og formalkunnskap fortsatt har en solid posisjon, blir slik kunnskap utfordret (Gibbons et al. 1994). Kunnskapen som ligger til grunn for forvaltningen, er gjenstand for forhandlinger mellom 
forskningsmiljøer, forvaltere, kommersielle selskaper, bransjer og lokalsamfunn. Dagens kunnskap, hevder Nowotny (2003, s. 155), «er ikke bare validert i sin disiplinære sammenheng. ... Den er også utfordret av et større fellesskap som insisterer på at deres stemme skal bli hørt og kan være like gyldig ... som de fra avgrensede vitenskapelige miljøer.» Dette er hva som skjedde på Svalbard, da forslaget om avstenging av Øst-Svalbard dukket opp. Både beslutningen og dens kunnskapsbase ble dratt i tvil. Forslaget var verken vitenskapelig eller offentlig robust, slik mange oppfattet det.

Dette kapitlet forteller to historier. Den første handler om forslagene om avstenging av Øst-Svalbard og protestene som fulgte (se Nyseth \& Viken 2015). Den andre historien handler om utvikling av et sett med retningslinjer (guidelines) for ilandstigning av turister. Historiene er forbundet, da utvikling av nye retningslinjer for ilandstigning var en del av protesten. Retningslinjene representerer et mykere forvaltningsregime og demonstrerer alternative måter å håndtere turismeområder og turistaktiviteter på, og de demonstrerer en ansvarlig reiselivsnæring. I begge historiene er spørsmål om kunnskap sentralt: Hvilken kunnskap, eller hvilken type kunnskap bør ligge til grunn for beslutninger og forvaltningsregimer?

Kapitlet starter med en presentasjon av turismen på Svalbard, etterfulgt av den teoretiske rammen for analysen, governans og turistretningslinjer. Dataene som ligger til grunn for kapitlet, blir deretter presentert, etterfulgt av først en beskrivelse av avstengingssaken, dernest en beskrivelse av prosessen hvor turistretningslinjene ble etablert. I en diskusjon mot slutten ses saken som en hegemonikamp mellom to kunnskapstyper.

\section{Svalbardturismen og miljøsituasjonen}

Turismen på Svalbard startet i siste halvdel av 1800-tallet. Øyene har vært under norsk kontroll siden 1925, men er av mange sett på som et område som Norge forvalter på vegne av det internasjonale samfunnet. Ifølge Svalbardtraktaten (fra 1925) har Norge et ansvar for å bevare øyenes natur. Derfor har miljøforvaltning stått høyt på agendaen siden de første verneregimene ble opprettet på slutten av 1920-tallet (jf. Viken 2011). På den andre siden har øyene lenge blitt betraktet som naturressurser som kan og bør utnyttes. Det startet med hvalfangst i farvannene tidlig på 1600-tallet, fangst på sel og bjørn fram til cirka 1980, og fra siste halvdel av 1800-tallet ulike for- 

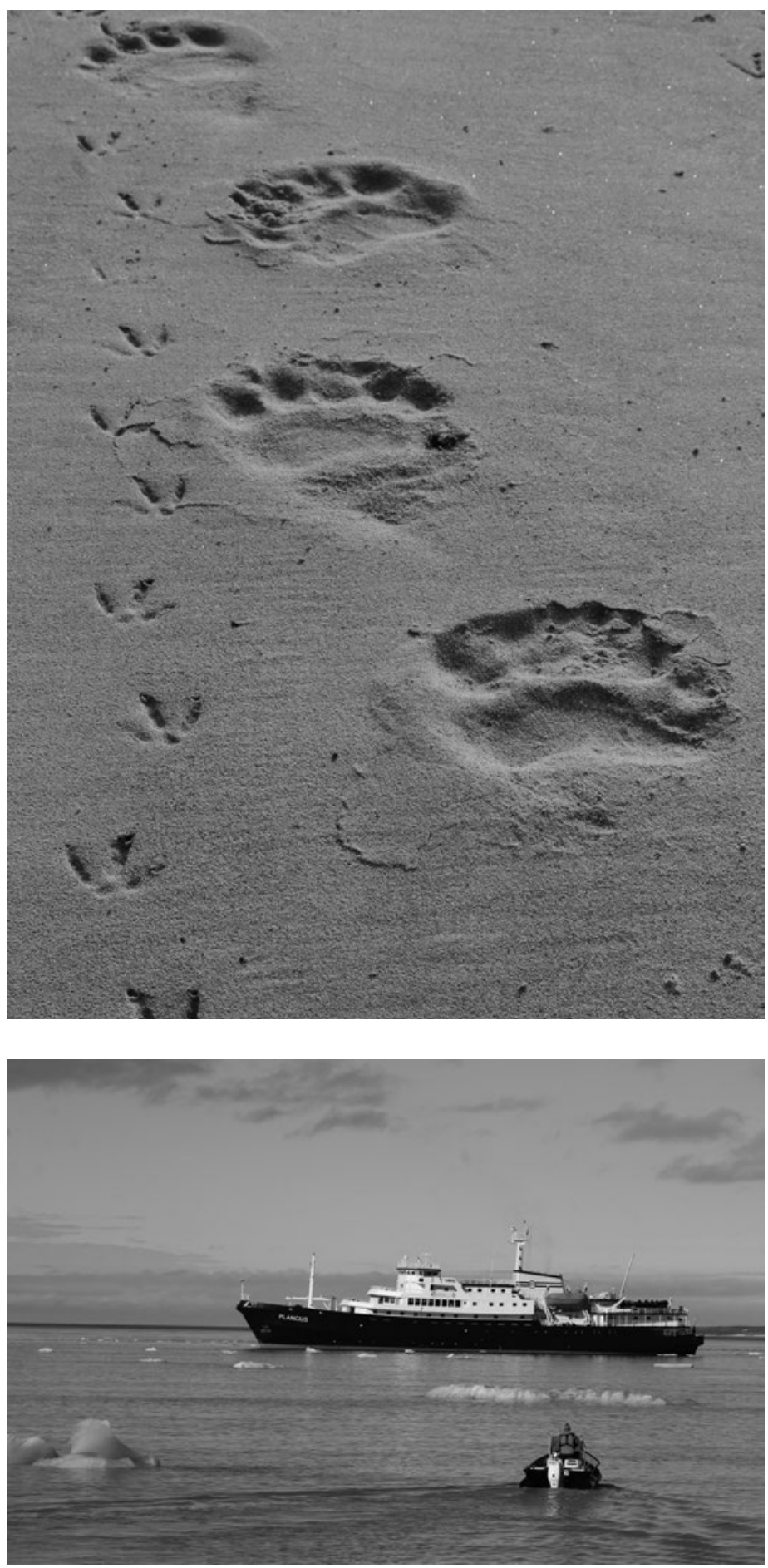

Svalbard - hvem sitt land er det? Foto: Ole Magnus Rapp. 
mer for gruvedrift og turisme. Siden slutten av 1980-tallet har politikken vært at det skal være et mangfold av næringsaktiviteter på øyene, ikke bare gruvedrift. Dette krevde at man utviklet et relativt standard lokalsamfunn i Longyearbyen, den største bosetningen på øya. Blant de 'nye' næringene var service, undervisning, forskning og romindustri (drift av antenner og håndtering av satellittdata), og reiseliv som en aktivitet drevet i og fra Longyearbyen. Å satse på turisme viste seg å være en vellykket politikk. Det har vært en jevn økning både i aktivitetene og antall besøkende siden tidlig på 1990-tallet (ibid.). Også cruisevirksomheten har økt, med ilandstigning og aktiviteter mange steder på og rundt øyene. Både økningen og spredningen aktualiserte spørsmål om regulering, overvåking og kontroll.

I 2011 var det cirka 80000 turister, cirka 48800 av dem var cruisepassasjerer, som gikk i land på til sammen cirka 140 steder, men 80 prosent av ilandstigningene fant sted på 112 steder (Amundsen 2011a, Sysselmannen på Svalbard 2011), hvorav 31 regnes som særlig utsatt. Turistene til Øst-Svalbard telte 6345 i 2010, en tredobling siden 2004, og disse turistene gjorde til sammen 15526 ilandstigninger. De fleste av turistene besøker imidlertid bare noen få steder (2,5 i snitt), og mange av besøkspunktene har mindre enn hundre besøkende per år (Svalbard Reiseliv 2004). Besøksstedene er valgt på grunnlag av særlig to kriterier, at det er noe å se og gjøre på stedet, og like viktig, at det er mulig å gå i land fra gummibåter (zodiaker). Det er Isfjord-området og vestkysten av Spitsbergen som er Svalbard-turismens kjerneområder.

Miljøsituasjonen på Svalbard ble karakterisert som tilfredsstillende på begynnelsen av 2000-tallet (Presterud 2003). Det finnes områder hvor turismen har satt spor, og hvor man har hatt tilløp til erosjon som følge av tråkk fra turistene, men generelt er de lokale miljøproblemene små. Virkningene av globale miljøproblemer er langt mer alvorlige. Svalbard har vist seg å være et egnet sted for observasjoner av globale miljø- og klimaendringer. Alle langtidsvirkningene av turismen er imidlertid ikke kjent, og det vil alltid være behov for overvåking og forskning på ringvirkningene.

Tradisjonelt har feltene turisme og miljø på Svalbard vært styrt av generelle lover, policy-dokumenter som stortingsmeldinger og interne rapporter, og beskyttet gjennom vernebestemmelser om nasjonalparker eller naturreservater. Det er også utviklet relativt omfattende informasjon om dette, og det foregår en kontinuerlig overvåking fra Sysselmannens side som også inkluderer politiarbeid. I 2002 ble miljøprofilen betydelig styrket 
av svalbardmiljøloven. Denne loven gir for eksempel myndighetene rett til å stenge av et område dersom menneskelige aktiviteter utgjør for stor belastning på miljøet. Den generelle oppfatningen er imidlertid at det er mange andre måter å verne miljøet på, og at disse bør testes ut før områder stenges for menneskelige aktiviteter.

Generelt står man fritt til å bevege seg på og rundt Svalbard. Bare noen få steder er stengt, det gjelder noen naturreservater og siden 2010 områdene rundt ti kulturminner. Det er forbudt å plukke blomster, å nærme seg dyr og å forfølge isbjørn, og motorisert ferdsel utenom veiene er ikke tillatt verken sommer eller vinter. Snøskuterkjøring er imidlertid et unntak, som en aktivitet som ikke var regulert før den nye loven fra 2002, og ansett som et uvurderlig gode på øyene. Havet langs kysten er ikke sterkt regulert. Bortsett fra i naturreservater har cruiseskipene tilgang til det meste av kysten, både for seiling og ilandstigning.

\section{Regulering og forvaltning av miljøet}

Slik samfunnet er organisert i dag, er et reisemål utviklet og drevet av næringsaktører og organisasjoner, men det er også styrt, regulert og forvaltet av myndighetene. Begrepene er beslektet, men henspiller på ulike nivåer og faser i det politisk-administrative systemet (Jessop 1999). Enkelt sagt refererer styring til prosesser hvor grunnlaget for forvaltning blir satt gjennom at politiske diskusjoner og beslutninger nedfelles i policydokumenter og planer. Styringsprosessene danner rammer for regulering og forvaltning. Regulering refererer til prosesser der regler (for eksempel lover og forskrifter) blir besluttet. Svalbards forvaltning henviser til prosesser hvor slike lover og regler implementeres; gjennom planer, beslutninger, praktiske ordninger, overvåking, evaluering og kontroll. Det er alltid en sammenheng mellom regulering og forvaltning. Forvaltning omfatter også ordninger som stimulerer, forenkler, støtter eller på annen måte gjør bedrifter i stand til å eksistere og tjene penger. I forvaltningen av turismen i uberørte og sårbare områder trengs det gjerne spesielle forordninger. Hendee og kolleger (1992, s. 181) nevner en hel serie av styringsprinsipper som kan gjelde i naturområder. De skiller mellom å forvalte et område som en ressurs og å forvalte menneskelige aktiviteter og innflytelse; håndtering av et område som en helhet eller som separate deler; og som et valg 
mellom en minimal eller en altomfattende styringsmodell. De anbefaler også å betrakte offentlig regulering som en nøkkel til aksept og suksess i utnyttelse av naturen, og anbefaler overvåking som et styringsverktøy.

En viktig del av reiselivsforvaltningen er besøksledelse - «visitor management». Besøksledelse er ofte brukt som et verktøy for å sikre et bærekraftig eller levedyktig reiseliv. Dette kan best oppnås gjennom å tilby høy kvalitet på opplevelsene og gjennom å fremme aktsomhet i omgangen med naturen. Besøksledelse er også definert som en «prosess til forening av de potensielt konkurrerende behovene til den besøkende, stedet og vertssamfunnet» (Grant 1994, sitert av Kuo 2002, s. 88). Dermed er målene for besøksledelse å kombinere omsorg for de besøkende med lokale behov og miljøvern. Midlene og metodene for dette er mange. Det er for eksempel laget et skille mellom hard og myk besøksledelse, hard som anvendelse av regler og fysiske virkemidler, myk som undervisnings- og informasjonsvirkemidler (Kuo 2002, s. 89).

Blant de harde styringsverktøyene er tradisjonell regulering. Dette er den gamle modellen på Svalbard, hvor regelverket håndheves av myndighetene. For å være effektiv må slik forvaltning omfatte politiarbeid, avstraffelse av regelbrudd og overvåking. Men slik regulering sies å redusere turistopplevelsene (Kuo 2002, s. 91). Blant regelverkene på Svalbard er svalbardmiljøloven den viktigste (2002). Den inkluderer forskrifter med detaljerte bestemmelser for enkelte områder - for eksempel hyttebygging. Den «hardeste» formen for regulering er selvfølgelig å stenge av et område; forby tilgang og alle (eller nesten alle) aktiviteter. Dette har som nevnt vært foreslått for Øst-Svalbard. Men oftest representerer reguleringen bare begrensninger på bruken, ved å angi hvordan man bør eller snarere ikke bør oppføre seg. Slike regler kan underbygges med fysiske ordninger som skilter, gangveier, utkikkspunkter, gjerder eller andre installasjoner som verner om naturen eller kulturarven (Kuo 2002). På Svalbard har det vært diskusjoner om merking av stier, som noen mener gir falsk trygghet. Fysisk skjerming med taugjerder for å lede turistene har vært brukt, blant annet i Magdalenefjorden, og som beskyttelse rundt gamle graver. Men den generelle holdningen på Svalbard synes å være at fysisk tilrettelegging virker forstyrrede på opplevelsen av natur og kulturarv. Derfor er det ikke utbredt med fysiske reguleringer. «Behold naturen urørt» er budskapet både fra de fleste turistene og turismeaktørene.

Økonomiske styringsstrategier blir av mange sett på som lite ønskelige, og effekten er omstridt. Men på Svalbard finnes det et par positive eksem- 
pler. Besøkende til Svalbard må alle betale 150 kroner for å slippe i land på øygruppen. Denne avgiften går til et miljøfond som siden 2007 har støttet mange miljøtiltak. Avgiften har vært en måte å finansiere andre former for regulering på, som informasjon og opplæring, og som det vi skal beskrive i fortsettelsen, finansiering av utvikling av retningslinjer for ilandstigningssteder - «site guidelines». Cruisepassasjerene betaler dessuten 80 kroner hver til Association of Arctic Expedition Cruise Operators (Aeco), cruiseskipseiernes egen organisasjon, som også ved en rekke anledninger har tatt forvaltningsansvar.

Informasjon er altså et styringsverktøy av den myke sorten. Men det er mange måter å gjøre det på, deriblant noen som er ganske fysiske, som skilting. Informasjonsskilter er et verktøy som særlig brukes ved kulturminnene på Svalbard. Informasjonen som gis, er kort og enkel, av den typen som er intuitivt forståelig (Kuo 2002). I våre dager dominerer informasjon på internett, også som på stedet-informasjon. Et virkemiddel i grenselandet mellom regler og informasjon er turistretningslinjer - guidelines. Disse representerer et styringsverktøy som normalt ikke har en juridisk status; «[D]e [reglene] er gitt for å oppfordre besøkende til å engasjere seg i mer passende atferd og aktiviteter ved å gjøre dem mer bevisst på ressursene», sier Kuo (2002, s. 93). For virkelig å lykkes i å skape ansvarlige turister bør en fortolkende tilnærming velges, hevder Tilden (1957). Slik han bruker begrepet, betyr det informasjon formidlet av mennesker - guider - med omfattende kunnskaper. Han ser fortolkning som en pedagogisk virksomhet som produserer mening for turisten, ikke bare fakta (1977, s. 8), og han legger til: «Gjennom fortolkning utvikles forståelse og verdier som beskytter [miljøet]» (ibid., s. 38). Dette oppnår man ikke på samme måte med nedskrevne retningslinjer.

Et viktig spørsmål i utviklinga av turisme og dens styresett er som nevnt kunnskapsgrunnlaget. Gibbons og kolleger (1994) hevdet alt på 1990-tallet å ha observert en gradvis vektforskyvning fra såkalt modus 1- til modus 2-kunnskap. De to typene er oppsummert av Goddard og Chatterton (1999); modus 1-kunnskap er «homogen, vitenskapelig og hierarkisk» (ibid., s. 687), mens modus 2-kunnskap er «heterarkisk, transparent, sosialt ansvarlig og refleksiv». Gibbons sjøl (2000) understreker at modus 2-kunnskap er sosial og kontekstsensitiv. "[S]amfunnet snakker tilbake til vitenskapen, ikke generelt og med forhåpninger, men spesielt og imperativt», hevder Gibbons (ibid., s. 161). I en annen sammenheng skriver Nowotny, Scott og Gibbons (2001, s. 203) om samfunn, vitenskap, 
marked og politikk i modus 2-samfunnet som en sammenblandet sak. Kunnskapen skal ikke bare være gyldig, men også samfunnsmessig robust. I tilfellet nevnt på Svalbard forsøkte man med den gamle typen kunnskap, altså basert på modus 1-kunnskap. Men dette mislyktes på grunn av det faktum at reiselivsnæringa og lokalsamfunnet ikke godtok det. De fleste aktørene er også der fostret opp tilpasset til en modus 2-kunnskap, mens Sysselmannskontoret tidvis henger igjen i det gamle kunnskapsregimet.

\section{Datagrunnlaget}

Nedenfor presenteres forslaget om avstenging, og den påfølgende protesten og utviklinga av turistretningslinjer er beskrevet. Dataene er dokumenter, pressemeldinger, intervjuer, uformelle samtaler og observasjoner. En del av dataene ble samlet inn gjennom deltakelse på et tokt fra sør til nord på vestkysten av Svalbard, hvor det første settet av stedsspesifikke retningslinjer ble produsert. Jeg har sjøl vært involvert i turismeplanleggingen på Svalbard på 1990-tallet og ble invitert til å delta på reisen som observatør. Siden omkring 1990 har jeg også hatt et forskerblikk på turismeutviklinga (Viken 2011). På toktet var jeg ikke en del av gruppen som monitorerte tilstanden og formulerte retningslinjene. Jeg var med for å observere hvordan prosessen foregikk. Jeg hadde mange samtaler med de involverte, hvorigjennom jeg skapte meg innsikt i bakgrunnen for prosjektet og metodene som ble brukt. Jeg gjorde observasjoner, intervjuer, overhørte diskusjoner og samtaler. Jeg snakket med aktørene om bakgrunnen for prosjektet, om deltakernes perspektiver, miljøsituasjonen, fordelene med retningslinjer og fremtidsutsiktene for turismen på Svalbard. Jeg snakket med representanter for prosjektgruppen; lederen for turismeretningslinjeprosjektet, toktleder (for denne reisen), forskerne som var ansvarlig for datainnsamlingen, to representanter fra Sysselmannskontoret, to eksperter på fauna og flere med erfaring som turleder og guide. Etterpå deltok jeg også på årsmøtet i Aeco (Association of Arctic Expedition Cruise Operators) og har hatt flere samtaler med folk som er involvert i eller ansvarlige for tilstøtende prosesser, som utviklinga av forvaltningsplanen for Øst-Svalbard. Jeg snakket også med tre turledere fra to cruiseskip som vi møtte under ilandstigninger. Det bør også legges til at tre av informantene bodde i Longyearbyen, og også representerte stemmene til lokalbefolkningen. 
Foruten dokumenter er dataene som ligger til grunn for dette kapitlet, samtaler eller det som er kalt talehendelser. En talehendelse eller samtale er en diskusjon hvor det er noen forventninger eller normer som dirigerer samtalen (Wolfson 1976). I de fleste tilfellene tok jeg initiativet og ga talen en retning, for eksempel et aspekt jeg var nysgjerrig på. Dette vil sjølsagt påvirke samtalen. De jeg snakket med, var klar over det faktum at jeg er en reiselivsforsker som har skrevet om turismen på Svalbard. Jeg var altså ikke en helt tilfeldig samtalepartner. Som Kellermann og hennes kolleger (1989, s. 27) sier, forekommer ikke samtaler i et vakuum: «... samtaler oppstår i sammenheng med tanke og kunnskap». I noen tilfeller hadde samtalene mer eller mindre formen av et intervju, da jeg gravde etter en dypere eller nøyaktig forståelse. Dette berører et metodologisk aspekt, om fortellinger dukker opp fra formelle intervjusituasjoner eller fra uformelle eller spontane samtaler (Wolfson 1976). Sistnevnte skal være mer naturlig, men jeg tror aldri jeg trådte ut av min rolle som observatør og forsker. Men dataene er av begge typer og ble analysert på samme måte.

\section{Fortelling 1: Forslag om avstenging av Øst-Svalbard}

\section{Bakgrunnen: forslag om avstenging}

Øst-Svalbard ble vernet på 1970-tallet og har status som naturreservat, og området er blant annet regulert gjennom en eksisterende forskrift. På et møte i Det interdepartementale polarutvalget (Polarutvalget) ble det i 2004 besluttet å etablere en arbeidsgruppe som skulle vurdere en forskrift for farvannene rundt Svalbard. Rapporten som ble laget, viser at det har vært en viss uenighet i gruppen. Det mest kontroversielle forslaget var det som innebar avstenging av Øst-Svalbard. Argumentet som ble brukt, var at Øst-Svalbard skulle være et såkalt referanseområde for forskning. I forslaget ble det argumentert for at området skulle forbli upåvirket av den moderne utviklinga, slik at området i framtida kunne sammenholdes med områder hvor slik påvirkning var uunngåelig. Forslaget innebar mer eller mindre avstenging av Øst-Svalbard, om lag en tredjedel av øygruppen. Miljøverndepartementet oversendte dette til Sysselmannen på Svalbard. Forslaget hadde ikke vært gjenstand for politiske forhandlinger da det ble forelagt Sysselmannen, som sendte det ut på høring. Forslaget var ikke for- 
ventet, og den påfølgende høringen ga kommentarer både for og imot. Det vitenskapelige grunnlaget for forslaget ble dratt i tvil i flere av uttalelsene. Etter en gjennomgang av kommentarene ble en ny høring gjort, der noen av aktørene ble bedt om å utdype sine synspunkter. Blant disse var Norsk Polarinstitutt, som også hadde hatt en representant i gruppen bak forslaget. Flere anså dette som en besynderlig håndtering av saken.

En aktørgruppe som var sterkt berørt, var medlemmene i Aeco, altså organisasjonen for cruiseskipsnæringa i Arktis. Organisasjonen frontet motstanden, men valgte en strategi som involverte en rekke virkemidler og aktører. Organisasjonen argumenterte med at avstenging ville bety en innskrenking av medlemmenes aktiviteter. Aeco jobbet også lokalt i et nettverk som diskuterte implikasjonene. Aeco hadde også møter med lederen i Unis, det lokale universitetet og formannen for lokalstyret, det øverste lokalpolitiske organet i Longyearbyen. En annen strategi var å ha møte med statsråder som hadde tilknytning til saksfeltet, for å presentere sitt syn, og et møte med parlamentarikere fra Troms. Dette resulterte i at saken ble tatt opp i Stortingets spørretime. En tredje strategi var å anvende medier. I særlig grad ble Svalbardposten et debattorgan i saken. Avisa uttrykte motstand mot avstengingen på lederplass. En fjerde strategi var å engasjere en advokat spesialisert i forvaltning av polarområdene, en femte å skape oppmerksomhet internasjonalt. Utenlandske ambassader ble kontaktet og informert om hva deres lands cruisenæringer hadde i vente. Strategiene var å informere, overbevise og bygge allianser. Dette pågikk over flere år, og i 2009 betalte det seg. Miljøverndepartementet besluttet da at forslaget skulle settes til side til fordel for utvikling av en forvaltningsplan for Øst-Svalbard. Sysselmannen på Svalbard ledet arbeidet med denne planen, og reiselivsnæringa, både Svalbard Reiseliv (DMO) og Aeco, hadde representanter i planutvalget. Blant de mange arbeidsgruppene i denne prosessen var det også en for reiseliv. Et utkast til en forvaltningsplan ble presentert mot slutten av 2011, og den ble endelig vedtatt i 2013.

\section{Prosessen slik den ble oppfattet av noen interessenter}

Flere av informantene viste i intervjuene til en gruppe mennesker innen sentralforvaltningen og noen forskningsinstitusjoner som har stor innflytelse på svalbardsaker, og som er imot turismen på Svalbard. Informantene 
kunne navngi personene. Blant personene som støttet avstengingen, var også lederen av Norsk Polarinstitutt, som i Aftenposten (2006) uttrykte at forslaget var en seier for forskningen. Disse menneskene har dannet seg et «monsterbilde» av turismen, hevdet en informant. «De behandler Svalbard som om det var deres egen private eiendom», sa en annen.

Flere informanter mente at avstengingsgruppen besto av mennesker med høye stillinger i myndighetsorganer og organisasjoner med ansvar for Svalbard. Flere av dem hadde også hatt roller som bisittere i Polarutvalget, på grunn av sin svalbardkompetanse. Slik informantene så det, ga dette dem større innflytelse enn deres posisjoner skulle tilsi. Utviklinga på Svalbard er politikk og ikke administrasjon, hevdet en av informantene. Disse menneskene ville uansett hatt innflytelse i saker som denne, da det er relativt få som har svalbardkompetanse. Dette gir dem posisjoner og makt. Men systemet kan representere et demokratisk problem.

\section{Lokalsamfunnets stemme}

Sjøl om Øst-Svalbard er et område som bare noen få har besøkt, var lokalsamfunnet i Longyearbyen imot avstenging av Øst-Svalbard. Det er et stort område, og det var åpenbart støtende for lokalbefolkningen å miste retten til å ferdes der. Avstengingen fikk åpenbart stor symbolsk betydning. Svalbard skal være en arena for menneskelig aktivitet, slik folk flest ser det, ikke bare et laboratorium for naturvitenskapelig forskning. Saken ble derfor mye omtalt i lokalavisen, særlig høsten 2011. Følgende uttalelser er blitt ytret i den lokale avisen (Amundsen 2011a og b):

- Dette er trakassering (redaktør av Svalbardposten)

- Det er nesten så du gir opp. Her skapes regler. En slik omfattende lukking er ikke nødvendig. Imidlertid styres Sysselmannen åpenbart av Miljøverndepartementet (nestleder i Longyearbyen lokalstyre)

- Hvis området lukkes slik foreslått, vil Universitetsstudiet på Svalbard utestenges fra sitt naturlaboratorium, både når det gjelder utdanningsprogram og forskningsaktiviteter (leder av Universitetsstudiene på Svalbard) 
- Sårbarhetsvurderingen fra Norsk Polarinstitutt er et av de verste verker som noensinne har kommet fra dette instituttet (leder av en stor turoperatør)

- Ifølge forskerne er det ikke behov for et slikt referanseområde. Hva er da argumentet? (leder av Longyearbyen lokalstyre)

Dette forteller at cruisenæringa langt fra var den eneste lokale motstanderen av den foreslåtte avstengingen. Dermed ble det også en konflikt mellom lokalsamfunnet og sentrale myndigheter, eller som de lokalt ser det, en liten gruppe ekstreme proteksjonister i etater og organisasjoner som håndterer politikk for og forvaltning av Svalbard. Og som noen så det lokalt, er det også en konflikt mellom moderne og gammeldagse måter å styre på, og om hva som bør være kunnskapsbasen for slik styring.

\section{En foreløpig sluttpå historien}

I november 2012 ble det presentert en forvaltningsplan for Øst-Svalbard. Her ble det foreslått et sonesystem med fem soner: en sone A som referanseområde for forskning, åpen for alle, men med meldingsplikt, en sone B (Tusenøyene), lukket for alle i hekkesesongen (15.05.-15.08.), en sone C for de mye besøkte områdene, en sone D for beskyttede og avstengte kulturarvsteder og en sone E som dekker Kong Carls Land for beskyttelse av isbjørn. De to siste begrensningene har allerede eksistert i noen år. Dette innebar at cruiseturismen nesten kunne fortsette som før, med mindre unntak. Cruiseindustriens og lokalsamfunnets protest endte med nederlag for forkjemperne for avstenging, eller i det minste delvis; ifølge planen er fortsatt ganske store områder stengt for turisme i sommersesongen.

\section{Fortelling 2: Utviklinga av turismeretningslinjer på Svalbard}

Da Aeco ble klar over forslaget om avstenging av Øst-Svalbard, ble organisasjonen en forkjemper for interessentene mot, som beskrevet ovenfor. En av deres strategier var også å vise en ansvarlig oppførsel i sin måte å utøve turismen på. Derfor tok organisasjonen initiativ til å utvikle retningslinjer for besøksstedene i området (site guidelines). Som en del av 
dette arbeidet ble alternative forskningsmiljøer invitert inn, med sikte på å utvikle alternativ kompetanse på miljøet på Svalbard. Prosjektet ble finansiert av Svalbard miljøvernfond, som administreres av Sysselmannen på Svalbard. Således er det ganske tydelig at sentrale aktører på Svalbard $ø$ nsket velkommen prosjektet og de valgte strategiene. Prosjektet hadde til hensikt å ende opp med retningslinjer for de mest brukte besøksstedene på vestkysten og ikke området som skulle lukkes. Utviklingsprosjektet Aeco Guidelines 2011 var i utgangspunktet en reise fra sør til nord på vestkysten av Spitsbergen. Om bord på skipet var prosjektgruppen ( 6 personer), inkludert generalsekretæren for Aeco. Med var også innleide eksperter i ornitologi (2), botanikk (1) og kulturarv (1), tre observatører (en representant for Miljøfondet, en journalist og en reiselivsprofessor) samt en gruppe webdesignere (6), som skulle tilrettelegge retningslinjene grafisk og lage nettsider. På alle besøksstedene ble gruppen satt i land med gummibåter. Ornitologene skannet området før gruppen som helhet ble satt på land. Prosjektgruppen og ekspertene laget en oversikt over hvert område med hensyn til dyre- og planteliv og fylte ut et skjema som anga sårbarhet og attraksjonskraft for stedet. Tilbake på skipet etter en inspeksjon oppsummerte gruppen sine funn, og de utarbeidet et utkast til en tilstandsrapport og retningslinjer for stedet. Journalisten som var med som observatør, ble involvert i å skape så fengende tekster som mulig. Etter et par dager kom webdesignerne med forslag til en standard for nettsidene. Retningslinjene var så godt som ferdige da toktet ble avsluttet.

\section{Behovet for retningslinjer}

Det er selvfølgelig flere argumenter for å utvikle et sett med retningslinjer. På turen ble guider og representanter for turoperatørene eller cruiseskipene spurt om sin mening. Ingen av dem som ble snakket med, støttet en avstenging av Øst-Svalbard, og alle så utvikling av retningslinjer som nyttig, blant annet fordi det hadde vært uklarhet omkring eksisterende regler. Det er flere regler som er relevante for turoperasjon på Svalbard, og det gjøres ofte endringer. Det er åpenbart vanskelig for turoperatørene å vite hva som til enhver tid er gjeldende regler. De intervjuede ønsket velkommen retningslinjer som informerer dem om hva de kan gjøre, og hvor. For eksempel trodde en guide på et cruiseskip at turistene ikke hadde lov til å gå inn mellom gravene i Smeerenburg, en nederlandsk hvalstasjon fra tidlig 
på 1600-tallet. For ikke å gjøre noe galt beordret hun dem om ikke å gjøre det. En guide på et annet skip trodde ikke at man kunne gå nærmere enn hundre meter fra kulturarvforekomster, noe som også er feil. Det ble hevdet at Sysselmannens nettside ikke var tydelig angående disse aspektene. Nye retningslinjer - guidelines - for området ville skape klarhet og gi guidingen legitimitet, mente flere av dem jeg snakket med. En representant for et av cruiseskipsselskapene hevdet at da han startet som turleder på Svalbard i 1981, syntes han det var galt at turistene plukket med seg ting fra tidligere tider (som suvenirer). Han hadde forsøkt å hindre dette, men opplevde å bli mistrodd av turistene. Han følte at han hadde manglet autoritet. Derfor mente han at en ganske detaljert regulering ville skape klarhet. Ved å kunne referere til en organisasjon som cruiseindustrien kollektivt har grunnlagt, ville han få en autoritet som han ikke hadde hatt som individuell guide. En liknende holdning ble uttrykt av en representant for et annet cruiseselskap. Han fortalte også at retningslinjene med Aecos stempel ikke bare gir legitimitet, men også er noe å diskutere i møter med passasjerene. De fleste skipene har gjennomgang (recap) av dagens opplevelser som del av kveldsprogrammet om bord. Guiden, som også var foreleser om kvelden, hevdet at cruiseoperatørene forplikter å utvise samfunnsansvar, og at alle må støtte opp om en ansvarlig styring av områdene. Han understreket også at de fleste cruiseselskapene bidrar til miljøarbeidet gjennom avgiften til miljøfondet og Aeco-avgiften. Man bør ha en ydmyk tilnærming til den arktiske naturen og de som forvalter den, hevdet han; det er et privilegium å kunne vise disse områdene til publikum.

\section{Hva er virkningene av prosjektet?}

Guidelines-prosjektet demonstrerer en aktiv besøksledelse som appellerer til ansvarlighet og etikk, og som skaper miljøvennlige holdninger og verdier. Retningslinjer eliminerer ikke behovet for lover, regler og kontroll, men har en mer appellerende form. En avstenging ville ikke ha læringseffekt og ville skape miljøkriminalitet fordi folk fortsatt ville ta seg inn i området, ulovlig, ble det hevdet. For Svalbard som helhet er det sannsynligvis viktigere å utvikle en ansvarlig turisme enn å forby turisme i noen områder. Avstengingsforkjemperne representerte en negativ tilnærming, som informantene var skeptiske til; avstenging skaper ikke holdninger. Turistretningslinjene representerer en metode for hvordan turismen kan eksistere sammen med 
fugler og dyr. Å skremme en gruppe gjess er ikke ulovlig, men kan skade fuglene betydelig - for eksempel så mye at moren og kyllingene hennes kommer fra hverandre. Dette må man bli fortalt, slik at man unngår å gjøre det. Å trampe på et kulturarvelement er ulovlig, men mange steder kan det være vanskelig å forstå hva som er et kulturminne, grensene mellom kulturarv og steinhauger er ofte utydelige. Et enkelt informasjonstiltak kan fortelle turistene hva som er lovlig og ansvarlig oppførsel. Men også retningslinjer har sine begrensninger. En representant for cruiseindustrien legger vekt på forskjellene mellom informasjon, retningslinjer og formidling. For han er faglærte guider en forutsetning for gode turoperasjoner. Selskapet hans, sa han, har normalt opptil seks-sju guider med fagbakgrunn i geologi, biologi, marinbiologi, arkeologi eller annen relevant vitenskap om bord på skip med vel 100 passasjerer. Han tror ikke på kortsiktig opplæring og at retningslinjer er et tilstrekkelig grunnlag for god formidling. Følgende autoetnografiske fortelling illustrerer forskjellen mellom retningslinjer og interpretasjon:

Vi ankom på kysten av et område som hovedsakelig er et hekkeområde for gås. Vi ventet en stund, for ikke å forstyrre fuglene. Vi gikk vi opp en bakke, veldig grønn av fuglenes gjødsling. Vi betraktet fuglene på sjøen og $\mathrm{i}$ et fuglefjell over, og vi så store moseområder. I bakgrunnen var det en varde. Stedet var fint, men ikke veldig spennende. Så kom kulturminneeksperten bort til gruppen. Hun kunne fortelle at varden trolig ble reist av Adolf Hoel, grunnleggeren av Norsk Polarinstitutt. Han lagde kart over Svalbard og satte opp varder som målepunkter. Vi snakket om Hoels arbeid, og samtalen fortsatte. En stund etter kom botanikeren. Hun pekte på en ekstra grønn moseflekk. Det var torvmose, kunne hun meddele, ganske spesielt for Svalbard, hvor det ikke er mye torv. Hun snakket med stor entusiasme, og tilhørerne ble underholdt og lærte om det spennende livet til mose og torv.

Denne lille rapporten illustrerer betydningen av dialog eller interpretasjon. Med særs kompetente guider fikk opplevelsen på dette besøksstedet en ekstra dimensjon. Dette illustrerer også manglene i en turistretningslinje; de kan isolert sett aldri gi slike opplevelser. Uansett om det er strenge regler eller myke retningslinjer, er det behov for formidling som bare levende mennesker kan utøve. Retningslinjer er ingen garanti for gode opplevelser. 


\section{Diskusjon: en kamp om kunnskapshegemoni}

Det er en kamp om hegemoniet på Svalbard om hvordan naturen skal tolkes, brukes og forvaltes. Dette er også en kamp om kunnskapstyper og systemer. Og det er et spørsmål om makt. Inspirert av Laclau og Mouffe (1985) kan hegemoni defineres som et "politisk prosjekt for avgrensing eller lukking av en bestemt betydning» (Meriläinen et al. 2008, s. 587). Det dreier seg om forholdet mellom kunnskap og makt. Slik Foucault så det, handler relasjonen like mye om hvordan makt råder over kunnskap, eller hva slags kunnskap som slippes til, som om det mer tradisjonelle synet at kunnskap er makt. Makt er slik Foucault så det, spredt og opptrer både her og der. Denne saken har vist at kunnskap heller ikke er entydig definert. Den hierarkiske beslutningen om å stenge av Øst-Svalbard for å sikre fremtidig forskning hadde ikke et kunnskapsgrunnlag som andre aksepterte. Det fantes for eksempel ikke vitenskapelige bevis for at turisttrafikken i området skadet naturen, hevdet cruisenæringas representanter. Unis, de lokale universitetsstudiene, argumenterte mot avstenging av Øst-Svalbard, og hevdet at mennesket er et naturlig element i naturen, også på Svalbard (Braathen et al. 2011). Dette viser også at det er i ferd med å skje en forandring i synet på kunnskap, med større aksept for modus 2-kunnskap (Gibbons et al. 1994). Den gamle typen kunnskap og maktposisjoner ble utfordret av nye typer akademikere og mennesker som stilte spørsmål om beslutningsgrunnlaget, krevde gjennomsiktighet og var tvilende til legitimiteten til den planlagte avstengingen. Reiselivsnæringa demonstrerte i sitt prosjekt for utvikling av turismeretningslinjer nye måter å samle inn kunnskap på, og anvendte en tverrfaglig tilnærming, der ulike typer kompetanse laget omforente rapporter om miljøtilstanden på besøksstedene. Dette dannet så grunnlag for retningslinjene som ble produsert, og skapte en modell for framtidig utforming av slike retningslinjer (Amundsen 2011b). Resultatet passer godt inn med hvordan modus 2-kunnskap er oppfattet av andre. Ifølge Tribe (1997, s. 652) vil «[m] odus-2-kunnskapens [...] suksess vurderes ut fra sin evne til å løse et bestemt problem, kostnadseffektivitet, og dens evne til å etablere konkurransefortrinn».

De som foreslo avstenging, møtte derfor motstand også blant de ansatte hos Sysselmannen, som brukte miljøfondet til å finansiere utviklinga av retningslinjene, hvor alternativ kunnskap og forhandlinger mellom aktø- 
rer fant sted. Elam og Glimell (2004) karakteriserer det som her er vist eksempel på, som sosialt omforhandlet kunnskap. Når saken endte med avvisning av en altomfattende avstenging, var det også en seier for den moderne typen styring der forhandlinger, tilpasninger og kompromisser er en del av spillet. I løpet av åra har modus 2-kunnskap fått innpass hos Sysselmannen (Viken 2006, 2011), arbeidet med forvaltningsplanen bar preg av det. Det betyr ikke at tradisjonell forskningsbasert kunnskap har mistet sin posisjon, ei heller at man samarbeider eller har dialog om alt som har med turismen å gjøre (Viken \& Nyseth 2018).

I våre dager er det konkurranse innen forskningen, og det er ikke bare ett vitenskapssyn som gjelder. Som vist i dette kapitlet eksisterer alternative forskningsmiljøer også for kunnskapsproduksjon knyttet til miljøforhold på Svalbard. Men det er ingen stor uenighet blant forskerne om svalbardmiljøet. Det står relativ bra til, men det er risiko for forverring (som på de fleste steder). Derfor ble føre-var-prinsippet anvendt som grunnlag for forslaget om å forby all annen næringsvirksomhet enn forskning på Øst-Svalbard. Men uten vitenskapelig forankring for et slikt forslag, bare en antatt risiko, ble det et spørsmål om hvorvidt forskernes standpunkter var mer verdt enn de andres (Nyseth \& Viken 2015). Fra et bio- eller økosentrisk ståsted bør man kanskje mene det. Ingen benekter at naturvern skal være et styrende prinsipp, men plasseringen av mennesket i dette bildet er omstridt. Og videre er det betimelig å spørre om noen menneskers faglige forankring skal gi dem mer makt enn andres. Fra et demokratisk ståsted er svaret nei, det finnes mange slags ekspertise. Kunnskap om miljøtilstanden tilsier ikke direkte hva som er egnet forvaltning. Og forskerne har, som vi har sett, ulike syn og ståsteder; ikke engang naturviterne er samstemte om hva som er nødvendige tiltak.

\section{Konklusjon}

I dette kapitlet har vi omtalt en konflikt om bruk av og tilgang til deler av Svalbard, det som kalles Øst-Svalbard, og som i sin helhet er et naturreservat. Det er beskrevet en alternativ strategi til avstenging, utviklet av Aeco, cruiseoperatørenes egen organisasjon. Som vist eksisterer det alternative strategier. Aecos protester hadde massiv støtte lokalt på Svalbard. Som vist var dette også en konflikt om kunnskapsgrunnlag og styringsmodus, og 
en kamp om hegemoni. Slik det var da saken pågikk, var den gamle tenkningen omkring kunnskap utfordret av det vi har kalt modus 2, hvor både kunnskapsgrunnlag og forvaltningstiltak forhandles fram i et felt med mange aktører. Dette reiser også noen spørsmål. Først er det et spørsmål om vurdering av miljøsituasjonen; bør også de aktørene som er involvert - de som representerer presset på miljøet, være en del av forskningen der miljøtilstanden måles? Er troen på den objektive vitenskapen borte, er all kunnskap avhengig av akademisk forskning som er omforent og omsettelig? For det andre, hva med makt til å ta avgjørelser i en slik situasjon; bør den spres? Er det ikke naturvitenskapen som sitter med fasiten i spørsmål om naturen og dens trusler? Er ikke også forskningssektoren kommersiell i disse dager, med all den konkurransen som eksisterer om finansiering? Og er det gamle systemet med en mektig reguleringsinstans så diskreditert at dens avgjørelser mangler legitimitet? For det tredje, kan vi stole på en aktør som reiselivsnæringa, at den er i stand til å opptre ansvarlig overfor publikum og det internasjonale samfunnet? Det er utenfor rammen av dette kapitlet å svare på disse spørsmålene. Men de viser at det er både behov for forskning og å overvåke forskningen, og kontinuerlig ha dialog om rollene til reiselivsnæringa, forskningsmiljøene og de styrende institusjonene, på Svalbard som de fleste andre steder.

\section{Litteratur}

Amundsen, B. (2011a). Sårbarheten kartlagt. Svalbardposten, nr. 38, 6.

Amundsen, B. (2011b). Stengt, men mindre strengt i øst. Svalbardposten, nr. 49, 12.

Braathen, A. et al. (21 personer) (2011). Er Øst-Svalbards unike forskningsmuligheter tapt? Kommentar fra geologiavdelingen ved Unis. Svalbardposten, nr. 42, oktober 28.

Elam, M. \& Glimell, H. (2004). Knowledge Society as the Republic of Science Enlarged: The Case of Sweden. Working paper. Gothenburg: Section for Science and Technology Studies, Gothenburg University

Gibbons, M. (2000). Context-sensitive science. Mode 2 society and the emergence of context-sensitive science. Science and Public Policy, 27, 159-163. https://doi.org/10.3152/147154300781782011 
Gibbons, M., Limoges, C., Nowotny, H., Trow, M., Scott, P. \& Schwartzmand, S. (1994). The new production of knowledge. London: Sage.

Goddard J. B. \& Chatterton, P. (1999). Regional Development agencies and the knowledge economy: harnessing the potential of universities. Environment and Planning C: Government and Policy, 17, 685-699. https://doi.org/10.1068/ c170685

Grant, M. (1994). Visitor management. Insights, A41-A46.

Hendee, J. C., Stankey, G. H. \& Lucas, R. C. (1992). Wilderness management (2. utg.). Golden CO: North American Press, Fulcrum Publishing.

Jessop, B. (1999). Regulation theories in retrospect and prospect. Environment and Society, 19 (7), 153-216. https://doi.org/10.1080/03085149000000006

Kellermann, K., Broetzmann, S., Lim, T. \& Kitao, K. (1989). The conversation MOP: Scenes in the stream of discourse. Discourse Processes, 12, 27-61. https://doi.org/10.1080/01638538909544718

Kooiman, J. (2003). Governing as governance. London: Sage.

Kuo, L. I. (2002). The effectiveness of environmental interpretation at resourcesensitive tourism destinations. International Journal of Tourism Research, 4 (2), 87-101. https://doi.org/10.1002/jtr.362

Laclau, E. \& Mouffe, C. (1985). Hegemony and socialist strategy. Towards a radical democratic politics. London: Verso.

McKercher, B. (1992). Tourism as a conflicting land use. Annals of Tourism Research, 19, 467-481. https://doi.org/10.1016/0160-7383(92)90131-8

Meriläinen, S., Tienari, J., Thomas, R. \& Davies, A. (2008). Hegemonic academic practices: experiences of publishing from the periphery. Organization, 15, 584-597. https://doi.org/10.1177/1350508408091008

Nowotny, H. (2003). Dilemma of expertise. Democratising expertise and socially robust knowledge. Science and Public Policy, 30, 151-156. https://doi. org/10.3152/147154303781780461

Nowotny, H., Scott, P. \& Gibbons, M. (2001). Re-thinking science. Knowledge and the public in the age of uncertainty. Cambridge: Polity.

Nyseth, T. \& Viken, A. (2015). Communities of practice in the management of an Arctic environment: monitoring knowledge as complementary to scientific knowledge and the precautionary. Polar Record, 3. juni. https://doi. org/10.1017/S003224741500039X

Presterud, P. (2003). Vurdering av landmiljøet på Svalbard: Påvirkninger, tilstand og tiltak. [Assessment of the land-based environment on Svalbard: Impacts, situation and actions]. http://miljo.npolar.no/mosj/mosj/reviews/review023.pdf 
Rhodes, R. (1997). Understanding Governance: Policy Networks, Governance, Reflexivity and Accountability. Buckingham: Open University Press.

Svalbard Tourism (2004). Reiselivsutviklingen i Longyearbyen. En evaluering. [The tourism development in Longyearbyen. An assessment]. Longyearbyen: Svalbard Tourism Board.

Sysselmannen for Svalbard (2011). Øst-Svalbard. Rapport fra arbeidsgruppe forskning/utdanning. Longyearbyen: Sysselmannen på Svalbard.

Tilden, F. (1957). Interpreting Our Heritage. Chapel Hill, NC: University of North Carolina Press.

Tribe, J. (1997). The indiscipline of tourism. Annals of Tourism Research, 24, 638-657. https://doi.org/10.1016/S0160-7383(97)00020-0

Viken, A. (2006). Svalbard. I G. Baldachino (red.), Extreme Tourism. Lessons from the world's cold water islands (s. 128-142). New York: Elsevier Science.

Viken, A. (2011). Tourism, research, and governance on Svalbard: a symbiotic relationship. Polar Record, 47, 335-347. https://doi.org/10.1017/ S0032247410000604

Viken, A. \& Nyseth, T. (2018). Co-management in environmental planning. An alternative to the precautionary principle. I S. Kristjánsdóttir (red.) Nordic Experiences of Sustainable Planning: Policy and Practice (s. 48-63). London: Routledge. https://doi.org/10.4324/9781315598529-4

Wolfson, N. (1976). Speech events and natural speech: Some implications for sociolinguistic methodology. Language in Society, 5, 189-209. https://doi. org/10.1017/S0047404500007028 


\section{Svalbard - tidlig et populært reisemål}

Svalbard ble tidlig et reisemål. Det finnes for eksempel beretninger fra Bartolomeus von Löwenighs jaktekspedisjon i 1830. Det var åpenbart en trofejakt, men han formidler også åpenbare naturopplevelser: «Underbart skjønt var utsynet over disse, delvis himmelblå, delvis hvite, delvis maigrønne eller rødlige fjellene, som i de forunderligste former, som templer, altre, klipper, sopp, padder eller drager, likesom svevet over de lange, mørke bølger» (Elstad 2004, s. 477). I sin beretning fra reisen formidler von Löwenigh også kunnskaper om øyriket og om tidligere ekspedisjoner dit, og han plasserer seg sjøl i en heroisk sammenheng, hevder Elstad (ibid.). Trolig var denne reisen relativt typisk for de første svalbardturistene, en kombinert sportsjakt og privat polarekspedisjon. Etter hvert fikk reisene til Svalbard mindre ekspedisjonspreg og ble mer og mer typiske turistreiser, omtrent slik vi kjenner dem i dag.

Et av de første merkeåra for turismen på Svalbard er 1871 - da ble den første gruppereisen med dampskip organisert til Svalbard fra Hammerfest. Ti år seinere ble det arrangert en reise som i ettertid er blitt kalt The Spitsbergen Swindle. Det ble lovet mer enn turoperatøren kunne holde, jakt på hare og laksefiske, noe som var umulig å oppfylle, men sjøl om noen klagde, var det også dem som lovpriste opplevelsene de hadde hatt, og omtaler et landskap som «er uten sammenligning vakrere enn noe annet stykke landskap jeg noensinne har sett lenger mot sør» (ibid., s. 478). På 1890-tallet opprettet Vesteraalens Dampskibsselskab en fast skipsrute mellom fastlandet og Svalbard - «Sportsruten» ble den kalt. Selskapet bygde også et hotell på Hotellneset utenfor dagens Longyearbyen, en prefabrikkert bygning i dragestil, med 30 senger, solveranda og peisestue (ibid., s. 479). Selskapet ga sågar ut sin egen avis, Spitzbergen Gazette. Den rommet ikke minst reiseberetninger fra Svalbard, men 
også populærvitenskapelige artikler om øyrikets natur og om tidligere ekspedisjoner. Etter tre år ga man opp virksomheten, og det gikk nye hundre år til man virkelig satset skikkelig igjen på landbaserte turistaktiviteter i Longyearbyen. En av grunnene til at man ga opp, var konkurransen fra cruiseskip fra andre land, det var trolig mer komfortabelt å følge samme båt helt hjemmefra. John M. Longyear, grunnleggeren av gruvedriften i Longyearbyen og mannen som har gitt stedet navn, fikk vakt sin interesse for Svalbard som cruisepassasjer i 1901. Siden den gang har Svalbard mer eller mindre uavbrutt vært et mål for cruiseskip.

Det ble også gjort forsøk på turistvirksomhet i Ny-Ålesund på 1930-tallet. Man etablerte Nordpolhotellet, som også ble drevet i tre år, i perioden 1936-1939. I 1934 hadde man fått i gang en ny fast skipsrute - trafikkert av D/S Lyngen til Svalbard, først og fremst for å betjene fastboende, men den tok også med turister. Det fortelles at den på 1960-tallet hadde passasjerer fra 18 ulike land. Med unntak av perioden 1940-1951 ble ruten opprettholdt til og med 1982, fra 1966 som en forlengelse av Hurtigruten, men med andre skip enn Lyngen. To til tre tusen passasjerer fulgte med til Svalbard på 1970-tallet.

I tillegg til cruise- og annen skipsbasert turisme har det hele tida foregått en viss ekspedisjonspreget turisme. Svalbard kan by på ekstreme friluftslivsopplevelser, og sportsturister fra mange land fristes til skiturer på eller kanoturer rundt Spitsbergen, eller til å gå fotturer om sommeren. Disse aktivitetene var slik at de krevde mye forberedelser både av fysisk trening og med hensyn til tilrettelegging, og fortsatt er det mange som i hovedsak organiserer disse turene selv. Men i dag kan man kjøpe tilrettelegging og turledelse av det lokale reiselivet om man ønsker det. En form for sports- og ekspedisjonspreget turisme som oppnådde en viss popularitet, var safarijakt på isbjørn. Jaktsafarier ble tilbudt fra 1850-tallet og framover (Kjær 2018). Kommersielle ekspedisjoner ble organisert ut fra Tromsø. Tidlig på 1950-tallet ble safarijakt et satsingsområde, og i 

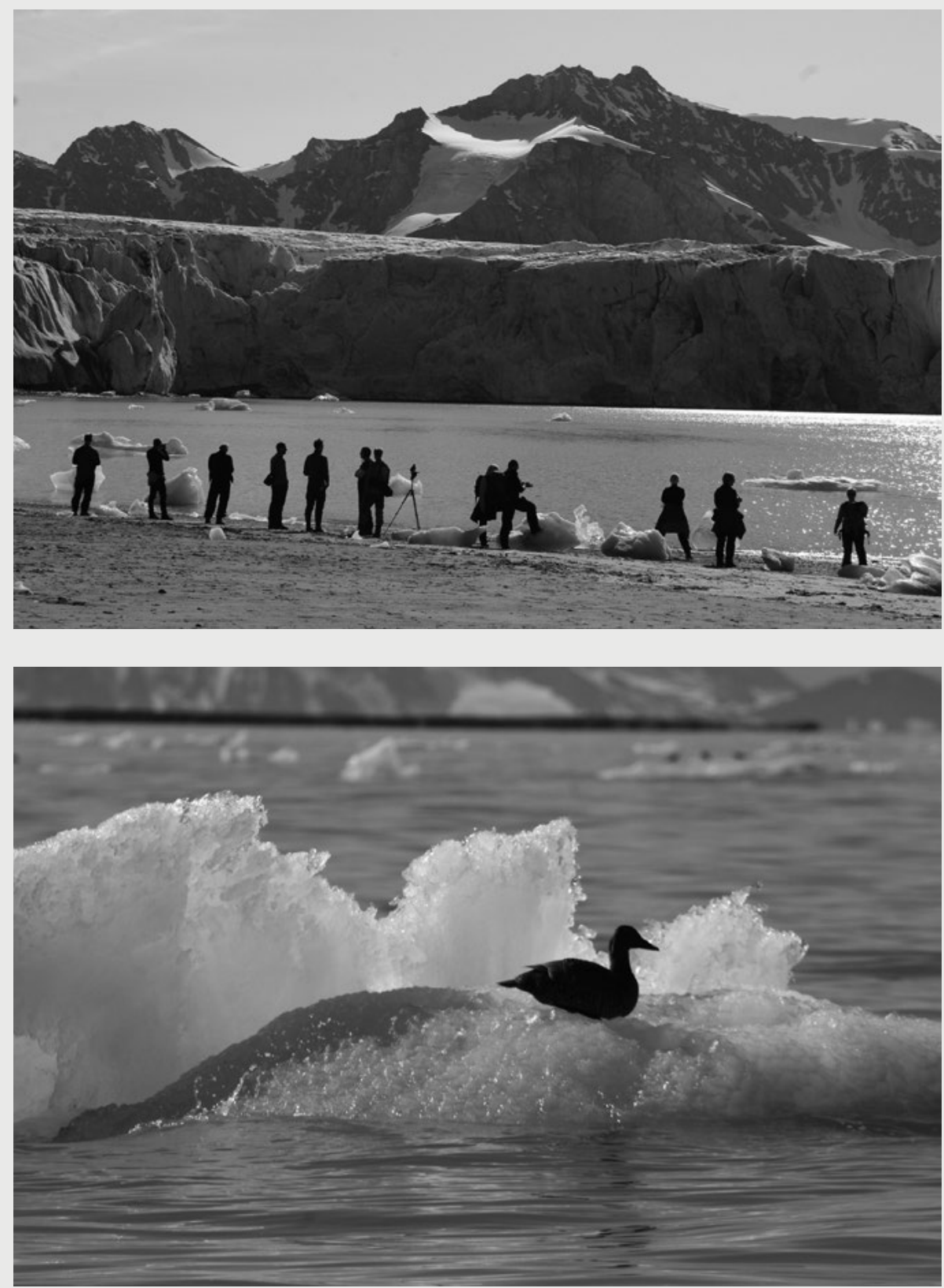

Svalbard: ulike typer besøkende. Foto: Ole Magnus Rapp. 
1960-åra ble det rapportert om opptil 86 felte isbjørner på det meste. To fartøy hadde regelmessige turer - de rakk sju-åtte turer per sesong. I 1973 tok virksomheten slutt da isbjørnjakt ble forbudt.

Svalbards turismehistorie har to hovedsider. Den ene er at turismen til en slik øy kan foregå relativt uavhengig av hva som skjer på land, i alle fall med de skipene man har hatt til rådighet siden slutten av 1800-tallet. Cruiseturismen har foregått omtrent på samme måte i over hundre år. Den andre siden av historien er at landbasert turisme er komplisert og ekstremt avhengig av offentlig politikk og infrastruktur. Når det gjelder den politiske siden, så markerte myndighetene i etterkrigstida helt fram til nærmere 1990 at de ikke prioriterte turismeutvikling, og at de av naturvernhensyn var skeptiske til slik virksomhet. Infrastrukturmessig var det lenge også vanskelig, først og fremst fordi Svalbard bare var tilgjengelig med båt, og fordi det var dårlig med forsyninger. Skulle man ferdes på Svalbard, måtte man bringe med seg sitt eget utstyr og sine egne forsyninger - en reise dit måtte organiseres som en ekspedisjon. Da flyplassen sto ferdig i 1975, endret forutsetningene seg radikalt, men ikke før på slutten av 1980-tallet kunne man få kjøpt overnatting og nødvendige forsyninger på stedet. Egentlig ble stedlig turisme motarbeidet inntil myndighetene i en stortingsmelding i 1990 - Næringstiltak for Svalbard - åpnet opp og i realiteten snudde på hælen, turisme skulle være et prioritert virkeområde fra da av (Næringsdepartementet 1990).

Tabell 13.1: Begivenheter i svalbardturismens historie fram til 2000

1871 Organisert tur med dampskip til Spitsbergen.

$1896 \quad H$ Hotelletablering i Adventfjorden, på Hotellneset - nedlagt etter to sesonger.

1890-tallet Regelmessige dampskipsanløp fra Troms $\varnothing$.

1934 Svalbardruten med D/S Lyngen etablert - ruten opprettholdt fram til 1968 (med unntak av åra 1940-1951), da Hurtigruten overtok for noen år.

$1937 \quad$ Hotelletablering i Ny-Ålesund.

1951 Huset åpnet som en kafé - også tilgjengelig for tilreisende. 


\begin{tabular}{|c|c|}
\hline 1850-1971 & Safarijakt etter isbjørn (all isbjørnjakt forbudt i 1973). \\
\hline 1975 & Dagens flyplass åpnet, og regulær flytrafikk ble etablert. \\
\hline 1981 & Svalbard museum åpnet for publikum, stiftet i 1979. \\
\hline 1985 & Første matvareutsalg (Ferskvaren) åpnet som en del av Kafé Busen. \\
\hline 985 & $\begin{array}{l}\text { Campingplassen ved flyplassen fikk nytt servicebygg og driften etablert i } \\
\text { ordnede former. }\end{array}$ \\
\hline 1980-tallet & $\begin{array}{l}\text { Formidling av overnatting gjennom billettkontoret til Store Norske } \\
\text { Spitsbergen Kulkompani. }\end{array}$ \\
\hline 1989 & $\begin{array}{l}\text { Reisebyrået (og seinere turoperatørselskapet) Spitsbergen Travel opprettet } \\
\text { som underselskap av Store Norske Spitsbergen Kulkompani. }\end{array}$ \\
\hline 1989 & Turoperatørselskapet Svalbard Polar Travel etablert. \\
\hline 1990-tallet & $\begin{array}{l}\text { Gruve } 3 \text { brukt som visningsanlegg (museum), fra } 1996 \text { (dels siden 1993) i regi } \\
\text { av selskapet Svalbard Wildlife Service. }\end{array}$ \\
\hline 1992 & $\begin{array}{l}\text { Turistinformasjon/ destinasjonsselskapet Info-Svalbard etablert som en } \\
\text { avdeling i Svalbard Samfunnsdrift (seinere tillagt Svalbard Samfunnsdrift). }\end{array}$ \\
\hline 1994 & Første reiselivsplan utarbeidet av Svalbard Næringsutvikling. \\
\hline 1994 & $\begin{array}{l}\text { Funken Hotell (i } 2020 \text { Funken Lodge) åpnet - eies av Spitsbergen Travel. Skilt } \\
\text { ut som eget underselskap fra } 1995 .\end{array}$ \\
\hline 95 & Svalbard Polar Hotel (i 2020 Radisson Blue Polar Hotel Spitsbergen) sto ferdig. \\
\hline 1995 & Galleri Svalbard åpnet. \\
\hline 1997 & Ny reiselivsplan utarbeidet av Svalbard Næringsutvikling. \\
\hline 2001 & Info-Svalbard overdratt til Reiselivsrådet og omdøpt til Svalbard Reiseliv AS. \\
\hline 2001 & $\begin{array}{l}\text { TFDS, hovedaksjonær i Spitsbergen Travel overtar aksjemajoriteten i Svalbard } \\
\text { Polar Travel. Selskapet heter nå Hurtigruten Svalbard. }\end{array}$ \\
\hline
\end{tabular}

I 2000 sto reiselivsnæringa for vel 15 prosent av de samlede antall årsverk i Longyearbyen, men dersom alle ringvirkningene regnes med, svarte reiselivsaktivitetene for mer enn en fjerdedel av arbeidsinnsatsen på stedet. Myndighetenes engasjement i turismeutviklinga manifesterte seg på 1990-tallet blant annet i at Svalbard Næringsutvikling, et selskap dannet for å skape alternative arbeidsplasser til gruvedriften, opprettet en avdeling til å forestå turistinformasjon og vertskap (Info-Svalbard). To ganger sto også Svalbard Næringsutvikling bak utarbeidelsen av en reiselivsplan (1994 og 1997). Svalbard viste seg fort å fange både investorenes og turistenes interesse, og i dag gir reiselivet grunnlag for en solid og dynamisk næring. På 1990-tallet ble det etablert to nye hoteller og en lodge (hotell med hyttepreg) med vanlig internasjonal standard, en rekke 


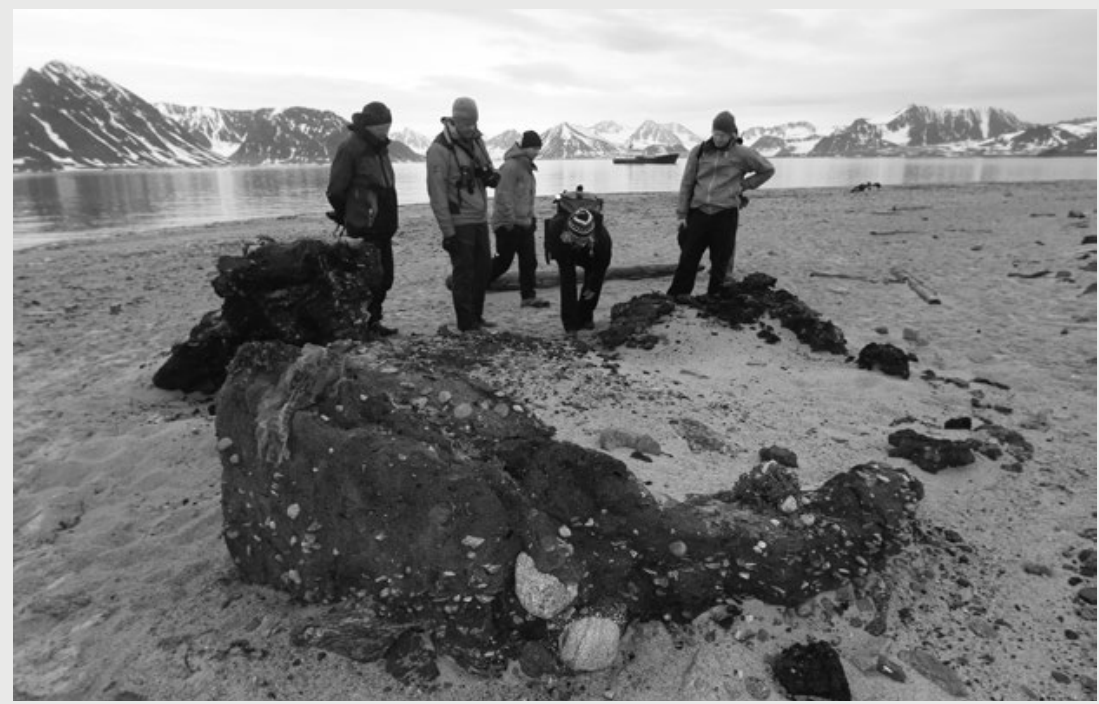

Oljeproduksjon: en miljøtrussel over 400 år (Smeerenburg og et hvalkokeri fra 1600-tallet). Foto: Ole Magnus Rapp.

turoperatørselskaper, flere trafikkselskaper og som nevnt en turistinformasjon. Hotelldriften og turoperasjonen var dominert av to relativt store selskaper. Disse ble i 2001 slått sammen. Selskapet, som eies av Hurtigruten, har siden vært den dominerende reiselivsaktøren i Longyearbyen.

Mens Longyearbyen tidligere var dominert av en tradisjonsrik gruveindustri, preges stedet i dag like mye av turismen. Gruvedriften var på grunn av subsidiebehov og andre problematiske sider (blant annet miljømessige) svært omdiskutert rundt 1990 og mistet noe av sin legitimitet, og er i 2020 under avvikling. Omlegging til annet næringsliv førte til store endringer i svalbardsamfunnet; både livsbetingelsene, landskapet, stedsånden og kulturen. Sentrale institusjoner fra gruvetida er borte. Noen av gruvetidas fasiliteter er i dag i bruk av reiselivet. Det som lokalt ble kalt Stormessa, eksisterer som en restaurant. Busen, ordet betyr gruvearbeider, var lenge en kafé (til 2007), og Lompen, busens (arbeidernes) arbeidsklær er et handlesenter. Etter hvert vil bare de færreste kjenne til ordenes opprinnelse. 
Tegnene på at stedet er et gruvesamfunn, er nesten forsvunnet; bare Taubanesentralen og noen bukker (master) står igjen som monumenter over en svunnen tid. Brakkebyene er fortrengt av moderne boligkomplekser, og bybildet domineres av universitetsbygget, museet, sykehuset, store og små butikker, andre næringsbygg, og av hoteller og restauranter. Vareutvalget i butikkene er i vesentlig grad blitt turistifisert, butikkene "pynter» seg med vimpler og annet som skal trekke kundene inn, og plakater om ukens opplevelsesprogrammer er slått opp både her og der. Arbeiderkulturen er avløst av en forbrukerkultur. Endret næringsgrunnlag og kultur har også ført til endringer i synet på turismen blant folk i Longyearbyen. Inntil midt på 1990-tallet var det en relativt utbredt skepsis til turismen i mange miljøer. Turistene ble av mange sett på som en slags pariakaste, en gruppe man vitset om og holdt avstand til. Avstand er det kanskje fortsatt, men Longyearbyen er blitt et sted av og for fremmede, og skillet mellom turister og boende er ikke særlig tydelig. Det nye synet på turismen kan forklares med endret befolkningssammensetning, men bunner også i at reiselivet er blitt en anerkjent økonomisk sektor.

\section{Litteratur}

Elstad, Å. (2004). Polarturisme. I E.-A. Drivenes \& H. D. Jølle (red.), Norsk Polarhistorie III. Rikdommene (s. 477-478).

Oslo: Gyldendal.

Kjær, K.-G. (2018). Arktisk jaktsafari. Storviltjakt i lshavet 18591909. Stamsund: Orkana.

Næringsdepartementet (1990). St.meld. nr. 50 1990-91.

Næringstiltak for Svalbard. Oslo: Næringsdepartementet. Viken, A. (2001). Fra gruvebus til turistbuss. I T. B. Arlov (red.), Fra company town til folkestyre. Longyearbyen: Svalbard Samfunnsdrift. 



\section{DEL V: EPILOG}





\section{UTFORDRINGER I DAGENS NORSKE TURISME}

\section{Paradokser og dilemmaer i norsk reiseliv}

Denne boka er en samling caser, som hver på sin måte får fram paradokser eller dilemmaer knyttet til utviklinga av reiseliv som fenomen og næring. Reiselivet er både en mulighet og en utfordring for mange lokalsamfunn. Tematikken er stor, og det er langt flere spørsmål som kan reises, enn det som gjøres her.

Reiseliv kan drives i mange formater og på mange måter. Mange steder i Norge drives det som attåtnæring eller i kombinasjon med andre aktiviteter, og ambisjonene er deretter. Paradokset er at jo mer man lykkes i å utvikle reiseliv som næring, jo større er utfordringene, utfordringer som ofte må løses på samfunnsplan eller av myndigheter. Mange steder skjer dette gradvis og uten stor debatt. Men ofte skjer det ting man ikke har tenkt over. Vi omtaler ofte dette som paradokser. Det som bryter med eller kontrasterer det gjengse, med doxa: litt uventet, litt annerledes enn tenkt, endringer som skaper nye utfordringer, uforutsatte konsekvenser. Boka viser hvordan utviklinga i reiselivet i distriktene, først og fremst i Nord-Norge, har sine paradokser. Et av de store paradoksene er at mye av det vi diskuterer i dag, ikke er nytt. I en historisk ramme for boka viser vi hvordan mange av dagens reiselivsfenomener har røtter i gammel tid, hvordan noen av utfordringene i dagens reiseliv - for eksempel cruiseturismen - har eksistert siden den moderne turismen begynte for cirka 150 
år siden. Et av paradoksene er altså at dagens doxa og paradokser har en tendens til å gjenta seg.

I flere kapitler har forholdet mellom store og små bedrifter, stordrift og vekst vært illustrert og problematisert og holdt opp mot alternative næringsformer. Stordrift gir størst inntjening, men sjelden de største opplevelsene. Dette har vi illustrert med å sammenholde opplevelser på Hurtigruten med opplevelsene i et lite, nedlagt fiskevær. Vi har også vist hvordan små bedrifter har viktige roller i lokalsamfunnet, og at lokalsamfunnet er viktig for driften. Mye av det som foregår i det vi kaller reiselivet, gjenspeiler ikke de mest etablerte økonomiske modellene, men er vevd inn i nettverk av familie og lokalsamfunn. Reiselivet på landsbygda er ofte kombinasjonsnæring, småskala og familiebasert, og bidrar til at folk kan bo der, paradoksalt nok. En del av denne virkeligheten er og at individer og lokalsamfunn inngår i større sosiale eller produktive systemer, ofte med nasjonale og internasjonale forgreininger. Folk omstiller seg eller arbeider andre steder enn der de bor. Flere av casene viser til vekst i reiseliv i utkantstrøk, på tross av makrotrender og myndigheter som favoriserer sentralisering og konsentrasjon. I et av bokas kapitler vises det hvordan små samfunn sjøl kan ta styringa og representere en motkraft når samfunnsutviklinga med vekst, stordrift og modernisering - dagens doxa - betyr nedleggelse av institusjoner som barnehage, skole, fiskebruk og butikk, og utarming og fraflytting fra bygda. I slike prosesser kan reiselivet representere en mulig vei framover.

Et av paradoksene som er blitt pekt på i denne boka, er at jo mer vellykket en bedrift er, jo større er sjansene for at man lokalt mister styring og eierskap. Når bedriftene har et betydelig overskudd, er de også interessante som investeringsobjekter. I boka vises det hvordan dette har skjedd eller skjer med rorbuene i Lofoten, på Nordkapp og for Hurtigruten. Dette er den kapitalistiske økonomiens dynamikk. Men som eksemplet fra Lofoten viser, eksisterer det motkrefter og eksempler på at lokal involvering og drift også har sine fordeler. Men det krever bevisste og reflekterte eiere, som ikke bare verdsetter økonomisk utvikling og inntjening. I svært mange av casene i boka er økonomi bare en av forutsetningene for næringsvirksomheten. Stedstilknytning, familierelasjoner og livsstil er mange ganger like viktige faktorer. Folk bor der de bor fordi de ønsker å bo der, de driver bedrifter og institusjoner fordi bygda de bor $i$, trenger det. 
I flere av casene i boka er det stedets eller aktørenes indre energi i kombinasjon med krefter eller aktører utenfra som er suksessfaktoren. Nordkappturismen er stort sett skapt av markedet, men også av lokale aktører. En ny giv i turismen i Kjølleford er skapt med Hurtigruten som katalysator. Selskapet drev både fødselshjelp og veiledning i en startfase, men de lokale aktørene gjorde arbeidet og etablerte bedriftene som få år seinere sysselsatte nærmere ti mennesker. Hvalturismen på Andenes kom i gang fordi noen fortalte at her hadde man en ressurs som kunne utnyttes $i$ reiselivssammenheng, og fordi at det fantes noen lokale mennesker som hørte på dem og tente på ideen. Det er altså relasjoner og samspill som har vært drivkraften i disse tilfellene.

I en av casene har vi fokusert på utviklinga av en attraksjon, Hvalsafari Andenes. Det var en utvikling som viser viktigheten av relasjoner mellom mennesker, men også mellom kunnskapstyper. I utviklinga av attraksjonen kunne man støtte seg til både naturvitenskap, designfag og lokale tradisjoner. Slik skapte man en vellykket attraksjon. Men Hvalsafari Andenes ble ikke den store drivkraften i reiselivet på Andøya. I mange år holdt besøket seg på cirka 15 000, og med begrenset effekt på omlandet. Altså gikk ikke destinasjonsutviklinga like greit som attraksjonstilblivelsen. Det antydes at dette kanskje bunner $i$ at å utvikle en destinasjon betinger helt annen kunnskap, og helt andre og politiske prosesser. Men paradoksalt er det.

Vi har også presentert to kapitler rundt temaet besøksforvaltning. Det ene (13) viser hvordan man gjennom å tilrettelegge for turisme - gjennom produksjon av retningslinjer (guidelines), skapte legitimitet rundt reiselivsutviklinga på Svalbard. Også her dreier det seg om kunnskap. Sjøl om naturvitenskapen er viktig for å kunne karakterisere naturtilstanden, er det ikke den eneste kunnskapen som trengs. I prosessen trengs også evne til å forhandle, overbevise og å finne kompromisser. Casen viser hvor viktig det er med dialog og respekt for alternative faglige ståsteder. I det andre kapitlet (12) om besøksforvaltning viser vi at det er behov for å sette temaet på dagsorden, både i næringa og hos myndighetene. Vi har fri tilgang til naturen i Norge for alle som vil, uansett hvor de kommer fra. Dette kalles allemannsretten. Paradokset er at dersom for mange realiserer retten, er det problematisk. Turismens frihet er også en trussel, det er grenser for hvor mange som kan benytte seg av den, uten at friheten blir et problem.

I boka er det også presentert noen caser hvor reiselivet ikke er hovedfokus, men på ulikt vis har bidratt til utvikling eller løsning av saker som 
lenge preget lokale agendaer. Ett av tilfellene er hvordan reiselivet, som en sidespiller, bidro til å løse en konflikt om en vei mellom to militære skytefelt i Målselv. Folk som arbeidet med et reiselivsprosjekt, ble konfrontert med en sak som hadde gnagd lokalsamfunnet lenge, at man ikke kunne enes om en sammenbindingsvei som måtte gå gjennom et reinbeite. Reiselivsaktørene fikk i stand dialog mellom partene, og saken løste seg. Samsnakking, initiert av reiselivsaktører og en fleksibel og framoverlent ordfører, løste saken. Paradokset er mye knyttet til doxa, altså gjengse forestillinger om veitraseer, motpartenes stridighet og manglende forhandlingsvilje. Men konflikten viste seg å være løsbar gjennom å utfordre stivnede posisjoner og syn, og gjennom å snakke sammen. I andre caser har vi antydet at løsningen på dagens utfordringer - manglende næringsutvikling, kan ligge i å åpne opp for utvidet satsing på reiseliv. Når hverdagen stritter imot, må man kanskje se i nye retninger. For eksempel kan reiselivet være en mulig satsing i en del utkantbygder.

I resten av dette kapitlet drar vi opp noen av utfordringene norsk reiseliv står overfor, og peker på noen hoveddilemmaer og paradokser som er relativt påtrengende. Først tar vi for oss stordrift og vekst. Er stordrift et nødvendig paradigme, eller finnes det alternativer? Paradoksalt nok er stordrift og vekst et mantra i reiselivet sjøl om de fleste reiselivsbedriftene er små. Hvorfor anerkjennes ikke småbedrifter og alternative driftsformer - det er dette som er mye av limet i Bygde-Norge - i politikken og akademia? Dernest drøftes fjerneierskap. Hvordan og hvorfor skal vi motsette oss fjerneierskap og fjernstyring? Er lokalt eierskap en forutsetning for et demokratisk næringsliv? Et tredje tema nær beslektet med de første to er utviklinga i cruisenæringa. Paradokset her er at det som var starten på turismen i Norge, har blitt en utfordring og trussel både for turismen som helhet, og for mange lokalsamfunn. Skal cruiseindustrien fortsatt få ekspandere og nyte godt av dårlige politiske radarer og svaksynte politikere? Etter mediestormene de siste åra er det lite som tyder på at de har folket med seg. Her foreslås radikale reguleringer - ingen er tjent med den utviklinga som i dag finner sted. Til sist drøftes allemannsretten, den er som nevnt utfordret. Prinsippet er flott, men den må forvaltes annerledes enn i dag. Og diskuteres. Til sist - i en konklusjon - påpekes det at prinsippet om bærekraft tilsier noen dyptpløyende debatter også i og om reiselivet. 


\section{Vekst og stordrift - finnes det alternativer?}

Neil Leipers har skrevet om turismen som næring. Han mener turismen som sådan er svak. Grunnlaget for dette finner han ved å anvende anerkjente prinsipper fra økonomi og ledelse. Leiper $(1990,2008)$ identifiserer turismen som differensiert og fragmentert, lønnsomheten er for lav, organiseringa er svak og profesjonaliteten sviktende, og feltet utgjør ikke en, men flere næringer (Leiper 1990). Hans karakteristikker er avledet av storbedrifts- og vekstnormen som over tid har inntatt det turismeteoretiske feltet (Saarinen 2004, 2014; Viken 2014). Sjøl om han belyser viktige aspekter ved turismen, snakker han ned næringa. Han tar ikke hensyn til fordelene eller mulighetene knyttet til de egenskapene han kritiserer. Dermed reduserer han turisme til kun et forretningsfenomen, og desavuerer turisme som et område for alternativ økonomisk og økologisk drift, og som et forretningsområde dominert av smådrift og familieforetak.

Også i norsk turismeforskning har et dominerende perspektiv vært at turismen er en svak næring, for eksempel eksponert av Flagestad og Hope (2001). De betrakter en destinasjon eller turistresort som økonomiske enheter og sammenlikner dem med bedrifter. Enhetene er åpenbart forskjellige fra en idealbedrift som en strategisk forretningsenhet, og forfatterne spør hvordan man skal oppnå et foretaks ledelsesmessige og forretningsmessige kvaliteter i en destinasjon. Dette representerer i seg sjøl en naturalisering av en forretningsmessig måte å forstå turismen på. For å oppnå «strategisk suksess» i bærekraftig destinasjonsutvikling mener Flagestad og Hope at vi må erkjenne økonomisk vekst som en premiss som overstyrer alle andre hensyn. Menneskene som bor der, og omgivelsene de er del av, er sekundære sider ved en destinasjon (Flagestad \& Hope 2001, s. 450). Flagestad og Hope argumenterer altså for å utvikle destinasjoner som strategiske forretningsenheter (ibid., s. 451). De sier også eksplisitt at deres teoretiske tilnærminger tar sikte på å fremme økonomisk effektivitet (ibid., s. 453).

Argumentet til Flagestad og Hope (2001) bygger på ideer fra Michael E. Porter (1990). Porters arbeid, og spesielt hans klyngemodell, har stått sentralt i reiselivsforskningen siden 1990-tallet, også gjennom studier av turismen innenfor avgrensede geografiske områder (se for eksempel Jackson \& Murphy 2006; Zhang, Qu \& Guo 2011). Porter baserte sin modell på analyser av nasjonalstaters konkurranseevne utviklet for andre næringer 
enn turismen. Ikke desto mindre har hans arbeid blitt mye brukt for å analysere destinasjoner dominert av små og mellomstore bedrifter. Slike studier har hevdet at klyngeeffekter kan kompensere mangel på størrelse og økonomisk styrke, og derigjennom bidra til økonomisk vekst. Jo flere små og mellomstore bedrifter som samarbeider og organiserer seg i tråd med ideen om firmaet og stordriftsfordeler, jo bedre fungerer de økonomisk. Gjennom samarbeid kan småbedrifter «likne en stor bedrift med mange separate profittsentre», og dermed «oppnå stordriftsfordeler», hevder Hjalager (1997, s. 4). Ideene som fremmes gjennom disse teoretiske diskusjonene, har bidratt til å etablere et bestemt syn på turismen og de forvaltningsmessige og politiske systemene omkring den. For eksempel har Innovasjon Norge hatt flere utviklingsprogrammer som spesielt støtter prosjekter med klyngeetablering som mål.

Turisme oppsto som næring og studiefelt i en historisk epoke der vekstprinsippet fremmet av Schumpeter og støttet av en økonom som Keynes påvirket samfunnsutviklinga og den politiske tenkningen over hele verden. Det er med dette mantraet at den norske velferdsstaten og velstanden er utviklet. Men samtidig har det funnet sted utvikling som bryter med denne tenkningen. Småbedrifter og småskala produksjon har funnet sted både innenfor tradisjonelle og moderne næringer. Både innen det vi kaller opplevelsesnæringer og kulturnæringer er det en overvekt av bedrifter som ikke primært søker vekst. Derfor har kritiske røster omtalt vekstparadigmet som en fetisjisme (Hamilton 2003) og en neoliberalistisk ideologi hvor markedet er blitt Gud (Frank 2001).

Vekstparadigmets dominans i turismeforskningen viser hvordan turismeforskere har bidratt i prosesser der «kapitalismens ekspansive og imperialistiske ... egenskaper» applauderes, og hvor turisme blir et eksempel på hvordan «... kulturlivet på flere og flere områder blir omfavnet av pengetransaksjoner og kapitalsirkulasjonens logikk», uttalte Harvey (1989, s. 344), mens Lefebvre har konstatert at fritida er blitt forvandlet til en industri (Lefebvre 1991, s. 384), og noe han betrakter som «... en seier for neokapitalismen ...» (ibid., s. 384). Andre har kalt denne utviklinga spektakularisering (Debord 2012 [1977]) eller disneyfisering (Bryman 1999). Ritzer (1993) har brukt begrepet mcdonaldisering om disse fenomenene og hevder at de handler om kapitalismens seiersgang, og transformasjon av folk flest til mer eller mindre viljeløse offer for og statister i kapitalkreftenes velregisserte og profittmaksimerende oppsetninger. 
Likevel, det finnes alternative utviklingsforløp. Småskala produksjon dominerer fortsatt i reiselivet. Motsatsen til vekst er ikke nødvendigvis ikke-vekst, men henspiller på at målene er andre og mer sammensatte. Noen anser evig vekst som en umulighet (Heinberg 2011), og særlig dersom vi skal få til en bærekraftig utvikling. Forskningen viser at det i mange næringer, og særlig innen turisme, er mange andre verdier i spill, ofte knyttet til livsstil, familieliv, politikk, religion, ideologi eller samfunnsverdier ut over det å tjene penger (jf. Peters, Frehse \& Buhalis 2009). For mange små bedrifter er det å overleve hovedmotivet. Når det gjelder destinasjoner, som samfunn og aggregater av bedrifter, er økonomisk vekst ofte av sekundær betydning. A skape jobber, opprettholde et boligmønster, utvikle en region eller støtte en landlig livsstil kan være like viktig. Slike verdier finner man i studier over hele verden, og teoretiske modeller av økonomiske systemer som fungerer på slike premisser, eksisterer også. I de fleste av disse tilnærmingene er vekst av liten betydning.

På landsbygda er landbruket og fiskeriet ikke like viktig som før, en hybrid økonomi har vokst fram med nisjeproduksjon innen jordbruk, kultur og turisme. Som nevnt observerte den norske samfunnsviteren Ottar Brox (2006) på 1990-tallet - i motsetning til det han hadde spådd et par tiår tidligere - at folk fortsatt levde langs norskekysten, men at mange hadde andre yrker, blant annet jobbet langt flere i det offentlige. Mange steder er den uformelle økonomien en viktig del av dette, sjølhushold og ikke-kommersiell utveksling av varer og tjenester er en del av hverdagen. Turismebedrifter er ofte sentrale i slike blandingsøkonomier. De representerer næringsvirksomhet, bringer inn folk og aktiviteter og tilbyr møtesteder som kafeer og barer, og er arenaer for lokale arrangementer (se kapittel 10 i denne boka). Et annet aspekt av denne økonomien er at folk som driver små bedrifter, ofte kombinerer det med andre jobber, et mønster som har lange tradisjoner i mange landdistrikter (jf. Bryden \& Bollman 2000). Dette er gjerne også en ganske fleksibel økonomi, som involverer mennesker som ikke er bundet opp til strenge livsløp eller ukentlig tidsplaner (Curchin 2013). Hybridøkonomien bør utvikles og tilpasses små og mellomstore bedrifter, og den må ikke ses på som et problem. Mange steder utgjør den selve livskjernen. Dessverre er ikke hybridøkonomien særlig påaktet i forskning og akademia. Slik reiselivet er, med en overvekt av små bedrifter, burde hybriditet og mangfold være et like fokusert mantra som vekst. 


\section{Fjerneierskapet over naturressursene; kolonialisering og imperialisme}

Norsk reiseliv selger først og fremst på vakker og utfordrende natur. Når naturen settes inn i en produksjonssammenheng, kalles den gjerne naturressurser. Råvaren er natur, produksjonen består i å tilrettelegge attraksjoner og aktiviteter, transport, overnatting og bespisning. Dette kan være produksjonsmidler i hendene på lokale aktører, men hele tida og i økende grad er eksterne eiere og drivere involvert. Tendensen er at jo større anlegg eller utstyr, jo mindre er de lokale eierandelene og den lokale kontrollen. De eksterne investorene er gjerne lokalisert til kapitalens sentra. Lokalsamfunnene tjener ofte lite på denne virksomheten, men hovedproblemet er at overskuddet som skapes, ikke går til reinvesteringer på stedet, men går ut av lokalsamfunnet. Et annet ord for en slik modell er imperialisme (Galtung 1971). Begrepet «imperialisme» kan tilbakeføres til Lenin og Marx, men har også vært anvendt for å karakterisere våre dagers forhold mellom den rike og den fattige verden (Galtung 1971; se også kapittel 6 i denne boka), hvor den rike verden øker sin rikdom på bekostning av den fattige verden. Sjøl om dette først og fremst er en teori anvendt på utviklingsland, har modellen også vært anvendt på forholdet mellom nasjonale sentra og periferi, hvor poenget er at sentrum øker sin rikdom gjennom verdiskaping i periferien. Turismen har sjølsagt vært kritisert for å ha en slik karakter (Britton 1982). Turismens vesen er at folk fra sentrum - de store byene - drar ut derfra for å oppleve andre steder, ofte til det de regner som periferier. Siden de bruker penger der, blir kapitalen med på lasset, for å tjene penger også på folks opphold utenfor kapitalsentraene.

Modellen som her er skissert, er kjent fra mange sektorer. Den gjelder i fiskeriene, innen fiskeoppdrett og i flere av reiselivets bransjer. I fiskeriene har en større og større andel av kvotene havnet i hendene på stadig færre, og havgående og kapitalkrevende fiskefartøy står for en stadig økende andel av norsk fangst (Grytås 2019). Eierne av fartøyene blir stadig færre og større. Innen fiskeoppdrett skjer det noe liknende. Eierskapet blir mer og mer konsentrert $\mathrm{i}$ et fătall selskaper. Det finnes ingen lokaleide anlegg i Finnmark, og bare tre i Troms. Eierne er norske selskaper, norskdominerte multinasjonale selskaper, japanske eller andre utenlandske selskaper. I reiselivet har det også funnet sted en prosess fra lokalt til nasjonalt og 
internasjonalt eierskap over tid. Hotellene i Finnmark var opprinnelig private. På 1970-tallet var det fylkeskommunen som eide dem. De solgte til SAS, som i 1998 la ned sin hotellvirksomhet, og Rica kom inn som driver av alle de større hotellene i Finnmark. I 2016 opphørte hotellkjeden Rica, men den eksisterer som et eiendomsselskap som disponerer mange av hotellene de tidligere også drev. De solgte driftsselskapene til Scandic, en internasjonal hotellkjede med svenske og norske eiere. Men det er også andre aktører i dette landskapet, i alle fall der hvor det er gode penger å tjene, som i Tromsø og Bodø. Thon og Choice er to andre kjeder med tilstedeværelse i landsdelen. I begge disse tilfellene er det identifiserbare eiere, som altså gjør forretning i landets utkant. Det finnes lokal- eller regionaleide hoteller, men de er relativt få, og stort sett mindre. De siste tiåra har denne tendensen også gjort seg gjeldende i rorbubransjen (se kapittel 7 om Lofoten i denne boka), men så langt ikke i campingnæringa.

I transportbransjen er mønsteret liknende det i hotellsektoren. Hurtigruten har hatt ulike eierstrukturer. På 1980-tallet var den eid av tre selskaper, ett fra hvert av de nordligste fylkene. I løpet av 1980- og 1990-åra skjedde flere fusjoner, og man endte opp med ett selskap i 2003. Etter hvert har en tidligere spredt administrasjon blitt sentralisert til Tromsø. Tidlig på 2000-tallet ble Trygve Hegnar, en kjent norsk investor og avismann, majoritetseier i selskapet. Det betød at kontrollen gikk ut av regionen, over på en nasjonal aktør. I 2014 solgte Hegnar seg ned, og 28 prosent av aksjene ble overdratt til en investorgruppe i London. Smått om senn har eierskap og kontroll over selskapet gått ut av Nord-Norge og endt opp i utlandet. I bussbransjen har det skjedd noe liknende med stadige fusjoner og nye drivere. Dels er dette et resultat av at det kreves konsesjon. Rutene legges med jevne mellomrom ut på anbud, og nye selskaper kan få tilslagene. Dette er en tilpasning til EU-krav om konkurranse. Men resultatet er ofte inntog av eksterne eiere og drivere. En av de store aktørene i det nordnorske bildet er Torghatten AS. Selskapet driver både ferger, bussruter og er hovedeier i flyselskapet Widerøe. Så langt har dette selskapet ikke blitt solgt ut av landsdelen.

Innen lokal turoperasjon og guiding var det år tilbake stort sett lokale selskaper. Men tidlig på 2000-tallet kom en oppkjøper på banen, og selskapet overtok guidingen i Nordkapp, Tromsø og flere steder i Lofoten. Som nasjonal agent for cruisebransjen har selskapet også stor innflytelse over cruiseskipenes valg av seilingsruter og besøkshavner. Så langt har slike 
overtakelser i liten grad skjedd i den nordnorske opplevelsesnæringa. Men det er tendenser. I 2019 har flere av de bedriftene knyttet til opplevelsesproduksjon i Troms slått seg sammen. Mønsteret er altså det samme i de fleste bransjene.

Der stordrift er mulig og profitabelt, er tendensen at finansaktører overtar selskapene. Dette reiser spørsmål knyttet til eierskap og kapital. For det første er økonomien helt frikoplet fra idealer om demokrati. Det gjelder i særlig grad våre naturressurser. Hvem skal styre disse, og hvordan skal utbyttet av virksomhet basert på disse ressursene fordeles? I noen norske næringer kreves det at det betales skatt av overskuddet fra en ressursbasert produksjon - det kalles grunnrente. Oljeproduksjon på norsk sokkel beskattes 78 prosent, og i kommunene er vannkraftproduksjon en viktige inntektskilde, både gjennom eierskap og beskatning. Tilsvarende ordninger diskuteres både for fangst og fiskeoppdrett, næringer som i stor grad er basert på produksjon av fellesskapets goder, tilgang på henholdsvis fisk og kaldt havvann. Det som diskuteres, er hvordan lokalsamfunnene som er berørt, skal nyte godt av sin egen ressurs. Reiselivet har gått under radaren i denne sammenhengen. Den benytter seg av steder, natur, frisk luft, vann og offentlig infrastruktur. Næringas ansatte betaler skatt, og kundene betaler avgifter, som merverdiavgift, på linje med folk flest. Men lokalsamfunnene som preges av turismen, får ingenting igjen for fellesressursene som er grunnlaget. Det er på tide også å drøfte dette spørsmålet.

\section{Cruiseturismen - hvem tjener på den?}

Cruiseturismen i Norge er i vekst. Veksten skyldes både flere anløp, større skip og en global utbredelse og alminneliggiøring av denne formen for turisme. Norge hadde 1809 cruiseanløp i 2016, noe som representerte en dobling på 20 år. Til sammen var det cirka 659000 cruiseturister innom Norge det året, hver med cirka fire ilandstigninger i gjennomsnitt, viser tilgjengelige undersøkelser fra Innovasjon Norge og Transportøkonomisk institutt (TØI). Det finnes tilbud i alle prisklasser, og i store deler av den vestlige verden (og til dels i den østlige) har middelklassemennesker råd til å koste på seg et cruise. Og i tråd med dette utvikles produksjonsteknologien for storproduksjon. Skipene blir større og større. Gjennomsnittlig tar skipene som besøker Norge om lag 1500 passasjerer, de største over 5000. 

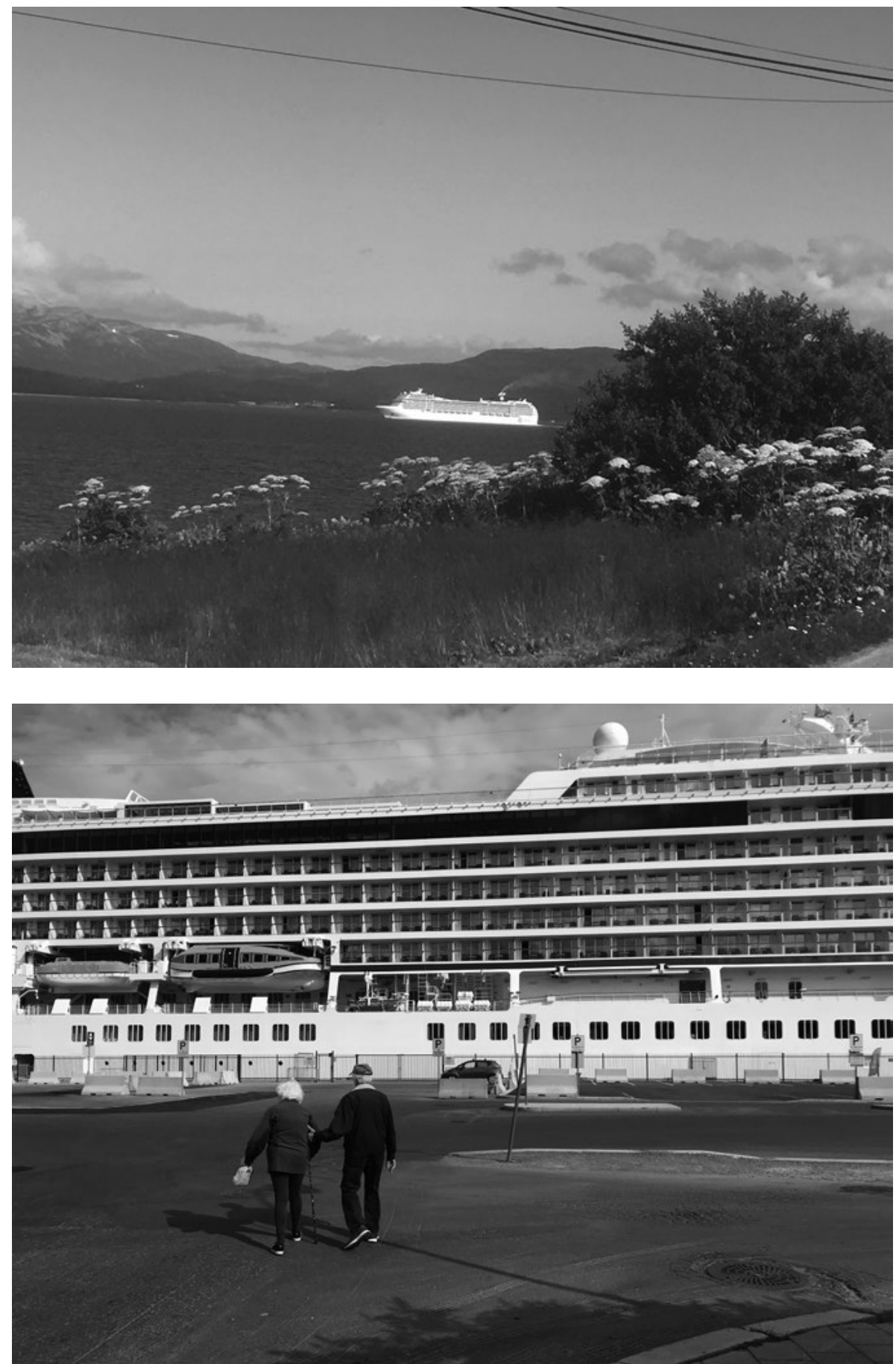

Cruiseskip - fra skipsfart til blokkbebyggelse på kjøl. Foto: Arvid Viken. 
Det har vært en årlig vekst på cirka fem prosent. Fra 2016 til 2017 økte antallet besøkende med cirka 100000 (Innovasjon Norge 2018). Dette er det nærmeste vi kommer masseturisme i Norge.

Forretningsideen i cruisenæringa er at turistene skal bruke mest mulig av sine penger om bord, på servering, fornøyelser og shopping. Dette er god butikk for redere, turoperatører og investorene bak, som både rommer norsk og internasjonal kapital. Vertslandet tjener noe gjennom havnevesen, havneservice, suvenirbutikker, guideselskaper og attraksjoner. Hvor mye er uklart, da en rekke undersøkelser viser ulike tall. Ut fra en sammenlikning av ti undersøkelser anslår TØI at hver cruiseturist brukte i snitt mellom 600 og 700 kroner per ilandstigning i 2018 (Dybedal 2019). I en annen rapport anslås dette forbruket til omtrent en fjerdedel av hva andre turister bruker (Epinion 2014). 40-60 prosent av turistene kjøper guidet tur i land, viser undersøkelsene. Slike turer selges om bord eller på forhånd, for en pris som gjerne er opp mot eller over det dobbelte av det man betaler operatøren i land. Likevel representerer det en vinn-vinnsituasjon for skipet og næringene i land. Men følgende er også en del av det store bildet: Cruiseskipene seiler stort sett under bekvemmelighetsflagg, betaler ikke skatt, moms eller alkoholavgifter slik andre reiselivsbedrifter gjør, og de ansatte har stort sett lave lønninger og dårligere arbeidsforhold enn norsk standard. Hovedsida ved cruiseturismens økonomi er altså at internasjonal (inkludert norsk) kapital gjør profitt på norske naturressurser og fellesgoder samt på internasjonal arbeidskraft. Det er dårlig butikk for landet, sjøl om det også er store norske eierinteresser i cruisenæringa. De norskeide skipene er imidlertid i all hovedsak registrert i utlandet.

Cruisehavnene drives stort sett av kommunalt eide selskaper. Kommunene, eller først og fremst lokalpolitikere knyttet til havnevesenet, er som regel ivrige pådrivere for å øke trafikken, og myndighetene bistår i finansieringen av havneprosjekter. Jo flere anløp, jo bedre butikk. Det er grunn til å sette spørsmålstegn ved kommunenes rolle og offentlig medfinansiering av havnene. Cruisehavnene burde kunne være sjølfinansierte. Det er derfor behov for kritiske analyser, utført av aktører som ikke står næringa for nær. Bergen har tatt tak i problematikken, men tiltakene er foreløpig svært moderate.

Cruiseturismen er nemlig ikke problemfri. Skipene representerer miljøutfordringer (se for eksempel Dybdahl \& Jacobsen 2019). De forurenser og innebærer miljørisiko. Går et skip på grunn, kan vi få store 
utslipp i trange farvann, som de norske fordene stort sett er. Men først og fremst representerer skipene luft- og havforurensning. Mediene har vist eksosskyen over Geiranger, og lokalpolitikerne krever tiltak. Med god grunn. Skip er verstingene blant transportmidlene når det gjelder utslipp av $\mathrm{CO}_{2}$ og $\mathrm{NO}_{x}$ per personkilometer. Elektrifisering under landligge er et prioritert tiltak hos norske myndigheter, men det tar åpenbart tid. $\mathrm{Og}$ koster penger. Mange steder preger cruisebesøk bybildene. Det gjør noe med de fleste steder når tusenvis av turister streifer omkring, stedene er ikke lenger lokale. Rapporter fra Bergen og Stavanger viser at folk har fått nok, og rorbueiere i Lofoten fortviler over cruiseturistenes lite idylliske myldring. Cruisedominans går dessuten ut over stedenes renommé i andre turistmarkeder, sies det. Dersom man i stedet for å slippe til de største skipene satset på mindre kystcruiseskip, eller det man ofte kaller ekspedisjonscruise, ville man unngå mange av dagens problemer. Slike cruise tilbys nesten ikke i Norge, men er en kjent modell fra destinasjoner som Svalbard, Hellas, Karibia og Galapagos. Det er på tide med en strukturendring av cruisenæringa.

Cruisenæringa er imidlertid kjent for å være vanskelig å regulere. Den er lite transparent og i liten grad utviklet i dialog med stedene cruiseskipene besøker og berører. Den går under radaren i mange henseender eller er beskyttet av internasjonale regler for sjøfart. Skipene kan tilsynelatende ferdes hvor de vil, og legge til kai eller ankre opp der det er tilrettelagt for det. Sjøl om det er endringer på gang, går mange skip på tungolje der det ikke er forbudt. Den kan med fordel forbys i alle kystnære farvann. Det går også an å favorisere små skip, eller forby de større, eller ilegge en sterkt progressiv avgift etter størrelse. Hva med en maksimalgrense på 300 passasjerer for cruiseskip i norske forder? Kanskje burde man differensiere størrelsesgrensene etter hvor trange og miljøutsatte farvannene er, og hvor store stedene er? Man kunne og regulere hvor mange skip som får legge til om gangen, og hvor mange turister som får gå i land samtidig, altså innføre slot-tider (tidslommer). Så langt har man bare foreslått en rapporteringsplikt for skip som går inn i verdensarvfjordene.

Elektrifisering av havnene i for eksempel Stavanger, Bergen, Ålesund, Geiranger, Flåm, Ballstad, Tromsø og Nordkapp, og utvikling av havnefasiliteter og miljøtiltak av ulike slag, må kunne finansieres gjennom en cruiseavgift. På Svalbard har man en avgift på 150 kroner per turist som går til miljøtiltak. Cruisenæringa har ikke protestert på den ordninga. Regjeringa 
la i 2017 fram en stortingsmelding om reiseliv. Der foreslås tilrettelegging av elektrisk strømtilførsel i havnene. For øvrig framstår dokumentet som viljeløst i spørsmålet om cruiseutviklinga. Altså er regjeringa fornøyd med tingenes tilstand. Diverse medieoppslag somrene 2017, 2018 og 2019 vitner om et sviktende grunnlag for denne tilfredsheten. Dette er også en rimelig fortolkning av tilgjengelig forskning. Her må det tas grep. Og det er et paradoks at den bransjen som startet turismen i Norge, er blitt den største trusselen mot både turismen og norsk natur.

\section{Turismen - en trussel for allemannsretten?}

Allemannsretten sikrer oss rett til å ferdes og å oppholde oss i naturområder som ikke er dyrket eller regulert og brukt til andre formål. Prinsippet er først og fremst hjemlet i friluftsloven fra 1957, men er en gammel hevd (se Reusch 2015). Det praktiseres i hele Norden og et fătall andre land. I resten av verden er det stort sett slik at grunneier bestemmer hvem som skal kunne ferdes på hans eller hennes grunn. Allemannsretten er høyt skattet av oss nordmenn, som utøver et omfattende friluftsliv, og vår kultur er sterkt knyttet til naturen og aktiviteter i den. Sjøl om friheten er stor, er den begrenset gjennom en rekke lovreguleringer, for eksempel av motorisert ferdsel, telting, jakt og fiske mv. Og kommunene kan gjøre sine stedstilpassede reguleringer og ilegge avgift på bruk, for eksempel for tilgang til en badestrand eller et utkikkspunkt.

Allemannsretten gjør at naturområder kan betraktes som et fellesgode. Fellesgoder er de godene vi deler som bosatte i et område, og forvaltes som regel av myndighetene. Vi omtaler disse godene ofte som infrastruktur, innretninger som skal gjøre livet enklere for oss, og som er finansiert gjennom skatter og avgifter. Blant myndighetenes oppgaver er også å ta vare på og tilrettelegge naturområder. Spørsmålet som har dukket opp, er om denne infrastrukturen og de offentlige forpliktelsene gjelder overfor alle brukere, uansett hvor de kommer fra. Slik debatten har vært de siste åra, synes det å være mange som mener at slik kan det ikke være. Turister betaler ikke skatt slik innbyggerne gjør, og «snylter» altså på det som det bofaste fellesskapet finansierer. En hake ved en slik tankegang er at det gjør vi alle når vi er ute og reiser, vi benytter oss hele tida av andres infrastruktur og fellesgoder. Og få reiser mer enn nordmenn. Kanskje jevner det 
seg ut? Eller kanskje ikke helt? Enkelte steder er laget for turisme - som bade- og skiresorter - og forberedt på å ta imot mange turister. Andre steder, som ikke er tilrettelagt for det, opplever likevel en uforholdsmessig stor tilstrømming og belastning, slik Venezia, Roma, Paris, London og vårt hjemlige Lofoten gjør det. Både allemannsretten og fellesgodene blir utfordret når de besøkende blir for mange. Enkelte steder skal det ikke så mange besøkende til før det for noen fortoner seg som for mange. I Norge opplever vi også at den frie tilgangen til naturen er en fare for turistene sjøl; mange av dem er ikke skikket til å vandre fritt i vår natur. Derfor har vi fått noen nye problemstillinger: Hvordan skal man redde ned alle som trenger eller ønsker det, hvordan skal slike tilfeller unngås, og hvem som skal betale for redning og forebyggende tiltak? Særlig trafikken til Trolltunga ved Odda har utløst denne problemstillingen. De færreste kommuner er vant til å takle slik turismevekst som Odda opplevde rundt 2015. Hvordan kan slike utfordringer håndteres?

Løsningene ligger svært sjelden i å stenge av eller formelt begrense tilgangen til områder. Det ble forsøkt ved Reinebringen ytterst i Lofoten, men folk fortsatte å gå dit (og nå er der en sherpatrapp). Det ble også foreslått for Øst-Svalbard tidlig på 2000-tallet, men møtte sterk motbør, blant annet fra reiselivsnæringa (Viken \& Nyseth 2017; se kapittel 14 i denne boka). Hva er da alternativene? Først og fremst er det å ta besøksforvaltning og regulering opp som temaer i politikk og myndighetsutøvelse. Man kan organisere seg vekk fra mange av problemene knyttet til store antall turister. Det det ble for eksempel i sin tid gjort på Nordkapp, hvor det på 1980-tallet fløt med søppel og skit, og det manglet steder for et beskyttet opphold. Det ble bygget et stort turistanlegg på stedet, og avgiften for å komme inn ble økt vesentlig. Dette skjedde på statsgrunn og i et område omfattet av allemannsretten. Ordningen virket og virker fortsatt, sjøl om tiltakene har irritert en del forsvarere av den frie ferdselen (se kapittel 7 i denne boka). Altså kan man oppføre en bom ved inngangen til et naturområde og ta penger for at man skal slippe forbi. Inngangspengene vil så kunne dekke utvikling og drift av nødvendige fasiliteter, herunder parkering, pleie av naturen og om nødvendig en forsikringsordning som dekker kostnader ved redning. Slike arrangementer kan man installere ved starten av stier og utfartsområder, og for eksempel ved innfartspunktene til Lofoten. Lovverket er ikke til hinder. Hvem som skal gjøre det, og hvordan, er en forhandlingssak. Ved Trolltunga tok man grep i 2017, med veiledere i 
fjellet, en ny vei opp fra dalen, bedre informasjon på internett og skilter og redningshytter i terrenget. Man har også tatt grep ved Preikestolen, men med en annen modell som involverer kommunene omkring. Begge steder har problemene blitt vesentlig redusert.

En annen del av problemet er at sjøl med en aktiv besøksforvaltning kan det bli for mange turister. Avgifter og inngangsbetaling kan redusere antallet, men trolig er organisatoriske grep mer effektive. Det mest nærliggende eksemplet er tilgangen til mange kulturarvsteder, der en må stå i kø for å slippe til. Det finnes også steder som i prinsippet er stengt, og hvor man må søke om å få adgang. I Mount Everest-massivet er tilkomsten regulert på denne måten. Andre steder, for eksempel på Galapagos, prøvde man å sette tak for antall turister, men det viste seg vanskelig å gjennomføre. Man kan også regulere tilkomsten for bestemte typer trafikkerende; for eksempel ved å forby private kjøretøyer innenfor et bestemt område. Man kunne ha gjort dette både på Nordkapp og i Å og Nusfiord i Lofoten altså lage parkeringsplasser et stykke unna, med kontinuerlig busstransport og sykkelutleie til og fra attraksjonene. Slike forvaltningssystemer er ikke like enkelt å administrere alle steder eller for alle typer turisme. Uansett fordrer det samarbeid, partnerskap mellom stat, kommuner, organisasjoner og private aktører. Myndighetene har imidlertid et særlig ansvar for at noe blir gjort, når det er fellesgodene og den lovregulerte allemannsretten som er i spill. Disse kreftene bør ikke få fritt spill. Friheten som har vært viktig for norsk turismeutvikling, er paradoksalt nok i ferd med å skape behov for å begrense den.

Det er behov for revisjon av allemannsretten. Det er simpelthen ikke plass til alle i vår natur, i alle fall ikke uten at deres atferd styres. Det betyr at det må gjøres en rekke tiltak i og rundt norske naturområder, og særlig de mest brukte utfartsstedene. Det må utvikles og vedlikeholdes stier, og det må anlegges toaletter og søppelsystemer, og ikke minst trengs det nye parkeringsplasser. Videre må informasjonssystemene forbedres, og noen steder bør man lage retningslinjer (guidelines). Man må også finne fram til betalingssystemer, slik at det ikke er norske skattebetalere som betaler for alt, men at brukerne også bidrar, og det må utvikles forsikringsordninger. Og alt dette (og mere til) må administreres. Altså trengs det en helt annen om mer omfattende besøksforvaltning enn den man har hatt til nå. 


\section{Konklusjon: Bærekraft krever handling}

De utfordringene som er tatt opp i dette kapitlet, er i hovedsak saker som må løses politisk. Politikerne er opptatt av det grønne skiftet. Når det gjelder reiselivet, må dette innbefatte diskusjoner om hvordan vi kan styre veksten, kapitalen og de store næringsaktørene. Og så dreier det seg om å drøfte hvordan friheten - til å besøke alle småsteder og til å ferdes i naturen - kan forvaltes. Sentralt i dette er spørsmålet om hvordan tilrettelegging og påkrevd forvaltning skal finansieres. Mange av utfordringene som er pekt på, framstår som paradokser, altså som noe som kontrasterer en ønsket eller verdsatt utvikling. Turismen er ønsket, og den er på sett og vis en miljøvennlig næring, men blir et problem når den blir for stor. Det kan helt enkelt bety at det er for mange turister på et sted samtidig, det medfører trengsel, uønsket nedtråkking, sporsetting og redusert trengsel. Fordi mange mennesker skal håndteres, reises store hoteller, flere fly settes inn, og skipene blir større. En slik utvikling skaper nye og andre problemer - for eksempel knyttet til forurensning, og nye debatter om turismens berettigelse oppstår. Stort sett er samfunnet dimensjonert for å håndtere de menneskene som bor på stedet, ikke alle andre. Derfor er det også mange som stiller spørsmål ved at Innovasjon Norge - nasjonens markedsføringsorgan i utlandet - reklamerer med fri adgang til norsk natur. Skal det virkelig være slik? Skal all verdens mennesker ha fri adgang til «vår natur»? Tross alt betaler vi som bor her skatt, som blant annet går til å vedlikeholde både natur og kultur, noe de besøkende slipper.

Men det er ikke bare menneskene som har bevegelsesfrihet. Kapitalen, teknologien og informasjonen har tilsvarende friheter. I stadig større grad styres folks atferd - også som turister - av ulike sosiale medier. Internasjonal teknologi er overalt i reiselivet, fra datamaskiner til fly, fra bookingsystemer til TripAdvisor, fra betalingskort til vippssystemer. Hotellene, cruiseskipene og flyselskapene er internasjonale, sjøl om også norske investorer deltar. EUs friheter betyr at utenlandsk kapital fritt kan kjøpe opp norske bedrifter, bedriftene kan bemannes med utlendinger, og overskuddet går dit eieren har registrert sitt selskap. Kapitaleierne bestemmer over det de eier. Derfor betyr eksternt eierskap at produksjonsmidlene og de som betjener dem, er under utenlandsk herredømme. Sjølsagt må også disse aktørene følge norsk lov, men den norske arbeidslivsmodellen 
er utfordret. Færre ansettes, flere leies inn, og utleierne av arbeidskraften deler ikke nødvendigvis prinsippene for det norske arbeidslivet. Reiselivet er i stor grad preget av slike tendenser. Paradokset er at vi ønsker frihet og har det - vi har også gitt tilslutning til EUs frie bevegelsesprinsipp, men friheten fører altså til at det norske arbeidslivssystemet blir utfordret og til dels undergravd, og at verdier som skapes, går ut av landet. Skal vi og bør vi gjøre noe med dette?

For å kunne by etterslektene tilsvarende opplevelser - det er det bærekraft dreier seg om - må vi gjøre noe. I denne boka er det pekt på forhold knyttet til alle sider ved bærekraften, økonomisk, økologisk, sosiokulturell og turistisk bærekraft. Er det økonomisk bærekraft å overføre styring av kapital og produksjonsmidler til eksterne aktører? Skal dette kunne gjøres uten å beskatte grunnrenta? Er det forsvarlig ut fra et økologisk perspektiv å tillate cruiseskip på størrelse med norske byer å seile i våre fjorder og gå på land i våre småsteder? Hva skjer med kultur og sosialt liv på steder som overstrømmes av turister? Og hvordan går det med turismen på steder der turistene står i kø for å få innblikk i norsk småstedsidyll? Spørsmålene er mange og viktige, og svarene er ikke nødvendigvis bærekraftige. Paradoksene må inkluderes i debattene om reiselivets utvikling. Temaene må møtes med dialoger, debatter, prioriteringer og omforente strategier. Utviklinga bør ikke bare skje.

\section{Litteratur}

Britton, S. G. (1982). The political economy of tourism in the third world. Annals of Tourism Research, 9, 331-356. https://doi.org/10.1016/01607383(82)90018-4

Brox, O. (2006). The political economy of rural development. Modernisation without centralization? Delft: Eburon.

Bryden, J. \& Bollman, R. (2000). Rural employment in industrialised countries. Agricultural Economics, 22, 185-197. https://doi.org/10.1111/j.1574-0862.2000. tb00017.x

Bryman, A. (1999). The Disneyfication of society. The Sociological Review. https://doi.org/10.1111/1467-954X.00161 
Curchin, K. (2013). Interrogating the hybrid economy approach to indigenous development. Australian Journal of Social Issues, 46, 16-33. https://doi.org/10.1002/j.1839-4655.2013.tb00269.x

Debord, G. (2012). Society of the spectacle. London: Bread and Circuses Publishing.

Dybedal, P. (2019). Cruiseturisters forbruk i Norge - en sammenlikning av resultater og metoder i ti undersøkelser. TØI rapport 1702. Oslo: Transportøkonomisk institutt.

Dybedal, P. \& Jacobsen, J. C. S. (2019). Mer barekraftig cruiseturisme. Framtidssisser for cruiseutvikling på Vestlandet. TØI rapport 1686. Oslo: Transportøkonomisk institutt.

Epinion (2014). Turistundersøkelsen cruise 2014. Oslo: Innovasjon Norge.

Flagestad, A. \& Hope, C. A. (2001). Strategic success in winter sports destinations: a sustainable value creation perspective. Tourism Management, 22 (5), 445-461. https://doi.org/10.1016/S0261-5177(01)00010-3

Frank, T. (2001). One market under God: Extreme capitalism, market populism, and the end of economic development. New York: Doubleday. https://doi.org/10.17077/2168-569X.1373

Galtung, J. (1971). A Structural Theory of Imperialism. Paper. Oslo: International Peace Research Institute. https://doi.org/10.1177/002234337100800201

Grytås, G. (2019). Skatteparadis i blå åker. Plan, 3, 36-43.

Hamilton, C. (2003). Growth fetish. London: Pluto Press.

Harvey, D. (1989). The condition of postmodernity. Oxford: Blackwell Publishers. Heinberg, R. (2011). The end of growth: Adapting to our new economic reality. Gabriola Island: New Society Publishers.

Higgins-Desbiolles, F. (2006). More than an "industry": The forgotten power of tourism as a social force. Tourism Management, 27, 1192-1208. https://doi.org/10.1016/j.tourman.2005.05.020

Hjalager, A.-M. (1997). Tourism destinations and the concept of industrial districts. Paper for ERSA conference, Dublin, august 1999. Århus: Science Park. Innovasjon Norge (2018). Nøkkeltall Cruise 2017-2018. En oversikt over norsk cruisenering. Rapport. Oslo: Innovasjon Norge.

Jackson, J. \& Murphy, P. (2006). Clusters in Regional Tourism: An Australian Case. Annals of Tourism Research, 33, 1018-1035. https://doi.org/10.1016/j. annals.2006.04.005 
Lefebvre, H. (1991). Critique of everyday life. Volume I. London: Verso.

Leiper, N. (1990). Tourist Attraction Systems. Annals of Tourism Research, 17 (3), 367-384. https://doi.org/10.1016/0160-7383(90)90004-B

Leiper, N. (2008). Why 'the tourism industry' is misleading as a generic expression: The case for the plural variation, 'tourism industries'.

Tourism Management, 29 (2), 237-251. https://doi.org/10.1016/j. tourman.2007.03.015

Peters, M., Frehse, J. \& Buhalis D. (2009). The importance of lifestyle entrepreneurship: A conceptual study of the tourism industry. Pasos, 7 , 393-405. https://doi.org/10.25145/j.pasos.2009.07.028

Porter, M. E. (1990). The Competitive Advantage of Nations. New York: The Free Press. https://doi.org/10.1007/978-1-349-11336-1

Reusch, M. (2015) Allemannsretten. Oslo: Universitetsforlaget.

Ritzer, G. (1993). The McDonaldization of society. Thousand Oaks, CA: Pine Forge Press.

Saarinen, J. (2004). Destinations in change. The transformation process of tourist destinations. Tourist Studies, 4, 161-179. https://doi.org/10.1177/1468797604054381

Saarinen, J. (2014). Transforming destinations: A discursive approach of tourism destinations and development. I A. Viken \& B. Granås (red.), Tourism destination development. Turns and tactics (s. 47-62). Farnham: Ashgate.

Viken, A. \& Nyseth, T. (2017). Co-management in environmental planning. An alternative to the precautionary principle. I S. Kristjánsdóttir (red.), Nordic Experiences of Sustainable Planning: Policy and Practice (s. 48-63). London: Routledge. https://doi.org/10.4324/9781315598529-4

Zhang, Y., Qu, H. \& Guo, Y. (2011). A study of the agglomeration of China's convention industry: An economic and neo-economic geography framework approach. Tourism Economics, 17 (2), 305-319. https://doi.org/10.5367/ te. 2011.0035 


\section{Forfatterpresentasjon}

Rune Benonisen har mastergrad fra NMBU (Ås). Han har arbeidet i reiselivsnæringen og i offentlig forvaltning. Han er i dag ansatt som verneområdeforvalter knyttet til fylkesmannsembetet i Troms.

Christian Ekeland har doktorgrad i reiseliv fra UiT Norges arktiske universitet. Den handlet om interesseutvikling og reiselivsopplevelsens kontekstavhengighet. Han arbeider som næringsutvikler i en Troms-kommune.

Anniken Førde er professor ved UiT Norges arktiske universitet og underviser i temaer relatert til samfunnsplanlegging. Hennes hovedfelter er stedsutvikling og turisme. Hun har skrevet en lang rekke bidrag til bøker og tidsskrift i inn- og utland.

Ragnar Nilsen er professor emeritus ved UiT Norges arktiske universitet. Han har primært forsket i utviklingen av fiskeriene og norske kystsamfunn. Han har skrevet en rekke artikler og deltatt i flere bøker i feltet, både som redaktør og forfatter.

Toril Nyseth er professor ved UiT Norges arktiske universitet, hvor hun primært underviser og forsker innen feltet samfunnsplanlegging. Hun har redigert en rekke bøker, og bidratt til bøker og tidsskrifter innen temaer knyttet til blant annet sted, kommune og planlegging.

Carina Olufsen har mastergrad i reiseliv, og har vært stipendiat i reiseliv. Hennes interesse er hvordan endringer innen fiskeri og reiseliv bidrar til endring, men også til stabilisering av bosetting i Nord-Norge. Hun arbeider for tiden i administrasjonen ved UiT Norges arktiske universitet.

Ola Sletvold er pensjonist, men har i en mannsalder undervist og forsket innen reiseliv. Han har de seinere år forsket i temaer knyttet til destinasjonsutvikling, cruisevirksomhet og utviklingstrekk ved turismen. 
Gaute Svensson har en doktorgrad i turisme fra UiT Norges arktiske universitet. Den handlet om forholdet mellom turisme, friluftsliv og lokalsamfunn. Han er for tiden ansatt som forsker og arbeider med problemstillinger knyttet til verneforvaltning, gruveindustri og forskningsformidling.

Arvid Viken er professor emeritus ved UiT Norges arktiske universitet. Han har de siste 30 årene drevet forskning og undervisning knyttet til reiseliv. Hans fokus har primært vært på turismens relasjon til samfunnet omkring, som har vært omhandlet i flere bøker, men hans bøker favner også stedsutvikling og grenseproblematikk. 